\title{
RECONSTRUindo CajueIRO SECO: \\ Arquitetura, política social e cultura popular em Pernambuco (1960-64)
}

\section{Diego BEJA INGLEZ DE SOUZA}

Dissertação apresentada em dezembro de 2008 à Faculdade de Arquitetura e Urbanismo da Universidade de São Paulo para obtenção do título de Mestre em arquitetura e urbanismo.

Reprodução autorizada para fins não comerciais, desde que citada a fonte e comunicado o autor. Para dúvidas ou comentários, escreva para diegobis@gmail.com

Esta pesquisa contou com o apoio da Fundação de Amparo à Pesquisa do Estado de São Paulo - FAPESP

\section{Orientador Prof. Dr. José Tavares Correia de Lira}

Área de concentração: História e fundamentos sociais da arquitetura e do urbanismo 


\section{AGRADECIMENTOS}

Cá em São Paulo, agradeço a FAU USP, projeto coletivo do qual me orgulho em fazer parte, ao Zé, mais que orientador, a FAPESP pelo apoio, a toda a minha família, especialmente a Lygia Rodrigues e as avós Maria Luiza e Enaura, a Luciana Ferrara, por tudo, aos amigos João Clark, Paula Prates, Adriana Alves, Juliana Braga e Carolina Heldt pela ajuda na finalização e pelo companheirismo, aos sempre parceiros Pablo, Ciro, Tiago e Paula do Roda Arquitetura pelo apoio, aos colegas do grupo pela vital interlocução, aos primos Luiz Murillo e Beto Inglez de Souza, ao Miguel Pereira pela conversa sobre o IAB e a UIA, ao Sandor e Andrea, pela leitura e debates sobre a história do "Partidão", aos professores Carlos Monteiro de Andrade e Ermínia Maricato pelas precisas observações na banca de qualificação e contribuição na formação, aos professores Nabil Bonduki e Ana Paula Koury, aos arquitetos e professores Alexandre Delijaicov, Álvaro Puntoni e Helena Ayoub, com quem tanto aprendi colaborando na disciplina AUP 152, às professoras Maria Ruth do Amaral Sampaio, Mônica Junqueira de Camargo, à Regina, a Rejane e demais funcionários da Biblioteca Eduardo Knesse de Mello (FAU USP); ao professor Jorge Hajime Oseki (in memoriam);

No Recife, muito obrigado ao Renato Menezes pela hospedagem e amizade; Luiz Amorim, pela disposição em participar da banca e acompanhar o trabalho; Acácio Gil Borsoi pela disponibilidade e generosidade; Geraldo Santana e principalmente Geraldo Gomes da

Para a Guida (in memoriam), Silva pelas valiosas pistas; Vital Lira, Lívio Xavier, Germano Coelho, Maurício Castro, Francisca Veras, Maria Lucia Mello pelas entrevistas concedidas, aos moradores do Cajueiro Seco, especialmente Dona Maria e Seu Inácio; aos funcionários do Arquivo Público Estadual (APEJE), particularmente Marcília Gama e Hildo Leal Rosa, aos funcionários da Biblioteca Joaquim Cardozo (CAC-UFPE) e da Biblioteca Pública do Estado de Pernambuco, aos funcionários da Iconografia da FUNDAJ, aos arquitetos Noé Sérgio Barros, Milton Botler, Ney Dantas, Múcio Jucá e Bruno Barreto, pelos animados debates e conversas. 


\section{ABSTRACT}

This dissertation focuses on Cajueiro Seco's housing experience taken place in Pernambuco, Brazil, during Miguel Arraes term as state governor between 1963 and 1964. Often seen as paradigmatic in terms of communal participation and the merging of modern and vernacular solutions, the experience is here examined as a part of wider social, political and cultural histories. On the one hand, the work relates the local episode with discussions, proposals and achievements on housing and urban reform in Brazil and Latin America during the 1950s and 1960s. On the other hand, it analyses the architectural experience in face of contemporary political and cultural debates concerning national development and underdevelopment, Kennedy's Alliance for Progress programs, João Goulart's national reforms program, urban and rural social mouvements, the Popular Culture Mouvement and the Frente do Recife in Pernambuco etc. By observing different actors involved on the conception, concretion and interruption of that experience, the work surpasses authorial references to the prefabricated adobe design in order to reevaluate the role of collective processes in architectural historiography.

\section{Keywords}

Modern architecture, Social policy, Housing, Self-help, Pre-fabrication, Adobe, Popular Culture, Acácio Gil Borsoi, Recife, Pernambuco, 1960's Brazil

\section{RESUMO}

A dissertação trata da experiência habitacional do Cajueiro Seco, realizada em Pernambuco durante o governo Miguel Arraes, entre 1963 e 1964. Freqüentemente considerada um paradigma nacional de participação popular e aproximação entre o moderno e o vernacular na arquitetura, a experiência é aqui analisada como parte da história social, política e cultural do período. Por um lado, relaciona o episódio local com as discussões do período sobre habitação e reforma urbana em congressos do IAB e da UIA, na tentativa de situar a experiência no âmbito das propostas e realizações em pauta no Brasil e América Latina. Por outro, situa a experiência em meio aos debates políticos e culturais contemporâneos acerca do desenvolvimento e subdesenvolvimento nacionais, a Aliança para o Progresso de Kennedy, as Reformas de Base do período João Goulart, os movimentos sociais urbanos e rurais, a Frente do Recife e o Movimento de Cultura Popular em Pernambuco etc. Ao mapear os diversos atores envolvidos na formulação, concretização e interrupção da experiência, o trabalho ultrapassa as referências autorais do projeto da taipa pré-fabricada, de modo a repensar o lugar dos processos coletivos na historiografia da arquitetura.

\section{Palavras chave}

Arquitetura moderna, Política social, Habitação, Auto-ajuda, Préfabricação, Taipa, Cultura popular, Acácio Gil Borsoi, Pernambuco, década de 1960 no Brasil 


\section{RECONSTRUINDO CAJUEIRO SECO:}

Arquitetura, política social e cultura popular em Pernambuco (1960-64)

$\underline{\text { INTRODUCCÃO }}$

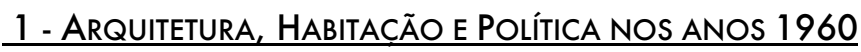

1.1_ A crise dos CIAM e o Team X

1.2_ Habitação e Pré-fabricação nos Congressos da UIA e no IAB

1.3_O Seminário de Habitação e Reforma Urbana

1.4_O Congresso da UIA em Havana/63

1.5_Experiências participativas na construção da habitação social

1.6_ Impasses da política habitacional brasileira

1.7_Anos 60: os arquitetos e as políticas

2 - A EMERGÊNCIA DO POPULAR NA POLÍTICA E NA CULTURA

2.1_ Entre Havana e o Mundo Livre

2.2_ Subdesenvolvimento e a SUDENE

2.3_ Ligas Camponesas, Igreja e a "Cubanização"

2.4_ A Frente do Recife

2.5_ Governo Arraes: o "povo" no governo

2.6_ O Movimento de Cultura Popular

2.7 USAID, Aliança para o Progresso, IBAD e a resistência

2.8 O golpe de 64 em Pernambuco
3 - HABITACÃO E URBANIZACC̃̃O NO GRANDE RECIFE

3.1_ O SSCM e a política habitacional em PE

3.2_ Urbanismo e metropolização do Grande Recife

3.3_O plano habitacional pernambucano de 1962

3.4_A invasão dos Montes Guararapes

4 - CAJUeIRo SECO: O PROJeTO, AS REALIZAÇÕES E SEUS DESDOBRAMENTOS 147

4.1_ O Plano para o Cajueiro Seco e a reforma urbana

148

4.2 Experiências de Pré-fabricação em Pernambuco

4.3_ Borsoi e a arquitetura moderna em Pernambuco

160

4.4 _O projeto da taipa pré-fabricada

171

4.5_Ocupação do território e autoconstrução

À GUISA DE CONCLUSÃO

204

Bibliografia, fontes, acervos e siglas 


\section{INTRODUCÃO:}

"Com dez eu pego na casa com vinte assento os esteios

Com trinta reparto o meio quarenta eu não me atraso

Com cinqüenta eu cavo a base sessenta porta e janela

Setenta obra tigela oitenta eu ripio a barro

Com noventa eu bato o barro e com cem eu tô dentro dela"

Samba de dez linhas

Dj Dolores e Orquestra Santa Massa em Contraditório?, de 2002

\section{Cajueiro Seco e as histórias da arquitetura}

A experiência de projeto e construção do núcleo habitacional do Cajueiro Seco, realizada no grande Recife durante a primeira gestão de Miguel Arraes à frente do governo de Pernambuco (196364), tem sido referenciada na historiografia como um episódio ímpar na história da arquitetura moderna brasileira. Propõe-se aqui um estudo da experiência do Cajueiro Seco para além da curiosidade, excepcionalidade ou mesmo como mito de origem das práticas mutirantes e participativas.

A articulação entre a política de um Estado democrático, os movimentos populares e a vanguarda intelectual e artística da profissão teria produzido uma solução arquitetônica original para o problema habitacional no país, num momento singular de inflexão na história do projeto habitacional no Brasil e das relações do arquiteto com os territórios populares, as políticas urbanas e suas dinâmicas.

Alguns autores entendem o Cajueiro Seco como um desdobramento e resposta característicos do momento de crise do movimento moderno em direção a um novo paradigma que inclui os valores, formas e saberes locais, vernaculares e populares. Outros vêem Cajueiro Seco num momento de virada tanto das políticas autoritárias de enfrentamento da questão habitacional quanto das soluções elitistas ou eruditas da arquitetura moderna ${ }^{2}$ Recentemente, a experiência tem sido considerada como uma das remotas origens das atuais experiências e políticas de construção por mutirões ${ }^{3}$. Há ainda quem olhe para o Cajueiro Seco a partir do prisma específico da história da arquitetura e se esforçe para situá-lo na discussão acerca da linha pernambucana de arquitetura e dentro

\footnotetext{
1 Bruand, Yves, Arquitetura Contemporânea no Brasil São Paulo: Ed. Perspectiva, 4a Ed., 2003

${ }^{2}$ SEGAWA, Hugo, Arquiteturas no Brasil 1900-1990 São Paulo: EdUSP, 1999

3 ARANTES, P edro in FORTY, Adrian e ANDREOLI, Elisabetta (ORG), Arquitetura Moderna Brasileira, Londres, Phaidon, 2004
} 
da ampla trajetória profissional do arquiteto Acácio Gil Borsoi ${ }^{4}$, autor do projeto de pré-fabricação da taipa ali implementado.

Deslocada de seu contexto, a experiência surge frequentemente na historiografia da arquitetura pelo esforço de conciliação, em termos de projeto, entre pré-fabricação e autoconstrução tradicional, enquanto que no plano da história das políticas habitacionais não transcende à condição de manifestação utópica com características de exceção.

O fato é que esta experiência, que ecoaria nos debates em torno das possibilidades e limites da casa popular a partir dos anos 60, particularmente em São Paulo, não foi ainda estudada em profundidade. As questões específicas que operavam em seu interior - arquitetura, pedagogia, política social e cultura popular permanecem pouco exploradas e uma leitura geral da articulação destas questões é o objeto principal deste trabalho.

A despeito de seu lugar na historiografia oficial da arquitetura moderna brasileira, a experiência do Cajueiro Seco vem sendo tratada de maneira excessivamente esquemática, tanto dentro da trajetória individual do arquiteto Acácio Gil Borsoi quanto na arquitetura moderna pós-Brasília. Bruand, em comentário paralelo à discussão acerca da "Escola do Recife", já observava:

4 NASLAVSKY, Guilah Arquitetura moderna em Pernambuco, 1951-1972 : as contribuições de Acácio Gil Borsoi e Delfim Fernandes Amorim São Paulo, 2004
"Porém o interesse de Borsoi pelas técnicas do passado e a falta de qualquer opinião preconcebida "modernista" aparece num projeto (1963): a comunidade rural (sic) de Cajueiro Seco, em Pernambuco. Achando que o único modo de combater a miséria da população local era a elaboração de um processo que permitisse aos habitantes construírem eles mesmos suas casas ao lhes serem fornecidos os elementos indispensáveis, Borsoi teve a idéia de voltar ao processo tradicional do pau a pique: elaborou um sistema de racionalização e de pré fabricação dos painéis de estrutura; estes painéis, assim como o equipamento sanitário mínimo previsto, foram fornecidos pela cooperativa formada para este fim; para a cobertura, utilizou rolos de palha trançada igualmente preparados de antemão e em série. Dessa maneira, conseguiu oferecer casas acessíveis àquela população, dotadas de um conforto relativo mas suficiente em relação às condições climáticas e ao desenvolvimento econômico e mental dos beneficiários" (BRUAND, 2003 p. 147)

É provável que o caráter piloto da experiência no ambiente de esperança que caracterizava a atividade cultural e política do período tenha algo a ver com o aparecimento do que Segawa chamou de uma nova atitude do arquiteto para com o morador:

"Um primeiro reconhecimento dessas contingências limitadoras foi tentado por Acácio Gil Borsoi, em 1963, em Pernambuco, onde, por iniciativa do Serviço Social contra o Mocambo, o arquiteto propôs, para a comunidade favelada ( $\mathrm{sic}$ ) do Cajueiro Seco, casas segundo um sistema de pré fabricação de componentes construtivos baseado na taipa - sistema tradicional associando uma malha de madeira revestida com barro - uma arquitetura de custo baixo e factível dentro das limitações orçamentárias da população de baixa renda. A proposta buscava integrar um certo repertório construtivo tradicional, a fixação da população no local com a alternativa de morar em casas de melhor qualidade, sem violentar as características culturais e cotidianas da comunidade favelada. O golpe de 1964 interrompeu a experiência, sem possibilidade de avaliação." (SEGAWA 1999)

Uma lacuna notável na historiografia sobre mutirões e autoconstruções é a falta de articulação entre os debates sobre a questão do habitat no pós-guerra movidos pelos arquitetos 
dissidentes dos Congressos Internacionais de Arquitetura Moderna (CIAMs) e da União Internacional dos Arquitetos (UIA) com a discussão local nos congressos brasileiros e panamericanos de arquitetura e habitação. Falta também uma leitura articulada das experiências brasileiras e latinoamericanas no campo da habitação e da participação popular, como as brigadas habitacionais cubanas, o PREVI em Lima, Peru, propostas de arquitetos brasileiros como Carlos Frederico Ferreira, Eduardo Knesse de Mello, Rodrigo Lefevre até mais recentemente a atuação de assessorias e $\mathrm{ONGs}^{5}$, que vem sido estudadas isoladamente.

Tratado como episódio marginal, excêntrico, incapaz de ser avaliado, a experiência de Cajueiro Seco parece perder sua inserção na história. De um lado, as soluções ali apresentadas parecem inteiramente descoladas do campo contemporâneo (local, nacional e internacional) de questionamentos acerca da postura profissional dos arquitetos modernos para com a habitação e a cultura dos usuários, típicas do $2^{\circ}$ pós guerra.. ${ }^{6}$

De outro, referências locais importantes como a trajetória do Serviço Social Contra o Mocambo (SSCM), o governo Miguel Arraes ou o Movimento de Cultura Popular (MCP) devem ser aprofundadas

\footnotetext{
${ }^{5}$ Ver Caio Santo Amore de CARVALHO A lupa e o telescópio - o mutirão em foco Mestrado FAU USP São Paulo: FAU USP, 2004

${ }^{6}$ SMITHSON 1968, OCKMAN 1993
}

para uma completa problematização dos significados da experiência ${ }^{7}$.

Por certo, a experiência do Recife teve suas ressonâncias em outros contextos. Algumas das questões levantadas pela experiência regional dialogam com os outros centros produtores de arquitetura brasileira. Se no Rio de Janeiro o trabalho de Carlos Nelson Ferreira dos Santos contribuiu para aproximar a arquitetura da antropologia no reconhecimento da arquitetura real das favelas a partir do final dos anos 60, no Cajueiro Seco anteciparam-se questões e se formularam propostas que dialogam com o debate sobre a industrialização da construção no bojo da arquitetura moderna produzida pelos paulistas.

"Publicada na Revista OU... lado a lado com o projeto da Casa do Juarez, Cajueiro Seco indicava a qual caminho Rodrigo Lefevre passaria a dar maior atenção, imaginando inclusive quais os termos para uma política pública mais democrática." (ARANTES, 2002)

A experiência de Cajueiro Seco ainda ecoa no debate da arquitetura brasileira pós- $64^{8}$ como uma das poucas experiências na história da arquitetura moderna brasileira em que se sintetizou o

\footnotetext{
${ }^{7}$ Cavalcanti 1978, Melo 1985, LiRa 1997
}

${ }^{8}$ Desde os artigos de Lina Bo Bardi na Revista Mirante das Artes , um deles com o sugestivo titulo de "Ao limite da casa popular", reconhecendo o esforço coletivo para viabilizar a experiência, passando pela matéria publicada pela revista Ou... editada em 1968 pelos estudantes da FAU USP, em clima acalorado entre o lápis e o fuzil, até o recente artigo de Pedro Arantes para o livro Arquitetura Moderna Brasileira editado pela Phaidon inglesa. 
saber ligado a práticas artesanais de uma comunidade com uma proposta de industrialização de componentes e modulação dos espaços em função de peças pré-moldadas no canteiro.

Guilah Navslavky, em estudo minucioso sobre a contribuição de Borsoi, Delfim Amorim e Mario Russo na formação da tal "arquitetura moderna em Pernambuco", dedica ao episódio o mesmo tratamento - como exceção ou peculiariedade. Em nota de rodapé, afirma:

"Em 1963, houve uma experiência peculiar na obra do arquiteto quando participou do Governo de Miguel Arraes e atuou na diretoria do Departamento de Construcões do Serviço Social Contra o Mocambo (SSCM) juntamente com o arquiteto Gildo Guerra, presidente do serviço e o arquiteto Flávio Marinho Rego." (NAVSLAVKY 2003, p.216)

O enquadramento que Ana Paula Koury dá à experiência talvez seja dos mais precisos para entender o Cajueiro Seco, inserido nas mobilizações em torno da reforma urbana, dialogando com uma certa "arquitetura construtiva". Em nota de rodapé, comenta a proposta de auto-ajuda para situações emergenciais, entre outras medidas:

"o modelo para a formulação desta proposta parece ter sido uma remoção de habitações precárias, realizada em Cajueiro Seco (PE), coordenada pelo arquiteto Acácio Gil Borsoi. A obra previa a instalação de um conjunto habitacional para população de baixa renda, com emprego de tecnologias não convencionais e se destacou por ser a primeira iniciativa a elaborar um plano de desenvolvimento comunitário sustentável, através do incentivo a produção local, integrando técnicas de pré-fabricação a sistemas construtivos vernaculares como a "casa de sopapo" ou "barro armado". Acácio Gil Borsoi foi coordenador dos debates do $2^{\circ}$ Grupo do SHRu, A habitação e o aglomerado humano. " (KOURY, 2005)
Para Borsoi, de fato, o Cajueiro Seco foi um projeto extraordinário na sua vasta obra. Um caso paradigmático numa trajetória profissional que integra desde obras públicas como sedes de órgãos públicos em diversas capitais nordestinas e conjuntos habitacionais nas suas periferias, antes, durante e depois do $\mathrm{BNH}$, às intervenções delicadas junto ao patrimônio histórico na região central do Recife às encomendas privadas de prédios de apartamentos de elite em Boa Viagem ou residências unifamiliares nos mais nobres bairros nordestinos.

A partir de uma visão original do patrimônio moderno de arquitetura, o Cajueiro Seco aparece também no recém-publicado "Obituário Arquitetônico", de Luis Amorim, entre outros exemplares "mortos" do que foi a produção de "arquitetura moderna pernambucana":

"Outras mortes estão vinculadas à fragilidade da própria construção. O projeto habitacional Cajueiro Seco (1963), de iniciativa do governo estadual e coordenado por Acácio Gil Borsoi, foi desenvolvido para abrigar provisoriamente a população que havia ocupado terras do Parque Histórico Nacional dos Guararapes, em Jaboatão dos Guararapes. O sistema construtivo utilizado foi a tradicional taipa de pau-a-pique, alterada para promover uma produção em larga escala. A interrupção do programa e a falta de suporte técnico para manter sistema tão frágil fizeram desaparecer as unidades construídas." (AMORIM, 2007, p.36)

No livro recentemente publicado pelo escritório de Acácio Gil Borsoi acerca de sua obra, o Cajueiro Seco aparece com um destaque inédito, como marco na origem de uma série de trabalhos 
ligados a habitação e ao desenvolvimento de comunidades marginais propostos pelo arquiteto ao longo de sua carreira.

Partindo do seu suposto isolamento e da sua condição de excepcionalidade, este trabalho procura recuperar o que foi o Cajueiro Seco, objetivando o estudo histórico do projeto e construção do núcleo, buscando reestabeler os elos entre as soluções arquitetônicas adotadas, o contexto sócio-político e cultural do período e o debate contemporâneo acerca da habitação social no campo da arquitetura. É o próprio objeto que o pede à medida que a mobilização, no seu interior, de determinadas soluções construtivas e projetuais relacionam-se estreitamente com formas de compreensão da cultura regional e da questão social predominantes no Recife desde os anos 50\%. O Cajueiro Seco é aqui entendido como uma situação interessante para, ampliado o foco de análise, entender o contexto no qual aquela conjunção de fatores arquitetônicos e extra-arquitetônicos foi capaz de introduzir novas atitudes dos profissionais no sentido de uma maior aproximação com as necessidades, possibilidades e demandas populares.

${ }^{9}$ A abordagem regionalista do problema habitacional ocupa parte significativa do debate entre intelectuais e profissionais pernambucanos entre os anos 20 e 40, repercutindo diretamente sobre o campo arquitetônico entre os anos 50 e 60 (LIRA 1997/2002)

\section{Consideracões acerca do método e relacões entre histórias}

Para esclarecer as circunstâncias nas quais se desenvolveu a experiência do Cajueiro Seco, faz-se necessário um mergulho no passado recente de Pernambuco e do Brasil, em histórias ainda não consolidadas em versões definitivas e, necessariamente, divergentes entre si.

Procuramos focalizar um período restrito para apanhar a teia mais complexa e sincrônica de relações entre os campos disciplinares para além da arquitetura, sobretudo a partir da pesquisa das fontes primárias, do trabalho de leitura e catalogação do cotidiano expresso nos jornais locais da época, dos prontuários, inquéritos e relatórios feitos pelo DOPS no momento imediatamente subsequente ao Golpe de 64. Destacam-se també entrevistas concedidas pelos personagens desta história ou observadores do período que de alguma forma se relacionam com o contexto no qual se deu a experiência do Cajueiro Seco.

As entrevistas cumprem o papel de canal de acesso à história oral, viva, contraditória e necessariamente parcial; a história recente faz um diálogo com o jornalismo social, investigando os fatos, suas interpretações e memórias através de uma pluralidade de vozes. Observadores privilegiados do período contribuem com suas memórias através dos livros de um dos articuladores da "Frente do Recife" Paulo Cavalcanti, do sociólogo Francisco de Oliveira, que colaborou na 
Sudene nos seus anos iniciais e do jornalista carioca Antônio Callado, que na reportagem social "Tempo de Arraes" dá a sua visão do ocorrido. As próprias narrativas dos personagens fazem o contraponto com memórias que afloram nas entrevistas. Os jornais detalham dia-adia o desenvolvimento dos fatos, refletindo as tensões e controlando as atenções num momento em que a mídia diária impressa era um dos principais campos da disputa política em diálogo com as massas.

Ao analisar um período relativamente curto, como os quatorze meses do Governo Arraes, ao longo dos quase três anos do mestrado, afloram muitas questões que naquele momento estavam condensadas. A política e a cultura dos anos 60 , revolucionando-se mutuamente, não são passíveis de divisão em linhas de influência e desenvolvimento linear para análise. A leitura integrada, que busca a articulação de elementos aparentemente dispersos, no mesmo período se impõe. Procura-se tomar distância do objeto como prática para experimentar uma visão crítica sobre os fatos recentes da história da arquitetura e da política no Brasil.

Para entender o Cajueiro Seco, lançamos mão ainda da leitura do território sobre o qual se assentam todos estes fatos. A relação direta do pesquisador com este espaço também é um meio fundamental para entender a história de um lugar e seu desenvolvimento até os dias atuais, a partir da perspectiva local. Hoje o bairro abriga a última estação do metrô de superfície recifense ainda em fase de implantação, marcando mais uma margem da metrópole do Nordeste, um novo perímetro de irradiação ${ }^{10}$.

Uma referência metodológica importante para a pesquisa é o trabalho de Carlo Ginzburg "O queijo e os vermes", no qual associamse para a leitura das idéias, do mundo e da vida do moleiro Menocchio conceitos da micro-história ${ }^{11}$ aplicados ao entendimento da cultura popular no período. A partir dos inquéritos e depoimentos prestados por Menocchio à Inquisição, que pretendia condená-lo por sua visão peculiar da criação do mundo, Ginzburg consegue ver o choque entre a cultura oral e a escrita, popularizada pelo advento da imprensa. A partir de um objeto muito específico, questões gerais sobre a ética e o pensamento da época afloram, num constante movimento de transição entre a história pontual e específica e o contexto no qual ela se dá. Assim como no caso de Menocchio, a história do Cajueiro Seco é resgatada dos fragmentos de uma experiência obscurecida pela ditadura militar.

Se a opção por um evento muito específico, recortado micrologicamente no tempo e no espaço sugere uma pesquisa mais fina das relações e circunstâncias de produção nele envolvidas, esta investigação histórica demanda um foco no presente. A experiência do

\footnotetext{
${ }^{10}$ Ver BALTAR, Antônio Bezerra Diretrizes de um Plano regional para o Recife Recife: Escola de Belas Artes, 1951

${ }^{11}$ LEVI, Giovanni. Sobre a micro-história. in: BURKE, Peter . A escrita da história: novas perspectivas. São Paulo: Editora da UNESP, 1992. p. 133-161.
} 
Cajueiro Seco relaciona-se com uma longa trajetória de políticas habitacionais formuladas e praticadas em Pernambuco. De Vargas a Lula, da Liga Social Contra o Mocambo(LSCM) às Zonas Especiais de Interesse Social (ZEIS), esta história faz emergir um conjunto de conflitos e possibilidades no trato da questão habitacional, até hoje objeto de preocupações por parte de profissionais, estudiosos, políticos e cidadãos.

A partir de uma relativa distância, procura-se desenvolver um estudo crítico, livre de memórias afetivas, baseado na observação e na pesquisa que enfatiza a importância do trabalho de campo e do olhar atento e independente para um território que apresenta múltiplas questões e referências históricas no trato da habitação popular, no qual surgiram práticas e atuações que serviram como modelo de intervenção no âmbito nacional.

As leituras de documentos, depoimentos e espaços se combinam e frequentemente conflitam com o pouco que há de bibliografia específica sobre o Cajueiro Seco. Por um lado os artigos de periódicos publicados repetidamente dos anos 60 até os dias de hoje indicam a permanência do tema e a atualidade dos problemas para os quais apresentava-se o Cajueiro Seco como solução e por outro a monografia de Borsoi aponta para uma revalorização que ele tem feito da experiência. O novo enfoque dado ao projeto pelo próprio autor de certa maneira atesta ser o momento oportuno para discutir tais questões, já que a publicação também representa a cristalização de uma versão do fato arquitetônico a partir da visão e da trajetória pessoal do arquiteto que merece ser lida a partir da história e da crítica.

Assim, o Capítulo 1 apresenta um amplo panorama das discussões e experiências contemporâneas ao Cajueiro Seco procurando apresentar trajetórias profissionais e questões que vinham sendo debatidas pelos arquitetos até os anos 1960. O Capítulo 2 faz um esforço no sentido de olhar de um ponto de vista extra arquitetônico para emergência do popular na política e na cultura no Brasil e especificamente em Pernambuco. Já o Capítulo 3 apresenta as questões da habitação, do urbanismo e das invasões de terras que antecederam à experiência do Cajueiro Seco propriamente dita, abordada no Capítulo 4, do ponto de vista de sua inscrição na luta pela reforma urbana, das experiências de pré-fabricação em curso no estado, do significado na trajetória de um arquiteto moderno (Borsoi) da casa pré-fabricada em taipa proposta e do ponto de vista da ocupação efetiva daquele território.

O que buscamos com o trabalho, a partir destas referências metodológicas e da estrutura apresentada, é compor um quadro que esclareça o projeto, a construção e os desdobramentos da experiência do Cajueiro Seco no campo da cultura arquitetônica e das políticas habitacionais. Pretendemos oferecer ao interessado no assunto não uma versão definitiva dos acontecimentos e seus desdobramentos, mas insumos para a reflexão e o debate acerca de uma história da arquitetura brasileira que seja plural, crítica e complexa, afastada da 
autoreferência e dos tons laudatórios e simplistas que por vezes ecoam nas publicações do gênero. Relacionar a história da arquitetura com a história social e cultural de um período tão efervescente e fértil como os anos 60 é fundamental para alcançar tal objetivo. 


\section{1- ARQUITETURA, HABITAÇ̃̃o e PARTICIPACC̃̃o NOS ANOS 1960}

Os desenvolvimentos que se deram no campo de debate e atuação arquitetônicos ao longo do século $X X$ várias vezes se aproximaram de idéias, tanto no campo do urbanismo como na arquitetura em si, comunitárias e participativas, baseadas em um sujeito e uma sociedade moderna que, de alguma maneira, se transformavam à medida em que se urbanizavam. Para contemplar algumas célebres experiências e pontuar algumas que em particular as matrizes de pensamento que podem ter a ver com a experiência do Cajueiro Seco, nem tanto por influência mas por compôr um panorama de um saber acumulado e compartilhado pelos arquitetos e intelectuais brasileiros até os anos 60 e também apontar outros registros de experiências de ajuda mútua e urbanismo comunitário contemporâneas à experiência pernambucana, indicando suas datas, particulariedades ou diferenças.

Para isso, é importante ter em mente tanto propostas clássicas do urbanismo das Cidades jardins proposto por Ebenezer Howard na virada do século XIX pro XX e os desenvolvimentos e revisões de suas idéias postas em prática ao longo do século, chegando até os anos 60 com as New Towns inglesas e escandinavas, onde, em cada qual ao seu modo, estavam presentes as idéias de participação do usuário de um novo modelo de cidade na construção do seu lugar.

Nos EUA, a expressão deste debate em outras condições tanto territoriais quanto no estágio de desenvolvimento do capitalismo geraram a resistência aos grandes projetos infraestruturais e fortalecimento das comunidades através do movimento conhecido por Advocacy planning. A pesquisadora Mary Comerio analisa vinte anos desse tipo de ação como anti-arquitetura, expressão política de um engajamento contra o impacto sobre um patrimônio, ambiente ou comunidade sem correspondente propositiva ou espacial. Podemos considerar que parte significativa dos arquitetos americanos estava envolvida na pesquisa e prática da pré-fabricação da casa como produto que vai dar na casa móvel e trailer parks como espaço da pobreza, tal como analisada por Colin Davies em "The prefabricated Home". Havia ainda parte dos arquitetos que enveredavam a discussão pelos meandros dos materiais locais e das tecnologias alternativas, num discurso próximo do nascimento da idéia de ecologia e sustentabilidade.

Literalmente do outro lado, interpretando a Guerra Fria como contingente histórico, devemos contemplar também as experiências dos construtivistas russos e demais "pioneiros da arquitetura soviética". A atuação da comissão pública de projetos de habitação - o Stroikom, os projetos do seu diretor Moises Ginzburg e as propostas decididamente revolucionárias contidas em projetos como o Narkomfin, conjunto habitacional entendido como "condensador social" devem ser entendidas dentro do processo de coletivização que se processava na União Soviética pré-Stalin. O projeto de Ginzburg e Milinis para o Conjunto Narkomfin, construído pelo Comissariado do povo para as finanças, órgão da alta burocracia estatal portanto, foi detalhadamente 
analisado por Álvaro Puntoni ${ }^{12}$. As novas tipologias habitacionais mínimas são combinadas a espaços e equipamentos comunais, como ginásio, biblioteca, cozinhas e sala de jantar coletivas .

"Seu programa e organização espacial induziam a socialização das atividades até então consideradas individuais" (...) A arquitetura é o desenho da solução social e política, que devem ser necessariamente anteriores" (PUNTONI,2004,p.23).

Os conceitos, tipologias habitacionais e equipamentos projetados e normatizados pelo Stroikom e particularmente a idéia de "ruacorredor" estenderão sua permanência na arquitetura moderna ao longo do século $\mathrm{XX}$, transposta por Le Corbusier para a Unité de Marseille e transformada nas obras e projetos brutalistas ingleses elaborados pelos Smithson em Robin Hood Gardens e o escritório público do LCC em Golden Lane.

A idéia de revolução também permeia a base ideológica comum dos arquitetos envolvidos com os projetos habitacionais promovidos em Frankurt durante a gestão do arquiteto socialista Ernst May, que depois da ascenção das forças nazistas vai trabalhar em projetos na URSS, continuando as pesquisas acerca do espaço mínimo e de novas formas de morar para a sociedade industrializada que foram banidas da Alemanha por seu caráter social e comunitário. Hannes Meyer, outro arquiteto alemão envolvido na revolução da célula habitacional, reaparece no México depois da diáspora de europeus pelo mundo que

\footnotetext{
${ }^{12}$ Álvaro PUNTONI. O projeto como caminho - Estruturas de habitação na área central de São Paulo. A ocupação de vazios na Avenida Nove de Julho. São Paulo: FAU USP, Doutorado, 2004.
}

trouxe parte deles ao Brasil e posteriormente na África, dando sua resposta do que seria o engajamento real dos arquitetos nos problemas habitacionais mundiais.

Toda essa questão de certa forma flerta com algumas questões fundantes das principais linhas que dominaram a produção e o pensamento arquitetônico no século XX: "Arquitetura ou revolução?", prenunciava Le Corbusier em 1922 "Por uma arquitetura". A constatação corbusiana de que a revolução no mundo e nos seus meios de produção do espaço se dava naqueles anos e seu aviso para que os arquitetos mudassem seus métodos para participar dela foi tendenciosamente lida por anos. No intuito de colocá-lo de um dos lados do muro, permaneceu a idéia de que a arquitetura e a revolução seriam incompatíveis, o oposto do que dizia o arquiteto. No Brasil, a questão colocada por Artigas - "O que fazer?" dividiu vertentes de pesquisa, leitura e projeto dos espaços habitacionais, principalmente em São Paulo, opondo posições e práticas sob discursos próximos, dentro de um quadro de politização e engajamento. O golpe de 64 catalizou e acelerou o afastamento do povo pobre da arquitetura, produto caro contratado pelo estado, burguesia esclarecida e amigos ricos e bem intencionados.

No quadro, panorama de experiências que se segue, destacam-se as contemporâneas ao Cajueiro Seco que dialogam com as questões de participação e envolvimento dos arquitetos com os territórios populares que suscita, estabelecendo a priori uma distinção com relação à idéia de influência, excluindo-a do mecanismo que circula as idéias e fatos 
arquitetônicos contemporâneos; mais do que isso pretende-se identificar algumas permanências - tais como a produção pública, a utópica industrialização, as propostas de unidades de vizinhança e principalmente a participação. 


\subsection{A crise dos CIAM e o Team 10}

Frequentemente abstraiu-se o fato de que o Cajueiro Seco foi realizado em um momento de grandes questionamentos acerca dos paradigmas de projeto para a habitação social estabelecidos pelo Movimento Moderno. Nesse sentido, ele precisa ser lido tanto à luz dos debates sobre a questão do habitat no pósguerra movidos pelos arquitetos dissidentes dos $\mathrm{CIAMs}^{13}$ e ligados à recém-criada União Internacional dos Arquitetos (UIA), quanto em nível regional através dos congressos brasileiros e panamericanos de arquitetura e habitação.

Antes de avançarmos na conjuntura internacional contemporânea, será preciso retomar alguns conceitos e paradigmas constitutivos do debate habitacional no interior dos CIAMs.

Frampton estabelece uma divisão esquemática das três fases dos Congressos: a primeira fase, compreendendo os três primeiros CIAMs, conduzidos pelos arquitetos socialistas reunidos em torno da Neue Sachlichkeit (Nova objetividade), marcou a adoção dos critérios funcionais e pretensamente científicos de análise dos diversos projetos e situações urbanas apresentados. O $2^{\circ}$ Congresso, celebrado em 1929 em Frankfurt, discutiu a habitação

\footnotetext{
${ }^{13}$ Congressos Internacionais de Arquitetura Moderna
}

mínima, apresentou como exemplos paradigmáticos os diversos conjuntos que estavam sendo produzidos pela municipalidade local, cujo serviço de habitação era dirigido por Ernst May, também diretor desta edição do $\mathrm{CIAM}^{14}$. O terceiro Congresso estendeu até a escala da cidade a concepção e método de análise desenvolvidos, encerrando a primeira fase dos CIAMs. A célebre Carta de Atenas foi elaborada durante o IV CIAM, celebrado a bordo de um navio em cruzeiro no mar Mediterrâneo, sintetizando as funções básicas do viver na cidade (Trabalho, descanso, lazer e transporte) e marcando o predomínio do chamado "grupo latino", capitaneado por Le Corbusier, Josep Lluis Sert e o secretário geral Siegfried Giedion e a segunda fase dos congressos.

Na medida que a participação nos CIAMs aumentava, contando com o afluxo de arquitetos jovens e estudantes, os questionamentos sobre a validade dos paradigmas rígidos estabelecidos nas fases iniciais se generalizava, abrindo espaço para uma nova geração e uma nova fase dos congressos. No IX congresso, celebrado em Aix-en-Provence as críticas em torno da idéia de habitat foram colocadas e a discussão de uma "Carta do Habitat" ficou marcada para o próximo Congresso, que seria organizado pela nova geração que formulou a crítica ao

14 Ver Giorgio CIUCCI. "The invention of the modern movement". Oppositions reader 24, p.552. 
generalismo das propostas universalistas então na base do pensamento dos CIAMs.

Foi no próprio âmbito dos Congressos que se desenvolveu a crítica aos pressupostos funcionalistas do movimento moderno, sobretudo a confiança generalizada nas virtualidades democráticas e universalistas da produção em série e da organização total do espaço habitado. Reunidos no grupo que ficou conhecido como Team 10, a geração mais jovem formada por Peter e Alison Smithson, Aldo Van Eyck, Jacob Bakema, Georges Candillis e Shadrach Woods entre outros propunha uma nova forma de discussão, baseada em projetos e estudos pontuais, bem como nas diversas experiências e circunstâncias de intervenção dos membros do grupo. Foi desse embate de posições que resultou a extinção dos CIAMs como instituição em 1956.

"Para desencadear o impulso do desenho coletivo, a conexão no âmbito real parece ser crucial: para que os habitantes saibam, sem pensar conscientemente, onde oferecer suas habilidades... vestir-se, plantar um jardim, jogar, dirigir, inovar, conseguir seus propósitos e os do grupo. As possibilidades de todas estas conexões diretas e reais parecem ter sido esquecidas em todos os lugares a não ser nos mais estranhos, e segue sendo estranho que essa conexão real se aprofundo mediante a ressonância de uma arquitetura cuja base reside na cultura da máquina." (SMITHSON,1974,p.140)

Um dos pontos nevrálgicos das discussões foi justamente a cisão em torno do entendimento do conceito de habitat, tema proposto para o Congresso de Dubrovnik; se para Le Corbusier e seu grupo habitat eram "os espaços destinados à habitação (...) uma das funções especificadas na Carta de Atenas". A noção de habitat defendida pelos jovens sustentava-se em um conceito ampliado que considerava não apenas a moradia, a unidade residencial, mas os espaços de convívio e os espaços públicos, domínios que permitiam a existência de uma vida coletiva no âmbito da moradia. (BARONE, 2001, p.64-65).

"A casa ideal é a que alguém pode fazer sua sem alterar nada. Fazêla sua de maneira habitual, ou seja, dentro dos limites da moda do momento e sem sentir pressão alguma por comunicar a trivial singularidade de cada um ou por se acomodar de maneira absurda. (...) O que parecia que estamos buscando é o desenho mais amável que, enquanto segue proporcionando um esboço das medidas das estruturas e sucessos internos (cômodos, atividades, colocação as instalações, apoios), se mantém aberto a interpolação, e inclusive a sugira, sem que mude." (SMITHSON, 1971, p.126)

As imagens fotográficas de Nigel Henderson feitas no East End londrino e divulgadas na exposição "Paralell of life and art" durante o IX CIAM, foram incorporada pelo casal Smithson na grelha que elaboram para o X CIAM como uma resposta à separação de funções urbanas estabelecida em congressos anteriores e cristalizada na Carta de Atenas. Henderson, juntamente com casal Smithson e os artistas Richard Hamilton e Eduardo Paolozzi, fundou o Independent Group na Inglaterra, que congregou artistas com o intuito de debater e analisar a cultura contemporânea visual.

As imagens de Henderson feitas nas ruas de Bethnal Green, onde ele morava com sua mulher, a socióloga Janet Henderson, que ali desenvolvia uma pesquisa sobre a casa e família típicas da classe 
trabalhadora inglesa, permaneceram no imaginário de gerações de arquitetos como uma espécie de denúncia do abandono, pelos princípios estabelecidos nos primeiros CIAMs, da sociabilidade cotidiana e dos usos espaciais espontâneos.

O casal Smithson se notabilizou tanto pela contribuição teórica no debate em torno do habitat, introduzindo a questão da identidade e do pertencimento no projeto da habitação contemporânea, quanto pelos seus projetos habitacionais que radicalizavam algumas das propostas modernas como a "casa no ar" e a rua elevada como em Robin Hood Gardens e Golden Lane.

O "Novo Brutalismo" inglês, cuja obra inaugural da qual deriva o conceito segundo Banham seria a Escola de Hunstanton, projetada pelos Smithson e construída entre 1949 e 1954, associa a tradição miesiana com o compromisso social transposto para uma estética derivada da expressão da construção rigorosamente planejada. Em textos publicados em diversas revistas, os Smithson observam a realização de parte das utopias modernas de consumo do design materializada nas cadeiras projetadas por outro casal, Charles e Ray Eames, em um balanço crítico das realizações da primeira metade do século que está na base do pensamento arquitetônico inglês do após Segunda Guerra. (SMITHSON, 2001)

Dentre os diversos projetos produzidos pelos arquitetos do grupo, destaca-se aqui o conjunto da Cité Verticale em Casablanca, Marrocos, projetado em 1952 por Georges Candillis e Shadrach
Woods no interior do ATBAT- África, ateliê organizado por Le Corbusier para desenvolver o projeto da Unité de Marseille. O projeto viria a ocupar um papel de destaque na publicação organizada por Alison Smithson, "Team 10 Primer" (SMITHSON, 1968), ao olhar para os países subdesenvolvidos como campo fundamental da arquitetura contemporânea. A experiência no Marrocos surge como episódio isolado no contexto dos CIAMs, mas o respeito as tradições das comunidades nos projetos habitacionais viria a se converter num ponto fundamental de parte da arquitetura produzida a partir daí.

O projeto da cidade nova em torno de uma Universidade em Toulouse, na França, elaborado nos anos 60 e construído progressivamente até os anos 80 talvez seja o projeto mais ambicioso da dupla Candillis e Woods, refletindo no território europeu algumas questões em torno de variações tipológicas desenvolvidas no Marrocos de conceitos urbanísticos ligados à experiência das "New Towns" ${ }^{\prime 15}$ (Cidades novas) inglesas e escandinavas.

\footnotetext{
${ }^{15}$ As Cidades Novas propostas foram criadas num contexto de intervenções
} públicas para o controle urbanístico do crescimento desordenado de Londres (com agravamento da situação de habitação em cortiços), intervenções que ganharam novos empenhos nos debates sobre o modo de reconstrução de Londres atingida pelos bombardeios de 1940. Assumindo em 1945, logo o governo trabalhista designou uma comissão para o planejamento de 14 Cidades Novas que no ano seguinte já foram iniciadas, sendo 8 imediatamente na "área externa" de Londres. 
Tendo como marcos teóricos as idéias de Ebezener Howard e Patrick Geddes e como marco legal o decreto que assim caracterizou 28 cidades britânicas, as "New Towns" eram peças fundamentais do plano de reconstrução inglês, nas quais seriam alocadas as pessoas que haviam perdido seus lares e estavam relacionadas com o plano Abercrombie para Londres, fixando populações em cidades menores e aliviando a capital. As "New Towns" incorporavam espaços comunitários, parques e um desenho urbanístico que privilegiava o automóvel não usual nas antigas cidades Européias. Tais conceitos foram sendo aprimorados e adaptados em função da reação e dos usos dos seus habitantes, ao

Esse planejamento teria seguido em muitos aspectos as recomendações de Howard para as cidades-jardim, no entanto, as Cidades Novas "deveriam ser construídas, via de regra, por corporações estatais, uma para cada cidade, e diretamente financiadas pelo Ministério da Fazenda" (HALL, 2002, p.153) assim considera que "a cidadejardim via-se agora nacionalizada e burocratizada" (HALL, 2002, p.134), segundo Hall, desvirtuando o plano inicial ainda que teriam constituído de fato um dos melhores lugares para se trabalhar e viver. O plano de Howard, ao contrário do que grande parte da crítica apontaria, formulava uma cidade de grande densidade, construída pela comunidade e autogovernada (HALL, 2002, p.103). Hall aponta ainda que Howard (...) não via suas cidades-jardim como colônias para os pobres indignos. Pelo contrário: elas deveriam ser fundadas e administradas pelo stratum imediatamente superior - a Classe C de Charles Booth - que assim se haveria de libertar da servidão do cortiço urbano. Sua solução não era paternalista - fora, talvez, algumas poucas nuanças residuais; ao contrário, estava firmemente assentada na tradição anarquista" (HALL, 2002, p.107). A idéia de Howard seria de cada cidade ser construída até atingir seu limite planejado, quando se começaria outra a pouca distância, formando com o tempo um conglomerado em que essas cidades estariam ligadas por um rápido sistema de transporte, servindo assim à residência, ao emprego e serviços, equivalentes às oportunidades econômicas e sociais da grande cidade (HALL, 2002, p.109). longo de três gerações de "New Towns": a primeira na urgência do pós guerra, a segunda já no começo dos anos 60 e a terceira entre o fim dos anos 60 e os anos 70, da qual a mais célebre New Town, Milton Keynes é legítima representante.

Para além do ambiente dos CIAMs, outras transformações que tocavam na questão do habitat e do planejamento e desenvolvimento de um território estavam ocorrendo e constituindo também referências para o debate arquitetônico, como o trabalho de Hassan Fathy junto as comunidades removidas para New Gurma, no Egito (1947) e a adesão de arquitetos como James Stirling ao vernacular experimentado por Le Corbusier nas Maison Jaoul. A realização das Unités d'Habitation pelo arquiteto franco-suíço em Marselha e Berlim também foi um importante marco, estabelecendo uma nova tipologia e escala de edifício habitacional urbano que serviu de referência para a arquitetura realizada em diversas partes do mundo na segunda metade do século XX. Em termos téoricos, a formulação da idéia de regionalismo crítico por Kenneth Frampton já em 1980 se tornaria uma importante referência para o entendimento do que estava sendo feito naqueles anos e como orientação para uma atitude do arquiteto ligado a um território específico.

Tais realizações interessam diretamente a esta pesquisa por terem sido visitadas por Acácio Gil Borsoi em viagem à Europa 
em 1960. Comissionado pelo Itamaraty para conhecer o que estava sendo feito em termos de arquitetura e design no velho continente, a viagem visava também a atualização de conteúdos e referências junto ao curso da arquitetura da então Universidade do Recife (atual UFPE), que naquele momento passava por uma reestruturação curricular coordenada por Borsoi, Delfim Amorim e o então aluno Geraldo Gomes.

De acordo com Guilah Naslavsky "Essa viagem inicia um momento de inflexão, uma nova fase na obra do arquiteto que se estende até fins dos anos 70." (NASLAVSKY, 2004, p.193) Afastando-se da idéia de influência direta das realizações européias sobre o arquiteto brasileiro para explicar realizações posteriores como o Cajueiro Seco, não podemos de reconhecer o repertório e imaginário arquitetônico do profissional, que atuava num meio já muito bem informado, como atestam as referências do professor Antônio Bezerra Baltar ao urbanismo inglês do pós guerra já em $1951^{16}$.

Nessa viagem, Borsoi visitou os bairros populares escandinavos e as obras dos arquitetos conhecidos como neoempiristas - Arne Jacobsen, Alvar Aalto e Erik Gunnar Asplund assim como as escolas de Ulm e Darmstadt na Alemanha. Na Itália, iria a Milão, interessado nas questões de design mas visitou ali

${ }^{16}$ Ver item 3.2. também alguns conjuntos habitacionais da reconstrução italiana, além da Torre Velasca, obra mais importante e paradigmática do escritório BBPR.

Borsoi foi recebido nesse escritório pelo arquiteto Peressutti, um dos sócios, e entrou também em contato com os editores da revista Zodiac, importante meio de veiculação das idéias de arquitetos e teóricos italianos como Aldo Rossi e Ernesto Rogers, este último também sócio do BBPR. Na Inglaterra, conheceu as obras e o escritório de projetos habitacionais do London City Council, além de algumas das "New Towns" em construção, como Crawley, Stevenage e Milton Keynes, além de Welwyn, uma das cidades jardins construídas por Louis de Soissons a partir da influência de Howard. Visitou ainda o conjunto habitacional Ham Common, de James Stirling, obra fortemente influenciada pela chamada "fase brutalista" de Le Corbusier, também vista por Borsoi na França através de seus exemplos mais paradigmáticos: a capela de Ronchamp e a Unité $d^{\prime}$ habitation de Marselha. O próprio arquiteto, em entrevista, narra animadamente suas trajetórias pelo exterior e as experiências que visitou:

"Eu fui ver desenho industrial, era professor da escola e soube que o Itamaraty ia dar essa bolsa de um ano, parece que era 500 dólares por mês, passagem... E eu tava passando de carro na cidade quando eu li aquele negócio, Vou entrar nisso. Porque eu queria ir pro MIT, em Chicado, meu interesse era lá, porque o Bauhaus quando saiu da Alemanha foi pra Massachussets, tinha o Moholy-Nagy, tinha o Breuer, aquele pessoal todo então eu queria entrar lá. Quando eu cheguei no Itamaraty, o diretor lá, me 
deram a bolsa, foi até uma surpresa, tinha até uma passagem porque o Artigas ia pra China e eu também tava envolvido, conhecia o Prestes, o pessoal todo, tinha um congresso no Rio...

Eu ia lá nessa viagem, tinha lugar marcado mas surgiu esse negócio. Aí ele disse: "Você não vai pra lá, de jeito nenhum, vou te dar uma carta, vai pra Europa e vai visitar os países, os ministros culturais, todas as embaixadas como se fosse um ministro", me deu passaporte azul... E tudo que eu desejasse ver a própria embaixada fazia o contato, o encarregado cultural, marcava as entrevistas aí eu ia lá e quando eu chegasse naquele país... Eu tava fazendo aquele edifício dos padres, da Rua Dantas Barreto [Edifício Santo Antônio] e eu que construí aquilo ali, não teve engenheiro não, você viu aquelas paredes todas, foi tudo modulado, o cobogó, modulado, desenhado, tudo certinho, o pormenor... E eu tava trabalhando naquele projeto com o Frei Serafim, que era um provincial, uma pessoa importante na Alemanha e ele disse: "Vou te dar uma bolsa alemã e você vai ficar hospedado na escola que tem em Baden, na Westfallen, no norte, fronteira com a Holanda e você fica lá como ponto de apoio".

Eu fui pra lá, fiquei num quarto na torre da Igreja, corri toda a Alemanha, comprei um carro, os padres trouxeram o carro pra mim. Tava cheio do dinheiro e o padre me levou pra toda a Alemanha Ocidental. Desde a Baviera, norte ao sul... Depois eu fui à Berlim mas o padre não foi, fui sozinho, eu e minha mulher, depois eu comprei o carro e saí pela Europa. Dinamarca, Holanda, Bélgica, Suécia, voltei, fui pra Inglaterra, fiquei na Casa do Brasil na Inglaterra e na Suécia conheci um cara que tinha uma firma inglesa, tava num grupo de ingleses visitando a escola de desenho em Estocolmo muito boa e eu tava eu e minha mulher sozinho pra visitar a escola e o cara nos chamou pra incorporar o grupo.

Fiquei muito amigo do cara e ele disse pra lhe procurar quando fosse à Inglaterra. Ele era diretor, me mostrou o prédio e eu vi a tecnologia de construção deles, muito interessante naquela época e passei um mês correndo todas aquelas cidades satélites de Londres, todas elas eram montadas dentro do que eu pensei depois vim a adaptar ao Brasil, que era você apoiar na renda, aquela Welvin que era uma cidade do Ebezener Howard, foi transformada, tenho até hoje o projeto dela aí na biblioteca, foi toda remodelada, reestruturada de forma a criar um distrito industrial, uma área industrial, superior à uma área de habitação da cidade, urbana. Pra você ver o interesse deles." 17

${ }^{17}$ Entrevista de Acácio Gil Borsoi ao autor, em setembro de 2007. 


\subsection{Habitacão e Pré-fabricacão nos Congressos da UIA e no IAB}

Os CIAMs iniciaram sua trajetória de debates focados no tema da habitação mínima e encerraram um ciclo com o Team 10 propondo novas abordagens e enfoques do conceito de habitat. Já a União Internacional de Arquitetos (UIA) marca sua atividade como uma coalisão mundial amparada nas Nações Unidas em torno de uma agenda pacifista no pós-guerra, anti-liberal e anti-totalitária; fértil campo de disputas para a polarização política em plena guerra fria. As múltiplas questões debatidas nos CIAMs serviriam como base teórica comum para os arquitetos reunidos em torno da UIA, partindo de uma visão extremamente positiva e por vezes ingênua dos progressos da ciência aplicada à arquitetura que estão na base das propostas das primeiras gerações até as constatações e complexidades ligadas ao após Segunda Guerra.

Estes questionamentos estavam na base da discussão dos Congressos da UIA e de grande parte da arquitetura que iria ser realizada no mundo. A UIA ampliou a escala do debate para o global, incorporando em sua estrutura tensões típicas do momento político de polarização entre os blocos socialista e capitalista, incluindo em sua agenda tanto os problemas do subdesenvolvimento e da desigualdade social, como a questão ecológica de conservação dos recursos naturais.
De acordo com o arquiteto Miguel Pereira ${ }^{18}$, vice presidente da UIA no período 1996-99, ao contrário dos CIAMs, a UIA não pretendia focalizar temas ou posturas específicas dos arquitetos e tinha como preocupação principal a representação política e global da categoria, marcando posição com relação a governos e entidades locais e internacionais, dentro de um espírito típico do segundo pós guerra análogo ao da ONU e da Unesco, supra-partidário e em defesa da paz, tentando manter-se neutro com relação à polarização entre o "mundo livre" e o bloco socialista da Guerra Fria.

No entanto, Miguel Pereira vê um vínculo entre a composição da UIA, principalmente em seus anos mais férteis, e a tradição dos CIAMs, insinuando uma genealogia comum e a sucessão legítima entre ambos na congregação internacional dos arquitetos. Um desses vínculos encontra-se provavelmente na preocupação com o sentido social da arquitetura, que ainda que de modo bastante diferenciado atravessou o ideário profissional e intelectual dos arquitetos ao longo do século XX.

Já Peter Smithson, protagonista do Team 10 e da crise dos CIAMs, via a questão como uma decorrência da cisão entre desenho e função social da arquitetura que ficara evidente imediatamente após a Segunda Guerra, enxergando a UIA como uma ampliação da faceta progressista e conciliatória dos pioneiros empenhados em "difundir a arquitetura internacional".

"Mas, no começo dos anos 50, a exposição Britain can Fake it demonstrou, com demasiada clareza à aqueles jovens de então, que as

${ }^{18}$ Miguel Pereira, Entrevista ao autor, São Paulo, abril de 2007. 
boas intenções não eram suficientes. Voltava a necessidade de desenhar e de um compromisso concomitante do significado do desenho. Basicamente, isto era o que separava a maioria do Team 10 da maioria do CIAM, já que muitos dos membros do CIAM também eram da UIA aparentemente só porque as duas organizações eram internacionais e a reforma é sempre o motor, e o escudo, dos intermediários" (SMITHSON, 1974, p.137)

A questão da habitação entrou nos debates travados dentro da UIA não pela sua leitura como programa primordial da arquitetura, mas pela chave do subdesenvolvimento de grupos de nações e das questões macroeconômicas e do planejamento territorial, tentando reconhecer as práticas regionais que poderiam ser transplantadas muito mais do que desenvolver ali os conceitos universais do habitat humano como nos CIAMs. O Congresso de Havana, em 1963, marcou um momento no qual afloraram as discussões das políticas e das práticas que estavam na base de uma arquitetura engajada no desenvolvimento territorial que ocupava um espaço internacional de debates, conglomerando expressiva participação dos arquitetos do mundo. Depois dos anos 60, a representatividade da UIA foi irregular, assim como a participação em seus Congressos como instâncias máximas de reunião dos diversos Institutos de Arquitetos dos países.

Também no Brasil, a temática habitacional suscitou a mobilização dos profissionais envolvidos com a questão. No primeiro Congresso de Habitação, promovido em 1931 pelo Instituto de Engenharia em São Paulo, consolidou-se no país uma tendência já observada mundo afora desde a virada do século XIX ao XX de congregar técnicos e profissionais em torno do problema da habitação, de modo a difundir soluções, propostas e estudos diversos considerados relevantes.

Desde os congressos pan-americanos de arquitetura na década anterior, os arquitetos brasileiros se engajaram nessas discussõese a partir do final da década de 1930 a passaram a se reunir com os colegas do continente na organização de um I Congresso Panamericano de Vivienda Popular, realizado em Buenos Aires. A Jornada de Habitação Econômica, realizada pelo IDORT (Instituto de Organização Racional do Trabalho) em 1941, contava com a participação de engenheiros, arquitetos e sociólogos ligados à vertente americana que fundou a Escola Livre de Sociologia e Política, além do geógrafo francês Pierre Monbeig e o industrial Roberto Simonsen. Nesses eventos, a questão habitacional ficou marcada por uma abordagem multidisciplinar que interessava a praticamente todas as classes, saindo vitoriosa a tese de que a casa própria e unifamiliar seria a mais adequada para a população brasileira. Neles, a matriz higienista somava-se aos progressos da engenharia civil, à normatização, estandardização e padronização das construções, bem como ao aprimoramente das técnicas de gestão das camadas populares, propondo como casa ideal a própria e isolada no lote, ao contrário da posição dos arquitetos posteriormente reunidos em torno do IAB.

"Além de criar a ilusão do progresso econômico, contribuindo para a estabilidade da ordem macropolítica, a habitação passou a se considerada fundamento da constituição moral da sociedade e do bom trabalhador, avesso a desejos e práticas desviantes. Portanto, se a casa própria e a difusão da propriedade burguesa e sua dócil aceitação pelo operariado só seria possível através da moradia individual e da eliminação 
dos cortiços. Nesse sentido, o papel da família, com sua função de reproduzir a ordem e moral estabelecida, era essencial." (BONDUKI, 1998, p.84)

Para os arquitetos reunidos em 1945 no I Congresso Brasileiro de Arquitetos, todavia, as casas construídas pelo Estado deveriam ser alugadas e não vendidas. A posição coadunava-se com as idéias do Partido Comunista do Brasil que havia sido recentemente legalizado e tinha certa influência no IAB. Mas, segundo o arquiteto Henrique Mindlin, autor de tese específica aprovada no evento, a propriedade pública dos imóveis era uma forma de assegurar a conservação dos edifícios.

"Outra conclusão (do I Congresso) é a que aconselha a construção de habitações de aluguel e não para venda pois a casa passou a ser considerada como um 'serviço de utilidade pública' (água, esgotos, luz, transportes, etc...) Ora, o Estado, que não pode facilitar a cada cidadão os meios de aquisição de sua casa, poderá, contudo, assegurar a cada família o direito ao uso de habitação decente, mediante aluguel cômodo e compatível com o padrão comum da vida organizada" (ENGENHARIA, NOV. 1945 APUD BONDUKI, 1998, p.82)

A tese dos gaúchos Demétrio Ribeiro, Nelson Souza e Enilda Ribeiro apresentada ao IV Congresso Brasileiro de Arquitetos, em 1954, trazia uma visão atenta para os abismos sobre os quais a arquitetura ainda tentava se equilibrar.

"A única solução para os problemas da nossa arquitetura estará na sua verdadeira democratização.(...) 1) A arquitetura brasileira está ameaçada de degenerescência devido ao seu isolamento do povo 2) a única possibilidade de desenvolvimento da arquitetura brasileira reside em sua democratização, na base da satisfação das necessidades materiais e espirituais do povo. 3) Os conhecimentos teóricos dos arquitetos sobre os problemas sociais, históricos e estéticos desempenham um papel decisivo na evolução da arquitetura." (XAVIER, 2003, p.204-206)
Embora a tese se refira apenas marginalmente à questão da habitação, o texto dá o tom da visão crítica com a qual os arquitetos começaram a enxergar o campo da sua profissão inserido no contexto brasileiro, eternamente "em vias de desenvolvimento":

"As soluções técnicas e economicamente mais aconselháveis para enfrentar o problema da habitação popular não são postas em prática, não havendo por isso condições objetivas para o desenvolvimento das experiências relativas a essa questão" (Xavier, 2003, p.204-206)

A I Jornada de Nacional de Habitação foi promovida pelo IAB, em junho de 1962 e serviu como começo da organização do debate dos arquitetos que culminaria no Seminário de Habitação e Reforma urbana (SHRu), em 1963. Na Jornada, os arquitetos participantes sugeriram alterações das leis que estavam sendo formuladas em torno das questões habitacionais e urbanas, como a que recomendava a criação do Ministério da Habitação. Os anos 60 representaram um momento ímpar na autocrítica da produção arquitetônica nacional e no envolvimento do IAB no debate das políticas públicas e da questão habitacional.

"A Política Habitacional, que o IAB, por uma década inteira, acompanhou, sempre numa atitude de crítica, foi inventada em função de uma necessidade de ocupação de mão-de-obra. Não se tratava de resolver o problema de habitação. Nós até sabemos disto. Isto foi afirmado durante 10 anos." (PEREIRA, 1984, P. 41)

Desde o primeiro inquérito de arquitetos, realizado em 1961, assim como na série "Arquitetura brasileira após-Brasília Depoimentos" $^{\prime \prime}$ a questão da habitação social estava presente nas questões feitas pelo IAB aos expoentes da arquitetura brasileira. Tanto 
Borsoi como Flávio Marinho Rêgo dão suas contribuições em mais de uma das publicações, nos permitindo inclusive acompanhar o desenvolvimento de alguns debates a partir de referências e argumentos presentes nas edições anteriores que vão se tornando os discursos comuns entre grupos de arquitetos.

Borsoi, em 1961, declarou que o caminho para a solução do problema da habitação no Brasil "implicaria em uma reforma do sistema político-social brasileiro" (ARQUITETURA IAB/GB Nº1, 1961). Depois de quase vinte anos, da experiência de Cajueiro Seco e de alguns conjuntos para o $\mathrm{BNH}$, já veria a mesma questão de um prisma mais reformista, dentro das condições possíveis:

"Nós, arquitetos, devemos ter consciência de que vivemos dento de uma estutura capitalista, e que se quisermos fazer alguma coisa neste campo será tentando compatibilizar o social e o econômico com o arquitetônico" (BORSOI, 1982)

Flávio Marinho Rêgo, respondendo à mesma questão no Inquérito de 1961, articulou uma resposta mais complexa, que soa familiar se considerarmos as experiências e o discurso que se desenvolveram a partir daí:

"Sente-se no entanto que dentro do nosso esquema social uma série de medidas poderiam (sic) ser tomadas para tentar, se não resolver de uma maneira clara e permanente o problema, pelo menos encaminhá-lo: a industrialização da construção procurando desenvolver métodos de préfabricação que fossem capazes de baratear os preços; uma legislação rigorosa com vistas a coibir a especulação imobiliária; o estudo das migrações procurando fixar o homem ao campo diminuindo o superpovoamento das cidades; a obtenção ou aproveitamento de áreas existentes próximas aos locais de trabalho; a criação de créditos populares a longo prazo e com juros baixos; a fixação dos aglomerados improvisados existentes. Pela melhoria das construções, com o fornecimento de materiais de construção básicos, auxílio técnico e utilização voluntária de mão de obra residente, procurando estimular o auxílio mútuo. A idéia é transformar aqueles aglomerados (favelas etc...) em bairros, aparelhando-os da melhor maneira possível e procurando utilizar sua implantação natural e desenvolvimento espontâneo. Os casos deveriam ser estudados de per si, cada qual exigindo um trabalho próprio. A recuperação não deveria ser feita através de um planejamento idealizado e imposto e sim por um planejamento orgânico a longo prazo, que se amoldasse às contradições e particularidades existentes em cada caso.

Um planejamento desse tipo permitira preservar as tradições culturais daquelas sociedades em formação (música popular, costumes religiosos particulares, artesanatos, etc.) e recuperar o pequeno número de marginais existentes pela ontegração em seu habitat natural, harmonizado socialmente sem a destruição de sua tradição cultural e introdução de costumes impostos e racionalizados." (ARQUITETURA IAB/GB N³, 1961)

É a partir dessa base comum de discussões e posições que o IAB se preparou para o Seminário de Habitação e Reforma Urbana (SHRu). Para entender a motivação e conteúdos do SHRu é importante acompanhar os artigos publicados durante o ano de 1963 na revista "Arquitetura", editada pelo departamento da Guanabara do Instituto.

Em editoriais sucessivos, escritos embora não assinados por Maurício Nogueira Batista, e na série de artigos intitulada "O problema da habitação e os arquitetos" o empenho do IAB em "criar uma consciência nacional do problema habitacional" se soma à discussão de aspectos específicos do problema habitacional brasileiro bem como da função social da arquitetura. Na revista, pesquisadores, sociólogos e arquitetos de várias regiões do país escreveram a esse respeito: foi o caso dos artigos de Antônio Carolino Gonçalves ("As migrações para o Recife - Aspectos do crescimento urbano"), José Arthur Rios ("Favelas"), Maurício Roberto ("As favelas do Rio, encaminhamento 
para sua solução"), José Claudio Gomes ("Para uma nova política da habitação popular"), Maurício Nogueira Batista ("A lei do inquilinato e a habitação"), Eduardo Kneese de Mello ("Habitação na URSS"), além da tradução de artigos estrangeiros como os de Claude Bourdet ("A Batalha da habitação"), sobre a situação habitacional e as propostas francesas) e do CINVA, órgão dedicado à habitação na América Latina ligado à OEA sediado no Peru ("Habitação e Saúde").

O editorial da edição de abril de 1963 reproduziu trechos da "Mensagem Presidencial ao Congresso Nacional" nos quais o governo João Goulart abordou diretamente a questão habitacional e as dimensões do problema, anunciando a edição de uma outra Mensagem ao Congresso como o "primeiro passo para a formulação de uma política habitacional capaz de disciplinar o vertiginoso e desordenado crescimento urbano". Nela o presidente escreveu:

"A questão habitacional no Brasil é infelizmente, ainda mais ampla. O operariado classificado das cidades e amplos setores da chamada classe média sofre também com a ausência de condições adequadas à habitação do homem civilizado. As formas do mal morar configuram-se na submoradia suburbana, pobre, feia e triste, que obriga seus moradores a perder, diariamente, quatro ou cinco horas, ao se deslocarem para os locais de trabalho e deles regressarem; na infra-habitação das cabeças-de-porco e das chamadas "hospedarias"; na habitação desconfortável e superlotada dos quarto-e-sala conjugados, que se estão constituindo em verdadeiras favelas de concreto armado"19.

Com base nas diretrizes gerais fixadas na mensagem, O IAB assegurou "ao Presidente da República a irrestrita e integral colaboração dos arquitetos na implantação e execução de uma política nacional de

\footnotetext{
19 "Mensagem Presidencial". Arquitetura IAB/GB No 10, 04/1963.
}

habitação". A disposição do Governo Jango em lidar com essas questões podia ser atestada pela criação do Conselho Federal de Habitação, criado naqueles meses através do Decreto 1.281.

No editorial da edição de maio de 1963, o foco foi a reforma urbana, que, segundo a publicação, "passou a ter repercussão quase idêntica à da Reforma Agrária" embora constituísse um grupo de palavras pouco preciso, que servia como slogan publicitário e demagógico enquanto não se precisasse o significado do termo e a concretização de suas ações.

"A Reforma Urbana tem sua raiz na terra. A terra da cidade deve ser usada em benefício da coletividade e não para proveito de alguns de seus membros. (...) A Reforma Urbana deve ser feita na origem. Na terra onde vamos construir a cidade. Para tanto, é necessário disciplinar o seu uso e a sua posse. A propriedade da unidade residencial, em si, é o que menos importa, dentro de uma estrutura urbana sadia. Tê-la como propriedade privada ou tê-la como usufruto permanente, que diferença representa para aquele que, na casa, busca apenas construir um lar, ou a sua morada? Esta diferença pode significar muito, para aquele que visa na necessidade humana de morar, a oportunidade de especular" (ARQUITETURA IAB/GB $\left.\mathrm{N}^{\circ} 13,1963\right)$

Foi na mesma edição de Julho de 1963 que se publicou o artigo "Política Social do Mocambo", de autoria de Gildo Guerra e creditado ao Serviço Social contra o Mocambo (SSCM), que versava sobre as causas e origens desse tipo de habitação no Recife bem como sobre a determinação do governo Miguel Arraes, desde seu discurso de posse, em enfrentar o problema. Segundo Guerra, era possível constatar a ineficiência da política anti-mocambos até então praticada, criticandoIhe a falta de foco nas classes menos necessitadas ao eleger os trabalhadores organizados como principais beneficiários, e elogiando 
as invasões de terrenos como "manifestações positivas do instinto de autoconservação e do direito de abrigar suas famílias".

O mocambo, visto como mal social pelo Serviço Social Contra o Mocambo passou a ser compreendido como efeito do "desajuste e do desemprego", a política do Serviço "Contra o Mocambo" converteu-se então em uma Política Social do Mocambo, cujos pontos eram:

“a) Organizar comunidades, disciplinando e orientando tecnicamente as construções, com o aproveitamento dos próprios recursos dos grupos sociais; b) Coordenar as obras de responsabilidade do poder público, ligadas à ação do SSCM; c) Transformar em renda toda mão de obra ociosa, com aproveitamento em oficinas de artesanato e pequenas indústrias locais. (...)

Tudo isso visa à recuperação do homem pelo seu próprio esforço, aumentando a confiança em si mesmo e o proporcionando através da melhoria do seu nível social, político e econômico, que venha a se integrar definitivamente na sociedade" ${ }^{\prime 20}$.

O Cajueiro Seco não é explicitamente referido no texto posteriormente creditado à Gildo Guerra, mas na imagem que ilustra o artigo, uma visão aérea da área é identificada com a legenda: " $1^{\mathrm{a}}$ experiência piloto: Cajueiro Seco".

Já no artigo publicado em outubro de 1963, o foco é a "experiência em construção" do Cajueiro Seco, desenvolvida por Gildo Guerre e Acácio Borsoi e introduzida por Flávio Marinho Rêgo:

"uma iniciativa corajosa e realista para encaminhar o angustiante problema humano e social de uma enorme e desesperada massa humana

\footnotetext{
20 "Política social do Mocambo". Arquitetura IAB/GB №13, 07/1963.
}

marginalizada." ${ }^{21}$.

O projeto apresentado do desenvolvimento da comunidade periférica a partir da sua inserção no limite da Região Metropolitana do Recife e do desenho urbanístico, a partir da idéia de um "sistema rígido de superquadras e quadras".Apresentam-se também os projetos dos equipamentos comunitários: a unidade sanitária composta de tanques, banheiros e chafariz projetada por Borsoi em alvenaria de tijolos e o conjunto de Comércio e Oficinas e Escola Primária, num sistema de pré-fabricado composto por cobertura em treliça metálica apoiada em postes nos quais foram montados painéis de divisórias. O projeto de casa de taipa com estrutura pré-fabricada, no entanto é mencionado no texto que trata da assistência técnica aos moradores, entre outros planos das casas a serem construídas ${ }^{22}$. ${ }^{21}$ "Cajueiro Seco, uma experiência em construção".
out/1963.
${ }^{22}$ "Cajueiro Seco, uma experiência em construção". Arquitetura IAB/GB N¹6 out/1963. 


\subsection{O Seminário de Habitação e Reforma Urbana}

Consta que a idéia de organizar um seminário para discutir as questões relacionadas à habitação popular partiu simultaneamente dos departamentos de São Paulo e Rio de Janeiro do Instituto de Arquitetos do Brasil durante reunião do Conselho Superior da entidade em Porto Alegre. Por sugestão dos paulistas, fundamentada na Mensagem Presidencial ao Congresso Nacional e com o apoio do Ministro Almino Afonso, o Seminário contemplaria também a questão da Reforma Urbana, visando obter "uma definição clara da reforma urbana brasileira", além de indicar "as bases de uma política nacional de habitação e planejamento urbano", objetivo do seminário que o IAB da Guanabara já estava organizando com o apoio dos Institutos de Previdência (IPASE). Por sugestão do Conselho Superior, decidiu-se juntar os dois eventos num Seminário Nacional no mês de julho de 1963 com uma etapa em cada cidade $^{23}$.

As sessões realizadas no Hotel Quitandinha, em Petrópolis, RJ e na sede do IAB de São Paulo mobilizaram cerca de duzentos profissionais, entre arquitetos, sociólogos, economistas, assistentes sociais, deputados, juristas e engenheiros. A revista Arquitetura é a principal fonte de informações sobre o evento, já que partir da

${ }^{23}$ Arquitetura IAB/GB Nº12, 1963 edição de agosto de 1963 passou a publicar relatos e o texto integral das resoluções do SHRu. Tendo como balizas os problemas brasileiros de habitação e aproveitamento territorial, os profissionais do conclave constataram que

"estes problemas básicos do desenvolvimento brasileiro vinham sendo escamoteados por uma cortina de fumaça demagógica" que apresentavam a questão da moradia "como sendo de ordem meramente assistencial e quantitativa"

Tal procedimento acabava por atribuir ao Governo a responsabilidade exclusiva do problema ao mesmo tempo que escondia a sua verdadeira problemática.

"Cidades não dotadas de infraestrutura capaz de absorver senão pequenas parcelas da imensa mão-de-obra ociosa - aumentada pelas contínuas correntes de párias criados por uma estrutura agrária arcaica passaram a 'inchar' desmesuradamente ${ }^{24}$

Note-se que tanto o argumento quanto a referência à estrutura agrária arcaica e à idéia de inchaço das cidades constituía um discurso recorrente na apresentação da problemática urbana e social no período, aparecendo também na problematização da questão do mocambo feita por Josué de Castro em Homens e Caranguejos, referindo-se à Brasília Teimosa e a Agamenon Magalhães:

"A metrópole pernambucana ia virando uma mocambópolis. E foi por isso, na defesa de sua estética ameaçada, que o governador do estado deu início a uma grande campanha contra os mocambos. Contra esta lepra urbana que ameaçava recobrir toda a beleza senhorial da capital do Nordeste, toda a casta e fina nobreza dos seus antigos solares, com estes sórdidos borrões de miséria. Mas nesta campanha contra os mocambos, o

${ }^{24}$ Arquitetura IAB/GB No12, 1963 
governador não procurou analisar onde se assentavam as verdadeiras raízes do mal. Pensava que estas raízes estavam fincadas ali mesmo na lama dos mangues e que bastaria arrebentar estas raízes para que viesse a desaparecer a vegetação braba dos mocambos. Nem ele nem seus auxiliares se davam conta de que aquela vegetação dos mocambos, que brotava como uma flor de lodo na vasa dos mangues, tinha raízes que se alongavam pelo solo do país e pelo subsolo de suas estruturas sociais arcaicas. Produto do feudalismo agrário que oprimia e explorava há séculos toda aquela pobre gente que acabava, um dia, preferindo o fedor dos mangues ao fedor das malocas dos engenhos, das novas senzalas fracionadas em torno das novas casas-grandes." (CASTRO, 1966, p.107)

Os debates e conclusões do Seminário avançaram no sentido de uma visão mais complexa da questão habitacional, inclusive ao se referirem à indústria da construção, entendendo-a como parte do problema e diagnosticando que a oposição feita pelos representantes do setor à idéia de reforma urbana e ao atendimento das demandas habitacionais das camadas mais baixas da população indicava a origem especulativa dos lucros imobiliários. ${ }^{25}$

A primeira semana de debates foi organizada em torno de quatro grupos de trabalho, tendo como títulos respectivamente: I-A situação Habitacional no país, II- A habitação e o aglomerado urbano, III- Reforma Urbana - Medidas para o estabelecimento de uma política de planejamento urbano e de habitação e IV- A execução dos programas de planejamento urbano e de habitação. Em São Paulo, os trabalhos elaborados pela Comissão Relatora foram submetidos à plenária, emendados e aprovados em sua

\footnotetext{
${ }^{25}$ SHRU, "Resoluções". Arquitetura IAB/GB No14, ago1963.
}

essência, gerando o documento " Resoluções ", que na edição publicada na revista Arquitetura foi introduzido pela Mensagem do Ministro do Trabalho e Previdência Social, Amaury Silva, na qual se lê:

"Tenho a convicção de que a mesma imposição de consciência que nos leva a defender a reforma agrária deve levar-nos a defender a reforma urbana - não para um futuro longínquo e indefinido, mas para esta geração, para este período de renovação das estruturas da sociedade brasileira (...) É preciso agora defini-la e acompanhar essa definição de um trabalho de esclarecimento que evite, a seu respeito, os mesmos equívocos e as mesmas perversas inverdades com que se procura obstar a realização da reforma agrária. Estou convencido de que este Seminário, o primeiro conclave sob o patrocínio oficial sobre o tema, sem disfarces, da reforma idealizada e promovida sob a inspiração do Ministro Almino Afonso, é o começo desse trabalho e, em certo sentido, o começo da própria reforma." 26

As Resoluções estruturam-se em três etapas: a primeira reúne constatações e considerações iniciais de ordem geral, em, seguida aborda as afirmações de direitos, responsabilidades, possibilidades e dificuldades a enfrentar. Finalmente, as propostas, de forma bastante direta, concentram-se na questão da aprovação das reformas de base como condição sine qua non para o estabelecimento da Política Habitacional e da Reforma Urbana esboçado na sequência do documento.

Na fase de Considerações, entendia-se o "problema habitacional na América Latina não como situação de emergência (...) mas como o

${ }^{26}$ SHRU, "Mensagem ministerial". Arquitetura IAB/GB №14, ago1963. 
resultado das condições de subdesenvolvimento provocadas por fatores diversos, inclusive por processos espoliativos".

No Brasil, a situação habitacional era caracterizada pela "desproporção cada vez maior nos centros urbanos entre o salário ou a renda familiar e o preço de locações ou de aquisição de moradia e pelo déficit crescente de disponibilidade de prédios residenciais" ${ }^{27}$ não por falta de construções, mas pelo fato de que as

habitações construídas naquele momento destinavam-se às classes favorecidas.

Novamente a precariedade da estrutura agrária aliada ao surto industrial não planejado eram apontados como causa das migrações e, consequentemente, da explosão demográfica das cidades brasileiras. Constatava-se também a "incapacidade da iniciativa privada de prover o aumento da oferta de moradias de interesse social no mesmo ritmo do crescimento urbano", assim como o entrave ao desenvolvimento tão almejado pelos brasileiros que representava a ausência de uma política habitacional sistemática no país. Como possibilidade, constatava-se o "emprego de tecnologias novas no país, ainda que dispersas e limitadas, algumas apresentando interessantes características regionais", o que, ainda que de forma abstrata, representava a esperança e a ação do conjunto dos arquitetos brasileiros entusiasmados com os processos

${ }^{27}$ Arquitetura IAB/GB №16, 1963 construtivos experimentados até ali, sugerindo-se talvez alguma relação com a experiência do Cajueiro Seco. ${ }^{28}$

A etapa de afirmações das Resoluções estava centrada nos "direitos fundamentais do homem e da família", entre os quais o direito de habitação, cuja plena realização justificaria "limitações ao direito de propriedade e uso do solo", o que dava o tom do discurso geral implícito no documento. A condição de habitação da maioria da população, "à margem do desenvolvimento econômico", era considerada incompatível com o grau de civilização já alcançado pelo País.

O item 4 deste trecho afirmava que "situação contrasta flagrantemente com os conceitos de democracia e justiça social e só poderá ser superada pela atualização da estrutura econômica nacional e por um considerável avanço construtivo, através da coordenação de esforços e da racionalização de métodos de produção ${ }^{29}$

Evidenciava-se a crença do grupo reunido no Seminário na superação dessas injustiças pelo progresso tecnológico da indústria da construção, uma vez redirecionada para os setores desfavorecidos e devidamente regulamentada dentro de um espírito capitalista mais desenvolvido. Assumia-se que o problema habitacional era de responsabilidade do Estado e que a sua política habitacional, executada através de planos nacionais e territoriais,

\footnotetext{
${ }^{28}$ Arquitetura IAB/GB No16, 1963

${ }^{29}$ Arquitetura IAB/GB Nº16, 1963
} 
deveria ser relacionada ao processo de desenvolvimento geral do país e não encarada pontualmente nem de forma assistencial. Para tanto, o plano deveria basear-se no estudo das demandas e necessidades, uma vez que "as leis reguladoras do mercado tem-se mostrado incapazes de conduzir às soluções desejadas". Mais adiante, o documento expressamente declarava ser "imprescindível a adoção de medidas que cerceiem a especulação imobiliária, sempre anti-social, disciplinando o investimento privado no setor ${ }^{\prime 30}$

O plano habitacional sugerido estruturar-se-ia em torno de quatro diretrizes básicas, a saber:

“a) a capacidade de amortização ou pagamento das diversas camadas da população b) o estabelecimento de tipos e dimensões de moradias adequados à realidade regional, econômica e demográfica c) as relações entre a moradia, o trabalho e os serviços urbanos e d) o custo dos serviços e equipamentos urbanos". ${ }^{31}$

Chamava-se a atenção também para a importância da regulamentação das locações urbanas como parte do plano habitacional, de maneira a "relacionar de forma justa o aluguel à renda familiar", talvez sob a inspiração da reforma urbana cubana, que estabelecia uma porcentagem máxima da renda familiar passível de ser comprometida na locação do imóvel, desvinculandoa do valor relativo do mesmo.

\footnotetext{
30 "Projeto de Lei para criação da SUPURB". Arquitetura IAB/GB №16. out/1963.

${ }^{31}$ "Projeto de Lei para criação da SUPURB". Arquitetura IAB/GB Nº16. out/1963.
}

Outro ponto que revela a atualidade da discussão refere-se à melhoria progressiva das condições de sub-habitação, "em bases locais, inclusive estimulando o esforço próprio, a ajuda mútua e o desenvolvimento comunitário", ponto de fundamental importância para este trabalho, já que se aproxima de maneira contundente à experiência do Cajueiro Seco, naquele momento a única em prática no Brasil que mobilizava estes conceitos, com a consolidação do pensamento e das propostas de uma geração de arquitetos e profissionais envolvidos com o tema.

A etapa de afirmações concluía-se com a constatação de que para a execução da política habitacional brasileira seria necessária a criação de um "Órgão central Federal, com autonomia financeira e autoridade para atingir seus objetivos", proposta que será detalhada no projeto de lei para a criação da SUPURB (Superintendência de Política Urbana) e que, segundo autores como João Arlindo Serran indica para o aproveitamento de parte das propostas do SHRu imediatamente após o golpe militar, com a criação do Banco Nacional de Habitação (BNH), cujo desenho institucional poderia ser aproximado ao sugerido no documento.

As propostas derivadas do Seminário tinham um caráter mais pontual, sintetizando as indicações levantadas, concentrando-se na questão da aprovação e aplicação das reformas de base, na modificação do Artigo 141 da constituição e no envio do projeto de 
lei ao Congresso de Política Habitacional e Reforma Urbana, cujos pontos eram melhor descritos na seqüência do documento, e na necessidade de se obter, junto ao IBGE, o máximo de informações sobre habitação, além do desenvolvimento de metodologia específica para a determinação qualitativa e quantitativa da escassez de moradias atual e projetada para o futuro.

Se nos alongamos nessa explicação do teor das resoluções do Seminário é por entender que ele cristaliza grande parte do pensamento sobre a questão da habitação naqueles dias. A atualidade de algumas dessas idéias pode derivar do seu aproveitamento em parte por uma geração de profissionais que tiveram grande influência como técnicos na concepção de políticas públicas para a área de habitação social.

A redação do projeto de lei para a criação da SUPURB, baseado nos pontos discutidos no SHRu, coube ao arquiteto Artur Lima Cavalcanti, deputado federal pelo PTB pernambucano, exprefeito do Recife, figura central da Frente ampla de esquerda que elegeu Miguel Arraes Governador e elo de ligação entre o Seminário e a experiência do Cajueiro Seco. Tal relação é corroborada pela $5^{a}$ proposta do Seminário, que tratava das normas e diretrizes para melhoria dos conjuntos de sub-habitação. Nela, definia-se a orientação de:

"Organizar as comunidades disciplinando e orientando tecnicamente as construções, com o aproveitamento também dos próprios recursos dos grupos sociais;

Coordenar as obras de responsabilidade do Poder Público;

Tornar produtiva toda mão de obra ociosa local, mediante seu aproveitamento em oficinas de artesanato e pequenas indústrias locais. "132

Ou seja, praticamente os mesmos itens e o mesmo texto incluso na "Política Social do Mocambo", publicado na revista Arquitetura alguns meses antes, o que nos indica que além da influência dos representantes pernambucanos no evento, a atuação do Governo Arraes no campo da habitação era considerada um modelo de teste para a política nacional que estava sendo formulada, aproveitando-se das experiências locais que estavam sendo postas em prática pela primeira vez no Cajueiro Seco, o que explica em parte a notoriedade que o assentamento viria a obter na história das políticas públicas, quase um tipo de comunidade a se implantar nos mesmos métodos em diversas regiões do país. Além de Artur Lima Cavalcanti, Gildo Guerra, presidente do Serviço Social Contra o Mocambo, estava presente nos debates do Hotel Quitandinha como representante do Governo de Pernambuco (o único Estado com representação oficial no evento), que naquele momento tinha o "mais bem formulado" programa de habitação, seguindo bases progressistas, e um órgão executor da política habitacional com uma longa história de atuação desde o Estado

\footnotetext{
32 "Projeto de Lei para criação da SUPURB". Arquitetura IAB/GB №16. out/1963.
} 
Novo, através do SSCM, e que, tanto por suas práticas quanto por sua expressiva produção, vinha chamando a atenção do governo federal $^{33}$.

Segundo Geraldo Gomes, a experiência do Cajueiro Seco foi apresentada no SHRu e debatida com muito interesse, na medida que representava já uma aplicação de parte das práticas que estavam sendo debatidas, num momento no qual Pernambuco tinha um papel de destaque no panorama de atuações governamentais para a área e Recife representava a terceira maior cidade do Brasil, na qual a "crosta de mocambos" materializava o "inchaço" descrito pelo documento. ${ }^{34}$

Na justificativa que antecede a íntegra do projeto de lei para a criação da SUPURB publicada na revista Arquitetura, além da reafirmação dos princípios do uso da propriedade condicionado ao bem-estar social como ponto de partida para a Reforma Urbana, falou-se na institucionalização da prática de "mutirão" como política pública:

"Este é um sistema de trabalho coletivo que tem por fim o aproveitamento máximo da mão-de-obra e dos recursos naturais do meio, para barateamento das construções e, mesmo, do equipamento urbano. Experiências já demonstraram que essa forma de organização popular, na qual toda a comunidade oferece o seu quinhão de esforço, para a obra

\footnotetext{
${ }^{33}$ Ver item 3.1.

${ }^{34}$ Entrevista de Geraldo Gomes ao autor, em julho de 2006.
}

comum é plenamente possível. Para que se institucionalize, nada mais é necessário que financiamento e educação. O processo educativo é dos mais rápidos e inclui, apenas, a conscientização do homem e umas poucas técnicas assimiláveis em horas. Quanto ao financiamento, apresenta-se muito abaixo dos padrões vigentes. É que pelo processo descrito, como, de resto, se prevê facilmente, a utilização de capital, nas obras, é em nível muito reduzido". ${ }^{35}$

Sobre o tal capital, residiam as esperanças da política social trabalhista de retorno do capital investido em um sistema fluido que realizasse habitação popular, a partir da experiência adquirida nos órgãos federais ligados à habitação desde o Estado Novo, os Institutos de Aposentadoria e Pensão (IAPs) e do próprio Serviço Social Contra o Mocambo.

"Essa participação popular, de fato, já vem sendo, em princípio, a mola propulsora dos empreendimentos, pelo menos no que diz respeito à casa própria. Com efeito, é baseado sempre no retorno dos financiamentos que órgãos como Fundação da Casa Popular, as Caixas Econômicas Federais e os Institutos de Previdência levam a efeito seus programas de construção. No fundo, porém, essa rotação de recursos se reduz a uma ilusão; porque, de fato, em virtude de não haver um mecanismo eficiente de retificação monetária, tais órgãos se descapitalizam rapidamente, mantendo, já hoje, praticamente paralisadas suas carteiras imobiliárias. De modo que, se em princípio, há a participação da poupança privada, no setor, na prática, o que se verifica exatamente é um processo de vasos comunicantes, pelo qual o Estado, de um modo ou de outro, termina por pagar, em grande parte, os empreendimentos.Complemento de tais providências é o que está disposto no art.19 e que se refere à política que, em vasta região do País, se denomina de mutirão. (...)

Art.19. Fica autorizada a SUPURB a efetivar planos de ajuda mútua para instalação, recuperação ou trasladação de populações desajustadas, realizando a promoção social dessas comunidades, por intermédio de

35 "Projeto de Lei para criação da SUPURB". Arquitetura IAB/GB №16, out/1963. 
financiamento a longo prazo da área territorial urbana e dos materiais e equipamentos essenciais à moradia, dentro de um planejamento urbanístico global." ${ }^{36}$

A votação do projeto de lei que criaria a SUPURB no Congresso Nacional estava marcada para o dia 2 de abril de 1964 e nunca aconteceu. Nas palavras do líder comunista Paulo Cavalcanti, "o golpe de estado de $1^{\circ}$ de Abril estava na ante-sala." (CAVAlCANTI, 1978, p.335)

O texto contundente produzido no SHRu como produto dos debates, assim como o projeto de lei da SUPURB, continham algumas indicações técnicas e políticas que propunham uma transformação radical das cidades brasileiras assim como alterar os rumos caóticos que o crescimento súbito suscitava.

"Os documentos do Seminário demostram a articulação dos arquitetos para solucionar os principais problemas da arquitetura e do urbanismo através do binômio industrialização e planejamento. As propostas incluem medidas para enfrentar problemas centrais como a renda da terra, a elaboração de uma política de Reforma Urbana, e de um

${ }^{36}$ "Projeto de Lei para criação da SUPURB". Arquitetura IAB/GB No16, out/1963.

${ }^{37}$ Conta Maurício Castro em entrevista em ago/2007 que em ! de Abril de 1964 estava no Rio de Janeiro juntamente com Artur Lima Cavalcanti para uma reunião do Conselho Superior do IAB, , que foi imediatamente suspensa em virtude do golpe. Quando a reunião foi reconvocada, na semana sequinte, Artur Lima estava já foragido e Maurício Castro cometeu a "gafe" de solicitar ao Conselho Superior que se manifestasse formalmente contra a prisão dos professores e arquitetos Acácio Gil Borsoi e Delfim Amorim e outros, sendo informado depois que havia um acordo mais ou menos tácito de não se tocar no assunto durante a reunião. Arthur Lima Cavalcanti teve seus direitos políticos e mandato cassados no Ato Instucional $\mathrm{N}^{\circ} 1$ e, segundo Francisco de Oliveira, foi um "jovem político promissor, Artur finou-se provalvelmente no whisky."(Oliveira, 2008, p.53)
Plano Nacional de Habitação. No conjunto, foram uma tentativa de equacionar os entraves causados pela propriedade privada do solo urbano no planejamento e crescimento coordenado das cidades e de disponibilizar áreas de interesse social para a produção em massa da arquitetura." (KOURY, 2005, p.17-66)

O descarte das propostas de reformas estruturais na questão da terra urbana pelos militares por questões de incompatibilidade ideológica, não impediria que algumas de suas sugestões mais engenhosas fossem aproveitadas, para outros fins, na criação do $\mathrm{BNH}$. A relação entre alguns pontos discutidos no SHRu é feita por por protagonistas do período como Borsoi, Geraldo Gomes e Maurício Castro e reiterada por autores como SERRAN e KOURY, que pontua bem suas principais diferenças com as propostas implementadas já no regime militar. 


\subsection{O Congresso da UIA em Havana/63}

Em outubro de 1962, Havana tornara-se o centro de uma geopolítica dividida entre os imperialismos norte-americano e soviético. Mais do que nunca na história, o confronto entre as duas superpotências mundiais parecia aproximar-se de uma guerra nuclear, a ser deslanchada precisamente a partir de Cuba. Não fosse a habilidade política de Fidel Castro, Nikita Kruschev e John Kennedy, o mundo poderia ter acabado ali. Foi nesse contexto que, em 1963 realizou-se o VII Congresso da União Internacional dos Arquitetos em Havana. Segundo Liernur:

"A influência do marxismo e, em geral, a vigência dos tópicos retóricos, os métodos, os estilos, as idéias e utopias da 'esquerda' haviam começado ser especialmente notáveis a partir de 1963, quando teve lugar em Havana o VII Congresso Internacional de Arquitetos. Apesar dos esforços para apresentá-lo como 'apolítico', o Congresso e especialmente o Encontro Internacional de Estudantes não escaparam da forte atração exercida pela recente 'Revolución' e seus líderes, com o apoio dos representantes dos países 'socialistas' e do 'terceiro mundo'. De modo que nas resoluções finais o progresso da arquitetura ficou vinculado à planificação econômica, a reforma agrária, as mudanças na estrutura econômico-social, no protagonismo popular, na posse e controle dos meios de produção e a superação da 'dependência'" (LIERNUR, 2001, p.337338, tradução do autor)

Analisando a compilação das teses elaboradas para o Congresso fica nítida a divisão do mundo em pólos opostos, entre desenvolvidos e "em vias de desenvolvimento" (eufemismo para subdesenvolvidos), entre alinhados com a União Soviética e os alinhados com os Estados Unidos, que por razões óbvias boicotou o evento, entre socialistas e capitalistas, entre a cortina de ferro e o mundo livre. Para entendermos essa divisão é importante situarmos a lógica implícita na plataforma da Aliança para o Progresso, motor da política externa do Governo Kennedy para a América Latina em contraponto ao entusiasmo que as vitórias da Revolução cubana suscitavam no continente ${ }^{38}$

Se por um lado a UIA se apresentava como organização apartidária, alegando que o local do VII Congresso já estava definido antes da Revolução e por isso mesmo deveria ser mantido, viria a promover também em 1963 o célebre concurso para o monumento à vitória cubana na Playa Girón (ou Baía dos Porcos, o nome depende do ponto de vista), no qual o segundo lugar coube ao projeto dos brasileiros Fabio Penteado e Ubirajara Giglioli.

É interessante perceber através dessas teses e relatos acerca do VII Congresso como essas polarizações produziam impacto na arquitetura: de um lado, os países socialistas, principalmente do leste europeu apresentando em grossos fascículos bem ilustrados, com fotografias, desenhos e detalhes, as suas tecnologias de préfabricação pesada e modulada em painéis de concreto e treliças metálicas, e, de outro, os países capitalistas limitando-se a cumprir o roteiro do inquérito solicitado pela UIA, que versava sobre o desenvolvimento de uma região, o planejamento regional, a

\footnotetext{
${ }^{38}$ Ver item 2.7
} 
habitação, as técnicas construtivas e a exposição de um exemplo bem sucedido de unidade de vizinhança. ${ }^{39}$

O relatório cubano tem um especial interesse por ser a expressão das realizações do país sede do evento, que também era o campo privilegiado das novas possibilidades e experimentações na ilha do socialismo latino americano alimentada pelo tal "ouro de Moscou". Ao contrário dos países da cortina de ferro, Cuba, por suas condições peculiares e antiimperialistas tentava desenvolver experiências construtivas e expressões únicas do moderno ressignificado pela apropriação pelo povo. O interesse por conhecer as realizações e a vida pós revolucionária na ilha atraiu muitos arquitetos e participantes, fazendo com que o evento ganhasse proporção e relevância na história dos encontros de arquitetos. ${ }^{40}$

A arquitetura cubana vinha de uma sólida tradição moderna patrocinada pelo capital norte-americano, além de uma pequena elite local a ele relacionada, que nos momentos imediatamente anteriores à revolução estavam desenvolvendo obras de arquitetura moderna da qualidade dos Edifícios Focsa e o Hotel Riviera. Quando houve a mudança de rumos políticos na ilha, Fidel fez um chamado pessoal à classe de arquitetos para que se engajassem na

${ }^{39}$ UIA. Congres de L'union Internationale des Architectes, Havana, 1963.

40 UIA. "Cuba". Congres de L'union Internationale des Architectes, Havana, 1963. questão habitacional e urbana; muitos deles cooperaram e se lançaram em diversas experiências construtivas e formais que constituiram uma nova arquitetura cubana, como no caso da Cidade Universitária de Havana, das Escolas Nacionais de Arte, da Unidade de vizinhança Havana do Leste e da Sorveteria Coppelia. (SEGRE, 1987)

A situação de Cuba antes da Revolução de 1959 em muitos aspectos pode ter soado familiar aos participantes brasileiros, especialmente aos pernambucanos. A monocultura do açúcar, a desigualdade entre classes e a crise habitacional, assim como sua expressão - os bohíos, de fisionomia muito similar aos mocambos. É curioso notar a vinculação do bohío com a cultura pré-colombiana que se faz no documento, distinta da origem africana que usualmente se apresenta do mocambo. A leitura brasileira e cubana do fenômeno do mocambo-bohio urbano concordam em apontar a origem social do problema na estrutura agrária colonial e no latifúndio. ${ }^{41}$

A Reforma Urbana em Cuba se deu de maneira política, reduzindo pela metade os aluguéis e abrindo caminho para que os cubanos pudessem adquirir o imóvel em que já residiam e a construção de novos conjuntos pôs em prática a alta tecnologia

${ }^{41}$ UIA. "Cuba". Congres de L'union Internationale des Architectes, Havana, 1963. 
soviética de pré-fabricação pesada que foi "tropicalizada" e posteriormente adaptada, dando lugar a novas experiências locais que buscavam a leveza da peça em concreto armado como meio de empregar mais mão de obra e menos equipamentos na montagem dos edifícios. ${ }^{42}$

A construção por brigadas de ajuda mútua aparece sem muito destaque, restrita a pequenas comunidades rurais e projetos padrão. A realização apresentada com mais ênfase é mesmo a unidade de vizinhança de Havana do Leste, mais tarde Ciudad Camilo Cienfuegos, que se impôs por sua escala, diversidade tipológica e urbanismo complexo e generoso em programas e espaços públicos. ${ }^{43}$

O relatório apresentado pela delegação brasileira ao Congresso parece equilibrar-se entre os pólos do capitalismo e do socialismo, fundando talvez uma nova categoria de subdesenvolvidos que pendia para a esquerda. Talvez por refletir a euforia democrática anterior ao golpe de 1964, durante o Governo João Goulart, e o alinhamento político radical da classe dos arquitetos.

O extenso volume elaborado pelo IAB de São Paulo acerca das características físicas do país e do desenvolvimento da

\footnotetext{
${ }^{42}$ UIA. "Cuba". Congres de L'union Internationale des Architectes, Havana, 1963.
}

43 op. cit. economia e das cidades brasileiras do período colonial até aquele momento, bem como dos entraves que o obstavam ("Um dos problemas mais importantes e urgentes da atualidade brasileira é a transformação da sua estrutura agrária.(...) o enorme desequilíbrio econômico que existe entre as diferentes regiões do país e a desigualdade profunda das classes sociais" ${ }^{44}$, incluía também um balanço do estado presente da arquitetura e do urbanismo no país através de um amplo panorama histórico e dos principais marcos na política habitacional como atuação Fundação da Casa Popular e a criação do Conselho Federal de Habitação.

O relatório inclui uma rápida análise da planificação regional no país (tema obrigatório e central do congresso) e da atuação de alguns órgãos como a Comissão do Vale do São Francisco (CVSF), a Superintendência de Desenvolvimento da Amazônia (SPVEA) e do Nordeste (SUDENE) e a Comissão Federativa da Bacia ParanáUruguai (CIBPU).

Além de apresentar uma descrição da Superquadra de Brasília como exemplo realizado de enfrentamento do problema arquitetônico nacional, o documento brasileiro incluia ainda as resoluções e propostas de cunho radical do Seminário de Habitação e Reforma Urbana.

\footnotetext{
${ }^{44}$ UIA. "Relatório do Brasil". $\quad$ Congres de L'union Internationale des Architectes, Havana, 1963.p.7 e p.20.
} 
Jorge Wilheim, no artigo "Notas de Viagem - VII Congresso da UIA", publicado na revista Acrópole de out/nov de 1963, descreveu o clima do congresso: entusiasmo e curiosidade principalmente dos brasileiros com relação às realizações arquitetônicas cubanas, com ênfase nas técnicas de pré-fabricação pesada e leve em concreto aplicadas aos programas habitacionais e educacionais, determinação clara de intercâmbio de tecnologias entre os países desenvolvidos e os subdesenvolvidos entre daiquiris gelados a toda hora $^{45}$.

A delegação brasileira era uma das mais numerosas, entre os quase duzentos participantes estavam importantes figuras da arquitetura nacional como Vilanova Artigas, Acácio Gil Borsoi, Jorge Wilheim, Alberto Xavier entre outros e muitos estudantes como o pernambucano Geraldo Gomes da Silva, levados a Cuba no navio soviético "Nadesdka Krupskaya" que em sua viagem inaugural foi ao Chile buscar os arquitetos e estudantes dos países andinos, a Santos buscar os brasileiros do Sul do país e ao Recife buscar os nordestinos, pernambucanos fundamentalmente.

De acordo com Geraldo Gomes, grande parte dos livros, publicações e documentos adquiridos em Havana desembarcaram

\footnotetext{
${ }^{45}$ Luis SAIA, "Não é com vinagre que se apanha mosca - Congresso de Cuba" e Jorge WILHEIM, "Notas de Viagem - VII Congresso da UIA". Acrópole 300, São Paulo, out/nov, 1963.
}

no Recife, que durante o breve governo de Miguel Arraes era considerado, como Cuba, "Território livre das Américas", e daí seguiram por terra para os estados menos progressistas de origem dos demais participantes do congresso. Com o advento do golpe militar, grande parte desse material foi destruído e muitos dos participantes do conclave foram chamados pela repressão "a prestar esclarecimentos". ${ }^{46}$ (Entrevista do autor em agosto de 2006)

Oficialmente, o Brasil não organizou uma exposição de realizações como fizeram outros países, mas Jorge Wilheim chamou a atenção para o "exemplo de casa popular mínima feita segundo a técnica do "pau-a-pique", com elementos semi-industrializados; trata-se de obra em execução no projeto de Cajueiro Seco, importante experiência do Serviço Social contra o Mocambo, do governador de Pernambuco". Segundo, o arquiteto pernambucano Geraldo Gomes, tanto em Havana quanto no SHRu o Cajueiro Seco foi apresentado e muito discutido, o que explica em parte sua inclusão na historiografia da arquitetura como um dos primeiros momentos nos quais a participação do usuário e sua mão de obra foram incluídos num programa de habitação popular, o que acontecia também em Cuba naqueles anos, embora de forma distinta.

"A pré fabricação soviética era totalmente diferente, no SHRu se discutia isso, havia uma outra preocupação que era dar trabalho ao desempregado e a pré-fabricação não dá emprego, pelo

${ }^{46}$ Entrevista de Geraldo Gomes ao autor, em agosto de 2006. 
contrário, tira, embora barateie o produto excluía a participação da população e não era isso que convinha.

Para Cuba foi uma maquetezinha e uns desenhos de Borsoi. Uma experiência que estava sendo feita aqui, ocorreu a Borsoi fazer essa maquetezinha. Uma coisa muito simples, era mais uma idéia que foi localizada em Cajueiro Seco numa ocasião específica e num governo específico e nem em Havana houve muita repercussão, era uma experiência muito tímida, no princípio, não se pode dizer que era uma experiência vitoriosa, de jeito nenhum, era uma proposta". ${ }^{47}$

O segmento Imóveis e Móveis, do conservador Diário de Pernambuco, destacou em manchete a participação no evento:

"Pernambuco mostrou casa de taipa ao encontro de arquitetos:

Havana", descrevendo a proposta como um trabalho acadêmico dos então estudantes "Arnaldo (sic) de Holanda e Ricardo Pontual sob orientação do Professor Borsoi", cujo plano piloto estaria sendo executado em Cajueiro Seco. ${ }^{48}$

\footnotetext{
${ }^{47}$ Geraldo Gomes da SILVA Entrevista ao autor, Recife, set/ 2007.

48 "Pernambuco mostrou casa de taipa ao encontro de arquitetos: Havana". Imóveis\&Móveis - Diário de Pernambuco, Recife, 14/11/1963.
} 


\subsection{Experiências participativas na construcão da habitação social}

Em um artigo publicado nos anos 80 na revista Built Environment, em que analisou os vinte anos anteriores de certa arquitetura com as comunidades ${ }^{49}$, a arquiteta norte-americana Mary

Comerio estabeleceu algumas distinções entre as práticas norteamericanas e européias nesse campo. Desenvolvidas a partir dos anos 60, nos Estados Unidos, à luz do ativismo idealista "anti-arquitetura" na contracorrente dos grandes projetos urbanos, ou na Europa em meio ao investimento na organização e na sociabilidade coletiva como base dos projetos de habitação social, ambos os casos atestariam uma crescente politização dos arquitetos e um olhar atento aos territórios populares.

O caso brasileiro nos anos 1960 não parece relacionar-se diretamente como essas experiências, mas a distinção ali estabelecida pode nos ajudar a compreender a pluralidade de caminhos e propostas que por vezes se fundem em um discurso específico.

Para superar o caráter episódico e excepcional normalmente atribuído ao projeto de Cajueiro Seco, é necessário buscar as articulações entre a experiência pontual, o debate contemporâneo sobre a arquitetura e habitação e outros projetos e realizações baseados na participação popular. Senão para mapear os diferentes modos pelos

\footnotetext{
${ }^{49}$ Mary COMERIO. "Design and Empowerment:20 Years of Community Architecture". Built Environment, vol. 13 №1.
}

quais eles vieram à tona, ao menos para perceber o entrecruzamento ali de variadas idéias e propostas. Digna de nota neste percurso é a experiência da fábrica de móveis Unilabor ${ }^{50}$, no bairro do Ipiranga em

São Paulo, que a partir dos anos 1950 viria a aliar o desenho moderno na produção e apresentação dos produtos com práticas autogestionárias de organização do trabalho, nas decisões dos rumos da empresa e em atividades culturais voltadas ao desenvolvimento da comunidade, instalada no terreno da Igreja do Cristo Operário. Estabelecida com base na ideologia dominicana do Frei João Batista Pereira dos Santos a partir da conjunção da disposição de alguns trabalhadores com artistas de vanguarda como Geraldo de Barros, Flávio Império e Alexandre Wollner, a experiência se notabilizaria em São Paulo pela introdução de um ideário cooperativista na avançada esfera do desenho industrial.

Se a atividade da Unilabor encontrou grande eco em Pernambuco, uma outra experiência participativa em São Paulo, já nos anos 60, ganharia espaço na imprensa local, ao lado das notícias sobre o Cajueiro Seco e as realizações da florescente "arquitetura moderna pernambucana". No suplemento do Diário de Pernambuco intitulado "Imóveis e Móveis", muitas foram as notas acerca das realizações do Movimento Universitário de Desfavelamento (MUD), que a partir de

\footnotetext{
${ }^{50}$ Mauro CLARO. Unilabor - Desenho industrial, arte moderna e autogestão operária. São Paulo: Editora SENAC, 2004
} 
1963 passara a reunir em São Paulo estudantes de diversas áreas de conhecimento, ligados ao pensamento católico progressista do período, para trabalhar nas favelas da Móoca, Vergueiro e do Canindé. O cotidiano desta última seria descrito pela "favelada" Carolina de Jesus no livro "Quarto de despejo", que alcançou certa popularidade na época.

" O MUD financia as casas de alvenaria (em substituição aos barracos) tendo já extinguido, praticamente, as favelas da Móoca, em trabalho conjunto com a Cruzada Pio XII. Das 101 famílias que moravam em barracos, apenas três continuam nessas condições. Depois da Móoca seguiram-se diversas localidades onde não só providenciaram a extinção dos barracos, como ofereceram assistência médica. Para conseguir fundos, os estudantes fazem campanhas, angariando donativos em festivais e sorteios, contam, também, (sic) subvenções públicas. Conseguiram, até o momento, mais de vinte e cinco milhões de cruzeiros, tudo já empregado na construção de casas de tijolo." ${ }^{51}$

Tomando como ponto de partida a reintegração de posse deferida a favor da família proprietária, representada por Mina Klabin Warchavchik, o MUD elaborou projetos de relocação dos moradores destas favelas, a partir de um plano que passava pela "promoção das famílias a uma situação melhor de vida" ${ }^{52}$, pela assistência médica básica, orientação jurídica para compra dos terrenos e por um processo de educação das famílias. Com personalidade jurídica própria e

\footnotetext{
51 "Estudantes querem acabar com as favelas: São Paulo". I I\&M - Diário de PE Recife, 29/09/1963.

${ }^{52}$ Movimento Universitário de Desfavelamento. Relatório do trabalho na favela do Vergueiro. São Paulo: MUD, 1963, p.7.
}

baseado no voluntarismo de fim de semana dos universitários e de grupos católicos, o grupo de "Planejamento da construção e financiamento da habitação" do MUD constituiu por pouco tempo "uma espécie de assessoria técnica" ${ }^{53}$, elaborando projetos simplificados para o que os favelados construíssem suas novas casas em terrenos na periferia com verba arrecadada pelo MUD junto à fundações estrangeiras e aos governos municipais e estaduais.

Os projetos não apresentam inovação arquitetônica alguma e refletem a concepção da casa própria isolada no lote afinada com a ideologia católica, exceto pelo projeto multifamiliar elaborado para o lote em Jandira por Paulo Bruna, no qual há uma proposta de um condomínio popular com espaços de sociabilidade comuns e unidades mais elaboradas. A solução da auto ajuda dos favelados foi cogitada, mas logo descartada por conta da falta de habilitação dos mesmos, que participavam tão somente como ajudantes e não estavam aptos para coordenar a construção, na avaliação dos mudenses. A falta de mão de obra, de experiência e tempo dos estudantes, assim como a alta dos preços de materiais de construção e a pouca participação dos futuros moradores foram elencados como as principais dificuldades enfrentadas pelo MUD, que por fim logrou "desfavelar" a Favela do Vergueiro, abrindo espaço ali para os empreendimentos imobiliários

\footnotetext{
${ }^{53}$ Segundo Magaly Pulhez, que em sua dissertacão de mestrado analisa historicamente o envolvimento dos arquitetos com a questão do popular e a formação desse tipo de entidade até a forma atual.
} 
que deram origem ao pujante bairro conhecido como Chácara Klabin, homenageando e enriquecendo seus proprietários.

Na América Latina, os arquitetos vinham progressivamente se aproximando da questão habitacional e da política. Desde 1959, por exemplo, em Cuba, brigadas de habitação por ajuda mútua vinham sendo organizadas e institucionalizadas como uma resposta possível ao compromisso político assumido pelo governo revolucionário de eliminar do país as favelas, substituindo as 80.000 moradias precárias por novas habitações, integradas ao novo sistema público de saúde e educação, através dos Comitês de Defesa da Revolução (CDRs), que levavam o Estado e o poder à escala do bairro.

É verdade, todavia, que em pouco tempo, tais sistemas de ajuda mútua seriam abandonados ${ }^{54}$. Segundo Segre,

"essa solução, que respondia à necessidade de dispor, em um tempo curto, de uma abundância de obras, teve escassa duração por causa da irregularidade produtiva dos trabalhadores, pelo baixo rendimento da construção, pela qualidade inferior das obras em relação àquelas construídas pelo Estado e pela criação de núcleos fechados de população inadaptada dentro da cidade. (...) Apesar disso, essa experiência foi positiva do ponto de vista arquitetônico e humano, ao serem erradicadas de imediato 35 favelas que albergavam 20.000 pessoas, com a construção de 4.700 casas." (SEGRE, 1987, p.85)

As propostas mais avançadas no campo da habitação popular em Cuba materializaram-se no conjunto projetado em Havana del

\footnotetext{
${ }^{54}$ Evidentemente, existem muitas diferenças entre as brigadas cubanas e as outras experiências de ajuda mútua nos países capitalistas, mas é interessante notar que a crítica feita a esse sistema em Cuba também difere muito da crítica contemporânea ao mutirão feita no Brasil por sociólogos como Francisco de Oliveira em Crítica à razão dualista, e Lúcio Kowarick em Escritos Urbanos, São Paulo: Editora 34, 2000.
}

Leste, construído entre 1959 e 1963, no qual algumas das premissas do urbanismo moderno foram aplicadas com variações de tipologias habitacionais e soluções de pré-fabricação pesada.

Parte das propostas ali experimentadas foi creditada por Segre à difusão na América Latina das New Towns inglesas e escandinavas e das experiências soviéticas, através da revista carioca Módulo, dirigida por Oscar Niemeyer (SEGRE, 1987, p.86). Em todo caso, o conjunto viria a ocupar um lugar de destaque na tese cubana enviada ao VI Congresso da União Internacional dos Arquitetos (UIA) em 1963, quando visitado por arquitetos e estudantes de todo o mundo nessa e em outras ocasiões. ${ }^{55}$

O fato é que em paralelo à implantação das reformas agrária e urbana, o governo cubano pôs em prática a estruturação de 350 núcleos em várias províncias da ilha, o que no interior de um programa mais amplo de aprimoramento das condições de vida e trabalho integrava uma estratégia de inversão da tendência à migração para as zonas urbanas. Estes núcleos foram um campo importante para a adaptação, ou a "tropicalização" de diversas patentes de pré-fabricação cedidas pela URSS e outros países do leste europeu para a construção de milhares de unidades na ilha.

Com o apoio soviético ao desenvolvimento cubano, a alta tecnologia de pré-fabricação de então, desenvolvida através das

\footnotetext{
${ }^{55}$ UIA. "Cuba". Congres de L'union Internationale des Architectes, Havana, 1963.
} 
pesquisas soviéticas e "carimbadas" por todo o Leste Europeu, era o ponto de partida para os projetos e obras em Cuba.

Apenas na segunda metade da década de 1960 a qualidade dos conjuntos edificados começou a ser criticada por uma nova geração de arquitetos e estudantes universitários, comprometida com o ideário revolucionário e diretamente convocada à ação por Fidel Castro, doravante engajados na pesquisa e proposição de novos sistemas e tipologias, como o de moldes deslizantes e o paradigmático conjunto de Manágua, baseado em painéis leves de materiais diversos e em plantas flexíveis. Projetado em 1968 pela arquiteta Célia Guevara, o conjunto de Manágua procurava, conforme a definição dos socialistas, "eliminar a imagem autônoma da residência individual e estabelecer uma continuidade entrelaçada das células estruturadas em dois andares, através de uma urbanização contínua em torno de um espaço social central", em contraponto com a solução capitalista do lote privado e da construção unifamiliar. (SEGRE, 1987)

O percurso de experiências e os desenvolvimentos de diversos sistemas construtivos e propostas habitacionais em Cubanas foi pouco estudado. Talvez por seu isolamento do debate internacional, ou em razão da conjuntura política e produtiva bastante peculiar à ilha, algo que a própria historiografia da arquitetura cubana viria a reforçar. No importante documento da "Arquitetura e Urbanismo da Revolução Cubana", escrito pelo ítalo-argentino Roberto Segre, não há menção, por exemplo, ao debate e cooperação internacional em torno da habitação, planificação e pré-fabricação no Congresso da UIA, que segundo Liernur, representou um momento de cristalização e síntese das propostas habitacionais e do engajamento político na arquitetura latino-americana, tocando diretamente na questão do "protagonismo popular". (LIERNUR, 2001, p.337-338)

A verdade é que a realidade latino-americana passara a figurar nas discussões internacionais, oferecendo alternativas valiosas para o enfrentamento do subdesenvolvimento em todo o mundo. Em 1963, por exemplo, a eleição do arquiteto Fernando Belaunde Terry para a presidência do Peru e as realizações de seu governo (1963-1968) no campo da habitação popular foram acompanhadas de perto pela comunidade arquitetônica internacional.

A principal dessas realizações talvez seja o concurso internacional que resultou na construção parcial do conjunto PREVI em Lima, no qual se aliavam projetos de arquitetos modernos mundialmente conhecidos à mão de obra dos usuários para criar unidades mínimas que seriam progressivamente aperfeiçoadas e ampliadas por seus moradores. Dentre os autores de alguns dos projetos ali realizados, além de arquitetos peruanos, figuravam os ingleses, James Stirling e Charles Corrêa, com larga experiência em trabalhos de habitação social na Índia, os suíços do Atelier 5, além de arquitetos ligados ao Team 10 como o holandês Aldo Van Eyck e Georges Candilis e Shadrach Woods, engajados no Atelier du Batiment (ATBAT), que, a partir de 1951, realizaram projetos habitacionais no Marrocos (SMITHSON, 1968 e BARONE, 2000, p. 77). 
Das 1500 unidades pensadas incialmente para o conjunto, foram construídas 500 no conjunto conhecido como Proyecto piloto 1, que contou com uma pequena usina de pré-fabricação de elementos construtivos e assessoria técnica do Instituto de Vivienda peruano nos projetos de ampliação das casas e supervisão da obra. O projeto do PREVI representa por um lado a principal realização de um governo progressista, liderado por um arquiteto que mobilizou as esperanças do povo peruano e que foi derrubado por um golpe militar mas também uma incorporação das críticas de John Turner na formulação de novos programas habitacionais, apontando para uma mudança de paradigma no que tange à construção do habitat popular. ${ }^{56}$

Desde o fim dos anos 1950, o arquiteto inglês John C. Turner trabalhava em Lima, no contexto do intercâmbio técnico estabelecido entre o Peru e a Inglaterra, observando as dinâmicas das barriadas ${ }^{57}$ e seu poder de auto construção e organização. Em 1963, a revista norteamericana Architecural Design publicou o número especial "Dwelling resources in South America", elaborado por Turner, que inclui exemplos de programas habitacionais na Venezuela, Chile, Colômbia, além do Peru, muitos deles concretizados a partir dos

${ }^{56}$ Existem artigos e pesquisas recentes sobre a experiência do PREVI, dentre eles: Fernando García HUIDOBRO, Diego TORRES e Nicolás TUGAS, "Arquitectura, vida y transformaciones". Provecto Elemental, UCC, Santiago, Chile na IV Bienal Iberoamericana de Arquitectura 2004; Sharif S. KAHATT, "PREVI Lima: Experimental design strategies competition for mass housing". Seminário "Urban Transformations", GSD Harvard University, 2007.

57 Barriada é a denominação peruana para os bairros populares construídos em terrenos invadidos, equivalentes às favelas brasileiras. recursos da Aliança Para o Progresso e das pressões populares organizada na forma de associações de "pobladores" ou expressa nas invasões de terrenos-, baseados na prática da auto construção, auto ajuda ou auto empreendimento mais ou menos assistidas por arquitetos e outros técnicos.

As experiências habitacionais sulamericanas ficaram de tal modo marcadas no imaginário de John Turner que se tornaram referência onipresente na atividade prática, política e teórica que o consagraria mundialmente a partir dos anos 70, como um dos principais críticos da provisão habitacional em forma de grandes conjuntos periféricos pelo Estado e como influente entusiasta da auto ajuda e do "desenvolvimento progressivo" da unidade habitacional no lote. Em certa medida, pode-se relacionar a influência adquirida pelo projeto do PREVI com a penetração das idéias de Turner no âmbito do Banco Interamericano de Desenvolvimento (BID) e do Banco Mundial, que passaram a ter grande ingerência nas políticas públicas, especialmente ligadas à habitação. ${ }^{58}$

Turner chegou ao Brasil em 1968, convidado pelo SERFHAU a conhecer a realidade habitacional de cidades brasileiras como São Paulo, Rio de Janeiro, Brasília e Recife, entre outras. Seus "conceitos e

\footnotetext{
${ }^{58}$ A ideologia dos Bancos pautou e continua sendo importante referência para elaboração de programas por parte de governos municipais, estaduais e federais, que tem de se adaptar as regras impostas pelos Bancos para obter financiamentos. Ver Pedro ARANTES, "O ajuste urbano: as políticas do Banco Mundial e do BID para as cidades latino-americanas". Dissertação de Mestrado, FAUUSP, 2004
} 
idéias" foram divulgados pela primeira vez no país nas páginas da revista Arquitetura/GB, que publica no mesmo ano "Barreiras e canais para o desenvolvimento habitacional nos países em vias de desenvolvimento", além de suas impressões sobre a questão habitacional brasileira. Turner propõe a inversão de algumas lógicas correntes: considerava os conjuntos de habitação de baixo custo como os problemas e as favelas e mocambos como a solução, ao contrário do Ihe foi apresentado; colocava a unidade habitacional depois da segurança e da localização na lista de prioridades relativa à habitação; entendia o déficit habitacional não como de quantidade de unidades mas de serviços, equipamentos; de qualidades do território.

A crítica e as propostas do arquiteto inglês abririam espaço para outras visões, ligadas à economia e à sociologia, frequentemente divulgadas por consultores internacionais que recomendam práticas e metodologias para a aplicação dos recursos emprestados dos Bancos Mundial e Interamericano de Desenvolvimento (BID), que vêem na institucionalizão da auto ajuda um meio objetivo de desenvolver lugares para a acomodação das classes perifericamente incluídas no capitalismo.

Uma importante referência latino-americana que também se desenvolvem a partir dos anos 1960 foram os conjuntos realizados pelas Cooperativas de Vivienda por Ayuda Mútua do Uruguai. Tendo como marco legal a Instituição da Ley Nacional de Viviendas em 1968, a partir das experiências das cooperativas rurais pioneiras organizadas em 1966, e agregadas em torno da Federación Uruguaya de
Cooperativas de Habitação por Ayuda Mútua (FUCVAM), as cooperativas uruguayas produziram perto de 16 mil unidades até hoje e constituíram um paradigma e um modelo para outros programas de mutirão autogerido, notadamente o FUNAPS Comunitário, em São Paulo, entre 1989-1992.

A vinculação com o movimento de moradia local, a assessoria técnica de arquitetos, engenheiros e outros profissionais resultando em projetos mais elaborados do ponto de vista da arquitetura e da urbanização e o emprego de elementos pré-fabricados de concreto leve são aspectos que no Brasil encontramos em experiências pontuais e no Uruguai fazem parte de um modo de produzir habitação social com bastante aceitação.

Não podemos deixar de lembrar, no entanto, que as cooperativas habitacionais inserem-se num país com larga tradição cooperativista em diversos setores da economia, que teve um ciclo de urbanização e desenvolvimento intenso antes da primeira metade do século, e que produziu uma classe de "trabalhadores urbanos expulsos da cidade formal e consolidada (BARAVELLI, 2007, p.61), que constitui grande parte da demanda por habitação.

Além disso, a produção da casa através da ajuda mútua é um dentre vários programas habitacionais no Uruguai, que incluem desde o financiamento total ou parcial de imóveis comprados no mercado privado, construção de habitações por poupança prévia (a rigor, se tratam de cooperativas de consumo de habitação, como as que existem 
no Brasil até hoje como Bancoop, Paulicoop e etc), chegando até o subsídio total para "habitações mínimas".

Outro aspecto importante que particulariza a experiência uruguaia é a questão da propriedade coletiva dos conjuntos construídos, detida e controlada pela cooperativa que o criou, mantendo assim a instituição coletiva viva e ativa depois da obra. A politização em torno da questão da propriedade coletiva e da FUCVAM é tamanha que a última tentativa que o Governo militar uruguaio (1973-1985) fez para tentar desmobilizar a Federação, depois de impedir a formação de novas cooperativas, foi justamente propor a individualização da propriedade e dos financiamentos das unidades construídas nas cooperativas. A proposta foi derrotada em todas as consultas populares e a reação à ela acabou fortalecendo a FUCVAM como um símbolo do cooperativismo da luta por moradia no país, já no ocaso do regime militar, que sentiu nesse episódio um duro golpe. (BARAVELLI, 2007)

Feitas estas observações preliminares, não podemos deixar de mencionar a alta qualidade dos conjuntos produzidos em Montevideo, tanto do ponto de vista do projeto das unidades e das urbanizações como do ponto de vista construtivo. As tipologias inovadoras, a integração dos espaços comerciais, o uso tradicional do tijolo de barro cozido e a aplicação da pré-fabricação leve de elementos como vergas, soleiras e marquises, entre outras inovações, está melhor discutida em trabalhos focados no tema como o Mestrado de José Baravelli e uma série de publicações uruguaias editadas pela própria FUCVAM ou pela Universidad de La República. ${ }^{59}$

Já nos anos 70, inseridos em um contexto diverso, os conjuntos realizados pelo Serviço Ambulatório de Apoio Local (SAAL) implantado em Portugal logo após a Revolução dos Cravos (1974), que derrubou o regime salazarista, dialogam com problemas similares aos latinoamericanos no que diz respeito a associação entre os arquitetos e os futuros moradores na luta pelo direito à cidade em um país de desenvolvimento incipiente. Conforme alguns dos pesquisadores que continuam estudando criticamente as operações SAAL até hoje, a matriz latino-americana parece estar na base da experiêncìa portuguesa:

"O programa SAAL inspirou-se em experiências similares da qual a mais conhecida é o movimento dos "pobladores» do Chile do tempo de

${ }^{59}$ A produção das cooperativas no Uruguai continua sendo um ponto importante da política habitacional daquele país e referência internacional de provisão de habitação social. No Brasil, o Cajueiro Seco consta como exemplo pioneiro interrompido pela ditadura militar mas a associação mais direta que parte da historiografia faz com a "escola paulista dos mutirões" é com a tradição das cooperativas uruguayas. As imagens em Super 8 das realizações e do trabalho no Uruguay exibidas em diversas associações de bairro e periferias de São Paulo por Guilherme Coelho, então estudante da USP, parecem ter marcado mais a memória dessas gerações de mutirões e mutirantes do que a experiência pernambucana. Em uma pesquisa sobre os mutirões no Brasil coordenada pela Assessoria Técnica Usina estabelece-se uma relacão direta entre as Cooperativas do país e o mutirão Vila Nova Cachoeirinha, precursor da primeira geração de mutirões ainda na época do Governo de Jânio Quadros. Essa genealogia do mutirão paulista é retomada por diversos autores como Carvalho e Arantes. José Eduardo BARAVELLI, $\underline{\mathrm{O}}$ cooperativismo uruguaio na habitação social de São Paulo : das cooperativas FUCVAM à Associação de Moradia Unidos de Vila Nova Cachoeirinha. Dissertação de Mestrado, FAUUSP, 2007. 
Salvador Allende. O SAAL propunha-se apoiar as iniciativas dos próprios moradores que viviam em más condições de habitação e que, por iniciativa própria, normalmente por via de Comissões de Moradores e/ou de Cooperativas de Habitação, procuravam construir casas com condições de habitabilidade dignas."

A partir da gestão do arquiteto Nuno Portas no Ministério de Habitação e Urbanismo, os conjuntos construídos pelas SAAL foram campo fértil para o amadurecimento da relação dos setores populares com arquitetos e estudantes, reunidos em brigadas técnicas de levantamento, projeto e obra, formando e integrando gerações de arquitetos modernos como Fernando Távora, Álvaro Siza e Eduardo Souto de Moura ${ }^{61}$. Os projetos elaborados associavam a arquitetura ao urbanismo integrando os conjuntos ao tecido histórico das cidades, ocupando muitas vezes o miolo dos mesmos quarteirões antes

60 "O SAAL foi o 25 de Abril nos bairros das cidades" Lisboa, 2005 Disponível em http://pimentanegra.blogspot.com/2005/08/o-saal-foi-o-25-de-abril-nos-bairros.html

${ }^{61}$ Siza, em entrevista a El Croquis em que comenta os conjuntos projetados para

Haia e Berlim, assinala "a necessidade de articular a identidade cultural e o respeito às diferenças com o desenvolvimento produtivo" e insere a condição portuguesa num quadro no qual "a boa construção artesanal começa a ser uma coisa rara e cara; não há operários qualificados e ainda não se dispõe de técnicas que existem em outros países. Vivemos um período de transição que nos força a adotar estratégias intermediárias para as quais a experiência de outros sistemas é muito valiosa como meio de flexibilizar nossa forma de operar."Contra esse processo, Siza sugere que "deveríamos todos evitar essa divisão entre projeto e direção da obra, tratando de forçar o processo em sentido inverso, instigar um maior contato entre a indústria e o pensamento de arquitetura. Existem métodos de trabalho que permitem essa relação", numa formulação que aproxima o discurso do arquiteto europeu com as idéias e práticas latinoamericanas.

"SALVANDO LAS TURBULENCIAS - entrevista con Alvaro Siza"; "Viviendas sociales en Schilderswijk Ward". In: El Croquis, Madrid, No.68/69, 1994. p. 3-45 e 114-125. ocupados pelas "ilhas" de sub-habitações, garantindo acesso independente e diálogo com o já anteriormente construído, como nas "Operações" de Antas e São Vitor, no Porto.

"Contrariamente à política anterior, um dos objetivos do SAAL é manter os habitantes nos mesmos lugares de residência" (DAVID, 1976, P.70)

Outro ponto importante da política das SAAL era a questão da propriedade coletiva, defendida pelo Estado e pelos habitantes, que aliada à solução projetual da alta densidade e baixa verticalização, resultava em volumes compactos e uma imagem arquitetônica de comunidade integrada.

A autoconstrução foi experimentada em apenas parte dos conjuntos, especialmente no Sul, no Algarve, em comunidades de pescadores e operários da construção civil como a do Olhão.

"Considerada pelos trabalhadores como uma dupla exploração, a idéia de autoconstrução foi progressivamente ultrapassada. Em lugar preferiu-se os conceitos de autosolução, autocontrole e autodireção das operações" (DAVID, 1976, P.70)

Embora contando com recursos financeiros limitados e duração curta, as Operações SAAL foram consideradas como "medida revolucionária no campo da habitação" e enfrentaram desde o escárnio à oposição cerrada nos seus primeiros momentos, passando a figurar posteriormente como um ponto de inflexão na arquitetura européia segundo Bernard Huet, que declarou que "O nosso futuro passa doravante pela experiência portuguesa" na edição de 1976 dedicada à Portugal da revista então dirigida por ele, a Architecture D’aujord Hui. 
A partir deste número monográfico da revista francesa, que foi a primeira divulgação internacional da experiência portuguesa, muitas pesquisas e publicações analisam as Operações SAAL criticamente, como O Processo SAAL e a Arquitectura no 25 de Abril de 1974, produto do doutorado de José António Bandeirinha e o documentário "Paz, Pão, Habitação... As Operações SAAL", de João Dias, ambos lançados em 2007, o que de certa forma atesta o interesse e o impacto da experiência, a despeito de sua pouca duração.

Além da proposta de aproximar os projetistas do processo de construção, a experiência portuguesa relaciona-se com a latinoamericana na medida em que opera em meio ao déficit social como oportunidade de invenção de soluções pouco convencionais, em alguns casos em diálogo estreito com as práticas populares de construção e apropriação do espaço. Foi o que notou Alvaro Siza ao recomendar a intervenção crítica do saber profissional, distante seja das soluções tecnocráticas habituais, seja do discurso populista de negação da própria técnica:

"(...) A Brigada não adopta posições simplistas do tipo "aprender com o povo" ou "ensinar o povo". Intervém, com a sua capacidade técnica, aceitando e criticando as circunstâncias da sua própria formação e aderindo totalmente ao objectivo de que o controlo das zonas degradadas deverá caber às populações que as habitam, no sentido da sua apropriação e recuperação; controlo que, à partida, deverá necessariamente ser alargado à própria cidade e à sua envolvente.(... $)^{\prime \prime 62}$

${ }^{62}$ Álvaro SIZA VIEIRA, in Lotus Internacional, nº13, Milão, 1976.
No Brasil dos anos 1960, diversas foram as contribuições profissionais e intelectuais ao desenvolvimento dos temas da participação, da autogestão e da racionalização da produção no campo da casa popular. No Rio de Janeiro, as experiências do arquiteto Carlos Nelson Ferreira dos Santos na urbanização de favelas notabilizaram-se pelo envolvimento dos profissionais nas lutas urbanas e pelo estabelecimento de um novo paradigma de atuação do arquiteto, que lançava mão de abordagens antropológicas para compreender o "indivíduo dentro da favela" e "indíviduo e a favela dentro das áreas metropolitanas" (PULHEZ, 2007, P.74).

A experiência do projeto de urbanização da favela de Brás de Pina, que resistia à remoção e a relocação para a malfadada Vila Kennedy, figura como marco inicial de formação do grupo Quadra, espécie de assessoria técnica composta por Carlos Nelson e outros colegas arquitetos então recém formados, contratados por iniciativa da comunidade para elaborar um projeto para a urbanização. A partir desta e outras experiências de urbanização de favelas, de relação direta e próxima entre arquiteto e morador e de seus estudos em antropologia, Carlos Nelson foi gradativamente aproximando os campos disciplinares, convertendo-se num autoproclamado "antropoteto", entendendo a questão da casa popular pelo prisma do consumo de sua apropriação e do seu significado para a vida econômica do pobre, polemizando com os paulistas que nesse momento, já nos anos 70, elaboravam a crítica da produção das periferias do capitalismo. 
Em São Paulo, nos anos 60, havia uma polarização de posições a respeito do enfrentamento da questão do projeto da nova casa popular: de um lado a abóbada de tijolos baseada na manufatura do operário formulada e experimentada pelo grupo Arquitetura Nova, e do outro, o concreto industrializado proposto para o conjunto Zezinho Magalhães, pela equipe coordenada por Vilanova Artigas. Essa dicotomia de posturas teria reflexos também na abordagem tecnológica da construção da casa popular.

Talvez seja esse momento o momento no qual os arquitetos ligados à pesquisa das técnicas vernaculares e à participação do operário na obra apartam-se daqueles que propunham a industrialização dos componentes pré-fabricados em massa como única resposta compatível com a extensão do problema habitacional brasileiro. A proposta de Rodrigo Lefevre de um canteiro autogerido e as críticas aos processos modernos da produção arquitetônica, considerados por Sergio Ferro como despóticos e alienantes, punham em cheque o otimismo dos arquitetos em face à pré-fabricação ou à industrialização da construção civil. Algo que, de modo diverso, ainda empolgava profissionais da geração anterior como Vilanova Artigas ou Eduardo Knesse de Mello. ${ }^{63}$ Essa polaridade, claramente expressa nas

\footnotetext{
${ }^{63}$ Já as três gerações de mutirões em São Paulo (de acordo com Carvalho (2004) a experiência pioneira em Vila Nova Cachoerinha, os mutirões da gestão Erundina (1989-1992) e os da gestão Marta Suplicy (2001-2004)) constituem o exemplo mais próximo de realizações concretas que articulam no Brasil as práticas de mutirão como política pública e a arquitetura, nos mostrando a permanência de conceitos como autogestão e território popular para além das idéias de um ou outro arquiteto.
}

publicações institucionais da FAU USP de então - as revistas Desenho e OU... - ecoa até hoje, principalmente em São Paulo, nas discussões acerca do tema.

Foi em meio a experiências e idéias como essas que se constituiu o "episódio" do Cajueiro Seco. Apesar de bastante variadas e mesmo divergentes entre si, elas parecem ter convergido para o enfrentamento dos processos desiguais de urbanização e a transformação da posição tradicional do arquiteto, como técnico especializado, detentor de um saber erudito de alcance universal.

Ao questionar as soluções habitacionais até então praticadas, seja do ponto de vista do método construtivo, seja do ponto de vista do método de projeto, tratava-se de afirmar um outro vínculo político entre os profissionais e as camadas populares. Não por acaso, o ideário de ajuda mútua, participação ou autogestão que aflorou nesse processo vinculava-se diretamente às políticas progressistas e mesmo revolucionárias, aos movimentos insurgentes e aos embates locais com o problema do subdesenvolvimento ${ }^{64}$. E tanto em Cuba, quanto no Peru, Chile e Portugal, assim como no Brasil, a mudança de paradigma profissional viria associada às novas agendas socialistas e à mobilização popular. No entanto, não podemos deixar de lembrar que já nos anos 1960 o ideário da "ajuda mútua assistida" era apropriado

${ }^{64}$ Não por acaso, é o sociólogo Francisco de Oliveira, que nos anos 60 era técnico da SUDENE e acompanhou de perto experiências como a do Cajueiro Seco, o responsável pelo entendimento do subdesenvolvimento como produto inexorável da expansão do capitalismo, para além da visão cepalina. Ver Francisco OlıveIRA, Crítica à Razão dualista / O ornitorrinco. São Paulo: Boitempo Editorial, 2003. 
pelos programas dos Bancos Internacionais de Desenvolvimento, sediados em Washington e controlados pelos norteamericanos.

Analisando os casos referidos sob a ótica de Comerio, podemos agrupá-los em torno dos pólos da realização concreta coordenada por arquitetos maduros e das propostas idealistas politicamente engajadas, porém frágeis do ponto de vista da sua viabilidade e inserção no sistema econômico vigente e na cidade existente, como expediente classificatório para entender as diversas ideologias e posturas que nos anos 60 convergiam sobre a questão da habitação popular e a autoajuda.

Se Comerio começa sua análise só nos anos 1960, é importante mencionar que autores como Richard Harris e Ray Bromley relativizaram a importância do trabalho de John Turner para a disseminação da auto ajuda assistida mostrando-nos que muito antes dele, outros teóricos e técnicos ligados aos órgãos de habitação americanos e quase que como uma consequência natural ao Banco Mundial e ao Banco Interamericano de Desenvolvimento, como Jacob Crane e Charles Abrams já advogavam pelo que conhecemos genericamente como mutirão.

Afastando a tendência de construir uma genealogia ${ }^{65}$, enfatizar algum suposto pioneirismo ou a velha idéia de novidade, queremos abrir caminho para uma análise crítica do episódio do Cajueiro Seco, nutrindo-se para isso da leitura das experiências contemporâneas e analisando posteriormente seus desdobramentos, enxergando pequenas especificidades e muitas ressonâncias em torno de uma idéia que parece e pareceu, em distintos contextos, a mais simples e óbvia para lidar com um problema dos mais complexos.

O quadro apresentado reforça o interesse pelo Cajueiro Seco, já que, num episódio interrompido e isolado de grande parte dessas experiências (exceção feita no caso do MUD), floresceram questões que continuariam a ser discutidas por décadas, sem que o caso pernambucano fosse considerado nesse debate, permanecendo em relativo isolamento.

Vemos no Cajueiro Seco o arquiteto de formação modernista repensar seus conceitos, a formulação de um programa habitacional paradigmático, a ocupação do poder pelos setores populares e pelas forças de esquerda e a tentativa clara de se impôr o modo de vida norteamericano como alternativa à revolução; tudo isso estimula uma análise aprofundada do episódio à luz das experiências contemporâneas que, partindo de problemas genericamente parecidos mas conjunturalmente diferentes, chegaram a soluções análogas, cujas diferenças revelam muito.

\footnotetext{
${ }^{65}$ Para isso, teríamos que começar a contar essa história a partir das experiências de Hassan Fathy em New Gurma nos anos 40, para não falar do mutirão "ancestral" praticados tanto pelos caipiras descritos por Antônio Cândido quanto pelos Incas que habitavam o território peruano antes da colonização espanhola..
} 


\subsection{Impasses da política habitacional brasileira}

A atuação dos Institutos de Aposentadoria e Pensão (IAPs) na provisão de habitação social através de suas carteiras prediais produziu cerca de 140 mil unidades entre os anos de 1937-64. Quantitativamente pouco se comparado ao déficit habitacional brasileiro da época, mas segundo Bonduki,

"do ponto de vista qualitativo, a produção de conjuntos habitacionais pelos IAPs merece destaque tanto pelo nível dos projetos como pelo impacto que tiveram, definindo novas tipologias de ocupação do espaço e introduzindo tendências urbanísticas inovadoras" (BONDUKI, 1998, P. 127).

Como campo para a arquitetura moderna, a produção dos institutos constituiu uma importante aplicação de vários dos princípios funcionalistas e de experimentação em termos de unidades e tipologias em edifícios que marcaram a paisagem das capitais brasileiras e que ainda hoje são reconhecidos e disputados por suas qualidades.

No entanto, a produção dos IAPs tem seus limites que as distanciam do campo de interesse específico deste trabalho, na medida em que representavam um forma indireta de ação governamental, fracionada entre os segmentos corporativos diversos da classe trabalhadora, o que não incluía a população moradora de mocambos ou favelas, precária e forçosamente inserida na sociedade de consumo e no processo de urbanização da sociedade brasileira, no sentido amplo atribuído por Antônio Cândido à condição dos "Os parceiros do Rio Bonito" (CÂNDIDO, 2001).

Era clara a direção dos Institutos, cada qual com seu estatuto, no sentido de proporcionar habitação tão somente a seus associados ou trabalhadores formais em nível equivalente e não assumir o fardo da questão das favelas, cortiços e a habitação dos excluídos da estratificação social por categoria profissional, característica da política trabalhista do Estado Novo, inspirada no fascismo.

As carteiras prediais dos IAPs serviam como instrumento para a política populista do Estado Novo, segundo a qual "tem direito quem tem a carteira assinada", apropriando-se de uma demanda de apelo popular mencionada diretamente por Vargas em seus discursos para distribuir privilégios entre os bem relacionados com os quadros burocráticos dos Governo e dos Institutos (BONDUKI, 1998).

Dentro dessa visão, os favelados eram marginais sem direito à proteção do Estado e não se cogitava a concessão do financiamento sem grantias reais de segurança do patrimônio dos institutos e perspectiva de retorno, principais e declaradas atribuições dos IAPs.

"Independente desses casos escandalosos de clientelismo e apropriação privada de recursos públicos, merece exame mais aprofundado o caráter corporativo dos institutos, que estabelecia uma distinção entre quem podia e quem não podia ser beneficiado, não pelo aspecto social, mas pela associação a corporação. Traçou-se, com isso uma linha divisória entre os cidadãos com direitos sociais, entre os quais os 
trabalhadores assalariados, e os sub-cidadãos, que não tinham lugar na nova ordem social" (BONDUKI, 1998, P.109)

Havia na época uma pressão por parte dos trabalhadores para que os investimentos das carteiras imobiliárias fossem dirigidos a eles próprios na medida em que a principal contribuição a formar o patrimônio dos Institutos vinha dos impostos descontados na folha dos assalariados.

"Essa tensão permanente entre uma perspectiva social e outra atuarial marcou as atividades das carteiras imobiliárias dos IAPs e, em consequência, o surgimento das políticas de habitação social no Brasil" (FARAH, 1983 apud BONDUKI, 1998)

Vargas, em 1945, fez um discurso no Pacaembu transmitido pelo rádio, no qual acenou claramente com a possibilidade de "inverter 500 milhões de cruzeiros" em uma "política de mais largo alcance relativamente ao emprego dos fundos acumulados". Para tanto, seria necessário unificar os Institutos sob a égide do Instituto de Serviço Social do Brasil (ISSB) e criar um poderoso e eficiente órgão federal para lidar exclusivamente com a questão da habitação, o que não foi conseguido nem por ele nem por seu sucessor, Dutra.

A atuação dos IAPs, entre o Estado Novo e o Golpe militar, portanto, serve de marco para este trabalho porque revela o início da atuação governamental no campo da habitação e os problemas resultantes da falta de uma política habitacional definida e viável, acumulando experiências e realizações que serviriam de base para a elaboração de um plano mais claro e consequente, cuja inexistência é celebrada por diversos autores daqueles dias até hoje.

A Fundação da Casa Popular (FCP), criada nos primeiros momentos do Governo Dutra, imediatamente após a Segunda Guerra, com a expectativa política de que a casa própria afastasse o trabalhador brasileiro do comunismo, entrou para a história como o primeiro órgão do governo federal com a atribuição de solucionar o problema habitacional, como "um verdadeiro órgão de política urbana". Mas a atuação do órgão acabou sendo bombardeada por diversos setores à direita (como a indústria de materiais de construções e o mercado imobiliário) e à esquerda (como o PCB, que via na idéia da casa própria um instrumento de apaziguamento das massas).

"Intervir na questão da moradia era politicamente importante, pois " com a crise, esse problema passara a ter grande visibilidade política e adquirira potencial para articular um consenso, pois incorporava demandas populares (habitação e emprego) e empresariais (especialmente das indústrias de materiais e da construção civil). Ademais, a habitação constituía uma peça importante do discurso conservador e de setores da Igreja católica, que identificavam a posse de um imóvel à estabilidade social." (MELO 1991 apud BONDUKI, 1998)

Criticada por diversos setores do espectro político, tendo sofrido vetos importantes no projeto de lei que a institui em 1946, especialmente na questão da origem dos recursos que financiariam tamanha empreitada, a FCP pouco produziu em termos de unidades. Em seus vinte anos de existência, construiu em torno de 18 mil unidades, nem 15\% da produção dos IAPs, grande parte delas em seus primeiros cinco anos de existência, sobrevivendo no período 
subsequente até o golpe de 64 como uma instituição sem rumo, importância ou direção.

Grande parte do pouco que produziu a FCP baseou-se no tipo ideal de casa isolada no lote unifamiliar em cidades pequenas do interior, afinado com a ideologia da Igreja e do subúrbio norteamericano, na contracorrente das propostas dos arquitetos modernos que projetaram os IAPs. Seria um erro induzir à polarização maniqueísta entre o apartamento moderno nas grandes cidades e a arcaica casinha no lote, até porque existem gradações e contra-exemplos, mas tais tipos ilustram as intenções políticas que pautavam as distintas atuações dos IAPs e da FCP.

A produção de habitação moderna brasileira vem sendo melhor estudada recentemente pela historiografia de arquitetura, permitindo iluminar distinções e variações no interior das grandes coordenadas que informam a história das políticas habitacionais no país. Uma das questões trazidas à tona foi o trânsito de profissionais de uma mesma geração entre os IAPs e os projetos para a FCP e a iniciativa privada, disseminando e diluindo por esferas distintas da produção, e por regiões diversas do país, os referenciais modernos de habitação social e econômica.

Se analisarmos a implantação da tipologia duplex ou maisonettes, nos edifícios urbanos no Brasil teremos um exemplo da sintonia e integração das propostas praticadas pelos IAPs, pela FCP e por parte da iniciativa privada (SAMPAIO, 2002) entre si e com a arquitetura moderna internacional.

Propostas por Le Corbusier desde os utópicos immeubles-villas às concretas Unités d'Habitation e intensamente usados pelos arquitetos do London City Council ${ }^{66}$ [fontes], a unidade duplex foi realizada pioneiramente no campo da habitação social no Brasil em 1939 por Carlos Frederico Ferreira, no Edifício Inconfidência no Recife, projeto do IAPI, reaparecendo nos projetos de Eduardo Knesse de Mello para os IAPs (Ed. Japurá 1947-SP) e para o Banco Hipotecário Lar Brasileiro (Guapira e Hicatu - Jardim Ana Rosa 1952- SP), no Edifício Anchieta, projetado pelos irmãos Roberto e no internacionalmente reconhecido Pedregulho, de Affonso E. Reidy, no âmbito do Departamento de Habitação Popular do Rio de Janeiro.

Tais projetos representavam a cristalização de uma geração de arquitetos modernos experientes, que acreditavam no edifício urbano implantado em terrenos relativamente centrais como tipologia adequada à habitação social, na qual a unidade era a célula essencial, cuidadosa e generosamente dimensionada, iluminada e ventilada interligadas entre si por "ruas elevadas" que se conectam e complementam o espaço público urbano,

\footnotetext{
${ }^{66} \mathrm{O}$ escritório público de arquitetura habitacional do London City Council que durante a gestão dos trabalhistas nos anos do após Segunda Guerra e produziu conjuntos paradigmáticos como Roehampton, Longborough Road entre outros.
} 
transformado em parque quando em terreno periférico ou oferecendo o térreo como espaço para a cidade em terreno urbano, oferecendo por vezes lavanderias coletivas, terraços de uso comum, centros comunitários ou comércio local.

O uso da tipologia duplex pela iniciativa privada foi também implementado dentro do contexto da "Habitação Econômica", como no Edifício Eiffel, na Praça da República, projetado por Niemeyer na mesma época dos emblemáticos edifícios Copan e Montreal, que representariam uma forma de investimento interessante para a classe média que acumulava algum patrimônio e o investia em apartamentos "econômicos" que seriam alugados para a classe empobrecida que não seria atingida por programa habitacional e não se dispunha a autoconstruir na periferia.

Tal tendência revelou uma operação oportuna do capital imobiliário que nesse momento se acumulou e se avolumou e mais tarde migrou para outras atividades igualmente centrais do capitalismo como a imprensa e as comunicações e o setor financeiro. O caso da incorporadora Banco Nacional de Investimentos - BNI, que alavancou o capital que construiu a Folha de S. Paulo e teve sua estrutura incorporada pelo Bradesco é analisado por Rossella ROSSETO, 2002 que estudou também a invenção da tipologia kichenette nesses mesmos empreendimentos como forma de burlar a legislação e obter um produto ainda mais condensado em termos de áreas, investimento e retorno financeiro.
Dentre a escassa produção da FCP se destaca o Conjunto Residencial de Deodoro, com 1.314 unidades. Construído pela Fundação da Casa Popular e projetado por Flávio Marinho Rego em 1954, no Rio de Janeiro, Deodoro nos interessa particularmente, tanto por representar de maneira concreta essas propostas em sintonia quanto por ter sido projetado por um arquiteto pernambucano formado no Rio em 1950, que iria colaborar na concepção do projeto de Cajueiro Seco.

Deodoro é um dos poucos exemplos de conjuntos de grande escala e inseridos na região metropolitana carioca produzido pela FCP, articulando blocos laminares mais compactos como duas estruturas longilíneas serpenteante de 450 e 250 metros de extensão, provável referência ao bloco principal do Conjunto do Pedregulho.

Naquele momento, Flávio Marinho Rego já era uma figura importante no debate da arquitetura brasileira e no IAB-RJ, tendo trabalhado com Oscar Niemeyer e com Jorge Machado Moreira e acumulado experiência em habitação popular como assistente de Reidy no Departamento de Urbanismo do RJ, no estágio de trabalho concedido pelo Ministério de Reconstrução do governo francês em 1954-55 para conhecer a reconstrução de cidades bombardeadas na Europa Ocidental, além de ter elaborado os projetos do Museu Goeldi em Belém (1954) e o Museu de Zoologia da USP (1959).

Flávio Marinho Rêgo era conhecido por seus contemporâneos de IAB como Maurício Castro (Entrevista ao autor, Set/2007) por ardorosas defesas de opiniões por vezes polêmicas, como sua particular posição e avaliação perante Brasília: 
"Eu acho que Brasília foi o fechamento de um ciclo na arquitetura

brasileira.(...) Realizou-se ali uma arquitetura que, na minha opinião, já estava atingindo sei limite de utilização no Brasil. (...) A influência que

Brasília representou para as novas gerações foi muito pequena. Nós não sentimos que Brasília tenha representado em termos de formulação de arquitetura, um impacto. Poderia ter representado. Não representou" (IAB, 1982 , p. 152-153) 


\subsection{Anos 60: os arquitetos e as políticas}

"O que é que você fez desde que está diplomado O que é que você fez pra se ver realizado Trabalha, ganha dinheiro, anda bem alimentado Nada disso companheiro é grande pra ser honrado Você só fez atender ao homem que tem dinheiro Que faz obra pra se ver, pra agradar o turista Que deixa o pobre morrer, que tira o pobra da lista Na lista dos seus amigos, amigos capitalistas São escolas hospitais teatros apartamentos Construções industriais, verdadeiros monumentos Tudo isto o pobre vê, ele não pode tocar Perdido por essas terras que não pode cultivar Sem ter casa para morar, sem ter livro pra estudar, Sem ter um olhar amigo, um ombro pra se encostar Mas se você é honrado não deve se conformar Põe a prancheta de lado e venha colaborar O pobre cansou da fome, cansou de tanto esperar E vai partir para a luta, que Cuba soube ensinar"

\section{"Samba do arquiteto" Oscar Niemeyer,1962}

\footnotetext{
${ }^{67}$ Extraído da gravação original disponível em

http://dearquiteturas.blogspot.com/2008/08/samba-do-arquiteto.html
}

Seja ocupando espaços de poder representando o povo e falando em nome dele como no caso de Belaunde Terry ou Arthur Lima Cavalcanti, seja engajando-se nas práticas populares em torno da habitação social como nos casos de John Turner ou Carlos Nelson Ferreira dos Santos, o fato é que os anos 60 se caracterizaram por uma intensa politização dos arquitetos, acompanhando as tendências revolucionárias que marcariam a década na política e na cultura. Acontecimentos como a crise dos mísseis, o assassinato de Kennedy, o golpe militar de 64 no Brasil e as revoltas estudantis de maio de 1968 em Paris não deixariam de afetar o campo da arquitetura, doravante permeado pelas grandes polarizações ideológicas ${ }^{68}$ que redefiniam as expressões concretas do subdesenvolvimento, da marginalidade e da dependência a partir de sua inserção nas lógicas globais de expansão do capitalismo.

Em São Paulo, a polarização atingiu profundamente os arquitetos da esquerda e a FAU USP, dividida entre as posições do PCB defendidas por Vilanova Artigas e o engajamento revolucionário de ruptura com o projeto nacional-desenvolvimentista, em torno do grupo Arquitetura Nova (KOURY, 2003 e ARANTES, 2002). Tal polarização radicalizou-se com o advento do golpe militar, dividindo os arquitetos entre aqueles ligados à resistência armada ao regime de exceção e os

\footnotetext{
${ }^{68}$ Sobre o engajamento político dos arquitetos nesse contexto, ver Aracy AMARAL. "A polêmica sobre a função social da arquitetura" in Arte para quê??. São Paulo: Studio Nobel, 2003
} 
profissionais do desenho que preferiam adotar uma postura mais conciliatória projetando para o Estado obras de inegável qualidade.

Em Pernambuco, é possível que a esquerda nacionaldesenvolvimentista tivesse maior prestígio na conjuntura reformista dos anos 1960, seja antes seja depois do golpe. Talvez em razão do enraizamento histórico do PCB na grande política e no Estado desde 1945 e sobretudo com a estruturação da Frente Popular em meados da década de 1950.Inclusive em um meio profissional que, reivindicando princípios e valores diversos daqueles disputados no Rio de Janeiro e em São Paulo, por vezes manifestava alguns sinais de identificação com plataformas desenvolvimentistas de combate às disparidades regionais e afirmação de políticas populares comprometidas com a realidade nordestina.

Cajueiro Seco não é expressão única nesse sentido, mas a ação de figuras como Antonio Bezerra Baltar junto ao CEPEU, Arthur Lima Cavalcanti, Gildo Guerra, Liana de Barros Mesquita, Neide Motta de Azevedo (LAPROVITERA, S/D), entre outros jovens arquitetos vinculados à SUDENE e à Faculdade de Arquitetura da Universidade do Recife.

Borsoi, é verdade, insiste em declarar que as idéias e a produção de Vilanova Artigas, apesar de conhecidas e respeitadas localmente, não teriam tido grande repercussão no debate arquitetônico pernambucano. No entanto, sem pleitear a influência de um sobre o outro, idéia que pressupõe uma hierarquia entre as duas situações, é possível reconhecer posturas comuns entre pernambucanos e paulistas nos anos 60. Seja no interesse pelo tema da pré-fabricação, seja no investimento em programas sociais de obras públicas, seja ainda na preocupação com os aspectos construtivos da arquitetura. O fato é que, guardadas as proporções e as especificidades devidas, é possível reencontrarmos compromissos sociais e matrizes produtivistas comuns aos dois casos. A despeito da atuação local de arquitetos formados no Rio, ou da clara referência às obras cariocas, de Pampulha a Brasília, entre as primeiras turmas de arquitetos modernos formados na FAUR (LAPROVITERA, S/D). Libertando-se portanto de uma visão restrita a "Escolas" na arquitetura brasileira, vemos nestes aspectos construtivos e sociais traços de uma arquitetura brasileira desse período, na qual podem se agrupar a produção de figuras tão distintas quanto Acácio Borsoi, Vilanova Artigas, João Filgueiras Lima, Lina Bo Bardi, Sérgio Ferro entre outros outros.

Segundo Geraldo Gomes da Silva, a participação dos arquitetos pernambucanos na construção de Brasília foi restrita. Embora profissionais, professores e alunos tenham visitado os canteiros de obras da nova capital, à exceção de Glauco Campello, não participaram diretamente de projetos. No entanto, a percepção da obra tendeu ao entusiasmo peculiar à visão desenvolvimentista de origem, passando despercebidas as imensas contradições entre o concurso e o projeto, o canteiro e o desenho denunciadas em São 
Paulo, seja por críticos como Geraldo Ferraz ${ }^{69}$, seja por Sérgio Ferro e os membros do Arquitetura Nova.

A intervenção de Gilberto Freyre no debate sobre Brasília no início da década de 60, foi, no plano local, certamente uma exceção. E suas restrições lançadas contra o projeto da nova capital como intrusão urbanística, polida e formosa no cenário regional agreste dos sertões, absolutamente indiferente às promessas contemporâneas de um Brasil inter-regional, ao ideário afro-lusobrasileirista, assim como à realidade multidisciplinar da urbanização e às novas orientações empiristas do urbanismo ${ }^{70}$, não parecem ter obtido grande impacto na opinião profissional.

Não obstante, retomando a interessante teoria de Carlo Ginzburg sobre a cosmogonia do moleiro Menocchio como uma expressão do choque da cultura popular com a escrita, popularizada pelo advento tecnológico da imprensa, é possível em parte compreender a politização da arquitetura no Brasil nos anos 60 como uma expressão

\footnotetext{
${ }^{69}$ Ver José Tavares Corrêa de LIRA, "Comunicação", "Crítica modernista e urbanismo: Geraldo Ferraz em São Paulo, da Semana a Brasília". In Anais em CDROM. XI Encontro Nacional da ANPUR. Salvador: 23 a 27 de mai. 2005.

${ }^{70}$ Gilberto Freyre. "Brasília". Brasis, Brasil, Brasília. Rio de Janeiro, Record, 1968, pp. 175-197.
}

da reação dos arquitetos ao contraste entre as formas futuristas de Brasília $^{71}$ e as arcaicas condições que as produzem.

Tanto as análises de Sérgio Ferro sobre o despotismo do desenho em suas relações técnicas e sociais com o canteiro, quanto os trabalhos de assessoria de Carlos Nelson Ferreira dos Santos aos movimentos de favela no agenciamento de seus direitos à cidade, ou as pesquisas de Lina Bo Bardi a partir do pré-artesanato nordestino como alternativa a um processo de industrialização do país que se desenvolvia em detrimento das condições de vida, trabalho e cultura do povo, tornam evidentes as contradições que cercam os arquitetos empenhados no sonho modernista.

O fato é que, a partir da experiência de Brasília, muitos dos arquitetos comprometidos com as reformas de base, os governos populares e os movimentos sociais seriam levados a pensar as questões produtivas inerentes à prática liberal do projeto, o que acabaria por se tornar um divisor de águas nas formas de engajamento profissional dos arquitetos no período, bem como uma das características fundantes de parte da arquitetura brasileira contemporânea.

O golpe de 64 atingiu também a classe profissional, apartando o campo de trabalho em pelo menos três posições muito recorrentes: em primeiro lugar, os arquitetos do mercado, que viriam a se beneficiar de um contexto de produção imobiliária ativada pelos grandes aportes do

\footnotetext{
${ }^{71}$ Ver também os documentários "Brasília: contradições de uma cidade nova" (1967) de Joaquim Pedro de Andrade e "Conterrâneos velhos de guerra" (1991) de Vladimir Carvalho
} 
Banco Nacional de Habitacional; em segundo lugar, os profissionais engajados, ligados direta ou indiretamente ao "partidão", que ora continuariam a intervir nas obras públicas, em uma postura estratégica de "evitar o confronto direto" com os militares, ora a atuar em nichos de mercado sensíveis à experimentação projetual, tecnológica e produtiva na arquitetura;em terceiro, os arquitetos "revolucionários", que diante das frustrações teóricas e práticas, seriam levados a recusar a própria prancheta como espaço de dominação, opressão e alienação do trabalho.

Vilanova Artigas, que em 1952 perguntara-se "O que fazer?" nos caminhos sem saída da arquitetura moderna, em 1965 apontaria "Uma falsa crise" d'O Desenho em 1967. No entanto, arquitetos que no começo dos anos 1960 estavam envolvidos em projetos culturais para além da profissão pareciam perder espaço e vigor. Foi este o caso de Lina Bo Bardi, cujas exposições realizadas em espaços por ela projetados, como "Bahia no Ibirapuera", realizada em 1959 durante a V Bienal de Arte de São Paulo, ou "Civilização do Nordeste", montada no no Museu de Arte Popular instalado no Solar do Unhão, em Salvador, em 1963, viriam muito de suas energias utópicas

72 "'O que fazer?', perguntava Artigas ao final de Caminhos da arquitetura moderna: 'Arquitetura ou revolução?'. Ao repor no contexto da Guerra Fria o famoso dilema taylorista, e leninista, a propos, afastava-se radicalmente da exortação corbusieriana: para além de uma arquitetura administrada, calibrada com a sociedade maquinista, o arquiteto brasileiro reincidia contra o engodo humanístico, 'uma certa ganga utópica' da profissão em regime capitalista. Para Artigas, nem uma coisa nem outra, responderia: 'até lá...uma atitude crítca em face da realidade" J.T.C. LIRA, "Apresentação" in VILANOVA ARTIGAS, J.B. Caminhos da arquitetura . São Paulo: Cosac Naify, 2004 arrefecerem-se no final da década, como na mostra bem mais civilizada "A Mão do povo brasileiro", que inaugurou o MASP da Avenida Paulista em 1969. ${ }^{73}$

A Arquitetura Nova, cujas propostas e práticas também extravasavam o campo liberal de atuação do arquiteto para o teatro, as artes plásticas, a teoria e o canteiro de obras, seria desmobilizada, restando ao arquiteto Rodrigo Lefevre a perpetuação no campo acadêmico das utopias coletivistas ${ }^{74}$.

Também as propostas pedagógicas mais generosas que estavam sendo implantadas na FAU USP ao longo dos anos 1960 nos Fóruns de ensino foram comprometidas ou obstadas. Simbolicamente foram antingidas as personalidades influentes de Vilanova Artigas, Paulo Mendes da Rocha e Jon Maitrejean, cassados da Universidade pelo regime militar enquanto vários alunos e professores eram processados, presos ou torturados pelos órgãos de segurança pública.

Oscar Niemeyer, o arquiteto da capital federal recentemente inagurada e agora ocupada pelos militares, referência central tanto na arquitetura brasileira quanto no "partidão", seguirá para um período de auto-exílio na França, onde realizaria projetos emblemáticos como a sede do Partido Comunista Francês (1967) e a Universidade de Constantine, na Argélia (1969).

\footnotetext{
${ }^{73}$ Ver Mayra RodRIGUES, Exposições de Lina Bo Bardi, Trabalho Final de Graduação São Paulo: FAU USP, 2008 e Juliano PereIRA, A ação cultural de Lina Bo Bardi no Nordeste(1958-1964) Mestrado EESC USP São Carlos: EESC USP, 2001. ${ }^{74}$ Ver mestrado de Rodrigo LeFEVRE, FAU USP, 1981.
} 
Em Pernambuco, também as principais lideranças da Faculdade de Arquitetura seriam desmobilizadas: os professores Amorim e Borsoi foram presos, assim como o líder estudantil Geraldo Gomes da Silva, que se viu obrigado a estudar na prisão para completar o curso $^{75}$. Gildo Guerra, o arquiteto que presidia o SSCM de Arraes, foi perseguido e exilou-se no Chile e segundo Borsoi, continuou a trabalhar no campo da habitação social como funcionário do Banco Interamericano de Desenvolvimento na América Latina ${ }^{76}$. O arquiteto e deputado Artur Lima Cavalcanti teve seu mandato e direitos políticos cassados em abril de 1964 pelo Ato Institucional № 1 .

Depois da breve prisão, Borsoi daria sequência à sua carreira profissional, afastando-se num primeiro momento do tema da habitação social para dela se reaproximar em conjunturas mais favoráveis, através do $\mathrm{BNH}$, em propostas de primorosa qualidade projetual mas desprovidas dos conteúdos "revolucionários" que transformariam a experiência do Cajueiro Seco no mito de origem dos mutirões autogeridos, dos projetos de habitação participativos e do aproveitamento moderno das técnicas tradicionais de construção.

75 De acordo com entrevista ao autor realizada em setembro de 2007, o professor Ayrton Carvalho permitiu que ele fizesse provas da cadeia, enviando-lhe parte da bibliografia dos cursos sob sua responsabilidade para o cárcere.

${ }^{76}$ Acácio Gil BORSOI Entrevista ao autor, Recife, set /2007. 


\section{A EMERGÊNCIA DO POPULAR NA POLÍTICA E NA CULTURA}

Para compreender a dimensão da experiência do Cajueiro Seco, é necessário pensar o momento político e cultural dos anos 1960, período ao mesmo tempo fértil e conturbado. Para entender o episódio nem como uma decorrência imediata dos debates e realizações no âmbito estritamente profissional ou como consequência de uma plataforma política que passava pelas questões da cultura popular, optamos por destacar alguns pontos e questões que estavam colocados naqueles anos em Pernambuco, que contribuem com outras leituras e significados a partir da perspectiva extra arquitetônica. Longe de traçar panoramas que não refletiriam as diversas faces de cada uma das trajetórias e histórias apresentadas que recentemente vem sendo estudadas, o que se busca aqui é destacar algumas experiências e acontecimentos em sua relação com a situação na qual se inscreve, iluminando assim a experiência do Cajueiro Seco a partir de campos disciplinares fora dos limites da arquitetura.

No Brasil, particularmente em Pernambuco nos anos 1960, a tensão política se coadunou com a fermentação de novas idéias no campo cultural de modo a revolucionar mutuamente os campos. A ligação entre os aspectos específicos da disputa política e os acontecimentos no plano da cultura, notadamente na relação da cultura erudita com a popular, não podem ser entendidos como simples relação causal. O importante aqui é reconhecer o papel central que o "povo" ocupava pela primeira vez, nas formulações de intelectuais, políticos, artistas e arquitetos na "revolução brasileira", alternativa nacional para a superação do subdesenvolvimento.

Do ponto de vista político, a proposta para este capítulo é expor os conflitos e a radicalização do quadro político brasileiro nos anos 60 , bem como a fragmentação e o confronto das forças populares e reacionárias que viriam a desestabilizar o equilíbrio de valores e padrões de legitimidade das instituições no Brasil, no contexto das Reformas de Base e da guerra fria. Contemplam-se também os acontecimentos e propostas culturais como o Movimento de Cultura Popular pernambucano, o papel do Nordeste no panorama simbólico e imaginário da nação e o potencial transformador que naquele momento se atribuiu ao povo, considerado talvez pela primeira vez como categoria histórica. Embora tais questões se relacionem intensamente com os processos políticos, notadamente a ascensão das forças populares representadas pela esquerda, os debates culturais constituem um campo com certa autonomia, que muito mais do que refletir um engajamento, fornecem elementos e proposições para o debate político, numa interação mútua que está na base da "Revolução" que se processava.

Aumentou o interesse dos intelectuais na cultura popular, refletindo a esperança no povo como força transformadora e como manancial de formas puras da arte, em estreita relação com a sua vida. A posse de Arraes no Governo de Pernambuco revestiu-se de significados, inscrevendo o "povo como categoria histórica" tanto na vida política quanto no campo cultural. O Movimento de Cultura 
Popular (MCP) talvez seja a principal síntese das novas práticas políticas que envolviam o novo governo popular e a sociedade civil para a superação das dificuldades e deficiências educacionais e culturais do povo. Evocá-lo aqui é importante para inscrever no mesmo contexto trajetórias que desenvolvem idéias abstratas de um projeto coletivo em ebulição como as de Paulo Freire, Abelardo da Hora, Eduardo Coutinho entre muitos outros artistas, educadores e intelectuais que estavam em Pernambuco nos anos 1960, cujas idéias e obras podem ter a ver com as dos arquitetos pernambucanos que naquele momento configuravam uma "Escola do Recife".

Inúmeros são os estrangeiros que estão dedicados à pesquisa e ao registro da arte e da cultura popular no Nordeste como os fotógrafos Pierre Verger e Marcel Gautherot ${ }^{77}$ mas não por acaso a maior expressão do valor que se dá à cultura popular vem através da arquiteta Lina Bo Bardi, que organizou a exposição "Civilizacão do Nordeste", em Salvador em novembro de 1963. Ali ficou clara a contraposição que se propunha ao desenvolvimento industrial e ao projeto construtivo brasileiro; (re)conhecer o subdesenvolvimento seria etapa necessária à sua superação. O lugar do Nordeste dentro do imaginário nacional e no quadro de desigualdades regionais deve ser considerado; da "Invenção do Nordeste" como região à cristalização da imagem recorrente de atraso e subdesenvolvimento, há um vasto campo de pesquisas reveladoras da riqueza e diversidade culturais aberto por Mario de
Andrade, no qual se inserem a atuação do Centro de Estudos Folclóricos da FAU USP, as pesquisas de Lina, o Museu de Arte da Universidade do Ceará, do próprio Instituto Patrimônio Histórico e Artístico Nacional (IPHAN) e diversos pesquisadores a ele ligados.

Procuramos inscrever o período entre as principais coordenadas políticas que ajudam a entender o clima e as tensões em Pernambuco durante o breve e conturbado Governo de João Goulart, num contexto internacional de Guerra Fria extremamente acirrada com a Crise dos Mísseis, no qual nos interessa particularmente a atuação da Aliança para o Progresso no Brasil, a SUDENE, o fenômeno das Ligas Camponesas, a conquista gradual do poder pela ampla Frente do Recife e o golpe de $1^{\circ}$ de abril de 1964. Alguns destes episódios da história recente do país ainda estão sendo devidamente pesquisados e estudados, cabendo aqui trazê-los a memória para não serem desconsiderados em análises isoladas da cultura, das artes ou da arquitetura.

\footnotetext{
${ }^{77}$ ver Aujourd Hui, Edição especial Brasil, 1964.
} 


\subsection{Entre Havana e o Mundo Livre - O governo Jango}

Desde a posse em 1962, o governo de João Goulart foi marcado por tensões e articulações políticas entre extremos cada vez mais polarizados, que cogitaram por diversas vezes o abandono da democracia como meio de superar a crise política que se instaurara com a renúncia súbita e inesperada de Jânio Quadros. A posse do vicepresidente, prevista pela Constituição vigente no caso de renúncia do titular, foi questionada por parte da sociedade brasileira, apoiada pelos ministros militares, que preferiam abrir mão das instituições democráticas conquistadas, a ver o Brasil comandado por uma figura ligada ao mesmo tempo ao trabalhismo getulista e, suposta e equivocadamente, ao comunismo. Segundo o brasilianista Thomas Skidmore, a chave para a compreensão desse momento está nas divergências entre os militares, entre os que viam Jango como "um notório agitador dos meios operários", que tinham "temor constante de que um movimento operário 'sindicalista' pudesse destituir as forças armadas da sua posição de grupo mais poderoso no cenário político brasileiro", e aqueles que tomaram parte na "frente legalista" que, junto com amplos setores da sociedade civil, garantiu por fim a posse do vice de Jânio Quadros.

O regime parlamentarista apareceu como sugestão de uma Comissão do Congresso rumo a um acordo que garantisse o cumprimento à Constituição sem dar todos os poderes ao ex-Ministro do Trabalho de Vargas, forçado a renúncia em 1954 pelos mesmos militares e pelos mesmos motivos que agora obstavam sua posse. (SKIDMORE, 1976, p.257)

Durante o período parlamentarista, Jango tratou de desconstruir sua imagem ligada ao comunismo e tentou reunir a aliança entre o Partido Trabalhista Brasileiro (PTB) e Partido Social Democrático (PSD) que sustentava o getulismo, para então iniciar a campanha pela restauração do presidencialismo, que foi aprovado em plebiscito em Janeiro de 1963. O plebiscito, no qual o Sim ao Presidencialismo venceu com aproximadamente $80 \%$ dos votos, foi considerado por Jango sua verdadeira eleição, abrindo caminho para suas propostas transformadoras. (BANDEIRA, 1978, p.88)

Jango então passou a preparar as bases para aquelas que seriam as grandes realizações de seu governo: por um lado a estabilização econômica, baseada nas recomendações e apoio do FMI e dos EUA e no Plano Trienal ${ }^{78}$, e as Reformas de Base, que diminuiriam as desigualdades da sociedade brasileira e abririam caminho para o desenvolvimento do país em patamares superiores aos já conseguidos, sob todas as perspectivas. A tarefa não era simples, especialmente para um Governo que via sua sustentação política corroer-se ao longo do mandato e que tinha como meta aliar o desenvolvimento dos melhores tempos de Juscelino (algo em torno de 7\%) a baixíssima inflação do período Dutra (10\%).

\footnotetext{
${ }^{78}$ Elaborado pelos Ministros San Tiago Dantas (Fazenda) e Celso Furtado (Planejamento).
} 
Durante o período Jango, as relações entre o Governo Brasileiro e o americano foram ficando progressivamente tensas. Se a relação diplomática e comercial entre os dois países durante os períodos Dutra e Juscelino foi tranquila, toda a política externa americana com relação ao Brasil teve de ser revista quando o nacionalismo trabalhista voltou ao poder. As crescentes invasões de terras, greves e mobilizações populares alarmavam os americanos, assim como o questionamento da hegemonia das empresas de capital estrangeiro (principalmente norteamericanas) por parte do governo federal. No plano regional, a ascensão de governos populares, notadamente o de Arraes em Pernambuco e as posturas de líderes da esquerda como Brizola e Julião começaram a ser monitoradas pela inteligência militar estadunidense.

A questão dos investimentos estrangeiros no país é um marco interessante das expectativas e possibilidades que mobilizavam a atuação do Governo. Jango foi a Washington pessoalmente negociar um acordo com o presidente John Kennedy e o embaixador americano Lincoln Gordon para acabar com o monopólio americano nos setores estratégicos no Brasil, como energia elétrica, telefonia e transportes. O ponto fundamental desse acordo estabelecia que as indenizações da nacionalização das companhias americanas fossem investidas no país, de modo a reter o investimento estrangeiro, retomar a soberania nacional nesses setores e regulamentar o que já vinha sendo feito intempestivamente por governadores de linhas tão opostas como Leonel Brizola e Carlos Lacerda.
As medidas antiinflacionárias recomendadas pelo FMI minavam o apoio popular à figura de Jango, ao mesmo tempo em que o detalhamento do que seriam as Reformas de Base dava vazão aos sentimentos dos setores poderosos que viam no Governo Federal e seus aliados, como Brizola, uma ameaça à segurança nacional. Sobretudo, a questão da reforma agrária representou nesse momento as intenções, as dificuldades e as pressões com as quais lidava Jango ao governar, servindo como uma espécie de termômetro para a tensão política interna.

"É fácil perceber que as reformas de base não se destinavam a implantar uma sociedade socialista. Eram apenas uma tentativa de modernizar o capitalismo e reduzir as profundas desigualdades sociais do país, a partir da ação do Estado. Isso porém implicava uma grande mudança à qual as classes dominantes em geral, e não apenas os latifundiários como se pensava, opuseram forte resistência" (FAUSTO, 2007, p. 448-449).

Em alguns setores da sociedade consolidou-se o consenso em torno da Reforma Agrária, ainda que o conceito carecesse de definição e regulamentação até que seus efeitos fossem sentidos. Tal consenso abria também precedente para a discussão da Reforma Urbana, tão potencialmente revolucionária quanto próxima do cotidiano e no centro das preocupações de um país em desenvolvimento e urbanização. Apoiada pessoalmente por Almino Affonso e Amaury Silva (que se sucederiam no Ministério do Trabalho), os quais representavam a vertente à esquerda do PTB conhecida como Bloco Compacto, a idéia da Reforma Urbana baseava-se na função social da propriedade expressa no princípio constitucional citado no projeto de 
lei da SUPURB pelo também petebista, deputado e arquiteto pernambucano Artur Lima Cavalcanti, discutida no capítulo 1, item 3:

"Não será inovação, mesmo, a proposta. Na verdade, ela é uma consequência do que desejou o legislador constitucional brasileiro e o impôs, no artigo 147 da atual Carta Magna, que diz: O uso da propriedade será condicionado ao bem-estar social." "79

Em março de 1964, Jango pôs em prática uma estratégia que acabou por revelar-se desastrosa para o seu futuro político. Depois da derrota no Congresso do projeto de lei que alterava a constituição para viabilizar a reforma agrária a partir das indenizações em títulos da dívida pública, resolveu abandonar a faceta conciliatória que mais comprometia sua sustentação política do que a ampliava e implantar as reformas por decreto e pôs à prova o apoio popular construído junto aos "dispositivos" sindical e militar.

Durante o célebre "Comício da Central", que reuniu cerca de 150 mil pessoas no Rio de Janeiro, em 13 de março de 1964, Jango anunciou a assinatura e detalhou o conteúdo de dois decretos que questionavam o respeito à propriedade privada e mexiam com os ânimos dos conservadores: um deles nacionalizava todas as refinarias de petróleo, consolidando o monopólio da Petrobrás e outro regulamentava uma tímida reforma agrária. Conhecido como o decreto da SUPRA ${ }^{80}$, declarava sujeitas à desapropriação terrenos acima de 100

\footnotetext{
${ }^{79}$ Arquitetura IAB/GB , Projeto de Lei para criação da SUPURB, Rio de Janeiro, nº

${ }_{19}^{79}$ Arquitetura IAB/GB , Projeto de Lei para criação da SUPURB, Rio de Janeiro, $n^{\circ}$
}

${ }^{80}$ Superintendência da Política Agrária hectares situados nas faixas de terra lindeiras a estradas e ferrovias e acima de 30 hectares ao longo de rios e açudes. Como se sabia que o Governo Federal não dispunha de recursos para o pagamento das indenizações nos termos da lei - à vista e em dinheiro - que afinal não foi alterada consolidou-se o receio de que o Governo passaria a confiscar as terras sem qualquer contrapartida.

Para completar, no "Comício da Central", no qual também discursaram os governadores Miguel Arraes e Leonel Brizola, figuras temidas da esquerda dita "radical", Jango ainda mencionou a Reforma Urbana, que já estaria em preparação, o que assustava a burguesia rentista. A estratégia de Jango previa a realização de outros comícios daquelas proporções em diversas capitais nos quais outros decretos seriam assinados, culminando numa grande concentração popular em São Paulo na comemoração do $1^{\circ}$ de Maio, data preferida por Vargas para suas inclinações à esquerda.

Antes disso, na madrugada de 31 de março de 1964, efetivou-se a "Revolução redentora" ou o Golpe militar, que pôs fim ao breve e conturbado período de Jango. A intervenção das forças armadas no processo político brasileiro era conclamada há tempos pelos setores conservadores da sociedade brasileira, como faz ver o artigo "Alvorada vermelha", assinado por Assis Chateaubriand e publicado no Diário de Pernambuco em julho de 1963:

"Tratemos de pôr a classe militar na política, dentro da política, cada dia politicando mais e mais identificada com o grande e grave problema do 
país, em face de si mesmo, do hemisfério e do mundo livre ${ }^{\prime 187}$

Antes mesmo de março de 1964 já se anunciava abertamente o golpe militar na imprensa em matérias como "Brasil nos minutos finais da democracia" e "Jânio Quadros prevê golpe antes das eleições presidenciais de $65^{\prime \prime 83}$. Nas vésperas do golpe, para o jornal americano Times, o equilíbrio político no Brasil se reestabeleceria com $1^{\circ}$ de abril de 1964 pois "Ao mover-se o Presidente para a esquerda, deve-se produzir um golpe procedente da direita, segundo a tradição latinoamericana" ${ }^{84}$.

O ocaso do Governo João Goulart revela por um lado o fim do ciclo de "desenvolvimento nacional autônomo" e por outro a falência do esquema populista construído por Vargas, que Jango tentava reimplantar em um "contexto de mobilizações e pressões sociais muito maiores que no período Vargas". (FAUSTO, 2007, p.447) Nos mostra também o fracionamento da sociedade brasileira em categorias e mentalidades mais complexas, que não eram ainda compreendidas pelos seus governantes, assim como o jogo de forças e poderes que estabilizariam o país. João Goulart sempre foi visto como indeciso,

81 Chateaubriand, A. "Alvorada Vermelha". Diário de Pernambuco, Recife, 9/jul/1963.

82 "Brasil nos minutos finais da democracia". Diário de Pernambuco, Recife, 4/dez/1963.

83 "Jânio Quadros prevê golpe antes das eleições presidenciais de 65". Diário de Pernambuco, Recife, 11/jan/1964.

84 "Times prevê golpe de direita no Brasil". Diário de Pernambuco, Recife, fraco e confuso, mas é certo que durante o seu breve governo, para o qual ele foi levado indiretamente por circunstâncias surpreendentes, afloraram expressões de novos atores políticos, que, ao ocupar seu espaço, acabaram por abalar a "estrutura arcaica" do próprio sistema democrático brasileiro. 


\subsection{Subdesenvolvimento e a Sudene}

"As transformações estruturais da economia brasileira, ocorridas no último quarto de século [1937-1962] e intensificadas no decênio mais recente, abrem perspectivas que apontam para um dos grandes desafios lançados ao homem no século XX: a pequena nação patriarcal que, nos albores do século, apenas emergia de um rudimentar sistema social escravista, poderá vir a ser uma das primeiras nações pela magnitude de sua população, a diversidade de seu ecúmeno, a riqueza das formas de adaptação do homem ao meio físico, a complexidade e harmonia das relações étnicas, a fecundidade de uma cultura que traduz a interação com um meio cujas ricas solicitações são um chamado à afirmação de todas as forças criadoras do homem.(...) Abriremos uma nova fase de transformações qualitativas em nossa formação de nação continental ou caminharemos para uma cristalização da estrutura já estabelecida?" (FURTADO, 1962, p. 106-107)

A política de atuação do Estado no sentido de promover a industrialização e o desenvolvimento em diversas regiões ${ }^{85}$ do país teve seu auge durante o período JK; a construção de Brasília, meta síntese do

${ }^{85}$ Tomemos por definição do conceito de "região" a formulada por Francisco de Oliveira em Elegia para uma re(li)gião: "Uma região seria, em suma, o espaço onde se imbricam dialeticamente uma forma especial de reprodução do capital e, por consequência, uma forma especial de luta de classes, onde o econômico e o político se fusionam e assumem uma forma especial de aparecer no produto social e nos pressupostos da reposição" (OLIVEIRA, 1977/2008, p.148). Concluindo o livro ele completa : "A expansão do capitalismo monopolista no Brasil aponta, no limite, para a dissolução das regiões" (op.cit., p.175). Escrito em 1977, o livro será uma importante referência para o entendimento da Sudene e das contradições que mobiliza nas classes políticas e populares em Pernambuco nos anos da Sudene, Elegia para uma re(li)gião foi republicado em outubro de 2008, acrescido de "A noiva da revolução", que coloca Recife no lugar da cidade da revolução e da contradição. Os dois textos serão importantes guias no entendimento da realidade pernambucana dos anos 1960 e sintetizam a visão de um participante dos acontecimentos e a ótica precisa das ciências sociais e econômicas. Optamos por marcar diferentemente os anos de produção dos dois textos reunidos no mesmo volume publicado pela Editora Boitempo em 2008 para anotar os dois diferentes momentos. plano elaborado durante a campanha presidencial, representou sua principal expressão material e simbólica.

Abrindo o país para o investimento estrangeiro, o governo de Juscelino mudou as características da economia nacional e logrou industrializar principalmente a região Sul e Sudeste do Brasil a partir da expansão da infraestrutura e da produção maciça de aço, automóveis e eletrodomésticos, entre outros bens de consumo.

O momento político que vivia o Brasil no começo dos anos 1960 era visto por Celso Furtado como a hora da "Pré-revolução brasileira" ${ }^{186}$; o país havia conseguido um certo grau de diferenciação de sua economia e trouxe para dentro de seu território os centros de decisão concernentes ao seu futuro econômico, superando assim uma fase de economia colonial. O próximo passo seria a "conquista da autodeterminação" e o desenvolvimento para além do mero crescimento, que havia se dado sem trazer melhores condições de vida para a maioria da população.

"Temos em nossas mãos os instrumentos de autodeterminação que até há pouco eram apanágio de uns quantos povos privilegiados. E temolos com uma consciência de sua efetividade, que até há bem pouco tempo nem mesmo esses povos possuíam. Essa tomada de consciência, de que o nosso destino de povo está na dependência de nossas decisões, coloca esta geração em uma posição singular. (...)

As decisões de construir Brasília, de rasgar o território nacional, de sul a norte e leste a oeste, de grandes estradas e de abordar de frente $o$ problema dos desequilíbrios regionais, assim como o grande movimento de opinião visando a romper a anacrônica estrutura agrária, indicam

${ }^{86}$ Celso FURTADO. A pré-revolução brasileira. Rio de Janeiro: Fundo de Cultura, 1962. 
claramente a direção em que estão apontando as forças mais progressistas do país." (FURTADO, 1962, p. 115)

A filosofia que estaria na base das propostas de Furtado seria comum e recorrente entre atuações e discursos contemporâneos:

"(...) atitude otimista com respeito à autodeterminação consciente das comunidades humanas. Trata-se em última instância, de um estágio superior do humanismo; pois, colocando o homem no centro de suas próprias preocupações, reconhece, contudo, que a plenitude do desenvolvimento do indivíduo somente pode ser alcançada mediante a orientação racional das relações sociais." (FURTADO, 1962, p. 17)

O nacionalismo e a independência da nação face aos conflitos da Guerra Fria também marcariam o pensamento do economista paraibano, autor da "Formação econômica do Brasil":

"Subordinar o futuro de nossa cultura às conveniências de ordem tática de um ou de outro dos grandes centros de poder militar moderno, é dar a luta perdida de antemão, pela carência total de objetivos próprios finais." (op.cit., p. 19)

O desenvolvimento, particularmente o do Nordeste $^{87}$, seria uma contingência, mais do que uma opção e a possibilidade de superação desse estágio era mais palpável do que se poderia supor.

"Poucos de nós temos consciência do caráter profundamente antihumano do subdesenvolvimento. Quando compreendemos isso, facilmente explicamos porque as massas estão dispostas a tudo fazer para superá-lo" (FURTADO, 1962, p. 23)

\footnotetext{
${ }^{87}$ É importante problematizar os limites e a própria história do surgimento da idéia de Nordeste tal qual o conhecemos contemporâneamente, como um "recorte espacial de relações [culturais] e de poder", o que faz o historiador Durval Muniz de Albuquerque Jr em A invenção do Nordeste e outras artes, de 2006. "A identidade nacional ou regional é uma construção mental, são conceitos sintéticos e abstratos que procuram dar conta de uma generalização intelectual, de uma enorme variedade de experiências efetivas. Falar e ver a nação ou a região não é, a rigor, espelhar estas realidades, mas criá-las" (ALBUQUERQUE JR, 2006, P.27)
}

O Recife - a metrópole regional estigmatizada também como cidade da miséria e do atraso - era uma metonímia do quadro da estagnação do Nordeste que assistia uma revoada de racionalidade com a SUDENE e Celso Furtado:

"Assim, nos anos 50, como de há muito, a cidade refletia a situação de paralisação econômica por que passava a região Nordeste. Por um lado, não apresentava o processo de industrialização em desenvolvimento no Centro-Sul e, por outro, recebia a população migrante do campo não absorvida pelas atividades econômicas urbanas.(...) Essa situação de paralisação econômica era reportada à dominância da economia açucareira. Impunha-se desentrelaçar a economia regional da produção açucareira e promover a industrialização do Nordeste; impunha-se transformar as estruturas de dominação e o atraso regional vinculados ao domínio açucareiro. Essa foi a idealização política maior dos intelectuais e dos industriais da época, para enfrentar os entraves econômicos, a miséria do povo e o crescimento populacional. (PONTUAL, 2001, p.38)

Cabia à nação e ao seu povo realizar as mudanças na "anacrônica estrutura agrária" e acelerar a industrialização, sintetizando para isso as experiências históricas dos dois blocos de países desenvolvidos.

"O problema fundamental que se apresenta é, portanto, desenvolver técnicas que permitam alcançar rápidas transformações sociais com os padrões de convivência humana de uma sociedade aberta."(FURTADO, 1962, p. 26)

Um dos obstáculos e particularidades que se deveria considerar era a "dualidade da estrutura político-social brasileira", dividida entre o setor rural e a classe operária. "É que a nossa sociedade é aberta para a classe operária, mas não para a camponesa" (FURTADO, 1962, p. 28) Essa singela constatação lança luzes sobre os principais conflitos de poder ocorridos nos anos 1960 como também explica de maneira 
contundente as migrações campo-cidade, inseridas num processo de transformação econômica integrado. A permanência "estrutura agrária anacrônica" seria a única responsável por uma "revolução de tipo marxista-leninista", que significaria um retrocesso do sistema políticosocial brasileiro. (op.cit., p. 30)

A partir de uma visão da economia integrada à outras disciplinas e à vida cotidiana do homem, Furtado propôs a intervenção decisiva do Governo Federal nas questões estruturais.

"A situação presente de grandes tensões que observamos no Brasil, que criou a consciência da necessidade de reformas básicas inadiáveis, decorre em grande parte, a nosso ver, da aceleração do desenvolvimento industrial nos últimos quinze anos.(...) As grandes tensões sociais que caracterizam a vida nacional na fase atual parecem ter sua causa principal no desajustamento existente entre as expectativas criadas pelo próprios desenvolvimento no conjunto da população e o limitado acesso permitido aos frutos desse desenvolvimento." (FURTADO, 1962, p. 40-41)

A Superintendência para o Desenvolvimento do Nordeste Sudene $^{88}$ era o órgão enfim criado em 1959 para enfrentar o subdesenvolvimento nordestino e nacional. Furtado, acadêmico

${ }^{88}$ Para a criação da Sudene também afluíram as resoluções do Congresso de Salvação do Nordeste: "O Congresso de Salvação do Nordeste [1956] conclui pela necessidade inelutável de se eliminarem os entraves ao desenvolvimento regional (...) para incrementar a industrialização e obter o bem estar das populações regionais (...) outros entraves deverão ser afastados, como os efeitos das secas periódicas e o regime da grande propriedade improdutiva.(SOARES apud PONTUAL, 2001,p.38) paraibano que vinha da experiência da $\mathrm{CEPAL}^{89}$, foi seu primeiro diretor e corporificou o espírito do órgão, baseado na atuação estatal concentrada sob a orientação de um quadro tecnocrático competente a partir de sua sede no Recife. Sobre ele, declara Francisco de OLIVEIRA, companheiro de trabalho e responsabilidades na Sudene:

"Celso era a Razão entrando no Nordeste, depois de um longo eclipse que começara com a derrota da Praieira em 1848; é quase possível vê-lo em seu cavalo branco, em seu Rocinante, qual Quixote racional.(...) Alto, acima da média regional, feições talhadas a foice, o carisma de sua palavra, ele - um weberiano que preferia encarnar a ação racional transmitia, pela fascinação, uma convicção a que poucos escapavam." (OLIVEIRA, 2008, p.65)

Para Furtado, então também ministro do planejamento, o Nordeste ocuparia papel central dentro de uma política de desenvolvimento nacional e a SUDENE teria duas tarefas básicas:

"Provocar um processo rápido de industrialização e, simultaneamente, reconstruir sobre novas bases a economia agropecuária" (FURTADO, 1962, p. 54).

Principal incumbência do órgão, "o desenvolvimento econômico do Nordeste deverá assumir a forma de um duplo processo de elevação da produtividade e de adaptação progressiva às condições ecológicas regionais" (FURTADO, 1962, p. 59)

As ações da SUDENE, orientadas pelos seus sucessivos Planos Diretores $^{90}$ localizavam-se principalmente no interior, divididas em quatro linhas básicas: produção de alimentos na zona úmida do

\footnotetext{
${ }^{89}$ Comissão Econômica para a América Latina, órgão ligado às Nações Unidas estabelecido a partir do fim dos anos 40 em Santiago do Chile que constitui principal Escola de pensamento econômico ligada ao Terceiro Mundo.

${ }^{90}$ A atuação do órgão e suas diretrizes políticas se pautaram pelos sucessivos Planos Diretores, elaborados respectivamente em 1961 (I), 1966(II e III) e 1968 (IV).
} 
Nordeste; desenvolvimento no semi-árido de uma agricultura resistente aos efeitos da seca; colonização do Maranhão; desenvolvimento da irrigação no São Francisco. ${ }^{9 !}$

Segundo Callado, a SUDENE constituiria uma estrutura técnica estável, independente da política partidária dos nove Estados nordestinos, auxiliando-os a realizar planos e projetos territorialmente maiores que as unidades da federação, ou seja, em bases realmente regionais e em períodos mais longos do que o mandato dos governadores. (CALLADO, 1964)

A ligação direta com o Governo Federal justificava-se pelo fato de que "o desenvolvimento econômico do Nordeste exigirá reformas institucionais que somente poderão ser equacionadas e executadas por um órgão que goze de extraordinária autoridade na região" (FURTADO, 1962, p. 62), mas também aponta para uma nova forma de participar da política e intervir na economia, uma verdadeira "reformulação das funções do Estado", adequada e necessária no contexto do subdesenvolvimento. Assim, "a luta pelo desenvolvimento é também uma luta pela racionalidade na política", processo que se expressava no rompimento de um ciclo de atitudes isoladas e tecnocráticas: "a ação do técnico, em nossa geração, tem necessariamente, uma dimensão social." (op.cit., p. 63)

Tais posturas decididas e transformadoras levavam os representantes das oligarquias a questionar: "Celso Furtado é

${ }^{91}$ C P D O C - FGV - Dicionário Histórico- Brasileiro, Disponível online em http://www.cpdoc.fgv.br/dhbb/verbetes htm/2219 3.asp acessado em 10/nov/2008. comunista? A SUDENE é estatizante?" ${ }^{\prime 92}$. Em matéria publicada na imprensa sobre a visita de industriais paulistas ao Recife, conclui-se que não, embora se reconheça uma "onda" contra a SUDENE, que viria do fato de que ela contrariava interesses, notadamente da chamada "Indústria da seca" e explicitava as contradições do desenvolvimento da região. "A industrialização do Nordeste significa a sovietização do Nordeste!", bradava da tribuna o senador Argemiro Figueiredo, "entre o pitoresco e o trágico" ${ }^{\prime 3}$.

Para OliveirA, ao contrário de criar a luta de classes, a Sudene era exatamente produto dela: "o conflito de classes que aparece sob as roupagens de conflitos regionais ou dos "desequilíbrios regionais" chegará a uma exacerbação cujo resultado mais imediato é a intervenção "planejada" do Estado no Nordeste, ou a Sudene." (OliveirA, 1977/2008, p.246)

Orientar os investimentos públicos e criar estratégias para reter o investimento privado "singularizaria a ação da SUDENE como órgão de desenvolvimento regional: o haver combinado o planejamento das obras públicas, o estudo sistemático dos recursos naturais, o fomento à pesquisa tecnológica e a formação de pessoal técnico, isto é, o haver combinado a ação direta do Governo com a administração das múltiplas formas de incentivo à iniciativa privada" (FURTADO, 1962, p. 61)

Apesar de focado na zona rural, o órgão reunia as experiências feitas em toda a região que apontavam para as possibilidades de melhoria das condições de vida a partir de tecnologias simples e

92 "Celso Furtado é comunista? A SUDENE é estatizante?". Jornal Pequeno, Recife, 21-27/out/196

${ }^{93}$ De acordo com Francisco de Oliveira, "o Estadão em São Paulo desdenhava, de modo acintoso, a tentativa de industrialização do Nordeste, que maldosamente insinuava estar baseada nos moldes de um planejamento grosseiramente assimilado à experiência soviética de economia dirigida" (OLIVEIRA, 2008, p.77) 
recursos escassos, aproveitando e sistematizando experiências feitas antes ou fora de sua jurisdição. O arquiteto Acácio Gil Borsoi em entrevista diz que uma demonstração da montagem de uma casa segundo o sistema de pré-fabricação da taipa proposto para o Cajueiro Seco foi feito no terreno da Igreja do Carmo para o próprio Celso Furtado.

Além do apoio a agricultura e pesquisas com diversos tipos de sementes e alimentos, a SUDENE abriu diversos poços no sertão, construiu lavanderias e banheiros coletivos e chafarizes, "o único monumento cabível nas praças do interior nordestino", socializando o acesso a água. (CALLADO, 1964)

A partir da assinatura do Acordo com a United States Agency for International Development - a USAID, em 1962, a SUDENE transformou-se no principal canal de recursos estrangeiros, cuja aplicação seria por ela coordenada. A imbricação da "ajuda" estrangeira com as preocupações de Kennedy com o potencial revolucionário da América Latina viria a se concretizar na Aliança para o Progresso, objeto de item à parte.

A organização da Cooperativa do Tiriri talvez tenha sido a ação mais bem sucedida coordenada pela SUDENE naqueles anos iniciais. Uma vez esgotadas as possibilidades de negociação intermediadas pelo Ministério do Trabalho entre camponeses e usineiros, o apoio da SUDENE foi solicitado e a ação do órgão se deu no sentido de organizar uma cooperativa dos trabalhadores rurais, estabelecendo os valores da remuneração dos trabalhadores em função de sua produtividade e do arrendamento das terras proporcional ao volume de cana cortada. A cooperativa excluiu as mulheres e as crianças do trabalho árduo do corte da cana, redirecionando as primeiras à cooperativas de corte e costura e as segundas às escolas nas quais foi aplicado o Método Paulo Freire de alfabetização.

É importante lembrar que eram os anos do "Acordo do Campo", que estendia aos camponeses os benefícios da legislação trabalhista e regulamentava tarefas e quantidades do trabalho agrícola; consequentemente, organizaram-se os sindicatos rurais, com o apoio do PCB e de setores da Igreja, além das Ligas Camponesas. As "agitações" no campo sempre em disputa com a "arcaica estrutura agrária" e agravada com uma certa "reestruturação produtiva" do setor canavieiro concorreram para marcar com conflitos violentos a aplicação das medidas que intervinham na relação entre latifundiários e usineiros e sua força de trabalho.

O usineiro Rui Cardoso, proprietário de 5 engenhos e da usina que processava a cana colhida nessas terras teve a sensibilidade de perceber que com o advento do Acordo do Campo, os custos de produção se elevariam imediatamente e que a solução do cooperativismo era a mais viável do ponto de vista estritamente capitalista, coisa que os seus colegas usineiros se recusaram a aceitar, impondo à experiência de Tiriri uma série de sanções. (CALLADO, 1964)

Ao mesmo espírito podemos associar o projeto Tracunhaém, elaborado por Josué de Castro com a cooperação da SUDENE e da ASCOFAM (Associação Mundial de Luta contra a Fome) cujos pontos 
fundamentais e interligados eram o desenvolvimento da comunidade e o enriquecimento da farinha de mandioca, solução simples e baseada na cultura e alimentação popular de suprir a dieta da população. ${ }^{94}$

Callado via em Tiriri o embrião da pacífica revolução brasileira, que transformaria o país de uma forma criativa, sem o recurso da violência comum às revoluções acontecidas em outros países e que por essa razão era também combatida por extremismos à direita e à esquerda.

"Se se pudesse eliminar a gritante injustiça social em que vivemos e manter o regime democrático - talvez víssemos o Brasil entrar na fase histórica brasileiramente, sem derramamento de sangue." (CALLADO, 1964)

De certa forma, a cooperativa de Tiriri é uma experiência análoga a Cajueiro Seco, na medida em que lida com a população que transita entre a base da sociedade rural em transformação e à margem da cidade, nas beiradas do urbano. O desajustamento dessa população tanto numa situação quanto na outra é o ponto de partida para o reconhecimento da questão como característica de uma nação em incipiente industrialização e rápido processo de urbanização ${ }^{95}$.

Naquele momento, com as experiências de Tiriri e Cajueiro Seco estavam sendo tratadas as causas e as consequências, baseadas no cooperativismo e no reconhecimento do direito ao território da população que flutuava por Pernambuco refletindo um processo

\footnotetext{
${ }^{94}$ Ver Projeto Tracunhaém em ANDRADE, M. et alli in Josué de Castro e o Brasil . São Paulo: Fundação Perseu Abramo, 2003

${ }^{95}$ Considerar aqui o processo tal qual descrito em Parceiros do Rio Bonito, de Antônio CÂNDIDO.
}

inacabado e incongruente de modernização capitalista. Tiriri também começou como uma invasão de terras federais (no caso da RFFSA) a que se seguiu uma ação governamental (da SUDENE) para assentá-los e organizar uma estrutura produtiva que os integrasse à sociedade de classes, transformando o singelo camponês numa figura ativa do desenvolvimento regional.

"Tiriri é a prova de que se pode acabar com o latifundiário sem precisar enforcá-lo num cajueiro. (...) Pernambuco, com suas Ligas Camponesas, seus comunistas, seus padres, tomou nojo da estagnação em que vivia, da estagnação em que, com menor pungência, vive o Brasil inteiro. Há caminhos para que o Estado saia dessa estagnação sem recursos à violência. Se esses caminhos forem obstruídos, tenho a impressão de que é certo o apelo à violência."(CALLADO, 1964, p.176)

$\mathrm{O}$ combate e a relativa esterilidade da experiência explica-se basicamente por que "naquele momento, em Pernambuco, qualquer experiência democratizante e modernizadora era logo tachada de comunista e inspirada na revolução cubana". (ANDRADE, p.45, 1989)

Depois de 1964, a atuação da SUDENE foi descaracterizada a partir da ingerência do Banco Mundial e dos militares, ganhando a partir daí o estigma de órgão corrupto e ineficaz que acabou por justificar sua extinção, já no governo FHC. O Governo Lula, dando importância estratégica ao planejamento e desenvolvimento da região, recriou a SUDENE em Janeiro de 2007, através de lei específica.

De concreto, o monumental edifício-sede projetado nos anos 1970 por Maurício Castro e construído no bairro recifense da Várzea ${ }^{96}$,

\footnotetext{
${ }^{96}$ Nos anos iniciais, a SUDENE era sediada no Edifício JK, no centro do Recife, projetado por Hélio Duarte para o IAP em 1950, a maior estrutura em concreto
} 
hoje abriga um Tribunal de Justiça, além do arquivo e da Biblioteca da antiga SUDENE, que permaneceu inativa por anos. De acordo com OLIVEIRA, a mudança da sede expressa a ressignificação e reestruturação que sofreu o órgão:

"Por contraste, logo que os milicos puseram a mão na Sudene, uma de suas primeiras providências foi alugar uma casa luxuosa para residência do superintendente e logo depois construíram o imenso prédio em frente à Cidade Universitária, que hoje mais parece o cemitério dos sonhos da transformação. Furtado havia previsto: quando uma instituição começa a pensar no prédio próprio é que começou a morrer" (OLIVEIRA, 2008, p.68)

No entanto, o mesmo Francisco de OliveIRA, trinta anos atrás, quando ele escreve "Elegia para uma re(li)gião", faz um balanço interessante da experiência:

"a Sudene não foi uma farsa: precisamente porque foi um embate de raras proporções na história nacional, travado pelo tipo de forças sociais que o travaram, a Sudene foi um empreendimento de uma audácia inédita na história nacional. Ela anunciava um dos dois novos: se os vencedores tivessem sido as forças populares, o Nordeste e o Brasil de hoje seriam muito diferentes; tendo sido vencedoras as forças do capitalismo monopolista, chamadas a socorrer combalidos latifundiários e barões do açúcar, essa vitória também mudou o curso da história." (Oliveira, 1977/2008, p.131-132)

Aos questionamentos de OLIVEIRA quanto ao que havia sobrado da Sudene acrescentamos os nossos sobre a Sudene atual, teimosamente recriada pelo presidente símbolo da "integração regional", vindo de algum dos sertões de Pernambuco para as periferias de São Paulo.

\section{"Nesse sentido, não se pode pensar que a Sudene de hoje é a de}

armado do Nordeste. O edifício foi posteriormente transferido para o patrimônio do INSS e está desocupado até hoje.

ontem e a de sempre. A de hoje encarna apenas a vontade social do capitalismo monopolista e a do Estado no Brasil; não encarna mais as aspirações populares." (op.cit., p. 132) 


\subsection{As Ligas Camponesas, o papel da lgreja e a "Cubanizacão" de Pernambuco}

"A luta simbolicamente mais importante se deu em Pernambuco, pela posse do Engenho Galiléia, situado no município de Vitória de Santo Antão. A propriedade era um engenho de "fogo morto", isto é, já não funcionava para produzir açúcar e tinha sido arrendada aos camponeses, na forma de pequenos sítios. Sob ameaça de expulsão das terras porque o proprietário queria retomá-las, aparentemente para destiná-las à pecuária, os posseiros resistiram por meios legais durante cinco anos. Afinal, a propriedade foi desapropriada pelo governo federal" (FAUSTO, 2007, p.444)

As Ligas Camponesas foram fundadas em 1955, no Engenho Galiléia, que servia de inspiração e exemplo à massa de camponeses que se organizava no interior por terem finalmente conquistado a desapropriação das terras em que plantavam. No começo dos anos 1960, as Ligas haviam conquistado base e representação suficientes para impor a necessidade da reforma agrária "na lei ou na marra".

Eleito deputado federal em 1962 pelo Partido Socialista Brasileiro (PSB) pernambucano, Francisco Julião era o líder das Ligas Camponesas, tanto nas manifestações e ocupações no campo quanto no Congresso Nacional. Parte da opinião pública, embora francamente refratária a todas as idéias socialistas ou "comunistas", reconhecia que era necessário transformar as tais "arcaicas estruturas agrárias brasileiras".

As precárias condições de trabalho no campo explicavam as migrações e do inchaço das cidades expressos nas aglomerações dos mocambos, assim como na escassez de gêneros alimentícios. Ambos aspectos eram interpretados como sintomas do desequilíbrio da condição produtiva e econômica brasileira, que comprometiam o desenvolvimento projetado.

A referência da Revolução Cubana era tão forte e tão próxima que ofuscava a visão da nação para um modelo de reforma agrária que não fosse de inspiração socialista ${ }^{97}$. A modificação da Constituição para que as desapropriações pudessem ser pagas com Títulos do Governo, foi rejeitada pelo Congresso, inviabilizando a reforma nas bases propostas por Jango, sem diminuir as pressões dos camponeses organizados.

A partir da implementação do "Acordo do Campo", que estendeu os direitos trabalhistas como salário mínimo e $13^{\circ}$ aos cortadores de cana e a regulamentação do trabalho rural por parte do Governo Arraes, expressa na Tabela do Campo, a Igreja e o Partido Comunista Brasileiro passaram a organizar os camponeses em sindicatos agrícolas, dividindo forças com as Ligas, que propunham atuação mais radical, partindo para a reforma agrária "na marra". As divergências entre o PCB e as Ligas camponesas ficaram claras durante os debates no I Congresso Nacional dos Trabalhadores Agrícolas, realizado em Belo Horizonte, em 1961, no qual surgiu o movimento pela sindicalização no meio rural.

Os latifundiários, privados da ajuda da Força Pública estadual que, antes de Arraes, estava sempre a seu serviço defendendo suas

\footnotetext{
97 "Para Pernambuco, 1963 foi o ano da agitação". Diário de Pernambuco, Recife, 1/jan/1964. "Agitadores mobilizam operariado para a guerra revolucionária em Pernambuco". Diário de Pernambuco, Recife, 29/fev/1964.
} 
propriedades e interesses, se armavam para as batalhas em torno da posse da terra que temiam estar por vir. Os camponeses, com seus instrumentos de trabalho - foices e facas, reivindicavam seus direitos recentemente conseguidos, frequentemente sendo recebidos à bala pelos donos da terra, como ocorreu no episódio da Usina Estreliana, no qual cinco camponeses foram metralhados covardemente pelo usineiro José Lopes Siqueira e seus capangas. Todos os jornais publicaram a imagem da chacina, na qual se vêem corpos alvejados pelas costas evidenciando a sumária execução.

A questão agrária mobilizava atuações, trajetórias, sacrifícios e rendeu prestígio político a muitas figuras para além de Francisco Julião, que via sua influência se diluir frente às diversas tendências e vertentes do movimento popular que se estabeleciam.

O documentário "Cabra marcado para morrer", de Eduardo Coutinho, nos aproxima do universo rural e do ambiente político no interior nordestino daquele tempo, além de expressar o corte que o golpe militar representa em diversas trajetórias políticas e também culturais $^{98}$. O filme teve sua realização interrompida pela intervenção no Engenho Galiléia, no qual se davam as filmagens e só foi retomado nos anos 80, no ocaso do regime de exceção. "Cabra marcado para morrer" retrataria a história do assassinato de João Pedro, o líder camponês assassinado em 1962 e a diáspora da viúva Elizabeth

\footnotetext{
${ }^{98}$ Roberto SCHwarz. "O fio da meada" in Que horas são? São Paulo: Cia das Letras, 1987.
}

Teixeira e alguns de seus filhos por pequenas cidades do sertão, sob a proteção da clandestinidade.

Rememorando sua vida com João Pedro até seu assassinato, Elizabeth destaca a migração para a periferia recifense, onde se dá a formação política do casal, especificamente em Jaboatão dos Guararapes, cidade que ganhou o apelido de "Moscouzinha" por ser a primeira a eleger um prefeito do Partido Comunista, em 1947. A história do casal Teixeira, exemplifica um fenômeno mais geral, a relação entre a crescente politização nas cidades e os movimentos sociais do campo e o aparecimento das lideranças camponesas, que normalmente vinham da cidade com o propósito de mobilizar os camponeses. É muito rara a figura do líder autenticamente camponês; o que se observa é a influência direta do movimento urbano que via na organização política camponesa um importante campo de fortalecimento de suas bases populares.

Outro aspecto interessante que a história de João Pedro Teixeira e dos outros envolvidos no filme nos mostra que pode ser generalizada para um quadro mais amplo, é a associação dos camponeses ativos na política e nos sindicatos rurais e igrejas protestantes e pentecostais. A aproximação de João Pedro da Igreja Batista também se dá em Jaboatão, através de um colega de trabalho e militância.

Desde a encíclica Rerum Novarum, publicada pelo papa Leão em 1891, até a atuação do papa João XXIII (1958-63), notadamente no Concílio Vaticano II, do qual participou Dom Hélder Câmara vinha crescendo o envolvimento da Igreja na discussão das questões da terra 
e do trabalho. A igreja vinha se envolvendo na formulação de alternativas à polarização entre os mundos socialista e capitalista interferindo na organização do trabalho e propondo soluções na matriz do cooperativismo. O Movimento de Educação de Base também era uma seção da Igreja ativa nesses anos que buscava se ocupar um espaço atuando nas carências de suas das "bases" sociais.

Outros setores mais progressistas representadas pelo Abbé Pierre e dominicanos como Louis Joseph Lebret estavam se envolvendo diretamente com questão da pobreza e da sub-habitação, bem como com o ativismo político e também com a arquitetura moderna ${ }^{99}$. A experiência da Unilabor, coordenada por um Frei dominicano, comentada no item E do capítulo 1 refletiria também estas proposta naqueles anos 1950 e 60.

A base canavieira da economia aproximava a situação cubana à da zona da mata Pernambucana e a população mobilizada em torno das tendências de esquerda numa capital portuária estrategicamente posicionada na América ligavam o Recife a Havana. A imaginação fértil de usineiros e políticos ameaçados e armados como João Cleofas, Edgar Bezerra Leite e Wilson Lins cunhou nas páginas do Diário de Pernambuco o termo "cubanização" para designar o que acontecia no Estado então governado por Arraes, que a essas alturas seria "o nosso

\footnotetext{
${ }^{99}$ Ver o Convento de La Tourette, projeto de 1953 do arquiteto franco-suíço Le Corbusier e uma série de capelas e igrejas realizadas pela Ordem em São Paulo.
}

Fidel Castro" ${ }^{\prime 100}$. Para a oligarquia pernambucana, interessava reunir todas as tendências de esquerda sob a liderança de Arraes, que estaria a serviço do "Ouro de Moscou"101, canalizando contra o governador o sentimento de insegurança e terror disseminado entre as classes média e alta.

A eles responde Henrique de Figueiredo, nas páginas do Lornal Pequeno:

"Somente os velhos ignorantes, os retrógrados emparedados na sua própria mediocridade desconhecem o surto desse progresso e não querem adaptar-se às tendências atuais do socialismo. Acham que toda e qualquer reformulação, que essa apregoada reforma de bases possuem um cheiro de comunismo e indicam como vermelhos aqueles que aceitem as idéias vitoriosas da nova sociologia política.(...) Fosse Pernambuco entregue ao sr. João Cleofas ou a outro candidato de catadura igual, com uma educação política deficiente e chinfrin, o que seria de nós? A continuação da má aplicação dos dinheiros públicos e o continuísmo da fome, do analfabetismo e da miséria do povo. Esperando dos Estados Unidos ou de São Paulo a sua ajuda econômica que nos avilta e que nos degrada." ${ }^{102}$

Segundo Callado, dentre os líderes populares brasileiros, foi sobre Francisco Julião que a revolução cubana exerceu maior poder de atração. Ele já tinha ido à Cuba algumas vezes, tinha 4 filhos estudando

\footnotetext{
100 "Miguel Arraes será o nosso Fidel Castro". Diário de Pernambuco, Recife, 19/out/1963. E "Processa-se cubanização gradativa de Pernambuco". Diário de Pernambuco, Recife, 19/out/1963.

101 "Arraes comanda desordem e Pernambuco está entregue aos comunistas, diz mons, Câmara". Diário de Pernambuco, Recife, 24/mar/1963. E "Comunistas mandam no estado e há cobertura oficial para os agitadores". Diário de Pernambuco, Recife, 27/mar/1963.

102 “A "Cubanização" do Sr. Cleofas". Jornal Pequeno, Recife, 17-23/fev/1963.
} 
na ilha e segundo seus detratores, recebia ajuda financeira e treinamento militar cubano. Figura controversa, Julião exercia oposição ferrenha tanto ao Governo Jango quanto ao Governo Arraes, dimuindo o campo de manobras do governo estadual entre a esquerda e a direita, fornecendo argumentos para aqueles que queriam ver a revolução agrária em andamento como pretexto para a contra-revolução ${ }^{103}$.

\section{(CALLADO, 1964)}

De acordo com Andrade, "O prestígio de Julião, misto de revolucionário e romântico, que usava, na luta, a Bíblia e o Código Civil, começaria a cair no início da década de 60, por recusar-se a um entrosamento com a linha do Partido Comunista e por não ter conseguido organizar o crescimento, tumultuado e rápido, das Ligas." (ANDRADE, 1989, p.41)

Depois do advento do relatório Kruschev, dividiram-se os comunistas brasileiros, a expressiva maioria mantendo-se ao lado de Prestes e do PCB e surgindo tendências revolucionárias inclusive em

\footnotetext{
${ }^{103}$ A "confusão" parece comum a outros países latinoamericanos naqueles anos, como se intui num trecho Mario Vargas Llosa em um romance autobiográfico que guarda relação do contexto lationamericano (visto do exílio) com a situação do Peru governado pelo arquiteto Belaunde Terry. Comentando a atuação de uma guerrilha maoísta no país em uma carta, o tio advogado do alter ego de Llosa declara: "Brincando de guerrilheiros, esses idiotas só vão conseguir entregar de bandeja aos militares o pretexto para um golpe de Estado. E nos impingir mais oito ou dez anos de ditadura militar. Quem vai pensar numa revolução contra um governo civil e democrático que, aliás, toda a oligarquia peruana, a começar por La Prensa e El Comercio, acusa de comunista por querer fazer a reforma agrária? O Peru é uma confusão, sobrinho, você faz bem em ir morar no país da clareza cartesiana." Mario V. Llosa. As Travessuras da Menina má. São Paulo: Alfaguara, 2006.
}

Pernambuco, compostas principalmente por estudantes dispostos a partir para a luta armada, como relata Andrade:

"um grupo de três estudantes de arquitetura fixou-se em Itambé, passando a agir em nome da Vanguarda Leninista. Pouco experientes, eles se expunham muito em manifestações e no apoio às reivindicações dos trabalhadores. Percorriam engenhos e sítios da área à procura de filiação ao sindicato, organizaram os camponeses para a luta e tentaram realizar um Congresso Camponês, mas a polícia os prendeu, instaurou um processo, até a ocasião em que foram transferidos para a Casa de Detenção no Recife. A esta altura combatiam Arraes e Julião e se isolavam da própria esquerda militante. Ao chegarem à capital já a notícia da prisão de políticos pernambucanos se espalhara pelo Brasil e eles passaram a ter um tratamento excepcional que permitia, inclusive, contato com adeptos e aliados na própria prisão" (ANDRADE, 1989, p.42)

Além dos três presos políticos de Arraes entrevistados no cárcere por Callado, ficou célebre a figura de Jeremias, um estudante paulista engajado na vanguarda revolucionária morto brutalmente em confronto aberto com latifundiários. (CAVALCANTI, 1978)

Assim, como fez ver Skidmore, a esquerda brasileira estava fragmentada em diversas tendências, muito dividida para formar o " $\mathrm{V}$ Exército" operário imaginado pelos militares golpistas. O brasilianista acredita que a radicalização no quadro político brasileiro assim como os avanços rumo às reformas de base do Governo Jango representam uma superestimação da base e do poder da esquerda no Brasil. O fato é que num momento de abertura e euforia como a que vivia o país no começo dos anos 60, apareciam tanto as divergências entre diversos espectros ideológicos, quanto as novas forças populares que até então nunca haviam participado do processo político brasileiro. A tendência é que essa participação aumentasse proporcionalmente aos esforços de 
alfabetização $^{104}$, constituindo uma importante força que tenderia a desequilibrar o estável jogo político controlado por latifundiários.

Havia participação dos comunistas na vida política brasileira, na imprensa, em diversos sindicatos e órgãos públicos, de forma especialmente aberta e franca em Pernambuco, mas o fato é que não havia organização e consenso em torno de uma revolução no Brasil, ao contrário do que os americanos queriam levar a crer. Ninguém mais insuspeito para afirmá-lo do que o General Justino Alves Bastos, comandante do IV Exército na época da "Revolução redentora", por ele apoiada, que questionado pelo repórter da conservadora revista "O Cruzeiro" sobre se haveria revolução comunista em organização declarou:

"A resposta é negativa. O que havia aqui era agitadores com repercussão escassa. Líderes e sublíderes sem massa comunista arregimentada. Isto se deve ao fato de termos populações ordeiras, tradicionalmente religiosas. Como organização, o comunismo nada valia" (CALLADO, 1964, p.37)

104 A constituição de 1946 estabelecia que só os alfabetizados poderiam votar, o que imprimia às campanhas de alfabetização um duplo potencial, gerando cidadãos conscientes e eleitores. Dessa possibilidade se abre uma outra questão no seio da esquerda, principalmente em Pernambuco: lutar pela concessão do direito ao voto ao analfabeto ou alfabetizá-lo? Antônio CALLADO. Tempo de Arraes: padres e comunistas na revolução sem violência. $1^{\text {a }}$ ed. Rio de Janeiro, José Alvaro Editor, 1964, 2a ed. Rio de Janeiro: Paz e Terra, 1979. 


\section{$\underline{2.4}$ A Frente do Recife}

No plano nacional, durante o Governo Jango, o poder político foi se fragmentando dentro de múltiplas tendências à direita e à esquerda. A histórica aliança entre o PTB e o PSD havia sido desfeita e a União Democrática Nacional dividia-se entre o combativo Carlos Lacerda e o moderado Magalhães Pinto. Os militares dividiam-se em torno do respeito à democracia e à Constituição e cresciam dentro da esquerda setores revolucionários que divergiam das posturas cautelosas do PCB e de seu líder Luiz Carlos Prestes, ainda marcados pelo fracasso da Intentona de 35, determinados a lutar pela legalidade. Tal divisão se acentuaria com a divulgação do Relatório Kruschev, em 1956, que revelava uma face surpreendente e desconhecida do stalinismo, gerando rachas internos e críticas ao modelo socialista soviético ao qual o PCB se filiava. (FAUSTO, 2007; SKIDMORE, 1976; e BRAYNER, F. IN RESENDE, 1987)

No Recife, condições peculiares vinham agrupando diversas tendências progressistas de esquerda e obtendo significativas vitórias políticas locais $^{105}$. Desde a restauração do direito ao voto, em 1945, o

\footnotetext{
${ }^{105}$ As etapas descritas por Francisco de Oliveira balizam a emergência do proletariado como ente político:

"a). entre 1945 e 1950, o proletariado emerge com feição própria, através até de um partido operário, o Partido Comunista, situando-se na correlação de forças políticas autonomamente no contexto regional e ligando-se nacionalmente ao proletariado do resto do país, principalmente do Centro-Sul; b) 1950 a 1958, o proletariado submerge numa coligação de forças comandada pela oligraquia agrária algodoeira-pecuária, em oposição à burguesia industrial nordestina (...) c) 1958 a 1961, o proletariado muda de partner político; juntar-se-á à burguesia
}

Partido Comunista vinha crescendo, elegendo representantes e tornando-se uma importante força política naquela que era a terceira maior cidade do país. A despeito da decretação da ilegalidade do partido em junho de 1947 e da perda de muitos mandatos conquistados através do voto em janeiro de 1948, como os do Senador Prestes e o do deputado Gregório Bezerra, seus integrantes continuaram ativos na política brasileira, participando ativamente de sindicatos, manifestações e publicando jornais diários por todo o país. Em Pernambuco, o partido tinha base sólida e lideranças históricas importantes como Cristiano Cordeiro, um dos fundadores do partido em 1922, Bezerra, Hiram Pereira, Paulo Cavalcanti, Clodomir Morais e Davi Capistrano.

A ampla coalizão de esquerda que uniu socialistas e comunistas e se tornou conhecida como "Frente do Recife" se consolidou como tal em torno da candidatura do engenheiro Pelópidas Silveira à prefeitura do Recife em 1955. Pelópidas se notabilizara como administrador público competente em sua primeira gestão na prefeitura durante apenas um semestre em 1946, realizando diversas obras públicas importantes para o cotidiano da cidade e intervindo junto aos interesses das camadas populares, estabelecendo padrões de higiene nas feiras públicas e regulando do preço do pescado durante a semana santa,

industrial nordestina, esta sob o Comando de Cid Sampaio em PE, mas numa coligação em que a subordinação do proletariado era mais formal do que real: aí, realmente é já uma forma de potência igual à da burguesia industrial; d) 1961 a 1964, o proletariado comanda pela primeira vez a coligação de forças; seu partner, por estranho que pareça, será a oligarquia agrária algodoeira-pecuária, esta claramente subordinada."(OLIVEIRA, 1977/2008, p. 238) 
impedindo abusos por parte dos comerciantes e garantindo o tradicional feriado religioso numa medida de grande alcançe popular.

"Em tão curto período, revolucionou porém os velhos hábitos de administração, arregaçando as mangas e impulsionando os planos urbanísticos de uma cidade que precisava modernizar-se" (CAVALCANTI, 1978, p. 251).

Na primeira eleição para governador depois do Estado Novo, em 1947, os socialistas e comunistas lançaram o nome de Pelópidas ao Governo do Estado, obtendo uma expressiva vitória na Capital e nas cidades que compunham o Grande Recife, mas perderam o pleito no restante do Estado para Barbosa Lima Sobrinho, do PSD.

Aliando a imagem de eficiente administrador com as expressivas vitórias da esquerda recifense, Pelópidas foi eleito prefeito em 1955 pela Frente do Recife, que congregava além dos socialistas e comunistas, os trabalhistas, força política importante no país e no estado, que abrigava desde herdeiros políticos de Vargas a comunistas que optavam por participar da vida política partidária, ainda que seu partido de origem estivesse com o registro cassado. O vice prefeito eleito, Viera de Menezes, pertencia à legenda do PTB, que elegra também o médico e geógrafo pernambucano Josué de Castro como deputado federal por sua legenda, figura de peso e afinidades ideológicas com o socialismo. Não custa lembrar que foi a legenda do PTB que abrigou grande parte dos comunistas e seus mandatos durante a ilegalidade do PCB (como Hércules Corrêa e Luiz Tenório de Lima), o que acabou por dar argumento aos setores mais conservadores que queriam ver no nacionalismo trabalhista uma tendência associada ao "perigo" comunista.

Em Pernambuco, neste momento os comunistas e socialistas não alinhavam-se não só aos trabalhistas mas também aos setores progressistas da Igreja Católica, acordando bases comuns de um programa humanista, relativamente independente dos seus dogmas específicos.

Pontual enxerga a eleição de Pelópidas como os "primeiros sinais de desmonte da estrutura pessedista", cujo colapso ocorreria com a eleição de Arraes para o governo do Estado em 1962 (PONTUAL, 2001, p.41). Francisco de OLIVEIRA vai mais além, atestando numa análise integral do possível locus da revolução brasileira, Recife, "a noiva da revolução":

"o Recife da Sudene foi provavelmente o lugar central do conflito de classes no Brasil do final dos anos 1950 e toda a década de 1960; (...) o elo mais fraco da cadeia do colapso do populismo, cujo epicentro, na verdade, encontrava-se em São Paulo."(OliveiRA, 2008, P. 65)

Durante a sua gestão, Pelópidas implantou o serviço de bondes elétricos, inaugurou as Avenidas Norte e Conde da Boa Vista, idealizou e operacionalizou o abastecimento de alimentos como serviço público, incorporou ao patrimônio público diversos parques e equipamentos, como o Sítio da Trindade, o Parque da Jaqueira e o Teatro do Parque e promoveu audiências públicas no Teatro Santa Isabel e em diversos bairros, registrando os apelos da população e debatendo diretamente com eles os problemas da cidade, hábito que Arraes viria a herdar. (CAVAlCANTI, 1978, p. 256 e PONTUAL, 2001) 
"Não teria tido êxito o governo da Frente do Recife se não tivesse contado com o apoio das associações de bairros, de forma organizada. A idéia partira do próprio Pelópidas, inspirado nas comissões de bairros ou de moradores de São Paulo." (CAVALCANTI, 1978, p. 257-258)

A participação popular seria de fato uma marca importante da gestão do engenheiro, transformada em plataforma política comum aos políticos da Frente do Recife. O próprio Pelópidas expõe a sua relevância:

"Durante a nossa campanha eleitoral, preconizamos e incentivamos a criação, nos diferentes bairros, de associações apartidárias que traduzam os interesses desses núcleos de população. Preocupava-nos o divórcio sempre existente entre as administrações e as vastas camadas populares, deixando as primeiras sem uma visão de conjunto de nossa realidade e as segundas relegadas ao mais cruel desamparo(...). Abre-se, assim, uma nova era para o Recife, onde as camadas mais sofredoras do povo podem fazer ouvir a sua voz, junto aos responsáveis pela coisa pública, de forma organizada e sem os prejuízos dos sectarismos de partido ou de facções" 106

As memórias dos engajados na campanha "humanista" destacam sempre a lisura, objetividade e sensibilidade de Silveira, traços que também seriam atribuídos à Arraes:

"O interesse público predominava, o povo sentindo que participava do presente e do futuro de sua cidade. Muitas obras de subúrbio se realizaram em regime de mutirão, a prefeitura entrando com instrumentos de trabalho e veículos, o povo, por seu turno, fornecendo mão-de-obra, nas tarefas emergentes (sic) de canalizar águas de chuva, drenar córregos, abrir valetas, aterrar alagados, construir pequenos muros de arrimo para evitar deslizamento de morros.

Nunca o povo do Recife fora chamado a cooperar diretamente com os poderes públicos, como então. Muitos planos de urbanismo e engenharia foram enriquecidos com sugestões adequadas, nessas reuniões

${ }^{106}$ Mensagem de Pelópidas Silveira à Câmara, Diário Oficial , 13/03/1956, apud PONTUAL, 2001, p. 135. de técnicos e leigos." (CAVALCANTI, 1978, p. 257-258)

No campo da habitação, embora tradicionalmente ligada à esfera estadual através do SSCM, Pelópidas propôs novo enfoque que seria incorporado pela autarquia durante o governo Arraes.

"Daí o governo de Pelópidas Silveria ter determinado como diretriz para as intervenções o sentido da periferia para o centro, assistindo as populações pobres dos altos e dos córregos, enfim dos mocambos. Além do decreto que permitia a reforma de mocambos sem a prévia autorização dos proprietários dos terrenos, foi empreendido o loteamento popular. A conjunção desse decreto com o loteamento constitui-se numa tática governamental inovadora no trato da moradia para os pobres no Recife." (PONTUAL, 2001, p. 196)

Além da sucessão de expressivas votações da Frente do Recife nos pleitos, outras campanhas como "O petróleo é nosso", a defesa dos interesses nacionalistas e pacifistas e eventos regionais, como os Congressos de Salvação do Nordeste (1956), foram apoiados pela coalizão coordenada pelos comunistas, o que acabou por disseminar ainda mais seu prestígio.

Na eleição de 1952, que tinha por objetivo escolher o próximo governador depois da morte de Agamenon Magalhães, que tal qual Getúlio, voltara reeleito e deixara a vida e o mandato, a Frente do Recife conseguiu mais uma expressiva vitória no Recife e em Olinda com um candidato escolhido de última hora, Osório Borba, enfrentando as forças tradicionalmente poderosas do Estado, representadas pela aliança do PSD e da UDN em torno da candidatura de Etelvino "Extermínio ${ }^{107 " ~ L i n s, ~ e x-c h e f e ~ d e ~ p o l i ́ c i a ~ d o ~ E s t a d o ~ N o v o, ~}$

${ }^{107}$ OliveIRA, 2008. 
que acabou por ser eleito com os votos do interior do Estado e intensa fraude eleitoral.

Na eleição seguinte, UDN e PSD voltaram a se opor, lançando o usineiro João Cleofas e o General Cordeiro de Farias, respectivamente. Os comunistas, a contragosto, apoiaram oficialmente Cleofas ambicionando derrotar o pessedismo ligado à figura de Agamenon Magalhães, dividindo os votos entre o usineiro e o voto em branco. Mais uma vez, as forças populares pesaram para que a eleição fosse ganha na capital e perdida no Estado, ainda que divididas por uma edição falsa do seu principal órgão de imprensa, o jornal "Folha do Povo", manipulando o apoio dos comunistas. Assim foi eleito Cordeiro de Farias, que teve o governo marcado pelo início da incompatibilização do PSD com as chamadas "Classes produtoras" e comerciantes, em torno da reforma da legislação tributária. O então deputado Miguel Arraes desponta nesse momento como líder da campanha contra a "escorchante" proposta do Governo aliando-se com as "classes produtoras", das quais já havia sido representante como advogado no Instituto do Açúcar e do Álcool.

Outra figura que ganhou projeção nesse momento foi a do usineiro Cid Sampaio, que representava a classe patronal reunida no Centro de Indústrias de Pernambuco, do qual era presidente. A oposição ao aumento de tributos, assim como à violência policial, uniram a burguesia e a classe operária numa aliança inédita até então, consolidada num grande comício e na indicação de Cid Sampaio como candidato das então formadas "Oposições Unidas de Pernambuco", que refletiam a determinação do PCB de se aliar com a burguesia contra a oligarquia.

A disposição de conquistar o Governo estadual, amparada nas expressivas vitórias eleitorais na capital, levou a Frente a aliar-se com a UDN, indicando como vice Pelópidas Silveira, ainda que fossem evidentes as diferenças ideológicas do partido com as forças de esquerda.

Segundo Francisco de OLIVEIRA, a principal componente da Frente era o Partido Comunista Brasileiro, com representatividade ímpar entre o povo naqueles anos:

"No Recife, o PCB era uma realidade política incontestável. Dominava o movimento operário organizado, tinha uma larga penetração nos meios proletarizados não formalmente operários, dispunha de quadros intelectuais importantes, como aliás em todo o Brasil e no mundo, no auge dos anos 1920 a 1956, quando começou a refluir com a invasão da Hungria e o relatório Kruschev, elegia deputados estaduais e vereadores através de outras siglas, como era notório e sabido.(...) A eleição de Pelópidas Silveira em 1955 e a de Miguel Arraes em 1959 para a prefeitura do Recife, e depois a de Arraes em 1962 para governador e outra vez Pelópidas em 1963, não teriam logrado sem o Partidão comandando a famosa Frente do Recife. Moviam-se como peixes n'água nos meios populares. Vi muitas vezes, naquelas eleições memoráveis, a familiaridade do PCB, de seus militantes e lideranças, com os morros e zonas pobres da cidade, o que equivale a dizer com a maior parte do Recife. Não chegavam de fora, mas eram de dentro."(OLIVEIRA, 2008, p.99)

Ao longo do seu governo, no entanto, a incompatibilidade de práticas e posturas de Cid Sampaio com as do núcleo da Frente não demorou a evidenciar-se, o que acabou por ocasionar o rompimento dos comunistas com o governo, radicalizando ainda mais a tensão política no estado. 
Para além do Partidão, o Partido Socialista Brasileiro em sua "formação pré-64" também era um componente importante da Frente:

"Partido de corte mais intelectual do que operário ou popular, tinha, entretanto, uma presença ativa na política recifense. O partido de Pelópidas Silveira, Antonio Baltar ${ }^{108}$, Chico Julião, Carlos Luís de Andrade, Carmita Andrade e Osório Borba, nas décadas referidas; de Antônio Cândido em São Paulo." (op.cit., p.104)

Em 1960, a Frente do Recife promoveu a candidatura de Miguel Arraes à prefeitura da capital, articulada por Paulo Cavalcanti, em meio a muita resistência de diversos setores políticos e jornalistas. Os socialistas queriam lançar o engenheiro e professor da faculdade de arquitetura Antonio Bezerra Baltar, que por seu "catolicismo arraigado" foi preterido pelos comunistas.

Arraes, embora reconhecido como deputado atuante e de posturas coerentes, era visto como uma figura que não distribuiria

${ }^{108}$ A dupla de engenheiros formados na mesma turma é aqui apresentada por Francisco de Oliveira dentro da sua atuação partidária:

“Pelópidas foi o primeiro grande prefeito popular do Recife, projetando-se ainda na saída do Estado Novo getulista, quando foi nomeado prefeito pelo interventor, na transição entre a ditadura de Vargas e o novo regime democrático. Administração ativa, inovadora, rasgando avenidas - a avenida Norte, tão importante para o surgimento de tantos bairros populares - e horizontes, fiscalizando ativamente o comércio dos gêneros que compunham a alimentação popular, nas feiras livres e nos mercados públicos. A cidade o elegeu duas vezes, reconduzindo-o ao Executivo municipal, e em 1964 encontrou-o firme no Palácio do Campo das Princesas, defendendo os mandatos constitucionalmente populares. Baltar era o grande pensador do urbanismo recifense, mestre emérito da Escola de Belas Artes, também arquiteto do modernismo brasileiro, colaborador do grande padre Lebret, religioso hoje relembrado em rua do Recife. O método sociográfico do padre Lebret foi responsável por um dos melhores trabalhos sobre o desenvolvimento do Recife, de Pernambuco e do Nordeste, patrocinado pela então CODEPE, com a intensa e decisiva colaboração de Baltar que conhecia a cidade como a palma da mão." (OliveIRA, 2008, p.104) tantas regalias, banquetes e whiskies para aqueles que o apoiaram, hábitos correntes na política local.

A experiência administrativa de Arraes era avalizada também pela sua participação nos governos de Barbosa Lima Sobrinho e Cid Sampaio como secretário da Fazenda. Assim, a candidatura de Miguel Arraes, formalizada pelo inexpressivo Partido Social Trabalhista, apoiada pela união de forças de esquerda e pela burguesia no poder, suportada pelas "Classes produtoras" e pelo próprio governador, venceu a disputa pela prefeitura do Recife.

"Apesar de discordar de certos métodos usados por alguns auxiliares do prefeito, estou convencido de que o governo de Arraes, no seu conjunto, foi o que melhor serviu ao Recife. Aplainado o caminho por Pelópidas, (...) a Arraes coube, com o seu agudo senso prático, realizar uma obra que força nenhuma apagará da história da cidade.

Se Pelópidas era o administrador de visão das grandes obras públicas, voltado para um planejamento englobado da cidade, Arraes era o homem sensível ao cotidiano, Ihano no trato com os humildes, aberto à discussão dos problemas sociais, sabendo lidar com o povo, auscultandoIhe as queixas e reclamos, pacientemente." (CAVALCANTI, 1978, p.285)

Segundo Cavalcanti, a principal realização de Arraes à frente da prefeitura foi a concepção inicial do Movimento de Cultura Popular ${ }^{109}$, ampliada com o envolvimento orgânico de intelectuais, artistas, técnicos populares em torno das questões da educação, conscientização e elevação do nível cultural do povo, a partir de seus próprios referenciais.

\footnotetext{
${ }^{109}$ Abordamos superficialmente esta importante referência para os anos 60 em Pernambuco porque ela será objeto específico do item do capítulo.
} 
No campo da educação, a prefeitura ampliou a rede de escolas de alfabetização através da construção de novas unidades, enquanto o núcleo católico do MCP, que mergulhou fundo na pesquisa da cultura popular e na aproximação do conceito de conscientização ao da alfabetização. A esquerda tradicional preocupava-se com o cumprimento de metas de governo como alavanca para as próximas eleições.

A urbanização da cidade seguiu o ritmo imposto por Pelópidas, sendo realizadas no período importantes obras na região central como a Ponte do Limoeiro, o alargamento da Rua da Aurora. A prefeitura atuava nas regiões nobres como Boa Viagem, que foi objeto de um plano específico de urbanização, elaborado a partir da participação e aporte dos proprietários, mas principalmente nos subúrbios populares, através do saneamento de córregos nos subúrbios e melhoria de vida dos moradores dos mocambos. O sistema de bondes elétricos implantado durante os governos de Pelópidas foi inaugurado (op.cit., p.289).

No plano do governo estadual Cid Sampaio e Pelópidas se afastavam, dividindo forças e abrindo um vácuo para a sucessão, enquanto as realizações de Arraes na prefeitura lhe davam cada vez mais espaço. A possibilidade de Arraes eleger-se governador do Estado ganhou força. O apoio de João Goulart, líder do PTB feito presidente da república, seria fundamental no caminho até o Palácio das Princesas mas a resistência dos trabalhistas teve de ser vencida em sessão popular no Teatro de Santa Isabel, colocando seus dirigentes em xeque.
Francisco de OlivelRA, personagem ativo dos Tempos de Arraes, sintetiza a saudável agitação que se processava e que revolucionaria os meios da cultura e da política brasileiras a partir de Pernambuco:

"Num ciclo memorável e ainda muito mal estudado na sua relevância para os novos tempos brasileiros, concomitante às Ligas [Camponesas], deu-se a organização dos trabalhadores urbanos num embrião de central sob a direta influência do Partido Comunista, as eleições de Pelópidas Silveira e em seguida de Miguel Arraes para a prefeitura de Recife, a seca de 1958, que detonou a criação da Sudene, a efervescência cultural do MCP e a radical inovação pedagógica e libertária de Paulo Freire, a conquista do governo estadual de Pernambuco pela Frente do Recife, à testa o maneirista Miguel Arraes, manhoso como se fosse político mineiro. Diz-se que a história escolhe, às vezes um personagem que não se parece com ela. Era o caso de Arraes, um conciliador por excelência que as circunstâncias transformaram num revolucionário"(OLIVEIRA, 2008, p.61)

As etapas de gradativa conquista dos poderes políticos pelas vias democráticas descritas por Francisco de OLIVEIRA balizam a emergência do proletariado como ente político e algumas das contradições em suas conquistas:

"a). entre 1945 e 1950, o proletariado emerge com feição própria, através até de um partido operário, o Partido Comunista, situando-se na correlação de forças políticas autonomamente no contexto regional e ligando-se nacionalmente ao proletariado do resto do país, principalmente do Centro-Sul; b) 1950 a 1958, o proletariado submerge numa coligação de forças comandada pela oligarquia agrária algodoeira-pecuária, em oposição à burguesia industrial nordestina(...); c) 1958 a 1961, o proletariado muda de partner político; juntar-se-á à burguesia industrial nordestina, esta sob o Comando de Cid Sampaio em PE, mas numa coligação em que a subordinação do proletariado era mais formal do que real: aí, realmente é já uma forma de potência igual à da burguesia industrial; d) 1961 a 1964, o proletariado comanda pela primeira vez a coligação de forças; seu partner, por estranho que pareça, será a oligarquia agrária algodoeira-pecuária, esta claramente subordinada."(OLIVEIRA, 1977/2008, p. 238) 
O crescimento da campanha de Arraes era acompanhado pelo aumento de atividade do $\operatorname{IBAD}^{110}$ e dos recursos, empenhados na promoção dos candidatos da oligarquia, por intermédio de Cid Sampaio (BANDEIRA, 1978). Os americanos, através da CIA e do IBAD, apoiados por grandes comerciantes e industriais, investiram grande soma de dinheiro em Pernambuco com o objetivo de atrapalhar o caminho de Arraes ao poder estadual, usando para isso programas de tv e assistencialismo médico e dentário nos bairros pobres, sem sucesso. O candidato usineiro João Cleofas, que já havia sido derrotado por Agamenon Magalhães e por Cordeiro de Farias, foi então derrotado pela terceira vez.

"As eleições de 1962 converteram Pernambuco num palco de especulações doutrinárias, as discussões ampliando-se sobre as origens internas e externas do subdesenvolvimento, os fatores do colonialismo apontados como entraves à expansão da economia e da cultura nacional, a reforma agrária reivindicada, os trabalhadores surgindo como força atuante, enfim, a Revolução Brasileira posta em questão." (CAVALCANTI, 1978, p. 303)

Além da importante vitória de 1962, que além de Arraes governador elegeu diversos deputados federais como os trabalhistas Josué de Castro e o arquiteto Artur Lima Cavalcanti, a Frente do Recife ainda logrou eleger mais uma vez Pelópidas Silveira prefeito do Recife em 1963, alinhando politicamente as esferas municipal, estadual e federal. Tal fato que se repetiria somente com a recente eleição, pelo novo PSB, de Eduardo Campos, neto de Arraes e seu principal herdeiro político para o mesmo posto do qual seu avô foi removido em 1964, aliado do prefeito João Paulo e do presidente Lula, do PT. O terceiro mandato de Pelópidas como prefeito, foi, no entanto, mais curto do que o de Arraes e terminou na mesma ocasião, obstado pelos militares que cercaram o Palácio das Princesas.

110 Instituto Brasileiro de Ação Democrática. A atuação do IBAD será melhor apresentada ao longo deste capítulo. 


\subsection{Arraes: o povo no governo}

"Esse fato novo - o aparecimento do povo como categoria histórica - é o que explica que eu hoje aqui me encontre, não em nome do povo, não em lugar do povo, mas, eu - um homem do povo, o povo, para assumir o governo do Estado" (ARRAES, 1963)

O discurso de posse de Miguel Arraes na investidura do cargo de governador merece ser analisado como um importante documento das disposições e compromissos políticos do novo governo. Para além do tom demagógico comum a esse tipo de expressão, podemos entender o que ele significa em termos de mudança de rumos na política do Estado, desde sempre cumpriu a função de defender os interesses dos irmãos xifópagos, latifundiários e usineiros, na expressão de Moniz Bandeira.

"Nesse discurso ele afastava a hipótese de tentar aplicar programas ideológicos desvinculados da realidade nordestina e salientava a sua opção humanista; um humanismo nordestino, brasileiro, voltado para o conhecimento da realidade, para as aspirações do povo e para a solução dos problemas que o afligiam. Para ele eram necessárias várias reformas, dando ênfase especial ao problema agrário, ao problema da habitação popular, ao respeito aos direitos do povo e às leis, à saúde, à difusão do ensino" (ANDRADE, 1989, p.52)

A abertura para a participação do povo nos assuntos de Estado era uma marca constituinte da sua trajetória política.

De acordo com Andrade, "A participação popular, desenvolvida pelo Movimento de Cultura Popular (MCP) e pelo setor sindical, incomodava a burguesia urbana, ao mesmo tempo em que o creditava [Arraes] frente à classe média e à população pobre não só do Recife como de todo o estado para a possível sucessão de Cid Sampaio" (op.cit., p.36)
No discurso de posse, há o reconhecimento e caracterização do atraso e da miséria, um chamado à ação e uma clara inserção no projeto nacional de desenvolvimento e a menção direta à revolução brasileira.

"Vivemos hoje um tempo brasileiro, marcado nem de pessimismo nem de otimismo, nem de desencanto nem de ilusão, mas, da vontade de fazer e de trabalhar, da determinação de descobrir, de estudar, de planejar, de construir. O processo de mudança, de que somos autores e atores, caracteriza esse tempo. A revolução brasileira, de que tanto se fala, é o projeto nacional que dá sentido e confere dignidade à condição de político, de militar, de administrador, de governante, de intelectual, de cidadão no Brasil dos nossos dias.(...) Tempo de fazer o homem brasileiroo que morre de fome nas secas do nordeste e o que vive subnutrido e doente nas grandes concentrações urbanas, o que é vítima das endemias que matam lentamente e o que se desespera por não poder dar aos filhos água e pão - fazer desse homem brasileiro o centro de todas as preocupações, a fim de ajudá-lo a sobreviver e ascender à condição de consumidor e criador de riqueza (...) A revolução brasileira nada mais é do que o esforço de todo um povo para superar essas condições de atraso e de miséria. Esforço consciente e honesto, no sentido de fazer com que 70 milhões de brasileiros tenham uma vida mais digna e participem do processo político nacional, dando -lhe conteúdo democrático e popular" (ARRAES, 1963)

Segundo Geraldo Gomes, os esforços empenhados na campanha eleitoral foram tão grandes que deixaram os planos e programas para o governo em segundo plano, retomados sob regime de trabalho intenso apenas depois da vitória eleitoral, que elegeu Arraes da Frente do Recife e Paulo Guerra da UDN como vice governador ${ }^{111}$. Segundo Callado, "tudo em Pernambuco era empírico e era novo", fazendo do

${ }^{111}$ Geraldo Gomes da SILVA, entrevista ao autor, set/2007. 
estado "o maior laboratório de experiências sociais e o maior produtor de idéias do Brasil" (CALLADO, 1964, p.46).

Alguns programas vinham da gestão de Arraes à frente da prefeitura, como o Movimento de Cultura Popular (MCP), que ao passarem para o âmbito do Governo do Estado, se chocavam com institutos e servidores já estabelecidos. A Fundação da Promoção Social, por exemplo, havia sido criada durante o Governo usineiro para se contrapor ao MCP em nível municipal. Uma vez alinhados politicamente os governos estadual e municipal, a FPS perdia a razão de ser, o que levou Arraes a propor sua extinção ainda em 1963.

"Iniciava-se um governo inteiramente voltado para as reivindicações populares e preocupado com os desafios da realidade pernambucana, nordestina e brasileira. Mas um governo que se defrontaria com uma série de problemas de ordem interna - grande incidência de pobreza entre a população rural e urbana, predomínio de poderosos grupos econômicos, sequiosos da manutenção do poder, baixas condições de educação e saúde, deficiência de recursos- e dificuldades de ordem externa, de vez que era hostilizado tanto pelo governo federal, formalmente seu aliado, como pelos americanos que temiam a formação de uma nova Cuba na América Latina" (ANDRADE, 1989, p.40)

Segundo Germano Coelho, secretário de Educação e presidente do MCP, havia uma concorrência interna entre os departamentos e quadros já estabelecidos e os do governo popular, em que pese aí a forte influência americana através do IBAD e da Aliança para o Progresso nos assuntos da gestão.

"Os Engenheiros do estado não queriam trabalhar nas obras do estado, só queriam trabalhar nas obras da USAID por que eles pagavam mais. Você tinha uma competição entre estrangeiros e nacionais desmoralizando o serviço público. (...) Tinha um poder paralelo aqui dentro $^{\prime \prime 112}$

No campo da saúde, a principal inovação proposta pelo Governo Arraes foi o Serviço de Assistência Itinerante (SAI) que levava grupos de jovens médicos ao encontro da população com o intuito de disseminar práticas de profilaxia, saúde e saneamento como forma de prevenção, diminuindo assim os casos de enfermidades. Os jovens médicos lançavam mão da linguagem popular e das medidas simples de saúde, traduzindo o vocabulário médico em literatura de cordel e baseando suas receitas em ingredientes comuns e acessíveis a toda a população, frequentemente de maneira integrada com ações do MCP.

"(...)precisamos acabar com o tipo de governo paternalista e compadresco, que julga conceder favores ao povo, doar coisas ao povo, para criar um tipo de governo que possibilite a participação do povo no próprio processo administrativo.(...)E por isso o povo precisa ajudar a escola, e ele a ajuda quando participa dos debates que precedem a construção, quando participa das dificuldades para construir e manter a escola, quando se capacita de que é necessário ajudar a professora a integrar-se no meio das famílias onde a escola funciona. Essa participação do povo contribui para modificar a própria concepção da escola." (ARRAES, 1963)

A crença inabalável nas premissas do MCP e o papel político que se atribuía ao povo surge em comentário que Arraes faz à jornalista Tereza Rozowykwiat, já em outras circunstâncias incluída em sua biografia do "mito":

"O MCP foi fruto das circunstâncias políticas da época e, sobretudo, de um pensamento oposto ao regime que está aí. Isto é, nós entendemos que é mobilizando o povo de todas as formas que os problemas podem ser resolvidos e, mobilizando, inclusive, através da valorização do que o povo

${ }^{112}$ Germano COELHO, entrevista ao autor, set/2007. 
criou como cultura, para que haja uma afirmação também sob este aspecto, dos grupos de pessoas das comunidades. As transições só podem ser feitas se o povo está mobilizado, se participa do processo." (ROZOWYKWIAT, 2006, p.34)

$\mathrm{Na}$ educação, as ações mais criativas do Governo Estadual estavam vinculadas ao MCP, objeto de item específico no próximo capítulo. A Secretaria de Educação, dirigida por Germano Coelho, cuidou principalmente de realizar concursos públicos para resolver a questão dos excedentes, professoras sem concurso que davam aula em caráter precário, situação que se generalizava no Estado e gerava mobilização da classe que lutava pela simples efetivação.

O instrumento do concurso estava completamente desacreditado, na medida em que as nomeações para os cargos eram campo fértil para o clientelismo político e o favorecimento dos apadrinhados. A garantia da nomeação no primeiro concurso para professores realizado no governo Arraes resolveu de certa forma o problema, afastando inclusive centenas de pessoas que já davam aulas sem ter condições para tal, o que ficou evidenciado com a sobra de vagas que resultou do concurso.

A Secretaria de Educação promoveu também, logo que assumiu, um exame crítico do material didático adotado pelo governo federal, chegando à conclusão que haveria que formular outras bases de ensino a partir do zero. Elaborou então um plano educacional, premiado pelo Ministério da Educação e Cultura (MEC) como o melhor programa estadual, mas não chegou a ser posto em prática como advento da ditadura militar. ${ }^{113}$

No que tange à habitação, os novos funcionários comissionados do Serviço Social Contra o Mocambo enfrentaram forte resistência as suas idéias e vontade de executar uma política de habitação em bases diversas das quais os engenheiros funcionários públicos de carreira estavam acostumados.

Segundo Borsoi, a constatação da impossibilidade de realizações de fato com a burocracia estabelecida foi o que levou-o, juntamente com Gildo Guerra, a propor outra lógica de provisão de habitação. Tal postura, no entanto, já estava delineada por Arraes no discurso de posse, no qual ele se refere diretamente a questão da habitação, indicando para um contexto no qual a participação popular seria essencial.

"Quando se vai construir um conjunto de casas, o povo deve debater amplamente o problema da habitação popular; não podemos impingir ao homem humilde e à sua família, apenas porque são humildes, um tipo de moradia cujo projeto eles nem conhecem, não foi por eles discutido" (ARRAES, 1963)

Na historiografia política local, a partir da sensibilidade para a gravidade da questão urbana e da mudança de paradigma da atuação do Estado e suas novas relações com o povo surgiu.

"a famosa experiência de Cajueiro Seco, bairro situado ao sul do Recife, entre terras de propriedade dos beneditinos e da Usina Muribeca, nos Guararapes. Neste terreno o SSCM, órgão estadual, adquiriu uma área não construída, loteou-a e encaminhou para lá um grande número de famílias sem casa própria. As pessoas recebiam um lote, eram financiadas

${ }^{113}$ Germano CoELHO, entrevista ao autor, set/2007. 
para a aquisição do material de construção, orientadas por engenheiros e arquitetos do governo e construíam as suas próprias casas, de acordo com seus gostos e necessidades. Procurava-se assim fazer com que o próprio trabalhador participasse da construção, quebrandoa uniformidade das vilas populares planejadas. O custo da construção tornava-se bem mais baixo, de vez que eles procuravam se organizar em mutirões, a fim de que 0 empreendimento andasse com maior rapidez" (ANDRADE, 1989, p.48)

No entanto, tanto o Programa de Habitação do Governo do Estado publicado em 1962, já no ocaso do governo de Cid Sampaio quanto o Acordo celebrado entre a United States Agency International for Development (USAID) e o SSCM em outubro do mesmo ano, incluído no programa da Aliança para o Progresso pernambucana, se referem à auto ajuda como meio de provisão habitacional. Mais do que especular sobre quem teria sido o "pai da criança". A permanência da autoconstrução assistida em programas de governo e recomendações de natureza ideológica distinta quando não oposta nos mostra que a habitação popular era um campo de disputa político importante, no qual recomendações e posturas confundiam-se, até que sua implementação explicitasse suas diferenças práticas e conteúdos.

A relação entre o governo central e o novo governo estadual era tensa, embora Arraes se colocasse sempre ao lado de Jango pelas

\section{Reformas de Base:}

"Miguel Arraes, que fazia um governo moderno e renovador em Pernambuco, apesar de apoiá-lo, era hostilizado pelo governo federal a ponto de se dizer que Jango designara o general Justino Alves Bastos para poder fiscalizá-lo. Sabe-se também que ao propor a decretação do Estado de Sítio, Jango pensava em destituir, de uma só cartada, dois governadores que Ihe eram incômodos: Lacerda, à direita, na Guanabara, por ser um dos seus maiores opositores; e Arraes, à esquerda, em Pernambuco, por ser uma liderança em crescimento, que se expandia no espaço que reservara para si." (ANDRADE, 1989, p.21)

Figura central da Frente do Recife, o jornalista, advogado e articulador político, Paulo Cavalcanti em suas memórias expôs as crescentes incompatibilidades entre os comunistas, Arraes e as forças políticas tradicionais do Estado, representadas pelo PSD e pela UDN, que acabaram por dificultar as relações daqueles que sempre tinham tido acesso aos altos escalões do governo. Cid Sampaio rompe com o Governo, especialmente depois do episódio da denúncia dos acordos com Washington, do qual se beneficiou o seu governo. A oposição se acirrou até chegar ao ponto de propor a eliminação física do Governador Arraes durante uma reunião na casa de Cid, fato que foi amplamente denunciado no jornal A Hora, órgão de imprensa do PCB, sucessor da Folha do Povo ${ }^{114}$.

A pressão sobre o governador Miguel Arraes feita pelas forças de direita estava inscrita e imbricada com as feitas sobre o presidente João Goulart, como revelou a matéria "Na crise pernambucana está em jogo o destino do regime", originalmente publicada no Estado de S. Paulo com o título "O Estado de revolução em Pernambuco" e reproduzida no Diário de Pernambuco:

"Faz mais de um ano que esta folha adverte o país contra o risco imenso que ele corre devido à atitude revolucionária do governador Arraes, cada dia mais firme na sua determinação de gerar a desordem, como condição prévia e indispensável do estabelecimento do totalitarismo das esquerdas em Pernambuco.(...) O que vem acontecendo em Pernambuco é a consequência lógica da indisfarçada

\footnotetext{
114 "Usineiros apelam para o terrorismo - Proposta numa reunião na casa de Cid a

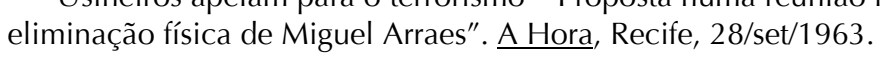


proteção que ao governo bolchevista daquele unidade da Federação dispensa o Executivo Nacional" ${ }^{\prime 115}$

A posição de Arraes entre extremismos de direita e esquerda,

diante da incongruência das realidades do campo e das cidades, era extremamente delicada. De acordo com Andrade, Arraes,

"preocupado em manter as reformas dentro dos padrões legais, teve que conter a fúria dos que se opunham às reformas e a reação dos radicais que desejavam que estas se fizessem com maior rapidez, antecipando-se ao momento histórico vivido." (ANDRADE, 1989, p.43)

Para OliveIRA, no entanto, o principal conflito que emergia com Arraes era de hegemonia na dita "integração nacional" e os "desequilíbrios regionais":

"O governo Miguel Arraes em Pernambuco estava, na verdade, em oposição não apenas à burguesia industrial regional, mas principalmente em oposição à burguesia industrial que se tornava nacionalmente hegemônica a partir do Centro-Sul." (OLIVEIRA, 1977/2008, p. 241)

115 "Na crise pernambucana está em jogo o destino do regime". 


\subsection{O Movimento de Cultura Popular}

Surgido em setembro de 1961 durante a gestão de Miguel Arraes na prefeitura do Recife, o Movimento de Cultura Popular (MCP) como uma proposta do prefeito, estabelecendo-se como entidade privada sem fins lucrativos, financiada por convênios com os poderes municipais e estaduais e apoiada pela sociedade civil.

Criado em um momento de grandes discussões no país em torno dos temas da cultura e da educação popular ${ }^{116}$, o MCP logo se constituiu em uma das principais referências nacionais de aproximação entre Estado e sociedade civil, universidade e vida urbana, intelectuais e povo.

Ao contrário das perspectivas folcorísticas, ilustradas e vanguardistas, as coordenadas de ação do movimento pareciam alinhar-se a um ideal de conscientização das massas populares a partir de suas próprias condições de vida social, econômica e cultural. Inserindo-se no contexto reformista do período, o MCP faria convergir perspectivas tão diversas quanto o nacional-desenvolvimentismo, o populismo trabalhista, o socialismo cristão, o marxismo-leninismo e a mobilização camponesa nordestina.

\footnotetext{
${ }^{116}$ Para entender a criação do MCP inserida no contexto nacional, ver Aracy AMARAL. "Anos 60: da arte em função do coletivo à arte de galeria" in Arte para quê? A preocupação social na arte brasileira 1930-1970. São Paulo: Studio Nobel 2003 e Renato ORTIZ, Cultura brasileira e identidade nacional. São Paulo: Brasiliense, 2005
}

A publicação paulista "Arte em revista", que dedica grande parte dos seus números aos anos 1960 na cultura e na arte, em antologia dedicada ao "popular" um balanço das atividades do MCP relativo ao ano de 1963, que serve como um instantâneo das realizações e da trajetória do movimento até aquele momento. O documento é introduzido por uma declaração do então governador Miguel Arraes, que explicou o MCP como uma "nova atitude" de aproximação da realidade "de homens de todas as tendências religiosas ou políticas", uma aliança entre "estudantes, intelectuais e camadas populares" Esses argumentos serão recorrentes no entendimento do $\mathrm{MCP}$, reforçados pelo próprio Arraes em diversas ocasiões (MAURíCIO et alli, 1978, p.101).

Para Arraes, o MCP representava uma coalizão entre distintas tendências progressistas comprometidas com a superação das deficiências educacionais e culturais das camadas populares. Nessa união e nessa abertura estaria sua principal força.

Germano Coelho, o primeiro presidente do MCP, explicita o momento dramático de origem do movimento, usando as metáforas naturais para referir-se às estruturas sociais da cidade e do campo:

"O Movimento de Cultura Popular nasceu da miséria do povo do Recife. De suas paisagens mutiladas. De seus mangues cobertos de mocambos. Da lama, dos morros e alagados, onde crescem o analfabetismo, o desemprego, a doença e a fome. Suas raízes mergulham nas feridas da cidade degradada. Fincam-se nas terras áridas do Nordeste. Refletem o seu drama, como síntese dramatizada da estrutura social

\footnotetext{
117 "Que é o MCP?" Arte em revista, No3.
} 
inteira"

No texto do médico Miguel Newton Arraes ${ }^{119}$ que apresenta as razões e realizações do movimento colocam-se os principais objetivos do Movimento: "promover e incentivar a educação de crianças e adultos e proporcionar a elevação do nível cultural do povo". Ligado inicialmente a programas de alfabetização da Secretaria de Educação do município, os trabalhos logo se estenderiam para outros campos através do Departamento de Formação da Cultura - divisão do movimento criada para "interpretar, desenvolver e sistematizar a cultura popular" (MAURíCIO et alli, 1978, p.17).

O MCP seria "um órgão de caráter técnico, rigorosamente apolítico e pluralista(...), um lúcido esforço da comunidade inteira para acelerar a elevação do nível material e espiritual do povo, através da educação e da cultura. Nunca do assistencialismo, do empreguismo, de eleitoralismo." 120

O investimento em educação, a cultura e criação de novas atitudes são vistos como os conceitos chaves, etapas necessárias e fundamentais à "autodeterminação" do povo. A renovação das práticas pedagógicas e a participação popular funcionariam como mecanismos políticos de transformação.

De acordo com Miguel Newton Arraes, "a obsessão do MCP é

118 "Que é o MCP?" Arte em revista , Nº3. Nesta publicação, o texto não está assinado, mas em Maurício, 1978 foi publicada uma entrevista de Germano Coelho de onde parecem ter saído as declarações presentes em Arte em Revista. (MAURícIO et alli, 1978)

${ }^{119}$ O segundo presidente do MCP e primo do governador, médico envolvido também com o Serviço de Assistência Itinerante (SAI)

120 "Que é o MCP?" Arte em revista, No3 educar para a liberdade. Para a autonomia. Para a maioridade. (...) Educar, recorrendo a processos informais, nas praças públicas e em plena rua. Educar pelo rádio. Pelo cinema. Pela televisão. Pela imprensa. Educar, explorando novos métodos e técnicas de educação. Experimentando. Adaptando. Criando. Educar recreiando. Educar, informando. (...) Concebendo a educação e a cultura como um processo ininterrupto de aquisição, cria uma instituição que não estratifica conhecimentos, nem paralisa o progresso social, num mundo essencialmente dinâmico."

Os objetivos últimos estavam expressos - "a valorização do homem brasileiro, a desalienação de nossa cultura e a emancipação econômica e social do país" ${ }^{121}$; tal programa seria visto como subversivo pelas oligarquias políticas, que trataram de estimular o combate ao movimento antes e depois do golpe.

Em análise das matrizes teóricas e propostas do MCP realizada por Germano Coelho, o primeiro presidente do MCP, em entrevista realizada nos anos 1970, fica clara a vinculação do movimento com o nacionalismo, bem como a ideário nacionalista, bem como com a idéia do povo e das tradições populares nordestinas em especial como depositários de uma cultura autenticamente brasileira:

"Alguns desses Estados [do Sudeste], devido à miscigenação maior com estrangeiros, sentiram, a riqueza imensa do Nordeste. Guardamos mais, até pela falta de processo de industrialização agudo entre nós, essas tradições. Ora, dentro dessa perspectiva de que a experiência do MCP foi acompanhada, debatida e foi, de certa forma, vivida no plano nacional, podemos dizer que a mensagem do MCP se somou a outras que vinham se acumulando no país, no sentido de preservação da cultura popular brasileira" (MAURíCIO et alli, 1978, p.27).

O caráter formativo e de troca entre os segmentos sociais através da cultura também é enfatizado por Coelho no mesmo depoimento:

121 "Que é o MCP?" Arte em revista, No3. 
"O MCP não criou a cultura popular, a cultura popular sempre existiu entre nós. Apenas foi um movimento, entre outros, que procurou desenvolver essa cultura popular e sobretudo, ligar à juventude e à intelectualidade a cultura do povo. E procurou mostrar, também, ao nosso povo e aos nossos intelectuais que grande parte de sua inspiração seria fortalecida por esse contato.(...) É incrível que se tenha olhado para o MCP como se fosse uma coisa singularíssima. Era uma experiência, entre outras, de desenvolvimento da cultura encaminhada, inclusive, com muita abertura de espírito e com um desejo muito grande de não manipular a cultura popular, mas aprender com o povo. E quem tinha mais a lucrar nesse contato, no ponto de vista da arte, eram os próprios artistas, os intelectuais, os teatrólogos. Eles poderiam criar muito mais brasileiramente na medida em que eles tivessem contato com as nossas raízes populares." (MAURícIO et alli, 1978, p.27-28).

Tais conceitos chaves (como raízes populares) e atitudes (aprender com o povo e criar brasileiramente) estavam na plataforma política da Frente do Recife e de Arraes, mas certamente elas ecoam também idéias e propostas na base da atividade da Sudene na sua fase inicial.

Dentre as realizações elencadas no balanço de 1963, destacamse a Campanha de Alfabetização, a criação de 414 escolas, 49 Clubes de mães, Centros Artesanais e de Cultura e Cursos profissionalizantes, parte deles funcionando através de convênios com outros órgãos e secretarias como os Centros Educativos Operários do SSCM. ${ }^{122}$ Apresentam-se ainda como conquistas ligadas ao MCP a criação da Galeria de Arte do Recife, às margens do Rio Capibaribe, o Teatro de Cultura Popular, trabalhos de pesquisa e publicações como a "Página de Cultura Popular" do jornal última Hora, o álbum de gravuras

122 "Convênio SSCM MCP leva teatro aos subúrbios", Última Hora. Recifa, 20/mar/1963
"Meninos do Recife", de Abelardo da Hora e também o filme "Cabra Marcado para Morrer", de Eduardo Coutinho, que naquele momento iniciava sua produção.

O Serviço de Assistência Itinerante (SAI), que levava saúde, educação sanitária e profilaxia à população antes que ele precisasse ir ao hospital é outra atividade ligada ao MCP, que reflete a disposição do novo governo e dos setores progressistas de ir ao encontro do povo.

De acordo com Vital Lira ${ }^{123}$, um dos médicos envolvidos no SAI juntamente com Ciro de Andrade Lima, Bianor Teodósio, Geraldo Torreão e outros ${ }^{124}$, a iniciativa surgida no Recife foi expandida ao âmbito do Estado com a pretensão de tornar-se a política de saúde do governo popular, fato que oficialmente não ocorreu pela entrega da Secretaria de Saúde a outras forças políticas como contrapartida do apoio eleitoral à Arraes.

Assim, o SAl estruturou-se em paralelo à Secretaria, como uma "falange" que ocupava postos de saúde e encampava equipamentos ociosos, promovendo a educação sanitária através de livretos de cordéis e levando à medicina preventiva aos interiores do Estado de maneira simples e direta. Essa disposição de ir de encontro aos problemas que assolavam o povo dos jovens profissionais que se

\footnotetext{
${ }^{123}$ Vital LIRA, entrevista ao autor, Recife, abr/2008.

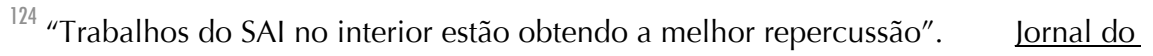
Commercio, Recife, 13/Jul/1963.
} 
formavam na Universidade do Recife está inscrita no espírito geral da época e do lugar. ${ }^{125}$

Um referencial teórico importante para o MCP era o movimento Peuple et Culture francês (AMARAL, 2003, p. 318, internacionalista e ligado às vertentes progressistas da igreja católica. A relação entre a matriz européia e sua versão nacional se dava através da figura de Violeta Arraes, irmã do Governador e casada com Henri Gervaiseau, também um ideólogo do movimento. Com o apoio do Ministro Darci Ribeiro, o MCP pernambucano seria um modelo sob o qual se implantariam outros movimentos nos demais estados brasileiros, "um exemplo a ser levado a todo o país" (RIBEIRO apud MAURícIO et alli, 1978, p.18)

Arraes, na abertura do I Encontro Nacional de Cultura Popular, um entre vários eventos inaugurais em torno do tema que propunham o debate e a "conceituação do que é cultura popular hoje, no Brasil" que se dariam no Recife naqueles anos, como o I Encontro Nacional de Alfabetização e Cultura Popular, explica o caráter universalizante e ambíguo do movimento:

"É necessário fazer movimentos de Cultura Popular para integrar cada vez mais o povo no processo democrático. Negamos que esses movimentos sejam subversivos mas não que sejam revolucionários." ${ }^{126}$

Nas "Páginas de Cultura Popular" do jornal última Hora, o pintor e escultor Abelardo da Hora, ponta de lança entre os artistas

${ }^{125}$ Vital LIRA, entrevista ao autor, Recife, abr/2008.

126 "Arraes diz que Cultura Popular serve para humanizar sociedade". Lornal do Commercio, Recife, 5/set/1963. ligados ao Partido Comunista engajados no MCP, tinha espaço pra expor plenamente suas idéias acerca da relação da cultura popular com a solução dos problemas da vida cotidiana, destacando sua constante atualização e relações com as revoluções:

"A cultura popular é a própria afirmação do homem na vida, é a sua permanente presença marcada na prática da criação, dos instrumentos e todos os bens materiais. É a presença constante e viril a todas as adversidades vencendo as forças da natureza, para suprir suas necessidades vitais. A cultura popular tem compromissos imediatos com a vida e seu desenvolvimento. A realidade objetiva é o seu campo de ação, a cultura popular é por isto participante, prática e objetiva. Ela também possui seus meios e formas de expressão.(...)O conteúdo da cultura popular é progressista e revolucionário porque atende às necessidades vitais, reais e imediatas do homem sem divagações teóricas e sem subterfúgios, enquanto a cultura acadêmica e livresca é unilateral, contraditória e polêmica, assenta-se em suposições e relega a importância da prática no conhecimento humano e na conceituação das verdades, desprezando o nexo com a prática da vida, carrega elementos reacionários contra as lutas que desenvolve o povo na prática histórico-social, na conquista de bens materiais indispensáveis à vida do homem."

Abelardo da Hora elabora as conexões entre o povo e uma democracia participativa através dos organismos fomentados também pelo Estado, esclarecendo o papel do movimento dentro de um programa mais amplo de conquista dos espaços institucionais do estado pelo povo defendido pelo PCB na época:

"O MCP visa esclarecer o povo da importância de sua cultura, sufraga elementos do contingente da cultura popular e a ele se incorpora para impulsionar o processo de desenvolvimento, depõe o ensino tradicional, acadêmico e livresco, mobiliza intelectuais e artistas, educadores, estudantes e povo para levar à prática a emancipação política e social da pátria brasileira. São os próprios elementos da cultura popular o

${ }^{127}$ Abelardo da HORA. "Cultura popular e MCP". última Hora, nov/1963. 
mais forte instrumento e arma poderosa na elevação da consciência popular para a consecução desses objetivos" ${ }^{128}$.

Da ótica do PCB, apresentada por BRAYNER, F. IN REZENDE, afastando-se em sua leitura tanto da "mistificação infamante" quanto da "glorificação saudosista", o MCP seria um espaço privilegiado dentro da Frente do Recife para a construção da aliança do proletariado com a burguesia, etapa estratégica para a tomada do poder e implantação do socialismo. Mais do que uma questão de classe, a cultura e o Nordeste no quadro político brasileiro representavam uma questão de desigualdade regional, que justificaria inclusive alianças com tradicionais adversários políticos, o que tem um sentido específico no caso pernambucano. Tal aliança seria a base da transformação em curso:

"A revolução já se fez. O povo pernambucano resolveu revolucionar os métodos de governo (...) nisto reside a subversão: industrialização, nacionalismo, elevação do nível de vida das classes menos favorecidas." (BRAYNER, F. IN REZENDE, 1987, p.194-196)

A relação do MCP e da SUDENE com as transformações políticas

em curso nos anos 1960 deve ser considerada cuidadosamente, como uma interação mútua no sentido de ampliar e integrar os limites da atuação política, que lidaria com a questão das desigualdades regionais e excluiria as práticas assistencialistas.

"Desde o Congresso de Salvação do Nordeste (1956) que os comunistas postulam uma prática não assistencialista do Estado em relação à região e colocavam na ordem-do-dia a questão agrária e as causas das "disparidades regionais".(...) É pois no interior de uma crise,

${ }^{128}$ Abelardo da HORA. "Cultura popular e MCP". Última Hora, nov/1963.. e por causa dela, que o MCP ganhou a dimensão política que ousou lograr. Foi, sem dúvida, uma das mais importantes estratégias políticas assumidas pelas forças populares no início dos anos $60 \mathrm{em}$ Pernambuco. A questão central de todo o movimento é a própria questão da HEGEMONIA, do estabelecimento de uma cultura política nova, de uma contra-ideologia e de uma "ação pedagógica para a revolução", que significou, efetivamente, um caminho alternativo para as camadas que emergiam à cena política e forjavam novas formas de organização política." (op.cit., p.201-203)

Em outro artigo publicado na "Página de Cultura Popular" da última Hora, Abelardo da Hora reitera e completa seu entendimento de arte popular como expressão do embate com a erudição e a alienação, reforçando sua inserção na cisão do mundo contemporâneo e estendendo sua crítica à arte abstrata ${ }^{129}$ :

"Estamos em uma conjuntura em que até calar é um compromisso assumido. É falso o conceito de arte apolítica, de arte pela arte, porque toda forma tem um conteúdo. O abstracionismo é uma manifestação formalística que, pretendendo não assumir compromisso, tenta calar o conteúdo mas é uma afirmação de alheamento com todas as suas implicações."

A pedagogia do MCP era apresentada como reação progressista aos sistemas de ensino tradicionais, dentro de uma linha que unia Anísio Teixeira e sua proposta de "Educação para Todos" à Darcy Ribeiro, então ministro da Educação. O controle do programa de alfabetização era disputado no seio do movimento por tendências

${ }^{129}$ Sobre a posição dos comunistas dentro do debate entre figuração e

abstracionismo e suas relações com a polêmica concreta e neoconcreta, ver Aracy AMARAL. "Realismo versus abstracionismo e o confronto com a Bienal" in Arte para quê? A preocupação social na arte brasileira 1930-1970. São Paulo: Studio Nobel, 2003 e Ronaldo Brito. Neoconcretismo. São Paulo: Cosac Naify, 2001.

${ }^{130}$ Abelardo da HORA. "Arte e Cultura popular". Última Hora, Recife, nov/1963 e Dez/1963. 
levemente divergentes, mas que concordavam que "o projeto políticopedagógico proposto colocaria em cena a própria questão da cidadania das classes populares" (BRAYNER, F. IN REZENDE, 1987, p.206), residindo aí as raízes da difamação que sofria por seus reacionários detratores. Sobre a educação formal, afirma da Hora:

"O pedantismo e os processos retrógrados eram a tônica do oficialismo escolar, até pouco tempo. Monteiro Lobato era tabú e dava demissão. Latim, matemática, "Os luzíadas", mau gosto, alienação: Assim se apresentava a escola no Brasil até há pouco, até o povo começar a influir nos destinos da Nação." ${ }^{131}$

A vitória de Arraes nas eleições de 1962, significaria a transposição de escala e de instância do MCP, então com atuação restrita ao Recife, em cuja prefeitura fora criado, que agora alcançava a escala estadual, levando o programa de alfabetização urbano ao encontro do povo do interior, constituindo um enorme desafio às teorias e práticas do MCP. Havia algo de revolucionário na emancipação intelectual do povo, fim último das atividades do MCP: "Tremei "Wall Street, tremei "barões da terra": chegou o MCP ensinando o povo a não ser mais escravo nem joguete de belicistas atômicos", vaticinava Frederico Rocha no jornal A Hora, relacionando o momento local com a conjuntura internacional da Guerra Fria. ${ }^{132}$

Também o Teatro de Cultura Popular (TCP) chegava ao interior através de um "Rush na zona da mata, fazendo apresentações nas

${ }^{131}$ Abelardo da HORA. "Arte e Cultura popular". Última Hora, Recife, nov/1963 e Dez/1963.

${ }^{132}$ Frederico Rocha. "Darcy Ribeiro e o MCP". A Hora, Recife, jan/1963. cidades e nos engenhos" ${ }^{\prime \prime 3}$. O teatro seria um campo privilegiado de exploração das novas idéias em torno da participação e dos novos temas que se pretendia introduzir no debate cultural da cidade, do Estado e do país. A colaboração com o Arena de São Paulo, que montara no Recife diversas peças e forneceria textos para as produções também seria fundamental para levar o TCP à outros estados brasileiros.

Embora o teatrólogo Hermilo Borba Filho fizesse parte do grupo fundador do MCP, juntamente com Germano Coelho, Ariano Suassuna, Abelardo da Hora, Aloízio Falcão, Paulo Freire, Francisco Brennand e Luiz Mendonça, em torno de sua liderança organizara-se o Teatro Popular do Nordeste, um desenvolvimento do Teatro do Estudante de Pernambuco, criado em 1946, que nesses anos constituía oposição direta ao TCP. "O TPN acusava publicamente o teatro do MCP de se utilizar da cultura popular para fazer "arte dirigida".

No Governo de Cid Sampaio, o TPN havia levado algumas peças nos Centros Educativos Operários (CEOs), em convênio com o SSCM, tal qual faria o TCP anos depois. Com o desenvolvimento das experiências do TPN, o próprio Hermilo chega, já nos anos 1970, à conclusão um tanto estéril de que "só quem pode fazer teatro popular é o povo" (MAURíCIO et alli, 1978, p.18). Entre a apropriação da cultura popular para fins políticos e o seu inverso, ficava Hermilo, que se apresentava como um "parasita do folclore" em seu discurso de posse como presidente da Comissão Pernambucana de Folclore. Para ele, o

133 "Teatro do MCP fará apresentações nos engenhos e usinas". A A Hora, Recife, 23/dez/1963. 
folclore era o "privilégio de povo subdesenvolvido" (MAURícIO et alli, 1978, p.36).

O cinema acompanha o movimento em direção ao povo e ia com a equipe de Eduardo Coutinho investigar e registrar as condições de vida no campo e os conflitos entre latifundiários e camponeses em tempos de Ligas Camponesas, produzindo as imagens iniciais do "Cabra Marcado para morrer".

Para além do teatro ou da alfabetização, cujos papéis dentro do movimento de aproximação ao povo já estão bem documentados por outras pesquisas, a produção interrompida do documentário em torno das questões da terra e do trabalho tem um significado especial no universo aqui considerado. A estréia interrompida do diretor Eduardo Coutinho era apresentada pelo Diário de Pernambuco como "Cinema Novo", com o "objetivo de contar um fato real, sem fugir, em sua temática, também ao aspecto de ficção" ${ }^{\prime 134}$.

A "estética da fome" de Glauber Rocha era de fato uma referência importante no panorama cultural brasileiro nesses anos, que iria inspirar tanto os cariocas dos movimentos neoconcretos e a arte marginal de Helio Oiticica aos projetos paulistas do grupo Arquitetura Nova, as cenografias de Flávio Império e o Teatro Oficina.

A análise e a leitura do "Cabra marcado para morrer" feita por Roberto Schwarz descortina algumas camadas de significados artísticos e sociais bastante relevantes.

134 “Pernambuco vai fazer Cinema Novo também: 'Cabra marcado para morrer'”. Diário de Pernambuco, Recife, 14/nov/1963.
"A idéia do primeiro filme nasce durante uma viagem da UNE volante ao Nordeste, em 1962, no quadro do CPC e do MCP, e traz a riqueza daquele momento extraordinário. Sob o signo da renovação cultural, aliavam-se a disponibilidade dos estudantes e as formas mais dramáticas da luta de classes (...). Seu sentido tácito, salvo engano, seria mais ou menos o seguinte: a justiça e a simplicidade da reivindicação popular emprestavam relevância à vida estudantil e à cultura, que por sua vez garantiriam ressonância nacional, admiração e reconhecimento civilizado à luta dos pobres" (SCHWARZ, 1987, p. 71-72)

"Se meditarmos no universo do filme, em que estão presentes somente populares e intelectuais, penso que reconheceremos que esta composição é o fundamento de seu clima tão particular" (op.cit., p. 77)

A conclusão do projeto nos anos 80 serve como metonímia da retomada das questões e propostas que estavam sendo aventadas nos anos 1960, agora em tempos democráticos, depois da ditadura militar e talvez munido de um certo espírito crítico que reparava a ingenuidade inicial $^{135}$. A análise contemporânea do "Cabra marcado para morrer" expõe seus principais valores e questionamentos, inserindo a produção do filme num quadro geral da onde podem partir analogias com outras experiências, incluindo a do Cajueiro Seco.

"Hoje parece óbvio que aquela aliança não tinha futuro político, e

\footnotetext{
${ }^{135}$ Sobre a continuação do filme em tempos democráticos, Schwarz constrói a relação entre aqueles movimentos populares e sua retomada pós ditadura: "O diretor, Eduardo Coutinho, retomava o seu trabalho, bem como as suas alianças de classe, transformando o tempo decorrido em força artística e matéria de reflexão. Neste ponto o cineasta se parece à sua atriz e figura principal, a militante camponesa que soube desaparecer, sobreviver à repressão, e reaparecer. (...) Metaforicamente, a heroína enfim reconhecida e o filme enfim realizado restabelecem a continuidade com o movimento popular anterior a 64, e desmentem a eternidade da ditadura, que não será capítulo final. Ou ainda, o cinema engajado e a luta popular reemergem juntos."
} 
que a revolução com estímulo de cima só podia acabar mal. No entanto ela canalizou esperanças reais, de que o filme dá notícias e nas quais se pressentem outras formas de sociedade. A relação entre assunto, atores, situação local e gente de cinema não é evidentemente de ordem mercantil, e aponta para formas culturais novas. Não se pode dizer também que o diretor se quisesse expressar individualmente: a sua arte trata de apurar a beleza de significados coletivos. Tem sentido, no caso, falar em autor?" (SCHWARZ, 1987, p. 73)

Em junho de 1963, Miguel Newton Arraes, assume a presidência do MCP, evitando assim o acúmulo de cargos sobre Germano Coelho, que assumira em fevereiro a Secretaria de Educação. Na posse de seu sucessor à frente do MCP, Coelho declara:

"Nesta hora Pernambuco todo se une, através de suas forças de vanguarda, ficando à margem apenas as forças da contra-revolução, que lutam inutilmente pela defesa de seus privilégios, pois não podem mais frustrar o avanço do Brasil. A hora é grave, mas rica em pronunciamentos por reformas radicais e estruturais". Na mesma ocasião, Arraes reforça o caráter pluralista e amplo do movimento: "Ninguém poderá destruir a unidade que se constrói no MCP (...) a formação de uma frente única para resolver os problemas do povo. (...) as idéias nascidas humildemente em algum recanto do mundo ganharam toda a humanidade, quando refletiam as necessidades mais profundas do espírito humano. A virtude do MCP é não ter dono, nem patrão, nem dirigente que dele se beneficie. "I36

Dentro do programa da Frente do Recife, a alfabetização era uma das principais "armas para a conquista e verdadeira emancipação nacional" e a erradicação do analfabetismo era uma meta importante, a ser alcançada imediatamente. A construção de grupos escolares préfabricados era elencada entre as medidas do governo para superar as dificuldades inerentes ao alcance dessas metas, bem como os

136 "Empossada a nova diretoria do Movimento de Cultura Popular." $\underline{\text { A Hora, }}$ Recife, 10/ago/1963. convênios com entidades populares e revisão dos métodos e materiais. O recurso à pré-fabricação e à arquitetura moderna estava também na base do programa do governo paulista de Carvalho Pinto com as obras do Convênio Escolar, das quais destacam-se os ginásios de Guarulhos e Itanhaém projetados por Vilanova Artigas.

O católico progressista Germano Coelho, presidente e posteriormente secretário da educação do governo Arraes e o pintor e escultor comunista Abelardo da Hora são figuras de proa do movimento que de certa forma caracterizam dois perfis distintos que naquele momento estavam comprometidos com a promoção da educação e da cultura populares através do MCP. Havia ainda uma polêmica entre o grupo de Germano e o de Paulo Freire acerca dos métodos para a alfabetização e conscientização popular: enquanto o primeiro estimulava a reelaboração das cartilhas, apoiando a produção do "Livro de alfabetização para adultos" escrito por sua então mulher Norma Coelho e Josina Godoy e premiado pelo MEC, Freire desenvolvia outros meios de levar conteúdos similares aos operários e camponeses, como as aulas com projeção de slides que já vinham sendo testadas nas experiências de alfabetização realizadas por ele e seu grupo no âmbito da Universidade do Recife. ${ }^{137}$

Alfabetizar era um passo rumo a conscientizar-se, um processo que simulava o encontro de intelectuais e populares:

"Forma-se, rapidamente, entre as massas populares a consciência da

\footnotetext{
137 "Reitor diz que todo o Brasil quer aplicar método Paulo Freire".

$\underline{\text { Jornal do }}$
} 
necessidade de alfabetizar-se. Aprender a ler e escrever começa a fazer parte das primeiras reivindicações inscritas na bandeira de luta dos trabalhadores do campo. (...) Essa nova consciência que vai se apoderando do povo é uma consequência de uma política, de uma pregação revolucionária e de uma concepção do processo de desenvolvimento da revolução brasileira que começa a frutificar." 138

A figura de Freire traz também a experiência dos católicos que estavam engajados no movimento humanitário do alfabetizar, como os Movimentos de Educação de Base (MEB) surgidos no nordeste, "cuja raiz consistia no abandono dos conceitos tradicionais de educação formal e na tentativa de rejeitar a escola como uma instituição que reproduz as estruturas formais de dominação" (OLIVEIRA, 1977, 2008, p. 245)

Introduzindo o balanço de 1963 na Arte em revista, o texto "O que foi o $\mathrm{MCP}^{\prime \prime}$ tenta pontuar a essência do movimento e avaliar suas influências, sem deixar de ressalvar: "Devido ao seu escasso tempo de existência, os resultados práticos da atuação do MCP não podem ser corretamente avaliados", uma vez que "o MCP foi dissolvido imediatamente depois do golpe de 1964, sob pesada repressão". Não podemos deixar de notar o mesmo destino e explicação aplicado à experiência do Cajueiro Seco, aproximando-as e inserindo-as num contexto de transformações e experimentações com ecos posteriores, em que pese o impacto do golpe.

Em entrevista generosamente concedida ao autor, Germano Coelho se recorda de um expressivo episódio da perseguição ao MCP:

\footnotetext{
138 "Alfabetizar e Conscientizar".
}

"O analfabeto não tinha direito a voto. Eu fui chamado ao IV Exército pelo comandante, que estava com essa cartilha na mão, me questionando por que nós falávamos tanto em mocambo, alagado, palafita, favela, dizendo que tudo isso é muito triste. Eu respondia: 'O analfabeto é quem mora no mocambo, ele não sabe escrever mas sabe bem o que é. O jangadeiro pesca no mar que é de todos. A Escola do MCP é como o mar do jangadeiro, não precisa ter sapato, roupa pra entrar e não se paga nada, a escola é do povo'. O general me levou até a porta, foi muito educado e me disse que a cartilha não era subversiva, mas chegava ao limite. Coisas curiosas da luta..."

No combate ao MCP, vemos a expressão da "crise de hegemonia" descrita por BRAYNER, F. IN REZENDE, 1978. O Governo Cid Sampaio, por exemplo, havia formado a Fundação de Promoção Social com intuito de combater a amplitude do MCP e recolocar a questão da educação popular sob tutela de um Estado de viés paternalista, de acordo com a tradição de Agamenon. Tratava-se de deter o processo de politização dos setores populares encaminhado pelo MCP que então era "acusado de ser reduto de comunistas financiado com o "ouro de Moscou""'. (BRAYNER, F. IN REZENDE, 1987, p.211)

Em uma nota no meio do informativo econômico do Diário de Pernambuco encontram-se dispersas "denúncias" de subversão atribuídas às experiências de alfabetização em curso, elementos de condenação da "agitação" no Estado:

"Aproveita-se o método Paulo Freire (...)para, no subliminar instruir o camponês contra a propriedade privada, o açúcar, o industrial, o comerciante, o profissional liberal, os padres(...), os, Bispos, os juízes e a Justiça. (...) exploram-se sentimentos de hostilidade de classe contra classe,

${ }^{139}$ Germano CoELHO, entrevista ao autor, set/2007. 
de pobre contra rico, de empregado contra patrão, de morador de mocambo contra morador de palacete" ${ }^{\prime 140}$

Uma semana antes de publicar que o "Times" prevê golpe de direita no Brasil" e duas antes da previsão cumprida, o Diário de Pernambuco escancara as acusações ao MCP, oferecendo as "provas" e recomendando inclusive as medidas que o poder constituído (ou a constituir) deveria tomar:

"Outra organização que deveria estar há muito tempo enquadrada na Lei de Segurança Nacional é o Movimento de Cultura Popular, filial do Partido Comunista, que age agora impunemente, provocando agora os camponeses da Zona da Mata, através do seu teatro dirigido ou como eles o chamam, participante. Veja-se o Guia do Alfabetizador, que foi editado pelo Movimento para orientar a aplicação do Livro de Leitura cuidadosamente elaborado, com base em subliminar de propaganda política e ideológica." 141

A disparidade de condições entre os centros urbanos e a zona rural também seria um dos fatores de desestabilização e combate do movimento, já que as estratégias e práticas formuladas na capital, quando aplicadas ao campo, encontravam condições diferentes, o que levava a uma radicalização de suas posturas, que colocava Arraes numa complexa posição de mediação:

"Na Capital, Recife, reduto tradicional das oposições e base política da Frente, o estímulo à autonomia política dos movimentos populares realmente se efetivava, através do MCP que significou uma ampla mobilização de intelectuais e povo em torno do problema da cultura e educação; do Serviço Social Contra o Mocambo, que procurava discutir com a própria população miserável da cidade os problemas de habitação

\footnotetext{
140 "Informativo Econômico". Diário de Pernambuco, Recife, 22/fev/1964

141 "Times prevê golpe de direita no Brasil". Diário de Pernambuco, Recife, 24/mar/1964.
}

(...); das Associações de Bairro que funcionavam como uma verdadeira Câmara de Vereadores, tudo isto são exemplos de como a política começava a sair de seu âmbito parlamentar e palaciano para ganhar as ruas. (...)Inversão interessante: ali onde o movimento popular era mais forte e tradicionalmente oposicionista (Recife), o Partido [PCB] mostrava-se mais cuidadoso em suas alianças e avaliações das correlações de forças; lá, onde a consciência camponesa era muito mais difícil de ser politicamente trabalhada e onde o movimento agrário enfrentava a fúria dos latifundiários, o Partido desenhava avaliações triunfalistas de vitória a curto prazo e irreversíveis." (BRAYNER, F. IN REZENDE, 1987, p.216-219)

O Centro de Cultura Popular (CPC) da UNE seria provavelmente o principal ambiente no qual ecoariam algumas idéias que também estavam no bojo do MCP, mas suas diferenças revelavam concepções distintas de povo e de cultura popular, que marcam o debate acerca do tema no país. ${ }^{142}$

Entrelaçando as análises dos autores de Arte popular e dominação com declarações de Germano Coelho, indica-se no texto o dilema:

"Não nos debruçamos sobre o povo para auxiliá-lo. Nós nos voltamos para o povo para aprender". A esta idéia, ao contrário do que propunha o CPC da UNE, subjaz a concepção de cultura popular segundo a qual a produção cultural do povo não reflete, pelo menos em absoluto, a dominação social e cultural a que é submetido. Pode, eventualmente, exprimir o conformismo com a opressão e a aceitação do status quo. "Mas isto não atinge nunca o samba em si, o frevo em si, que podem expressar também o inconformismo, a rebeldia e o anseio de emancipação nacional." 143

\footnotetext{
${ }^{142}$ Ver Renato Ortiz, 1985/2005 e Carlos Guilherme MOTTA, 1977.

143 "O que foi o MCP?" Arte em Revista, № 3.
} 
Ortiz, em Cultura brasileira e identidade nacional revela e analisa os pontos de contato da ideologia nacionalista com a conformação de uma idéia de cultura popular, expondo também algumas das contradições inerentes às propostas do Centro Popular de Cultura (CPC) da UNE.

"Para o CPC, a relação encontra-se invertida: são os intelectuais que levam cultura às massas.(...) existe uma contradição inerente à teoria do CPC; para legitimar a ação da "cultura popular" deve-se necessariamente negar a validade das próprias manifestações populares. Considerando-se o popular como "falsa cultura", ele se encontra fatalmente encerrado nas malhas da esfera da alienação. Toda atividade político-cultural é portanto imediatamente externa ao próprio movimento das massas, posto que naturalmente os fenômenos populares recaem nos limites da consciência inautêntica.(...) Toda manifestação popular tende portanto a ser inserida num espaço de subordinação que arbitrariamente é imposto a partir do alto. O problema se apresenta, pois, como relação de forças, não como alienação." (ORTIZ, 1985/2005, pp.68-78)

Posteriormente, já nos anos 1970, o MCP seria criticado por Ivan MAURíCıO por alimentar uma "visão romântica do povo", que se notava especialmente em um dos pontos apresentados no Plano de Ação do Governo Arraes: "Reviver as tradições populares, como instrumento de integração e complementação do ensino formal".

Tal visão de preservação dessas tradições puras perpetuaria também as condições de exploração a qual sempre haviam sido submetidas as classes populares, (de acordo com os autores do inventário Arte popular e dominação). Tal posição ficaria clara numa entrevista com Germano Coelho presente na publicação. (MAURícıO et alli, 1978)
Coelho, em entrevista concedida ao autor em que reafirma suas posições enquanto as organiza nas memórias que brevemente irá publicar, cantarola um verso que exprime de certa maneira a troca entre os intelectuais e o povo e que permanece na produção musical pernambucana até os dias de hoje, tanto na sua versão original quanto na incorporada por músicos contemporâneos: "Essa ciranda quem me deu foi Lia, que mora lá na Ilha de Itamaracá". ${ }^{144}$

A Exposição "Nordeste", inaugurada em 2 de novembro de $1963^{145}$ no Solar do Unhão convertido por Lina Bo Bardi no Museu de Arte Moderna da Bahia, em Salvador, é uma expressão importante do embate que se travou entre um projeto construtivo internacional que se implantava e as vertentes brasileiras que se punham a questioná-lo.

O MCP também operava nestes mesmos campos e a coexistência das iniciativas nos mostra diversas permanências no debate da formação cultural brasileira, além de sutis mas precisas divergências. A

\footnotetext{
${ }^{144}$ Germano COELHO, entrevista ao autor, Set/2007.

${ }^{145}$ Praticamente na mesma semana da inauguração da urbanização do Cajueiro Seco, ocorrida em 29 de outubro de 1963, coincidência que revela a simultaneidade e interação de propostas de arquitetos para lidar com o popular. Comentando os ecos da experiência do Cajueiro Seco em entrevista, Borsoi conta que foi ali que ele conheceu Lina: "Uma repercussão extraordinária, a Lina Bardi escreveu um trabalho na Mirante das Artes [publicada em 1967], eu fui conhecer a Lina Bardi através disso, ela veio me procurar, eu dei um presente a ela um cavalinho, [a cooperativa] já fazendo, o pessoal começou a produzir coisas em molde de gesso, São Jorge..." Seria arriscado supor que o tal cavalinho teria ido para a "Civilização do Nordeste"? Afinal de contas, o que mais teria interessado Lina Bo Bardi na experiência do Cajueiro Seco? É importante notar que a revista do casal Bardi no começo dos anos 1960, a Habitat, não publica artigo ou nota sobre a experiência. Geraldo Ferraz era o editor da revista enquanto Lina estava na Bahia o que pode explicar a ausência de qualquer menção à experiência.
} 
ocasião aproximou nos anos 1960 o Recife de Lina Bo Bardi, que reconhece que havia em Pernambuco

"um sentido social importante, o que dá à arte pernambucana um caráter de dramaticidade não encontrado em parte alguma do Brasil. Dramaticidade como aspecto de ligações com a terra e a paisagem" ${ }^{146}$.

A fase de pesquisas, expedições, estudos e questões elencadas por Lina constituiriam importantes episódios da formação do pensamento da arquiteta e do campo das histórias culturais populares do Brasil, de certa maneira abertos pelas expedições do "Turista aprendiz" Mário de Andrade. Desde então, as viagens dos intelectuais às raízes do Brasil vinham se tornando recorrentes e revelavam complexidades que acabariam por transformar as disciplinas e concepções dos próprios interessados na cultura popular, estimulando fértil debate que formou intelectuais de produção tão distinta quanto Antônio Cândido, Gilberto Freyre, Roberto Schwarz e Sérgio Buarque de Holanda, Florestan Fernandes, Roger Bastide e até mesmo os estudantes da primeiras turmas da FAU USP reunidos em torno do Centro de Estudos Folclóricos ${ }^{147}$ como Luis Saia e Julio Katinsky.

Ainda nos anos 1960, Lina já aponta que "há muita confusão a respeito de artesanato e arte popular. Esse problemas são encarados do ponto de vista folclórico de ajuda paternalista quando são problemas de sérias responsabilidades técnicas porque ligados ao futuro

146 "Arte em Pernambuco toma rumo definido, diz diretora do MAMB". Lornal do Commercio, Recife, 20/ago/1963.

${ }^{147}$ O Centro de Estudos Folclóricos (posteriormente Centro de Estudos Brasileiros) e o papel das viagens na produção de arquitetos e intelectuais está sendo recentemente estudado pelo arquiteto João Clark de Abreu Sodré, orientando de José T.C. de Lira no programa de mestrado da FAU USP. desenvolvimento industrial do país. "Folclore" é praticamente uma herança cristalizada de formas sem vida ao passo que uma verdadeira arte popular é a expressão viva de uma cultura". ${ }^{18}$

Tais declarações teriam causado "celeuma" segundo o jornal, que não via diminuído por isso o prestígio da "dama ítalo-paulistana". Na montagem da exposição que retratou a "civilização" do Nordeste estaria claro o questionamento do folclore e a elevação da cultura popular ao status de arte. A jornalista pernambucana Cristina Tavares, destacada para cobrir a abertura da exposição "Nordeste" ${ }^{\prime 149}$, nos dá um panorama da mostra, que entremeada com as declarações de Lina, também publicadas na última Hora, destacam o questionamento que ali se fazia:

"Matéria prima: o lixo. Cestarias, lataria, cerâmica de barro cozido ao sol, cada objeto risca o "limite do nada da miséria". "Este limite e a contínua e martelada presença do "útil" e "necessário" é que constituem o valor dessa produção, sua poética das coisas humanas não-gratuitas, não criadas pela mera fantasia"150 (...) Objetos de uso cotidiano do "pau-dearara" que pelas suas linhas e formas são uma "violenta" manifestação de arte. Formas cheias de eletricidade vital, desenho artesanal e industrial. Esta exposição é uma acusação não humilde que contrapõe-se às degradadoras condições impostas pelos homens; um esforço desesperado de cultura."

Lívio Xavier, o principal guia de Lina nas incursões pelos interiores do Ceará expõe em entrevista ao autor algumas diferenças que a arquiteta teria com relação às figuras pernambucanas ligadas ao

\footnotetext{
148 "Arte em Pernambuco toma rumo definido, diz diretora do MAMB". Jornal do Commercio, Recife, 20/ago/1963.

${ }^{149}$ Ver Rodrigues, M., 2008; e Pereira, J., 2001.

${ }^{150}$ Cristina TAVARES. "Civilização Nordeste - Lina Bardi". Última Hora, Recife, novembro/1963.
} 
MCP e às pesquisas em torno da cultura popular. Segundo ele, a concepção de popular dos Bardi contrastava radicalmente com a de Francisco Brennand e com a da decoradora Janete Costa, mulher de Borsoi.

Equiparar a arte de uma bem formada geração de artistas pernambucanos ao improviso e ao subproduto industrial causaria desconforto, surpresa e admiração. Os pernambucanos operariam numa linha de apropriação das formas populares nos trabalhos realizados para a elite e isso não interessava Lina ${ }^{151}$. A importância de Pernambuco na Exposição Civilização do Nordeste é por ele relativizada:

"Não me consta que Pernambuco tenha tido a mesma importância do Ceará. Aqui tinha muita gente atrapalhando, ela era meio que ridicularizada de vez em quando, aquela mulher com os panos na cabeça... Tu acha que grã-fino, dono de cana de açúcar ia contemporizar com uma mulher daquela, pelo fato de ela ser especialista em cultura popular? "152

A distinção dos conceitos de arte popular e folclore é retomada por Ariano Suassuna em artigo publicado no última Hora que pretende definir "O que é cultura popular", que por vezes produz arte de qualidade, especialmente quando o "quarto estado [o povo](...) exprime uma unidade nacional/153. A visão de Suassuna, fundador do

\footnotetext{
151 "Podia admitir a existência de Borsoi, mas não podia respeitar uma arte para casas de ricos. Ela conversava mas não trocava figurinhas com essa gente" Lívio Xavier, Entrevista ao autor, Set/2007

152 Lívio XAVIER, entrevista ao autor, set/2007.

153 Ariano SuAssunA. "O que é cultura popular". Última Hora, Recife, nov/1963.
}

MCP e formulador de uma concepção literária que insere o erudito no popular e vice versa tenta recolocar a questão, buscando em praticamente toda a clássica literatura européia um fundamento popular um tanto abstrato. Tal formulação de uma "Arte erudita a partir de bases populares" caracterizaria o Movimento Armorial, fundado nos anos 1970 por Suassuna, que representa uma vertente específica e bastante criticada de apropriação das dinâmicas culturais populares e sua transformação em produtos culturais elaborados, a serem digeridos pelas camadas mais elevadas e esclarecidas. ${ }^{154}$

Lívio Xavier, colaborador de Lina nas expedições pelos interiores e sertões, expõe no artigo O Artesanato no Ceará ${ }^{155}$ o que mostrara à arquiteta, descrevendo os centros e principais feiras de artesanato do estado e de algumas regiões nordestinas como o Vale do Cariri, "focos irradiadores da riquíssima literatura oral e xilogravura". O Museu de Arte da Universidade do Ceará, então por ele dirigido, seria mais uma instituição com a missão de preservar e defender essas "formas artísticas tão puras", trabalhando em cooperação com o MAMB.

Abelardo da Hora, pintor e escultor participante da exposição na seção de arte pernambucana, que contava também com Francisco Brennand, João Câmara, Vicente do Rego Monteiro, Corbiniano, Gilvan Samico e Ladjane, entre outros, expõe um dos principais antagonismos

\footnotetext{
${ }^{154}$ Movimento, № 97, 9/mai/1977 apud Arte popular e dominação.

155 Lívio XAVIer JR.. "O Artesanato no Ceará". 23/nov/1963.
} 
que a civilização do "Nordeste" propunha em relação ao desenvolvimento industrial sudestino:

"A cultura do Brasil que tem no nordeste a sua força mais viva, aonde ainda não foi possível entrar a influência do cosmopolitismo encontra alento no Solar. Neste sentido ele faz um grande reparo às Bienais de São Paulo, que cada dia ficam mais alienadas do ponto de vista da cultura brasileira"1156

Em artigo assinado por ele, completa sua visão da exposição em contraposição às Bienais, terminando por ligar a realidade contemporânea à história da independência da nação, referindo-se ao episódio das lutas coloniais dos Montes Guararapes:

"O nosso país tem sido acometido de interferências estranhas e mais estranhamente cumpliciadas por certo tipo de gente que se arvorou como mentores; seja no campo das nossas riquezas básicas ou da evolução e da cultura que difunde as idéias e politiza o povo brasileiro. O exemplo das Bienais de São Paulo e a nosso ver uma dessas desgraças no campo da cultura que utilizando o dinheiro público da nação, discrimina artistas brasileiros e impede uma visão autêntica de nossa arte, agindo contra a cultura brasileira, fomentando a alienacão e o cosmopolitismo. (...)A formação cultural do Brasil e a posição de comando nas lutas pela emancipação da pátria em todo o decorrer da história tomada pelo povo do Nordeste, tornaram nossa posição visada, mas defendida heroicamente, apesar das hostilidades de dentro e de fora de nosso país. Dificilmente se aliena os homens que fixam e transmitem a cultura nesta área do Brasil."157

Em artigo que destaca o sucesso da exposição no conservador Diário de Pernambuco, que "foi idealizada mesmo como uma réplica ao que vem sendo adotado na bienal de São Paulo." A divergência

${ }^{156}$ Abelardo da HORA. "Inaugurado em Salvador Museu de Arte Moderna". Jornal do Commercio, Recife, 5/nov/1963.

${ }^{157}$ Abelardo da HORA. "Arte e Artesanato". Última Hora, Recife, 28/nov/1963. seria entre abstracionismo e figurativismo, considerado "primitivista" pelos paulistas e mais carregado de regionalismo nos exemplos pernambucanos do que nos baianos ou cearenses para o pintor Wilton de Souza, que fala ao Diário. ${ }^{158}$ Aventa-se ali a possibilidade de Lina Bo Bardi projetar a conversão da antiga Casa de Detenção em "Palácio da cultura".

O pintor Francisco Brennand, naquele momento Chefe da Casa Civil do Governo Arraes, para além das diferenças que tinha com Lina muito mais interessada nas classes populares do que na arte do baronato industrial ${ }^{159}$, também se opõe ao conceito de folclore. Comentando a exposição do Unhão, declara:

"Nessa época de transição da sociedade brasileira devemos aproveitar a experiência do passado para as grandes realizações do futuro. Devemos desenvolver uma consciência de valores para que saibamos distinguir e compreender a importância dos motivos nacionais sem nos prendermos a elementos puramente folclóricos de nosso contexto geopolítico ou aos estilos e formas popularescas porque um povo só impõe sua marca cultural a outros povos quando sabe dar aos seus núcleos de origem popular uma dimensão intelectual universalizante". 160

A emergência do Nordeste como lugar privilegiado e repositário de valores autênticos da cultura nacional e popular pode ser medida com a influência do MCP e a Ação cultural de Lina Bo Bardi no

\footnotetext{
158 "Civilização Nordeste um sucesso na exposição de arte da Bahia". Imóveis e Móveis. Diário de Pernambuco, Recife, 4/dez/1963

159 Lívio XAVIER, entrevista ao autor, set/2007.

160 "Pintor Francisco Brennand fixa suas impressões sobre exposição do Solar do Unhão". Lornal do Commercio, Recife, 17/nov/1963.
} 
Nordeste $^{161}$, revelando uma ampla plataforma ideológica comum.

Algumas divergências nos mostram o desenvolvido e complexo patamar dos debates em torno da cultura popular naquele tempo, debates que só puderam ser retomados em um contexto de maior abertura, depois da redemocratização do país, nos anos 80 e que continuam a ser debatidos nos dias de hoje, frequentemente sem a mesma profundidade ou amparados em realizações concretas como nos conturbados anos 1960.

${ }^{161}$ Ver mestrado de Juliano A. PereIRA, 2001. 


\subsection{A Alianca para o Progresso, a USAID, o IBAD e as resistências locais}

A Aliança Para o Progresso foi a resposta imediata de Kennedy para lidar com América Latina depois da Revolução Cubana. Tendo por principal referência o bem sucedido Plano Marshall, a estratégia consistiu em despejar milhões de dólares sob a forma de ajuda direcionada (com destaque para a questão da casa própria) e com isso afastar os setores populares da sedução comunista.

Para Francisco de Olivelra, "A Aliança Para o Progresso foi a resposta norteamericana à emergência das classes populares no Nordeste, tendo sido assinado um acordo entre o governo brasileiro e o norteamericano que designava a Sudene como organismo coordenador do lado brasileiro. Quase puro papel, pois os gringos ofereciam dinheiro diretamente aos governadores, criando fatos quase consumados, imprensando a Sudene entre seu papel coordenador e a chantagem dos governadores. Enquanto isso, os norte-americanos treinavam as polícias militares dos estados do Nordeste em técnicas de informação, capacitação para guerra de guerrilhas, sabotagem, e espionagem, com viagens de estudo à escola do canal do Panamá e aos EUA"(OliveIRA, 2008, p.61-62)

Kennedy conduziu tal assunto pessoalmente e se mostrou preocupado com o que acontecia no Nordeste, a ponto de enviar para a região vários técnicos e observadores como Arthur Schlesinger Jr, George Mc Govern e Merwin Bohan, que desembarcaram no Recife em 1961 com a tarefa de elaborar um plano para o desenvolvimento regional. O estudo intitulado "Northeast Brazil Survey Team Report Missão de Estudos sobre o Nordeste do Brasil", conhecido como Relatório Bohan ficou pronto no começo de 1962 e serviu de base para a ação da Aliança para o Progresso, que tinha na região mais pobre do hemisfério um foco prioritário.

Francisco de OlivelRA, técnico da Sudene à época e testemunha do choque da invasão estrangeira com o planejamento estatal, traçou a trajetória da atuação da Aliança para o Progresso, de sua gestação até seus interesses por trás das aparentes boas vontades:

"O relatório de Merwin Bohan, antigo embaixador da era rooseveltiana designado por Kennedy para chefiar a missão da Aliança para o Progresso que faria o diagnóstico da situação do Nordeste, sugeria algumas medidas de apoio, sobretudo em forma de doações de gêneros alimentícios para as frentes de trabalho nas épocas de secas, formando estoques de emergência e desovando velhos estoques norteamericanos. Era hostil à utilização das instituições do Estado para a realização dos investimentos públicos, e já naqueles remotos anos favorecia o que veio a ser chamado "terceirização"; implicava com a atribuição de responsabilidades aos setores estatais e tentava vetá-los. Na verdade, no breve prazo entre a missão e o golpe de Estado de 1964, a Aliança não implementou nenhuma ajuda substantiva para o desenvolvimento do Nordeste. Mas recomendava, quase sem disfarces, a criação de milícias para combater os guerrilheiros da "Sierra Maestra" nordestina." (OLIVEIRA, 2008, p. 73)

As metas da Aliança para o Progresso eram "Teto, trabalho, terra, saúde, e educação", ideário que dependendo do ponto de vista poderia ser considerado de esquerda. A política do governo americano incorporava demandas tipicamente populares com o objetivo de disputar terreno com as forças de esquerda. ${ }^{162}$

Apesar da tensão geopolítica no começo dos anos 60 concentrarse em Cuba, Berlim e no Vietnã, Kennedy abriu um discurso feito em

162 Vandeck SANTIAGO. "O Plano de Kennedy para desenvolver o Nordeste". Suplemento especial, Diário de Pernambuco, Recife, 30/ago/ 2006. 
14 de julho de 61 declarando: "Nenhuma área tem maior e mais urgente necessidade de atenção do que o vasto Nordeste do Brasil" (Kennedy apud SAntiago, 2006). Menos de um ano depois, o presidente americano assinou com o brasileiro João Goulart o "Acordo do Nordeste".

"O Acordo do Nordeste hoje só é lembrado, vagamente, em obras específicas. Para Kennedy era algo tão importante que, por exigência dele, a embaixada no Brasil Ihe enviava relatórios diários sobre os andamentos dos trabalhos na região. Foi o primeiro teste da Aliança para o Progresso cujas metas, oficializadas em 17 de agosto de 1961, na conferência de Punta del Este (Uruguai), ambicionavam levar desenvolvimento à America Latina em 10 anos, com um investimento (dinheiro público e privado) de US\$ 10 bilhões. (...)'A Guerra Fria não será ganha na América Latina. Mas pode ser perdida lá, dizia Kennedy."1763

O Acordo, delineado em encontro de Kennedy com Celso Furtado no fim de 1961, estabeleceu que o empréstimo a juros e prazos favoráveis ao Brasil de US\$131 milhões seria integralmente investido em obras emergenciais no Nordeste. A principal divergência entre as partes residia na coordenação da aplicação dos recursos, os brasileiros entendendo que a tarefa caberia à SUDENE e os americanos pretendendo dirigi-los através do USAID, que estabeleceu na capital pernambucana uma grande estrutura administrativa para coordenar as ações da Aliança. Haviam quase vinte cônsules americanos no Recife, além de diversos "voluntários" do Peace Corps.

"A visão dos problemas do Nordeste também eram conflitantes (sic). Para a SUDENE o problema era de desenvolvimento; para a USAID, (...) a principal questão era de segurança - de impedir que a região viesse (pelas

\footnotetext{
${ }^{163}$ SANTIAGO, 2006.
}

armas ou pelo voto) a ser tomada pelos comunistas nacionalistas ou esquerdistas, um trio que na visão dos EUA era uma coisa só.

Os americanos começaram então a fazer convênios direto com os estados, passando por cima da autoridade da SUDENE e do próprio governo federal - tornou-se um caso de discussão sobre a soberania nacional." 164

Havia uma união de forças da extrema direita reunidas em torno do IPES (Instituto de Pesquisas e Estudos Sociais), patrocinados por empresários do sudeste que passaram a munir os militares com dados (muitos deles tendenciosamente forjados) sobre uma pretensa infiltração comunista nos governos estaduais e federal que constituiria a primeira fase de um golpe de estado que levaria o país ao alinhamento com a União Soviética.

As receitas para a elaboração de coquetéis molotov e instruções para o enfrentamento com as forças de segurança pública supostamente escritas por membros do PCB em papel timbrado do SSCM anexadas ao Inquérito Policial Militar (IPM) encontradas no acervo do DOPS provavelmente inscrevem-se neste contexto, já que, analisando a história do "Partidão", sabemos que os líderes comunistas não estavam dispostos a partir para a revolução naquele momento, ainda fortemente marcados pelo fracasso da "Intentona" de 35 e pela repressão que a ela se sucedeu, principalmente em Pernambuco.

O medo que a classe média, latifundiários e empresários tinham do comunismo foi intensamente alimentado e explorado como forma de apoio ao contragolpe reacionário que se concretizou em abril de

\footnotetext{
${ }^{164}$ SANTIAGO, 2006.
} 
1964, mas que já vinha sendo articulado desde o suicídio de Getúlio. O IPES produziu diversos filmes dirigidos pelo cineasta e fotógrafo francês Jean Manzon que ilustram bem os meios e o discurso anticomunista e golpista típico do instituto ${ }^{165}$.

O IBAD (Instituto Brasileiro de Ação Democrática) era outro órgão à serviço da CIA que atuou fortemente na campanha de 1962 subvencionando os candidatos da oposição ao governo Jango que assumissem um "compromisso ideológico" de defender o capital estrangeiro e condenar a reforma agrária (BANDEIRA, 1978, p.68).

"A CIA procurou igualmente penetrar no campesinato. Através do IBAD e de outros canais destinou muitos recursos ao Nordeste, não apenas visando combater a candidatura de Miguel Arraes ao Governo de Pernambuco, mas também Francisco Julião, refreando-lhe o crescimento. $O$ Padre Antônio Melo, vigário do Cabo, tomou a iniciativa de arrostá-las, juntamente com o Padre Paulo Crespo, agrupando camponeses num movimento diversionista, o Serviço de Orientação Rural de Pernambuco (SORPE), subvencionado pelo IBAD e pela Cooperativa League (CLUSA), mais precisamente pela CIA, que resolvera financiar, com recursos ilimitados, as cooperativas católicas, como forma de ajudar a reprimir o potencial revolucionário existente no Nordeste brasileiro" (BANDEIRA, 1978, p.70)

Em interessante reportagem publicada no calor dos acontecimentos, Antonio Callado descreveu o Padre Melo como alguém confuso, de orientação ideológica pouco clara, anti-Jango, antiJulião e pró-Lacerda por motivos inusitados e com a determinação clara de ocupar o espaço no "latifúndio improdutivo de almas" que o interior

\footnotetext{
${ }^{165}$ Marcos CORRÊA. O discurso golpista nos documentários de Jean Manzon para o IPES (1962/1963). Campinas, São Paulo. 2005. Dissertação de mestrado, Universidade Estadual de Campinas.
}

pernambucano representava naqueles tempos. Para o Padre Melo, a melhoria das condições de vida no campo afastaria o camponês do comunismo. Tornou-se feroz opositor de Arraes a partir do momento que este o denunciou como favorecido das verbas ibadianas. (CALLADO, 1964)

O padre Crespo reapareceu depois de mais de 40 anos na reportagem de Vandeck Santiago como um cooperativista de boas intenções, "nem capitalista nem comunista" disposto a aceitar ajuda de onde viesse com o nobre propósito de evitar a revolução violenta melhorando as condições de vida e trabalho do camponês. Com o apoio financeiro e técnico dos americanos, ele organizou várias cooperativas rurais, além da maior federação sindical de Pernambuco, a FETAPE (Federação dos Trabalhadores Agrícolas de Pernambuco), atuante até hoje ${ }^{166}$.

O IBAD foi fechado temporariamente em 1963 e foi objeto de uma Comissão Parlamentar de Inquérito do Congresso Nacional que investigaria as denúncias de intervenção na política dos estados. Apesar do contundente depoimento de Arraes, que apresentou diversos documentos que explicitavam que a origem dos recursos do IBAD vinha de grandes empresas multinacionais, principalmente americanas, a CPI foi "de alguma maneira controlada" nas palavras de Philip Agee, ex-agente da CIA. Dos nove deputados da Comissão, cinco estavam nas listas de pagamentos do IBAD, que garantia seu prestígio no Congresso

\footnotetext{
${ }^{166}$ SANTIAGO, 2006.
} 
à custa de expressivas somas de dinheiro remetidas a parlamentares da oposição à Goulart. (SKIDMORE, 1976)

A prática de alimentar uma opinião favorável a determinadas ideologias ou sistemas políticos através da distribuição de recursos à parlamentares sob a forma de apoio às suas campanhas não é novidade nem nos Estados Unidos nem no Brasil, como ilustra este caso, uma espécie de "primeiro mensalão"167.

Coincidentemente, a distribuição se dava através da agência de publicidade Promotion, comandada por Vernon Walthers, posteriormente apontado como agente da CIA. É dele a frase que, para tentar ilustrar a penetração comunista nos departamentos do Estado Brasileiro, esclarece a estratégia americana de intervenção silenciosa: "Eles estão cortando o presunto em fatias tão finas que quando os senhores se derem conta o terão comido todo" (WALTHERS apud CALLADO, 1964)

Outro episódio ainda por estudar dos Tempos de Arraes é o questionamento pernambucano da intervenção americana no Nordeste, organizado em torno do Grupo de Trabalho que respondeu ao imperialismo. O grupo foi estabelecido logo que Arraes chegou ao poder e era constituído por outros secretários de governo como Gildo Guerra, presidente do SSCM e políticos como Antônio Bezerra Baltar, entre outros.
O professor universitário Germano Coelho, que no início do Governo Arraes acumulava os cargos de presidente do Movimento de Cultura Popular e Secretário da Educação, foi o relator do grupo de trabalho dedicado a analisar os convênios feitos entre os Estados do Nordeste e o Governo Americano. Analisando tanto o conteúdo quanto os volumes de recursos distribuídos sob a égide da Aliança para o Progresso, o GT chegou a conclusões alarmantes.

"Haviam sido criados órgãos paralelos aos do governo federal para atuar nele; estabeleceram desníveis salariais entre os funcionários da USAID e do estado, desvalorizando o trabalho dos funcionários estaduais. e o organismo internacional exerceu uma discriminação entre os vários estados do Brasil, fornecendo verbas elevadas àqueles governados por autoridades ligadas aos grupos de direita, como a Guanabara, e importância ínfimas àqueles governados por políticos nacionalistas." (ANDRADE, 1989, p.50)

O dinheiro americano era canalizado para os governos que faziam oposição à João Goulart, principalmente ligados à UDN. Tal quadro era evidenciado pelo fato de que o governador que mais recebeu recursos era Carlos Lacerda, da Guanabara, estado que não fazia parte do Acordo do Nordeste e que seria o candidato preferencial dos americanos para a eleição presidencial de $1965^{168}$. De acordo com OliVEIRA, que na época em reuniões da Sudene com os americanos questionava se já havia passado o tempo dos Marines, que interviriam manu militari nas democracias latinoamericanas, depois do golpe já não havia dúvida:

"em poucos momentos da história brasileira, e sobretudo das

${ }^{168}$ Germano CoELHO, entrevista ao autor, set/2007. 
relações brasileiro-americanas, a interferência e a ingerência da potência imperialista do Norte nos assuntos internos do Brasil foi tão grande e tão descarada." (OLIVEIRA, 1977/2008, p. 257)

Germano Coelho narra com orgulho os detalhes da reunião feita na SUDENE na qual as conclusões do inquérito foram apresentadas pelo governador Miguel Arraes à Celso Furtado e ao embaixador Lincoln Gordon, que fez questão de estar presente quando soube que críticas ao programa da Aliança para o Progresso, do qual era coordenador no Brasil, seriam feitas.

Arraes leu trechos do relatório que citava economistas da American Economic Association declarando que o montante de recursos controlados por americanos no Brasil representava plena intervenção estrangeira no país. Gordon, economista proeminente, membro da associação, estranhou a referência aos seus colegas, pondo em dúvida a referência. Coelho, que havia estudado a obra de Gordon como economista do New Deal sobre as corporações públicas em seu mestrado em Paris, passou às mãos do embaixador a revista citada com as páginas marcadas, o que o fez passar o resto da reunião quieto, fumando seu cachimbo. "Eu estava esperando esse momento, chamei isso de casca de banana, que eu queria ver o embaixador escorregar (...) Calamos o embaixador americano" ${ }^{\prime 169}$.

Além da interferência direta dos departamentos de estado americanos na política interna brasileira, o que já havia ficado nas entrelinhas no caso da CPI do IBAD, o GT apontou os acordos feitos

${ }^{169}$ Germano CoELHO, entrevista ao autor, set/2007. pelos estados membros da federação diretamente com o governo federal de Washington como uma afronta a soberania nacional. Tal conclusão levou Germano Coelho à Brasília para levar a denúncia formal dos acordos ao então ministro da Justiça, João Mangabeira, que indicou o então senador Juscelino Kubitschek para levantar a questão no Congresso Nacional. Juscelino deu uma entrevista três dias depois do ocorrido declarando que Pernambuco tinha razão e que a Aliança para o Progresso tinha que ser revista ${ }^{170}$.

Em trecho específico do relatório do Inquérito da Aliança, que seria publicado no mesmo ano de 1963 pela editora Civilização Brasileira, há menção a um acordo firmado em 5 de outubro de 1962, ou seja no ocaso do Governo de Cid Sampaio, que destinava US\$ 200 mil para serem aplicados nas obras do Alto Jordão, no qual se prevê a auto-ajuda como uma das formas de provisão habitacional ${ }^{171}$. No mais, o problema das recomendações americanas para a habitação estava no fato, também observado em outras áreas como saúde e educação, de que o financiamento era condicionado à supervisão da aplicação dos recursos pela USAID.

O resultado do trabalho foi divulgado na $\underline{\text { Última Hora }}^{I 72}$ e editado em livro publicado pela editora Civilização Brasileira, de Caio Prado Jr., que também editou o discurso de posse de Miguel Arraes ${ }^{173}$.

\footnotetext{
${ }^{170}$ Germano COELHO, entrevista ao autor, set/2007.

${ }^{171}$ Ver item C do Capítulo 3 - "O plano habitacional pernambucano de 1962".

172 "Governo do Estado mostra a verdade sobre a Aliança para o Progresso - Análise
} 
Ali se faziam considerações sobre a estrutura institucional geral do programa desde o seu significado tal como colocado na Carta de Punta del Este, de 1959, partindo para a crítica do acordo com Pernambuco, destacando a "indevida ausência da Sudene, como órgão coordenador", além dos tópicos que analisavam por campos as especificidades do que estabeleciam as ajudas e verbas para a educação, habitação e saúde.

A principal questão era a "alienação da soberania nacional", já que a ajuda externa era dirigida aos governadores politicamente afinados com a política externa norteamericana, notadamente a UDN de Lacerda e Cid Sampaio, configurando uma verdadeira intervenção estrangeira no país. Além disso, os recursos da Public Law 480 que permitia aplicar os excedentes agrícolas americanos em outras nações basicamente trigo e leite em pó seriam pagos em moeda nacional e aplicados no próprio país, levando os americanos a controlar um enorme volume de recursos em moeda nacional ${ }^{174}$. Grande parte dos programas da Aliança tinha contrapartidas financeiras dos estados, que frequentemente entravam com a maior parte e tinham que se submeter aos procedimentos de controle dos organismos internacionais como o

crítica dos convênios. Conclusões a que chegou o grupo designado pelo governador Miguel Arraes para examinar os convênios firmados com a "Aliança para o Progresso". última Hora, Recife, 5/mai/1963.

${ }^{173}$ Miguel ARRAES. O povo no govêrno - Discurso de posse do Cargo de Governador do Estado de Pernambuco, em 31 de janeiro de 1963. Rio de Janeiro: Civilização Brasileira, 1963.

${ }^{174}$ Germano COELHO, entrevista ao autor, set/2007.
BID. Estava às claras a política de troca de colaboração por intervenção que sempre era apresentada como ajuda humanitária.

Sintomático é o fato do Diário de Pernambuco usar sempre o verbo "dar" associado aos Estados Unidos quando anunciava entusiasticamente as verbas que seriam emprestadas dos fundos internacionais que compunham a Aliança para o Progresso para os programas do Estado ${ }^{175}$, além de fazer aproveitar para jocosamente ironizar a postura do novo governo do Estado ${ }^{176}$.

Até o conservador jornal se viu obrigado a explicar a natureza da Aliança, depois de questionada por Arraes: em "Oitenta por cento dos fundos da Aliança vêm de países da A. Latina" ${ }^{\prime 177}$; o ministro Jack Rubish, responsável pela USAID Brasil concorda que a Aliança deveria

175 "EE.UU. deram 250 milhões de dólares para casas: parte será em Pernambuco". Diário de Pernambuco, Recife, 16/mar/1963. "Mais de 60 Milhões dão Estados Unidos para casas em Pernambuco". Diário de Pernambuco, Recife,_8/mai/1963. "Estados Unidos dão em Aliança 86 milhões para casas em Alagoas". Diário de Pernambuco, Recife,_jun/1963. "EUA deram mais de 86 milhões para habitação". Diário de Pernambuco, Recife, 19/jun/1963.

${ }^{176}$ Em nota não assinada, lê-se "Na hora de jogar para a arquibancada, porque é bonito e da moda atacar os Estados Unidos e a "Aliança para o Progresso", o pessoal do governo Arraes desanca, com todas as armas de que dispõe, a USAID os seus projetos e os acordos com ela celebrados. Na hora de receber o dinheiro que é bom, os gringos passam a ser os tais, e o expedito Gildo Guerra apressa-se em botar no bolso (não do seu, é óbvio, mas no do SSCM, de que é presidente) o s 60 milhões de cruzeiros doados pela malsinada "Aliança" Diário de Pernambuco Recife, 8/mai/1963. Por vezes o enfrentamento é até mais direto como em "Arraes sabota ajuda do estrangeiro ao NE", da Agência Meridional carioca Diário de Pernambuco Recife, 10/jul/1963.

177 "Oitenta por cento dos fundos da Aliança vêm de países da A. Latina". Diário de Pernambuco, Recife, 4/out/1963. 
ser revista, conforme declarara também Juscelino ${ }^{178}$, alertado para o problema pelos pernambucanos através de João Mangabeira, ministro da Justiça de Jango.

Depois da morte de Kennedy, no governo Lyndon Johnson a coordenação da Aliança para o Progresso foi entregue ao escritor Thomas Mann $^{179}$ e o projeto todo foi perdendo importância, considerado um fracasso pelos próprios americanos.

No projeto de lei que criaria a SUPURB, redigido por Artur Lima Cavalcanti como produto do SHRu, havia uma recomendação específica que se referia justamente ao controle dos recursos estrangeiros pelo órgão federal a ser criado, com o objetivo de evitar tal ingerência nos planos habitacionais estaduais, já incorporando portanto precauções contra os problemas apontados pelo Grupo de Trabalho.

"Art.18. Todo o empréstimo estrangeiro que se destine ao financiamento de qualquer plano habitacional ou de urbanização federal, estadual, ou municipal só poderá efetivar-se por intermédio da SUPURB. ${ }^{1780}$

$\mathrm{Na}$ época, as conclusões do grupo de trabalho sobre a Aliança para o Progresso alcançaram certa repercussão nacional, além de fazer com que os convênios entre Washington e o Estado de Pernambuco fossem imediatamente suspensos. Com o advento do Golpe militar no entanto, nenhuma providência foi tomado no sentido de restaurar a

\footnotetext{
178 "Juscelino: Aliança tem que ser revista". Diário de Pernambuco, Recife, 4/out/1963.

179 "Direção da Aliança entregue a Thomas Mann". Diário de Pernambuco, Recife, 5/jan/1963.

${ }^{180}$ Arquitetura IAB/GB, Projeto de Lei SUPURB, No 16, out/ 1963.
}

ofendida soberania nacional e o caminho ficou ainda mais aberto para a intervenção norteamericana nas políticas públicas brasileiras. Os famigerados Acordos MEC-USAID ${ }^{181}$, celebrados principalmente entre junho de 1964 e janeiro de 1968, em plena ditadura militar, são exemplos claros desse processo e expressam bem as consequências que tal ingerência produziu, nesse caso, na política educacional brasileira.
${ }^{181}$ Para o estudo dos acordos MEC-USAID, consultar as obras de J. O. Arapiraca, A
USAID e a educação brasileira: um estudo a partir de uma abordagem crítica da
teoria do capital humano (1982) e M. M. Alves, O beabá dos MEC-USAID (1968).
Sobre os impactos históricos dos MEC-USAID na educação brasileira, ver: L. A.
Cunha e M. Góes, O golpe na educação (1985); F. M. G. Nogueira, Ajuda externa
para a educação brasileira: da USAID ao Banco Mundial (1999). 


\subsection{O golpe de 64 em Pernambuco}

Conforme a polarização interna entre esquerda e direita se agravava, os Estados Unidos partiram para uma presença mais evidente em todos os escalões governamentais e de decisão do país, chegando ao ponto de infiltrar agentes e militares disfarçados como civis, especialmente em Pernambuco. Segundo Moniz Bandeira, havia no Estado, em 1963 cerca de 5000 boinas verdes (green berets) disfarçados de civis à espera de uma ordem para reprimir qualquer iniciativa revolucionária ou agir em caso de desvio da política do governo em franca direção à esquerda. A presença destes "cidadãos" norteamericanos serviria também para justificar uma intervenção maciça das forças armadas daquele país sob o pretexto de garantir a integridade física deles em um período beligerante.

Kennedy, em carta à João Goulart, havia solicitado apoio brasileiro à intervenção militar em Cuba quando da crise dos mísseis, pedido este que foi negado pelo governo do Brasil, dificultando as relações entre os dois países e fazendo com que o governo americano se alinhasse abertamente com as forças internas que queriam derrubar Jango.

Com o assassinato de Kennedy, em novembro de 63, subiu ao poder Lyndon Johnson, representante da ala democrata menos conciliatória que radicalizou as políticas sociais internas e a intervenção externa delineadas por Kennedy, como no caso do Vietnã.
Hoje vêm à público documentos que provam que a intervenção militar americana estava preparada caso a reação ao Golpe de 64 alcançasse a dimensão prevista pelos militares golpistas e pelos EUA. Uma gravação de uma conversa telefônica entre Lyndon Johnson e George Ball, assessor da Casa Branca, antes confidencial e hoje disponível na internet ${ }^{182}$, relata as providências que estavam sendo tomadas pelos americanos para apoiar os militares brasileiros: uma força-tarefa naval, munição e petroleiros carregados chegariam ao Brasil perto do dia 10 de Abril. A Casa Branca queria evitar o desgaste perante a opinião pública internacional, advindo de uma intervenção militar direta, mas não vacilaria caso os brasileiros entrassem em Guerra civil.

Entre as interpretações de revolução ou contra-revolução para o movimento de Abril de 1964, Manuel Correia de Andrade vê dois golpes sucessivos, um dentro do outro:

"Na verdade, em 1964 houve um golpe de Estado, quando as forças armadas, apoiadas por setores da classe média e pela classe alta destituíram um governo legalmente constituído e impedido de realizar as reformas de bas que pregava, por não contar com a maioria do parlamento." (ANDRADE, 1989, p.13)

A repressão em Pernambuco foi imediata e intensa, em todas as frentes do movimento popular. A mobilização de tropas do IV Exército comandadas por Justino Alves Bastos transformou o Campo das

${ }^{182}$ Americanos tramam apoio ao golpe de 64 . Disponível no canal do jornalista Luiz Carlos Azenha em http://br.youtube.com/watch?v=Q65Pz-sFci8 
Princesas, sede do Governo Estadual num cenário de batalha campal, cercando no Palácio o Governador Arraes, o Prefeito Pelópidas Silveira, o major Hangho Trench, comandante da Polícia do Estado e mais alguns assessores. Os militares chegaram a propor uma solução conciliatória, à brasileira, mas Arraes, emocionado, não aceitou qualquer limitação ao seu mandato, concedido pelo povo e saiu dali como prisioneiro do IV Exército. Passou por diversas prisões até ser libertado no Rio de Janeiro por um habeas corpus obtido pelo advogado Sobral Pinto, que o aconselhou a exilar-se ${ }^{183}$.

Um triste capítulo dessa história foi o espancamento de Gregório Bezerra, arrastado por jipes militares pela cidade do Recife e brutalmente torturado na Praça de Casa Forte, bairro da elite pernambucana. O líder comunista escapou da morte pela intervenção de uma freira que dava aulas num colégio próximo e teve receio do trauma que a visão da barbárie criaria em seus alunos. A resistência de Gregório às provocações e ofensas feitas por altos comandantes militares ajudaram a inscrever seu nome na história de resistência do Partido Comunista Brasileiro e a marcar seu nome como uma importante referência da luta contra a ditadura.

183 Arraes permaneceu exilado até a anistia, em 1979, quando retornou à

Pernambuco com enorme prestígio popular, que o fez ser reeleito governador por duas vezes. Escrito na Argélia, em 1968, "O Brasil, o povo e o poder", apresenta as versões e interpretações de Arraes, da recente história do Brasil e os significados do golpe, destacando suas relações políticas e de poder entre as classes dominantes e os movimentos populares. Ver Miguel Arraes. O Brasil, o povo e o poder. Ed. UFPE, 2006.
Os impactos do golpe sobre a "Revolução Brasileira" são comentados por Celso Furtado em depoimento ao jornalista Vandeck Santiago:

"Tenho a impressão de que o Nordeste, onde eu estava na época, foi a região mais prejudicada pelo golpe. O Nordeste foi surpreendido com uma política em andamento, um movimento social, através da Ligas Camponesas, da SUDENE e da Igreja Católica, que apontavam para uma outra direção, Tudo isso foi destruído. No Nordeste as consequências foram mais graves, pois a repressão exercida acabou com o movimento social existente, as Ligas e a Igreja Católica. A região do país que havia acumulado maior atraso social era o Nordeste. O atraso aumentou ainda mais com a mudança."

O historiador Manuel Correia de Andrade parece concordar com Furtado. Apresentando em entrevista seu estudo 1964 e o Nordeste, Andrade declarou:

"em 1964 a repressão política foi maior no Nordeste porque se admitia que o 'processo de comunistização' ali estava mais avançado e devia ser reprimido. Daí a tremenda perseguição que foi feita aos que colaboraram com Arraes, aos que tinham idéias de esquerda, mesmo não comunistas, contra os que reicindicavam melhores salários e melhores condições de trabalho, Contra os que refletiam sobre a precária situação da região e do país. Foram fortemente atingidas pessoas e instituições como a SUDENE, os órgãos ligados aos governos estaduais, sindicatos, a Igreja Católica, a Universidade tanto em seu corpo discente como no docente, as instituições de cultura, etc. Tudo que cheirasse a cultura popular, a interesses populares, a reformas econômicas e sociais, a investigação científica, etc. era suspeito e passível de perseguição." (ANDRADE, 1989, p.9)

\footnotetext{
${ }^{184}$ Vandeck SANTIAGO. "O Plano de Kennedy para desenvolver o Nordeste". Suplemento especial do Diário de Pernambuco, Recife, 30/ago/2006.
} 
No Cajueiro Seco a mobilização militar também foi concomitante à notícia da "Revolução". Seu Inácio, o sapateiro e um dos primeiros moradores ${ }^{185}$ relata que foi comprar pão no armazém local e o que havia nas prateleiras eram balas de fuzil, à disposição de quem quisesse participar ativamente da repressão. O líder comunitário Manoel Damião, que também era funcionário da Companhia de Saneamento Estadual teve de fugir dali, assim como muitas das pessoas que participaram ativamente da experiência. Durante o governo de Paulo Guerra, vice de Arraes comprometido com o golpe, os lotes no Cajueiro Seco continuaram a ser distribuídos e ocupados, dentro de uma proposta bastante diversa da inicial. O SSCM teve seus quadros e diretoria reformulados, assumindo uma diretoria alinhada com o Golpe que se pôs a "denunciar os convênios" ${ }^{186}$ feitos pela administração de Gildo Guerra.

Nas páginas da última Hora, provavelmente também já sob intervenção dos golpistas, lê-se que

"O Sr. João Pinheiro Lins, novo presidente do SSCM, ordenou intervenção na Cooperativa de Cajueiro Seco, denunciando ainda os convênios assinados entre o SSCM e várias Associações de Bairros." ${ }^{187}$

Com o advento do Banco Nacional da Habitação (BNH), o SSCM foi extinto, fechando um ciclo e passando para a história como um dos

${ }^{185}$ Ver seu depoimento completo no item 5 do Capítulo 4.

186 "Absurdo do SSCM". Diário de Pernambuco, Recife, abril/1964. E "Ivaldo Buril assumiu Departamento no SSCM". Última Hora, Recife, abr/1964.

187 "SSCM denuncia convênios". Última Hora, Recife, abr/1964. mais inovadores serviços habitacionais no Brasil, ainda que circunscrito às condições políticas locais.

Não há dúvida sobre a força do impacto do golpe sobre a região, desmobilizando rapidamente iniciativas e práticas que vinham amadurecendo em decorrência do exercício democrático, como atesta Francisco de OLIVEIRA:

"O golpe de 1964 abateu-se com especial fúria sobre Pernambuco e o Recife. Dizimaram a esquerda, o movimento dos trabalhadores, o movimento católico político-intelectual, o movimento estudantil; exilaram parte importante das lideranças, foram-se o clima de debate e as iniciativas inovadoras, o Movimento de Cultura Popular e Paulo Freire, a reforma transformadora da Sudene. Ficou apenas a voz solitária de dom Hélder Câmara" (OliveIRA, 2008, p.85)

Com respeito à participação direta do povo, o golpe também foi um momento de virada das ideologias e de personalidades políticas, trajetórias de luta e suas relações com as bases. A solução para o impasse criado com movimento militar de $1^{\circ}$ de Abril, sem resistência organizada pelos governantes, independentemente das vontades populares, encerrava um ciclo da história brasileira. De acordo com OLIVEIRA,

"Revelava-se um componente central do populismo: não se organizava o povo, nem mesmo as categorias organizadas da sociedade, e na "hora da onça beber água", tudo se decidia mesmo entre as elites. Se o comportamento na hora extrema revelou um antiaventurismo louvável, mostrou também que o povão servia principalmente como massa de manobra para o jogo político; não era sujeito, mas sujeitado." (OLIVEIRA, 2008, p.110) 


\section{3 - HABITACÃO E URBANISMO NO GRANDE RECIFE}

Neste capítulo, abordaremos as questões da habitação e do urbanismo no plano especificamente local, sobre o qual muito nos informam os jornais diários e acervos das Instituições pernambucanas, amarrando a história de um fato arquitetônico relativamente discreto com a história da política e de suas relações com o mocambo no Recife desde os anos 1920 até o momento do golpe. Nesta trajetória, é importante considerar a história do SSCM, criado pelo interventor do Estado Novo Agamenon Magalhães, que pessoalmente se empenhou em "solucionar" a questão do mocambo, por seus meios particulares, hoje criticados.

O panorama da produção e dos diversos entendimentos do mocambo por técnicos, artistas e intelectuais vem sendo analisado por diversos autores ${ }^{188}$, que vêm sendo reeditados recentemente por fundações empenhadas em organizar e divulgar as obras clássicas desses autores, como a Geografia da Fome e Mucambos do Nordeste, interessante relato das incursões "antropológicas" de Freyre e sua bicicleta pelas zonas pobres recifenses. Assim, abordaremos aqui mais especificamente as discussões relativas ao mocambo nos anos 60, período no qual as produções e edições também se intensificaram, no

\footnotetext{
${ }^{188}$ Como José Tavares Correia de LIRA, Mocambo e Cidade: regionalismo na arquitetura e ordenação do espaço habitado. Doutorado FAU-USP, São Paulo: FAU-USP, 1997; Alberto SouSA, Do mocambo à favela, entre outros estudos acadêmicos, além de obras seminais como Homens e Caranguejos, de Josué de Castro e Sobrados e Mucambos, de Gilberto Freyre.
}

ritmo de metropolização da cidade e estavam "insuportavelmente reunidas ${ }^{\prime 189}$, resultado de uma permanência de longa data do mocambo no debate, nos discursos e nos problemas da cidade, de certo modo, até hoje.

Para entender o lugar do Cajueiro Seco na rede de comunidades em torno do Grande Recife, temos de levar em conta o Plano para o Grande Recife elaborado por Antônio Bezerra Baltar em 1951. Para compreender o projeto urbano do Cajueiro Seco, é importante considerar o seu lugar numa transição das populações rurais rumo à urbanização de maneira gradual e controlada.

O plano habitacional publicado em 1962, no ocaso do Governo Cid Sampaio, merece ser analisado aqui por condensar um diagnóstico da situação habitacional recifense e as principais linhas de atuação estabelecidas até ali, para perceber no que elas seriam renovadas com a ascensão de Arraes ao poder estadual. Detectar as coincidências entre as propostas do plano e a plataforma política da Aliança para o Progresso é essencial para perceber os seus significados mais profundos, para além da mera provisão habitacional.

O último item deste capítulo acompanha o processo de ocupação dos Montes Guararapes, que já vinha desde o começo dos anos 1950, estimulado pelos beneditinos que detinham a posse dos terrenos e por alguns políticos, envolvidos com a grilagem de terras e cobrança de "aluguel de chão". O conflito destes com uma idéia de

${ }^{189}$ Como narra Ferreira GULLAR no documentário Brasília: contradições de uma cidade nova, de Joaquim Pedro de ANDRADE, 1967 
nacionalidade que passava pela preservação do sítio das batalhas pela restauração do domínio colonial, assim de ambos com a divisão regional do Serviço do Patrimônio, nos mostram que outros atores, além dos populares e dos arquitetos, também estavam envolvidos na luta pela habitação dos pobres e na conquista dos territórios da metrópole que se estruturava. 


\subsection{O Servico Social Contra o Mocambo (SSCM) e a institucionalizacão da política habitacional em Pernambuco}

A história do Serviço Social Contra o Mocambo, desde sua fundação pelo interventor do Estado Novo Agamenon Magalhães até a experiência do Cajueiro Seco, já em tempos de Arraes, merece ser aqui apresentada e comentada pelo que oferece à compreensão da importância da questão do mocambo na política e na sociedade pernambucana e ao entendimento da dimensão relativa do Recife como foco de problemas com a habitação popular e transformações nas soluções propostas pelos primeiros organismos públicos dedicados à habitação social no plano nacional cuja atuação fornece diversos elementos que ajudam a problematizar a formação da política habitacional antes de 1964 (MELO, 1982; SOUSA, 1990 e LIRA, 1997)

Antes da fundação da Liga Social Contra o Mocambo, em Pernambuco algumas iniciativas pioneiras, ainda que muito limitadas, foram praticadas pela municipalidade recifense com a Vila Proletária do Arraial, em 1921 e pelo Governo Estadual em 1920/21 com a Fundação A Casa Operária, cuja atividade não teve produção ou expressão significativa para além da Vila de São Miguel de Afogados e Engenho do Meio (SOUSA, 1990, p.104).

A Liga Social Contra o Mocambo foi fundada em 1939 como uma organização da sociedade civil, da qual o principal signatário era o Governo do Estado, além da Cooperativa de Usineiros e sindicatos, apoiava-se numa verdadeira "Campanha contra o Mocambo", que passava também pela imprensa e pelo capital imobiliário, "destinada a promover a extinção desse tipo de moradia e a incentivar a construção de casas populares dotadas de condições higiênicas e de fácil aquisição." ${ }^{190}$

"A 'Liga' surgiu com a finalidade específica de construir casas. Entretanto, os seus dirigentes logo perceberam ser necessário o apoio de um órgão com finalidade educativa e que facilitasse a penetração no meio proletário, onde pretendiam trabalhar. Assim, aproveitaram-se das idéias e métodos adotados pelos "Centros Educativos Operários" que funcionavam discretamente há bastante tempo e eram de sutil inspiração da "Companhia de Jesus" (...). Convém notar que a origem dessas agremiações se firmou na divergência filosófica entre espiritualistas e materialistas. Pretenderam, os primeiros, evitar que as classes mais desfavorecidas fossem absorvidas pelas idéias comunistas que agitaram intensamente o Grande Recife, inclusive com revolução sangrenta, no período de 1932 a 1937. Em sua fase áurea, os Centros Educativos, já subordinados à Prefeitura, na DRAS esboçaram um programa de educação entre o proletariado recifense, abrangendo vários ramos das ciências domésticas e um pouco de orientação social" (BEZERRA,1965, p.43)

O objetivo político da Liga era também lutar contra a organização e mobilização social; acreditava-se que a cessão da habitação digna afastaria o indivíduo do comunismo. Outra vertente do trabalho de colocar o indivíduo sob tutela do Estado era a assistência social propriamente dita, que se organizou em paralelo à Liga, na Diretoria de Reeducação e Assistência Social da prefeitura, que seria posteriormente fundida ao SSCM, em 1945 e coordenava as atividades

\footnotetext{
${ }^{190}$ Estatutos da LSCM, 1940 apud MELO, p.106.
} 
nos Centros Educativos Operários (CEOs), essencialmente voltados à prestação de serviços públicos de educação e saúde.

A atuação da Liga iniciou-se com a realização do Censo dos Mocambos de $1939^{191}$, no qual fez-se um panorama estatístico da dimensão do problema no Recife e avançou-se com algumas conclusões sobre a dinâmica econômica do Mocambo, identificando um mercado de construção e aluguel das habitações caracterizado como a "Indústria do Mocambo", que auferia ali lucros relativamente maiores que o mercado imobiliário formal. Observava-se a prática do aluguel de chão e uma nova modalidade de propriedade, a casa própria autoconstruída sobre terreno alugado, indício curioso da mobilidade a que o mocambo se submetia, transferido sucessivas vezes e reconstruído a partir dos mesmos materiais. A palafita representava nesse sistema o máximo da desvinculação entre a propriedade da unidade e a incerteza do chão.

Nesse momento, detectou-se um fato que seria repetidamente constatado em outros estudos posteriores acerca da questão: mais da metade da população recifense morava em mocambos, o que ensejava o questionamento do mito da marginalidade, surpreendente para a época e somente retomado em outros lugares depois de décadas. Nos mocambos moravam funcionários públicos, operários assalariados, portuários, trabalhadores informais, biscateiros e eventualmente marginais entre uma população que só fazia crescer e aparecer como

${ }^{191}$ Estado de Pernambuco/ Comissão Censitária dos Mucambos. Observações estatísticas sobre os mucambos do Recife, Recife: Imprensa oficial, 1939. símbolo do atraso na metrópole recifense, que procurava aproveitar o surto de desenvolvimento nacional.

As leituras do Censo orientaram a ação da Liga e as lacunas do diagnóstico, ainda que bastante completo para as ciências sociais da época, associadas aos objetos políticos da iniciativa, já indicavam quais seriam as consequências e problemas da política posta em prática.

Antes do Censo, vale destacar o estudo "Condições de Vida das Classes Operárias do Recife", de 1935, realizado por Josué de Castro para o Ministério do Trabalho de Vargas, ou seja, encomendado por Agamenon, no qual se desenharam conclusões que foram posteriormente reiteradas por analistas da estatura de Francisco de Oliveira e Lúcio Kowarick: o mocambo, assim como a periferia ou a favela, são consequências e causas explicadoras de um rebaixamento do nível de salários, aumento na taxa de exploração do trabalho e diminuição do custo da habitação baseada nas autoconstruções e espoliação $^{192}$.

Contrapondo-se à ideologia agamenonista e à erradicação dos mocambos estava também Gilberto Freyre, fazendo um elogio das virtudes do mocambo adaptado às condições ecológicas nordestinas em "Mocambos do Nordeste". O romantismo com que Freyre enxergava esse mocambo modelar era um dos principais pontos em polêmica com Castro (LIRA, 1997), que insistia em critérios objetivos para lidar com o fenômeno pelos quais não havia como relativizar as

${ }^{192}$ Lucio KOWARICK. Escritos Urbanos. São Paulo: Editora 34, 2000. 
precariedades do casebre, sem deixar de elogiar-lhe pela resistência e capacidade de improviso, reconhecendo seus direitos como parte explorada na divisão do trabalho.

"Retornemos a Gilberto Freyre. Os mocambos permitiam então fazer um estudo da arte popular da região exatamente porque se encontravam voltados para um ajustamento ao meio físico e ao espaço social. Em Gilberto Freyre, há uma leitura ecológica sem dúvida tradicional, da casa adaptada ao meio geográfico, que se desdobra porém em características formais e culturais bem específicas: a simplicidade de linhas, a economisa de ornamentos, o apoio quase exclusivo sobre as qualidades do material, a honestidade plástica. E não apenas neste sentido o mocambo era investido de valor; também ganharia precedência por realizar virtudes sociológicas de adaptação e mobilidade perfeitamente condizentes com as exigências contemporâneas da habitação urbana. Do primitivismo passava-se aos trações coerentes com uma estética moderna. Do ecologismo tradicional passava-se às suas virtudes sociológicas tal como modernamente era possível compreendê-las." (LIRA, 1997, P.96)

O próprio sociólogo pernambucano apresenta o problema real que o mocambo esconderia, para além de suas relativas qualidades construtivas:

"A verdade é que, por si mesma, a casa de palha não é nenhum horror nem vergonha. Pode ser até mais saudável, em clima tropical sendo higiênico o seu piso e higênica a sua latrina - do que a casa de alvenaria mal adaptada a esse clima. (...) É o problema dos mocambos, como problema social, muito mais do que o das mocambarias, como 'vergonha urbanística', que precisa de ser resolvido pelo Recife, pelo Nordeste, pelo Brasil"'193

Já para Josué de Castro, "o mocambo encerrava uma realidade ambígua: Mais próximo da realidade da senzala que do quilombo,

${ }^{193}$ Gilberto FreYre "Apresentação" in BeZERRA, D. Alagados, mocambos e mocambeiros 1965 Ver também LIRA, J.T.C. Hidden meanings: the mocambo in Recife Simpósio "City Words/ Les mots de la ville" SAGE: Londres/Paris, 1999 denunciava a sua inserção em um sistema de exploração social do trabalho reminiscente ao latifúndio da cana-de-açúcar cuja modernização tampouco parecia fornecer à maioria dos habitantes da cidade os seus benefícios. Assim como para Vasconcelos Sobrinho, era visto como um problema [da cidadel cujas origens podiam ser encontradas no campo." (LIRA, 1997, P.67)

No seu único romance, carregado de informações documentais sobre o Recife dos anos 50, Castro descreve a resistência da "Aldeia Teimosa" $^{\prime 194}$ (que depois se tornaria Brasília Teimosa) contra as remoções promovidas pelo governo. A simples demolição de mocambos foi de fato a primeira atitude da Liga, em ritmo muito mais acelerado do que a produção de novas unidades na Vilas - até 1945, para 12 mil mocambos demolidos haviam sido construídas pouco mais de 5 mil unidades.

"Tal esforço de destruição era evidentemente enorme, mas revelavase ineficaz, pois, como muitos barracos eram derrubados sem que seus moradores fossem transferidos para as habitações populares programadas (cujo ritmo de construção era bem inferior ao ritmo de demolições), novos mocambos eram erguidos pelas famílias desalojadas em lugares pouco visíveis, situados em áreas periféricas do Recife ou nos municípios vizinhos. Isto quer dizer que, na verdade, uma boa parte da ação destruidora levada a cabo acarretou simplesmente uma migração dos mocambos, das zonas centrais ou bem localizadas para a periferia urbana." (SOUSA, 1990, p.104)

Daí é que se percebe que a atuação da Liga na verdade acentuava o quadro de precariedades habitacionais, servindo como instrumento político em paralelo a um "plano modernizador" que

\footnotetext{
194 "De como os habitantes da Aldeia Teimosa construíram na marra a sua cidade" in Josué de CASTRO, Homens e Caranguejos São Paulo: Civilização Brasileira, 1967/ 2001.
} 
enxotava a "tinta grossa do borrão da miséria" para fora das novas perspectivas urbanísticas que então se abriam na "Veneza americana" com o mito da metrópole do Nordeste em florescimento.

Como em períodos anteriores e subsequentes, seja no Nordeste seja em toda a política brasileira, o clientelismo grassava e dava o tom em todas as repartições envolvidas no Serviço Social e na provisão de qualquer serviço ou bem. De fato, a Liga construiu também algumas vilas populares organizadas por categoria profissional - as célebres Vilas das Lavadeiras, das Cozinheiras, dos Contínuos mas é fácil perceber que nesse caso se deu algo que se repetiria em diversas outras experiências habitacionais de matizes distintas: as casas não foram alocadas para seus destinatários programados, servindo muito mais como instrumento de cooptação de lideranças e influências do que como medida efetiva para diminuir o déficit habitacional e melhorar as condições de vida daqueles que nos mocambos viviam.

Além deste caráter clientelista de desvio de direitos sobre as unidades, havia ainda a dimensão assumidamente clientelista de organização da sociedade por associações profissionais tipicamente estadonovistas e de inspiração fascista. Quem o explica é Marcus André B.C. de Melo:

"A política habitacional empreendida em Pernambuco conferiu um caráter fortemente corporativista às vilas. A habitação se converte, assim, no lugar de comunhão e de recriação de uma identidade profissional e corporativa, dissimulando as contradições sociais que só podem ser recuperadas politicamente por uma consciência de classe. Há que se relevar que este fato aponta a especificidade da política populista da habitação no Recife, dado que, afora as vilas dos institutos de aposentadoria e pensões, em lugar algum no Brasil se promoveu a criação de vilas corporativistas de segmentos profissionais não-organizados como contínuos, lavadeiras, cozinheiras, etc. o ideal corporativo, assimilado por Getúlio Vargas, será recuperado com propósito determinado pelo seu exMinistro do Trabalho, à frente da interventoria em Pernambuco." (MelO, 1982 p. 272)

No seu próprio jornal, Agamenon Magalhães esclarece a matriz ideológica por trás do seu governo:

"Contra a luta de classes, aconselhada pelo marxismo (...), surgiu na Itália, como na Alemanha, a experiência, hoje vitoriosa, da organização corporativa, das economias. Em vez do antagonismo entre o Capital e o Trabalho, a corporação realiza o acordo, a conciliação, a harmonia entre os fatores da produção. (...) Em todos os países, o sindicato surgiu contra o Estado (...). No Brasil, ao contrário, foi o Estado que criou o sindicato, disciplinando a sua constituição e dando-lhe função pública"'195

Em sua tese de mestrado, Melo desenvolveu a associação entre o surgimento da política pública em habitação social e o florescimento do populismo ${ }^{196}$, ambos apoiados sobre a mesma conjuntura histórica.

"Acredita-se que são comuns as determinações estruturais quer do populismo, enquanto fato 'político', quer da política urbana, quer da formação das áreas marginais" (MELO, 1982, p.158)

\footnotetext{
195 Agamenon Magalhães. "Renovação Social". Folha da Manhã, apud MelO, 1982, p.272

${ }^{196}$ Com relação ao "populismo" no Nordeste, discorda dele o sociólogo Francisco de Oliveira: "O caráter da cena política, das relações de classe, dos conflitos de classe no Nordeste não pode ser entendido, em resumo, sob a mesma rubrica do "populismo", que foi a forma de imposição da hegemonia da burguesia industrial no Centro-Sul. Faltavam no Nordeste os conteúdos específicos do "populismo": uma hegemonia burguesa que se impôs sem romper abertamente com a oligarquia agrária, um proletariado urbano que emerge em novas condições de expansão das forças produtivas, um Estado produtor que se tornava gradual e crescentemente o próprio núcleo da contradição, pela ambiguidade de suas relações com as classes dominantes e dominadas" (OLIVEIRA, 1977/2008, p. 224)
} 
Em 1945, a Liga foi transformada em autarquia ligada ao governo Estadual, quando adquiriu a denominação pela qual se tornou conhecida - Serviço Social Contra o Mocambo, inserindo-se numa rede de companhias estaduais de habitação em coordenação com a Fundação da Casa Popular, já no Governo Dutra e depois da ditadura de Getúlio.

"Na nova conjuntura histórica que se perfilou com a

democratização do após-guerra, assiste-se a um refluxo da campanha contra o mocambo, que passa a não contar mais com a mobilização de amplos segmentos da sociedade civil" (MELO, 1982, p.278)

Um importante retrato do que era e do que deveria ser sua atuação é o Regulamento do Serviço Social Contra o Mocambo publicado pela imprensa oficial recifense. No documento, estão definidas as principais incumbências e determinações institucionais da autarquia, diretamente ligada à interventoria federal no Estado, agora conduzida por Etelvino Lins.

Sua atribuição principal e declarada era "construir casas higiênicas e populares destinadas às classes menos favorecidas, protegendo-se contra os males da habitação insalubre e da promiscuidade da vida nos mocambos", mas além dela incluem-se "fazer propaganda das instituições nacionais, combater os maus hábitos, proteger os bons costumes, promover a formação de uma consciência nacional dos deveres cívicos e profissionais, desenvolver o ensino primário e profissional, dar assistência médica, promover estudos sistemáticos sobre o mocambo, atividades e formação do serviço social, educação física e divertimentos populares." 197

Percebe-se que várias atividades do estado estavam contidas no escopo da atuação de um só órgão destinado a atuar nos mocambos, os

\footnotetext{
${ }^{197}$ Regulamento SSCM, 1945, p.5-6.
}

quais abrigavam grande parte da população inserida no mercado formal de trabalho. A entidade estruturou-se entre três seções: o Departamento de Construções (DC), que além dos projetos e obras das novas unidades cuidava do patrimônio imobiliário acumulado da autarquia, leia-se recebimento e cobrança dos presumidos aluguéis e conservação das casas e conjuntos, e o Departamento de Reeducação e Assistência Social (DRAS), que responderia por diversos serviços de saúde, lazer, cultura e educação além da assistência social propriamente dita, além de um setor meramente administrativo.

A partir desta estrutura, o documento expôs as dinâmicas de construção e ocupação das casas nas Vilas Operárias, bem como seus mecanismos de contrato e cobrança perfeitamente formais ${ }^{198}$, dispondo também sobre o funcionamento dos Centros Educativos Operários, a quem cabia a aplicação dos serviços e recursos públicos e também um certo controle da vila. A DRAS, que até aquele momento fazia parte da Prefeitura do Recife era absorvida pelo SSCM, que também incorporava a Fundação A Casa Operária; parte do recurso que cabia à DRAS era doado por empregadores e sindicatos "amigos do operário".

Com o primeiro governador eleito depois do Estado Novo, Barbosa Lima Sobrinho, à frente do executivo estadual, não era tão simples alinhar fundos e recursos federais e estaduais como na época em que Agamenon se entendia diretamente com Getúlio; muitas semelhanças faziam do "China Gordo" uma expressão do líder

198 Inclusive prevendo a exigência de fiador por parte do morador do mocambo que pleiteasse a locação de uma casa do SSCM. 
personalista do Estado Novo na esfera nordestina. Tal qual Getúlio, Agamenon voltou ao poder pelo voto em 1951 e teve o mandato interrompido pela morte em 1954. Nem com a volta do alinhamento entre o governo estadual e o federal o SSCM voltaria ao ritmo de construções do período inicial. Nesse período, a instituição passou a se dedicar mais às atividades de assistência social, como o programa "Máquinas de costura" do que à construção de novas Vilas, enfrentando dificuldades previsíveis em cobrar de seus inquilinos e manter conservado seu patrimônio, o que acabou por ensejar o programa de Venda de unidades para os moradores em 1959. Em vinte anos de atividades, só haviam sido produzidas 5 mil novas unidades, algo em torno de um décimo dos mocambos recenseados em 1939. No começo dos anos 1960, os mocambos já eram mais de cem mil. (SOUSA, 2001, p.105)

A mudança de paradigma da locação para a casa própria entrou em consonância justamente com a ideologia que iria prevalecer a partir daí e que foi estimulada pela Aliança para o Progresso e organismos internacionais vinculados aos EUA que passaram a despejar recursos sobre o Nordeste, refletindo as preocupações de Kennedy com os avanços da esquerda brasileira e a "Síndrome de Cuba", analisada nos capítulos anteriores.
A partir do Acordo com o BID ${ }^{199}$, celebrado em 1962 pelo Governo Cid Sampaio diretamente com Washington, o SSCM passou a ter capital para adquirir terras e construir grandes conjuntos de unidades isoladas no lote, como o realizado no Alto Jordão, paradigma desse tipo de produção, referido no Plano de Habitação de $1962^{200}$. Nos anos 1960, tentando contrapôr-se ao Movimento de Cultura Popular estimulado pela prefeitura de Miguel Arraes, Cid Sampaio criara a Fundação de Promoção Social, para assumir as funções da DRAS em estrutura independente do SSCM e receber os recursos do BID.

Com a eleição de Arraes para governador e a denúncia dos convênios feitos diretamente pelos estados brasileiros com o governo federal americano, através da Aliança para o Progresso discutido no item C do capítulo, a pauta de atividades do SSCM teria que ser transformada por um compromisso de gestão, já que o acordo SSCMBID era um dos objetos principais da denúncia feita pelo então Governador apoiado pelo Grupo de Trabalho presidido por Germano Coelho. Gildo Guerra era um dos membros da comissão que atentamente analisou todos os contratos em vigência relativos aos

\footnotetext{
199 Pedro ARANTES em O ajuste urbano (2004) analisa a ingerência dos organismos financeiros internacionais no desenho das políticas públicas latinoamericanas a partir dos anos 1960 até dias atuais, especialmente a recomendação e incentivo aos programas de acesso a lote urbanizado e autoconstrução assistida, cujo principal entusiasta seria John Turner.
} 
empreendimentos e financiamentos em curso $^{201}$. A origem e o volume dos recursos alocados no plano habitacional teriam de ser revistos, assim como outro paradigma de conjunto habitacional e de casa popular em substituição ao modelo das Vilas, que ainda não havia sido apresentado.

Quando assumiu a Presidência do SSCM, Guerra se deparou com empréstimos em fluxo e obras em curso nos conjuntos do Alto Jordão, Ibura e com a situação habitacional descrita por Mario Lacerda de Mello como a "mucambópolis", na qual o fenômeno do mocambo isolado se generalizava, se sobrepunha e se integrava ao quadro de favelização comum à diversas cidades brasileiras, entre as quais o Recife, a terceira cidade mais populosa do país, se destacava pela magnitude da questão habitacional, contrapondo-se de certa forma à Brasília, num pólo entre o atraso e o progresso, o arcaico e o moderno.

A passagem da produção ao longo dos anos 1950 e 1960 do tipo ideal do mocambo - construído com materiais locais, adaptado e isolado no terreno, especificamente pernambucano para o modelo da favela - para um aglomerado da sobreposição de produtos industriais e restos, comum em todo o Brasil é analisada por Alberto Sousa em Do Mocambo À Favela, resultado de tese de doutorado em Paris sobre o tema. Curiosamente, o autor, que se esforça em detalhar as dinâmicas físicas e construtivas da situação habitacional no Recife ao longo do século XX, ignora as mecânicas econômicas e sociais, presentes em

${ }^{201}$ Analisado detalhadamente em "A Aliança para o Progresso, a USAID, o IBAD e a reação nacionalista de Pernambuco", item G do capítulo 2 deste trabalho. várias abordagens do tema, que acabam por estar na base do mocambo e da favela, sem significativa mudança de padrão nesse período e insiste em usar o termo "espontâneo" aos assentamentos populares cuja formação estrutural tenta apresentar.

Apesar do volume dos recursos emprestados pelo BID e da construção de milhares de unidades no Alto Jordão, as posturas e experiências inovadoras que marcaram a atuação do SSCM nos anos 1960 seriam condensadas na experiência do Cajueiro Seco. Alberto Sousa encerra sua análise sobre a produção da autarquia destacando a experiência sob diversos ângulos:

"É preciso ressaltar que a ação do SSCM apresentou certos pontos positivos no que diz respeito à experimentação de novas maneiras de abordar a questão da provisão de habitações populares. Uma experiência valiosa e renomada da instituição foi o projeto do bairro de Cajueiro Seco, um loteamento com cerca de 400 lotes urbanizados nos quais as próprias famílias pobres deveriam construir, num curto prazo e com a orientação técnica do SSCM, as suas moradias; este projeto foi implantado em 1963, isto é, mais de uma década antes que a idéia do lote urbanizado se tornasse o objeto de um programa de habitação popular financiado e preconizado pelo $B N H$. Ademais, o SSCM realizou também algumas experiências interessantes no campo da concepção de edificações. Por exemplo, a utilização de casas pré-fabricadas em cimento-amianto foi testada. Para poder oferecer casas mais baratas às famílias mais pobres, tentou-se fornecer a elas moradias incompletas (como as que continham apenas uma cobertura e um sanitário), que os seus adquirentes deveriam completar gradualmente segundo suas possibilidades e necessidades. E no projeto Cajueiro Seco, buscou-se modernizar a técnica tradicional da taipa, de maneira a permitir a construção de casas a partir de elementos préfabricados executados em conformidade com essa técnica." (SOUSA, 2001, p.107)

Pernambuco recebeu $20 \%$ das verbas destinadas à habitação no II Plano Diretor da SUDENE porque era o único estado nordestino que 
já tinha elaborado seu Plano de Habitação. Arraes, na época declarava à Última Hora, angariando pela chave do mocambo um apoio singular:

"O homem tem o direito de construir sua casa como melhor the aprouver, inclusive mucambo se assim achar melhor, ou somente assim estiver dentro de suas possibilidades financeiras. Manifestando-se na ocasião, o sociólogo Gilberto Freyre apoiou o plano, afirmando ser uma tese que defende a longos anos, a de que o mocambo, dentro de nossas condições sócio-econômicas, é perfeitamente aceitável desde que apresente condições sanitárias." ${ }^{202}$

Passados vinte anos de sua prisão e anistia, o próprio Arraes, em debate promovido pelo IAB no começo do anos 80, destacou a importância da experiência, ressaltando seus aspectos fundiários e autogestionários:

"Uma das experiências em matéria de terreno, de localização de população foi feita, mas já aí não na prefeitura, quando já me encontrava no governo de Pernambuco, com a implantação de Cajueiro Seco, para desviar uma invasão dos Montes Guararapes, que é patrimônio nacional, teoricamente guardado pela Aeronáutica e que hoje, vejo, está ocupado novamente por mocambos. Para retirar uma população que ali se localizou, conseguimos um outro terreno, em Cajueiro Seco, município já, de Jaboatão, e ali foram instaladas essas famílias, sob a direção de uma comissão eleita pela população que havia invadido o local. As decisões relacionadas com a cessão de terrenos eram tomadas por essa comissão e por assembléia gerais, realizadas pelos interessados. Não havia interferência de nenhuma autoridade e de nenhum funcionário, eram eles que decidam quem tinha ou não tinha direito ao local para construir seu mocambo. Pois nessas invasões, aparecem os chamados mocambeiros, isto é, pessoas que costumam aproveitar as invasões para construir mocambos que vão alugar, e esses eram retirados, negado o local, não pelo governo, mas por aqueles que a população havia escolhido para dirigir os

202 “Pernambuco receberá 100 Milhões para iniciar plano de Habitação Popular!”. última Hora, Recife, 19/jul/1963. trabalhos." ${ }^{203}$

Com o advento do BNH e da criação das Companhias de habitação popular em 1965, a atribuição de produção de novas unidades foi gradativamente assumida pelas novas COHABs implantando o paradigma do Conjunto Habitacional ${ }^{204}$. Ao SSCM coube levar adiante os serviços de assistência social, o que acabou por gerar uma transformação em sua estrutura e atividades em 1975, passando a denominar-se Serviço Social Agamenon Magalhães, que posteriormente foi incorporado à Secretaria de Desenvolvimento e Assistência Social do Governo do Estado, hoje sediada no mesmo endereço do antigo SSCM, na Avenida Cruz Cabugá.

\footnotetext{
${ }^{203}$ Instituto dos Arquitetos do Brasil - IAB-PE, 1982, p.23.
}

${ }^{204}$ Ver, entre a extensa bibliografia sobre o BNH, o artigo de Carlos Eduardo COMAS, O espaço da arbitrariedade - Considerações sobre o conjunto habitacional BNH e o Projeto da cidade brasileira. São Paulo: Projeto, 1986. 


\subsection{Urbanismo e metropolização do Grande Recife}

O documento que resume o plano ou as diretrizes para a elaboração de um plano elaborado pelo Engenheiro Antônio Bezerra Baltar como tese para obtenção da cátedra de Urbanismo na Universidade do Recife, em 1951, é uma importante síntese do pensamento urbanístico acumulado em Pernambuco até ali, um retrato da situação urbana no Recife dos anos 50, pela sua vinculação com os dados do Censo de 1950 e da mudança de escala do planejamento, passando do meramente urbanístico para o regional.

Outros planos já haviam sido elaborados para a cidade do Recife até aquele momento, desde o pioneiro Plano de saneamento de Saturnino de Brito (1918), que refletia a matriz higienista mas também continha importantes diretrizes urbanísticas, e os Planos de Nestor Figueiredo (1932), do arquiteto Atílio Correa Lima (1936) ${ }^{205}$ e o de Ulhôa Cintra (1942), entre outros estudos.

A escala metropolitana ${ }^{206}$ consistia na novidade do Plano de

\footnotetext{
${ }^{205}$ Ver José Tavares Correia de LIRA. "O urbanismo, a eugenia e os mocambos", "O urbanista, o Acaso e a Ossatura do Plano" e "Zoneamento, Política e Planificação" in Mocambo e cidade: regionalismo na arquitetura e ordenação do espaço habitado. Doutorado FAU-USP, São Paulo: FAU-USP, 1997.

${ }^{206}$ Para uma história da urbanização do Recife a partir de um prisma interessante e pouco habitual, que destaca o papel das forças populares e da habitação social dentro do conflito entre os territórios de formação social não capitalista (representada pela cidade dos caranguejos), submetidos à expansão da industrialização incipiente dirigida de fora da "metrópole regional" (do asfalto e do viaduto), ver Gadiel Perucci e Denis Bernardes O caranguejo e o Viaduto - Um ensaio de metaleitura sobre o Recife/ Notas preliminares para uma história social
}

Baltar, que incorporava diversas diretrizes parcialmente executadas dos planos anteriores ao planejamento pensado para além dos traçados físicos, considerando principalmente o desenvolvimento econômico e social de uma região.

Baltar vinculava-se ideologicamente aos setores progressistas da Igreja Católica, em particular às idéias do Movimento Economia e Humanismo formuladas na década anterior pelo frade francês LouisJoseph Lebret. Em discurso solene na Universidade do Recife, Baltar expôs as linhas ideológicas e de atuação do movimento, destacando o papel na Universidade na formulação de uma alternativa tanto ao "individualismo capitalista" quanto às radicalidades soviéticas, em busca de novas maneiras de organizar a sociedade a partir da economia e da cultura e do princípio abstrato do "bem comum".

Em síntese, "O valor humano é a referência de todos os valores. A realidade social é objeto de estudo da economia humana que ao mesmo tempo é ciência ou elaboração e fermento de transformação. A experiência reforçando a ciência e reciprocamente. (...) A pessoa humana e a comunidade onde ela vive são inseparáveis" ${ }^{207}$

A atitude ativa dos integrantes do movimento é assim resumida por Baltar: "Tomemos as nossas ferramentas e os nossos instrumentos - as nossas idéias e as nossas teorias - os nossos planos e os nossos programas de salvação e vamos com eles ao encontro do homem comum para ajudar a sua reabilitação, para reconstruir a sua vida esmagada por imensas e

do Recife São Paulo, 1980 "O vazio da cidade dos caranguejos, esmagados pelos aterros e pelos viadutos continua (...). O capital vigia, o trabalhador não pode parar. Os viadutos dilaceram a cidade (...). Recife, esplêndido mito, realidade cruel. Eis o dilema!"

207 Universidade, Economia e Humanismo - Preleção na Universidade do Recife discurso proferido em 1953 publicado como folheto pela Universidade do Recife (BALTAR, 1953, p.18.) 
indiferentes estruturas econômicas e políticas. Uma tarefa enorme de apreensão objetiva da realidade está ainda por fazer - um rol interminável de problemas por equacionar, uma multidão de possibilidades de solução por descobrir e promover." (BALTAR, 1953, p.25)

O Brasil foi um dos países nos quais o Padre Lebret atuou, fundando escritórios da Sociedade de Análises Gráficas e Mecanográficas para Análise de Complexos Sociais, a SAGMACS, em São Paulo e Rio de Janeiro, que ao longo dos anos 50 e 60 elaborou planos e estudos para cidades no Paraná, Minas Gerais, São Paulo, Mato Grosso e outros estados, além de desenvolver metodologia para pesquisa e ação em desenvolvimentos urbanos que está na base de diversas vertentes do pensamento urbanístico nacional.

Em 1955, uma equipe composta por Lebret e Baltar entre outros jovens técnicos à cargo da Comissão de Desenvolvimento de Pernambuco vai elaborar o "Estudo sobre desenvolvimento e implantação de industrias, interessando a Pernambuco a ao Nordeste", um documento igualmente importante para a compreensão da escala regional que caracterizava a região naquele momento. ${ }^{208} \mathrm{~A}$ caracterização do Recife como metrópole regional conecta diretamente o Estudo com o Plano, mas várias de suas proposições podem ser também aproximadas com o espírito criador da Sudene, encarando o desenvolvimento do Nordeste como um problema de solução nacional. (LEBRET, 1955, P.21)

\footnotetext{
${ }^{208}$ Louis-Joseph LEBRET. "Estudo sobre desenvolvimento e implantação de indústrias, interessando a Pernambuco a ao Nordeste". Comissão de Desenvolvimento Econômico de Pernambuco. Recife, 1955.
}

A influência de Baltar de 1951 extrapolava em muito o âmbito acadêmico, já que era membro da Comissão do Plano da Cidade do Recife e político atuante no Partido Socialista Brasileiro, tendo sido eleito vereador e senador (1959/63) por ele. Baltar formara-se engenheiro em 1938 pela Universidade do Recife na mesma turma de Pelópidas Silveira e Ayrton da Costa Carvalho, considerados por Geraldo Gomes da Silva como os "três mosqueteiros da arquitetura e do urbanismo modernos em Pernambuco" ${ }^{209}$, pela defesa que faziam já nos anos 1940 dos ideais modernos aplicados ao bem público. O estágio que fizeram na Diretoria de Arquitetura e Urbanismo (DAU) sob a coordenação de Luiz Nunes conectou os três engenheiros à geração pioneira que projetou e executou as obras públicas pernambucanas que adquiriram reconhecimento internacional através da exposição e catálogo Brazil Builds, como o Reservatório da Água do Alto da Sé de Olinda e o Pavilhão de Óbitos, atual sede do IAB local. ${ }^{210}$

A primeira parte da tese-plano de Baltar dedica-se a uma revisão das principais idéias do debate internacional acerca do urbanismo e revela a atualidade da discussão no Recife naquele momento - 1951, coincidentemente o mesmo ano em que Borsoi se radicou na cidade. Entre diversos autores citados criticamente por Baltar, estão "o genial" Le Corbusier, "José Luis" Sert, Ebezener Howard, Camilo Sitte, Lewis

\footnotetext{
${ }^{209}$ Geraldo GOMES. "Antônio Bezerra Baltar 1915-2003". Porta Retratos DOCOMOMO.

Disponível em http://www.docomomo.org.br/portaretratos\%20Baltar.htm.

${ }^{210}$ Segundo entrevista de Geraldo Gomes, o Pavilhão de Verificação de Óbitos foi construído por Ayrton Carvalho a partir dos restos das obras do Palácio da Justiça.
} 
Mumford, Siegfried Giedion e Patrick Geddes, referências ao urbanismo inglês das New Towns e as corporações públicas como a Tenesse Valley Authority.

A seguir, o autor passa para uma análise histórica completa, embora sucinta, da evolução urbana do Recife até aqueles dias, bem como dos planos que haviam sido elaborados para a cidade ao longo do século XX. Previa-se um "surto de crescimento" para o qual se devia prevenir antes de remediar, através da elaboração de um plano urbanístico que contaria com a participação de diversos profissionais além do arquiteto, reconhecendo de antemão seu caráter limitado por partir de um único saber.

"Encarando o futuro de uma cidade real e concreta, o Recife, tal como ela existe hoje com os seus encantos e as suas tremendas deficiências - procurei adotar, na análise e na concepção do plano de remodelação e expansão desse complexo urbano, o ponto de vista e a maneira de ver mais ampla do urbanismo moderno como o estão praticando à larga os ingleses a partir sobretudo da legislação britânica de 1947 sobre planejamento rural e urbano." (BALTAR, 1951, p.11)

Se nos planos anteriores o foco eram remodelações e obras na área central e sua conexão com os distantes subúrbios em desenvolvimento oriundos dos engenhos entre os quais as habitações pobres proliferavam, no plano de Baltar o desenho urbano teve importância secundária:

"O papel da técnica urbanística consiste precisamente em determinar o que há de aproveitável nas soluções espontâneas, incorporando-o aos conhecimentos adquiridos racional ou experimentalmente, num conjunto de disposições normativas e sugestões para um programa de obras e serviços que são os dois aspectos da atividade planejadora" (BALTAR, 1951, p. 37)
Estava colocado um novo papel no plano do saber técnico acerca dos problemas da cidade, o campo urbanístico, que entre os engenheiros e arquitetos, já incluía também desde cedo os sociólogos e juristas.

"Cremos que este é o caminho acertado: esses são os verdadeiros problemas do planejamento urbano e essa é a técnica de resolvê-los. Primeiro, o conhecimento objetivo da realidade urbana, através de inquéritos, pesquisas e observações e, em seguida, o aparelhamento do poder público em normas jurídicas e em equipamento técnico para atacar de frente com o auxílio da iniciativa privada a solução dessas questões cuja importância principal está em que condicionam irremediavelmente a vida dos grupos humanos naturais e de cada uma das pessoas que o compõe". (Baltar, 1951, p. 39)

Tanto os conceitos apresentados por Baltar quanto os problemas para o desenvolvimento humanista da cidade destacam-se pela sua atualidade. Previsões de soluções e entraves, que foram recorrentes ao longo da segunda metade do século XX estão aqui precisamente formulados:

"Evidentemente um dos obstáculos mais fortes à solução do problema é o controle da propriedade imobiliária urbana ou periférica das cidades. O arquiteto americano Louis Justement, propondo, a substituição por cidades novas das cidades velhas, aborda essa questão em termos que ele denomina de espaço de tempo moderno. São suas as palavras seguintes: 'O controle e a propriedade dos terrenos urbanos são o nó górdio do plano de cidade e o modo como resolvermos esse problema determinará o sucesso ou o fracasso de nossos esforços. As dificuldades de se obter uma solução efetiva da reconstrução urbana dentro da estrutura da propriedade privada da terra são tão grandes que o urbanista é capaz de desistir em desespero; na melhor hipótese tende a tolerar uma série de concessões inadequadas."(BALTAR, 1951, p. 34)

As propostas feitas estavam alinhadas com o que se praticaria em Pernambuco durante a gestão municipal do também Engenheiro 
Pelópidas Silveira, que seriam reformuladas no bojo da discussão do SHRu e deram origem ao projeto de lei da SUPURB redigido por Artur Lima Cavalcanti.

"A tese é a de que a municipalidade deve se apropriar de todos os terrenos cuja necessidade se verifique para o desenvolvimento de serviços públicos e utilidades indispensáveis ao bem comum - que incluem não somente vias públicas de trânsito, mas também parques, escolas públicas, centros culturais e até comerciais onde eles se tornam necessários pelo imperativo do preenchimento de determinadas funções da vida urbana em torno da residência dos habitantes da cidade." (BALTAR, 1951, p. 35)

A questão da habitação na metrópole recifense em formação não poderia deixar de ocupar lugar central na elaborada análise de Baltar, que constantemente se referiu às estratégias de equilíbrio da população entre o núcleo central e a "hinterlândia" tal como estava sendo posta em prática na Inglaterra naqueles anos como uma possível solução, sutilmente sugerida.

"Não há grande cidade no mundo sem o contraste do conforto com a miséria - slum, taudis, favela, mucambo são termos equivalentes no vocabulário urbanístico internacional." (op.cit., p. 29)

Do ponto de vista urbano, Baltar entende os territórios dos mocambos sob o prisma da dinâmica econômica e como fenômeno espacial e urbano próprio das metrópoles.

"Essa aglomeração excessiva não é aliás ocasional mas deriva da ganância especulativa dos proprietários de terrenos onde se localizam mucambos, os quais procuram tirar deles o maior rendimento possível por unidade de superfície. Não é estranho também ao fato, na sua fase primitiva de ocupação do mangue pelos mucambos o regime da enfiteuse dos chamados terrenos de marinha." (BALTAR, 1951, P.49)

Destaca-se a precisão e ponderação com que Baltar inscreve o mocambo na ecologia particular do Recife do ponto de vista das tradições e significados para a cultura., questão que naquele momento ainda suscitava paixões e opiniões contraditórias por parte dos intelectuais pernambucanos.

"O mocambo é, na realidade, uma síntese concretizada em forma pseudo-arquitetônica de todo um conjunto de desajustamentos de ordem econômica, social e mesmo psíquica. Tem-se apontado as virtudes de alguns de seus aspectos, tais como o de adaptação espontânea a determinadas condições econômicas e o de adequação as características do clima tropical. Mas, o grave do mocambo é o seu habitat, destituído de possibilidades para o estabelecimento de um padrão de vida civilizada, e aberto, pela precariedade dos materiais de que é construído, pela ausência de detalhes construtivos e higiênicos essenciais, a todos os perigos de infestação dos habitantes por moléstias próprias da região.

Como fato antropológico e de geografia humana o mocambo é uma revivescência da escravidão e da cultura e civilização africanas, transplantadas para o Brasil, enquanto fato econômico é o sinal sensível de uma carência de poder aquisitivo decorrente de desajustamento técnico profissional e desequilíbrio das condições do meio. Como fenômeno de psico-patologia social tem ainda um significado de conformismo geral com a miséria, sentimento coletivo dos mais funestos do ponto de vista do progresso da região. Atacar esse problema com possibilidades de êxito importaria em abordar questões extremamente profundas do complexo social vigente, fugindo a interferência dos meios normais de ação da iniciativa privada e mesmo do poder público, tal como atualmente se constitui." (op. cit. p. 59)

O prisma da evolução populacional do Recife é interessante tanto para observar o crescimento da cidade quanto sua relação com fenômenos da vida e da história nacional. O geógrafo pernambucano Mario Lacerda de Melo caracteriza o século XX como de "crescimento acelerado ou mesmo explosivo" da capital do estado, sucedendo fases de crescimento lento, acompanhado da consolidação do papel do porto e de expansão dos limites interiores com a colonização da 
"hinterlândia" pernambucana e fases de crescimento moderado, ciclo de certa forma análogo ao da industrialização da produção do açúcar, marco do início do vetor de migrações para o Recife.

"Entre 1940 e 1960 os recenseamentos registram haver a população do município do Recife passado de 348 mil para 797 mil, o que significa um incremento de 449 mil ou de 129\%. (...) Os muito elevados índices que se assinalaram a partir dos anos quarenta não encontram precedentes na evolução populacional da cidade. (...) Nos anos sessenta, mercê da natureza já caracteristicamente metropolitana do crescimento recifense, o aumento ocorreu menos no município núcleo e mais em vários dos municípios periféricos." (MELO, 1978, p.120-121)

Ao mesmo tempo em que crescia a região metropolitana do Recife, especialmente em suas margens periféricas, recebia a população vinda diretamente do campo. As estatísticas apresentadas por Melo que mostram o aumento da população urbana em correlação com a diminuição da rural quantifica uma população que se urbanizava, tanto do ponto de vista da antropologia quanto da geografia, do indivíduo e do fenômeno coletivo.

A geografia humana, disciplina que naquele momento se desenvolvia nas pesquisas do Instituto Joaquim Nabuco de Pesquisas Sociais (IJNPS, posteriormente convertido em Fundação, a FUNDAJ ${ }^{211}$ ),

${ }^{211}$ Ver, entre vários estudos editados pela FUNDAJ sobre o Recife e seus problemas, o trabalho de Daniel Uchôa Cavalcanti Bezerra Alagados, Mocambos e mocambeiros (1965), que nos mostra a inserção do mocambo numa economia local e num modo de produção da cidade, além de suas dinâmicas construtivas, espaciais e sociológicas específicas. O livro é o resultado de dois grupos de trabalho sobre o tema do mocambo na urbanização da cidade que mobilizou vários técnicos e políticos, incluindo Gildo Guerra, que então representava o IAPI e a Prefeitura de Olinda nas questões do Sítio de Peixinhos, objeto de outro trabalho patrocinado pelo IJNPS elaborado por Antônio Carolino Gonçalves. nos estudos de Mario Lacerda de Mello condensados em Metropolização e Subdesenvolvimento e do médico Josué de Castro, é uma importante base para a leitura de Baltar do fenômeno urbano, enquanto a metodologia para a pesquisa e propostas enunciadas no Plano guardam estreitas relações com a Economia e o Humanismo, bem como com a referência de um determinado urbanismo orgânico:

"O ser urbano encarado como um pseudo organismo - a primeira coisa a analisar é evidentemente o conjunto de suas funções - a fisiologia urbana, ocupando-se do seu desenvolvimento normal e a patologia urbana das suas perturbações. Todo um vasto caminho abre-se ao estudioso para uma análise objetiva dessas funções que sumarizadas para permitir uma primeira visão do problema se desdobram nas três categorias clássicas habitação - trabalho - recreação." (Baltar, 1951, p. 28)

O desajuste dessa população muitas vezes explica-se pela falta de lugar na estrutura produtiva canavieira, que viria a ser transformada com o advento do Estatuto do Trabalhador Rural, de 1963 contraposto ao expansionismo do setor açucareiro, que acabou por proletarizar os antigos camponeses que agora viviam nas pequenas cidades do interior. Eles também estavam sujeitos a ondas de migrações sazonais, episódicas ou constantes, podendo fazer parte da população da Região Metropolitana e participando ativamente da crise habitacional (MELO, 1978). Analisando os dados da população dos assentamentos precários recifenses, visualiza-se o processo de migrações, frequentemente sucessivas, através de regiões e estados do Nordeste. Melo já vinha estudando o fenômeno das migrações desde fins dos anos 1950, tendo já em 1961 publicado Migrações para o Recife pelo IJNPS, atual Fundação Joaquim Nabuco. 
O que vimos nesses anos foi caracterizado como explosão demográfica, expressão do subdesenvolvimento decorrente do choque entre o modo de produção arcaico e o surto de crescimento econômico, ainda que menos intenso que o sudestino, concentrado numa cidade antiga, capital comercial e social de uma região marcada pela desigualdade regional mas ancestralmente inserida na rede de lugares que formam o território nacional num quadro de desequilíbrio regional agudo que motivaria a política de investimento governamental através da SUDENE nos anos 1960.

Mario Lacerda de Melo também vê nos números que expressam a industrialização na metrópole recifense uma concentração das novas unidades produtivas na periferia, particularmente em Jaboatão, mas também em Cabo, Igarassu e Paulista, conformando uma aglomeração industrial dentro da região metropolitana, em processo análogo ao ABCD paulista. O quadro descrito por ele é de "metropolização por inchação" ${ }^{212}$ (MELO, 1978, p.203).

${ }^{212}$ Dentro dele, a questão da habitação permanece sendo, nos anos 1970, quando escreve, o primeiro item da problemática fundamental da Região Metropolitana Recifense, um dos espaços mais favorecidos pela política de incentivos governamentais e consequentemente de concentração industrial. Completam o quadro de precariedades a saúde, a educação e o subemprego, disfarçado de atividade de serviços ou terciárias nas estatísticas. A reestruturação produtiva que atingiu setores importantes da indústria pernambucana como o têxtil também acabou por frustrar a esperança de aumentos de postos de trabalho, não absorvendo esses contingentes populacionais que afluíam às cidades. "Não constituirá certamente exagero de linguagem ou força de expressão dizer-se que, no Recife Metropolitano, se manifestam e se refletem de forma concentrada, os problemas cruciais do subdesenvolvimento nordestino e que o equacionamento e a solução dessa problemática, do mesmo modo que a do Nordeste, continuam a
A periferização se impôs como inexorável ao processo de metropolização; a partir da dinâmica identificada, a proposta de Baltar consistia na criação de cidades-satélites em torno do Recife, que abrigassem trabalho, residência e lazer de parte dessa população em unidades de vizinhança capazes de minimizar os deslocamentos cotidianos e criar um sentido de comunidade.

Tal proposição será reiterada no estudo elaborado pela SAGMACS de 1955, no qual as cidades-satélites aparecem como uma transição entre o campo e o núcleo da metrópole dentro de uma urbanização baseada no desenvolvimento humano e comunitário, numa gradação hierárquica entre as cidades, ligando o sertão ao Recife através de uma trama de centros secundários a equipar (LEBRET, 1955).

"As cidades satélite do núcleo central, compor-se-á então de um certo número de unidades de vizinhança, número esse compatível com o equipamento a ela destinado, istó é com a capacidade dos serviços de água, de esgotos, de luz artificial, telefones, transportes e abastecimento geral planejados para essas unidades primárias da cidade regional. (...) As cidades satélites constituem desse modo como que federações de unidades de vizinhança, agrupadas organicamente em torno de um núcleo-sede de atividades de interesse comum a todas as unidades. A sua população global deve ser planejada para um limite de saturação de uma ordem de grandeza compreendida entre 30 e 60 mil habitantes afim de lhe permitir uma autosuficiência no domínio cultural e os benefícios de uma atividade econômica em escala ampliada." (BALTAR, 1951, P.101)

A inspiração na política das New Towns ${ }^{213}$ inglesas e alguns das suas propostas estavam presentes nas propostas de Baltar, assim como a idéia

representar um desafio ainda não enfrentado de modo satisfatoriamente eficaz." (MELO, 1978, P 225-226)

${ }^{213}$ Ver nota 4 no item 1 do capítulo 1 
de unidade de vizinhança, conceito que vai ser retomado por Borsoi no projeto urbano do Cajueiro Seco, como veremos no capítulo a seguir.

"As unidades de vizinhança - 'conjuntos (de 400 famílias) essencialmente residenciais dotados de um tipo próprio de autosuficiência' (BALTAR, 1951, P.98)- serão compostas em torno de um 'centro local' onde se reunem o comércio retalhista, de gêneros e de objetos de uso familiar quotidiano, as igrejas das várias confissões religiosas existentes e a escola primária" (BALTAR, 1951, P.99)

A autonomia destes novos núcleos é dada pela sua independência com relação ao núcleo central, constituindo um modelo de "descentralização orgânica" da expansão urbana, baseada na valorização da comunidade como "elemento fundamental da organização do espaço e das instituições urbanas". (BALTAR, 1951, P 95).

A verticalização do centro, desde que com baixas taxas de ocupação, seria a contrapartida adequada da periferização de baixa densidade equilibrada num modelo de "crescimento esférico" característico das cidades americanas observado por Joaquim Cardozo em Nova lorque. A crítica a elas também foi colocada:

"A residência no subúrbio foi a solução infeliz oferecida ao habitante da cidade grande - que perdendo as vantagens culturais da permanência na metrópole, não chega a readquirir a posse da natureza. Nem campo nem cidade, com as desvantagens desta e as daquele" (BALTAR, 1951, p. 32)

Em função da exígua superfície que o Recife ocupava face às previsões de crescimento da população, recomendava-se a integração dos municípios de Olinda, Paulista, São Lourenço e Jaboatão no planejamento urbano, configurando o "Grande Recife", seja por simples anexação ou estabelecimento de uma administração supra- municipal, metropolitana portanto, em consonância com a sugestão nesse sentido já feita por Mario Melo e refletiria o processo de conurbação que já estava em curso entre Olinda, Recife e Jaboatão.

A partir destas idéias e linhas de pensamento que estavam colocadas na discussão sobre os rumos da cidade do Recife nos anos 1950 e 1960 é que pretendemos compreender o lugar do Cajueiro Seco no crescimento e consolidação da metrópole regional nordestina.

Como uma comunidade modelo, Cajueiro Seco seria a experiência pioneira de um novo paradigma de urbanização, um novo modo de produção do espaço urbano e urbanização de uma comunidade marginal planejado a partir das dinâmicas sociais e humanas que estavam sendo analisadas e compreendidas ao longo daqueles anos. Pela descrição funcional do que seriam as cidades satélites propostas por Baltar em seu plano de descentralização orgânica do Recife e consolidação da região metropolitana, podemos supor que o conjunto do Cajueiro Seco equivaleria a duas de suas unidades de vizinhança, divisão que se reflete no projeto, dentro de uma nova cidade satélite entre Jaboatão e o Recife, entre a orla e os eixos rodoferroviários, ao sul do aeroporto, no distrito de Prazeres, que naquele momento começava a ser ocupado.

Tal suposição é corroborada pelo "Organograma do Recife cidade regional", no qual Baltar expôs de maneira esquemática a localização das três cidades satélites propostas. Uma delas localiza-se a sul do aeroporto e tinha seu núcleo urbano ligado ao centro do Recife através de uma via expressa rodo-ferroviária; transpondo estas 
coordenadas para a realidade, podemos supor que a localização do distrito de Prazeres e do Cajueiro Seco de alguma forma relaciona-se com o sítio da cidade satélite proposta por Baltar.

Tanto podemos entender esta coincidência tanto pela chave da disciplina urbanística moderna que considerava as dinâmicas que já estavam em curso em suas propostas, quanto pelo prisma da enorme influência política e profissional de Baltar e do pensamento urbanístico condensado no Plano de 1951 sobre as futuras gerações de técnicos e planejadores locais.

A chave da profunda ligação entre a política de habitação para os pobres e o urbanismo moderno na cidade foi apresentada por Pontual, comentando a atuação do primeiro Governo Municipal de Pelópidas Silveira (1956-1959) no campo dos mocambos.

"Além do decreto que permitia a reforma de mocambos sem a prévia autorização dos proprietários dos terrenos, foi empreendido o loteamento popular. A conjunção desse decreto com o loteamento constitui-se numa tática governamental inovadora no trato da moradia para os pobres no Recife. Na Mensagem à Câmara Municipal de 1956, Pelópidas Silveira, ratificando o seu programa de governo, anunciou (...) a aquisição de grandes áreas de terreno em subúrbios para loteamento e venda a longo prazo aos moradores de mocambos. O procedimento consistiu da compra de terreno pelo governo municipal, quando seriam feitas a divisão em lotes e a dotação dos serviços públicos essenciais. Após a execução dessas obras, os lotes seriam colocados à venda, sendo facultado ao comprador o prazo de 15 anos para amortizar a dívida e ficando a construção da habitação sob sua responsabilidade."(PONTUAL, 2001, p.196)

De acordo com a autora, trata-se da origem da transformação do foco das iniciativas de provisão de moradia popular; para além da unidade habitacional, o importante era o seu lugar no território. Mais do que isso, para PONTUAL:

"esse procedimento no trato da habitação para os pobres diferiu daqueles do SSCM, por focalizar como ponto crucial dessa problemática o acesso à terra, deixando a construção da casa para o acesso à terra urbana e ampliou a utilização do instrumento de desapropriação, até então empregado preponderantemente na abertura e pavimentação de avenidas, para o assentamento da população residente em mocambos, podendo ser considerada como precursora da aplicação da noção de função social da propriedade."(op. cit.)

Aqui estão as origens do pensamento e das práticas que vão transformar a atuação do SSCM e do próprio Estado quando a Frente do Recife chegar ao poder elegendo Miguel Arraes governador em 1962 e Pelópidas novamente prefeito em 1963. A participação da população organizada era estimulada pela gestão de Pelópidas através das Associações de Bairros, que por seu caráter territorial e apartidário abriam espaços de interação direta entre o executivo municipal e as carências do povo, driblando o clientelismo já instituído por partidos e vereadores. Tais práticas foram combatidas por seus opositores, que as viam e as denunciavam como infiltrações comunistas no estado. (PONTUAL,2001, p.135) 


\subsection{O plano habitacional pernambucano de 1962}

O documento que detalha o Programa habitacional do Estado de Pernambuco elaborado em 1962, já no ocaso do governo do usineiro Cid Sampaio, merece ser analisado detidamente por condensar tanto uma imagem clara da dimensão e formas da problemática habitacional local naqueles dias, quanto pela apresentação dos projetos que estavam sendo levados a cabo e que constituíam o modelo e as propostas com as quais se propunha a enfrentá-la. O Plano deveria servir como termo de referência do empréstimo pleiteado diretamente ao governo americano e aos órgãos de financiamento internacional, o que explica a inclusão de um sumário em inglês.

O documento foi elaborado pelos técnicos do SSCM como o engenheiro Otaviano de Oliveira Dias, também presidente do CREA, o arquiteto Mário Jorge Correia de Oliveira, representando também o IAB local e o economista Marco Aurélio de Alcântara, que também ocupava cargo na Fundação de Promoção Social, além do economista Antônio Germano Rodrigues, da Comissão de Desenvolvimento Econômico de Pernambuco (CODEPE), que havia se especializado no CINVA, em Bogotá e do sociólogo Antônio Carolino Gonçalves, da FUNDAJ, autor de Algumas Características Demográficas e de Habitação do Sítio de Peixinhos. Tal composição revela a participação dos engenheiros e arquitetos na formulação das políticas públicas, bem como a proximidade dos intelectuais da Fundação Joaquim Nabuco junto aos centros de poder.
Propunha-se ali a construção de 9.500 casas "de baixo custo e interesse social" em Alto do Jordão, no conjunto que posteriormente seria rebatizado de "Vila Kennedy" e "uma experiência pioneira na limpeza de mocambos das áreas de alagados", além de uma pesquisa sobre 4 áreas de mocambos no Recife: Coque, Alto do Mandu, Mustardinha e Totó.

O volume foi introduzido por um "Estudo sócio-econômico do projeto", no qual se afirmaram diretamente as intenções colocadas:

"A escolha do Recife justifica-se porque é o centro político e econômico de toda a região Nordeste do Brasil. O NE é uma das áreas de maior tensão social da América Latina. Sua população é quatro vezes maior que a de Cuba e o seu nível de renda per capita situa-se em torno de U\$ 100 anuais. As condições de vida são, em decorrência, precárias: subhumanas. A expectativa de vida da população é baixa; precárias são, também, as condições de vestuário, alimentação e habitação. A fome é crônica e leva as populações dos centros urbanos dos quais o Recife é a expressão máxima- tanto quanto as populações rurais, a níveis sociais e econômicos baixíssimos, somente comparáveis aos das populações mais pobres da Índia, Egito e Norte da África." 214

As referências, fontes e explicações dos conceitos indicavam o tom do documento, apresentando a questão habitacional didática e estatisticamente. A questão da migração do campo foi apresentada como o principal fator de diminuição da área ocupada por habitante, tomando por base o trabalho de Olen Leonard para as Nações Unidas, de 1951. Essa nova população ocupava a "área suburbana, em habitações anti-higiênicas, chamadas mocambos".

${ }^{214}$ Governo do Estado de Pernambuco, 1962. 
Passava-se então à "Política regional de habitação" proposta, resumidas em "linhas de orientação", das quais destacam-se:

"1- As condições de habitação predominantes no Nordeste do Pais são causas de desajustamentos sociais com repercussões intensas na vida familiar, que conduzem à completa desorganização social;

2- É problema das capitais regionais e particularmente do Recife, para onde convergem agricultores desajustados na zona rural, em busca de melhores condições de vida ou atraídos pela assistência que o Poder público ali concentra, com maiores recursos;

4- O excedente populacional acima da capacidade de absorção da economia local e da oferta de habitação, passa a constituir um contingente de pessoas desempregadas ou subempregadas, de nível econômico baixo e com problemas sociais agudos;

6-O governo do Estado, no seu programa, tem procurado situar o problema dentro da constatação das características de subdesenvolvimento econômico regional. Acredita que, através da industrialização e, consequentemente, do aumento da oferta de emprego e do nível de renda das populações, será possível melhorar as condições de habitação predominantes de Recife;

7-Simultaneamente, julga indispensável que o Poder público assista os grupos sociais em mobilidade vertical para o aproveitamento das suas poupanças, garantindo-Ihes a aquisição da casa própria." 215

O documento faz ainda sua profissão de fé, declarando que "O melhoramento das condições de habitação, para garantia da estabilidade da família, é um objetivo humanista e cristão que deve ser atingido", deixando mais claras as vinculações ideológicas e religiosas de registro cooperativista que estarão na base de suas proposições de auto ajuda.

${ }^{215}$ Governo do Estado de Pernambuco, 1962.
O detalhamento do plano para o Alto Jordão explicava as três fases do projeto, a inicial, já concluída integralmente pelo SSCM e as seguintes, para as quais se pleiteava o empréstimo do BID e se delineava o aspecto gerencial da implantação de 3000 casas ali, complementadas por instalações comunitárias como centro comercial, centro educativo operário (CEO), posto de saúde, grupo escolar e biblioteca. No orçamento do empréstimo, previa-se verba para "Assistência técnica", que seria usada em "a) constituição de um Centro de Documentação e Informação técnica, com sede no Recife e em b) pesquisas básicas sobre habitação e formação de pessoal, com adjudicação de bolsas de viagem e estudo sobre materiais de construção, desenho e planejamento" ${ }^{216}$, o que revelou a vinculação do grupo às instituições da pesquisa, bem como na crença da solução da questão como de ordem precisamente técnica dentro de interpretações sociológicas da questão.

O projeto do Alto Jordão havia sido iniciado em 1960, a partir de recursos do governo federal, cujo "critério predominante (...) foi a instalação de uma comunidade-piloto e a criação de instalações comunitárias, de modo a promover o seu desenvolvimento social através da mobilização de recursos ${ }^{\prime 217}$, tarefa esta última que cabia à Fundação de Promoção Social, que havia sido recentemente

\footnotetext{
${ }^{216}$ Governo do Estado de Pernambuco, 1962.

${ }^{217}$ Op. cit.
} 
constituída a partir de uma fração do SSCM "encarregada do serviço social de habitação".

A unidade habitacional proposta ali seria inicialmente de $49 \mathrm{~m} 2$ e três quartos, ampliados para $60 \mathrm{~m} 2$, contando também com o "esforço próprio dos moradores ao melhoramento das casas." As casas seriam adjudicadas segundo critérios como a capacidade de poupança das famílias, que mantinham os filhos na escola, prioritariamente às famílias "que cuidem bem das casas de aluguel - onde viviam antes da transferência - em relação à limpeza e manutenção". Estava claro desde o início do documento que o conjunto não era para habitantes de mocambos, era para uma "classe média" composta de "pequenos comerciantes, empregados na indústria e em serviços, militares e funcionários públicos". É curioso perceber a inversão do limite para o benefício, o "teto mínimo financeiro" para o conjunto do Alto Jordão era fixado em 4 salários mínimos.

Os critérios para plano de locações levavam em conta número de filhos e situações habitacionais e econômicas menos favoráveis, mas o programa de locações havia sido abolido em 1960 e as casas estavam sendo vendidas aos moradores segundo outro sistema de prioridades sociais.

Cabia à Fundação de Promoção Social dar "assistência permanente ao beneficiário, ensinando-o a morar com melhor utilização espacial e higiênica de sua casa e integrando-o no nível de conforto que a residência the pode proporcionar." Distribuiriam-se prêmios em dinheiro para aqueles que acabassem suas casas mais rápido.

O documento prosseguia com um resumo dos "Antecedentes históricos da instituição SSCM", apresentando seu amparo legal, finalidades e estrutura administrativa, destacando seu setor educativo, organizado em torno dos CEOs e atrelado à Fundação de Promoção Social (FPS), médico-assistencial e de habitação popular propriamente dito, "em níveis insuficientes à demanda", tendo construído de 1938 a 1961, 5.650 casas populares, organizadas nas vilas populares, que até o Plano de Vendas de 1960 eram alugadas.

Os orçamentos das casas e conjuntos apareciam detalhados em planilhas, assim como os montantes dos empréstimos solicitados ao BID (43\% do total de 890 milhões de cruzeiros) e ao "Acordo do Trigo" $^{\prime 218}(22,4 \%)$, além do investimento do Governo de Pernambuco $(33,9 \%)$ e suas destinações: $66,1 \%$ dos fundos iriam diretamente para as construções, $12,2 \%$ para os terrenos e urbanizações e havia uma verba de 6,6\% do total sob a rúbrica de Ajuda Mútua.

O segundo projeto proposto pelo documento tratava da habitação rural, como antídoto para o "gigantismo demográfico do Recife", propondo a construção de 4.000 casas nas cidades de Cabo, Paulista, Moreno, Garanhuns, Caruaru, São Lourenço da Mata e Pesqueira, baseando o programa no "Relatório e recomendações do

${ }^{218}$ Na verdade, se trata do Acordo do Nordeste, ou seja, recurso emprestado diretamente do governo norteamericano através da Aliança para o Progresso. 
expert das Nações Unidas" Olen Leonard sobre habitação no leste de Pernambuco (fundamentalmente no Recife), além do trabalho de Antonio Carolino Gonçalves, co-autor do documento, sobre as migrações para o Recife, onde atestava que $80 \%$ dos habitantes de mocambos vinham da Zona da Mata. Ou seja, o plano propunha ampliação da oferta habitacional nestas cidades não porque a demanda habitacional se concentrasse ali, mas como estratégia para desafogar o Recife desenvolvendo cidades que já tinham alguma importância, a alguma distância da capital, "fixando" as populações em seus locais de origem, de acordo com as indicações dos "Estudos para a localização de algumas indústrias interessando a Pernambuco e ao Nordeste" desenvolvidos pelo Padre Lebret para a CODEPE em 1955. Eram "cidades-barreiras para a contenção do fluxo rural - urbano" para "evitar a contínua inchação demográfica do Recife". ${ }^{219}$

Dialogando de perto com a questão rural, o projeto se pretende "desenvolver a consciência democrática dos problemas da comunidade; promover, em escala mais extensiva, a interação social de diferentes grupos e de pessoas de diferentes statuses (sic) na sociedade rural; estimular a compreensão para a liderança democrática e a formulação de associações de vizinhos que capitalizem o esforço da ajuda mútua". ${ }^{220}$

Tal agenda comunitarista e ruralista reminiscente ao conceito norteamericano de democracia pode soar avançada para o contexto do programa, mas temos de lembrar que justamente nesse momento os movimentos sociais no campo se acirravam levando diversos setores da política regional a recomendar o cooperativismo como alternativa à

\footnotetext{
219 Governo do Estado de Pernambuco, 1962.

${ }^{220}$ Governo do Estado de Pernambuco, 1962.
}

uma reforma mais radical. O programa, aliás, reconhecia a disputa em torno da terra no campo, fazendo referência logo no seu início à mobilização das Ligas Camponesas e à sindicalização rural.

A ajuda mútua dirigida ("aided self help", como o documento faz questão de traduzir) em regime de 8 jornadas por semana de trabalho em suas próprias casas era estimulada através do sistema de prêmios, acompanhadas por um time de assistentes sociais; o custo desse trabalho era calculado e incorporado à "contribuição brasileira"(sic). Nessa conta, o BID entraria com 462 milhões de Cr\$ de um total 690, e a participação brasileira, somada à poupança dos mutuários e à Ajuda Mútua representaria $69+54$ milhões, complementados pelos custos do terreno e urbanização que completavam os 228 milhões de investimento nacional no projeto II.

O Projeto III propunha-se a enfrentar a questão do mocambo construindo "4.000 casas inacabadas" para a "limpeza de mucambos" da zona do Coque, "onde vive uma população nitidamente marginal, em casas de madeira construídas sobre alagados".

Acreditava-se que "haverá a fixação do homem em áreas secas melhores, através de processos democráticos de mudança social, pois os habitantes integrarão uma comunidade socialmente organizada" (Gov.Est. Pernambuco, 1962).

A auto ajuda é proposta como meio atual e tradicional de construir a unidade habitacional:

"Construirão se as casas dentro de um sistema de ajuda mútua, estimulando-se também, e simultaneamente, o esforço próprio de cada morador. O sistema de ajuda mútua não é, inteiramente desconhecido da 
população do Coque, oriundo das zonas rurais, onde o costume é bastante difundido sob o nome de mutirão." 221

O projeto se propunha a intervir nas áreas de palafitas, "variante mais barata do mocambo, provocada por motivos econômicos" sobre as faixas de mangues, que Ihes forneceriam as madeiras e estacas da construção sobre a água. Constatavam-se as cenas de dejetos jogados à maré, rendas familiares muito abaixo dos mínimos, baseadas em "economia de biscates, alimentando-se frequentemente de crustáceos que o mangue fornece". Precisamente eram as mesmas cenas e condições que Josué de Castro já vinha estudando desde os anos 30 naquele mesmo local, base para seu trabalho científico acerca da fome e da sua ficção sociológica Homens e Caranguejos, de 1967.

O projeto propunha a implantação de 4 comunidades de 1.000 habitantes em diferentes áreas suburbanas do Recife, em terrenos desapropriados pelo Governo do Estado junto a Parques industriais e junto aos "serviços de assistência social e religiosa, já em funcionamento". A assistência técnica seria provida por um sociólogo e pelas assistentes sociais, ligados à FPS. Não havia lugar previsto para nenhum arquiteto ou engenheiro, além das contribuições voluntárias de estudantes da Universidade do Recife. ${ }^{222}$

$\mathrm{Na}$ descrição da unidade habitacional básica, três pontos interessam particularmente por apresentar características que podem ser ligadas ao que se concebia e recomendava naqueles anos como

\footnotetext{
${ }^{221}$ Governo do Estado de Pernambuco, 1962.

${ }^{222}$ Governo do Estado de Pernambuco, 1962.
}

processo de ajuda mútua, enunciando práticas que seriam mais adiante aproveitadas na experiência do Cajueiro Seco:

"A Agência Estadual de habitação construirá uma plataforma de concreto, proverá as comodidades sanitárias, WC e uma parede inteira divisória e os pontos de luz, as paredes de arcabouço e o teto. O mutuário comprará os materiais adequados para o acabamento e contribuirá com a sua mão de obra na conclusão da obra. Prevê-se a formação de uma cooperativa a ser dirigida pelos próprios mutuários, para revenda de materiais a preço de custo." 223

Completa o documento o artigo "Amostragem sobre habitação na Zona Suburbana", que deveria fornecer dados sobre o tal programa de "limpeza dos mocambos" ao Catholic Relief Service norteamericano, detalhado no projeto III, a partir do sistema no qual se forneceriam as plataformas de concreto de $7 \times 7 \mathrm{~m}$. implantadas em lotes de 10x20m., dotadas dos serviços básicos, no intuito de criar um "sistema de comunidades modelo em torno do Recife".

As comunidades estudadas eram a do Coque, formada principalmente por palafitas sobre o mangue, o Alto do Mandu, na qual viviam os operários de uma fábrica de tecidos em mocambos implantados nos morros, a Mustardinha, em que se propunha a substituição da população dos mocambos por uma classe média e a de Totó, à margem da estrada de ferro e bem servida pelos equipamentos da Fundação de Promoção Social.

A pesquisa apresenta em tabelas e quadros os dados que permitem ao leitor ter uma visão panorâmica do quadro de precariedade física das habitações, da intensa ocupação por famílias

${ }^{223}$ Governo do Estado de Pernambuco, 1962. 
numerosas, baixos padrões de renda, educação e saúde gerais, com algumas particularidades em cada uma das áreas.

Levando-se em conta as finalidades e momento no qual o programa de habitação foi produzido, ao final de uma gestão, compelido por uma questão de financiamento e não como meta integrante de um plano de governo, ficam evidentes as vinculações deste com a agenda civilizatória da Aliança para o Progresso, longe da mobilização popular que estaria na base das propostas do governo Arraes pouco depois.

No entanto, não podemos deixar de reconhecer que algumas das soluções sugeridas ali seriam implementadas pelo governo popular e apresentadas como novidade, dentro de um panorama de mudança alardeado. A partir das coordenadas deste programa habitacional, podemos situar com mais propriedade a matriz técnica e as novidades efetivamente introduzidas no Cajueiro Seco, que tanto interesse despertariam nas gerações seguintes de profissionais e políticos, bem como na historiografia da arquitetura. 


\subsection{A invasão dos Montes Guararapes}

Nos arquivos da $5^{\text {a }}$ Secretaria Regional do IPHAN, encontram-se as peças do processo do tombamento dos Montes Guararapes por sua importância simbólica e paisagística. O sítio das célebres batalhas dos Guararapes (em 1648 e 1649), no qual o invasor holandês começou a ser derrotado por uma associação dos índios, negros e portugueses, restaurando o domínio colonial em 1654 foi apropriado pelo Exército Brasileiro como marco simbólico de sua constituição, assim como de uma certa idéia de nacionalidade na defesa dos interesses brasileiros ${ }^{224}$. Em louvor ao heróico feito, resultado também do uso da topografia natural do sítio pela inteligência militar, o comandante das forças restauradoras Francisco Barreto de Menezes ali mandou construir a Igreja de Nossa Senhora dos Prazeres em 1656, inscrita no tombo de monumentos do Instituto do Patrimônio Histórico e Artístico Nacional (IPHAN) desde 1938

Ao longo da leitura dos documentos do arquivo da então Diretoria do Patrimônio Histórico ( $1^{\text {a }}$ Regional do SPHAN, hoje $5^{\text {a }}$ SR do IPHAN) e o Instituto Arqueológico do Estado ${ }^{225}$ percebe-se o empenho, desde os anos 50, em tombar os terrenos envoltórios da Igreja fazendo frequentes apelos aos governantes e da opinião pública.

\footnotetext{
224 "Berço da pátria" é o dístico do município de Jaboatão dos Guararapes
}

${ }^{225}$ IPHAN. Minuta de carta ao Presidente da República. 5 SR. Recife, s/d.
O IPHAN, na figura de seu longevo diretor, o engenheiro Ayrton Carvalho, vinha desde princípios dos anos 1950 acompanhando a ocupação da área e denunciando as invasões e transformação de sua cobertura vegetal e topografia pelo afluxo de mocambos que ali se avolumava.

O primeiro marco da discussão em torno do patrimônio e posse da terra foi a publicação da denúncia que em dezembro de 1953 o chefe da Diretoria regional da SPHAN (DPHAN) Ayrton Carvalho fez acerca de um projeto de loteamento popular conduzidos pelos monges beneditinos. Desde a morte do construtor da capela e comandante das forças da Restauração pernambucana Barreto de Menezes $^{226}$, era o Mosteiro de São Bento de Olinda que respondia pela posse da Igreja e imprecisas adjacências.

A partir daí, organizaram-se diversas comissões com o intuito de precisar os limites do que seria o Parque Nacional, enquanto o Mosteiro coagia por mandato de segurança a prefeitura de Jaboatão a aprovar o loteamento da área, tal qual um empreendedor privado, alegando para isso que com o crescimento da cidade se tratava de "área urbana de altos impostos e que é um imperativo urbanístico o seu loteamento" 227 .

Como o tombamento ainda não havia se dado de fato, embora houvesse consenso em torno da idéia de um parque para preservar o

\footnotetext{
${ }^{226}$ IPHAN. Histórico da questão. 5. SR. Recife, mai/1956.

${ }^{227}$ IPHAN. Histórico da questão. 5 SR. Recife, mai/1956.
} 
patrimônio pátrio, o direito do Mosteiro de lotear a área foi reconhecido na Justiça. Tal revés no processo judicial fez com que a DPHAN buscasse desapropriar os terrenos através de um projeto de lei ao Congresso Nacional elaborado pelo deputado Gustavo Capanema, ex-ministro da Educação e Saúde de Vargas, figura próxima de Rodrigo Melo Franco de Andrade, diretor nacional do SPHAN.

$\mathrm{Na}$ época, o mosteiro recebia foro e aluguel de alguns casebres cuja habitação vinha sendo tolerada ao longo dos anos e a DPHAN controlava as novas construções, cobrando dos monges o controle da ocupação. Não se sabe ao certo se essa tolerância derivava de interesses patrimoniais ou especulativos da Igreja ou outros agentes imobiliários na área, ou dos religiosos, que vinham incluindo as questões da terra, da casa e do trabalho na agenda ideológica de renovação eclesiástica como alternativa tanto à crueldade do capitalismo como ao comunismo "ateu e dissolvente".

De fato, desde a Rerum Novarum, que tocava diretamente na questão da terra até o concílio Vaticano II no pontificado do Papa João XXIII a Igreja vinha revendo seus conceitos em função das novas condições geopoliticas e do capitalismo, tentando ocupar o lugar de mediação e amenização de alguns conflitos sociais que se agravavam ao longo do século XX.

Além da atuação dos dominicanos, os próprios beneditinos estiveram envolvidos nas outras duas experiências pioneiras de autoconstrução em Pernambuco, o Conjunto de Dois Irmãos, com verbas e orientação da Aliança para o Progresso ainda no Governo Cid
Sampaio e a Vila São Bento, em Olinda, já depois durante a ditadura, em 1965, com o apoio das mesmas assistentes sociais que trabalharam no Cajueiro Seco e com antigos técnicos do SSCM. A figura de Dom Hélder Câmara, presente em ambas as experiências, aproximava o pensamento e a prática católica com as técnicas da Escola de Serviço Social que davam apoio às comunidades nesse trabalho político e religioso de base ${ }^{228}$.

É importante considerar aqui que uma vertente bastante significativa da esquerda brasileira provinha das ramificações da igreja católica na sociedade civil através das Comunidades Eclesiais de Base (CEBs) e que Dom Hélder nesse momento era a principal figura da Igreja que se aproximava dos movimentos sociais em Pernambuco.

Até o princípio dos anos 60 , o preço da desapropriação não havia sido pago ao Mosteiro nem o Parque constituído, mas as construções de casebres nas adjacências dos Montes se ampliavam, absorvendo a população atraída pelo crescimento vertiginoso que o Recife sofria naqueles anos. Mesmo fora dos terrenos do Mosteiro, o quadro de conflito em torno da posse da terra e o imbróglio jurídico frente a situação de fato era similar. Em ofício de março de 1960 ao diretor Rodrigo Melo Franco, Ayrton Carvalho chamou a atenção para os terrenos de Prazeres, próximos ao local onde se assentaria a experiência de Cajueiro Seco:

"Nas proximidades dos morros dos Guararapes entre a estrada

${ }^{228}$ Entrevista ao autor das assistentes sociais Francisca VerAS e Maria Lucia MeLLO, março de 2008. 
pavimentada e a linha de Rede Ferroviária do Nordeste, estão surgindo numerosos casebres, já tendo o fato repercutido na imprensa em virtude de um conflito surgido entre os donos dessas construções e elementos da polícia de Jaboatão, que derrubaram algumas delas, a pedido da Companhia de Terrenos Prazeres, de acordo com uma determinação do Juiz de Direito daquele município, que proibira novas construções mandando conservar as já existentes. O terreno é objeto de litígio entre aquela companhia e a Ordem Carmelita, ao que se informa." 229

As áreas alagadas conhecidas como Prazeres, entre a praia de Piedade e os Montes refletia também o processo de periferização da metrópole, desordenada e explorada por companhias privadas, grileiros e especuladores que avançavam sobre áreas de posse e propriedade conflituosas. Havia ainda desde o começo da década uma proposta de políticos como Humberto Barradas e Augusto Lucena de emancipação de um novo município independente da sede de Jaboatão naquelas terras, que se chamaria Muribeca, Guararapes ou Prazeres ${ }^{230}$.

O interesse da DPHAN no caso era proteger a totalidade da área, considerando inclusive o aspecto paisagístico e a visão panorâmica dos Montes, incluindo aí restrições de gabarito para as construções do outro lado da ferrovia, em Prazeres.

A estratégia era clara: "sugerir máxima urgência no tombamento daquela área, afim de que o Distrito possa ficar armado dos meios legais para agir numa emergência como esta. Por enquanto, temos que assistir a tudo de braços cruzados, vendo aumentarem as dificuldades para sanar o

\footnotetext{
${ }^{229}$ IPHAN. Ofício 28/60. 5. SR. Recife, 1/mar/1956.
}

230 "Colcha de retalhos querem fazer do município". Jaboatão Jornal, 11/jun/1961. E "Jaboatão obtém liminar contra o Município de Guararapes". Diário de Pernambuco. Recife, 5/mar/64. mal que está sendo feito" ${ }^{231}$

De fato, surgiriam outras "emergências" e a tensão política em torno daquelas áreas também se intensificaria. Há no arquivo do IPHAN a cópia de um "veemente apelo" que fez o Vereador Newton Carneiro $^{232}$ ao Mosteiro através da tribuna da Câmara Municipal do Recife em novembro de 1960

"no sentido de permitir que as famílias pobres do Recife possam ocupar os terrenos devolutos e abandonados que formam o distrito de Prazeres (...) vez que as obras que estão sendo empreendidas pela Prefeitura desta cidade obrigam as famílias pobres a procurar terrenos para construirem as novas moradias, os quais não são encontrados com facilidade e com os salários que percebem, não podem pagar aluguéis de casas ou quartos" 233

Tais processos eram recorrentes nos territórios populares recifenses, explorados por toda a sorte de políticos e intermediários e foi analisada pelo Engenheiro Daniel Uchôa Cavalcanti Bezerra, onde fica claro o papel do povo na consolidação das invasões:

"Entretanto, onde os reflexos se fizeram sentir com maior incidência foi sobre a classe dos mocambeiros. Isto porque, em realidade, a ocupação de fato das áreas alagadas ou semi-alagadas, era feita por eles. Os seus casebres de palha, de táboas ou pau a pique, realmente materializavam a ocupação da terra. Representavam a benfeitoria." (BEZERRA, D. Alagados, mocambos e mocambeiros, 1965, p.39)

${ }^{231}$ IPHAN. Ofício 28/60. 5 SR. Recife, 1/mar/1956.

${ }^{232}$ Newton Carneiro é hoje o prefeito de Jaboatão dos Guararapes e tem uma

histórica ligação com as "invasões". Foi acusado diversas vezes de estimulá-las, defendendo o direito a permanência na Câmara e corredores das prefeituras e cobrando aluguel em seu proveito, caracterizando a o aluguel do chão grilado.

${ }^{233}$ IPHAN. Ofício - Requerimento Câmara Municipal do Recife._5R. Recife, 17/nov/1960. 
A curiosa interferência do poder legislativo municipal no município vizinho nos revela, por um lado, uma face da intensificação da crise habitacional nos anos 60, normalmente explicada pela lógica das migrações, que todavia não podem ser menosprezadas. Afinal expulsão da população pobre das áreas mais centrais à medida que o processo era uma constante no Recife desde o início do século (LIRA, 1997). Por outro lado, chama a atenção para outra classe de promotores das invasões: os políticos, tanto quando promovem "limpezas urbanas" gentrificadoras quanto quando agem como grileiros, promovendo a invasão, oferecendo seu mandato como respaldo da ocupação das terras e explorando o drama social em proveito próprio, seja sob a forma de votos e apoio popular ou mesmo em espécie, sob a forma de "aluguel de chão" ${ }^{234}$.

Entre 1962 e o golpe a tensão ali concentrada entre o patrimônio e o crescimento da cidade atinge grau máximo, intensificando a correspondência entre o Distrito regional do SPHAN e o órgão nacional. Em ofício, Ayrton da Costa Carvalho fez um panorama da situação:

\footnotetext{
234 "O gabinete do prefeito recebeu denúncia (...) de que o vereador Newton Carneiro planejou a invasão do aterro do Cais do Apolo, durante o carnaval, para construir dezenas de mocambos ilegalmente, a pretexto de defender a população pobre. (...) O vereador já teria armazenado todo o material necessário à construção desses mocambos, bem como já teria mobilizado dezenas de "profissionais de mocambos" para o "trabalho". Para a invasão, o vereador escolheu os dias de carnaval porque, como ocorre todos os anos, todas as repartições públicas suspendem as suas atividades". "Cais do Apolo seria invadido no carnaval". Diário de Pernambuco, Recife, 18/jan/64. Ver também "PMR contra os profissionais das invasões de terrenos". Diário de Pernambuco. Recife, 15/jan/1964.
}

"Na noite que antecedeu o dia das eleições (7 de outubro) e na ausência dos soldados da Polícia Militar encarregados de vigilância foram edificadas (...) 12 casinhas, na sua maioria de madeira, cobertas com telha francesa, que foram imediatamente ocupadas por famílias necessitadas. Avisados pelo abade beneditino, Dom Basílio Penido, procuramos a Secretaria de Segurança Pública, solicitando providências. O delegado Epitácio Belém prometeu agir, mas as suas providências foram infrutíferas de vez que todos os mocambos estavam habitados. Procuramos também o novo comandante do $4^{\circ}$ Exército, General Humberto Castello Branco ${ }^{235}$, que de boa vontade se prontificou a falar com o comandante da Polícia Militar do Estado, Coronel Expedito Sampaio. Depois de vários entendimentos havidos entre as citadas autoridades, ficou estabelecido que iríamos com o Coronel Adolfo e mais um membro da comunidade beneditina ao local. (...) O Coronel ordenou ao miliciano que fizesse um levantamento de nome e profissão de todos os ocupantes, ficando acertado que a comunidade beneditina entraria com ação demolitória na Justiça. Outrossim, ficou acertado que o Prior de S. Bento forneceria a este Distrito e ao Coronel, a relação de todos os ocupantes realmente autorizados (foro, aluguel) e das ações em andamento no foro de Jaboatão, contra as invasões anteriores" ${ }^{\prime 236}$

Tal superposição de poderes e instâncias dá o tom da complexidade das soluções adotadas para lidar com a situação de fatos, que interessava a todos esses agentes - o Patrimônio, o Exército, a Igreja e ao povo.

A preocupação do diretor do patrimônio é significativa e reveladora, fechando o documento:

"julgamos muito grave problema devido ao estado de ânimo de exaltação e revolta das classes menos favorecidas, concorrendo para isso a

\footnotetext{
${ }^{235}$ Ele seria o primeiro presidente da república depois de abril de 1964

${ }^{236}$ IPHAN. Ofício 162/62. 5. SR. Recife, 23/out/1962.
} 
demagógica política em época de eleição". ${ }^{237}$

Em março de 1963, já eleito e recém empossado Miguel Arraes como Governador, houve uma nova série de denúncias de invasões nos jornais pernambucanos.

"Os sítios onde se feriram as batalhas dos Guararapes, de propriedade da Capela de Nossa Senhora dos Prazeres, estão sendo invadidos por cerca de três mil casebres' denunciou ontem em entrevista ao Diário o professor Ayrton Carvalho, chefe do $1^{\circ}$ Distrito da DPHAN. (...) 'Estas duas batalhas dos Guararapes são as primeiras afirmações de nacionalismo e ali foi conquistada a unidade nacional. É um patrimônio que deve ser respeitado. Todo indivíduo nacionalista deve preservar e venerar o local daquelas memoráveis batalhas. Espero que o governo do Estado, que já deu demonstração positiva, mandando sustar as construções, coopere com a DPHAN, procurando uma solução humana para os casos realmente existentes. ${ }^{\prime \prime 238}$

As denúncias de Ayrton Carvalho e as propostas de tombamento ocorreram juntamente com o impedimento policial de novas construções e a garantia de que as mil famílias que ocupavam os Montes não seriam expulsas até que o Governo providenciasse solução à altura.

"A Secretaria de Segurança Pública tenta, agora, evitar que surja nova Brasília Temosa (sic), porque os moradores recusam abandonar seus barracos." 239

${ }^{237}$ IPHAN. Ofício 162/62. 5 SR. Recife, 23/out/1962.

238 "Montes Guararapes invadidos por três mil mucambos: protesto". Diário de Pernambuco. Recife, 10/mar/1963.

239 "Polícia impediu". Última Hora. Recife, mar/1963.
Entre os poderes estaduais, federais e populares, a igreja mais uma vez ficou em posição complexa, entre o jogo político e o apelo da demanda social. Relatou Ayrton Carvalho:

"O abade Dom Penido nos tinha solicitado não mobilizar a imprensa para evitar exploração por parte da oposição e criar, assim, para nós, um clima desfavorável. (...) Estivemos em seguida com o Exmo. Snr. Arcebispo Dom Carlos Coelho que havia sido procurado por mais de 200 pessoas, logo após a intervenção enérgica da Polícia, e que desejavam permissão para concluir as casas iniciadas." 240

O quadro da situação apresentado pelo Diretor da DPHAN fornece alguns elementos destoantes de improviso e precariedade descritos por Borsoi na memória do projeto do Cajueiro Seco, insinuando algum agente promotor por trás das construções. O ofício comentava também o encaminhamento da solução que será depois localizada em Cajueiro Seco.

"As construções estão paralisadas e das 2.000 casas (aproximadamente) 800 já se encontram habitadas. As baixadas e os altos tiveram a arborização nativa e os coqueiros queimados e a mucambaria implantada. Na maioria são casas cobertas de telhas, com estrutura de madeira e tapumes de taboado. É trabalho planejado e de uma rapidez incrível.(...) Caso não se consiga a recuperação total do terreno, livrando-o do casario, se fará ele uma favela a mais, a qual, de maneira nenhuma, nada resolverá, sob o aspecto social dado ao caso.(...)Procuraremos informar V.S dos acontecimentos e entendimentos dos com o Arquiteto Gildo Guerra, presidente do Serviço Social Contra o Mocambo, no sentido de ser iniciada a demolição das estruturas das casas inacabadas e na remoção das outras já habitadas para local escolhido pela referida

${ }^{240}$ IPHAN. Ofício 28/63. 5 SR. Recife, 13/mar/1963. 
Autarquia." 241

Os moradores dão a sua versão dos acontecimentos em entrevistas, sempre glorificando a presença do Governador, que em cada uma de suas ações, pela sua sensibilidade social e presença de espírito ganhava correligionários para a vida inteira, como a mãe de Dona Maria, moradora entrevistada:

"Arraes chegou nos Montes Guararapes e organizou uma fila com o pessoal que tinha invadido lá, que até a polícia proibiu e ninguém batia nenhum prego, formou fila, muitas mães com crianças no braço e loteou isso aqui e deu pra todo mundo. A gente pagava todo ano um pouquinho. "242

Já em julho de 1964, data do próximo ofício do acervo que toca no tema, logo após a "Revolução", pode-se perceber uma mudança de tom. As invasões não haviam cessado e o documento agora dirigia-se ao Secretário de Interior e Justiça e agente da repressão João Ribeiro Roma.

"Agora uma nova invasão se está processando, com o recrudescimento das construções clandestinas de mocambos e taperas, na tentativa de criar 'fato consumado' e 'problema social' de fácil exploração sentimental. Cabe, agora, a este distrito (...) pedir o retorno urgente aos Montes Guararapes de patrulha permanente da Força Policial do Estado, que vinha mantendo continuada defesa do monumento. Ao lado da providência de caráter imediato e prático, o $1^{\circ}$ Distrito da DPHAN encarece a adoção de medidas que levam a solucionar a situação criada com a permanência ali de famílias que, embora ilegalmente, já estabeleceram residências no local, visando removê-las talvez com a

\footnotetext{
${ }^{241}$ IPHAN. Ofício 28/63. 5. SR. Recife, 13/mar/1963.

${ }^{242}$ Entrevista Dona Maria, moradora da Rua № 29, Jan/2007
}

renovada colaboração do Serviço Social Contra o Mocambo que já havia iniciado valoroso e louvável trabalho naquele sentido"243

Reconhecia-se o trabalho do governo anterior, mas a direção dos acontecimentos iam na mão inversa. Se antes acreditava-se que participação do povo resolveria o problema e a tolerância era medida de caráter humanitário, agora a repressão e a aplicação da lei se faziam urgentes. Só depois do golpe, de fato, o tombamento oficial dos Montes se processou, assim como a constituição do Parque Histórico Nacional dos Guararapes (PHNG), já nos anos 1970, convertido num monumento ao poder do Exército, que até hoje lida com a pressão dos mocambos que ocupam suas encostas mais íngremes e linhas de drenagem.

Um aspecto da história e da tradição cultural específica do local que não pode ser esquecido é a Festa de Nossa Senhora dos Prazeres, que acontece no dia 25 de Abril juntamente com a festa pagã da Pitomba, uma fruta característica do lugar com a qual as moradoras dos mocambos fazem um doce, vendido aos visitantes que afluem à Igreja nessa ocasião. Com a implantação do parque, algumas medidas para a urbanização da área foram tomadas, o que resultou num concurso público de arquitetura que escolheu o arquiteto Armando de Holanda ${ }^{244}$

\footnotetext{
${ }^{243}$ IPHAN. Ofício 54/64. 5. SR. Recife, 02/jul/1964.

${ }^{244}$ Holanda formou-se arquiteto na Universidade do Recife imediatamente antes do golpe e havia trabalhado como estagiário no SSCM, possivelmente no projeto da taipa pré-fabricada. Ele foi um dos poucos arquitetos pernambucanos a estudar na Holanda técnicas de racionalização do canteiro e o projeto do PHNG serviu como
} 
para projetar equipamentos para o Parque. As elegantes coberturas em forma de parabolóides hiperbólicos que abrigam banheiros públicos, lanchonete, posto de controle de entrada, cavalariça da PM e outros equipamentos hoje seguem sendo a infraestrutura para a visitação, ainda que mal conservadas.

Geraldo Melo, o prefeito "tocador de obras" de Jaboatão que nos anos 80 pavimentou as ruas de Cajueiro Seco com dinheiro do BNH através do projeto CURA (Comunidade Urbana de Recuperação Acelerada), em debate tenso promovido pelo IAB no ocaso da ditadura, ocasião em que posturas tecnocráticas e populares puderam confrontarse, proclamou a solução da questão dos Montes Guararapes que continuavam ocupados pelos mocambos, o "grande impasse do município de Jaboatão: Duzentos e quarenta e três hectares para preservar, vinte mil famílias para serem expulsas". E concluiu, de maneira tão objetiva quanto emblemática: "Uma revolução. Houve expulsão dos holandeses, agora nós faríamos a expulsão dos brasileiros. ${ }^{245}$

Mais uma vez, a solução seria a relocação daquele contingente populacional para a região de Prazeres e de Cajueiro Seco, que se urbanizava em ondas de reocupações sucessivas de famílias recorrentemente expulsas dos mesmos Montes Guararapes.

"Saiu uma turma e nunca falta quem volte, quem invada, eles proíbem mas com o tempo o povo com o jeitinho, no tempo que minha

exemplo das teorias formuladas em seu mestrado "Roteiro para construir no Nordeste". Teve sua vida e carreira abruptamente interrompidos nos anos 1970.

${ }^{245}$ Instituo dos Arquitetos do Brasil - IAB-PE, 1982, p. 70. mãe invadiu não tinha aquele povo todo não, mas devagarzinho o pessoal do quartel fecha os olhos ... tem vila lá, né? Quando chega o dia da Festa de Nossa Senhora dos Prazeres, é um meio de vida lá pro povo. Tem muita casa mesmo. "246

\footnotetext{
${ }^{246}$ Dona Maria, moradora da Rua 6 № 29A, entrevista ao autor, jan/2007.
} 


\section{4 - O CAJUeIRO SECO: A GÊNESE DO PROJETO, AS REALIZACÕES E SEUS DESDOBRAMENTOS}

O objetivo deste capítulo é, agora considerando o panorama apresentado, finalmente apresentar novos olhares sobre o Cajueiro Seco, a partir de suas relações com a política e a cultura local e com as transformações da cultura arquitetônica, expressas nas novas posturas e alinhamentos políticos dos arquitetos vistos no Congresso da UIA em Havana, nas discussões centrais e na atuação do IAB que culminaram no Seminário de Habitação e Reforma Urbana.

Passamos então à história particular da comunidade do Cajueiro Seco, enquanto grupo social, que em algum momento do passado recente começou a se concentrar em torno dos Montes e da Igreja dos Guararapes, patrimônio religioso de valor histórico e simbólico para a nacionalidade.

A solução apresentada pelo novo governo popular deveria envolver o povo e também os intelectuais - a florescente arquitetura moderna pernambucana poderia agora ser posta a serviço dos pobres.

O projeto urbanístico e o modelo de cidade se ali propunha-se implementar não é compreendido senão a luz de importantes referências como Brasília e as discussões em torno da reforma urbana.

Analisando o célebre projeto de pré-fabricação da taipa para as unidades do Cajueiro Seco, procuramos identificar precisamente suas realizações, experiências com equipamentos e práticas comunitárias, o impacto da sua brusca interrupção e o momento no qual os conteúdos presentes na proposta para a comunidade modelo são reduzidos ao projeto meramente arquitetônico de caráter exótico ou peculiar. Partese daí para um balanço crítico da experiência, que tenta superar a questão das unidades e das projetadas transformações para analisar os discursos, os conteúdos sociais e as práticas projetuais e construtivas ali condensados que permaneceram gerando impactos até os dias de hoje. 


\subsection{O Plano para o Cajueiro Seco: os idealizadores e a reforma urbana}

Nosso esforço aqui será contextualizar a atuação, em diferentes esferas governamentais, dos arquitetos Artur Lima Cavalcanti, Gildo Guerra e Flávio Marinho Rêgo, para além da persona de Acácio Gil Borsoi, o autor do projeto de pré-fabricação em taipa, o "pai da criança", como à ele se referiram alguns dos entrevistados. Um aspecto importante a ser abordado é o plano urbanístico proposto para o assentamento, que contém em si propostas e idéias inovadoras. É certo que tais propostas tem a ver com experiências recentes do urbanismo e importantes referências de realizações brasileiras e internacionais ${ }^{247}$ mas é importante também ter em mente a experiência do Cajueiro Seco inserida na discussão em torno da Reforma Urbana.

Analisando os discursos e debates contemporâneos ao projeto do Cajueiro Seco, notadamente no âmbito do SHRu (ver item 3 do capítulo 1), podemos perceber a inserção da experiência dentro de uma nova política habitacional em gestação, o que compreendia a provisão de serviços e infraestrutura urbana ao assentamento, sua inserção na metrópole e a promoção do desenvolvimento humano a partir da fixação do contingente em um lugar específico da periferia recifense. Tais princípios, como vimos, estão referidos no projeto de lei para a criação da SUPURB, redigido por Artur Lima Cavalcanti, que

${ }^{247}$ A referência no memorial do projeto a conceitos como Superquadra e Cidade Satélite aproxima os discursos e projetos para realidades distantes e distintas. condensava as propostas do seminário. Senão por outros motivos, é possível apanhar por aí um nível de interferência do arquiteto, deputado e ex-prefeito, figura influente na Frente do Recife. Não é improvável que Artur Lima Cavalcanti tenha tido alguma influência na concepção do plano habitacional, do qual Cajueiro Seco era pensado como uma comunidade piloto, no processo de enfrentamento das pressões populares por terra e habitação.

É certo que a influência de Lima Cavalcanti não deve ter sido formal. O arquiteto desempenheva um papel político mais amplo, ocupando naquele momento outros cargos e incumbências. A coincidência de termos e formulações entre o projeto de lei e a explicação do projeto do Cajueiro Seco veiculada nas revistas especializadas e na imprensa local é emblemática.

Antes de tornar-se político, Lima Cavalcanti formara-se arquiteto em 1954, numa das primeiras turmas do curso de arquitetura da Universidade do Recife, tendo Borsoi, além de Delfim Amorim, Antônio Baltar, Pelópidas Silveira e Ayrton Carvalho como professores e Gildo Guerra como colega de turma, de quem se tornaria sócio em uma empresa de projetos e construções.

Guerra, desde a Universidade já vinha se envolvendo com o movimento estudantil, atraindo o colega Artur Lima para a militância durante a campanha de Guerra para a presidência da União dos Estudantes de Pernambuco ${ }^{248}$.

${ }^{248}$ Lornal Pequeno, Recife, 17-23/fev/1963 
Depois de formados, Gildo Guerra acabou optando por uma linha de atuação mais radical do que a de Artur Lima Cavalcanti, próxima ao Partido Comunista Brasileiro. Lima Cavalcanti filiou-se ao PTB, legenda que o elegeu deputado federal em 1962, quando era viceprefeito de Arraes. Em meio aos debates em torno da sucessão de Arraes na prefeitura em 1963, o nome de Guerra foi cogitado mas logo descartado por "fortes obstáculos" ${ }^{249}$ e preterido por outros considerados mais consensuais e representativos da Frente do Recife como o próprio Lima Cavalcanti, que, a despeito de à epoca ser deputado federal, disputava o posto de candidato com Pelópidas Silveira, que acabou se elegendo prefeito pela terceira vez.

O prestígio político de Gildo Guerra - assim como a oposição à sua forma de ação - derivavam de sua colaboração durante a gestão de Arraes à frente da prefeitura do Recife, como Diretor de Obras Públicas, indicado pelo então vice-prefeito Artur Lima Cavalcanti.

Ao longo do começo dos anos 1960, a imprensa local registrou divergências entre os dois arquitetos, assim como a radicalização das posturas de Gildo Guerra, que culminaram na dissolução da sociedade comercial "Guerra e Cavalcanti" ${ }^{250}$. Declarações de Guerra à imprensa como "Mocambeiro não deve pagar foro a ninguém" em março de 1964, conclamando ao calote os moradores de mocambos e desafiando os possuidores e exploradores das áreas nas vésperas da ditadura deram

\footnotetext{
249 "Queimado", Jornal Pequeno, Recife,17-23/fev/1963
}

${ }^{250}$ Diário de Pernambuco Recife, 8/mai/1963 razão aos seus detratores que o consideravam radical e a repercussão delas nos jornais ajudam a entender o seu enquadramento como líder do suposto aparelhamento comunista do Estado, como denunciou a repressão reunida no DOPS. Em nota, o Diário de Pernambuco publicou uma declaração dada por Guerra "num restaurante da cidade" afirmando que "só com a revolução será possível acabar com os mocambos do Recife", maliciosamente construindo uma imagem do Presidente do SSCM vinculada à luta revolucionária comunista ${ }^{251}$.

Dentro da "repartição" formou-se também uma ala de oposição à gestão de Gildo Guerra, capitaneada pelos deputados Arnaldo Assunção (Procurador do SSCM "na vida extra-parlamentar)" ${ }^{252}$ e Paulo Rangel Moreira, (Ex-presidente do SSCM), engrossada pelos funcionários de carreira da autarquia, que viam sua letargia habitual abalada. Assunção estava envolvido na Câmara com o projeto de transformação do SSCM em Instituto de Habitação Popular, com "padrões semelhantes" aos do Peru, Colômbia e América Central. Declarou a coluna de notas políticas Periscópio, do Diário de Pernambuco:

"Às vésperas de receber um vultuoso empréstimo do BID para construir 23 mil casas populares, o SSCM vai precisar de nova estrutura técnica e administrativa inclusive para absorver o volume de trabalho que se anuncia" $^{253}$.

\footnotetext{
${ }^{251}$ Diário de Pernambuco, Recife, 18/jan/1964

${ }^{252}$ Diário de Pernambuco, Recife, 11/dez/1963

${ }^{253}$ Diário de Pernambuco, Recife, 11/dez/1963
} 
Pela origem dos recursos e referências institucionais fica clara a vinculação do modo de produção da habitação social e práticas ligadas ao financiamento internacional dirigido pelos interesses norteamericanos.

Em trechos do discurso de posse no cargo de titular do SSCM em 1963 publicados no jornal situacionista Última Hora, que então estava empenhado em divulgar e promover as ações do Governo Arraes, Gildo Guerra explicitou a mudança institucional que se operava na autarquia:

"Nossa tarefa é o bem maior; é zelar por uma política de ação, em cujo programa de trabalho objetivo evitaremos o paternalismo. (...) Empregaremos todo o nosso esforço no sentido de contribuir para o levantamento do nível social dos mais humildes e que permita a sua integração na sociedade e nos meios de produção" ${ }^{254}$

Tão cedo quanto em março de 1963, decorrido pouco mais de um mês da posse de Arraes, Guerra teve clareza do "programa de trabalho" a experimentar transferindo os invasores dos Montes Guararapes para o que viria a ser o Cajueiro Seco:

"Trata-se do emprego de suas poupanças com o apoio do governo na complementação dos serviços de urbanizacão. Já temos em vista quatro locais, um dos quais será escolhido para a instalação de novo núcleo residencial, onde serão construídas suas casas. Essas famílias edificariam suas residências de qualquer maneira, com os materiais de que dispõe $\mathrm{e}^{\prime 255}$.

A ampliação do campo da política pública e integração das ações governamentais para inserir na metrópole os grupos à margem da urbanização parecia ser a principal bandeira; a partir desta ótica as

254 "Gildo Guerra no SSCM: 'Nada de biombos para esconder a miséria'” Última Hora, Recife, 5/fev/1963

255 "Presidente do SSCM resolve problema do Monte Guararapes" Jornal do experiências meramente habitacionais praticadas perdia sentido. Referindo-se particularmente ao conjunto do Alto Jordão, executado em "colaboração" com a Aliança para o Progresso, Guerra sentenciou: "Cuidar, isoladamente da habitação é fazer biombo de alvenaria para esconder a miséria de nossa gente" ${ }^{256}$

O retrato da política habitacional do Governo de Cid Sampaio contrastava com o interesse público e popular. Segundo Guerra:

"o custo da iniciativa e o critério de distribuição das casas tornaram o plano desprovido de qualquer sentido humano ou social, dando lugar a que especuladores imobiliários se apoderassem do patrimônio público e aumentassem suas rendas ${ }^{257}$

Além de visitar os conjuntos que haviam sido entregues já no fim da gestão anterior como Alto Jordão e Ibura, Guerra realizou uma série de encontros e vistorias com os moradores dos mocambos do Coque, comunidades recém-implantadas como Dois Unidos, visitou a "favela" dos Montes Guararapes e estabeleceu conexões com os Departamentos Nacional de Obras e Saneamento, as Secretarias municipais e estaduais de Educação e Saúde e outras autarquias no sentido de organizar um plano de melhoramento das zonas de mocambos e apoio ao desenvolvimento das comunidades ${ }^{258}$. Apesar das críticas, as obras nos conjuntos do Ibura e Alto Jordão e seriam continuadas, uma vez

${ }^{256}$ Gildo Guerra no SSCM: ‘Nada de biombos para esconder a miséria'” Última Hora, Recife, 5/fev/1963

257 "Gildo inicia no Jordão guerra aos 'Biombos'”! última Hora, Recife, 7/fev/1963

${ }^{258}$ última Hora, Recife, Fev/1963 
recebida a última parcela do "convênio" (leia-se empréstimo) de habitação da Aliança para o Progresso ${ }^{259}$.

Segundo Guerra, "embora seja outra a política habitacional do Governo, toda ela voltada para as grandes massas da população que constrói mocambos, o Plano do Jordão será concluído, por não ser tecnicamente possível suspender um plano em sua fase final de execução". ${ }^{260}$

Posteriormente, outro empréstimo do BID seria firmado com o Banco do Nordeste com destino certo ao SSCM. Da assinatura do acordo, participaria Guerra, caso sua viagem aos Estados Unidos não tivesse sido obstada pelas autoridades de segurança norteamericanas, provavelmente por sua vinculação com o Partido Comunista. Para resolver esse impasse diplomático, que dá o tom das relações internacionais dos Governo pernambucano e norteamericano, um alto funcionário do BID veio para o Recife assinar o documento. ${ }^{261}$

Em conferência realizada em maio de 1963 para os prefeitos do Recife, Olinda e Jaboatão, Gildo Guerra expôs as diretrizes da política habitacional que capitaneava. Constatada a indisponibilidade dos recursos necessários para a erradicação dos 100 mil casebres existentes, tratava-se de "humanizar e sanear os mucambos".

${ }^{259}$ SSCM receberá Cr\$ 60 milhões da USAID para concluir casas do Alto do Jordão última Hora, Recife, mar/1963.

260 "Gildo Guerra explica dólares da 'Aliança': 'Não podemos para obras do Alto Jordão'" Última Hora, Recife, mar/1963.

${ }^{261}$ "A viagem e o empréstimo do BID", Última Hora , nov/1963 e "Cleanto comunica empréstimo do BID ao SSCM" Diário de Pernambuco 11/dez/1963
O Estado deveria "adquirir áreas no chamado Grande Recife, de preferência às margens das rodovias de acesso à cidade e das estradas de ferro, como vem sendo feito no Cajueiro Seco. (...) Até o fim do ano afirmou - seis mil famílias estarão localizadas em Cajueiro Seco, o que representará a acomodação de 30 mil pessoas." 262

Fica clara a dimensão metropolitana da experiência, inserida dentro de um plano territorial e habitacional para o Grande Recife, cujas diretrizes haviam sido dadas por Baltar em 1951. Para além do caráter de comunidade modelo ou do projeto piloto era preciso pensar a integração dos contingentes populacionais à margem da metrópole. Cajueiro Seco aparece aqui não como uma experiência isolada, mas como o lugar preferencial de uma nova cidade satélite que se conformaria entre a Zona Sul do Recife e Jaboatão, entre o eixo rodoferroviário e a praia.

Já em maio de 1963 o governo iniciava a comunidade de Dom Abade, em terreno próximo ao Cajueiro Seco, também adquirido dos Carmelitas, onde se instalaria uma comunidade nos mesmos moldes da experiência piloto. $^{263}$

A relação entre a questão fundiária e atuarial dos terrenos e investimentos governamentais e o retorno social dos beneficiários seria resolvida de uma maneira peculiar, talvez inédita dentro das políticas

262 “Gildo Guerra: Política do governo é humanizar e sanear os mucambos” Última Hora, Recife, mai/1963. No artigo "Combate ao Culex requer prédios higienizados" publicado no Diário de Pernambuco em 18/jan/1964 também há referência a um grande plano de autoconstrução de casas "dentro de um projeto moderno" nos 6 mil lotes de Prazeres, que integrariam um conjunto ainda maior de 15 mil lotes ali.

${ }^{263}$ Problemas da habitação popular continuam em Estudos no SSCM Lornal do Commercio, Recife, 8/mai/1963 
públicas de habitação: "Os terrenos, por sua vez, serão arrendados (Cr\$ 100 ao mês) $)^{\prime 264}$. Explicada juridicamente como o ancestral mecanismo do enfiteuse (ou aforamento) por Maria Lucia Mello ${ }^{265}$ que se difundiriu na cultura urbanística européia com exemplos como o projeto de H.P. Berlage para Amsterdam Sul, a prática era também velha conhecida dos recifenses. Tratava-se do popular "Aluguel de chão", comum nas áreas urbanas de mocambos, uma dinâmica especulativa informal e às vezes, ilegal de exploração da terra incorporada pelo Estado. A imagem da casa erguida com materiais próprios sobre um terreno alugado por um explorador, raramente por seu legítimo proprietário, denotando a mobilidade do mocambo e a incerteza do endereço, do seu território na cidade.

A parte sua posição política e técnica, Guerra expressa sua determinação em favor de uma "planificação conjunta" com a cooperação entre organismos de estado e a população beneficiada. Mais do que isso, declara sua fé no saber técnico moderno: "O aproveitamento das áreas deverá ser feito de maneira racional, obedecendo as características do urbanismo moderno." 266

Ao assumir a presidência de um órgão estratégico do governo popular de Arraes, Guerra transformou o quadro de funcionários do

264 "Gildo Guerra: Política do governo é humanizar e sanear os mucambos!” Última Hora, Recife, mai/1963

${ }^{265}$ Maria Lucia MeLLo Entrevista ao autor, Recife, Maio/2008

266 "Terrenos do SSCM para as casas dos portuários" Última Hora, Recife, 24/mai/1963 serviço e convidou seu ex-professor e amigo pessoal, o prestigiado arquiteto Acácio Gil Borsoi, para assumir o Departamento de Construções. Ao lado de Delfim Amorim, Borsoi era o mais solicitado profissional da cidade.

De maneira informal, Borsoi relata, com certo encantamento, o aparecimento da questão. Aos olhos do arquiteto, a experiiencia parecia introduzir em sua carreira eminentemente voltada ao mercado imobiliário e a uma clientela de elite, a possibilidade de uma atuação pública, voltada à produção da habitação social com a participação popular.

"Aí o Gildo chegou um dia, aquilo tava um negócio horrível, a burocracia da repartição era impraticável, uma sinecura terrível ${ }^{267}$, daquele jeito não se fazia nada. Disse: -Vamos fazer diferente, porque é que a gente não vai lá, pega esse pessoal que não tem nada a ver com o Governo, vamos fazer uma comunidade diferente.[A questão era] valorizar a pessoa, dar a autogestão pras pessoas. Aí fomos lá. Eu e ele no carro dele. Era um domingo Fomos lá no meio da invasão, os dois sozinhos. Ele tinha a liderança, sabia exercer liderança, era mais maduro do que eu. Chamou o pessoal pra ir na sala dele, na Cruz Cabugá no dia seguinte: -Vamos discutir, Dr. Arraes vai levar vocês pra outro lugar. Aí descobrimos que a Ordem dos Carmelitas tinha um terreno em Cajueiro Seco que era um terreno cheio de turfa, que afundava. Aí foi uma corrida infernal pelos recursos menores do Estado, um caminhão e um trator da Agricultura, terra

${ }^{267}$ Em outro momento, Borsoi descreve como era o fluxo de trabalho na repartição: "Tinha uma pilha de processos pra despachar todo dia, o processo assistencialista é assim: "Você não é capaz, eu vou te ajudar. Vou te dar uma casa mas a casa não te dou a casa não, a casa é minha e qualquer coisa você vem aqui." Mal construídas, umas porcarias, tudo quebrando. A sola da torneira ficava vazando, o cara ia até a Cruz Cabugá, montava-se uma ficha, aí ia o inspetor na Vila das Lavadeiras pra verificar, mandava pro engenheiro despachar pra comprar o negócio pra depois mandar um cara lá pra consertar a torneira. Deu cupim num caibro, porque era tudo vagabundo, você tinha que fazer a mesma coisa. Era um processo maluco, uma coisa incrível." Acácio Gil BORSOI, Entrevista ao autor, Recife, Set/2007 
pra aterrar. E eu fiz a parte do projeto, da urbanização da comunidade. Eram super quadras, uma malha de ruas e as unidades de habitação ficavam no centro. Ficava barato fazer uma rua espaçada e criar uma comunidade,pois não havia automóvel, podia fazer isso.

Tinha muitas assistentes sociais lá. Fizemos um levantamento e transferimos as 800 pessoas. Criamos um centro comunitário com uma gestão deles. O assunto era discutido com eles. Criaram-se dois setores de trabalho, tinha grandes armazéns e um chafariz. A primeira coisa que fizemos foi banheiro público. Eu fiz aquilo com uma caixa d'agua em cima um losango e um quadrado enviesado como símbolo, fizemos uma marca, Cajueiro Seco era um movimento diferente. Aquilo seria o seguinte: todas as comunidades que iríamos fazer iam ter aquela lavanderia pra sustentar aquele grupo numa fase transitória, durante a obra e a consolidação. Do lado tinha dois armazéns, um comportaria as cooperativas de produção, levantando as assistentes sociais as aptidões, costureiras, barro, gesso. A Lina até veio visitar e eu dei um São Jorge feito por um cara de lá."268

268 Acácio Gil BORSOI, Entrevista ao autor, Recife, Ago/2006. Em outra ocasião, ele rememora o projeto a partir das mesmas cenas, destacando alguns outros detalhes:

"Eu disse ao Gildo, vamos ver lá a Batalha dos Guararapes, o local da batalha, o terreno, que era do exército, aquilo era um sítio histórico que era defendido pelo exército brasileiro. Os caras não tomaram nenhuma atitude. O Arraes não teve participacão, não tinha nada a ver com isso. Era patrimônio federal. Eu e o Gildo, nessa conversa, dissemos: "Vamos fazer diferente, vamos fazer a remoção daquele pessoal pra um lugar decente". E ele disse: "Então vamos agora." Pegou o carro dele e nós fomos pro sítio, no meio daquele fuzuê, eu e ele só, fecharam em volta do carro dele e ele tinha uma qualidade de liderança muito grande e disse: "D Arraes vai resolver o problema de vocês, precisamos de cooperacão, vai dar um lugar direito pra vocês" e teve uma grande discussão e ele foi vendo os caras que eram mais agitados e mais inteligentes e disse: "Você, você e você amanhã estejam no meu gabinete na Cruz Cabugá que nos vamos discutir esse problema". E quando a gente estava voltando disse: "Gildo, vamos arranjar um terreno, que tenha meios de comunicacão fáceis, que seja mais ou menos plano, próximo de um lugar com infraestrutura, vamos fazer uma coisa direita, planejar aquilo tudo" e eu planejei toda a vila. Aquele terreno era dos Carmelitas, a Liga Social comprou dos Carmelitas, pagou baratíssimo, ali era um terreno de turfa, você enfiava uma vara e afundava no atoleiro. Nós fizemos um projeto com as quadras, superquadras, tinham umas ruas eram calçadas, mais ou menos usando aquela visão do Corbusier
A simplificação categórica feita pelo arquiteto na introdução de nossa primeira entrevista sobre o tema dá o tom das idéias e inspirações que estavam presentes em diversos âmbitos governamentais e da sociedade civil, organizada em instituições de classe, sindicatos e associações de bairros: "O Cajueiro Seco surgiu por uma razão muito simples: a euforia da liberdade." ${ }^{269}$

É curiosa a referência constante ao termo "Superquadra" nas explicações do plano urbanístico do conjunto.

Definitivamente, trata-se de um eco da experiência ainda muito recente de Brasília, onde a idéia de "Superquadra" foi reproposta como solução de localização, ordenamento e adensamento residencial ao longo do eixo rodoviário estrutural do plano piloto. Nas palavras de Lúcio Costa, como uma solucão de

"disposição que apresenta dupla vantagem de garantir a ordenação urbanística mesmo quando varia a densidade, categoria, padrão ou qualidade arquitetônica dos edifícios, e de oferecer aos moradores extensas faixas sombreadas para passeio e lazer, independentemente das áreas livres previstas no interior das próprias quadras." 270

Idéia portanto ao mesmo tempo voltada à valorização formal e paisagística, assim como à qualidade funcional e à variedade espacial

de V6, que é a vicinal, classificação em função dos acessos. Acácio Gil BorsOI, $\underline{\text { Entrevista ao autor, Recife, Set/2007 }}$

${ }^{269}$ Acácio Gil BORSOI, Entrevista ao autor, Recife, Ago/2006

270 Lucio COSTA "Memória descritiva do Plano Piloto" - 1957 in $\underline{\text { Registro de uma }}$ Vivência, Rio de Janeiro: Empresa das artes, 1995 p. 292 
de uma cidade inteiramente projetada. Algo talvez mais próximo das unidades de vizinhança do que de super quadras em si. ${ }^{27}$

"Dentro destas 'super-quadras' os blocos residenciais podem dispor-se de maneira mais variada, obedecendo porém a dois princípios gerais: gabarito máximo uniforme, talvez seis pavimentos e pilotis e separação do tráfego de veículos de trânsito de pedestres, mormente o acesso à escola primária e às comodidades existentes no interior de cada quadra"

Nada aparentemente mais distante do plano para o Cajueiro Seco, que do ponto de vista urbanístico pouco destoa das soluções

${ }^{271}$ Lewis MUMFORD (1982: 542) considera que as Cidades Novas inglesas constituem a maior aplicação do desenvolvimento do princípio de "unidade de vizinhança", ao lado do projeto de Chandigarh de Le Corbusier. A idéia de "unidade de vizinhança" viria a se contrapor à tendência de as relações sociais entre vizinhos se desaparecerem nas grandes metrópoles. Segundo Mumford:

"O princípio de organização de vizinhança era colocar dentro de uma distância percorrível à pé todas as facilidades necessárias diariamente ao lar e à escola, e manter fora dessa área de pedestres as pesadas artérias de tráfego que conduzem pessoas ou mercadorias que nada têm a ver com a vizinhança. Uma vez determinada a distância à pé, como o próprio critério de uma comunidade face a face, seguia-se que nenhum local de folgueiros para as crianças deveria ficar a mais de quinhentos metros das casas a que servia; e o mesmo princípio aplicava-se, com variações, à distância da escola primária e a da área de mercado local. Tanto a população quanto a propagação periférica de tal comunidade eram limitadas, e poderiam ser fisicamente definidas, quer por um sistema de estradas, quer por um cinturão verde, quer por ambas as coisas" (MUMFORD, 1982: 541).

Para Mumford a unidade de vizinhança se fundamentaria por sua vez nas experiências das comunidades suburbanas ${ }^{271}$ (1982: 540), onde muitas vezes "a própria ausência de qualquer estrutura de governo local promoveu a organização de vizinhos (...) o subúrbio resistiu, em alguns aspectos, as antigas idéias de participação democrática e iniciativa local" (1982: 539). Ele conclui então como as inovações do moderno urbanismo, e ainda mais se considerarmos o caso proposto por Le Corbusier para a Cidade Radiosa em que a "unidade habitacional" seria a "unidade de vizinhança", seriam inovações que "deriva(m)-se das inovações tanto físicas quanto sociais feitas no planejamento original do subúrbio romântico" (1982: 542). convencionais de loteamento em terrenos planos e do ponto de vista arquitetônico entrega aos moradores a resolução do programa habitacional nos limites do lote individual.

A proposta do Cajueiro Seco baseou-se na ordenação de lotes unifamiliares de tamanho regular para as famílias, que dividiriam os equipamentos públicos e coletivos indutores de um desenvolvimento possivelmente unifamiliar ou individual. Divididos por um córrego, que concentrava em suas margens quase todos os equipamentos públicos, propunham-se dois grupos de "superquadras", ambas compostas de quadras retangulares com 10 lotes unifamiliares de $8 \times 16$ metros por dois lotes de largura, evitando miolos de quadra e aumentando os espaçamentos entre as construções pela quantidade e largura das ruas.

Embora a região de Prazeres, na qual se localiza o Cajueiro Seco, já viesse sendo ocupada, o plano proposto aparece "ilhado" nos desenhos de implantação, ignorando algumas ocupações pré-existentes e reconhecendo somente a mais significativa, a Igreja do Carmo, antiga proprietária da gleba. Já na representação da situação da área é que fica clara sua inserção na área metropolitana do Recife, suas conexões com o Centro e com o interior e sua posição de pólo de onde partiria o crescimento planejado da nova cidade satélite.

Não há espaço coletivo público no interior das áreas destinadas às habitações, como há em Brasília. O único paralelo possível com a capital federal seria considerar todo o conjunto como uma unidade de vizinhança (possivelmente duas, divididas pelo córrego), racionalmente planejada e contendo em si os equipamentos necessários para a vida na 
comunidade. Formal e conceitualmente, a proposta urbanística experimentada no Cajueiro Seco parece ter mais a ver com o conceito de freguesia proposto pela equipe coordenada por Vilanova Artigas para o Parque CECAP Zezinho Magalhães alguns anos depois do golpe do que Brasília.

Mais uma vez as pontas do processo de urbanização brasileiro se uniam pela teoria e pela retórica. Naquele mesmo momento, a favela recifense que mais se desenvolvia, erguendo a bandeira da resistência, era emblematicamente, Brasília Teimosa. A proposta de Cajueiro Seco era anunciada em artigos da imprensa como uma alternativa para o embate entre a migração de miseráveis e a expansão da cidade que em Brasília Teimosa se materializava de forma insuportável para o recifense médio.

"Visa Cajueiro, sobretudo, evitar novas Brasílias Teimosas, Cais do Areal e os infectos e super-habitados córregos, altos e beiras de maré, onde não existe a mínima condição de higiene e, até mesmo, onde a salubridade é coisa desconhecida." 272

O suplemento Imóveis e Móveis, do conservador Diário de Pernambuco embarcou num certo entusiasmo pelas possibilidades da tal experiência habitacional que marcaria a gestão Arraes em notas como Usuário constrói sua casa, ecoando a condenação aos mesmos agrupamentos de mocambos:

"o novo núcleo residencial de Cajueiro Seco representa um esforço da técnica contra a implantacão de bairros imundos e toscos

272 “Mocambo lança ‘Bossa Nova': Cajueiro Seco” Última Hora Recife, 29/out/1963 como Brasília Teimosa e Cais do Areal, que tanto nos humilham e tão mal falam e gesticulam dos nossos foros de civilização. Cajueiro Seco é o planejamento, o bom senso dentro de linhas humildes (taipa), que mais tarde, à força do tempo, se transformará em bairros apresentáveis, tudo de acordo com a evolução social de nossa gente". ${ }^{273}$

Noticiando entusiasicamente a inauguração do núcleo, o diário Última Hora, em outubro de 1963 anunciou: "Mocambo lança 'Bossa Nova': Cajueiro Seco". Sanear os mocambos, disciplinando sua construção ao planejamento urbanístico seria a alternativa para lidar com a dimensão do problema e com o fato real que nem a moderna técnica e a industrialização conseguiriam se contrapor, especialmente nas condições de subdesenvolvimento do Brasil. "Nem mesmo para a casa pré-fabricada, solução que resolveu angustiantes problemas de habitação noutras nações de desenvolvimento acentuado, poderia mudar o aspecto geral dos mocambos recifenses." ${ }^{274}$

Além da urbanização da área, seriam inaugurados pessoalmente por Arraes, em 27 de outubro de 1963, o "ambulatório médico, centro de produção de sapateiros, lavanderia, posto de revenda da Companhia de Revenda e Colonização, banheiros, sanitários públicos, etc..."275

O papel dos equipamentos e das outras secretarias e instituções públicas, além dos outros campos disciplinares - como as técnicas provenientes da Escola de Serviço Social, foram mencionados por

\footnotetext{
273 "Usuário constrói sua casa" Diário de Pernambuco - Imóveis \& Móveis Recife, 23/nov/1963

274 “Mocambo lança 'Bossa Nova': Cajueiro Seco” última Hora Recife, 29/out/1963

275 "Arraes inagura hoje núcleo de Cajueiro Seco", última Hora, Recife, 27/out/1963
} 
Borsoi, ainda que aparentemente desvinculados de uma política de Estado do governo Arraes.

"Fizemos uma escola, o projeto era de um arquiteto que estava na direção da secretaria de educação, tudo pré-fabricado, era Jorge Martins Jr, que foi meu aluno também, ... Aterramos tudo, fizemos a escola, foi uma revolução." 276

Em junho de 1963 ficaram prontos os galpões nos quais funcionariam a cooperativa de sapatos e roupas e o posto da Companhia de Revenda e Colonização ${ }^{277}$. Borsoi menciona em entrevista também a cooperativa de materiais de construção, num movimento constante entre o projeto, o desejo e as realizações de Cajueiro Seco e outras experiências ao longo de sua carreria:

"Paralelo a isso o centro comunitário criava uma cooperativa com todos os materiais, porque é fácil dimensionar, o cara tinha direito de comprar da comunidade uma cota de materiais (não podia comprar mais portas pra não revender) por preço de custo. Você facilitava a desenvolver a casa dando uma certa liberdade. É o espírito do Cajueiro, que aliás é a favela que você vê no Rio, aquilo cresce da noite pro dia, tudo é tijolo, tudo é pré fabricado, aquele sistema maravilhoso de laje de treliça, antigamente era prel, tijolinho e a explicação de como constrói, aquela coluninha $10 \times 10$ que não sei como... na Rocinha tem prédios de sete pavimentos assim." (Entrevista AGB, Ago/2006)

Comentando a proposta de Borsoi para a pré-fabricação da taipa,

Geraldo Gomes esclarece a distinção entre a política urbana e a arquitetura:

"Em Cajueiro Seco o sistema sugerido por Borsoi era para as casas, os edifícios comunitários foram construídos com a técnica tradicional, não

${ }^{276}$ Acácio Gil Borsoi, Entrevista ao autor, Recife, Ago/2006 277 "Famílias de Cajueiro Seco trabalharão em regime de comunidade" Lornal do
Commercio, Recife 31/mai/1963 tinha nada a ver com pré-fabricação, nada. Lavanderia, mercado, isso foi parte da política definida na época e achavam que o conjunto teria que ter esses serviços, então deram prioridade à isso e construíram antes que as casas. $^{\prime 278}$

Aparentemente, naquele momento mais importante do que a técnica ou a forma da casa eram mesmo os serviços urbanos propostos e construídos:

"Todo o trabalho de urbanização, saneamento, abertura de ruas, meio-fio, deverão estar em fase de acabamento até o dia 15 de Julho (de 1963). Será, inclusive, debatido no Congresso Nacional de Arquitetos, que se realizará naquele mês." 279

A referência ao tal Congresso - o SHRu, como depois confirma o artigo "Plano do Mocambo no Seminário de Reforma Urbana!" nos remete à Artur Lima Cavalcanti, que com sua posição diferenciada de deputado federal, juntamente com seus colegas pernambucanos presentes ao encontro - entre eles os arquitetos Gildo Guerra e Borsoi, tem papel decisivo na redação das conclusões finais do SHRu, que, segundo a última Hora, incluia o próprio Plano de Habitação do Governo do Estado.

Borsoi reconhece as repercussões imediatas da experiência que o levariam à prisão:

"O negócio foi tão explosivo, recebi carta de Israel, da Índia, a Lina publicou na revista dela, Mirante das Artes. O Lacerda mandou a Sandra Cavalcanti incógnita para ver aquilo que tava dando

${ }^{278}$ Geraldo Gomes da SILVA, Entrevista ao autor, Recife, Set/2007

279 “Mocambo constrói casa em tempo récorde (Quatro horas) por CR\$200 Mil apenas", última Hora, Recife, 20/abr/1963. 
repercussão nacional. Teve aquele Congresso da Quitandinha (SHRu) que nós fomos foi uma repercussão explosiva." 280

Do Rio de Janeiro, Artur Lima concedeu à Última Hora um depoimento sobre o projeto de lei da SUPURB que apresentaria à Câmara já em outubro de 1963, explicando em linhas gerais o conteúdo do artigo constitucional. No que tange ao mocambo, expôs aos pernambucanos os mecanismos da política que estava sendo testada no Cajueiro Seco:

"Ao invés da solução demagógica de urbanizar aqueles núcleos miseráveis que nasceram desordenadamente, o próprio governo forneceria o chão para o homem construir a sua casa, através de sistema popularizado como "mutirão". As áreas urbanas desocupadas, uma vez desapropriadas, seriam tecnicamente preparadas, antes de serem entregues às famílias, mediante financiamento a longo prazo e ao alcance de todos. Ali, no pedaço de terra que lhe coubesse devidamente situado num traçado planejado, o homem construiria o seu mocambo ou barraco, tendo ao seu alcance condições essenciais tais como saneamento, transporte, abastecimento, escolarizacão, artesanato e demais serviços urbanos. Sendo proprietário da terra e estimulando por esses benefícios todos aos poucos iriam melhorando a sua habitação de palha, até transformá-la numa casa de alvenaria e telhas. A mesma política, ainda segundo o deputado, poderia ser empregada no que tange à habitação rural." ${ }^{281}$

A nota da repórter que completa a declaração do arquiteto e deputado dá uma pista da natureza social da proposta. Claramente fundada na complexa relação entre a cidade e as zonas rurais, como uma relação sociológica de transição humana de uma à outra. O

\footnotetext{
${ }^{280}$ Acácio Gil BORSOI, Entrevista ao autor, Recife, Ago/2006
}

${ }^{281}$ "Artur Lima: SUPURB será primeira meta para aprovar reforma urbana" última Hora, Recife, 7/out/1963 fenômeno de urbanização das periferias poderia ser antecipado por políticas habitacionais no próprio ambiente rural. Para isso, o projeto do Cajueiro Seco fornecia um exemplo válido. Algo completamente diverso da vida em um apartamento funcional moderno em Brasília, par dialético da crise habitacional, dentro de um arco amplo de situações urbanas e temas que mobilizavam o debate de arquitetos.

Nas festividades da inauguração da primeira parte da experiência do Cajueiro Seco, num domingo, 27 de outubro de 1963, entre diversos oradores, falou Arraes, sintetizando o significado político do conjunto para o seu governo:

"esse entendimento com o povo fez nascer esta vila de mocambos, que não está sendo inaugurada - porque não inauguramos uma obra que ainda vai melhorar e progredir. Colocamos apenas a pedra fundamental de uma obra da política que difere de outras políticas: a compreensão e o debate com o povo. "282

No começo de 1964, Arraes desapropriou a área de Bultrins, próxima a Olinda, terreno particular ocupado por diversos mocambos, depois de entendimentos entre os moradores e Gildo Guerra, representando o SSCM. Ali seria executado um plano "nos moldes do de Cajueiro Seco". Segundo o arquiteto,

"a medida de desapropriação dos "Bultrins" , que está incorporada a outros planos habitacionais do SSCM, significa que o governador Miguel Arraes já iniciou a reforma urbana no Estado" 283

282 “Inaugurada Experiência habitacional de Cajueiro Seco domingo passado” _ornal do Commercio, Recife 29/out/1963

283 "Bultrins: Vitória do Governo sobre o latifúndio urbano" Última Hora, Recife, Jan/1964) 
Cajueiro Seco, pois, mais do que uma experiência projetual ou de mutirão habitacional, surgia como experimento de reforma urbana. A série de artigos que celebram o primeiro aniversário do Governo Arraes publicadas na Última Hora entre Janeiro e Fevereiro de 1964 divulgam entusiasticamente os feitos da sua gestão (Arraes - Ano I), constituiem documentação histórica importante das propostas implementadas assim como, logo após o golpe de 1964, provas incriminadoras da subversão para as novas autoridades locais.

Na semana seguinte à publicação do artigo que destacou as Escolas pré-fabricadas do DOFSP ${ }^{284}$,que foi referido nos inquéritos policiais militares sobre o Departamento, o jornal dedicou algumas páginas ao Cajueiro Seco, abrindo com a manchete "Mocambo ensina à nação - Experiência pioneira de Cajueiro Seco é exemplo nacional" ${ }^{\prime 28}$.Introduzia-se ali o histórico da questão, chamando atenção para a "abordagem do problema da habitação na política atual do Governo, feita sob critério realista, subordinando a ação do Estado a uma orientação de rentabilidade efetiva dos investimentos imobiliários a uma perspectiva social" ${ }^{286}$

$\mathrm{Na}$ matéria "Arquitetos em vez de polícia para resolver as invasões" ${ }^{\prime \prime}$ incluída na série entusiástica ao aniversário da gestão Arraes,

\footnotetext{
${ }^{284}$ Ver item 2 deste capítulo

285 “Mocambo ensina à nação - Experiência pioneira de Cajueiro Seco é exemplo nacional" última Hora, Recife, Jan/1964).

286 "Mocambo ensina à nação" última Hora, Recife, Jan/1964).
}

destacam-se as outras comunidades nas quais o modelo seria generalizado: Sítio das Palmeiras, Totó, Dom Abade, Bultrins e Muribeca. É interessante notar a contraposição do saber técnico do arquiteto à força policial.

"Em todos os casos a ação social da nova política do Mocambo, atuando em seguida a invasões efetuadas por famílias enxotadas, em face de problemas sociais decorrentes da estrutura subdesenvolvida - é aplicada a mesma política experimentada em Cajueiro Seco" ${ }^{287}$

A matéria encerra-se com os pontos fundamentais da Política Social do Mocambo, tal qual divulgados na Revista Arquitetura e incorporados no texto do projeto de lei da SUPURB, como vimos no item 3 do capítulo 1.

Num balanço que o artigo faz, "Cajueiro Seco é acima de tudo uma experiência que caminha bem, uma definição da política de um Governo, um exemplo de auto gestão do povo na solução de seus problemas. O que há de grandioso e revolucionário ali - uma epopéia de trabalho e imaginação - foi apresentado, em tese pelo arquiteto Gildo Guerra, no último Congresso de arquitetos no Sul do país, tendo sido a única comunicação aprovada por unanimidade e sem restrições. Também no último congresso de habitação popular em Buenos Aires, a política do mocambo foi aclamada ${ }^{288}$.

Vale destacar a repercussão internacional da experiência, bem como a sua vinculação neste momento muito mais à figura de Gildo Guerra do que ao arquiteto Borsoi.

A inversão de sentido da política de estado para a habitação é a principal questão, para além das realizações pontuais, o que culminaria

\footnotetext{
287 "Arquitetos em vez de polícia para resolver as 'invasões'" Jan/1964

288 “Mocambo ensina à nação" última Hora, Recife, Jan/1964
}

Última Hora, Recife, 
com a exclusão do termo "Contra" do nome da autarquia, que passaria a se chamar Serviço Social do Mocambo. Gildo Guerra declara em conferência proferida para a Assembléia Legislativa do Estado, explicando a política habitacional e expondo a nova lógica:

"Hoje no pensamento do atual governo do Estado o homem que invade a terra e constrói seu mocambo, o homem que realiza com seu próprio esforço a sua habitação popular, este homem está dando solução a um gravíssimo problema social, está trabalhando em benefício de sua família e merece portanto todo o apoio e ajuda do poder público(...) Fazemos questão de frisar isto: nossa atual política é a do mocambo, e não poderia deixar de ser assim numa cidade onde $2 / 3$ de suas habitações são de mocambos"

Guerra ainda propunha uma revisão no Código de Obras que permitisse a inclusão do mocambo na cidade formal.

O Lornal do Commercio dava espaço também a críticas à política do governo; a preocupacão expressa pelo articulista João Silveira era que o SSCM acabasse por "estimular a criação de novas zonas de mocambos", erro condenável de acordo com seu artigo. ${ }^{289}$ Por outro lado, dava espaço para as diretrizes do plano habitacional do Governo, expresso na Política Social do Mocambo ${ }^{290}$.

Apesar de todas as evidências da vinculação entre a experiência e o projeto político de Arraes, Borsoi insiste no ineditismo da

289 "Muda de um polo a outro a política habitacional do SM" Jornal do Commercio, Recife, 7/abr/1963 e Plano de uma só face do Serviço Social Contra o Mocambo Jornal do Commercio, Recife, 17/ago/1963

${ }^{290}$ SSCM tem política habitacional e não estimula invasões, diz Guerra Jornal do Commercio, Recife, 19/jul/1963 experiência sob todos os aspectos, desvinculando-a de qualquer referência a priori:

"Não tinha programa de governo, não tinha nada, foi o primeiro auto ajuda no Brasil, pode ter existido em outros lugares, porque auto ajuda é a favela, o cara faz sozinho, mas oficialmente nunca se fez, planejando a infraestrutura... Esse negócio de centro comunitário também foi a primeira vez porque lá nós criamos uma comunidade com aquele pessoal, aqueles líderes do movimento Entretanto Agamenon Magalhães já tinha feito uma coisa parecida, os Centro Educacionais Operários, que era um centro social que arranjava emprego, mas era uma coisa assistencialista, não pela autogestão do grupo." ${ }^{291}$

Do reconhecimento de que a principal necessidade do morador do mocambo para além da casa era a terra e o trabalho, Gildo Guerra conclui, na matéria comemorativa do primeiro ano da Gestão Arraes, que Cajueiro Seco representa "a primeira experiência consequente de uma Reforma Urbana", assertiva que o jornal usa para encabeçar a reportagem ${ }^{292}$.

Tal síntese pode representar o exagero precipitado de um arquiteto engajado que logo veria suas melhores expectativas frustradas. Mas certamente dá elementos para que relacionemos a experiência pontual, seus reais significados em termos do direito à cidade e o quadro geral de crise de urbanização no país, que se agudizava nos anos 1960 e certamente não sofreria mudança de rumo muito significativa até o presente.

\footnotetext{
${ }^{291}$ Acácio Gil Borsoi, Entrevista ao autor, Recife, Set/2007

292 "Pernambuco faz Reforma Urbana - Gildo comandou reformas" Última Hora, Jan/1964
} 


\section{2_Experiências de Pré-fabricação em Pernambuco}

Um dos aspectos que articulam historicamente a experiência habitacional do Cajueiro Seco é o investimento na proposta de préfabricação dos componentes construtivos e funcionais da casa. A experiência, neste sentido, relaciona-se diretamente à discussão contemporânea sobre o tema, tanto em Pernambuco, como em outras partes do país e no exterior, e a partir das mais diversas vertentes projetuais e ideológicas.

No plano nacional, diversos arquitetos estavam apresentando suas versões da tal "casa pré-fabricada" ${ }^{293}$ ou de elementos construtivos pré-fabricados para habitação social ou econômica, aproximando a arquitetura do design de componentes. A casa pré-fabricada de Sérgio Rodrigues, exposta no MAM carioca em 1959, fazia uso do sistema construtivo de madeiras pré-cortadas, dentro da tradição norteamericana de construção industrializada e incorporava em painéis no térreo o trabalho de arquitetos pernambucanos como Arthur Lício Pontual e Glauco Campello e o cearense Goebel Weyne, cujo trabalho buscava integrar a arquitetura ao design. Sérgio Bernardes foi outro arquiteto a se engajar no desenho de componentes para a indústria da

293 Uma competente apresentação da história da casa pré-fabricada, tanto do ponto de vista das experiências dos arquitetos nos países desenvolvidos quanto da realidade do consumo de massas nos Estados Unidos é feita por Colin DAVIES em The prefabricated home construção civil, como no projeto para a Eternit de meios tubos de cimento amianto para coberturas planas. (NOBRE,2008)

Também para a mesma indústria, o paulista Carlos Millan projetou e executou nos anos 1960 uma casa inteiramente préfabricada usando o material ${ }^{294}$. Até Oscar Niemeyer se dedicou naqueles anos à concepção de moradias industrializadas para Brasília, cidade que abrigará também as primeiras experiências nesse campo de João Filgueiras Lima, o Lelé, destacando-se entre elas o conjunto de habitações para os professores da UNB, conhecidos como os prédios da Colina.

No projeto das casas de Bernardo Issler, em Cotia, e na de Boris Fausto, no Butantã, em São Paulo, Sérgio Ferro também fez experiências significativas de questionamento das dinâmicas da construção civil e propôs novas organizações da produção da arquitetura, que estariam na base de sua mais importante formulação teórica, o livro $\underline{\mathrm{O} \text { canteiro e o desenho. }}$

No plano internacional, durante o Congresso da UIA em Havana em 1963, a comunidade arquitetônica brasileira e internacional conheceu de perto as realizações da florescente e promissora arquitetura cubana, que a partir da alta tecnologia, subsídio soviéticos e um claro compromisso político, nacionalista e simbólico empolgava os arquitetos com sua versão da arquitetura social pré-fabricada aplicada ao mundo subdesenvolvido. A arquitetura e o subdesenvolvimento

\footnotetext{
${ }^{294}$ Ver Revista Acrópole.
} 
seriam os principais temas do conclave, no qual afloraram as discussões políticas e ficou patente a necessidade de transformações de base para o progresso da arquitetura social.

Em Pernambuco nos anos 60, a euforia em torno da idéia de préfabricação ${ }^{295}$ em arquitetura era veiculada nas páginas de jornais dedicadas à área, nos debates e realizações da arquitetura local e está cristalizada em três exemplos que destacamos aqui, por indicar distintas vertentes e conteúdos ideológicos implicados na construção industrializada: os Grupos Escolares do Departamento de Obras e Fiscalização dos Serviços Públicos do estado de Pernambuco (DOFSP), a Casa Beton e os Quonset Huts.

Da mesma forma que o Cajueiro Seco e a política habitacional do Governo Arraes, os projetos e primeiras realizações de Grupos Escolares pré-fabricados feitos no contexto do DOFSP eram assunto constante nas páginas dos jornais pernambucanos nos anos 60. Com uma agenda política ligada à alfabetização e à conscientização popular, com intensa colaboração do MCP, o Governo Arraes, representado pelo secretário de Educação Germano Coelho, buscava uma solução coerente para o déficit de salas de aula no Estado através

${ }^{295}$ Em um artigo do Jornal Pequeno assinado por Sigrid Von Voss diretamente de Hamburgo sobre Casas pré fabricadas na Alemanha oriental, lê-se que "De um dia para o outro a casa pré-fabricada passou a ser o 'último grito'. Na temporada de 1962 haverá, com certeza, uma alta conjuntura de casa pré-fabricadas que excederá as mais ousadas expectativas dos fabricantes importadores." Jornal Pequeno, Recife, 5-11/ago/1962 da racionalização e industrializacão dos componentes de um grupo escolar padrão.

O DOFSP era naquele momento um órgão com vasta tradição na cultura arquitetônica em Pernambuco. Herdeiro da antiga Repartição de Obras Públicas, criada ainda no goverdo de Rego Barros (1837-1844) e dirigido pelo arquiteto francês Louis Vauthier, a história do órgão dedicado as obras públicas em Pernambuco condensa o ímpeto de políticos, arquitetos e engenheiros empenhados em construir emblemáticas realizações arquitetônicas da cidade do Recife ${ }^{296}$. Desde o Teatro Santa Isabel e o Mercado de São José até o Palácio da Justiça ${ }^{297}$ e a Secretaria da Fazenda ${ }^{298}$, numa longa trajetória de atividades e mudanças institucionais, os projetos do órgão marcam a paisagem do centro da cidade até hoje.

${ }^{296}$ Ver ZANCHETTI, Silvio "Formação e consolidação da Repartição de Obras Públicas de Pernambuco (1836-1844)" Espaço e Debates, No 34, 1991

${ }^{297}$ Projetado nos anos 20 pelo greco-italiano Giacomo Palumbo, o Palácio da Justiça marca o apogeu do ecletismo tardio em Pernambuco, "uma das inúmeras e portentosas aberrações de estilização existentes no Brasil". Baltar,A. Luiz Nunes in Xavier, 2003 p.356, e também o original do texto "O episódio da Pampulha" de Joaquim Cardoso, Xavier, 2003. Para o historiador José Luiz Mota Menezes e Marcílio Reinaux, o Palácio da Justiça, inaugurado em 1930, é indiscutivelmente "o mais belo edifício eclético da cidade". MenEZES, José Luiz Mota e ReInaux, Marcílio O palácio da Justiça Recife: Liceu, 2002

${ }^{298}$ Projetado por Francisco Saturnino de Brito com referência direta ao projeto do MESP carioca, ícone do modernismo nacional. 
Foi no âmbito do Departamento de Arquitetura e Construção $\left(\mathrm{DAC}^{299}\right)$ que se deu a transição para a modernidade arquitetônica capitaneada pelo mineiro Luiz Nunes, produzindo obras expressivas e reconhecidas pela historiografia como o Reservatório d'àgua no Alto da Sé de Olinda, incluído na célebre exposição e publicação Brazil Builds, a Usina higienizadora de Leite, a Escola Rural Alberto Torres e o Pavilhão de verificação de óbitos, posteriormente transformado na sede do IAB local $\left.\right|^{300}$.

De acordo com Baltar, "Ali se reuniu uma primeira equipe de técnicos, artistas e artesãos com arquitetos paisagistas, engenheiros estruturais e condutores de obras, mestres pedreiros, carpinteiros e ferreiros, eletricistas e pintores, atuando em equipe, de cujo trabalho conjunto resultaram as primeiras realizações da arquitetura moderna no Nordeste do Brasil, naquele ano de 1935" (BALTAR in XAVIER, 2003 P.356)

Dela participava o poeta e engenheiro Joaquim Cardozo ${ }^{301}$, que "exerceu uma inapagável influência no progresso cultural de toda a

299 A DAC foi fechada na esteira da repressão à "Intentona Comunista" em 1935 e recriada em 1936 como Departamento de Arquitetura e Urbanismo (DAU).

${ }^{300}$ Segundo Geraldo Gomes, a obra do pavilhão foi realizada a partir das sobras das outras obras do DOFSP por Ayrton Carvalho, que colaborou com o Departamento, assim como seus colegas de turma da escola de engenharia Pelópidas Silveira e Antônio Bezerra Baltar. (Silva, Entrevista set/2007). Ayrton Carvalho seria também o mais longevo diretor da secretaria regional do IPHAN, atualizando no bojo do órgão a vinculação entre vanguarda da arquitetura moderna e a questão do patrimônio que estava na base da arquitetura carioca e na pessoa de Lucio Costa.

${ }^{301}$ Estranhamente, o original do texto "O episódio da Pampulha" de Joaquim Cardoso, teve o trecho sobre o "movimento de agitação criadora" em torno de Luiz Nunes que se dava no Recife em 1935 excluído da edição em Xavier, A. Depoimentos de uma Geração São Paulo: Cosac Naify, 2003 equipe" renovando elementos estruturais, de vedação e de circulação, como lajes cogumelo e mistas, "redescobrindo" o cobogó e dando "nova concepção funcional" para rampas e escadas "realmente novas, com equilíbrio e mesmo com uma certa audácia". Depois da morte de Nunes em 1937 e do Estado novo, a diretoria de obras voltou à "rotina anterior". Joaquim Cardozo se tornaria o principal engenheiro estrutural de Oscar Niemeyer, calculando os edifícios da Pampulha e de Brasília. (BALTAR IN XAVIER, 2003 P.357)

Não é difícil supor que a Diretoria também fosse um lugar estratégico dentro do governo do estado que poderia ser mais uma vez "renovada" com a ascensão de um governo com outros compromissos e plataformas.

Na gestão Arraes, quem assumiu a direção do DOFSP foi o arquiteto Jorge Martins Jr, formado no fim dos anos 50, nas primeiras turmas do curso de arquitetura da Universidade do Recife. Juntamente com os colegas de turma Glauco Campello e Arthur Lício Pontual, forma o atelier 415, do qual também fazia parte o designer Aloísio Magalhães.

Glauco Campello foi para Brasília trabalhar com João Filgueiras Lima enquanto Magalhães e Pontual trabalhariam nos anos 1960 e 70 no Rio de Janeiro, colaborando ativamente para a criação da Escola Superior de Desenho Industrial (ESDI), que materializava o última formulação do projeto concretista no Brasil (NOBRE, 2008), na véspera do Golpe de 1964 e dos questionamentos neoconcretos. 
Antes deles, no entanto, a oposição ao rígido funcionalismo da ESDI, derivado em parte da Escola de UIm e estimulado pela personalidade política de Lacerda, estava colocada pela atuação de Lina Bo Bardi no Nordeste, buscando uma resposta ao "tecnicismo e à racionalidade programática" (NOBRE, 2008, p. 77) através da cultura popular e da valorização do artesanato. ${ }^{302}$

No diário pernambucano Lornal do Commercio , o advogado, poeta e designer Gastão de Holanda fez um perfil de Jorge Martins Jr. acompanhando de uma entrevista, na qual o arquiteto realizou um balanço sintético da crise na arquitetura brasileira:

"A arquitetura atual brasileira reflete perfeitamente seu aspecto sócio-econômico. É fruto de um desenvolvimento rápido e desorganizado. Há, entretanto obras de boa qualidade arquitetônica e plástica incalculáveis, que são o resultado de tradições artísticas que nunca foram brasileiras por formação e sim por hábito.(...) A solução é bilateral, a arquitetura deve ir no encontro do povo e este elevar seu padrão social, compatível com a dignidade da vida humana" ${ }^{1303}$

A solução mutuamente engajada proposta por Martins Jr ecoava as proposições de encontro entre os setores populares e os intelectuais e técnicos como alternativa à desorganização do desenvolvimento brasileiro, presente também no MCP.

${ }^{302}$ Ver ANELLI, Renato Interlocuções com a Arquitetura Italiana na Constituição da Arquitetura Moderna em São Paulo Livre Docência São Paulo USP, 2001 e BARDI, Lina Bo. Tempos de grossura: o design no impasse. São Paulo: Instituto Lina Bo e P.M. Bardi, 1994.

${ }^{303}$ HOLANDA, Jorge Martins Jr e a arquitetura 6/out/1963
O projeto dos Grupos Escolares pré fabricados elaborado pelos arquitetos Gildo Montenegro e Maria Lucia Athaíde, funcionários do escritório público de arquitetura do DOFSP, foi apresentado ao público numa exposição na Galeria de Arte do Recife, situada na beira do Rio Capibaribe, na área central da Cidade. O sistema construtivo em concreto armado consistia em postes em seção $\mathrm{H}$, em cujas ranhuras deslizavam placas maiores ou menores, de peso compatível com a montagem manual.

Em 7 de julho de 1963, o Lornal do Commercio anunciou a montagem da primeira cobertura do edifício pré-moldado em menos de 60 minutos, tendo Arraes e o presidente do SSCM, Gildo Guerra, como testemunhas. Além do baixo custo (projetado em $40 \%$ mais barato do que os grupos convencionais) e da rapidez da montagem na obra, a inovação do sistema estrutural para as coberturas das escolas era sua adaptabilidade aos materiais complementares encontrados nas diversas cidades do estado nas quais os grupos seriam construídos:

“O material a ser aplicado na cobertura do vão, sobre as treliças metálicas, poderá ser de cimento amianto, madeirita (sic), alumínio, chapas galvanizadas ou mesmo telhas de barro." ${ }^{304}$

A construção toda ficaria pronta em 45 dias e custaria metade do sistema então convencional de alvenaria, que demandava 120 dias de obra. Além disso, a ausência de revestimentos e pinturas no concreto aparente minimizaria os custos de manutenção.

${ }^{304}$ Lornal do Commercio, Recife, 7/jul/1963 
Em outubro de 1963, o primeiro dos grupos escolares foi entregue à população do município de Paulista e o jornal última Hora propalava em manchete a "revolução do pré-fabricado". Ao distribuir as obras da secretaria pelo interior do Estado com um edifício modular necessário a praticamente todos os municípios, Jorge Martins Jr. e sua equipe marcaram sua gestão à frente do DOFSP ${ }^{305}$. Dez outros grupos já estavam em construção, um deles no Cajueiro Seco, que, segundo Borsoi, foi destruído pela intervenção militar no local na ocasião do golpe.

No entanto, numa das escolas do bairro, justamente a edificada no local previsto para o Grupo Escolar no "Plano Piloto", encontram-se ainda hoje algumas paredes e pilares do sistema proposto pelo DOFSP, denotando a permanência da estrutura pré-fabricada sob sucessivas reformas e ampliações ${ }^{306}$.

Segundo Jorge Martins Jr, 'o que nos levou a idéia da construção estatal a base de pré-fabricados feitos industrialmente foi a necessidade de manter um melhor nível de qualidade nas construções e edificando em um menor espaço de tempo, especialmente no interior do Estado, onde a carência de materiais cerâmicos de boa qualidade, além das deficiências de mão de obra, são evidentes ${ }^{\prime \prime 307}$

As análises de Martins Jr. da experiência e das condições para a arquitetura brasileira são interessantes ao retratarem determinadas posições dos arquitetos em face das contradições da "fase heróica da

\footnotetext{
305 "Governo leva arquitetura até o campo" Última Hora, Recife, out/1963

${ }^{306}$ MARTINS JR, Última Hora, Recife, out/1963
}

arquitetura moderna brasileira", revelarando a crença ainda vigente no desenvolvimento, na técnica e na arquitetura como instrumentos de transformação da sociedade.

"O arquiteto brasileiro aspira uma maior participação no processo de desenvolvimento do país. Recusa-se a continuar sendo o objeto de luxo cuja atividade restringe-se ao atendimento dos setores privilegiados da sociedade. Sabe que permanecer nesta posição marginal significa castrar o sentido social da profissão e o seu aspecto cultural mais importante: refletir materialmente o ser do povo" ${ }^{\prime 308}$.

Curiosa e emblemática é a articulação entre a realidade brasileira e o contexto da Guerra Fria, na abordagem destas experiências pioneiras de pré-fabricação de edifícios escolares. Partindo do reconhecimento da realidade nacional do subdesenvolvimento, Martins assim justificou uma pesquisa tecnológica socialmente orientada:

"Na realidade, não nos situamos numa fase de desenvolvimento que faz imperativo o sistema de pré-fabricação. Internacionalmente este se justifica segundo três fatores: 1) escassez de mão de obra, portanto elevado custo salarial e especialização artesanal, como acontece nos Estados Unidos 2)um parque industrial desenvolvido, como também ocorre na América do Norte 3) necessidade de cumprir um programa intensivo e a curto prazo de construcões para eliminar um "déficit" habitacional, como na União Soviética(...) O sistema pré-fabricado que apresentamos é válido para nós porque tivemos, antes de mais nada, a sensibilidade do real. Não dispomos de verbas para adquirir maquinaria pesada, temos sobra de mão de obra não qualificada e não dispomos de um parque industrial local ainda satisfatório. Os elementos pré-moldados foram estudados levando em conta o "homem", sua força física e capacidade técnica. Eles são leves e de pequenas dimensões, seus encaixes são simples e corriqueiros, a matéria prima é local (cimento, pedra e ferro). O desenvolvimento econômico e técnico abrem ao arquiteto um novo horizonte histórico: resolver funcional e esteticamente, uma nova realidade técnica e social e criar uma nova

${ }^{308}$ Diário de Pernambuco, Imóveis \& Móveis, Recife 11/dez/1963 
linguagem arquitetônica e humana para a época em que o arquiteto entregará sua obra ao desfrute de toda sociedade " 309

O projeto e as imagens da obra do primeiro dos Grupos escolares pré-fabricados em Paulista foram publicados na edição de outubro de 1965 da prestigiosa revista Arquitetura, do IAB/GB, inteiramente dedicada à questão da pré-fabricação. A capa desta edição consiste justamente numa imagem de uma janela inserida no painel-módulo do sistema de taipa proposto por Borsoi, que também é objeto de matéria na mesma edição como uma experiência surgida a partir do contato “com os grupos que construíram suas casas, segundo o processo de auto ajuda nos lotes do conjunto de Cajueiro Seco $^{\prime \prime 310}$. O foco aí é tão somente o processo de racionalização da taipa, tal qual na publicação Prefabrication: Taipa, elaborada pelo escritório de Borsoi e posteriormente apresentada em concurso internacional na Holanda já nos anos 70 .

Outro projeto ali publicado, entre diversos artigos técnicos sobre pré-fabricação foi o da Escola primária e refeitórios de operários para fábrica de tecidos Lanari S.A. ${ }^{311}$, cujo sistema construtivo baseado em postes e painéis pré-moldados com amplas coberturas sustentadas por treliças metálicas aparenta ser uma sofisticação do sistema que foi utilizado nos Grupos pré-fabricados pernambucanos, assim como as

\footnotetext{
${ }^{309}$ Diário de Pernambuco, Imóveis \& Móveis, Recife 11/dez/1963

310 "Pré-fabricação em taipa" in Arquitetura IAB/GB, No 40 Out/1965

${ }^{311}$ Arquitetura IAB/GB, No 40 Rio de Janeiro: Out/1965
}

plantas longilíneas em torno de páteos semi-abertos, conectadas por circulações avarandadas presentes nos equipamentos propostos para Cajueiro Seco. Não custa lembrar que Flávio Marinho Rêgo, figura central do IAB e próxima à Borsoi desde a formação comum no Rio de Janeiro, era pernambucano e consta como um dos colaboradores da experiência de Cajueiro Seco ${ }^{312}$.

Enquanto os jornais de esquerda divulgavam com entusiasmo as realizações do governo Arraes, tanto as páginas de arquitetura quanto a propaganda comercial do Diário de Pernambuco alardeavam o Plano Revolucionário de Casas Pré-fabricadas e a existência de um protótipo de casa padrão industrializada na Av. Conde da Boa Vista, no centro do Recife, que servia como stand de vendas da Casa Beton, kit habitacional montável em poucas horas passível de ser utilizado em contextos diversos, na praia, no campo ou na cidade. Lançada por uma empresa privada, a Beton construção, comércio e indústria Ltda. que se propunha inclusive a "solucionar o problema habitacional", a casa seria entregue em 30 dias, mais barata e de melhor qualidade do que as casas de alvenaria, com padrão de acabamento normal ou especial, de acordo com "o orçamento de cada pretendente". Segundo seus promotores, Célio Schwartz e os irmãos Júlio e Marleno Singer,

\footnotetext{
312 "Política Social do Mocambo" in Arquitetura N No 13, Rio de Janeiro: IAB-GB , 1963 E "Cajueiro Seco, uma experiência em construção" in Arquitetura № 16, Rio de Janeiro: IAB-GB, 1963
} 
sensíveis também ao problema educacional, o módulo poderia ser até convertido em sala de aula. ${ }^{313}$

A comercialização dos kits e dos serviços necessários à implantação da casa Beton era feita por uma imobiliária associada à empresa construtora, que providenciaria também terreno livre em algum dos seus loteamentos, caso o interessado já não dispusesse de lote próprio. O valor da casa seria dividido em "pequena entrada" e "suaves mensalidades", ficando clara a estratégia de vender além da "revolucionária" moradia outros produtos como a terra em algum subúrbio e o crédito imobiliário, se apropriando para isso do discurso tanto da técnica construtiva industrializada quanto da crise habitacional.

Do ponto de vista arquitetônico, pelo material gráfico apresentado, podemos depreender que tal sistema construtivo era aparentado ao da patente inglesa das Casas Uniseco, importada para o Brasil nos anos 50 pelas mãos e iniciativa do arquiteto Eduardo Knesse de Mello, que aliou a empolgação com o sistema conhecido numa viagem à Inglaterra à incipiente demanda brasileira por construções rápidas, simples e relativamente baratas para fundar a Uniseco do Brasil $^{314}$.

313 "Plano Revolucionário de Casas Pré-fabricadas" Diário de Pernambuco, Recife, 13/out/1963

${ }^{314}$ A UniSeco realizou alguns protótipos e alguns conjuntos de casas mas

acabou falindo, por razões melhor discutidas no trabalho de MONTENEGRO, 2007, levando o arquiteto a uma difícil situação financeira por fazer questão de cobrir as garantias sobre as casas produzidas.
Outra matriz de pré-fabricação presente em Pernambuco no período, assim como em outras partes do mundo, como o Alaska ou o Uruguai, era o célebre galpão militar americano conhecido como Quonset Hut. Desenhados a partir dos Nissen Huts ingleses, que já haviam provado sua eficiência na Primeira Guerra Mundial, os Quonset huts foram projetados para abrigar tropas em qualquer lugar do mundo, sob as mais mais diversas condições climáticas com um padrão mínimo de conforto.

Em tempos de paz, os Quonset Huts foram adaptados a diversos outros programas, como habitação social, igrejas, mercados ou ginásios e distribuídos na forma de "ajuda" a vários países sob a influência norte-americana, como o Brasil. A diáspora dos espólios da guerra e de seus aparatos militares convertidos em objetos de uso cotidiano é analisada no livro Quonset Hut: metal living for a modern age. Ali se conta a história do abrigo, que de solução militar utilitária passou a imagem de ícone da ideologia americana do após Segunda Guerra, tal como a Coca-cola ou o Cadillac.

O suplemento Imóveis e Móveis, do Diário de Pernambuco destacou em sua capa da edição de 4 de dezembro de 1963 a inauguração da Escola de Polícia, construída rapidamente a partir de apoio técnico americano e da combinação de módulos dos Quonset Huts. Nessa época, estabelecia-se a prática de planos de cooperação técnica com o governo norteamericano na área de segurança pública, que até hoje promove intercâmbios de policiais e agentes dos dois países para treinamento. 
"Conforme o prometido, o governo americano doou o material dos galpões e o governo do estado, além de proceder as instalações hidráulicas e elétricas doou o terreno(...)Os 12 prédios pré-fabricados, de alumínio laminado, foram distribuídos em cerca de 1.700 metros quadrados, pouco tempo depois, estava funcionando a escola de polícia de pernambuco. Para quem não conhece, "por dentro", a escola, a impressão é de que é impossível se viver nas casas pré-fabricadas. Protegidas com material especial junto ao teto e cobertura e revestidas, internamente, de material acústico, as casas (ou pavilhões) da escola de polícia representam o que de mais prático, econômico e moderno existe em construção" ${ }^{315}$

Em algumas imagens do Cajueiro Seco publicadas nos jornais da época, aparece ao fundo o edifício do ambulatório, também em forma de abóboda, feito de cimento amianto (material popularmente conhecido pelo nome dos seus maiores fabricantes, Brasilit ou Eternit). Embora a coincidência nos leve a supor que se trata de mais um dos Quonset Huts, exportado ao país em tempos de Aliança para o Progresso e $\mathrm{IBAD}^{316}$, precisamos atentar para as diferenças de materiais e modos de produção, mantendo a referência formal e ideológica aos galpões militares norteamericanos promovidos a modelos de casa popular industrializada $^{317}$.

315 Diário de Pernambuco, Imóveis \& Móveis, Recife, 4/dez/1963

${ }^{316}$ Sobre a "cooperação" internacional e a "ajuda" americana, ver o item 7 do capítulo 2

${ }^{317}$ Do ponto de vista meramente formal, tais galpões em forma de abóbadas

aplicados à habitacão popular podem evocar as propostas da Arquitetura Nova sintetizadas no mestrado de Rodrigo Lefèvre. Mas basta analisar o modo de produção para situar as distintas experiências em pólos ideológicos diametralmente opostos, apontando para a necessidade de uma leitura das proposições projetuais integrada nas condições produtivas e no seu ambiente cultural.
Os moradores remanescentes daquela época ao serem entrevistados referem-se ao "posto de saúde" feito de "telha brasilit" que permaneceu ali até os anos 80, até ser demolido e ter suas atividades médico-dentárias transferidas para o hospital construído em terreno contíguo à gleba do Cajueiro Seco. O lote foi ocupado posteriormente por uma nova família ${ }^{318}$, já que a construção havia sido implantada num lote de habitação e não no espaço destinado aos equipamentos, uma vez que o edifício era na realidade uma experiência de casa pré-fabricada.

Trata-se na verdade da principal experiência de casa préfabricada testada no Cajueiro Seco que pode estar ligada à implantação da fábrica da Brasilit ${ }^{319}$ no Recife naqueles anos. A questão que se coloca é saber qual é a razão que teria levado ao descarte deste modelo de casa e ao desenvolvimento da pré-fabricação em taipa.

É claro que a casa pré-fabricada em chapas curvas de fibrocimento não se adaptava à dinâmica da autoconstrução e da ajuda mútua nem ao crescimento progressivo da casa como metáfora para a integração do indivíduo e sua família à sociedade urbana. Além disso,

\footnotetext{
${ }^{318}$ Entrevistas com moradores ao autor, Jaboatão, setembro de 2007

${ }^{319}$ A implantação da fábrica da Brasilit no Recife, a partir de 1949, é significativa do ponto de vista de vários dos "subdesenvolvimentos" da economia brasileira: a empresa, de capital francês, recebeu incentivos da Sudene através da Lei 34/18, mecanismo analisado por Francisco de Oliveira em Elegia para uma re(li)gião e acabou dando o nome à favela contígua à fábrica, onde moram parte de seus operários. Enquanto isso, a publicidade da empresa se empenha em demonstrar seu envolvimento na solução da habitação social, desenvolvendo produtos e materiais novos para a construção civil, que receberiam incentivo através das políticas do $\mathrm{BNH}$.
} 
tinha um custo mais elevado do que a taipa, por mais barata que fosse em relação à construção de alvenaria, dita convencional.

Mas além desses pontos objetivos, podemos supor que tal negação da pré-fabricação "convencional", tal qual formulada e estimulada pelas vertentes construtivas ligadas à Bauhaus, à Escola de Ulm, a ESDI ou à FAU USP ecoasse uma resposta alternativa ao nacional-desenvolvimentismo, muito influente no Nordeste, que partia do pressuposto de que os problemas regionais precisavam ser enfrentados a partir de soluções regionais, ainda que modernizadas. Ou antes, da hipótese de que era possível pensar o desenvolvimento da referência ao saber popular acumulado. Talvez essa opção se ancorasse em premissas culturais semelhantes àquelas propostas por Lina Bo Bardi acerca das relações entre o pré-artesanato nordestino e os impasses nacionais do design ${ }^{320}$.

Na exposição Nordeste, por ela realizada no Solar do Unhão, depois de sua conversão em Museu de Arte Moderna da Bahia e na Escola de Desenho Industrial ali idealizada em consonância com o programa da Sudene para a cultura popular, a proposta parecia enraizar-se institucionalmente na região.

Devemos lembrar que foi nesse momento que Borsoi conheceu Lina, em visita ao Cajueiro Seco, interessada principalmente nas oficinais de artesanato que ali se implantariam ${ }^{321}$. Não nos parece

\footnotetext{
${ }^{320}$ Ver BARDI, 1994, op. cit.

${ }^{321}$ Acácio Gil BORSOI Entrevista ao autor, Recife, set/2007
}

descabido supor que as diferenças entre os dois modelos de préfabricação presentes nas casas-tipo do Cajueiro Seco remontavam à polêmica entre o projeto construtivo ou o "novo idealismo tecnocrático" (NOBRE, 2008 p.78).

As críticas à sociedade e produção capitalista despontavam em diversos campos da cultura, como no manifesto neoconcreto, nas exposições organizadas por Lina Bo Bardi e no cinema novo, que serviria de inspiração para a poética economia da Arquitetura Nova. (KOURY, 2005)

Outros projetos contemporâneos a Cajueiro Seco realizados por Borsoi nesse período podem ajudar a ilustrar e problematizar a importância específica do projeto da taipa pré-fabricada. Logo que voltou da viagem de estudos que fez à Europa em 1960, comissionado pelo Itamaraty, o arquiteto envolveu-se em um outro trabalho que se tornaria célebre por sua integração com o meio construído e como exemplo de integração com o patrimônio histórico do centro do Recife: o projeto e obra do Edifício Santo Antônio, no terreno do Convento de Santo Antônio, em 1962.

Para além da integracão com as "pré-existências ambientais", interessa destacar esta realização arquitetônica porque nela o arquiteto desenvolveu uma relação especial com a obra: além de coordenar o canteiro e a produção dos seus elementos, Borsoi desenhou componentes pré-fabricados leves para o expressivo brise soleil da fachada voltada para à Avenida Dantas Barreto, que reinterpretam o tradicional Cobogó pernambucano, atualizando sua produção e 
possibilidades expressivas. A interpretação da idéia de pré-fabricação aqui tem a ver com a ação do redesenho de um elemento tradicional adaptado a novas possibilidades construtivas e formais, mantendo a função arquitetônica.

No Edifício Santo Antônio o que vemos é uma sofisticação do design de componentes pré-fabricados, mobilizando uma indústria e um saber pré-existente, tanto construtivo quanto propriamente arquitetônico. A expressão moderna reflete sua ligação com arquitetura colonial brasileira e uma interpretação da tradição que tem a ver com a formulada por Lucio Costa, amigo pessoal e "mestre" de Borsoi.

O Edifício Guajirú, um dos mortos listados no "Obituário Arquitetônico" da arquitetura modernista pernambucana, também foi um exemplo paradigmático da arquitetura de Borsoi naqueles anos, no que tange às aproximações da arquitetura com a industrialização. Realizado em parceria com seu ex-aluno Vital Pessoa de Mello, o projeto de 1963, construído na Avenida Boa Viagem, constituía um pequeno edifício para moradia dos membros de uma mesma família, distribuída entre os seis apartamentos. Salta aos olhos a solução simples de pré-fabricação adotada, com a expressão aparente do concreto rústico e do tijolo cozido, próxima do neoempirismo escandinavo ou do retorno de Le Corbusier ao vernacular, como nas Maison Jaoul, de 1952-56, cujas ressonâncias foram sentidas imediatamente no conjunto Ham Common, de James Stirling em todo o mundo e no trabalho alguns arquitetos paulistas de sua geração.
A expressão da idéia de pré-fabricação, que Borsoi faz aqui, pode ser aproximada à arquitetura paulista. No Edifício Guajiru vemos a típica racionalização do projeto, feito a partir da coordenação modular e dos elementos e materiais de mercado, nos mesmos termos das práticas projetuais de diversos paulistas como Joaquim Guedes e Carlos Millan ${ }^{322}$.

É importante atentar para o envolvimento direto do arquiteto no canteiro, aproximando a atividade de Borsoi nesses anos às práticas e realizações de outros arquitetos como Lina Bo Bardi, Sérgio Ferro, Flávio Império e Rodrigo Lefevre, que acreditavam na presença do arquiteto na obra como medida para a reaproximação do pensar e do fazer da arquitetura, etapa essencial para a configuração de uma prática mais adequada ao estágio de desenvolvimento nacional. Tal proposição não nos parece despropositada especialmente se temos em mente a idéia de uma "arquitetura construtiva" ${ }^{323}$, tal qual formulada por Ana Paula Koury. Para além das escolas regionais, certas arquiteturas produzidas nos anos 1960 interessam por operar entre uma poética construtiva e os desafios da produção em massa. (KOURY, 2005)

A manufatura serial materializada na Casa de Cotia, de Sérgio Ferro, no uso dos materiais corriqueiros de maneira inovadora como

\footnotetext{
${ }^{322}$ Ver as monografias de Mônica Junqueira de Camargo sobre ambos: J Joaquim Guedes São Paulo: Cosac Naify, 2002 e Carlos Milan, no prelo.

${ }^{323}$ KOURY,A. Arquitetura construtiva: Proposições para a produção material da arquitetura contemporânea no Brasil Doutorado FAU-USP São Paulo: FAU USP, 2005
} 
nas abóbodas das casas de Rodrigo Lefevre transcendem o aspecto construtivo ao buscar uma nova organização do canteiro e seu correspondente par formal (ARANTES, 2002).

Em entrevista ao autor em setembro de 2007, Borsoi enfatiza seu reconhecimento e pela admiração da simplicidade dos materiais e processos de auto-ajuda adotados na construção das favelas, aproximando-se por vezes do discurso da dita escola paulista, da qual sempre fez questão de se distinguir, frequentemente por oposição.

A interpretação talvez mais radical que Borsoi vai fazer do tema da pré-fabricação está no projeto da casa de taipa pré-fabricada proposta para o Cajueiro Seco, no qual não só os componentes da construção são redesenhados para adaptar-se à produção comercial mas a própria idéia de indústria foi reproposta. A racionalidade arquitetônica é usada para propor uma nova indústria baseada nos princípios do cooperativismo, num movimento que aproximava as duas instâncias - economia e produção da casa, linha que foi desenvolvida posteriormente nas pesquisas de vários arquitetos ligados à FAU USP.

Lidando com a massa de trabalhadores informais, distantes do "operário-padrão", que não conheciam os instrumentos e ferramentas do trabalho da construção convencional, Borsoi atuou no redesenho do processo produtivo da taipa, devolvendo o saber fazer com o qual os invasores do Monte dos Guararapes podiam contar e lhes oferecendo a possibilidade de desenhar suas próprias casas a partir de um número reduzido de componentes modulares à disposição na cooperativa de materiais do conjunto.
Ao longo das diversas referências, que nos fazem pensar na fluidez com que os discursos migram entre práticas construtivas e projetos arquitetônicos diversos, o vínculo entre pré-fabricação e a arquitetura transformaram a experiência do Cajueiro Seco em um caso paradigmático, seja quando analisada à luz do intenso debate local sobre a pré-fabricação e a função social da arquitetura no período, seja quando confrontada com as complexas mediações políticas, culturais e institucionais que a restringem historicamente.

A experiência de Cajueiro Seco tem sua importância também por esboçar uma alternativa ao desenvolvimento industrial taylorista, ainda que restrita ao campo das idéias, como notou o arquiteto Geraldo Gomes da Silva, hoje talvez o principal pesquisador pernambucano acerca do tema da pré-fabricação e da arquitetura moderna local, colaborador tanto do DOFSP quanto do SSCM:

"A industrialização da arquitetura, essa utopia da casa como automóvel, não aconteceu em lugar nenhum; aconteceram exemplos esparsos, tímidos, de industrialização, alguns componentes, mas a arquitetura como produto industrial eu não conheço.(...) Então a préfabricação nunca houve, é um sonho que os arquitetos perseguem há muito tempo." ${ }^{324}$

${ }^{324}$ Geraldo Gomes da SILVA, Entrevista ao autor, Recife, Ago/2006 


\subsection{Borsoi e a arquitetura moderna em Pernambuco}

É recorrente na historiografia a explicação do fenômeno da arquitetura moderna pernambucana pelo aporte teórico, acadêmico e prático de arquitetos de fora - o italiano Mario Russo e principalmente o português Delfim Amorim e o carioca Acácio Gil Borsoi, que migraram para o Recife entre finais da década de 1940 e o começo dos anos 1950, para integrar o quadro de professores da Faculdade de Arquitetura da Universidade do Recife. A questão postulada por Bruand acerca da existência de uma "Escola do Recife" ainda reverbera nos debates e pesquisas acerca da produção local. Para além do "episódio de Luiz Nunes ${ }^{325 ",}$ caberia a Amorim e Borsoi o papel de "portadores da mensagem moderna" que inaugura a tal linha projetual.

"As bases para o surgimento da escola do Recife teriam sido, portanto das idéias de [Lucio] Costa, adaptadas ao contexto local, principalmente através da contribuição sistemática de um educador de sólida formação cultural - Amorim, com os aspectos próprios do local, além da natural contribuição de diversos arquitetos de excepcional qualidade ${ }^{326}$. Nas palavras de Bruand, 'é cedo demais para se falar de uma

${ }^{325}$ Parte da produção historiográfica desenvolvida sobre Pernambuco concentra-se no período que o arquiteto mineiro Luiz Nunes, formado na Escola Nacional de Belas Artes, implantou o Departamento de Arquitetura e Urbanismo e al desenvolveu projetos como o Pavilhão de Verificação de Óbitos (hoje sede do IAB local) e o Reservatório de Água do Alto da Sé em Olinda (1936), obra incluída no célebre Brazil Builds. Há quem argumente que está ali uma raiz da arquitetura moderna brasileira. Marques, S. Naslavsky, G. "Eu vi o modernismo nascer... e ele começou no Recife" in MOREIRA (org.) 2007 Ver principalmente CARDOZO,J. Dois episódios - Pampulha e o DAU e BALTAR, A Luiz Nunes in Xavier, A. 2003

${ }^{326}$ A obra de Delfim Amorim é de fato de qualidade e merece ser melhor analisada tarefa que não cabe aqui e tem sido desenvolvida por pesquisadores recifenses verdadeira escola do Recife, homogênea e original, mas é evidente que esta possibilidade não pode excluída'" (AMORIM, 2001 ${ }^{327}$ )

Acácio Gil Borsoi chegou ao Recife em 1951, indicado por Lucas Mayerhoffer para assumir a cátedra de Grandes Composições na Faculdade de Arquitetura da então Universidade do Recife. Formado em 1949 na Faculdade Nacional de Arquitetura, no Rio de Janeiro, Borsoi havia trabalhado como estagiário de Reidy nos projetos dos conjuntos do Pedregulho e Marquês de São Vicente e também com Alcides da Rocha Miranda no Serviço do Patrimônio, o que the aproximou tanto de Mayerhoffer quanto de Lucio Costa.

Outra experiência importante na sua formação profissional foi o trabalho nas marcenarias com o pai, imigrante italiano formado no Liceu de Artes e Ofícios de São Paulo, que havia executado os interiores da Confeitaria Colombo, o Palácio da Guanabara e o Café Assírio, no subsolo do Teatro Municipal do Rio de Janeiro.

Logo que chegou ao Recife, Borsoi recebeu algumas encomendas de residências unifamiliares, como a de Lisanel de Melo Mota. Os contatos com este cliente e principalmente com Pelópidas

como Luiz Amorim, Geraldo Gomes da Silva e Guilah Naslavsky. Amorim opera na interessante síntese projetual que relaciona modernidade e tradição, empenhandose também no ensino e na consolidação da estrutura curricular da Faculdade de Arquitetura da Universidade do Recife, onde atuou como professor de Pequenas Composições. Ver Instituto de Arquitetos do Brasil Delfim Amorim, Arquiteto Recife: IAB-PE, 1991, NASLAVSKY, 2004 e diversos artigos de Luiz AMORIM e Geraldo Gomes da SILVA.

${ }^{327}$ AMORIM, Luiz Escola do Recife: três paradigmas do objeto arquitetônico e seus paradoxos São Paulo: Vitruvius, 2001

Disponível em: http://www.vitruvius.com.br/arquitextos/arq012/arq012_03.asp 
Silveira, também engenheiro e professor, que se tornaria prefeito da cidade em algumas ocasiões, é que teriam franqueado a Borsoi as possibilidades de realizar na região central da cidade obras de grande importância, como os Edifícios União (1953), Caetés (1955) e Amazonas (1958), além do Hospital de Pronto Socorro (hoje da Restauração) $)^{328}$ no Parque Amorim e do Edifício Califórnia (1953), um dos primeiros da orla de Boa Viagem (NASLAVSKY, 2004).

O Conjunto de residências da Praça Fleming (1954), construído para o Banco Hipotecário Lar Brasileiro, também constituem ${ }^{329}$ um importante exemplo da primeira fase da arquitetura de Borsoi no Recife, que é recorrentemente entendida pela historiografia de arquitetura como rebatimento dos preceitos da Escola Carioca na qual se formara ou da arquitetura internacional ${ }^{330}$, talvez ainda hermética ao local.

${ }^{328}$ Projeto em parceria com o arquiteto Paulo Magalhães e Ayrton da Costa Carvalho, engenheiro chefe da Regional do SPHAN e também professor da escola, que havia cedido uma sala na repartição para Borsoi montar seu escritório, assim como faria com Delfim Amorim, outra figura central da arquitetura recifense daqueles anos.

${ }^{329}$ Ver Luiz AMORIM, Obituário da arquitetura - Pernambuco Modernista 2007 e Naslavsky, G. e Amaral, I. Praça Fleming: um conjunto residencial orgânico? São Paulo Vitruvius, 2003

Disponível em http://www.vitruvius.com.br/arquitextos/arq000/esp190.asp

330 "O traçado urbano e livre da Praça Fleming tem relações diretas com a obra de Lúcio Costa no Parque Guinle (1947) e com a reconstrução do segundo pós-guerra europeu, não só devido à contemporaneidade aos novos bairros ingleses, escandinavos e suecos, mas também devido à ausência de outros modelos de conjuntos habitacionais semelhantes" (NASLAVSKY, 2004, p.94)
Embora seja possível reconhecer elementos e soluções nesses primeiros projetos que possam ser aparentados de alguns célebres projetos cariocas com que Borsoi teve contato como estudante no Rio de Janeiro como o Pedregulho de Reidy e o Parque Guinle de Costa, nos parece que há mais história da cidade e da sua produção contida nestas linhas, para além da arquitetura.

As realizações de um profissional recém-chegado, que se engajou na Universidade e no ofício diz muito sobre o ambiente de receptitividade recifense às idéias da arquitetura "carioca". Algo que não vem de fora, que tem a ver com o estágio e ciclo de produção da capital pernambucana, expresso por alguns destes marcos urbanos, ainda presentes na paisagem da cidade. Ainda de acordo com Naslavsky, afora o "episódio de Luiz Nunes", "a produção local de arquitetura moderna em Pernambuco no início dos anos 50 reproduz a arquitetura do Rio de Janeiro" (NASLAVSKY, 2004, p.108).

Naslavsky marca os anos 1960 como uma fase de inflexão na obra de Borsoi iniciada a partir de sua viagem a Europa e afirmando que "o contato com as vanguardas européias do pós-guerra trouxe novos rumos à carreira do arquiteto" (NASLAVSKY, 2004, p.162)

$\mathrm{Na}$ introdução de "Arquitetura como manifesto", monografia publicada recentemente pelo escritório do arquiteto, Borsoi explica que

"Em 1963, assumi o cargo de Diretor da Liga Social Contra o Mocambo e realizamos a $1^{a}$ comunidade de auto-ajuda e geração de renda para as populações sem renda, Cajueiro Seco. Em 1964, todo este trabalho foi destruído e no ano de 1979, em forma de protesto 
pessoal contra o que o golpe sujo fez, pedi demissão irrevogável do quadro de professores titulares da UFPE ${ }^{337}$." (BORSOI, 2006, p.9)

Segundo LIRA, a experiência do Cajueiro Seco constituiu um momento importante de convergência em Pernambuco entre uma política social de habitação e um imaginário regionalista a respeito de arquitetura popular ali semeados desde os anos 1920 e 30. (LIRA in Sampaio (org.), 2002)

Apontando para o encontro entre dimensões políticas e culturais do projeto, a experiência rompeu com os referenciais pitorescos das vilas populares da Liga/ Serviço Social Contra o Mocambo, assim como com as propostas de verticalização praticadas pelos arquitetos dos IAPs, cujo exemplo mais significativo no Recife é o Edifício Inconfidência, de Carlos Frederico Ferreira (LIRA in Sampaio (org.), 2002, pp. 54-64) .

AMORIM vislumbra os significados da experiência para além da trajetória pessoal do arquiteto, como expressão de um "modernismo contraditório", circunscritos aos limites da arquitetura:

"Uma experiência pode exemplificar os paradigmas da modernidade e a subjugação aos paradoxos impostos pela cultura e limitação tecnológica regional. A proposta de habitação popular de Cajueiro Seco (1963), em Jaboatão, comandada por Acácio Gil Borsoi, expressa uma tentativa de racionalização construtiva e projeto social." (AMORIM, 2001)

${ }^{331}$ Borsoi foi contratado como Diretor de Construções do SSCM em fevereiro de 1963 pelo presidente da autarquia Gildo Guerra, seu ex-aluno e demitiu-se já em agosto de 1963, conforme nos informa o Diário de Pernambuco, Recife, 29/ago/1963. Notar o curioso uso da antiga denominação da autarquia, cujo nome fora transformado em Serviço Social do Mocambo, assim como a "retaliação" ou o "protesto pessoal" de Borsoi contra a Universidade, justamente no ano da anistia, em 1979.
Podemos ver, no entanto, que os clientes e os programas mudaram radicalmente ao longo dos anos 1960, para além das formas. Se no começo da década Borsoi projetava edifícios públicos no centro da cidade e se envolvia com uma experiência de habitação social, no fim da década se ocupou com os projetos para edifícios de apartamentos da orla de Boa Viagem (como o Mirage de 1967, Michelângelo e Portinari em 1969) e de residências unifamiliares para a burguesia, onde havia campo e recursos para todo o tipo de experimentações constrututivo-formais. Parte dos clientes das casas unifamiliares também estavam envolvidos com as incorporações imobiliárias e construções em Boa Viagem, como Antônio Queiroz Galvão, cuja casa foi projetada em 1968.

A tendência não era inteiramente nova. Desde os anos 1950, o desenvolvimento urbano e imobiliário da cidade vinha abrindo novas fronteiras de atuação ao arquiteto, no mercado de construções. Novos programas, como o edifício de escritórios, o edifício de apartamentos ou estruturas mistas de habitação, comércio e serviços, vinham mobilizando arquitetos como Borsoi, Amorim, Lucio Estelita, Maurício Castro, entre outros. Se os empreendimentos atualizavam não apenas novas formas projetuais, mas um engajamento na modernização dos padrões habitacionais locais em meio à existência modernamente definida como coletiva, era também porque os padrões de valorização e acumulação do mercado imobiliário e de construção civil começavam a mudar. 
Em alguns casos, essa tendência levava os arquitetos ao encontro de demandas econômicas, sobretudo na abertura de novas frentes de verticalização como nos bairros de Boa Vista, Pina ou Boa Viagem, na adoção de valores de racionalização de plantas, instalações e serviços (LIRA, pp. 64-73)

Tratava-se de atuar em face dos desejos de investimento e atualização dos padrões residenciais das elites, camadas de proprietários e médias da cidade e não no mercado de habitação popular, mas inscrevendo suas realizações no campo da habitação econômica.

Amorim expõe o compromisso moderno nas condições de subdesenvolvimento, o que ilumina o papel da habitação na sua obra e abre perspectivas para compreender a "inflexão" de Borsoi nos anos 1960:

"O projeto social moderno, por outro lado, supunha conquistas sociais a partir da reformulação dos meios de produção, barateamento de produtos e equipamentos pela produção em massa, e, consequentemente, acesso das camadas mais populares a esses mesmos produtos industriais e a uma habitação econômica, mas digna. Os arquitetos atuantes no contexto regional nordestino, enfrentaram o paradoxo de superar as deficiências tecnológicas e as desigualdades sociais, para estabelecer um modernismo contraditório." (AMORIM, 2001)

Em 1969, Borsoi projetou a sede do Banco de Pernambuco, no bairro do Recife, encabeçando a ponte Buarque de Macedo, uma das principais vias de acesso ao bairro histórico do porto e o Marco Zero da cidade, juntamente com a sede do Banco do Brasil, também projeto seu, de 1962?. Entre os dois projetos fica clara a contraposição entre os princípios funcionalistas "cariocas" e uma nova orientação "brutalista", com ênfase nos aspectos construtivos ${ }^{332}$. A distinção dessa linha para a chamada "Escola Paulista" foi estabelecida pelo próprio Borsoi, no $2^{\circ}$ Inquérito Nacional de Arquitetura:

"A arquitetura de autor após Brasília restringiu-se ao projeto individual e regional de cada arquiteto, perdendo sua característica de definição social como expressão coletiva, aspecto não muito alentador; como resposta de uma situação, depois de esgotadas as formas originais - e nem todos os arquitetos são luminares da forma - surgiram diversas expressões formais. No Centro-Sul, duas correntes se destacam: uma brutalista, verdadeiros "bunkers" de concreto, e outra saudosista de um pré-colonial iniciado com o emprego de materiais de demolição. No NorteNordeste, de um modo geral marginalizado dentro do plano da arquitetura nacional por diversos motivos, entre os quais aqueles relativos ao aspecto modesto das suas propostas arquitetônicas, surgiu uma outra linha de expressão ligada à terra e aos materiais locais" (IAB, 1982)

Contradiotoriamente, do ponto de vista formal, obras como o Fórum de Teresina (1972) ou o Edifício do Ministério da Fazenda em Fortaleza (1975) poderiam ser aproximadas com um certo brutalismo, mas são inegáveis algumas divergências, especialmente nas posturas e práticas dos arquitetos no período o regime militar.

Os arquitetos envolvidos com o Partido no Recife não encontraram espaço para trabalhar, vendo-se forçados a sair de Pernambuco, como Frank Svenson que mudou-se para Brasília e Geraldo Gomes que foi para a Paraíba logo após se formar, em 1965 e Gildo Guerra, que exilou-se no Chile e posteriormente foi absorvido pelos quadros técnicos do BID.

${ }^{332}$ Ver também "Identidade Nacional ou Regional? A obra de Acácio Gil Borsoi de Guilah Naslavsky e Izabel Amaral Do.Co.Mo.Mo. 5 
O engajamento de Borsoi na habitação social passa pelos programas e projetos para o BNH e reflete uma "consciência" que devem ter os arquitetos

"de que vivemos dentro de uma estrutura capitalista, e que se quisermos fazer alguma coisa neste campo será tentando compatibilizar o social e o econômico com o arquitetônico. (...) há muito tempo venho trabalhando dentro deste campo. Tenho procurado me inteirar dos programas habitacionais, a Autoajuda, Casas embrião, Cohabs, Inocoops, que sãop programas sociais do banco. Porém, de um modo geral, todos carecem, na essência, de respeito ao homem que os vai habitar" (IAB 1982)

Borsoi retomou a habitação social em Pernambuco no ano da anistia com o projeto do Conjunto Habitacional Ignez Andreazza (1979), conhecido como Caçote, no qual propôs um inteligente projeto para construção de unidades de variados tipos em blocos de 4 andares sobre pilotis. Não houve nesse caso projeto integrador da comunidade nem em torno de equipamentos coletivos ou programas assistenciais de geração de renda, até porque o público alvo do empreendimento já não era o mocambeiro invasor de terrenos de outrora.

Se a produção dos arquitetos pernambucanos configura uma "Escola" ou não, é um discussão da qual iremos nos furtar, assim como reafirmar o papel dos seus protagonistas - Borsoi e Amorim. Certo é que há uma significativa produção a ser contemplada, analisada e discutida pela historiografia ${ }^{333}$, destes e de outros arquitetos ali atuantes como Heitor Maia Neto, Maurício Castro, Reginaldo Esteves, Augusto Reynaldo e Marcos Domingues, entre tantos outros. Nos interessa

${ }^{333}$ Antes que seja completamente substituída pelos projetos da nova "Escola" do Recife, gerações de arquitetos formados pelos pioneiros que trabalhando em estreito mutualismo com o mercado imobiliário está logrando substituir por torres de edifícios os remanescentes da modernidade arquitetônica pernambucana, como mostra o "Obituário" organizado por AMORIM, 2007. menos suas particulariedades pessoais e estilísticas do que o significado do conjunto das suas obras para a construção do Recife como metrópole irradiadora da cultura arquitetônica para uma região. Para além das escolas, influências ou genealogias, o que há de singular no Recife é a interessante expressão do "modernismo contraditório", de acordo com Amorim, reflexo de uma arquitetura que opera no "paradoxo de superar as deficiências tecnológicas e as desigualdades sociais" (AMORIM 2001). 


\subsection{O projeto de taipa pré-fabricada}

O mocambo como tipologia também tomava as páginas dos diários. Independentemente da linha política, havia o consenso em torno do absurdo que representavam em termos de condições de vida. Tanto os jornais de esquerda quanto os ligados às oligarquias estampavam imagens contemporâneas das áreas de mocambos e comentários desesperançados em face de práticas habitacionais que consideravam condenáveis ${ }^{334}$. O tradicional Diário de Pernambuco enquadrava em editorial "O problema habitacional" a partir de um enfoque meramente econômico: o mocambo manifestava a falta de novas construções para atender ao aumento da população resultante do processo de "desruralização", decorrente da migração de parte do capital imobiliário para o financeiro, acentuada pela interferência social do Estado populista no mercado de aluguéis, através da Lei do

${ }^{334}$ "A cidade e os fatos - Cleophas de Oliveira - Mocambos" Diário de Pernambuco, Recife, 8/mai/1963 e 1/ago/1963 "Da terra nasce o mocambo: duzentos mil casebres no Recife desafiam o governo" Imóveis \& Móveis - Diário de Pernambuco, Recife, 1/set/1963 "Cem mil casebres no Recife são desafio ao governo" Imóveis \& Móveis - Diário de Pernambuco, Recife,15/set/1963 "Tende a agravar-se no Recife problema habitacional: mocambos invadem centro comercial e IAPS não financiam moradias" Imóveis \& Móveis - Diário de Pernambuco, Recife, 15/set/1963. Além da variação do dobro da cifra para o dobro, nota-se o tom de desafio que o jornal oligarca faz ao governo popular nesta última matéria: "Campanha de reforma urbana, nos mesmos moldes da agrária, aí então o governo começará a agir"
Inquilinato, o problema era exacerbado pela fuga dos "capitalistas investidores" do empreendimento imobiliário ${ }^{335}$.

Mais do que isso, "Contrastando com o progresso que se observa na cidade, onde as construções surgem em ritmo acelerado, estão os mocambos, em número sempre crescente, em toda parte, ousados atrevidos como nunca, como um brado de revolta contra o conforto e o bom gosto que se esforçam em dominar, suplantando a miséria, procurando mudar a face triste e negativa de nossa urbs pelo colorido risonho com que nos vamos, pouco a pouco nos habituando. (...)

Ninguém nega que o mocambo é, sob o ponto de vista pictórico, uma atração para os pintores, fotógrafos, turistas, particularmente aqueles que habitam uma terra onde eles não existem. (...) Todavia, são os mocambos para a cidade além de uma vergonha um verdadeiro obstáculo à expansão urbanística, ao traçado de novas ruas e avenidas, sem falar no mal que causa pela sua absoluta falta de conforto aqueles que tem a infelicidade de habitá-los" ${ }^{\prime 336}$

Enquanto as aglomerações de mocambos eram para as oligarquias um entrave ao desenvolvimento da "Veneza americana", as forças populares e diversas vertentes de intelectuais, artistas e técnicos viam nelas o sintoma de um desequilíbrio sócioeconômico, problematizando a integração de seus habitantes à metrópole, a partir do prisma "humanista".

É neste sentido que, nos jornais simpáticos à situação, a experiência do Cajueiro Seco era vista como uma tentativa de conciliação dos interesses nacionais com os setores populares, ora

335 "O Problema habitacional" Editorial, Diário de Pernambuco, Recife,23/fev/1963 e Imóveis \& Móveis - Diário de Pernambuco, Recife, 1/set/1963

336 "Mocambo do Recife é epidemia que desafia Governo e SUDENE" Imóveis \& Móveis - Diário de Pernambuco, Recife, 28/nov/1963 
representada pela figura de Arraes, que pessoalmente esteve nos Montes Guararapes ${ }^{337}$, ora por Gildo Guerra, que no lornal do Commercio, descreveu o projeto como parte de um esforço de solução da questão de terra naquela região da cidade:

"Expliquei-Ihes que tinham o direito de lutar para resolver seus problemas habitacionais, mas não da maneira anárquica que estavam tentando fazer, num local de valor histórico, que é um monumento de necessária preservação. Como responsável pelo setor estadual que cuida da habitacão, fiz ver o interesse do governo no sentido de dar solução adequada e razoável ao problema",338

Os poucos moradores remanescentes localizados ${ }^{339}$ também associam a primeira fase de ocupação do bairro e a "intervenção" no bairro à figura de Arraes, mencionando as cooperativas de materiais de construção e de sapataria e às casas de taipa, ainda dentro do processo tradicional, como uma etapa preliminar de suas casas atuais.

"No dia que Arraes foi lá, levou tudinho pra Igreja de Nossa Senhora dos Prazeres e doou, fez uma reunião com o povo e cedeu, mediu tudinho, veio os homens medir e viemos pra cá. Quando ele deu era pra gente fazer logo e aí a gente veio praticamente pra dentro d'água. Tava todo mundo precisando e pra não tomar, ou aparecer outro mais necessitado, aí teve que fazer logo. As vezes as caçambas vinham pra trazer barro pra ajudar... Tinha feito um armazém, que o povo comprava o material mais barato. Era

337 "Arraes vence Batalha dos mocambos nos Guararapes", Última Hora, Recife, 20/mar/1963)

${ }^{338}$ 'Presidente do SSCM resolve problema do Monte Guararapes' Lornal do Commercio, Recife, 10/mar/1964

${ }^{339}$ Os mesmos moradores confirmaram as dificuldades de localizar os moradores originais: "Foi embora muita gente mesmo... Muita gente ficou com medo quando Miguel Arraes deixou de ser governador." (Entrevista Dona Maria, moradora da Rua $6 \mathrm{~N}^{\circ} 29 \mathrm{~A}$, Jan/2007) "Foi muita gente presa daqui, quem trabalhava pro governo foi." (Entrevista Seu Inácio, Sapateiro, morador da Rua 6 Nº85, Jan/2007) telha, pau daqueles roliços e ripa, não era nem sarrafo, era ripa. E a gente comprava devagarzinho e ia pagando devagarzinho. "1340

Seu Inácio, o sapateiro que seria o mestre da cooperativa, referese também a um estágio primitivo de sua moradia. A descrição contrasta com sua casa atual, hoje um sobrado em estrutura de concreto e blocos furados, revestido de lajotas de cerâmica.

"A minha casa, a primeira casa, o primeiro dia que eu cheguei eu não tinha casa, foi quatro dias em uma lona e na outra semana já houve indícios (?) de fazer a casa. Com galho de estacas, com pau, comecei a medir aquilo ali. Agora, minha profissão, sapateiro, tinha de trabalhar. Aí quando o governo começou a passar olhando me convidou pra trabalhar numa cooperativa que eles iam fazer, pra ensinar o povo. Aí eu fiz mesmo rol das compras de ferramentas e material aí houve o rapa, a intervenção. Aí o governo... [saiu] $]^{\prime 347}$

O debate da arquitetura moderna e brasileira, o sonho da préfabricação e a personalidade de Borsoi também aparecem nas páginas da última Hora, sempre inseridos nos planos de habitação, educação e assistência social do Governo Arraes :

"Uma casa pré-fabricada, montada em apenas 4 horas, por três operários, foi apresentada ao povo e a imprensa, ontem, no Cajueiro Seco, pelo SSCM. Esse modelo poderá ser utilizado em larga escala no plano habitacional que o governo Miguel Arraes vem executando naquele bairro. A nova residência custa apenas duzentos mil cruzeiros, enquanto a do projeto da "Aliança para o Progresso" está orçado em um milhão de cruzeiros". Ainda de acordo o jornal, "Já residem no Cajueiro Seco cerca de 400 famílias, em casas edificadas com o seu próprio material, nos

\footnotetext{
${ }^{340}$ Seu INÁCIO, Sapateiro, morador da Rua 6 Nº65, Entrevista ao autor, Jaboatão, $\operatorname{Jan} / 2007$

${ }^{341}$ Seu INÁCIO, Sapateiro, morador da Rua 6 Nº6, Entrevista ao autor, Jaboatão,
} Jan/2007 
terrenos adquiridos pelo governo"342.

Se o discurso eloquente e entusiasta acerca das possibilidades políticas da pré-fabricação naquele momento - notadamente preço e prazo - nos faz lembrar tanto da pré-fabricação da taipa quanto de diversas experiências de racionalização da construção popular desenvolvidas no Brasil, as características arquitetônicas nos mostram que não era à taipa pré-fabricada que o jornal se referia:

"A casa pré-fabricada compõe-se de 4 blocos conjugados com duas lâminas de fibra-cimento (amianto). As divisões dos cômodos são em alvenaria, bem como as paredes do quarto e da sala, com janelas no espaço útil, além de meios de ventilação e iluminação." 343

Na época, o Diretor de Construções do SSCM, Acácio Gil Borsoi declarou que essas "casas pré-fabricadas poderão ter outras aplicações, servindo para funcionamento de escolas, ambulatórios, pequenos postos de saúde, etc ${ }^{\prime \prime 34}$, o que nos leva a supor contemporaneamente que se trata da casa de cobertura abobadada de cimento que virou o posto médico da Rua Dois (?) a que se referem moradores e jornais discutida no item anterior deste capítulo. A mesma "experiência" é referida em nota no Diário de Pernambuco, que dá mais atenção para os aspectos físicos da construção do que à sua vinculação com a política pública:

${ }^{342}$ "Mocambo constrói casa em tempo récorde (Quatro horas) por CR \$ $200 \mathrm{Mi}$ apenas", Última Hora, Recife, 20/abr/1963

343 "Mocambo constrói casa em tempo récorde (Quatro horas) por CR\$ $200 \mathrm{Mil}$ apenas", última Hora, Recife, 20/abr/1963

344 “Mocambo constrói casa em tempo récorde (Quatro horas) por CR\$200 Mil apenas", última Hora, Recife, 20/abr/1963
"O SSCM fez experiência, ontem, em Cajueiro Seco, instalando, em quatro horas, uma casa pré-fabricada, composta de duas lâminas de fibracimento (amianto), pesando cada uma 60 quilos, cobertas por duas lâminas superiores, do mesmo material, formando assim um bolhão de ar para o isolamento térmico. Tem 4 metros de largura por 8,10 de comprimento. São casas desse tipo que pretende o SSCM instalar no Recife, para operários" ${ }^{\prime 345}$

A construção, transformada em posto médico, aparece também na fala dos moradores, misturada às memórias das mobilizações iniciais ali em torno das políticas de Arraes:

"Tinha uma Comissão do mocambo. Não tô bem lembrado dos dirigentes não... dr Gildo... [Gildo Guerra?] Sempre vinha olhar, dizia pra ir se organizando que isso aqui ia crescer. E agora vou dizer que tá muito grande já.(...) Eu sei que chegava muita gente do governo pra olhar, tinha uns que não tinham nada, essa primeira casa que o governo fez aqui era um posto médico, tinha um rapaz que tomava conta que chamava Zé Ramos... Era fabricado de brasilit, redonda, feito quase um viadutozinho, a coberta era assim." ${ }^{346}$

Quando aborda o aspecto do conjunto, no artigo "Plano piloto para urbanização racional", publicado no suplemento Imóveis e Móveis, o Diário de Pernambuco procura descrever os aspectos físicos do "loteamento racional e moderno através de quadras e superquadras demarcadas em lotes populares" no qual se instalariam as "famílias atingidas pelo desajustamento social".

\footnotetext{
${ }^{345}$ Diário de Pernambuco, Recife, 21/abr/1963

${ }^{346}$ Seu INÁCIO, Sapateiro, morador da Rua 6 Nº6, Entrevista ao autor, Jaboatão, Jan/2007
} 
O artigo descreve a fábrica de roupas e calçados e os postos de revenda de materiais sempre na chave do cooperativismo, dando mais atenção ao processo de construção das unidades habitacionais com a

"fixação de normas e exigências mínimas para a autoconstrução, elaboração de planos de melhorias dos métodos de construção, com o auxílio de estudantes de arquitetura e engenharia, fabricacão no local e fornecimento do material de construção a baixo preço ${ }^{\prime 347}$.

O tema da participação dos estudantes traz à tona outra experiência coletiva que se fundava nos mesmos campos da experiência do Cajueiro Seco: o Centro de Habitação da Universidade do Recife $^{348}$, criado em 1963 e dirigido pela arquiteta e pesquisadora Neide Mota de Azevedo, autora de Métodos construtivos tradicionais no Nordeste, de 1978. Ao definir os "tipos" de casas nordestinas, a Casa de Taipa, a de Tijolo e a de Pedra, além da Casa Mista, Neide Mota tenta busca identificar uma "identidade própria" para o arquitetura habitacional popular ${ }^{349}$. (LAPROVITERA, S/D)

${ }^{347}$ "Plano piloto para urbanização racional” Diário de Pernambuco, Recife, 14/jul/1963

${ }^{348}$ LAPROVITERA, Ênio L'architecte et le peuple à Recife 1959-2008 Doutorado em conclusão Orientado por Helene Riviere D'arc Paris: Ecole des Hautes Etudes en sciences sociales s/d cópia do autor

349 Além das pesquisas em torno do caráter construtivo da casa popular na Faculdade de Arquitetura, Neide Mota era a coordenadora do convênio da Universidade do Recife com a Sudene, em estreita colaboração com a Escola de Serviço Social, onde participou de atividades didáticas. Mota colaborou com o treinamento das assistentes sociais para o projeto de auto ajuda empreendido pelo Mosteiro de São Bento de Olinda, ao qual se referem as assistentes sociais Francisca Veras e Maria Lucia Mello, entrevistadas pelo autor.
Uma idéia abstrata do mocambo higienizado parecia prefigurar a taipa pré-fabricada. Neste e em outros artigos do suplemento como "Mocambo é escola para arquitetos" arquitetonicamente aquilo que já vinha sendo enunciado localmente por gerações de pesquisadores sociais como Aluizio Bezerra Coutinho, Gilberto Freyre e Josué de Castro, no registro da tradição arquitetônica popular. A referência parece ecoar no discurso de personagens do episódio do Cajueiro Seco com relação a taipa. Geraldo Gomes, então estagiário do SSCM e líder estudantil da Faculdade de Arquitetura da Universidade do Recife, "evidentemente comunista" ${ }^{\prime 351}$, hoje professor de história da arquitetura da UFPE, é um dos que evoca a "excelência do mocambo" do ponto de vista ecológico:

"A taipa nunca deixou de ser usada, é mais fácil ter o barro do que tijolo. Existe o preconceito. A primeira coisa que o pobre coitado que mora na casa de taipa faz quando tem dinheiro é a fachada de alvenaria de tijolo. O mocambo é uma coisa ruim? Aloizio Bezerra Coutinho, antes de Gilberto Freyre, em 30, fez um trabalho mostrando a excelência do mocambo na tese dele sobre "Arquitetura nos países quentes", até mesmo do mocambo de palha, que do ponto de vista ecológico, Ihe parecia mais adequado do que o mocambo de alvenaria. O mocambo não é subhabitação. É usar o que se tem, como o Iglu, que

\footnotetext{
350 "Mocambo é escola para arquitetos" Diário de Pernambuco, Recife,, 14/jul/1963
}

${ }^{351}$ Segundo os termos a ele aplicados nos Inquéritos do DOPS, as repetidas perguntas dos agentes da Segurança Pública presentes nos depoimentos de diversos funcionários do SSCM e do DOFSP, por onde também passou como estagiário e as suas próprias declarações em duas entrevistas que gentilmente concedeu à pesquisa. 
é feito de gelo. O cara que mora na praia faz casa de palha de coqueiro." ${ }^{352}$

Já Borsoi, que responde pela autoria do projeto arquitetônico da taipa pré-fabricada, o inscreve na tradição moderna, através do seu amigo pessoal e mestre de sua geração, Lucio Costa, citando especificamente o projeto da vila de Monlevade, destinada a abrigar os operários da companhia siderúrgica Belgo Mineira:

"Porque a casa de taipa, a arquitetura de taipa, segundo Lucio Costa que fez [o projeto para] Monlevade ${ }^{353}$, é um processo mais antigo de construção. Tanto nas igrejas quanto na arquitetura de Ouro Preto. A taipa era um processo muito rudimentar. Você não precisava de tecnologia. O homem arma, a mulher tece e o garoto fecha. Com isso você tem a família trabalhando, como se fosse um passarinho. Então surgiu esse negócio, os caras pediram. Fizemos o centro social e uma cooperativa de materiais pra fugir do armazém, que cobra mais caro. Nós forneciamos o material a

${ }^{352}$ Geraldo Gomes da SILVA, Entrevista ao autor, Recife, Ago/2006

${ }^{353}$ Sobre os discursos e explicações para Monlevade ver o doutorado de Otávio Leonídio Carradas de razões- Lucio Costa e a arquitetura moderna brasileira Rio de Janeiro: Ed. PUC-Rio; São Paulo: Loyola, 2007. Comentando a explicação de Costa dos processos construtivos propostos para Monlevade, que incluíam paredes de taipa de mão sobre uma plataforma de concreto, afirma Leonídio: "De todos os motivos listados por Lucio Costa, um em especial merece a nossa atenção: aquele que vincula o emprego de um sistema constutivo moderno, o pilotis em concreto armado (uma técnica construtiva, por definição moderna) ao aproveitamento de um "primitivo processo de construir". Ele constitui o ponto crucial do projeto de Lucio Costa para Monlevade." Para o autor, o projeto da vila para a Companhia siderúrgica Belgo Mineira em Monlevade representa uma abertura de campo no trabalho de Costa e para a arquitetura moderna brasileira: "Um universo no qual Costa poderia vislumbrar algo que até então não considerara (algo que, no entanto, era a precondição para a definição de uma arquitetura brasileira e moderna): a conciliação do irrefreável desejo (ou a tarefa auto-imposta) de incorporar os novos sistemas e materiais de construção (a técnica moderna) com a precaríssima 'realidade social' da construção civil nacional (encarnadas, na ocorrência, nas precárias disponibilidades construtivas - de materiais de construção, de sistemas construtivos, de qualificação de mão-de-obra, de organização de canteiro etc.)" (LEONÍDIO, 2007, P. 131) preço de custo, tinha toda a estrutura, a organização daquela comunidade era gerida pelo centro social, tinha o staff todo da Liga Social, assistentes sociais, economistas. Foi muito bom isso aí, facilitou bastante. ${ }^{\prime \prime 354}$

Tal referência também aparece em alguns memoriais do projeto de sua autoria como no recente Arquitetura como manifesto. Mas em entrevista, ele faz uma distinção emblemática com relação ao projeto de Costa, que abre uma chave nova de percepção e questionamento da própria idéia de autoria. O arquiteto "renuncia" não só à definição da forma da sua obra (o que ancestralmente ocorre na casa popular vernacular), mas à escolha da técnica construtiva e dos materiais para definí-los como uma estratégia ou postura para lidar com a situação de subdesenvolvimento:

"[a racionalização da] taipa surgiu não como um negócio semântico, mas como uma decorrência da necessidade de você racionalizar o processo da taipa através de um meio de baratear e dar mais condições de permanência e durabilidade com a madeira imunizada e maior facilidade de construir a casa. Naquela época, e isso não aconteceu no Rio depois ${ }^{355}$ as pessoas não conheciam construção, não tinham nenhuma noção. A construção mais primitiva era feita com as mãos, sem prumo ou ferramenta. Então o homem arma, a mulher tece e o garoto fecha, a família toda com a mão. Isso eu presenciei. E nós botamos tijolo na cooperativa

${ }^{354}$ Acácio Gil BORSOI, Entrevista ao autor, Recife, Set/2007

${ }^{355}$ Aqui ele se refere aos projetos elaborados por ele na Pavuna, em 1999, no contexto do programa Favela Bairro e, onde vai dar uma trajetória de "projetos sociais" desenvolvidos ao longo de sua carreira apresentada na recente publicação retrospectiva Arquitetura como manifesto, editada pelo seu próprio escritório como produto da exposição da X? Bienal de Arquitetura. A experiência de Cajueiro Seco é justamente o marco inicial desta parte da atividade profissional de Borsoi, que passa pelo projeto dos Conjunto Habitacionais Ignez Andreazza (conhecido como Caçote), no Recife e Cafundá para o BNH nos anos 70 e 80 e dá no conceito de UVDR- Unidades de Vizinhança de Desenvolvimento de Renda, uma nova proposta para integração da habitação e trabalho. 
mas não havia jeito, eles queriam barro. A comissão da comunidade disse que queria barro e aí eu resolvi criar um processo tecnológico racional de construção de toda a casa. Instalação, armação, a palha com o próprio recurso. E montamos uma experiência aqui na Igreja do Carmo, que é do patrimônio. Celso Furtado viu, armamos em dez minutos, em quinze minutos armava-se a casa com os painéis." ${ }^{356}$

Geraldo Gomes relata em entrevista uma piada contada na autarquia, onde então estagiava, possivelmente por Paulo Brasil, que reflete o conflito entre a concepção formal e as necessidades imediatas da população:

"A lavanderia foi feita de tijolo aparente e conversando com a população, alguém dizia: "Tudo muito bem, mas esse seu Borsoi vem aqui todo dia e fica alisando tijolinhos enquanto a gente fica cagando no mato". Era uma crítica velada ao perfeccionismo de Borsoi, era muito mais urgente que as coisas ficassem prontas do que bonitas" ${ }^{\prime 357}$

Avançando na descrição do processo construtivo, Borsoi expõe o papel da racionalidade arquitetônica, construtiva e, porque não, social no projeto, delegando a forma final da casa dentro do lote de $8 \times 16$ metros ao seu ocupante e construtor, haja vista suas possibilidades e necessidades:

"Com uma serra circular, um tanque pra imunizar, gabaritos e um grampeador. Cortava-se a madeira, tirava-se a casca e com as peças faziam a armação, faziam o painelzinho modulado com a casa, o terreno e a rua, tudo em escala e essa modulacão permitia fornecer um tipo de porta e um tipo de janela. Com mais seis peças você dava a dimensão. E outra coisa que eles ensinavam é que todos eles faziam o desenho da casa. Fiz um papel modulado com as peças. Tudo encaixava, você dava a dimensão e os preços de cada peça. Então a sequência foi essa pra que eles pudessem

${ }^{356}$ Acácio Gil BorsOI, Entrevista ao autor, Recife, Ago/2006

${ }^{357}$ Entrevista Geraldo Gomes da SILVA, Entrevista ao autor, Recife, Ago/2006 desenvolver as casas mais econômicas e mais racionais. Estávamos fornecendo a eles um dimensionamento econômico. Vou gastar tanto pra fazer um quarto." "358

Do ponto de vista formal do processo construtivo talvez caiba uma livre analogia entre os painéis de trama de madeira preenchidos por barro propostos por Borsoi a partir da técnica tradicional da taipa de mão e o cobogó, marco inicial da idéia de pré-fabricação em Pernambuco. Os elementos vazados inventados pelo mestre de obras português Coimbra, o ferreiro Boeckmann e o engenheiro Góes (daí o nome da firma e da patente CO-BO-GÓ) que foram apropriados pelos arquitetos modernos como uma forma simplificada de quebra-sóis, característicos da arquitetura moderna brasileira ${ }^{359}$. Na verdade, haviam sido inventados em 1933, como uma maneira de construir paredes maciças com elementos leves, preenchendo os vazios com argamassa. (SILVA, 2007)

No âmbito do Departamento de Arquitetura e Urbanismo, dirigido pelo arquiteto Luiz Nunes teria surgido a idéia de usá-lo para fazer volumes transparentes a partir da reiterpretação do técnica de emprego de um material industrial corrente, de acordo com um dos

\footnotetext{
${ }^{358}$ Acácio Gil BORSOI, Entrevista ao autor, Recife, Ago/2006

${ }^{359}{ }^{86}$ SILVA Gomes da, Geraldo "A pré-fabricação e a racionalização na arquitetura moderna em Pernambuco na década de 30 do século passado" in MOREIRA, Fernando (org.) Arquitetura Moderna no Norte e Nordeste do Brasil Recife: FASA 2007
} 
colaboradores do DAU, Antônio Baltar. A principal e mais célebre realização dessa nova aplicação da invenção pernambucana provavelmente é a Caixa d'agua do Alto da Sé de Olinda, construída em 1937 e já publicada em 1943 no Brazil Builds, o catálogo da exposição do MoMA de Nova York sobre arquitetura brasileira.

Analisando a casa de taipa proposta por Borsoi, a despeito da retomada do processo de preenchimento dos vazios com o barro, podemos intuir que alguns dos princípios tipicamente modernos de "racionalização, uniformização e standardização", estavam avançando sobre os processos construtivos vernaculares, conectando a arquitetura à economia da produção da casa.

"E a taipa era um resultado. Era como você fazer uma casa racionalizada pro cara. Então você tinha um kit de madeiras, de painéis, um kit de teto, um kit de instalações e um papel pra você chegar e dizer assim: faça você mesmo. O que o americano faz. O cara se virava. Com o mesmo princípio. O homem armava, a mulher não tecia mas montava aquilo rapidamente. Uma casa que levava 7 dias ou um mês pra fechar, você fazia em horas, barro de um lado e barro de outro (sopapos). Racionalizava-se o material, porque você pegava uma peça de madeira, tem o esteio aqui e lá, aquele entrepano aqui não precisa dessas peças todas, serrava o meio, tirava as cascas, uma peça dava pra duas e a treliça dava as cascas pro lado, só pra segurar. O painel permitia você ter um tanque deste tamanho lo arquiteto abre os braços para simbolizar algo em torno de um metro], com querosene e veneno, mergulhava e tirava, como faz um automóvel." ${ }^{367}$

O grande valor seria a elevação do grau de consciência do sujeito em função da superação das dificuldades; o lote seria como

${ }^{361}$ Acácio Gil BORSOI, Entrevista ao autor, Recife, Set/2007 uma base, um ponto de partida para o desenvolvimento do cidadão e da comunidade. Na sequência, o próprio arquiteto relativiza o valor do projeto meramente arquitetônico, focando a metáfora da construção do indivíduo, para além da sua casa:

"O Serviço Social não dava nada. Aquilo pertencia à comunidade, que cobrava uma taxa e ficava com uma parte, era gestora da coisa toda. Você não pode fazer de cima pra baixo. As comunidades tem de ser orientadas pra que elas tomem lugar de gestor. E desenhar com o que eles querem. "1362

Tais idéias revelam a vinculação de Borsoi à idéia tipicamente americana do faça você mesmo (Do it Yourself - DIY) e ao design como procedimento para simplificar e padronizar os componentes para barateá-los

"Eu quando fiz Cajueiro Seco, desde aquela época, sempre pensei na racionalizacão da construção, uma coisa lógica, os americanos são um exemplo, faça você mesmo, monte as coisas, brasileiro tem pouco hábito de fazer as coisas, não tem uma oficina em casa." ${ }^{363}$

A decomposição e redesenho dos componentes construtivos, a partir das possibilidades do incipiente parque industrial nordestino e brasileiro, nos mostra que pode haver sintonia com o programa norteamericano das Case Study Houses, projetadas por arquitetos como Richard Neutra, Craig Elwood e o casal Eames para serem montadas a partir dos produtos de uma indústria desenvolvida para fins militares ociosa em tempos de paz.

\footnotetext{
${ }^{362}$ Acácio Gil Borsol, Entrevista ao autor, Recife, ago/2006

${ }^{363}$ Acácio Gil BORSOI, Entrevista ao autor, Recife, Set/2007
} 
As cadeiras de plástico moldado projetadas e executadas aos milhares pelos Eames junto à Herman Miller pode ter algo a ver também com as peças sanitárias moldadas em argamassa propostas por Borsoi, que aplica um material mais elementar para um objeto ainda mais essencial do que uma cadeira

Ao mesmo tempo, aparecem os ecos da crença na autoconstrução como recurso para a reprodução social da comunidade.

"No Cajueiro Seco, a pré-fabricação não era importante. Todo mundo acha que era importante. Eu sempre achei secundário. O importante era proporcionar um agenciamento populacional capaz de modificar um processo. (...) O assistencialismo sempre imperou em todas as épocas, uma das grandes soluções para o miserável, e cômoda que a burguesia usa é dar uma esmola. (...) Isso não funciona, isso gera párias, malandros. Porque se o cara vai receber uma subsistência, alguém tá tendo que trabalhar pra ele ficar desse jeito e você destrói na pessoa um valor muito importante: a aspiração, o desejo... (...) Você não se constrói, isso foi a minha maior preocupação quando eu fui ser diretor do Mocambo. ${ }^{1364}$

No artigo que detalha a experiência do Cajueiro Seco, publicado em outubro de 1963 na Revista Arquitetura, existe uma referência genérica à pré-fabricação em taipa dentro do item dedicado à assistência técnica. Entre os diversos pontos da experiência piloto da Política Social do Mocambo ali destacada, Borsoi aparece como o Diretor do Departamento de Construções (DC), que contava ainda com Flávio Marinho Rêgo e Mario Jorge Pedrosa, além de oito universitários, entre eles Geraldo Gomes e Armando de Holanda Cavalcanti:

"O mecanismo de assistência técnica está sendo estabelecido pelo Departamento de Construções do SSCM, em colaboração com os

\footnotetext{
${ }^{364}$ Acácio Gil BORSOI, Entrevista ao autor, Recife Set/2007
}

estudantes da Faculdade de Arquitetura do Recife. Um dos objetivos é a fixação de normas ou exigências mínimas para a autoconstrução. $O$ Departamento de Construções, está no momento, executando os planos das casas a serem construídas e experimentando os métodos de construcão a serem empregados, destacando-se entre eles um projeto de casa de taipa com estrutura pré-fabricada. ${ }^{1365}$

Na matéria "Pernambuco mostrou casa de taipa ao encontro de arquitetos: Havana" é que aparece pela primeira vez publicada uma imagem da maquete da casa de taipa pré-fabricada, tal qual se consagrou. Sempre explicada na chave do pioneirismo, ela foi apresentada ao Congresso da UIA de Cuba em 1963 como um projeto de alunos orientados pelo professor Borsoi:

"Pela primeira vez, uma casa de taipa foi apresentada como trabalho de uma equipe de técnicos num congresso internacional de arquitetura (...) uma equipe de acadêmicos de arquitetura, formada pelos estudantes Arnaldo (sic) de Holanda e Ricardo Pontual sob a orientação do professor Borsói (catedrático da cadeira de composição de arquitetura da Faculdade de Arquitetura da Universidade do Recife) estudou o problema, findou encontrando as soluções requeridas e apresentou projeto no "Primeiro encontro internacional entre estudantes e professores de arquitetura", realizado em Havana. O plano piloto, aliás, já foi executado em Cajueiro Seco, (...) ali os estudantes de arquitetura, depois de estudar um projeto beneficiando aquela gente, orientaram, pessoalmente, algumas pessoas a construir casas de taipa. No plano geral, ficou patente a possibilidade de serem construídas em série e "pré-fabricadas" as casas de taipa, bastando que fosse montada uma oficina especializada para tal fim" $^{\prime 366}$

365 "Cajueiro Seco, uma experiência em construção" In Arquitetura IAB-GB, N N 16
Rio de Janeiro: Outubro de 1963
366 "Pernambuco mostrou casa de taipa ao encontro de arquitetos: Havana" Imóveis \& Móveis Diário de Pernambuco Recife, $-14 /$ nov/1963 
A matéria, apesar de formulações um tanto confusas, indica chaves para um outro entendimento da experiência como uma possibilidade de racionalização da produção habitacional dentro de um trabalho coletivo, que envolvia pesquisa e idéias anteriores ao projeto arquitetônico, assim como finalidades extra-arquitetônicas. Na apresentação da experiência no Congresso, o texto destacava a novidade do trabalho no enfrentamento das necessidades populares em relação à produção modernista contemporânea:

"Foi levado em consideração o fator da maioria dos técnicos em arquitetura mais interessados na criação de projetos revolucionários dentro da estética modernista, jamais terem atentado para solução de problemas congêneres, porque só podiam trabalhar para a elite que estava em condições de construir". ${ }^{367}$

No arquivo da Secretaria de Desenvolvimento e Assistência Social, que funciona nas antigas instalações do SSCM, na Avenida Cruz Cabugá, encontramos um conjunto de desenhos que detalham todas as etapas de construção de uma casa de taipa à maneira tradicional; possivelmente um processo da pesquisa do projeto de racionalização mas talvez um "manual" da técnica com o objetivo de padronizar as autoconstruções. Provavelmente um desenho do estudante, um passo antes da síntese que faria Borsoi.

As primeiras referências às casas pré-fabricadas em taipa surgem na última Hora, em artigo retrospectivo assinado por Valdemir Veloso,

367 "Pernambuco mostrou casa de taipa ao encontro de arquitetos: Havana" Imóveis \& Móveis Diário de Pernambuco Recife, -14/nov/1963 em janeiro de 1964, entre outras experiências de pré-fabricação praticadas no Cajueiro Seco e no Estado:

"Pesquisas de pré-moldados possibilitaram ao SSCM encontrar o padrão ideal para um determinado tipo de habitação popular, com o emprego de material local (cimento e areia) e aproveitamento da mão de obra dos futuros habitantes das habitacões (sic.). Técnicos do SSCM fizeram, também, pesquisas no setor de construção de habitação popular para atender à população de renda média (salário mínimo e quatro vezes o mínimo), sendo realizados projetos de construção de casas de taipa que atenderão às camadas de baixo poder aquisitivo, por ser esse tipo de habitação o mais acessível ao povo" 368

No Jornal do Commercio, a única referência à idéia das casas de taipa higienizadas aparece num editorial que comenta a política de Habitação Popular e elaborava diversas críticas à atuação do Estado, acusando-a de "um retorno aos planos da administração anterior [Cid Sampaio]", embora reconhecendo e aprovando a "idéia de facilitar a construção de moradias de barro e taipa, garantido um mínimo das exigências de higiene (...) isto estaria aliás dentro da tese do sociólogo Gilberto Freyre da "higienização dos mucambos"

É interessante observar que a mesma experiência aparece nos jornais simpáticos a Arraes, como o lornal Pequeno, a última Hora e $\underline{A}$ $\underline{\text { Hora }}$, por sua dimensão de projeto urbano e integração social. No jornal $\underline{\mathrm{A} \mathrm{Hora}}^{370}$, ligado ao $\mathrm{PCB}$, não há qualquer menção ao projeto de

\footnotetext{
368 "'Mocambo' contra mocambos modificou tudo em 1963" Última Hora, Recife jan/1964.

369 "Habitação popular" Łornal do Commercio, Recife 29/set/1963

${ }^{370}$ Nova denominação da Folha do Povo
} 
taipa pré-fabricada ou à figura de Borsoi, ofuscada pela de Gildo Guerra, presidente do SSCM, que ocupava lugar de destaque como o arquiteto que estava corajosamente enfrentando o mocambo. ${ }^{371}$

Diversas são as ocasiões em que se publicam no jornal dos comunistas os princípios e trechos da Política Social do Mocambo, que sabemos de autoria de Guerra", considerada como uma "política realista", "um passo a frente para a solução de um problema cujas raízes somente serão extirpadas com as profundas transformações econômicas e sociais porque luta, afinal, a maioria do povo brasileiro". ${ }^{373}$ Mais uma vez, a metáfora vegetal para as estruturas arcaicas e a revolução como condição necessária à superação do subdesenvolvimento e da desigualdade.

Nas páginas do jornal A Hora, Gildo Guerra tinha espaço para expor plenamente as dimensões participativais da política:

"Essa presença do povo na busca de solução para o seu próprio problema habitacional, culminaria com a sua participação direta na execução dos projetos, dentro dos esquemas de ação e trabalho coletivo, democrático, de um governo pobre, mas integrado nas necessidades do povo, por uma política realista, sem demagogia nem assistencialismo oco, demandando os caminhos de revalorização do homem comum por seus

371 "Cajueiro Seco - Nova iniciativa de Novo Governo a serviço do povo" A Hora Recife, 16-23/mar/1963 "Cajueiro Seco Uma Experiência" A Hora Recife, 26/out1963 "Uma política realista para a habitação popular" A Hora Recife, 29/fev/1964

372 "Política Social do Mocambo" in Arquitetura № 13, Rio de Janeiro: IAB-GB 1963 e "Cajueiro Seco, uma experiência em Construção" in Arquitetura No 16, Rio de Janeiro: IAB-GB, 1963

373 "Política Social do Mocambo Cajueiro Seco em Execução" $\quad$ A Hora Recife, 1522/jun/1963 próprios esforços de recuperação." "374

Hoje, o discurso de Guerra parece ecoar em Borsoi, com a particularidade da referência à autogestão, conceito que nos anos 1960 ainda não parecia estar colocado como tal, aparecendo com pouca precisão na fala do arquiteto. Falava-se muito mais em "autoajuda", "auto-promoção", "auto-determinação" e "mutirão":

"quando você faz a autogestão, usa a força de trabalho do indivíduo, o empenho dele, a aspiração dele, você tá desenvolvendo um núcleo diferente, ele surge do aglomerado de pessoas iguais interessadas em vencer "375

Não por acaso, o jornal dos comunistas dava mais atenção às mobilizações populares em torno das Associações de Bairros ${ }^{376}$, do que às formas da arquitetura; ainda que divulgasse aqui e ali algumas realizações habitacionais socialistas. ${ }^{377}$

Para os comunistas pernambucanos as associações populares tinham a dimensão de instâncias de participação efetiva na vida

${ }^{374}$ Uma política realista para a habitação popular A Hora Recife,29/fev/1964

${ }^{375}$ Acácio Gil BorSOI, Entrevista ao autor, Recife, Set/2007

${ }^{376}$ Como na série de artigos publicados na Folha do Povo "Associações de Bairro, Núcleos de Organização do povo I II III IV e V" em fevereiro de 1959, curiosamente na seção "Folha feminina" dirigida por Neusa Cardim.

377 "Casas pré-fabricadas são montadas como automóveis" A Hora Recife,26/out/1963 "Arquitetos reuniram-se em Cuba: Depois de planejamento, problema habitacional pode ser resolvido" A Hora Recife,15-22/jun/1963

J.B. SILvA "As Associações de Bairro" A Hora Recife,8/fev/1963 "Empossada a Diretoria da Associação dos Amigos de Cajueiro Seco- Prazeres" A Hora Recife, 1522/jun/1963 Moradores de Cajueiro Seco desfazem explorações de Vereador e do Diário 29/fev/1964 Moradores dos bairros querem ajudar governo A Hora 16$30 /$ nov/1963 
política através da democracia direta, referências tanto aos sovietes quanto às organizações de bairros cubanas nos chamados Comitês de Defesa da Revolução (CDRs), observadas também pelos arquitetos e estudantes em viagem à Havana para o Congresso da UIA.

De acordo com o programa comunista, para reverter a tendência burguesa de colocar o povo "à margem do governo do Estado, em atitude passiva", as associações de bairro pernambucanas deveriam constituir o "traço de união entre o povo e os governantes, funcionando ao lado dos sindicatos e outros organismos de classe, como elementos de controle da administracão pública e de expressão das forças populares que marcham para ocupar, de direito e de fato, o seu lugar na direção do Estado" ${ }^{\prime 378}$.

A principal referência era o "Dr. Pelópidas Silveira, o inspirador e criador dessas entidades populares", que as estimulou no seu segundo mandato como prefeito do Recife, entre 1955 e 1959. Nos anos 1960, elas estavam reunidas na Federação de Associação de Bairros de Pernambuco; dentro da qual, a Associação de Cajueiro Seco ocupava o posto de um novo modelo de organização, o que explica o destaque à ela dado nas páginas da $\underline{\text { H Hora }}^{379}$

Já para as oligarquias, representadas pelo Diário de Pernambuco, Cajueiro Seco destacava-se como um projeto de apelo social dentre as diversas realizações recentes de um dos principais expoentes da

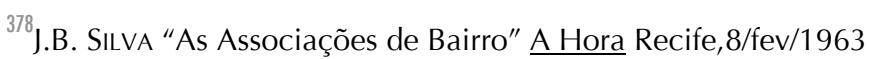

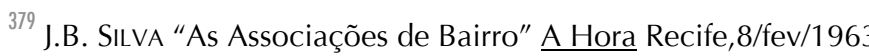

arquitetura moderna pernambucana, estimulada pelo capital imobiliário que estava transformando o Recife, marcando a paisagem da cidade com importantes exemplares do que de melhor produziu a arquitetura moderna brasileira. Este enfoque é particularmente notável no caderno "Imóveis e Móveis" do Diário de Pernambuco, que gozava de relativa independência editorial para publicar notícias e resoluções do SHRu ("por solicitacão de dirigentes locais do Instituto de Arquitetos do Brasil") e do Congresso da UIA de Havana ${ }^{380}$.

$\mathrm{Na}$ última Hora, jornal que divulgava as políticas de Arraes, Borsoi aparecia como um tipo especial de técnico, um artista, um professor, um intelectual que colaborava com o governo popular; supreendentemente, tão cedo quanto em 29 de agosto de 1963, seis meses depois da posse de Arraes, o Diário de Pernambuco publicava nota acerca do pedido de demissão do arquiteto como Diretor de Construções do SSCM, por alegada "medida de estrito interesse pessoal e profissional ${ }^{\prime 381}$. Entre as viagens para participar do SHRu (jul/63) e do Congresso de Havana, Borsoi desligou-se do SSCM, portanto antes da formulação ou pelo menos da publicação do projeto de pré-fabricação de taipa que ficou sendo conhecido como seu.

\footnotetext{
380 "S.Paulo: Seminário reunirá técnicos em habitação do país" Diário de Pernambuco Recife, 21/jul/1963, "Quatro representantes de pernambuco no seminário" Diário de Pernambuco Recife, 28/jul/1963 "Encontro internacional de professores e alunos de arquitetura: Havana" Diário de Pernambuco Recife, 31/out/1963 "Resoluções do seminário de habitação" em "IMÓVEIS \& MÓVEIS" Diário de Pernambuco Recife, 28/nov/1963, Diário de Pernambuco Recife, 4/dez/1963

${ }^{381}$ Diário de Pernambuco Recife, 29/ago/1963
} 
Como já ficou claro até aqui, o objeto deste trabalho não é exclusivamente o "projeto de Borsoi". Precisamos repropor o seu papel como autor da síntese arquitetural de um projeto coletivo, cujas bases já estavam colocadas no âmbito das políticas sociais locais, bem como dos debates e práticas da arquitetura brasileira, na qual tinha um papel importante a produção pernambucana naquele momento, e latinoamericana, para não restringir suas sintonias e ressonâncias ao Brasil ou a Pernambuco.

Somente em 1965, já depois do golpe portanto, é que os desenhos da pré-fabricação de taipa (plantas e detalhes das peças e processos construtivos) ganharam publicidade, bem como as fotos do protótipo executado. Entre outras experiências de pré-fabricação, incluindo a pré-fabricação em concreto fibroso com bambu substituindo armações em aço, o projeto foi divulgado em um número dedicado exclusivamente à pré-fabricação. $\mathrm{O}$ artigo quase não se referiu diretamente à "experiência do Cajueiro Seco" e fez uma leitura mais abstrata do sistema constutivo.

Nas páginas da Revista Arquitetura, Borsoi, o autor do texto que também seria republicado na revista dos Bardi, esclarece as condições nas quais se desenvolveu o projeto:

"Este trabalho surgiu de um contato direto com o problema da habitacão para as classes menos favorecidas. Não tivemos o intuito de estudar mais uma vez um tipo de casa barata, para ser distribuído entre populações marginalizadas; partimos, antes, do princípio de que a casa é o efeito e não a causa do desequilíbrio social e econômico e, assim sendo, deve ser encarada como espelho de uma realidade.(...)

Durante o contato direto com os grupos que construíram suas casa, segundo o processo de auto-ajuda, nos lotes do conjunto de Cajueiro Seco, surgiu a idéia de racionalizar o uso da taipa e mesmo pre-fabricá-la.(...)Da observação da utilização da madeira em uma casa de taipa, construída segundo a maneira tradicional, verificamos de imediato que racionalizando a fabricação dos entreliçados e subdividindo a madeira empregada, dandoIhes melhor aproveitamento, chegaríamos à duplicação da área vedada, com o emprego da mesma quantidade de material" 382

Os desenhos e fotos apresentados ali se eternizariam nas publicações posteriores sobre a experiência como nos artigos "Ao limite da casa popular", de Lina Bo ${ }^{383}$, publicado na Mirante das Artes e em "Cajueiro Seco: o caminho interrompido da autoconstrução industrializada", publicado na revista Projeto já nos anos 80. Exceção feita ao artigo publicado na revista $\underline{\mathrm{OU} . . .}{ }^{384}$, voz da dissidência ao PCB reunida na FAU USP, que tinha por base os dois artigos publicados na Revista Arquitetura antes de 1964. A análise de Lina Bo, realizada em 1967, depois da interrupção da experiência e frustração das expectativas dos arquitetos, ainda parece uma das leituras mais interessantes do Cajueiro Seco:

"saindo de uma realidade existente, mesmo se, para isto fosse necessário renunciar, por parte do arquiteto, a resultados formalmente atraentes e "modernos", para chegar, dentro de uma renúncia profissional decidida a priori, a um quase "limite" arquitetônico: o princípio da autoajuda e a "melhoria progressiva", diretamente ligada a fatores econômicos. Nada de romântico nestas soluções, nada de se inspirar nas Ocas e nas Favelas, ou a poesia da simplicidade camponesa (ou melhor, da indigência,

\footnotetext{
382 “Pré-fabricação em taipa” in Arquitetura IAB-GB №40 Rio de Janeiro, 1965

${ }^{383}$ Publicado na revista do casal Bardi Mirante das Artes, mar-abr/1967

384 "Mocambo no Recife - 1962:Núcleo habitacional do Cajueiro Seco" in
} №4 São Paulo, Jun/71 
como aconselha toda uma tradição literário-reacionária), mas uma procura direta de elementos formados por uma experiência (experiência técnica, mesmo se primitiva): a estrutura de "barro-armado", a casa de sopapo. Entre a possibilidade remota de um pré-moldado utópico e a realidade de um primitivismo contingente e superável, tecnicamente orientado, foi escolhida a segunda possibilidade. Até a construção de tijolos praticamente realizável, mas sociologicamente inviável no caso da autoajuda, foi eliminada. Atrás das pequenas soluções de Cajueiro Seco há todo um século de pesquisas e de tomadas de consciência; toda uma história da habitação do homem orientada pelos fatores econômicos e pela legislação social. (...) É um trabalho que toma consciência do subdesenvolvimento do país, não como fatalidade ou uma condenação, mas como um fator de contingência histórica. "1385

O material reunido na publicação Prefabrication:Taipa foi reorganizado pelo escritório do arquiteto em 1965, traduzido e republicado para participar de um concurso internacional do ICSID, o Conselho Internacional de Sociedades de Desenho Industrial, nos anos 1970, entidade ligada à UNESCO sediada inicialmente na França e Holanda $^{386}$ que nesse momento estava atualizando sua agenda de compromissos sociais da profissão. ${ }^{387}$ Esta publicação serviu

${ }^{385}$ Bardi, L. B. Ao Limite da casa popular in Mirante das Artes Etc... Mar/Abr 1967

${ }^{386}$ Na Holanda nos anos 1970 estivera também Armando de Holanda, realizando um curso sobre racionalização da construção no Baumcentrum, de acordo com Geraldo Gomes da Silva, Entrevista.

${ }^{387}$ The International Council of Societies of Industrial Design (Icsid) is a global notfor-profit organisation that promotes better design around the world. "The 1960s also witnessed a growth within Icsid's membership to include a number of noncapitalist countries of the time. This changed Icsid's outlook from being somewhat insular to being an inclusive and truly outward-looking organisation that transcended political boundaries. In this sense, Icsid became a bridge between two worlds, where industrial designers from all backgrounds could meet, exchange and learn from one another. Icsid members relished in the spirit of collaboration that was inspired by the inclusive nature of Icsid's work." In 1985, a groundbreaking provavelmente como fonte de imagens para diversas histórias da arquitetura brasileira como a de Sylvia Fischer e Marlene Acayaba, e a de Hugo Segawa, como denotam as legendas em inglês nas imagens. ${ }^{388}$ Na publicação, Borsoi reformulou a explicação do projeto, indo da necessidade premente do problema habitacional ao design do produto, à casa, construindo um discurso que se tornou recorrente:

"A idéia surgiu quando de um trabalho para comunidades de baixa renda que vivem aglomeradas em níveis de completa miséria e que necessitam de atendimento urgente, tal como a remoção para áreas salubres, num plano massificado, em que seria necessário o apoio da força de trabalho do homem ao programa social de recuperação. Pela constatação de que estes grupos sociais não possuem conhecimento além daquele que resulta de sua própria necessidade, dentro de sua realidade, do seu conhecimento artesanal e da utilização de suas próprias mãos, foinos possível desenvolver o trabalho. No uso da madeira em uma casa de taipa (barro armado), construída segundo a maneira tradicional verificamos que racionalizando a fabricação dos entrelaçados e subdividindo a madeira empregada dando-lhe melhor aproveitamento, chegaria à duplicação da área vedada, com o emprego da mesma quantidade de material, dando, assim, maior rendimento. (Prefabrication Taipa, ICSID)

Já Yves Bruand, serviu-se da revista Mirante das Artes como fonte para a inclusão do Cajueiro Seco na sua história da arquitetura

Interdesign was held by Icsid and UNESCO and in coordination with Icograda. The issue under investigation was the design of basic medical equipment for developing countries. The seminar brought together 4 doctors, 14 industrial and graphic designers, and 7 assistants to develop designs for basic furniture for rural health centres, packaging, transport, refrigeration, and injection of vaccines and the design of data collecting devices for field use. This Interdesign served as further evidence of the power of design as a tool for development in developing countries, and the role that Interdesign play in this. Disponível em http://www.icsid.org

${ }^{388}$ Introduzido por Vicente Wissenbach e publicado na Revista Projeto, nos anos 1980 
contemporânea no Brasil; ainda que a Habitat, revista dirigida pelo casal Bardi na altura dos acontecimentos, não dedicasse sequer nota ao Cajueiro Seco. Haviam referênciais e editoriais sobre o problema da habitação popular no Brasil, mas certamente a experiência do Cajueiro Seco chegou à Lina pela chave das suas pesquisas de artesanato e arte populares, ligadas à sua atuação no Nordeste. ${ }^{389}$

Pode-se apontar para uma apropriação que Borsoi faz do projeto como sendo uma solução autoral, mas o importante é perceber como o arquiteto foi responsável por traduzir em arquitetura as idéias sobre política pública de habitação e pré-fabricação, sintetizando uma expressão das idéias que estavam sendo debatidas e formuladas por um conjunto de arquitetos, cientistas sociais, políticos e intelectuais, resultando numa proposta diferenciada que trouxe também algumas referências pessoais.

Da mesma forma, é importante notar a mudança de discurso do arquiteto nesses anos, atentando para a permanência da questão da habitação popular como integração social. Hoje, o discurso de Borsoi sobre o tema absorve alguns raciocínios dos anos 1960 acrescido de outras referências do arquiteto, como o trabalho do economista inglês John Kenneth Galbraith, citado na epígrafe que encerra o capítulo de seu livro dedicado aos seus "projetos sociais", ${ }^{300}$ que aqui reproduzimos:

\footnotetext{
${ }^{389}$ Ver PEREIRa, J. 2001

${ }^{390}$ Curiosamente o único capítulo do livro impresso em papel de qualidade inferior.
}

"A maneira protetora e imediatista com que a classe privilegiada encara a sua própria posição faz parte da sua natureza. Vale lembrar mais uma vez que não existe nenhuma medida para aliviar a pobreza, ou para melhorar a vida e garantir a mobilidade ascendente das classes inferiores, que não exija atuação do Estado, apesar de toda a oratória e argumentação aparentemente sofisticada, em contrário - cuja finalidade não é produzir resultados, mas aliviar a consciência e os custos mais privilegiados. ${ }^{391}$ ${ }^{391}$ GALBRAITH, John Kenneth. Uma viagem pelo tempo econômico apud BORSOI,
Acácio Gil Arquitetura como Manifesto 2006 p 96. 


\subsection{Ocupacão do território e autoconstrucão}

Entre os visitantes ilustres que se interessaram pela experiência de Cajueiro Seco, estavam Hubert Beuve-Mery, fundador e editor dos jornais Le Monde e Le Monde Diplomatique (Última Hora, mai/1963), Lina Bo Bardi, Sandra Cavalcanti (ainda que incógnita), além de uma grande quantidade de políticos, intelectuais, médicos e arquitetos pernambucanos que foram conhecer de perto a experiência que ganhara tanta repercussão. A divulgação dela, ainda em desenvolvimento tanto na imprensa local e brasileira quanto nas revistas especializadas, nos Congressos e seminários de arquitetura e habitação explica parte da aura que se criou em torno da experiência interrompida e o que ela poderia ter sido.

O trabalho de conclusão de curso e o depoimento contemporâneo da assistente social (hoje professora doutora aposentada da Escola de Serviço Social da UFPE) Francisca Veras constituem importantes retratos da situação do Cajueiro Seco logo depois do golpe. Ela ajuda a esclarecer a experiência, suas ressonâncias e significados ao reconhecê-la de outro campo de conhecimento, em outra situação,

"O Cajueiro Seco era famoso porque era um projeto diferente, um projeto especial, não existia, que eu conheça, nenhuma comunidade que tinha um projeto urbanístico daquela forma e orientada pra ser autosuficiente. Porque o povo ia trabalhar ali mesmo, nas unidades que foram construídas. Quem fez era realmente avançado nesse sentido social. Era quase que uma sociedade modelo e ela foi muito visada porque se houve penetração dos comunistas eu não conheci, só ouvia comentários, receios e medos (...)A coisa ali tava se organizando de um jeito diferente e quando veio a revolução entrou uma orientação mais paternalista de novo. (...)Arraes tinha o discurso, de tudo diferente, mas na prática ele não tinha muito o controle. Por isso os programas eram mesmo paternalistas, ele tinha interesse de fazer trabalhos de base, para essa autodeterminação, essa coisa do povo ser outro povo." 392

Ela mesma hoje se surpreende com a possibilidade de ter realizado seu trabalho de organização de comunidades naquele local, logo depois da ditadura, quando ele passou a ser era visto como um dos epicentros da "cubanização" que se processava no Estado antes da "Revolução":

"Tinha gente que acreditava que estava havendo subversão e que eles iam corrigir, trabalhar o povo noutro sentido. $E$ eu as vezes fico me perguntando como, se você vai organizar o povo, porque o trabalho de Serviço Social é conscientizador, educativo..."

O professor Geraldo Gomes faz hoje uma leitura crítica e consciente da interrupção da experiência, o que nos remete ao quadro de expectativas frustradas que marcaram a queda de Arraes; algo inscrito no pretérito do futuro - o que poderia ter sido e não foi, como no poema do recifense Manuel Bandeira:

"Infelizmente foi uma experiência abortada, Borsoi não era comunista e nunca foi e quando veio o Golpe a primeira coisa que fizeram foi interromper Cajueiro Seco, no começo do Governo Arraes e pouca coisa foi feita. Nem sei se foi feita chegou a ser feita alguma casa no processo de pré-fabricação de taipa, se foi foi muito pouco, o protótipo e meia dúzia. Foi feito o arruamento, a lavanderia e as cooperativas, funcionou por pouco tempo. Era muito mais uma promessa, uma esperança, tudo indicava que ia dar certo mas não posso afirmar que deu

\footnotetext{
${ }^{392}$ FrANCISCA VERAS, Entrevista ao autor, Recife Mar/ 2008
}

${ }^{393}$ FrANCISCA VERAS, Entrevista ao autor, Recife Mar/ 2008 
certo, não se concretizou" ${ }^{394}$

O depoimento de Francisca Veras, bem como as descrições do assentamento e da sua população elaborados para compor o diagnóstico da comunidade que ela se propunha a reorganizar e mobilizar, constituem importante fontes de informações do que foi de fato realizado em Cajueiro Seco:

"(As casas) Eram mucambos mesmo, muito simples, as em volta. Quando eu fui já era esse traçado urbanístico mesmo. Dentro desse traçado era autoconstrução e ajuda mútua. (...)Eles dotavam a comunidade de serviços básicos, como se chama, construíam o mínimo, um posto médico, a sapataria, oficina de confecção e a cooperativa pra colocar uns produtos e ensinar a comunidade a se movimentar e ser autosuficiente ${ }^{1395}$

A análise feita por Veras na ocasião, logo após o golpe, contrasta com as esperanças dos antigos encarregados pelo SSCM. Ela descreve a comunidade como numa transição a caminho da sua "auto promoção e autodeterminação (...) uma novidade e uma vitória" (VERAS, 1964-65, p. 10) e à "organização social da comunidade", objetivos do trabalho que propunha naquele momento. Segundo ela, "Ali não se plantara o ideal da participação e responsabilidade democrática, porém, por outro lado não chegara a estabelecer-se o vício do paternalismo do poder público". (VERAS, 1964- 65, apresentação)

A comunidade também se encontrava em estágio transitório com relação à cidade, processo perceptível pelo perfil de seus 1615

\footnotetext{
394 Geraldo Gomes da Silva, Entrevista ao autor, Recife, Ago/ 2006

${ }^{395}$ FrANCISCA VERAS, Entrevista ao autor, Recife Mar/ 2008
}

habitantes, descritos como de saúde, educação, alfabetização e qualificação profissional deficientes: "Os seus hábitos de constumes são próprios das comunidades em transição como consequência do processo de urbanização em que vão se integrando" (VERAS, 1964-65, p. 16)

Reminiscente à tradição sociológica dos estudos de comunidade, de matriz inglesa e norteamericana, difundido no Brasil a partir dos anos 1940, a idéia de comunidade em transição, isto é, situada no contínuo rural-urbano tornara-se muito recorrente no estudo dos problemas sociais no Brasil na virada dos anos 1950 e 1960.

Tratava-se de examinar os extratos superpostos que os graus de hibridismo entre padrões e valores sociais próprios às sociedades rústicas em seu processo de urbanização, focalizando a passagem de comunidade à sociedade, das formas primárias de gregariedade e cultura aos padrões de solidariedade, tais estudos tenderam a focalizar os meios de vida dos grupos subalternos no processo de mudança social $^{396}$.

Curiosamente, alguns dos argumentos apresentados trabalho de Veras estão calçados na "crença na capacidade que tem todo homem de promover-se, passando de objetivo a agente do desenvolvimento de sua comunidade". Sua ressonância no discurso de Borsoi, revela uma peculiariedade da história no trato da habitação social em Pernambuco : as rede pessoais, ideológicas e políticas que ligavam a Escola de

${ }^{39}$ Ver Antônio CÂNDIDO, O problema dos meios de vida e Parceiros do Rio Bonito 
Serviço Social à Faculdade de Arquitetura, que aliás durante anos funcionaram em prédios contíguos na Av. Conde da Boa Vista.

Essa proximidade reflete também a composição dos quadros técnicos do SSCM, que integrava os dois campos disciplinares. Além disso, fica clara nas entrevistas realizadas com Francisca Veras e Maria Lucia Mello a vinculação do pensamento da assistência social com os setores progressistas da Igreja católica, via Dom Hélder Câmara, com quem colaboraram em diversos projetos, como o da Vila Dois Unidos $^{397}$. Tais projetos de auto-ajuda estimulados pela Igrja evidenciam o elo entre uma teoria social de modernização e a referência ao auto-empreendimento, à conversão do "marginal" em cidadão pelas suas próprias capacidades.

Veras nos dá preciosas informações para avaliar o que de fato foi realizado, à parte das melhores expectativas da gestão anterior e do clima de "medo e desesperança" que imperava depois da queda de Arraes.

Segundo ela, "o número de lotes inicialmente previsto era maior, mas o aterro não foi concluído e parte do equipamento comunal foi instalado numa área antes destinada à moradia. (...) A ocupação dos lotes antecedeu à instalação do equipamento comunal e nenhum trabalho de orientação técnico-educacional, indispensável à adaptação daqueles à nova situação habitacional, se fez acompanhar" (VERAS, 1964-65, p. 7)

Além das informações estatísticas e descrições dos aspectos físicos e práticas desenvolvidas na comunidade pelo governo Arraes, o

397 FrancisCa Veras, Entrevista ao autor, Recife Mar/ 2008 e Maria Lucia Mello, Entrevista ao autor, Recife Mar/ 2008 trabalho de Veras ${ }^{398}$ é permeado por críticas à política anterior, em que pese aí, para além das opiniões da autora, também o momento no qual foi elaborado:

"A edificação das casas pelo sistema de autoconstrução não estimulou a ajuda mútua, de estágio superior àquele. (...) Essa solução porém, não vem de encontro do que é uma aspiração do novo povo, não considerada na administração passada - o desejo da casa de alvenaria, de superação do mocambo e do "status" que o acompanha" (VERAS, 1964-65, p. 8)

Repõe-se aqui a esperança na técnica, seja ela a arquitetura ou a assistência social, que, posta à serviço do povo e em troca permanente com ele, criaria um novo homem, de "estágio superior" como sua casa, ainda que se reconheça seu direito de desejar também "status", para além da superação do mocambo.

Menciona-se um projeto elaborado conjuntamente com a SUDENE com o objetivo de receber financiamento desta para a construção das casas(VERAS, 1964-65, p.27), o que provavelmente deve ter a ver com a demonstração do sistema construtivo da taipa préfabricada feita para Celso Furtado, mencionada por Borsoi. Vale a pena evocar aqui a intensa troca de correspondência entre Lina Bo Bardi e Celso Furtado, que apontam para a amplitude do projeto de um novo design, calcado nas premissas da realidade brasileira.

Francisca Veras traz elementos que questionam do ponto de vista fundiário a "solução" da invasão dos Montes Guararapes e

\footnotetext{
${ }^{398} \mathrm{O}$ único até agora que trata especificamente de Cajueiro Seco encontrado na biblioteca do Centro de Artes e Comunicação da UFPE
} 
ocupação da gleba contígua ao que se conhecia como Cajueiro Seco originalmente, hoje Cajueiro de Dentro:

"A área ocupada pelo SSCM, no governo anterior, como solução para o problema da invasão dos Montes Guararapes, há vinte anos está em litígio entre particulares - a Usina Muribeca e a Ordem dos Carmelitas" (VERAS, 1964-65, p. 8).

De fato, a questão da propriedade da gleba já vinha de antes de 1960 e a situação dos lotes só foi regularizada nos anos 80, já no segundo mandato de Arraes, quando de seu retorno do exílio. Analisando a ocupação daquele subúrbio do ponto de vista do seu entorno, percebe-se que a gleba estava inscrita no quadro de disputas em torno da terra que se dava na região de Prazeres, frequentemente entre a Igreja e companhia privadas. Além disso, havia ainda a disputa pela emancipação de Prazeres, promovida por políticos como os vereadores Newton Carneiro e Augusto Lucena, que até hoje disputam os territórios eleitorais e residenciais populares de Jaboatão e Recife. Propunha-se a constituição de um novo município alavancado pela renda imobiliária do desenvolvimento que se prenunciava para o distrito das praias de Piedade e Candeias, deixando a antiga e emprobrecida Jaboatão no interior. ${ }^{399}$

A situação apresentada por Veras retrata a gestão anterior como de uma certa inconsquência com relação à sua própria política:

"a autarquia não fez qualquer estudo quanto aos investimentos feitos

399 "Desapropriação de terrenos em Prazeres" Jaboatão Jornal, Jaboatão, 28/ago/1960, "Edital de Citação Cia de Terrenos Prazeres" Jaboatão Jornal, Jaboatão, 28/ago/1960 e "Colcha de retalhos querem fazer do município" 」aboatão Lornal, Jaboatão, 11/jun/1960 na área a serem computados como custos, (...), que sem dúvida, contribui para a descapitalização do Serviço e evidencia um comportamento assistencialista" (VERAS, 1964-65, p.21)

Tais críticas nos trazem de volta as observações feitas por Artur Lima Cavalcanti sobre os problemas das políticas habitacionais brasileiras no projeto de lei da SUPURB. Encerrando um ciclo de práticas, debates e retóricas em torno da produção da casa popular, o projeto visava sistematizar procedimentos, até então sujeitos ao clientelismo e assitencialismo dos governamntes, a partir de uma forma regular de financiamento e planejamento. A idéia foi apropriada pelo regime militar e traduzida no modelo tecnocrático e centralista do Banco Nacional de Habitação, presidido por Sandra Cavalcanti, ${ }^{400}$ que impôs novas relações entre a problemática da habitação social, dirigismo estatal e capital imobiliário.

"O Plano Piloto habitacional de Cajueiro Seco, assim chamado na própria placa de inauguração, seria o início da efetivação no Grande Recife da política de criação de núcleos habitacionais cuja instalação da infraestrutura urbana e equipamento comunal ficavam à responsabilidade do poder público, cabendo à família a construção da casa, às suas expensas" (VERAS, 1964-65, p. 26).

Veras lista as realizações da administração do SSCM até abril de 1964. Há referências ao planejamento físico da comunidade, a

${ }^{400}$ A poderosa assessora de Carlos Lacerda no Estado da Guanabara, filha do deputado Tenório Cavalcanti, o "Homem da capa preta" ou o "Rei da Baixada", Sandra Cavalcanti havia enfrentado a favela carioca na base do autoritarismo, com remoções em massa para as distantes periferias como Vila Kennedy, batizada em sinal de agradecimento às verbas foram despejadas na Guanabara pela Aliança para o Progresso, "simpática" à figura de Lacerda; segundo o "Acordo do Nordeste", esse dinheiro deveria ser investido na promoção de habitação na região. 
pesquisas de caracterização sócio-econômicas, à instalação de um chafariz, do equipamento social básico e do posto de saúde instalado "numa casa pré-fabricada", porém não há nenhuma menção à casa de taipa pré-fabricada.

Pedro Celestino da Silva, apontador assistente, em depoimento no DOPS, depois do golpe, relatou que

"foi designado para trabalhar na comunidade de Cajueiro Seco, ao que parece no dia 18 de março de 1963; que incialmente sua obrigação funcional consistia em receber os caminhões de barro para o aterro das ruas e fazer o alinhamento das casas que estavam sendo construídas; que terminado o alinhamento, este último em parte, ele declarante passou a administrar, ou melhor fiscalizar a construção de uma casa pré-fabricada; (...) que daí por diante continuou na parte de fiscalização de obras que eram realizadas na comunidade de Cajueiro Seco tais como, chafariz, sapataria, artezanato e o posto de revenda da $C R C^{\prime \prime 401}$

A narração dos acontecimentos dos primeiros dia de abril de 1964 pelo ponto de vista do morador do Cajueiro Seco, o sapateiro Seu Inácio, dá a medida da dimensão da intervenção militar no bairro e do que aconteceu com as melhores expectativas da população:

"Eu vi tanto cacete por aí que fiquei até com medo. No dia da revolucão, eu fui comprar farinha, aqui tinha um mercadinho de farinha, eu trabalhava com uma carrocinha vendendo os calçados e quando eu fui entrar no mercado tinha só caixa de bala. Ele fez: "Você mora aqui, você não sabia disso? O governo... Mas não vai levar farinha não?" e eu disse: "Dessa daí não quero não". Era caixa de bala de fuzil. Depois, antes de eu sair da feira, chegaram os tanques de guerra por dentro das bananeiras. Polícia da roupa amarela? Eu vi os três levando pancada, tabefe no pé do ouvido e eles na carreira, batendo, eles correndo, mais ou menos umas dez horas, peguei a minha carrocinha e vim embora pra casa e disse pra minha

${ }^{401}$ Pedro Celestino da SILVA, Depoimento no Inquérito Policial Militar (IPM) do $\underline{\text { SSCM}}$, Acervo DOPS do Arquivo Público Estadual (APEJE) mulher: "Se der jeito nós fica aqui se não der a gente tem que... [ir embora]". Eu trabalhava aqui mas eu vendia mais no Correio, na cidade, vendia ali, pegava as encomendas do povo. Minha vida era essa (...)O Exército não ficou muito não. No início prenderam algumas pessoas, outras desapareceram. Tenho conhecidos que eu vi na cidade uns seis ou oito meses depois e o povo teve medo de vim falar comigo: "Como é que tu tá lá?" e eu disse: "Do mesmo jeito, trabalhando e vendendo, levando minha vida" Não é questão de revolução, de política. Eu, toda vida, graças a Deus, nunca me envolvi em nada de política. Os que tinham, pegavam um setor que eles trabalhavam, aqueles que estavam assinadinho eles iam lá, o pau comia." 402

Do ponto de vista burocrático, houve uma apropriação da experiência pela nova gestão do SSCM, comprometida com o golpe. Segundo a assistente social, então funcionária da autarquia, Maria Lucia Mello, num primeiro momento, durante a presidência do advogado João Pinheiro Lins, que foi tolerante, ofereceram-se condições para que o trabalho social continuasse em Cajueiro Seco.

Segundo ela, essa relativa abertura foi o que permitiu que sua orientanda, Francisca Veras, realizasse ali seu trabalho de conclusão de curso. Maria Lucia Mello descreve o clima na autarquia e as condições de trabalho depois da "Revolução":

"No dia da inauguração, a gente, tinha um equipe de engenharia e arquitetura, Mário Jorge, Marconi, foi surpreendido com essa turma dos Centros Educativos Operários, chegaram los novos encarregados pelos CEOs] e era como se fosse outro trabalho. As assistentes sociais, se a gente quisesse continuar, como eles eram os diretores dos Centros, todo processo político e burocrático passaria por eles. Evidentemente isso significava um

${ }^{402}$ Seu INÁCIO, Sapateiro, morador da Rua 6 Nº65, Entrevista ao autor, Jaboatão, Jan/2007 
recuo em relação à participação da população. "103

Em paralelo à esta relativa tolerância, realizavam-se sobre o Cajueiro Seco e o SSSCM investigacões sumárias e interrogatórios nos órgãos de Segurança Pública, coordenados pelo agente Milton Pinheiro Ramos, que depois assumiria a presidência do SSCM. Implantando uma linha de trabalho mais comprometida com a ideologia do Golpe de 1964, a nova gestão viria a inviabilizar o trabalho de assistência social e da própria Maria Lucia Mello, cuja permanência até aquele momento Ihe havia sido franqueada por ser considerada independente da gestão Gildo Guerra, ou seja não comprometida com a "subversão" ${ }^{404}$.

Veras se refere a uma reformulação da experiência depois do "movimento de 31 de março de 1964". Tanto em seus aspectos sociais, estimulando o desenvolvimento da comunidade (evitando à subversão) e do trabalho em bases cooperativas, quanto físicos, na medida em que o aterro original ainda não havia sido completado. Ela inclui no seu trabalho os desenhos do projeto urbano original, dos equipamentos comunitários e da revisão da implantação.

Em suas conclusões, Veras fez um balanço crítico da experiência,que constrasta bastante com a visão do Cajueiro Seco

${ }^{403}{ }^{106}$ Maria Lucia MeLLO, Entrevista ao autor, Recife Mar/ 2008 que se celebrizou:

"No que se refere à política habitacional de efetivação de núcleos para população de baixa renda, representa o Cajueiro Seco muito pouco. O que salta aos olhos é um conjunto de mocambos não higienizados. A preocupação político-ideológica era superior a de promoção humana daquele e de outros grupos em idêntica situação que não encontrariam nas novas comunidades o estímulo para uma autopromoção, pelo menos, a médio prazo. O que se procurava enfatizar era o regime de "enfiteuse" em vigor, responsável pelo pagamento de "chão" nos morros e alagados do Recife. Relegava-se como acidental, a melhoria das condições de vida daquele grupo ocupante de choças ou casas de taipa, sem higienização, objeto de um processo unilateral de politização que não se fazia acompanhar de uma orientação técnico-educacional"(VERAS, 1964-65 p.101)

Não obstante, a avaliação pouco entusiástica da estudante, a leitura dos documentos do acervo da Secretaria de Segurança Pública hoje parcialmente disponíveis no Arquivo Público Estadual dá a medida da importância de que se revestiu a comunidade de Cajueiro Seco no contexto de repressão política. Logo em 10 de maio de 1964 estabelece-se uma "Comissão Central" na Procuradoria Judicial do SSCM, presidida por Milton Pinheiro Ramos, que mais tarde tornar-se-ia agente de Segurança Pública, com "a atribuição de realizar investigações sumárias e processar representações, opinando sobre a conduta do servidor, ligadas aos crimes e atos" (Edital, 10/mai/1964) que a administração de Gildo Guerra estaria promovendo na autarquia.

Foram colhidos diversos depoimentos de funcionários menores na hierarquia da repartição, que refletem a tensão que existia entre os servidores de carreira e os cargos de confiança ligados à administração 
Arraes, fato observado em outras esferas do serviço público por Germano Coelho ${ }^{405}$.

A atuação do SSCM naqueles anos também foi objeto de um Inquérito Policial Militar, decorrente do relatório da tal Comissão Central, no qual se pretendia enquadrar a suposta comunização do aparelho de Estado pela infiltração de elementos do Partido Comunista. Gildo Guerra, como presidente da autarquia, foi o principal alvo de tais acusações:

"É de toda evidência que o Ex-Presidente do SSCM ao assumir a direção da Autarquia procurou ali instalar um dispositivo de sua absoluta confiança capaz de tranquilizá-lo a respeito do seu programa de favorecimento do esquema comunizante do Estado e até de sua implantação" 106

A presença de Ivo Valença ${ }^{407}$, "tido como vice presidente tão grande era a influência por ele exercida sobre todo o funcionalismo e tão sólido o prestígio que recebia da alta direção da entidade" ${ }^{408}$ nas atividades do SSCM sem que ele fizesse parte dos quadros e especificamente no Cajueiro Seco, "uma espécie de prefeito da

\footnotetext{
${ }^{405}$ Germano COELHO, Entrevista ao autor Recife, set/2007

${ }^{406}$ Telga Gomes de ARAújO, Relatório do Inquérito Policial Militar (IPM) do SSCM Acervo DOPS do Arquivo Público Estadual (APEJE), Recife, p.16

${ }^{407}$ Ivo "Jegue" Valença era de fato uma importante liderança do Partido Comunista Brasileiro em Pernambuco, juntamente com David "Touro sentado" Capistrano e Hiram Pereira. Depois do golpe de 1964, passou à clandestinidade e à resistência armada ao regime militar, sendo assassinado pelos órgãos de repressão em 1974 (OliveIRA, 2008, p.98-99)

${ }^{408}$ Telga Gomes de ARAújO, Relatório do Inquérito Policial Militar (IPM) do SSCM Acervo DOPS do Arquivo Público Estadual (APEJE), Recife, p.16
}

comunidade $^{\prime 409}$, serviam como prova inconteste do processo de "esquerdização", já que era sabida sua ligação com o Partido Comunista.

Na imprensa, mesmo antes do golpe, sua atividade já vinha sendo questionada por antigos colaboradores da autarquia ${ }^{410}$. Segundo Maria Lucia Mello, Ivo Valença ocuparia posição superior a de Gildo Guerra na hierarquia do PCB, o que explicaria seu prestígio ${ }^{411}$.

De acordo com os inquisidores, outra peça importante na implantação do "comunismo caboclo" ${ }^{412}$ seriam os Centros Educativos Operários (CEOs), cujam atividades eram à época coordenadas pela médica Naíde Regueira Teodósio, a cargo do Departamento de Reeducação e Assistência Social, em estreita ligação com as Associações de Bairro do Recife, "órgãos de base da estrutura do PC no estado" ${ }^{413}$.

Entre suas atribuições estavam locar as famílias nos lotes e coordenar a cobrança dos aluguéis dos terrenos e aplicação dos recursos nas atividades da cooperativa, do posto de saúde e da

409 Pedro Celestino da SILVA, Depoimento no Inquérito Policial Militar (IPM) do SSCM, Acervo DOPS do Arquivo Público Estadual (APEJE)

${ }^{410}$ A que título Ivo Valença foi admitido no SSCM, deputado indaga 4/out/1963 Diário de Pernambuco

${ }^{411}$ Maria Lucia MeLLO, Entrevista ao autor, Recife Mar/ 2008

412 Telga Gomes de ARAújO, Relatório do Inquérito Policial Militar (IPM) do SSCM Acervo DOPS do Arquivo Público Estadual (APEJE), Recife, p.20

${ }^{413}$ Telga Gomes de ARAúsO, Relatório do Inquérito Policial Militar (IPM) do SSCM Acervo DOPS do Arquivo Público Estadual (APEJE), Recife, p.27 
lavanderia coletiva implantadas no Cajueiro Seco. Para os agentes da repressão, essas atribuições e atividades confirmavam a "política de favorecimento a comunistas notórios" nos critérios de distribuição dos lotes e materiais de construção disponíveis na cooperativa.

Tais práticas são mencionadas nas entrevistas das assistentes sociais, que comentam ter presenciado comunicação entre Ivo Valença e os diretores do SSCM requisitando lotes a determinadas pessoas. É importante lembrar que a prática de favorecimento de aliados era usual nas repartições públicas pernambucanas independentemente de tendência político partidária, como aliás continua sendo, por todo o país, independente da região.

Naíde Teodósio, em depoimento ao DOPS, afirma que esteve no Cajueiro Seco algumas vezes para "mostrar a pessoas interessadas na política habitacional do governo", e que certa vez esteve com um Diretor do DENEru da Guanabara, sua senhora e uma senhorita norteamericana que fazia parte do grupo de voluntárias da Pátria com atuação no Estado da Guanabara ao que parece por força do convêncio entre o Governo daquele estado e a Aliança Para o Progresso" ${ }^{414}$. Borsoi, em entrevista ao autor, conta que Sandra Cavalcanti, Diretora da Assistência Social da Guanabara e assessora especial de Carlos Lacerda esteve incógnita em Pernambuco visitando Cajueiro Seco.

Naíde, além de suas atividades políticas e competência profissional que a tornaria referência nacional no campo da nutrição,

${ }^{414}$ Naíde Regueira TEODÓsıo Depoimento no Inquérito Policial Militar (IPM) do $\underline{\text { SSCM }}$ Acervo DOPS do Arquivo Público Estadual (APEJE), Recife, p.16 era casada com o médico Bianor Teodósio, como ela militante do PCB, que nessa época, juntamente com Vital Lira e Ciro de Andrade Lima entre outros jovens médicos, organizaram o Serviço de Assistência Intinerante no âmbito do MCP.

Ao analisar tais documentos, não podemos deixar de notar o tom de condenação a determinados temas e vertentes de pensamento, que até o momento da "Revolução" faziam parte do debate político da cidade, e que naquele momento tenso no qual tais depoimentos foram colhidos, serviam como as "provas" da suposta "subversão comunizante do estado sob o comando de Miguel Arraes". Naíde Regueira Teodósio foi inquirida na Casa de Detenção, sabe-se lá em que condições, e muitos outros não tiveram a oportunidade de "prestar esclarecimentos" porque encontravam-se em "lugar incerto e desconhecido", fugindo das perseguições que se tornaram usuais.

Pela consonância dos depoimentos da época e alguns relatos contemporâneos, podemos reconhecer que tenha de fato havido algum tipo de favorecimento a determinadas pessoas ligadas a setores sociais e grupos políticos, prática arraigada no contexto brasileiro, inclusive no campo da esquerda. No entanto, a interrupção brusca da experiência e a violenta perseguição dos envolvidos não pode ser justificada por esses elementos, que soam ao leitor contemporâneo como um pretexto conveniente para a repressão a uma determinada ideologia, da qual, além disso, nem todos os "indiciados" compartilhavam.

Nos depoimentos existem referências esparsas acerca da compra de madeiras e sacos de cimento pelo SSCM para venda na cooperativa 
do Cajueiro Seco e insinuações do desvio desses materiais para uma casa de praia construída para o governador Miguel Arraes em Candeias, onde morava Gildo Guerra, e denúncias do favorecimento de uma babá que trabalhava na casa de Madalena Arraes na seleção de uma casa do SSCM.

O inquérito do Agente de Serviço Social revela dados do funcionamento da Associação de Bairro antes do golpe. Segundo Ivanildo Florêncio de Souza, cabia a ela "selecionar e localizar os pretendentes aos terrenos do Cajueiro Seco" e que "sabe que se tratavam de elementos de tendência esquerdista", além de ter "conhecimento de que em várias ocasiões eram transportados moradores da comunidade de Cajueiro Seco para comícios políticos realizados na cidade do Recife" e que esse aliciamento era feito pela Associação de Bairro, bem como a cobrança dos aluguéis do terreno. Ivanildo "assistiu a inauguração de Cajueiro Seco onde falaram vários oradores, inclusive o Presidente da Autarquia, um Conselheiro do Serviço, o Governador do Estado e o Presidente geral das Associações de Bairro no Recife, também conselheiro da Autarquia"

O motorista do SSCM que atendia Gildo Guerra e sua família faz um interessante instantâneo do momento do golpe e do destino do presidente do SSCM:

"nos acontecimentos do dia 31 de março para o dia $1^{\circ}$ de Abril se encontrava no SSCM quando for a solicitado para conduzir o Presidente da autarquia até o Quartel do Dérbi; que ficou surpreendido quando ali chegou encontrando a tropa em rigorosa prontidão, com trincheiras cravadas e um número ilimitado de viaturas pertencia ao MCP, ônibus da CTU, Frente popular de educação, Sanemaneto do Estado, SUDENE, etc; que ao dirigir ao Quartel do Dérbi Dr. Gildo Mario Porto Guerra apanhou no caminho o Senhor Otávio Santos, pessoa a que sempre visitava e de quem era amigo; que durante a permanência dele no Quartel do Derbi, assistiu quando oficiais do exército prenderam o Coronel Hangho Trench; que após a prisão do referido coronel o Dr. Gildo Guerra Ihe deu uma importância para o almoço, liberando ele declarante; que o Dr Gildo Guerra saiu dirigindo a viatura do SSCM que se destinou a casa do $\mathrm{Sr}$ Otávio Santos; que posteriormente tomou conhecimento, através da esposa do Dr Gildo Guerra, se encontrar a viatura abandonada, no bairro da Torre, com as chaves no próprio veículo" 475

Além do SSCM, outros órgãos de Estado como o Departamento de Obras e Fiscalização do Serviço Público foram objeto de investigação por parte das forças que tomaram o poder em 1964. No Inquérito Policial Militar do DOFSP, que havia iniciado um programa de construção de grupos escolares pré-fabricados e executado um deles no Cajueiro Seco, os principais indiciados eram o diretor Jorge Martins Júnior e a arquiteta Maria Lucia Athayde, co-autora do projeto das escolas. Sobre o primeiro recaiu a acusação de ser "pessoa de inteira confiança do governo anterior", levado ao cargo por indicação do então Secretário de Viação e Obras Públicas e mais tarde prefeito deposto do Recife Pelópidas Silveira, que

"fez alterar a legislação reguladora das atividades desse órgão de sua secretaria, afim de que o indiciado, que era arquiteto, pudesse ocupar o referido cargo. Antes, só os engenheiros podiam exercer a importante chefia, que aliás, do ponto de vista técnica, a esses é que melhor se ajusta o quadro de suas atribuicões. Mas, o ilustre secretário de Arrais (sic) precisa de um ARQUITETO para os seus planos de

\footnotetext{
${ }^{415}$ Armando Rodrigues COELHO FILHO Depoimento no Inquérito Policial Militar (IPM) do SSCM, Acervo DOPS do Arquivo Público Estadual (APEJE), Recife
} 
implantacão comunista no Estado, e, especificamente do arquiteto Jorge Bezerra Martins Júnior." 416

O exagero é evidente em diversas passagens: tanto na qualificação de Pelópidas Silveira, imprecisa com relação à sua biografia e prática como prefeito da cidade quanto na autoridade com a qual se reveste um agente de Segurança Pública para falar do "ponto de vista técnico" sobre qual seria a melhor formação para exercer tal cargo. Curiosa e emblemática para o período é a nem tão sutil associação entre a figura do arquiteto e a ideologia comunista. Outro elemento de condenação de Martins Jr. é a ter declarado em seu depoimento ao DOPS que

"no seu entender, Miguel Arraes de Alencar e Pelópidas Silveira não tinham ideologias, mas idéias e eram sensíveis aos problemas nacionais; que o encaminhamento dessas idéias, a longo prazo, poderiam solucionar as questões sociais no Brasil" ${ }^{417}$

Outro fato destacado no relatório para incriminar Jorge Martins Júnior foi a publicação de "matéria publicitária" no diário última Hora comemorando as realizações do primeiro ano do governo Arraes. Além do jornal de Samuel Wainer ser identificado com a esquerda pelos militares golpistas, e tendo se envolvido ativamente na campanha de Arraes, pesa o fato de o diretor do DOFSP ter autorizado

"a elaboração de uma lista de constribuições particulares entre as firmas empreiteiras (...) com o objetivo de publicar em uma página do jornal Última Hora um noticiário concernente às realizações deste

${ }^{416}$ Telga Gomes de ARAújO, Relatório do Inquérito Policial Militar (IPM) do SSCM Acervo DOPS do Arquivo Público Estadual (APEJE), Recife

${ }^{417}$ Jorge MARTINS JR. Inquérito Policial Militar (IPM) do DOFSP, Acervo DOPS do Arquivo Público Estadual (APEJE), Recife departamento como também congratulações pelas realizações do governo Miguel Arraes por ocasião da passagem do seu primeiro aniversário" ${ }^{418}$.

$\mathrm{Na}$ sequência das matérias que destacam os grupos préfabricados, a edição da última Hora destaca também as experiências habitacionais que estavam sendo levadas à cabo no Cajueiro Seco com uma manchete expressiva: "Pernambuco faz reforma urbana".

Os interrogadores ainda cometeram a grosseria de insinuar uma relação extra profissional entre Jorge Martins Jr e Maria Lucia Athayde, usando para isso a liberação de ajuda de custos para a ida da arquiteta ao Congresso da UIA em Cuba, na condição de participante autônoma e não como representante do governo pernambucano, a despeito do fato dela ter participado às suas expensas de congressos Panamericanos em Buenos Aires e nos EUA. 419

A ida à Havana serviria também para condenar Geraldo Gomes da Silva, que havia estagiado tanto no DOFSP quanto no SSCM no período, e já era conhecido e monitorado como "líder esquerdista universitário da Faculdade de Arquitetura. Era comunista, sem dúvida" ${ }^{420}$.Geraldo Gomes tinha sido preso por ir à Cuba e pela sua participação na vida universitária em estreita ligação com o PCB.

\footnotetext{
${ }^{418}$ Jorge MARTINS JR. Inquérito Policial Militar (IPM) do DOFSP, Acervo DOPS do Arquivo Público Estadual (APEJE), Recife

${ }^{419}$ Maria Lucia ATHAYDE Inquérito Policial Militar (IPM) do DOFSP, Acervo DOPS do Arquivo Público Estadual (APEJE), Recife

${ }^{420}$ Telga Gomes de ARAújo, Relatório do Inquérito Policial Militar (IPM) do SSCM Acervo DOPS do Arquivo Público Estadual (APEJE), Recife
} 
Também faz parte do Inquérito do SSCM uma "minuta de carta dirigida por Gildo Guerra ao arquiteto Fausto Ferre Hechavarria, delegado no Brasil do $7^{\circ}$ Congresso da UIA, em Cuba", da qual se transcrevem trechos com o objetivo de transformar entusiasmo e camaradagem em condenação.

Até o desenhista da repartição foi obrigado a confessar que

"leu um artigo de certo padre francês veiculado em um dos periódicos desta cidade no qual aquele sacerdote chamava a atenção do contraste existente no estado do Ceará entre a opulência dos edifícios e a miserabilidade dos mocambos" 421

Concluídos os inquéritos, os funcionários "subversivos" foram demitidos e perseguidos. Gildo Guerra, segundo Borsoi, foi para o Chile e de lá tornou-se arquiteto do Banco Interamericano de Desenvolvimento (BID), atuando em políticas habitacionais na América latina, mostrando que a atuação do arquitetos inglês John Turner não é um caso isolado.

Dos anos 1960 até os dias de hoje, as casas vem sendo transformadas pelos esforços dos seus usuários e progressivamente ampliadas e revestidas de materiais de acabamentos de acordo com o gosto e as posses do morador e a disponibilidade do mercado.

Grande parte delas já ganharam segundos e terceiros andares sobre as lajes pré-fabricadas progressivamente em função dos seus próprios esforços, como em diversos núcleos de mocambos e favelas do Recife ou qualquer outra grande cidade brasileira. Algumas casas

${ }^{421}$ Luiz Mauro Coimbra de CASTRO Inquérito Policial Militar (IPM) do DOFSP Acervo DOPS do Arquivo Público Estadual (APEJE), Recife ainda conservam o volume e as linhas da casa popular brasileira elementar ${ }^{422}$ que foi reitepretada por Borsoi, mas da taipa em si nada resta.

Devemos lembrar aqui que a substituição da taipa por alvernaria já estava prevista inclusive nas memórias do projeto do Cajueiro Seco, indicando não ser o sistema constutivo em si o ponto fundamental do projeto, mas a afirmação de um ideal de ajuda mútua e construção de uma comunidade autosuficiente, inicialmente apoiada pelo Estado através de seus equipamentos e serviços.

A taipa de mão ou pau-a-pique, técnica original revista por Borsoi, sempre foi utilizada em construções secundárias ou de menos valor e importância e sofreu com isso os efeitos do preconceito. A família pobre, à medida que seus meios de vida o permitissem, tenderiam invariavelmente a substituir as paredes feitas do material por novas, feitas em alvenaria, como relatam os moradores do Cajueiro Seco.

É comum até hoje encontrar pelo interior do Brasil e particularmente do Nordeste casas de duas águas e paredes de taipa com a fachada feita de alvenaria encimada por uma platibanda com motivos decorativos geométricos, alguns deles até com uma expressão que poderia ser intepretada como moderna.

"O nosso povo tem um preconceito contra a taipa, o pessoal constrói a casa de taipa e o primeiro dinheirinho que tem faz a fachada de

\footnotetext{
${ }^{422}$ Aqui nos referimos à casa vernacular de porta e janela coberta por duas águas e cumeeira perpendicular à rua (origem do termo mocambo) presente em diversas regiões do Brasil e construída com simplicidade e materiais locais (Weimer, 2005)
} 
tijolo. Taipa é casa de pobre, quando melhora um pouquinho já está querendo mudar de status, embora a gente tenha construcões de taipa em Ouro Preto de 300 anos e o pessoal acha que taipa é uma coisa pouco duradoura"

As áreas previstas no projeto urbanístico como livres ou verdes foram ocupadas por construções irregulares, nas quais se sente a falta dos alinhamentos e espaçamentos entre as casas, principalmente em torno do córrego que corta o loteamento. Dos equipamentos públicos, os que resistem firmemente são as escolas, uma delas resultado de uma ampliação do Grupo escolar pré-fabricado construído pelo DOFSP na qual se reconhecem algumas paredes e pilares do sistema original e a outra resultado da conversão dos antigos galpões das cooperativas, que nada tem a ver com o projeto elaborado pelo SSCM.

Entre o momento do golpe e a conversão em escola, estes edifícios abrigaram uma unidade da FEBEM por anos, fazendo com que alguns moradores ainda assim se refiram ao lugar onde hoje está uma grande escola, que também abriga pequenas lojas diversas, sapatarias, cabelereiros e bares ao longo da Rua Dez.

Tais usos, exceto o espontâneo e inevitável bar, tem a ver com os cursos profissionalizantes que foram ministrados nesses galpões tanto antes do golpe quanto depois, como fabricação de calçados e corte e costura; o número de cabelereiros e sapateiros no bairro todo chama a atenção do visitante.

${ }^{423}$ Geraldo Gomes da SIIVA Entrevista ao autor, Recife Set/2007
O uso comercial se concentra ao longo da Rua Dez e na Rua Santo Elias, ao longo da qual existe uma feira permanente, um supermercado e diversas lojas de bens de consumo como eletrodomésticos, móveis, bicicletas além de serviços contemporâneos como videolocadoras, pontos de acesso à Internet etc.

O uso misto também se nota de forma dispersa em todas as ruas do loteamento original, que além dos serviços citados abriga também bares e lanchonetes, lojas de material de construção e sedes de sindicatos e grupos comunitários femininos. Curiosamente, no entanto, não há uma associação de moradores específica do Cajueiro Seco, o que talvez possa ser entendido se levarmos em conta as perseguições e traumas ali vivenciados.

A lavanderia coletiva resistiu durante décadas no mesmo lugar, porém acabou sendo demolida depois de depredada e saqueada. A falta de gestão do uso do espaço - tanto por parte do Estado quanto da comunidade, já desorganizada pela repressão, deve ter a ver com o abandono do equipamento e sua apropriação privada. Hoje, no local, funciona um lava-rápido de automóveis, que se alimenta da água do poço artesiano cavado para prover todo o bairro de água quando ali ainda não existia serviço de água encanada. No Inquérito Policial Militar do SSCM, comenta-se que a comunidade mantinha o local, arrecadando valores simbólicos por cada banho, lata d'agua ou trouxa de roupa a lavar.

O posto médico, construído em chapas curvas de fibrocimento, também permaneceu por anos, até que foi desativado e ocupado por 
uma família, que passou a viver ali e achou por bem substituí-lo por uma casa convencional.

Com o advento da expansão da cidade rumo a Zona Sul, o desenvolvimento da concentração industrial em Jaboatão ao longo da Avenida Mascarenhas de Moraes conhecida como Imbiribeira, do Distrito Industrial de Curado ao longo da antiga Rodovia BR 101 hoje PE 008, Prazeres como um todo passou a ter uma localização mais privilegiada. Ao longo dos anos 70 e 80 deu-se a urbanização e exploração especulativa da orla de Piedade e Candeias, substituíndo antigas casas de veraneio por edifícios de apartamentos que exploravam sua relação com a praia, replicando o processo que gerou Boa Viagem e que hoje é frequente em toda orla das grandes cidades litorâneas brasileiras, soterrando os últimos remanescentes arquitetônicos e os territórios populares da ocupação original ${ }^{424}$.

Este modo de produzir a cidade, naquelas glebas então ainda desocupadas, entre as paralelas linhas de rodovia, ferrovia e a orla, território que compreendia Cajueiro Seco, Prazeres e Piedade, fo estimulado e financiado, principalmente nos anos 80 com recursos do Banco Nacional de Habitação, que repassava empréstimos internacionais para as prefeituras. Foi este o caso da gestão de Geraldo Melo, que através dos sucessivos projetos CURA, expandiu as redes de infraestrutura às glebas de investidores (CURA-I Piedade) e a algumas áreas pobres contíguas (CURA-II, Cajueiro Seco e Prazeres), que se valorizavam acompanhando o deslocamento da atividade econômica para a construção civil que fermentava na orla.

Esses debates no princípio dos anos 80, mas especialmente no que teve como foco a cidade de Jaboatão, ficou clara a oposição entre o modelo de administração tecnocrática centralista, em coordenação direta com o governo federal, ainda naquele momento em mãos dos militares, e os representantes da sociedade civil organizada, que buscavam atualizar a agenda política na esfera municipal retomando as questões da democracia e da participação popular, da organização comunitária contraposta ao modelo de gestão das prefeituras como negócio, comprometidas com a especulação imobiliária e a indústria da construção civil (IAB-PE, 1982).

A ligação de aproximadamente $15 \mathrm{~km}$ entre a antiga sede do município e a faixa de praias foi talvez a principal obra do prefeito Geraldo Melo. Com ela, visava-se enfrentar a relação entre o distrito de Prazeres e o antigo centro de Jaboatão, que desde os anos 50 e 60 suscitava grandes debates na imprensa ora a favor da emancipação do distrito ora contra sua anexação pelo município do Recife.

Do ponto de vista da esfera municipal de Jaboatão, o que houve foi a transladação do centro administrativo e comercial do distrito para a faixa de terras entre a praia e os eixos rodoferroviários. A instalação da Prefeitura, do Fórum e da Câmara de vereadores da cidade ao longo da Avenida Barreto de Menezes, nas proximidades do Cajueiro Seco, atesta oficialmente o deslocamento oficial, acompanhado pela

${ }^{424}$ Ver AMORIM, 2007 
instalação ali de inúmeras lojas, bancos, restaurantes, supermercados e mais recentemente um Shopping Center.

Em 1981, a arrecadação de impostos municipais ali era cerca de dez vezes maior do que nos outros dois distritos que formavam Jaboatão(IAB-PE, 1982). Do ponto de vista da Região Metropolitana, antevista e proposta por Baltar, aquela seria a localização desejável de uma das novas cidades satélites que fariam do Recife uma metrópole regional.

Esse processo de urbanização acelerada da região.conconcorreu certamente para a elevação do valor dos terrenos em Cajueiro Seco, que juntamente com o aumento de renda da população local, apoiada pela propriedade da casa e a regularização da ocupação da terra nos anos 1980, acabou por elevar progressivamente o nível de vida ali, objeto último da experiência habitacional dos anos 1960. Avaliações críticas e de pós ocupação daquele território não podem deixar de ter a perspectiva do bairro dentro de Prazeres, de Prazeres dentro do município de Jaboatão e da cidade na periferia do "Grande Recife".

Deste ponto de vista, Cajueiro Seco tornou-se um importante lugar na periferia da metrópole, fato atestado pela instalação ali da última estação do Metrô do Recife, implantado a partir da infraestrutura ferroviária existente. A estação encontra-se pronta mas a linha ainda está funcionando parcialmente. Os impactos da efetivação da conexão ferroviária do bairro diretamente ao centro da cidade serão certamente intensos, provavelmente reforçando a característica do lugar como centralidade polar articuladora de modos de transporte e talvez levando a substituição dos atuais moradores por outras camadas de renda e usos não habitacionais.

O fato é que, da Avenida Guararapes, no centro do Recife pode se pegar um ônibus - tradicional veículo de urbanização periférica brasileira- diretamente ao Cajueiro Seco, de onde partem diversas linhas de ônibus e vans para periferias mais distantes. Na área que corresponde ao projeto original do Cajueiro Seco moram trabalhadores do intenso comércio local e do Shopping, funcionários públicos municipais de Jaboatão, militares ligados à Base Aérea do Aeroporto dos Guararapes, entre outros setores da pequena classe média. Trata-se hoje de um bairro popular razoavelmente atendido pelos serviços públicos essenciais sem muitas características físicas ou sociais que o diferem do entorno. Um dos últimos traços distintivos do bairro é o notável alinhamento, que se contrapõe aos arredores, ainda que seu calçamento, já careça de reparos. 


\section{À guisa de conclusão}

A pesquisa em torno de um objeto tão específico como a experiência interrompida do Cajueiro Seco revelou muitos outros fatores que um mero estudo acerca do projeto de arquitetura não dá conta de abarcar. O que procuramos demonstrar ao longo destas páginas foi a inserção da experiência nas mudanças de rumo no campo da profissão, assim como nos projetos de nação em disputa no começo dos anos 1960 e o papel dos grupos populares em seu interior.

Fundada na "admiração e reconhecimento civilizado da luta dos pobres" (SCHWARZ, 1987, p. 71-72), a experiência do Cajueiro Seco ainda conta com uma certa "eletricidade vital" que anima debates em torno da arquitetura e da participação, especialmente se considerado o seu caráter modelo de projeto político e social.

Retomando a observação de Schwarz acerca das relações entre cultura e política nos anos 1960, esta nova atitude para com o popular, que emprestava novos significados ao engajamento de artistas e intelectuais, tem muito a dizer dos caminhos tomados pelos arquitetos em sua aproximação à questão social no Brasil. A década era de fato um momento especial de articulações culturais e políticas, dificilmente compreendido em sua complexidade se analisado a partir de uma ótica restrita às compartimentações disciplinares.

Recife naqueles anos parece ter ocupado um papel peculiar. Segundo Francisco de Oliveira, essa cidade, que talvez como nenhuma outra exprimia as velhas contradições entre o arcaico e o moderno. "Noiva da revolução", Recife era o contraponto ao colapso do populismo cujo epicentro estava em São Paulo, formulando alternativas para um Brasil "que poderia ter sido e não foi"

Talvez por isso a condição quase mítica de que os "Tempos de Arraes" se revestem: "A história que se faz cotidianamente prepara o mito, pois sem este, ela fica incompreensível. Num longo caminho, em algum momento, a história vira mito." (OLIVEIRA, 2008, p.27) De Veneza Americana à manguetown, "esclerosada, destituída, depauperada, emputecida" ${ }^{425}$, Recife converteu-se em "emblema do desastre brasileiro".

Ao longo destas páginas, procuramos pontuar alguns fatos e trajetórias novos no campo da política social, da habitação e da arquitetura de modo a repensar as relações entre mito e história nesse processo. Pois se a aura do Cajueiro Seco, do arquiteto engajado no Tempo de Arraes e do MCP é parte constituinte e representativa da construção dessa história, nem por isso ela deixa de cristalizar uma versão parcial, por vezes redutora dos acontecimentos, dilemas e embates do período, ou de seus significados para a historiografia da arquitetura, da política e da cultura. É isso que tentamos apresentar, mais do que versões definitivas dos fatos ou a suposta genealogia das idéias.

${ }^{425}$ Fred Zero Quatro e mundo livre S /A "Cidade Estuário" in Samba esquema noise São Paulo: Baguela Discos, 1995 
Alguns aspectos da trajetória do arquiteto Acácio Gil Borsoi foram aqui evocados seja pelo que de representativo neles há dessa etapa formativa da arquitetura brasileira, seja pelo lugar que o próprio arquiteto atribui à experiência em sua vida e obra. O que procuramos evitar, todavia, foi reproduzir uma explicação meramente autoral e arquitetônica, tão recorrente nas narrativas disponíveis. Como se a experiência do Cajueiro Seco resultasse de lances geniais ou de um processo de maturação individual, perfeitamente reconhecível na trajetória desenvolvida pelo arquiteto. Muito ao contrário, procuramos enfatizar aqui as interferências, contribuições e conflitos decorrentes da política e da cultura, bem como suas correlações com os debates em torno da reforma urbana e das políticas habitacionais que se projetavam.

O fato é que a experiência do Cajueiro Seco expõe algumas ambiguidades que permaneceriam no bojo das políticas de auto-ajuda e mutirões contemporâneas. Enquanto desenho, tratava-se, por certo, de um projeto moderno, elaborado por arquitetos eruditos, que incorporava as tradições construtivas de um povo marginalizado. Enquanto experiência social e política, identificava-se às posições da esquerda popular pernambucana, mas as diretrizes que a apoiavam também podiam ser encontradas na plataforma ideológica da Aliança para o Progresso, donde a possibilidade de mobilização em seu interior de arquitetos comunistas, trabalhistas, socialistas católicos e liberais.
Outra ambiguidade que se entrevê no Cajueiro Seco diz respeito à relação entre a materialização arquitetônica de uma idéia do mocambo "higienizado" e "racionalizado", que como se sabe não era nova mas provinha de sugestões de Aluízio Bezerra Coutinho, Gilberto Freyre e Josué de Castro. Idéia que parecia sintetizar a tradição e a modernidade, a cultura popular e a profissional, ao menos no âmbito da imaginação arquitetônica. "Em plena década de 60, a velha sugestão regionalista parecia finalmente realizar-se." (LIRA in Sampaio (org.), 2002).

No plano da história social e cultural, a pesquisa revelou que o emblemático desenho da "taipa pré-fabricada" está longe de resumir a riqueza das discussões e impasses então colocados aos arquitetos. Na conjuntura de forte polarização campo-cidade então vivenciada, e de radicalização dos conflitos políticos e culturais entre forças afinadas com a burguesia usineira e as que se aglutinavam em torno das lutas de trabalhadores rurais, migrantes e pobres urbanos contra as condições de exploração e miséria. A tentativa de aproximação do arquiteto moderno ao popular é apenas uma parte de um processo que reuniu vários outros atores, entre arquitetos militantes e estudantes, engenheiros, assistentes sociais, médicos, artistas e educadores, moradores pobres do Recife, movimentos sociais, gestores públicos, programas e projetos de Estado, organismos de cooperação internacional, o Patrimônio Histórico, o Exército Nacional, grileiros e proprietários de terra, ordens religiosas, órgãos de repressão etc. 
Um dos propósitos desse trabalho foi reabrir o mito da aliança entre os arquitetos e o povo, examinado à luz de sua complexidade e ambiguidades históricas um de seus momentos mais luminosos. Cabe aqui evocar as palavras de Roberto Schwarz acerca das relações de produção envolvidas na realização do filme "Cabra marcado para morrer", de Eduardo Coutinho, e o contexto contemporâneo, análogo ao da experiência do Cajueiro Seco:

"Hoje parece óbvio que aquela aliança não tinha futuro político, e que a revolução com estímulo de cima só podia acabar mal. No entanto ela canalizou esperanças reais, de que o filme [assim como o projeto do Cajueiro Seco] dá notícias e nas quais se pressentem outras formas de sociedade. A relação entre assunto, atores [o povo], situação local e gente de cinema [ou de arquitetura] não é evidentemente de ordem mercantil, e aponta para formas culturais novas. Não se pode dizer também que o diretor [o arquiteto - Borsoi] se quisesse expressar individualmente: a sua arte trata de apurar a beleza de significados coletivos. Tem sentido, no caso, falar em autor?" (SCHWARZ, 1987, p. 73)

Também interrompido em 1964, em razão do golpe, e retomado 17 anos depois a partir dos depoimentos de camponeses que haviam trabalhado nas primeiras filmagens, a questão que se coloca é precisamente a da autoria. Não só porque a arquitetura, tal como o cinema, é arte social por excelência, produzida coletivamente (ainda que nem sempre à maneira industrial) e inseparável das divisões do trabalho, imediatamente entregue ao consumo de massas, sujeita a um novo modo de participação e recepção, mais distraída, utilitária, pelo hábito, tátil ${ }^{426}$. Mas porque, naquelas condições, arquitetura e cinema pareciam encaminhar-se para o reconhecimento do povo como ator legítimo no processo de criação, produção, representação e consumo. Sobretudo quando consideramos o filme para além da obra do diretor e do arquiteto individual, mas como obra coletiva que envolve sentimentos, energias e experiências de muitos outros personagens.

Seria exagerado supor que houve um desvio do significado do Cajueiro Seco depois do golpe de 1964? De certo modo, há uma predominância do entendimento da experiência que focaliza a questão meramente construtiva, tal como aparece na revista Arquitetura em 1965. A inserção do projeto como piloto de um dos programas de uma política consequente de habitação, que poderia ter sido implantada após a reforma urbana, que também tomava corpo naqueles anos, não pode ser minimizada. É importante reconhecer ambos os significados do Cajueiro Seco - o construtivo e o urbano, numa leitura integrada ao contexto político e cultural no qual surgiram.

Para tanto, devemos entender a experiência inserida no seu tempo, marcado pelo acirramento das tensões sociais e a emergência de esperanças em uma sociedade em processo acelerado de modernização e democratização, cujos conflitos pareciam exercer uma influência dinâmica nas relações de classe. O golpe de 1964 reafirmase como marco, não para explicar a descontinuidade da experiência e

\footnotetext{
${ }^{426}$ BeNJAmin, W. "A obra de arte na era de sua reprodutibilidade técnica". In Obras
} Escolhidas. Vol. 1, São Paulo: Brasiliense, 1986, pp. 192-194 
da assistência técnica e social, mas para sinalizar a suspensão das expectativas então canalizadas sobre a aliança entre intelectuais e povo.

Por certo podemos relativizar a importância do projeto da taipa pré-fabricada se olharmos para as poucas unidades construídas nesse sistema mas é importante reconhecer que muitas das casas das periferias recifenses já foram de taipa, reconstruídas por seus moradores à medida em que se "integravam" na sociedade de classes, objetivo implícito da experiência, que de certa maneira, foi alcançado. Assim, permanecem algumas questões que devemos levantar: em que medida a melhoria das condições construtivas das casas espelha a melhorias dos "níveis" de uma família? Qual a relação entre as características físicas da urbanização de um território popular e o "bem comum" de um bairro? A gestão dos equipamentos urbanos deve fazer a mediação entre a indivíduo e o Estado?

A leitura crítica da experiência do Cajueiro Seco fornece também elementos para o debate em torno das propostas atuais que insistem em ver o mutirão como panacéia para resolver a perene e crônica crise habitacional brasileira.

O período entre o fim da Segunda Guerra e o golpe militar inscreve a experiência, assim como outras, num momento de formulação de alternativas que não puderam ser vivenciadas plenamente, colocando-a em um tempo e espaço peculiares. Parafraseando Chico de Oliveira,
"Não quero fazer a história do Recife, pois para tanto não tenho artes. Quero fazer com que você ame e sonhe com essa cidade, que ao ler o lamento cantado em suas ruas, tenha saudade do passado que você não viveu, uma saudade benjaminiana, do que poderia ter sido e não foi; nos versos de Maiakóvski, tenha, com ela, com os que lá moraram e viveram, com os que lá vivem, saudade do futuro." (OLIVEIRA, 2008, p.27)

Esse tempo soa também como o pretérito do futuro, de Manuel Bandeira, o poeta recifense que nostalgicamente olhava para sua cidade. Walter Benjamim acaba por ser também uma referência importante para as questões aqui discutidas, em sua proposição de uma história à contrapelo. Algo que talvez Sérgio Ferro tenha sido quem mais cedo sugeriu como alternativa à história da arquitetura. Cajueiro Seco, assim como diversas outras experiências inovadoras nos anos 1960, dificilmente será compreendida se isolada deste tempo, no qual se projetava um futuro diferente, que foi obstado pelos militares, deixando em aberto muitas das questões ali apresentadas.

Reconstruir Cajueiro Seco não se insere, pois, de modo algum na tradicional "história dos subúrbios", sem qualquer importância" ${ }^{427}$, nem tampouco no âmbito ilustrado da história da arquitetura. Fala, antes, de uma história dos vencidos, seja pela historiografia da arquitetura moderna brasileira e pernambucana, seja nos debates em torno da

\footnotetext{
${ }^{427}$ A referência aqui é ao livro que escreveria Bentinho, o personagem principal de "Dom Casmurro", de Machado de Assis, depois de contar sua própria história para "aquecer". A história de ocupação posterior do bairro, do golpe até os dias atuais, não faz parte do escopo deste trabalho, que investiga historicamente seus marcos iniciais. Para contar "de como os habitantes do Cajueiro Seco construíram na marra a sua cidade", talvez mais adequados seriam outros suportes, metodologias, óticas e quiçá, autores.
} 
reforma urbana e no processo de urbanização no país. História de vencidos, que, do ponto de vista da arquitetura e do urbanismo, formulavam um Brasil "que poderia ter sido e não foi". Não é pouco. 


\section{BIBLIOGRAFIA}

-AlbuQUerque JR., Durval Muniz. A invenção do Nordeste e outras artes. Recife/ São Paulo: FJN, Ed. Massagana/ Editora Cortez, 2006.

-AMORIM, Luiz. Obituário Arquitetônico: Pernambuco Modernista. Recife: UFPe, 2007.

-Escola do Recife: três paradigmas do objeto arquitetônico e seus paradoxos. São Paulo: Vitruvius, 2001 Disponível em: http://www.vitruvius.com.br/arquitextos/arq012/arq012_03.asp

-ANDRADE, Manuel Corrêa de. 1964 e o Nordeste. São Paulo: Contexto, 1989.

-ANELLI, Renato Interlocuções com a Arquitetura Italiana na Constituição da Arquitetura Moderna em São Paulo Livre Docência São Paulo USP, 2001

-AMARAL, Aracy "A polêmica sobre a função social da arquitetura" in Arte para quê?. São Paulo: Studio Nobel, 2003

-ARANTES, Pedro. O ajuste urbano: as políticas do Banco Mundial e do BID para as cidades latino-americanas. Mestrado FAU USP, São Paulo: FAU USP 2004.

- Arquitetura Nova: Sérgio Ferro, Flávio Império e Rodrigo Lefevre, de Artigas aos mutirões. São Paulo: Ed. 34, 2002.

-ARANTES, Pedro e WISNIK, Guilherme in FORTY, Adrian e ANDREOLI, Elisabetta (org). Arquitetura Moderna Brasileira. Londres: Phaidon, 2004.

-ARRAES, Miguel. O povo no governo - Discurso de posse do Cargo de Governador do Estado de Pernambuco, em 31 de janeiro de 1963. Rio de Janeiro: Civilização Brasileira, 1963.

-O jogo do poder no Brasil. São Paulo: Ed. Alfa Ômega, 1981.

-O Brasil, o povo e o poder. Ed. UFPE, 2006.

-Arte em revista / Centro de Estudos de Arte Contemporânea São Paulo: O Centro/ Kairós, 1979 --1981 Nos. 1- Anos 60, 3 - O popular,4 - Arquitetura nova e 6 - Teatro.
-AZEVEDO, Sérgio e ANDRADE, Luis Aureliano Gama de. Habitação e poder : da Fundação da Casa Popular ao Banco Nacional da Habitação. Rio de Janeiro : Zahar Editores, 1982.

-BALTAR, Antônio Bezerra. Diretrizes de um Plano regional para o Recife. Recife: Escola de Belas Artes, 1951.

\section{-Universidade, Economia e Humanismo - Preleção na}

Universidade do Recife. Recife, 1953.

-BANDEIRA, Moniz. O governo João Goulart - As lutas sociais no Brasil 1961-1964. Rio de Janeiro: 5a Ed. Civilização Brasileira, 1978.

-BARAVELLI, José Eduardo. O cooperativismo uruguaio na habitação social de São Paulo : das cooperativas FUCVAM à Associação de Moradia Unidos de Vila Nova Cachoeirinha. Mestrado FAU USP, São Paulo: FAU USP 2006.

- BARDI, Lina Bo. Ao Limite da Casa Popular - Comunidade Cajueiro Seco. in Mirante das Artes № 21967 pp. 20-23.

-Tempos de grossura: o design no impasse. São Paulo: Instituto Lina Bo e P.M. Bardi, 1994.

-BARONE, Ana Cláudia Castilho. Team 10 arquitetura como crítica. São Paulo: Annablume, 2000.

-BENJAMIN, W. "A obra de arte na era de sua reprodutibilidade técnica". In Obras Escolhidas. Vol. 1, São Paulo: Brasiliense, 1986, pp. 192-194

-BeZERRA, Daniel Uchôa Cavalcanti. Alagados, Mocambos e Mocambeiros. Recife: Instituto Joaquim Nabuco de Pesquisas Sociais/ Imprensa Universitária, 1965.

-BONDUKı, Nabil Georges. Origens da Habitação Social no Brasil . Arquitetura Moderna, Lei do Inquilinato e difusão da casa própria. São Paulo: Estação Liberdade/ FAPESP, 1998.

-Arquitetura e habitação social em São Paulo 1989-1992 São Paulo: IAB/ Bienal 1995.

-BOrSOI, Acácio Gil. Prefabrication Taipa. Recife: Recife Gráfica, 1980.

- Cajueiro Seco; o caminho interrompido da autoconstrução industrializada. Projeto, São Paulo, 66: 51-54, Ago. 1984, v.1. 
- Entrevista à Revista Projeto Design No 257, Julho 2001. http://www.arcoweb.com.br/entrevista/entrevista17.asp

- Arquitetura como manifesto. Recife: 2006.

-Borsoi, Acácio et al.; coordenadores, Eliane FAERSTEIN, Jorge Castro, Sandra Monarcha Souza e Silva. II Inquérito Nacional de Arquitetura depoimentos. Projeto Ed. Associados: IAB-RJ, 1982.

-Borsol, Acácio Gil e Guerra, Gildo. "Política Social do Mocambo". In Arquitetura No 13. Rio de Janeiro: IAB-GB, 1963.

"Cajueiro Seco, uma experiência em Construção." In Arquitetura No 16. Rio de Janeiro: IAB-GB, 1963.

-BRITO, Ronaldo. Neoconcretismo. São Paulo: Cosac Naify, 2001.

-BROMLEY, Ray. "Peru 1957-1977: how time and place influenced John Turner's ideas on housing policy". In Habitat International, 27. 2003, p.271-292.

-BRuAnd, Yves. Arquitetura Contemporânea no Brasil. São Paulo: Ed. Perspectiva, 4a Ed., 2003.

-CABRAL, Renata Campello. Mario Russo: um arquiteto racionalista italiano no Recife. Mestrado EESC-USP. São Carlos: EESC-USP, 2003.

-CAmarGo, Mônica J. Joaquim Guedes São Paulo: Cosac Naify, 2002

-CARVALHO, Elba Maria de. Impressões Sociológicas sobre uma área marginal: Ilha Sem Deus Monografia Dep. De Sociologia do Centro de Ciências Sociais da Universidade Católica de Pernambuco. Recife, 1972.

-CARvalho, Caio Santo Amore de. A lupa e o telescópio - o mutirão em foco, Mestrado FAU USP. São Paulo: FAU USP, 2004.

-CALLADO, Antônio. Tempo de Arraes: padres e comunistas na revolução sem violência. $1^{\text {a }}$ ed. Rio de Janeiro, José Alvaro Editor, 1964, $2^{a}$ ed. Rio de Janeiro: Paz e Terra, 1979.

-CÂNDIDO, Antônio. Os parceiros do Rio Bonito: estudo sôbre o caipira paulista e a transformação dos seus meios de vida. São Paulo: Duas Cidades/ Editora 34, 2001.

-Cavalcanti, Paulo. O Caso eu conto como o caso foi: Da coluna Prestes à queda de Arraes. São Paulo: Alfa-Ômega, 1978.
-CASTRO, Josué de. A cidade do Recife: ensaio de geografia urbana Rio de Janeiro: CEB, 1954

- Documentário do Nordeste. São Paulo: Brasiliense, 1968 4a. Ed.

- Homens e Caranguejos. São Paulo: Civilização Brasileira, 2001 4a. Ed.

- "A Reivindicação dos mortos". In MANÇANO, Bernardo e WALTER, Carlos. Josué de Castro: Vida e Obra. São Paulo: Expressão Popular, 2000.

-CHAUí, Marilena de Souza. Seminários - O Nacional e o popular na cultura brasileira. São Paulo : Brasiliense/ FUNARTE, 1984.

-ChIEl, Chris e DeCKer, Julie. Quonset Hut: Metal Living for a Modern Age. Princeton Architectural Press, Princeton, 2006.

-CLARO, Mauro Unilabor. Desenho industrial, arte moderna e autogestão operária. São Paulo: Editora SENAC 2004

-COMAS, C.E. O espaço da arbitrariedade - Considerações sobre o conjunto habitacional BNH e o Projeto da cidade brasileira. São Paulo: Projeto, 1986.

-COMERIO, Mary C. "Design and Empowerment: 20 Years of Community Architecture". In: Built Environment, vol 13 No. 1.

-COutıNHO, Aluízio Bezerra. A filosofia das ciências naturais na Escola do Recife. Recife: Ed. Universitária, 1988.

-O problema da habitação hygiênica nos paízes quentes em face da "Architectura Viva". Rio de Janeiro: Oficinas Alba Graphicas, 1930.

-COSTA, Alcília. A produção arquitetônica moderna dos primeiros discípulos de uma Escola. São Paulo: Vitruvius,2008 Disponível em http://www.vitruvius.com.br/arquitextos/arq000/esp479.asp

-COSTA, Lucio Registro de uma vivência, Rio de Janeiro: Empresa das artes, 1995 p. 292

-DAVIES, Colin The prefabricated home Londres: Reaktion books, 2005

-Estado de Pernambuco. Regulamento do Serviço Social contra o Mocambo. Recife: Imprensa Oficial, 1945.

- Programa de Habitação Popular. Recife: Imprensa Oficial, 1962. 
-FAusto, Boris. História do Brasil. 12 ed. São Paulo: Edusp, 2007.

-FERRO, Sergio. O canteiro e o desenho. São Paulo: Projeto, 1979.

-FINEP/ GAP. Habitação Popular: Inventário da Ação Governamental. Rio de Janeiro / São Paulo: FINEP/ Projeto, 1985.

-FONTES, Breno Augusto Souto Maior. Políticas de planejamento urbano e segregação espacial município do Recife na década 1970-80. Recife: UFPE, 1986.

-FRAMPTON, Kenneth. História crítica da arquitetura moderna. São Paulo: Martins Fontes, 1997.

-FREYRE, Gilberto. Sobrados e mucambos: decadência do patriarcado rural e desenvolvimento do urbano; introdução à história da sociedade patriarcal no Brasil. 14. Ed. São Paulo: Global, 2003.

- Mucambos do nordeste. Rio de Janeiro: MESP 2a ed., 1965.

-"Apresentação" in Bezerra, D. Alagados, mocambos e mocambeiros, 1965

-FURTADO, Celso. A pré-revolução brasileira. Rio de Janeiro: Fundo de Cultura, 1962.

-GeiGer, Pedro P. "Reorganização do espaço no Brasil", in BARAT, Josef (org.) Política de Desenvolvimento Urbano: Aspectos Metropolitanos $\mathrm{E}$ Locais. Rio de Janeiro: IPEA, 1979.

-GINZBURG, Carlo. O queijo e os vermes São Paulo: Companhia das letras, 2006.

-GONÇALVES, Antonio Carolino. Mocambos em Algumas Áreas do Recife in Boletim do Instituto Joaquim Nabuco de Pesquisas Sociais. Recife, 1964/1965 Nos. 13 e 14.

-GONÇALVES, Antonio Carolino e CrUZ, Levy. Algumas Características Demográficas e de Habitação do Sítio de Peixinhos: 1961 in Boletim do Instituto Joaquim Nabuco de Pesquisas Sociais. Recife, 1961 No. 20.

-GramsCl, Antonio. Literatura e Vida Nacional. São Paulo: Civilização Brasileira, 3a. Ed.

-GUATTARI, Félix. Espaço e Poder: a criação de territórios na cidade in Espaço e debates, ano V $1985 \mathrm{~N}^{\circ} 16$.
-HALL, Peter. Urban and regional planning - Problems in modern geography. Londres/ Vancouver: David \& Charles/ Newton Abbot, 1975.

-HARRIS, Richard. A double irony: the originality and influence of John F.C. Turner in Habitat International 27, 2003, p.245-269.

-INSTITUTO DOS ARQUITETOS DO BRASIL. Arquitetura Brasileira após Brasília/ Depoimentos. E. Graeff/F.M. Rêgo/J. Guedes/J.F. Lima. Rio de Janeiro: IABRJ, 1978.

-Inquérito Nacional de Arquitetura/Depoimentos. Rio de Janeiro:

IAB-R], 1982

-Política Urbana, Planejamento e Democracia - Ciclo de Debates. Recife: IAB-PE/ Clube de Engenharia, 1982.

-Delfim Amorim, Arquiteto. Recife: IAB-PE, 1991

-JESUS, Carolina de. Quarto de despejo. São Paulo: Livraria Francisco Alves, 1960.

-KOWARICK, Lucio. Escritos Urbanos. Editora 34: São Paulo, 2000.

-KOURY, Ana Paula. Arquitetura nova. São Paulo: Romano Guerra, 2003.

-Arquitetura construtiva: Proposições para a produção material da arquitetura contemporânea no Brasil Doutorado FAU-USP, São Paulo: FAU USP, 2005.

-LAPROVITERA, Ênio L'architecte et le peuple à Recife 1959-2008 Doutorado em conclusão Orientado por Helene Riviere D'arc Paris: Ecole des Hautes Etudes en sciences sociales s/d cópia do autor

-LEBRET, Louis-Joseph. Estudo sobre desenvolvimento e implantação de industrias, interessando a Pernambuco a ao Nordeste. Comissão de Desenvolvimento Econômico de Pernambuco. Recife, 1955.

-LeFEVRE, Rodrigo. Projeto de um acampamento de obra: Uma utopia. Mestrado FAU-USP, São Paulo: FAU-USP, 1981.

-LEITE, João de Souza e TABORDA, Felipe. A Herança do olhar: o design de Aloisio Magalhães. Rio de Janeiro: Artviva/SENAC, 2003.

-LeONARD, Olen. Problemas da Habitação Rural no Leste de Pernambuco. Recife: Instituto Joaquim Nabuco de Pesquisas Sociais, 1960. 
-LEONíDIO, Otávio. Carradas de razões- Lucio Costa e a arquitetura moderna brasileira. Rio de Janeiro: Ed. PUC-Rio; São Paulo: Loyola, 2007.

-LLOSA, Mario V. As Travessuras da Menina má. São Paulo: Alfaguara, 2006.

-LEVI, Giovanni. Sobre a micro-história. in: BURKE, Peter. A escrita da história: novas perspectivas. São Paulo: Editora da UNESP, 1992. p. 133161.

-LIERNUR, Jorge Francisco. Arquitectura en la Argentina del siglo XX - La construcción de la modernidad. Buenos Aires: Fondo Nacional de las Artes, 2001

-LIRA, José Tavares Correia de. Mocambo e Cidade: regionalismo na arquitetura e ordenação do espaço habitado. Doutorado FAU-USP, São Paulo: FAU-USP, 1997

-"Hidden meanings: the mocambo in Recife" Simpósio "City Words/ Les mots de la ville" SAGE: Londres/Paris, 1999

- "Modernidade e Economia do Morar no Recife (1930- 1964)" in SAMPAIO, Maria Ruth Amaral de (org.) A Promoção Privada de Habitação Econômica e a Arquitetura Moderna 1930-1964. São Paulo: Rima/ FAPESP, 2002

- Apresentação in ARTIGAS, J. B. V. Caminhos da Arquitetura 4a Edição São Paulo: Cosac e Naify, 2004.

-"Crítica modernista e urbanismo: Geraldo Ferraz em São Paulo, da Semana a Brasília". In Anais em CD-ROM. XI Encontro Nacional da ANPUR. Salvador: 23 a 27 de mai. 2005.

-MAurícIO, Ivan Cirano, Marcos e AlmEIDA, Ricardo de. Arte popular e dominação - O caso de Pernambuco 1961-77. Recife: Ed. Alternativa, 1978.

-MelO, Marcus André B. C. de. A cidade dos mocambos: Estado, Habitação e Luta de classes no Recife (1920/1960) in: Espaço e Debates No 14 ano V, 1985.

- Estado, capital e política urbana na formação social brasileira: (uma interpretação histórico-metodológica). Mestrado MDU, Recife: UFPE, 1982.
-MELO, Mario Lacerda de. Metropolização e subdesenvolvimento: o caso do Recife. Recife: UFPE, 1978.

-Menezes, José Luiz Mota e ReInAux, Marcílio O palácio da Justiça Recife: Liceu, 2002

-MOHOLY-NAGY, Sibyl. Native genius in anonymous architecture. New York: Horizon Press, 1957.

-MonteneGro, Roberto A. L. Pré-fabricação e a obra de Eduardo Knesse de Mello. Mestrado FAU USP, São Paulo: FAU USP, 2007.

-MOVIMENTO UNIVERSITÁRIO DE DeSFAVELAMENTO. Relatório do trabalho na favela do Vergueiro. São Paulo: MUD, 1963.

-MOtTA, Carlos Guilherme. Ideologia da cultura brasileira (1933-1974). São Paulo: Editora Ática, 1977.

-MOREIRA, Fernando (org.). Arquitetura Moderna no Norte e Nordeste do Brasil. Recife: FASA, 2007.

-NASLAVSKY, Guilah. Arquitetura moderna em Pernambuco, 1951-1972: as contribuicões de Acácio Gil Borsoi e Delfim Fernandes Amorim. Doutorado FAU USP, São Paulo: FAU USP, 2004

-NASLAVSKY, Guilah e AMARAL, Izabel Identidade Nacional ou Regional? A obra de Acácio Gil Borsoi, Do.Co.Mo.Mo. 5

-NETO, José Batista. MCP: o povo como categoria histórica in: Rezende, Antonio Paulo, org. Recife: que História é essa? Recife: Fundação da Cultura Cidade do Recife, 1987.

-NOBRE, Ana Luiza. Fios cortantes: projeto e produto, arquitetura e design no Rio de Janeiro (1950-70). Doutorado PUC-RJ, Rio de Janeiro: PUC RJ, 2008 .

-OCKMAN, Joan (org.). Architecture Culture 1943-1968: a documentary anthology. Nova York: Rizzoli, 1993.

-OliveIRA, Francisco. Crítica à Razão dualista / O ornitorrinco. São Paulo: Boitempo Editorial, 2003.

Elegia para uma re(li)gião e A Noiva da revolução. São Paulo: Ed. Boitempo, 2008 
-Ortiz, Maria Cristina M. e Hue, Renata S. A. Minaçu e Recife: Histórias de habitações e seus habitantes. São Paulo: Projeto, 1987.

-ORTIZ, Renato. Cultura brasileira e identidade nacional. São Paulo: Brasiliense, 1985.

-PereIRA, Miguel. Arquitetura e os caminhos de sua explicação. São Paulo: Projeto, 1984

-PereirA, Juliano A. A ação cultural de Lina Bo Bardi no Nordeste(19581964). Mestrado EESC USP, São Carlos: EESC USP, 2001.

-PerruCl, Gadiel. Favelas do Rio e Mocambos do Recife: um relatório de estágio. Recife: Fundação de Promoção Social/ Depto Sócio-Econômico/ Divisão de Informação e Documentação, 1962.

-PerruCl, Gadiel e Bernardes, Denis O caranguejo e o Viaduto - Um ensaio de metaleitura sobre o Recife/ Notas preliminares para uma história social do Recife São Paulo, 1980

-PONTUAL, Virgínia. Uma cidade e dois prefeitos. Recife: Ed. da UFPE, 2001.

-PulHEZ, Magaly Marques. Espaços de favela, fronteiras do ofício: história e experiências contemporâneas de arquitetos em assessorias de urbanização. Mestrado EESC-USP, São Carlos:EESC-USP, 2007.

-PUNTONI, Álvaro. O projeto como caminho - Estruturas de habitação na área central de São Paulo. A ocupação de vazios na Avenida Nove de Lulho. São Paulo: FAU USP, Doutorado, 2004

-ReZENDE, Antônio (org.). Recife: Que história é essa? Recife: Fundação de Cultura da Cidade do Recife, 1987

-ROZOWYKWIAT, Tereza. Arraes. São Paulo: Iluminuras - Biografia, 2006.

-RAGON, Michel. L'architecte, le prince et la démocratie Vers une démocratisation de l'architecture? Paris: Albin Michel, 1977.

-Rodrigues, Mayra. Exposições de Lina Bo Bardi. Trabalho Final de Graduação, São Paulo: FAU USP, 2008.

-ROSSETTO, Rossella. Produção imobiliária e tipologias residenciais modernas - São Paulo - 1945/1964. Doutorado FAU USP, São Paulo, FAU USP, 2002.
-RUSSO, Mario. A tradução Arquitetônica da célula habitativa: Sua Evolução e previsões lógicas. São Paulo, FAU-USP, Concurso. 1956.

-SAMPAIO, Maria Ruth Amaral (org.) A promoção privada de Habitação Econômica e a Arquitetura Moderna - 1930/64. São Paulo: Rima/FAPESP, 2002.

-SANTOS, Carlos Nelson Ferreira dos. A cidade como um jogo de cartas. Niterói/ São Paulo: Universidade Federal Fluminense/Editora Universitária, 1988.

-Movimentos urbanos no Rio de Janeiro. Rio de Janeiro: Zahar Editores, 1981.

-SANTIAGO, Vandeck. "O Plano de Kennedy para desenvolver o Nordeste". Suplemento especial publicado no Diário de Pernambuco, 30/ agosto/ 2006.

-SEGAWA, Hugo. Arquiteturas no Brasil 1900-1990. São Paulo: EdUSP, 1999.

-SEGRE, Roberto. Arquitetura e Urbanismo da Revolução Cubana. São Paulo: Nobel, 1987.

-SERRAN, João Ricardo. lab e a política habitacional brasileira : 1954-1975 São Paulo: Schema, 1976

-SKIDMORE, Thomas. Brasil: de Getúlio a Castelo. Rio de Janeiro: Paz e Terra, 5 $5^{\mathrm{a}} \mathrm{Ed}, 1976$.

-SMITHSON, Alison Margaret. Team 10 primer. Londres: Studio Vista, 1968.

-SMITHSON, Peter. Nigel Henderson: "Paralell of life and art". Londres: Thames and Hudson, 2001.

-SILVA, Geraldo Gomes da. "Marcos da Arquitetura Moderna em Pernambuco" In: SeGawA, Hugo (Ed.) Arquiteturas no Brasil/ Anos 80. São Paulo, Projeto, 1988, pp 19-27.

-SILva, Geraldo Gomes da. "Antônio Bezerra Baltar 1915-2003". Porta Retratos. DOCOMOMO, disponível em

http://www.docomomo.org.br/portaretratos\%20Baltar.htm

-SERVIÇO SOCIAL DA INDÚSTRIA. Contribuição ao estudo das condições de habitação entre pescadores e operários de Pernambuco. Recife: SESI Depto. Pernambuco, 1950. 
-STORELLI, Franco (org.). Habitat e Architectture di terra le potenzialità delle tradizioni construtive. Roma: Gangemi Editore, 1996.

-SCHWARZ, Roberto. Que horas são? São Paulo: Cia das Letras, 1987

-TELES, José. Do Frevo ao Manguebeat. São Paulo: Ed. 34, 2000.

-TURNER, John F. Charlewood. "Dwelling resources in South America". In Architectural Design 33, 1963, p. 360-393.

- "Habitação de baixa renda no Brasil: Políticas atuais e oportunidades futuras". In Arquitetura. Rio de Janeiro: IAB GB, 1965.

- "Barreiras e Canais para o desenvolvimento internacional nos países em desenvolvimento". In Arquitetura. Rio de Janeiro: IAB GB, 1965.

- Vivienda, todo el poder para los usuarios: hacia la economia en la construccion del entorno. Madrid: Blume, 1977.

-UNIÃO INTERNACIONAL DOS ARQUITETOS. Congres de L'union Internationale des Architectes. Havana: UIA, 1963.

-Veras, Francisca S. Comunidade do Cajueiro Seco Recife. Ed SUDENE UFPE, 1964.

-VIEIRA, Álvaro Siza, "Salvando las Turbulencias: entrevista con Alvaro Siza"; "Viviendas sociales en Schilderswijk Ward". In: El Croquis, Madrid, No. 68/69, 1994. Pgs 3-45 e 114-125 in Lotus Internacional, nº13, Milão: 1976

-XAVIER, Alberto F. (org.). Depoimentos de uma Geração. São Paulo: Cosac Naify, 2003

-WEIMER, Gunter. Arquitetura popular brasileira. São Paulo: Martins fontes, 2005.

-WILHEIM, Jorge. "Notas de Viagem - VII Congresso da UIA". Acrópole 300, São Paulo, out/nov 1963.

-WISNIK, Guilherme Teixeira. Lucio Costa. São Paulo: Cosac Naify, 2003.

-ZANCHETTI, Silvio "Formação e consolidação da Repartição de Obras Públicas de Pernambuco (1836-1844)" Espaço e Debates, № 34, 1991 


\section{ACERVOS PESQUISADOS}

\section{Em São Paulo:}

Biblioteca Eduardo Knesse de Mello - FAU USP

Revistas Arquitetura - IAB Guanabara, Acrópole, Habitat, Mirante das Artes Etc, OU..., Projeto, Arte em Revista

\section{No Recife:}

Arquivo Público Estadual Jordão Emerenciano - APEJE

Acervo do Escritório do Arquiteto Acácio Gil Borsoi

Fundação Joaquim Nabuco - Fundaj

Museu da cidade do Recife

Instituto do Patrimônio Histórico e Artístico Nacional (IPHAN - 5 SR)

Companhia de Urbanização do Recife - URB

Biblioteca Joaquim Cardozo - CAC UFPE

Biblioteca Pública de Pernambuco

Secretaria de Desenvolvimento Assistência Social (SDAS/PE)

Acervo DOPS - APEJE

Jornais A Hora, Folha do Povo, Jaboatão Jornal, O dia virá, Jornal Pequeno, Diário de Pernambuco, Jornal do Commercio, Última Hora $\mathrm{NE}$

\section{ENTREVISTAS REALIZADAS}

Acácio Gil Borsoi, no seu escritório no Pina, Recife, em agosto de 2006 e setembro de 2007, registradas em video.

Geraldo Gomes da Silva, no seu escritório na Boa Vista, Recife, em agosto de 2006 e setembro de 2007, registradas em video.

Germano Coelho, no seu escritório na sede do CIEE na Boa Vista, Recife, em setembro de 2007, registrada em video.

Lívio Xavier, na sua casa na Torre, Recife, em setembro de 2007, registrada em video.

Maurício Castro, na sua casa na Torre, Recife, em setembro de 2007, registrada em video.

Vital Lira, no seu laboratório na Ilha do Leite, Recife, em setembro de 2007

Francisca Veras, na sua casa no Cordeiro, Recife, março de 2008, registrada em video.

Maria Lucia Mello, na sua casa em Parnamirim, Recife, março de 2008, registrada em video.

Geraldo Santana, no térreo do edifício em que mora nas Graças, Recife, em setembro de 2007.

Miguel Pereira, no seu escritório na República, São Paulo, em março de 2007.

Seu Inácio, na sua sapataria na Feira Livre de Prazeres, em setembro de 2007, registrada em video.

Dona Maria, no quintal de sua casa, em Cajueiro Seco, em setembro de 2007, registrada em video. 


\section{LISTA DE SIGLAS UTILIZADAS}

ATBAT - Atelier du Batiment

ASCOFAM - Associação Mundial de Luta contra a Fome

BID - Banco Interamericano de Desenvolvimento

CDR - Comitê de Defesa da Revolução

CEOs - Centros Educativos Operários

CODEPE - Comissão de Desenvolvimento Econômico de Pernambuco

CPC /UNE - Centro Popular de Cultura da União Nacional de Estudantes

CREA - Conselho Regional Engenharia Arquitetura

CVSF - Companhia Vale do São Francisco

DAC - Diretoria de Arquitetura e Construções

DAU - Diretoria de Arquitetura e Urbanismo

DC - Departamento de Construções

DOFSP - Departamento de Obras e Fiscalização de Serviços Públicos

DPHAN - Diretoria do Patrimônio Histórico e Artístico Nacional

DRAS - Departamento de Reeducação e Assistência Social

FAU USP - Faculdade de Arquitetura e Urbanismo da Universidade de São Paulo

FMI - Fundo Monetário Internacional

FHC - Fernando Henrique Cardoso

FUNDAJ - Fundação Joaquim Nabuco

IAP - Instituto de Aposentadoria e Pensão

IBAD - Instituto Brasileiro de Ação Democrática

IJNPS - Instituto Joaquim Nabuco de Pesquisas Sociais
INSS - Instituto Nacional do seguro Social

IPASE - Instituto de Previdência

IPHAN - Instituto Patrimônio Histórico e Artístico Nacional

LSCM - Liga Social Contra o Mocambo

MCP - Movimento de Cultura Popular

MEC - Ministério da Educação e Cultura

MUD - Movimento Universitário de Desfavelamento

PCB - Partido Comunista Brasileiro

PHNG - Parque Histórico Nacional dos Guararapes

PTB - Partido Trabalhista Brasileiro

PSB - Partido Socialista Brasileiro

PSD - Partido Social Democrático

RFFSA- Rede Ferroviária Federal

SAI -Serviço de Assistência Itinerante

SAGMACS - Sociedade de Análises Gráficas e Mecanográficas Aplicadas aos Complexos Sociais

SHRu - Seminário de habitação e reforma urbana

Sudene - Superintendência do Desenvolvimento do Nordeste

SUPURB - Superintendência de Política Urbana

SSCM - Serviço Social Contra o Mocambo

TPN - Teatro Popular do Nordeste

UDN - União Democrática Nacional

USAID - United States Agency International for Development 
01 MAPA DA REGIão METROPOLITANA DO RECIFE

Em cinza favelas mapeadas em 1978, em preto invasões mapeadas após 1978 (Ortiz e Hue, 1978, p.202), em laranja o Cajueiro Seco.

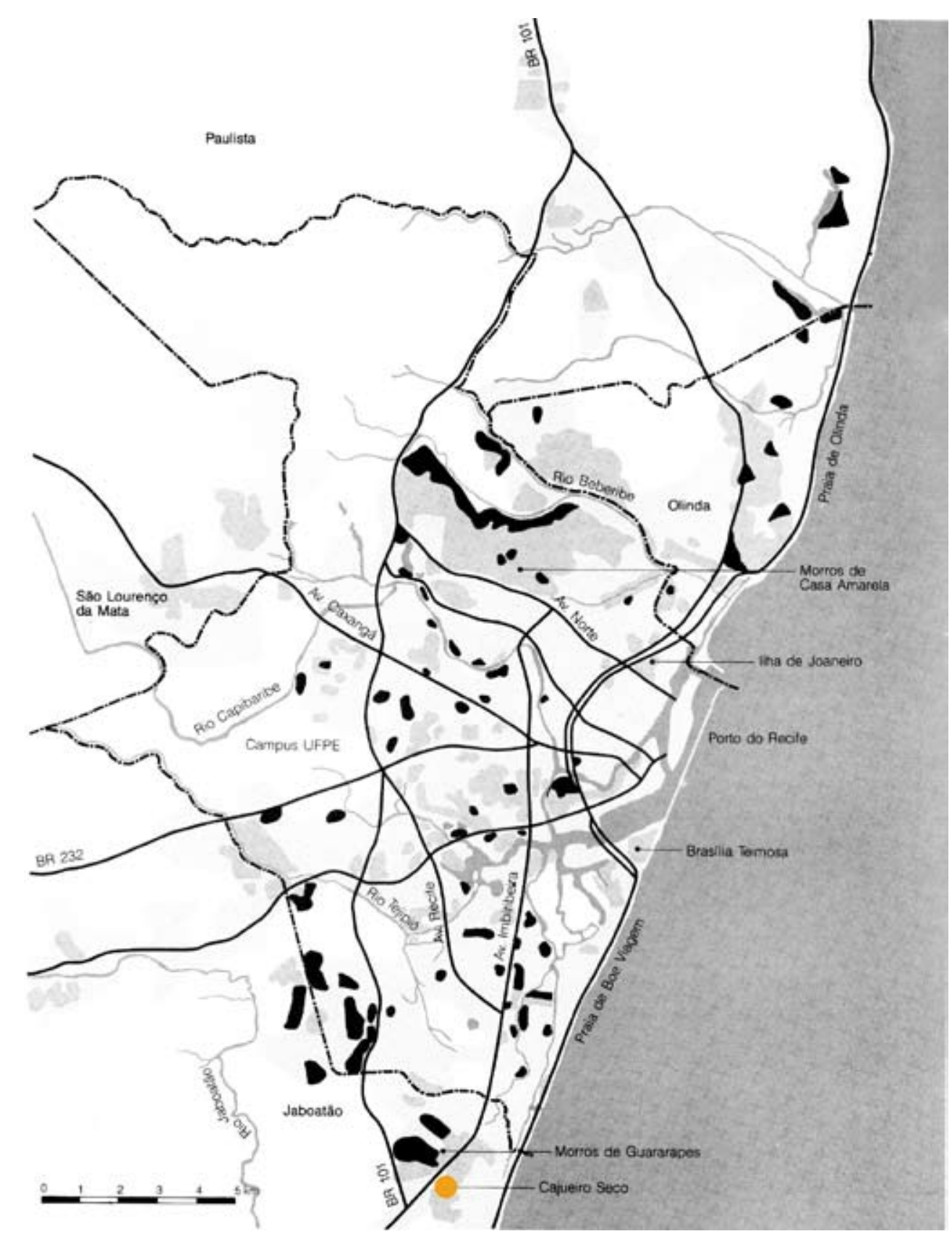




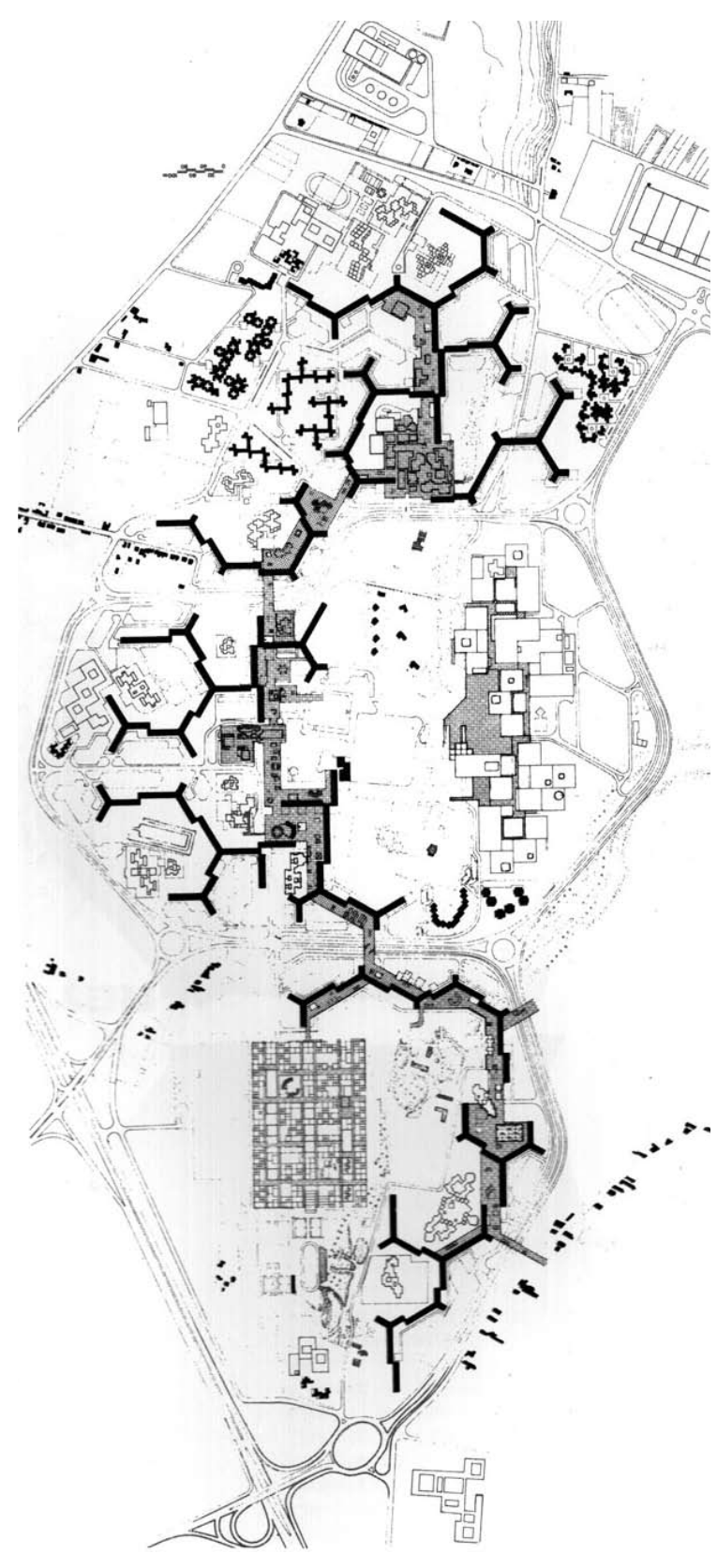

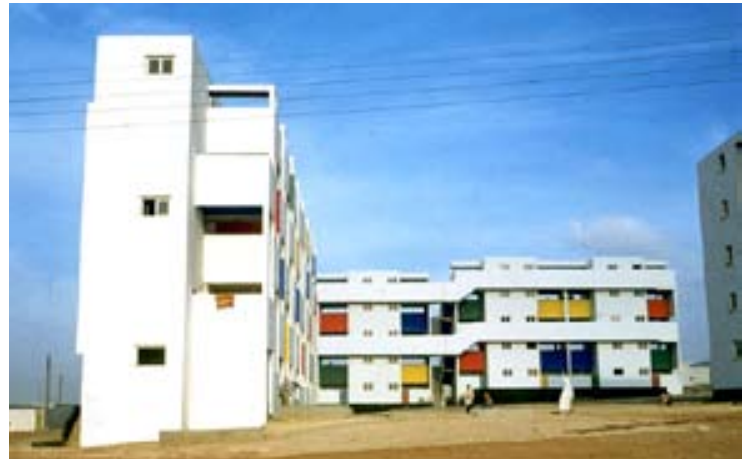

02 Projeto para Toulouse (CANDILIS e woods, 1967) 03 Projeto do at Bat em casablanca

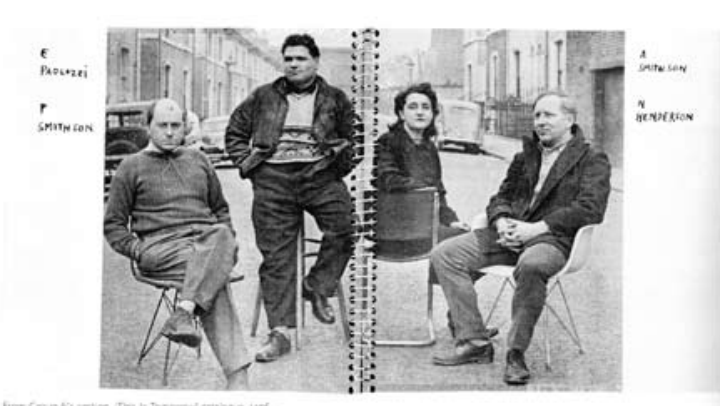

04 Independent group - Nigel Henderson, Edoardo Paolozzi, alison e Peter Smithson(Henderson, 2006) 05 Betnal Green (Henderson, 2006)

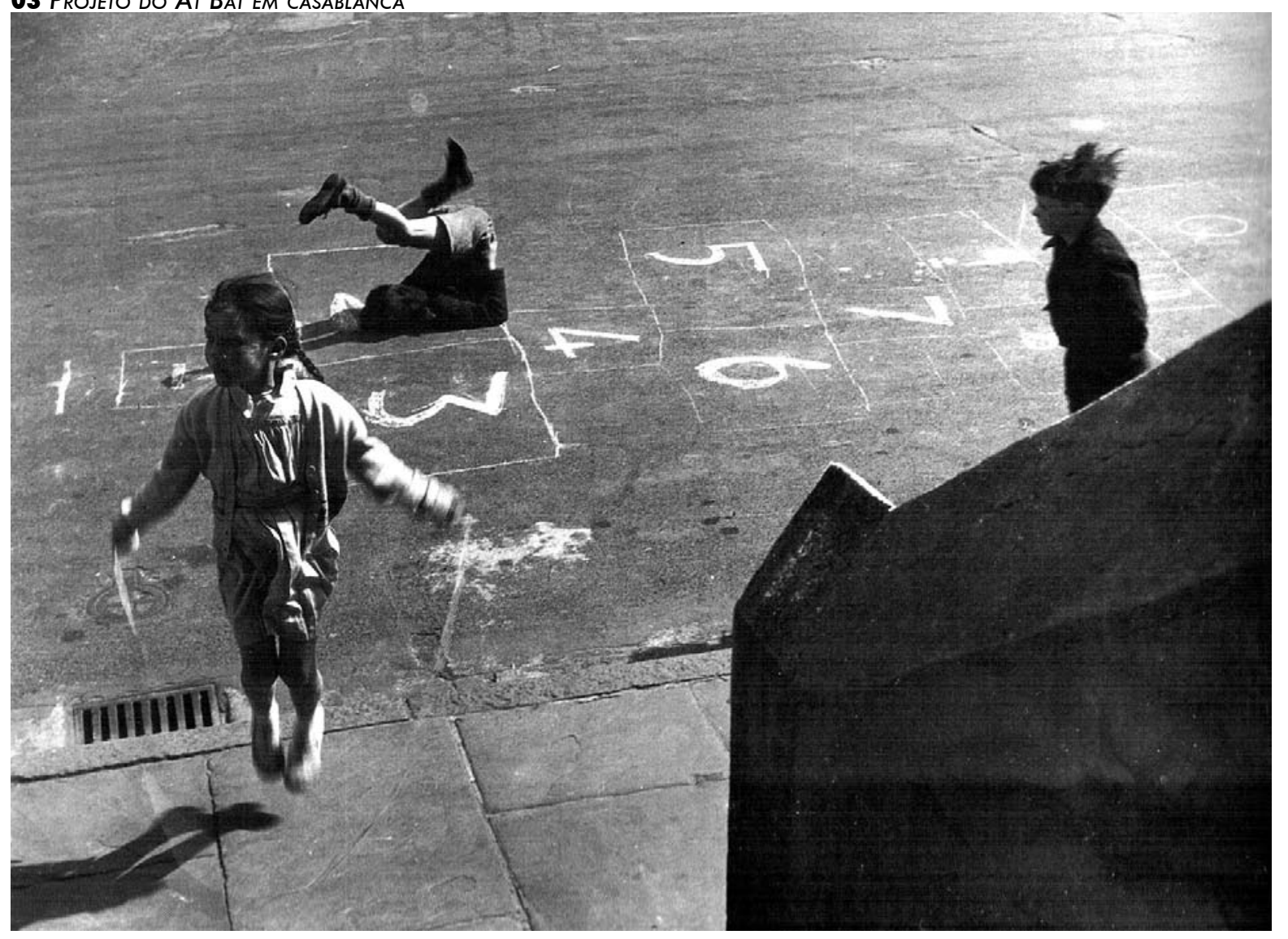



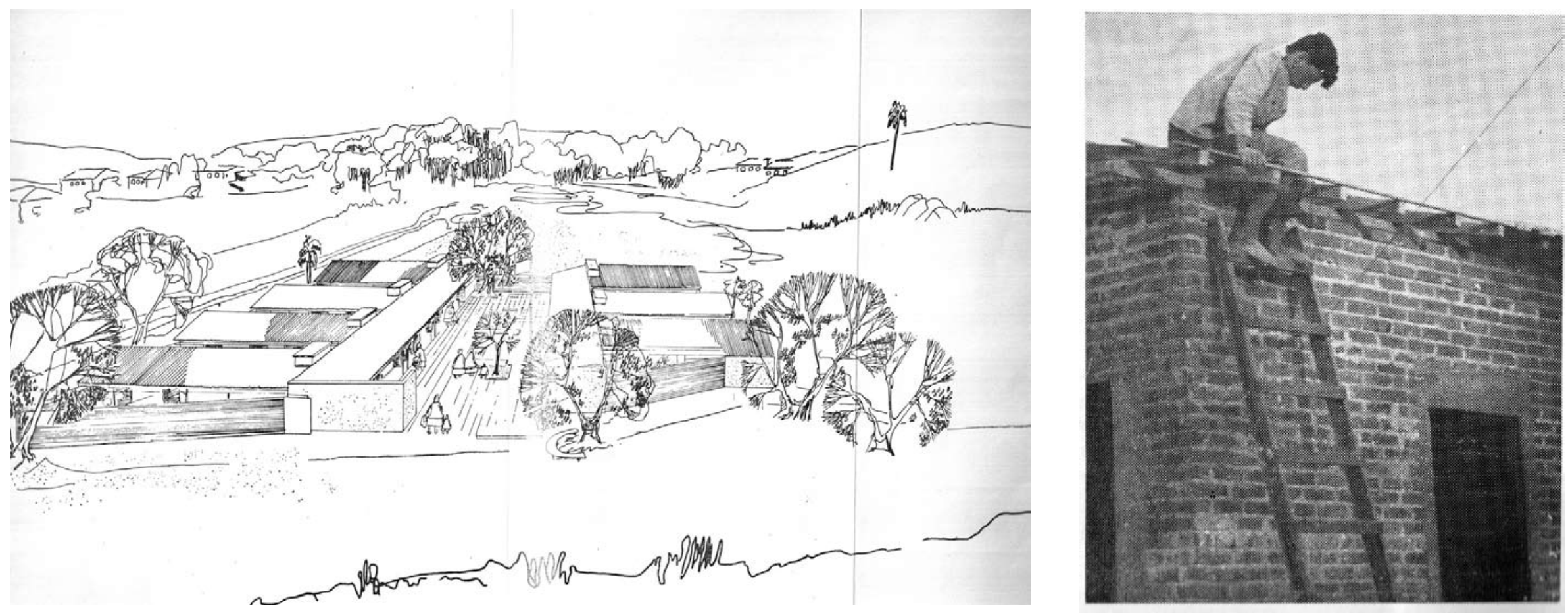

O interessado colaborando na construcão de sua easa

6 Projeto de Jandira, arQ. PaUlo bruna (MUD, 1965) 7 E 8 AJuda-Mútua No MUD (MUD, 1965)

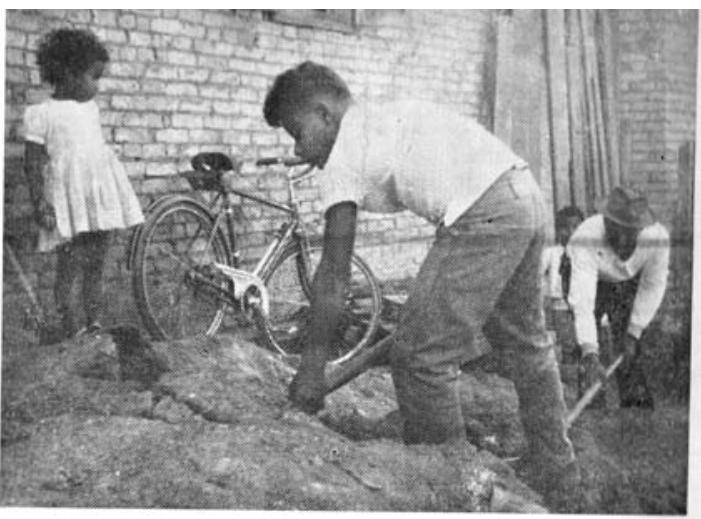

A familia colabora na construção de sua casa 

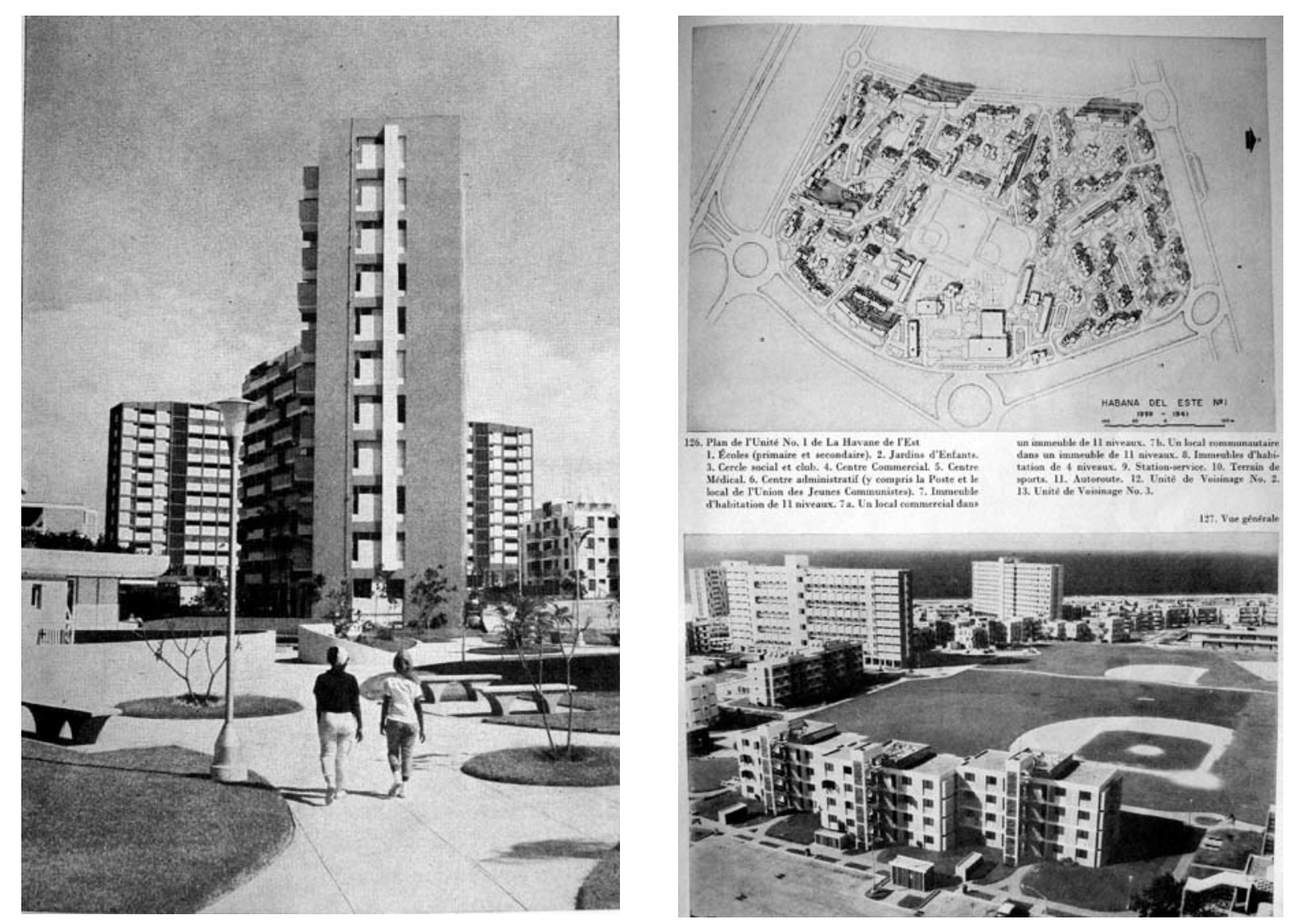

09 a 11 IMAGENS E PROJETO DO CONJUNTO DE HAVANA DEL ESTE (UIA, 1963 E SEGRE, 1987)

12 ARQUiteTURA MODERNA EM CUBA ANTES DA REVOLUÇÃO 13 BOHIOS (UIA, 1963)
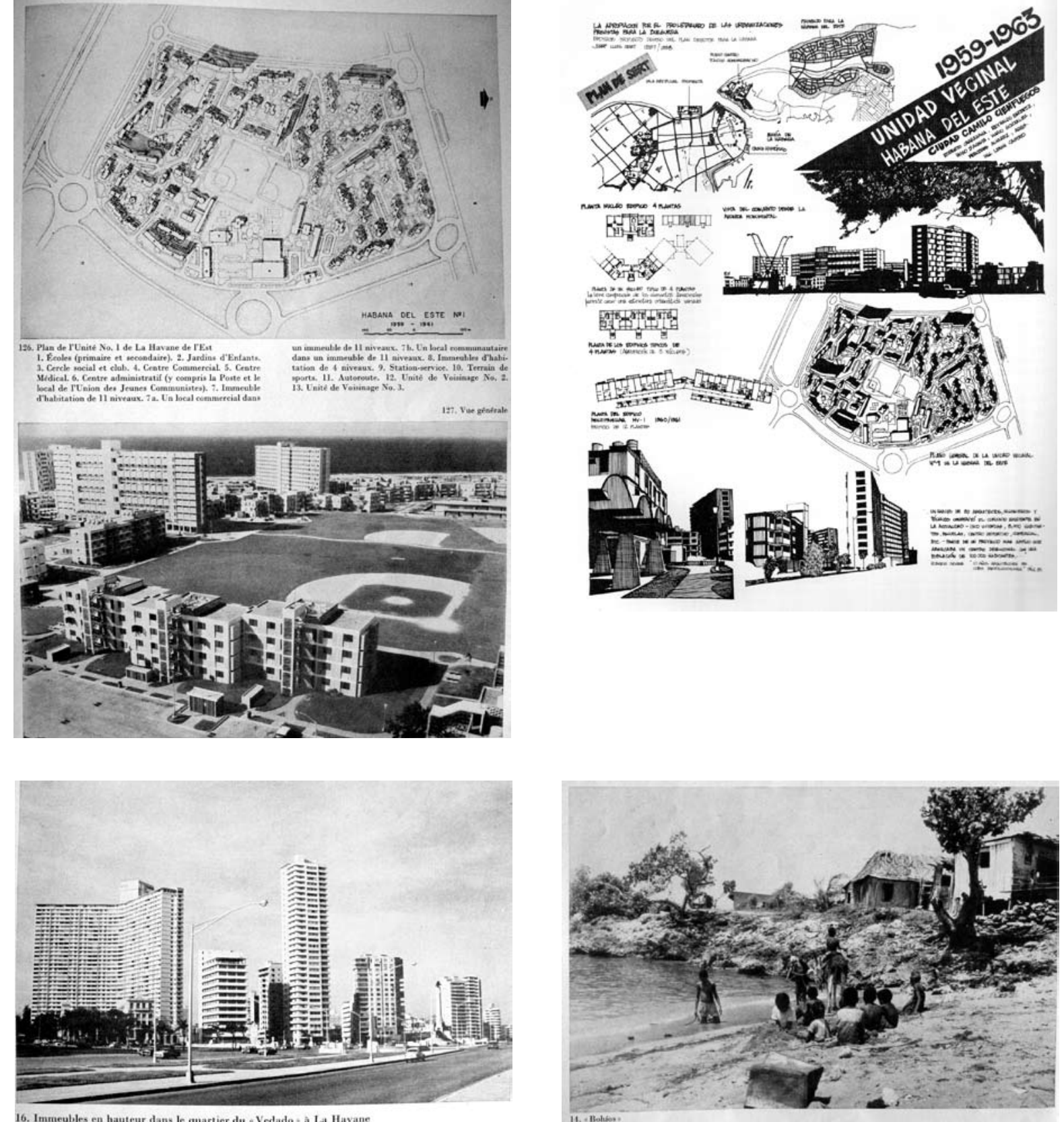

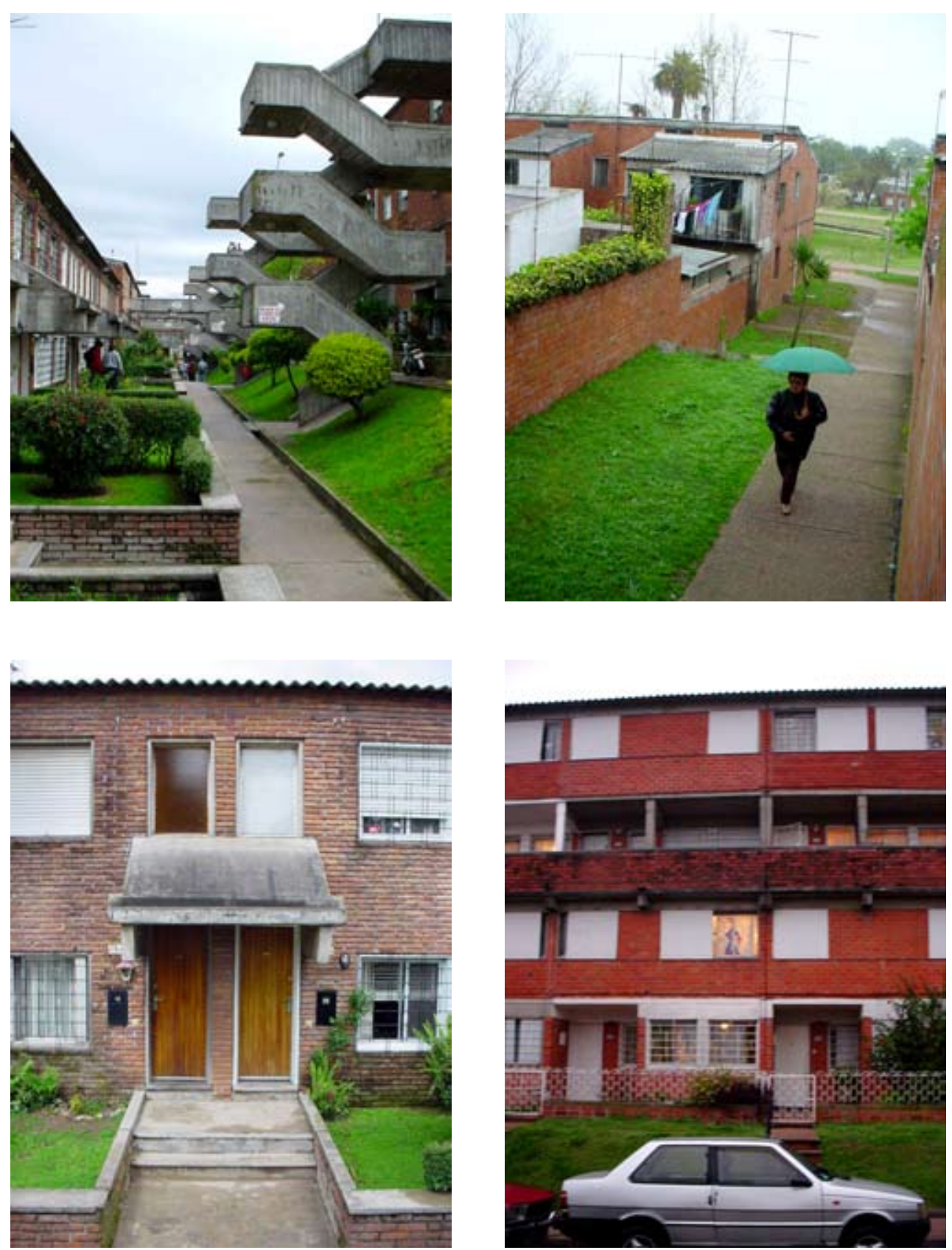


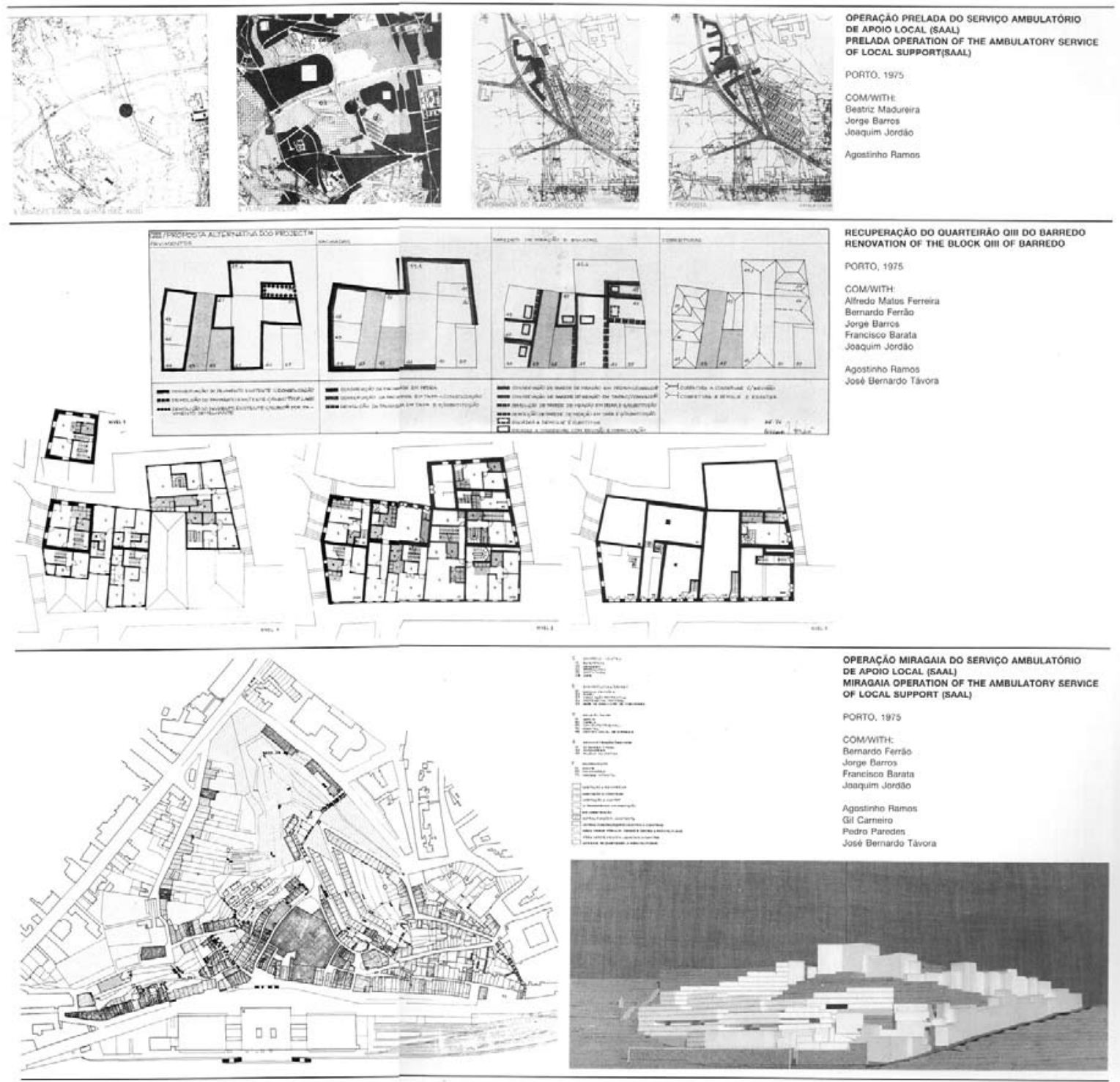

18 Projetos do SaAl (Távora, 1997)

19 ChaRge SOBRE O ENGAJAMENTO DOS ARQUITETOS POR-

tugueses na Revolução dos Cravos (Távora, 1997)

20 CARTAZ DE DOCUMENTÁRIO SOBRE AS SAAL (WWW.

PIMENTANEGRA.BLOGSPOT.COM)
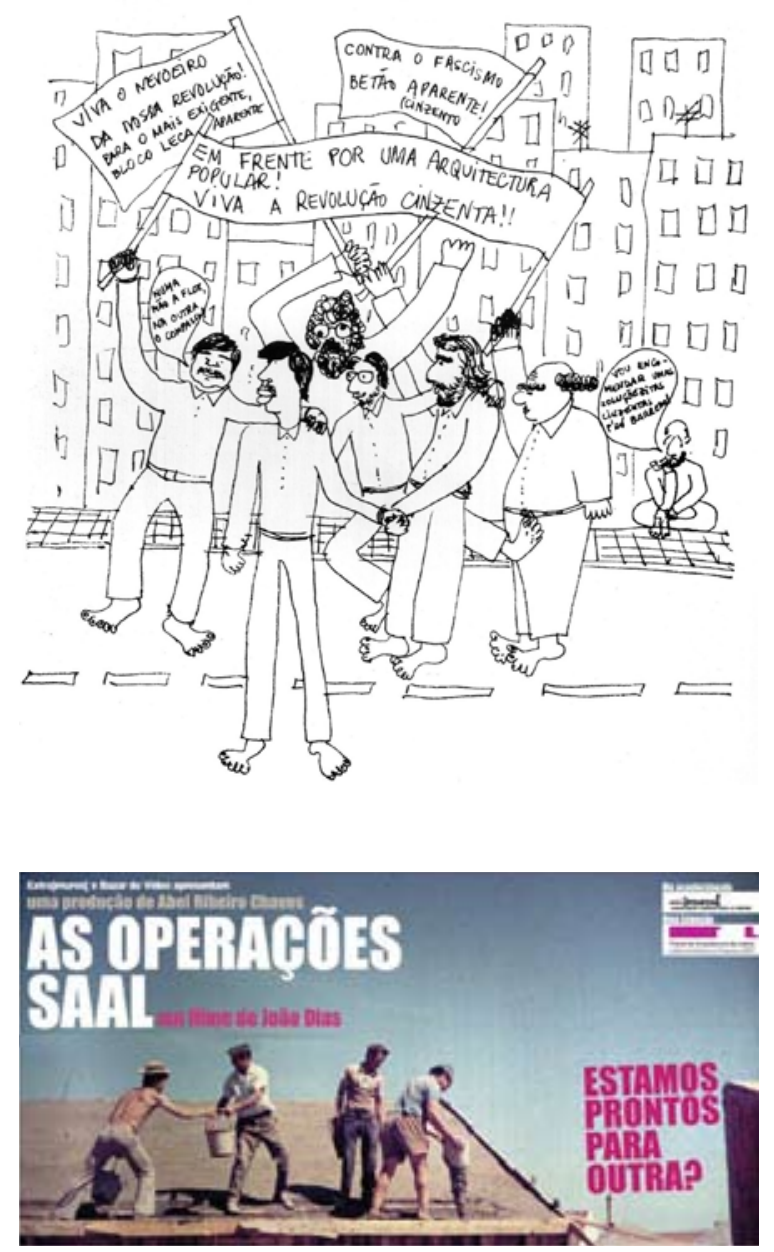
21 e 22 Projeto de Charles Correa para o CONJUNTO PREVI EM LIIMA (CORREA, 1999)

23 PROJETO DO ESCRITÓRIO PÚBLICO DI

DON City Council (LCC)

24 Jardim Ana Rosa, arQ. EdUardo KneEs

dE MELIO 1952 (Foto dO AUTOR, 2006)
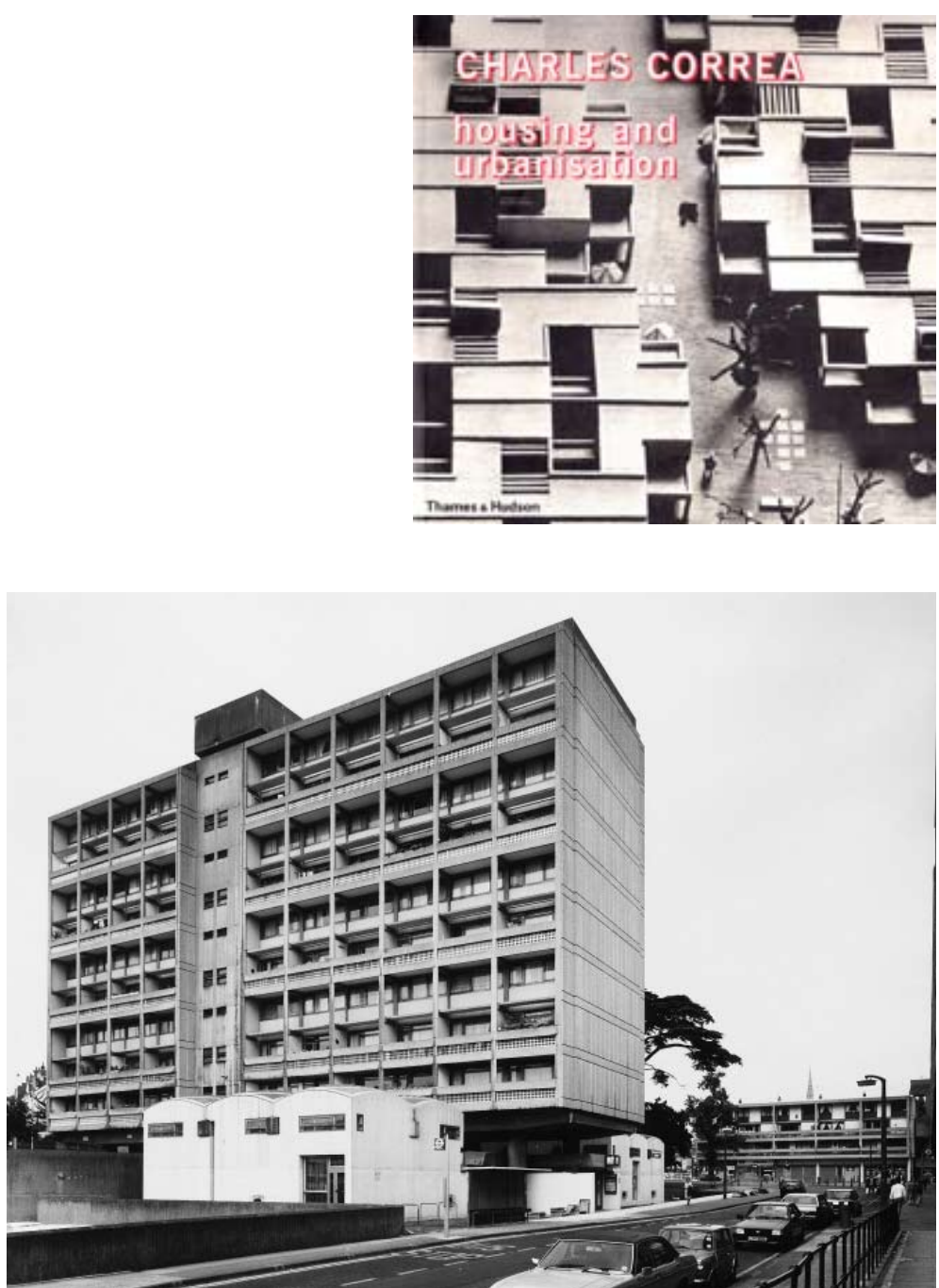

PREVI HOUSING

\begin{tabular}{l}
1969.73 \\
Lima, Peru \\
\hline
\end{tabular}

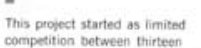

international architeds whor were insted
by the Government of Perv and the

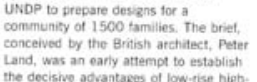

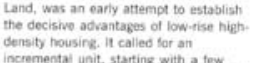

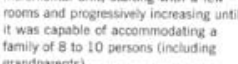

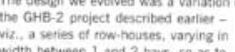

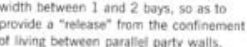
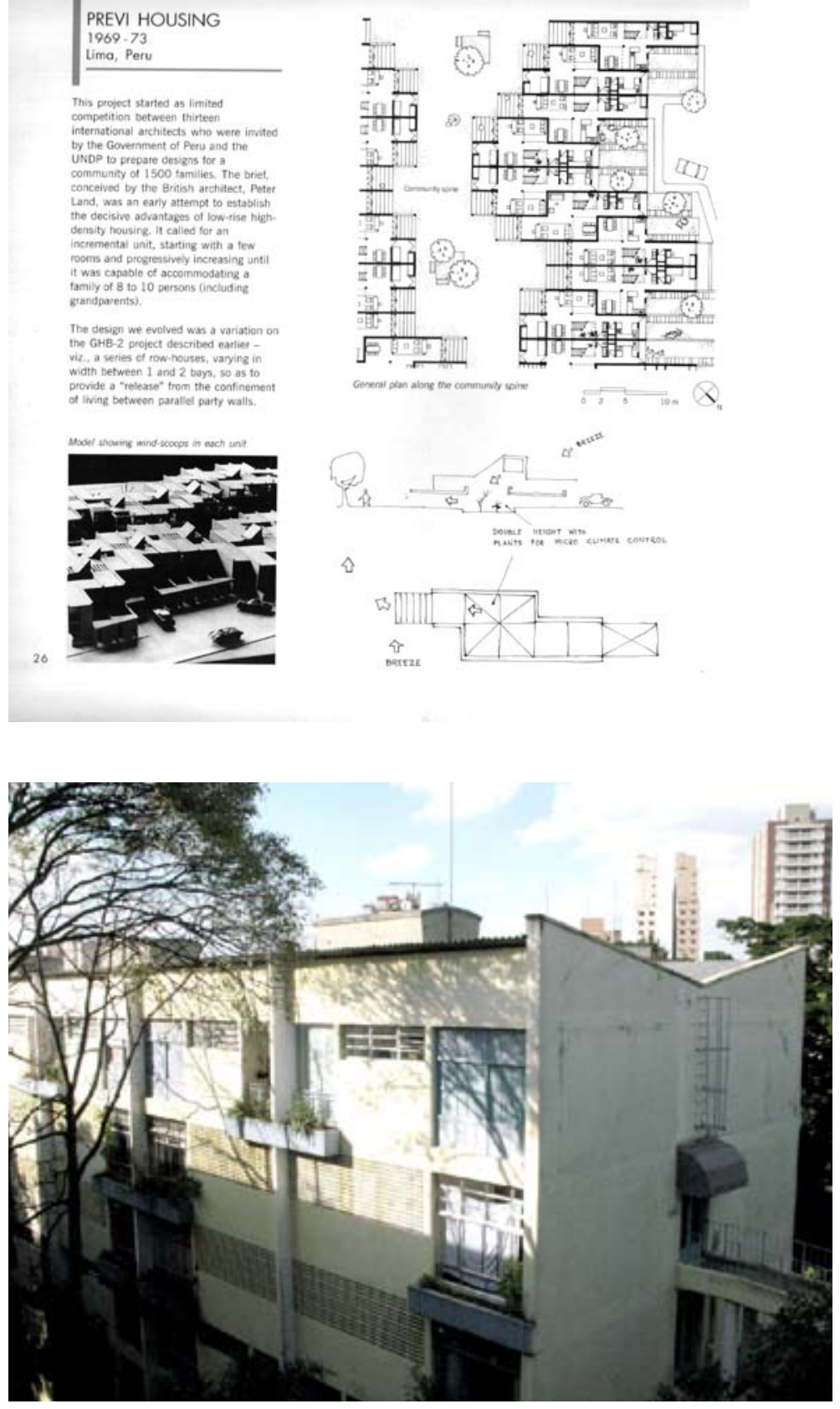


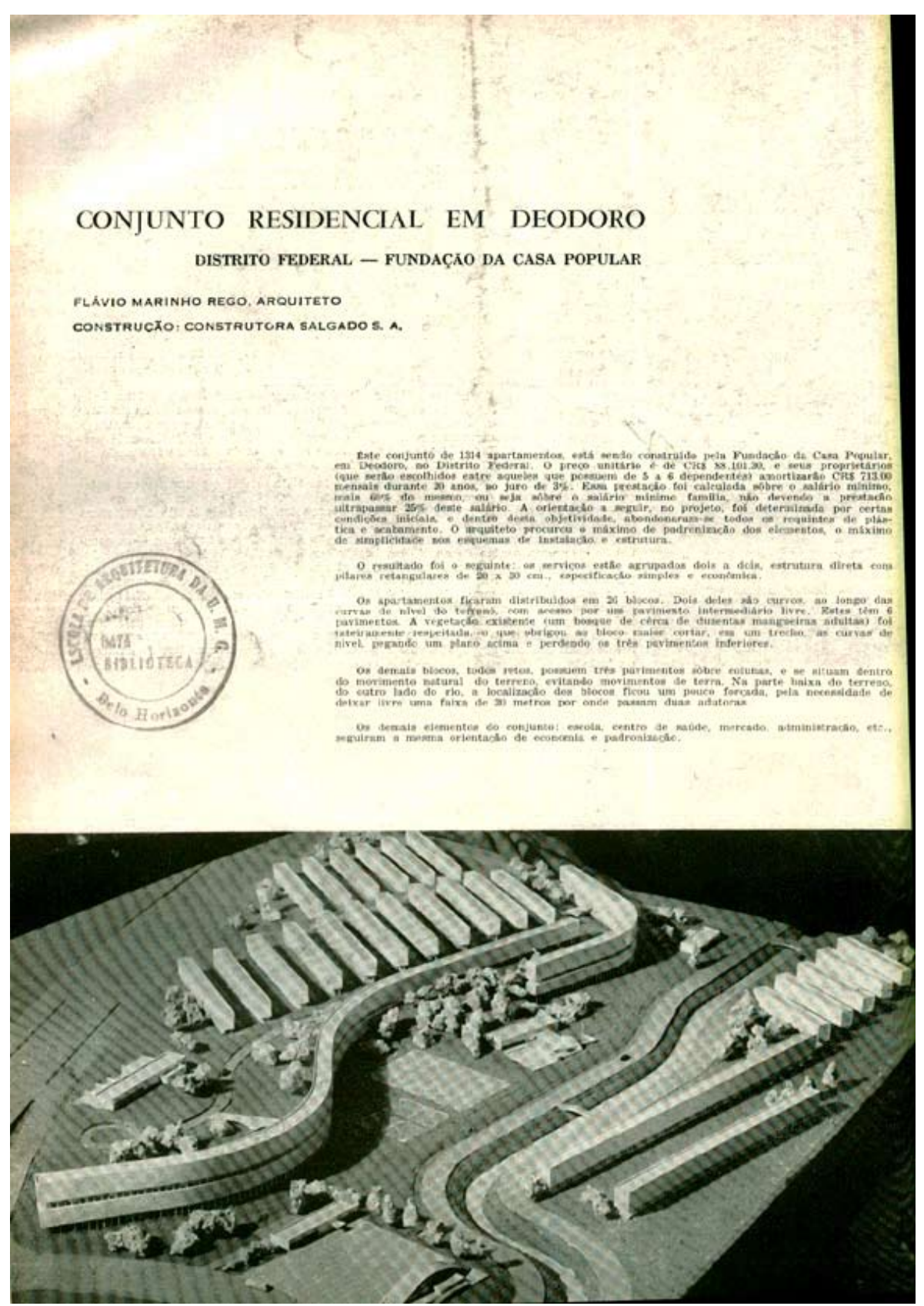

25 Conunto de Deodoro, Arq. Flávio Marinho Rêtgo (Ar-

QUITETURA E ENGENHARIA, 1954, N.31, P.26)

26 a 27 EdifícIo InCONFIDÊNCIA, ARQ. Carlos Frederico FerReIRA

(FOTOS DO AUTOR, 2006)
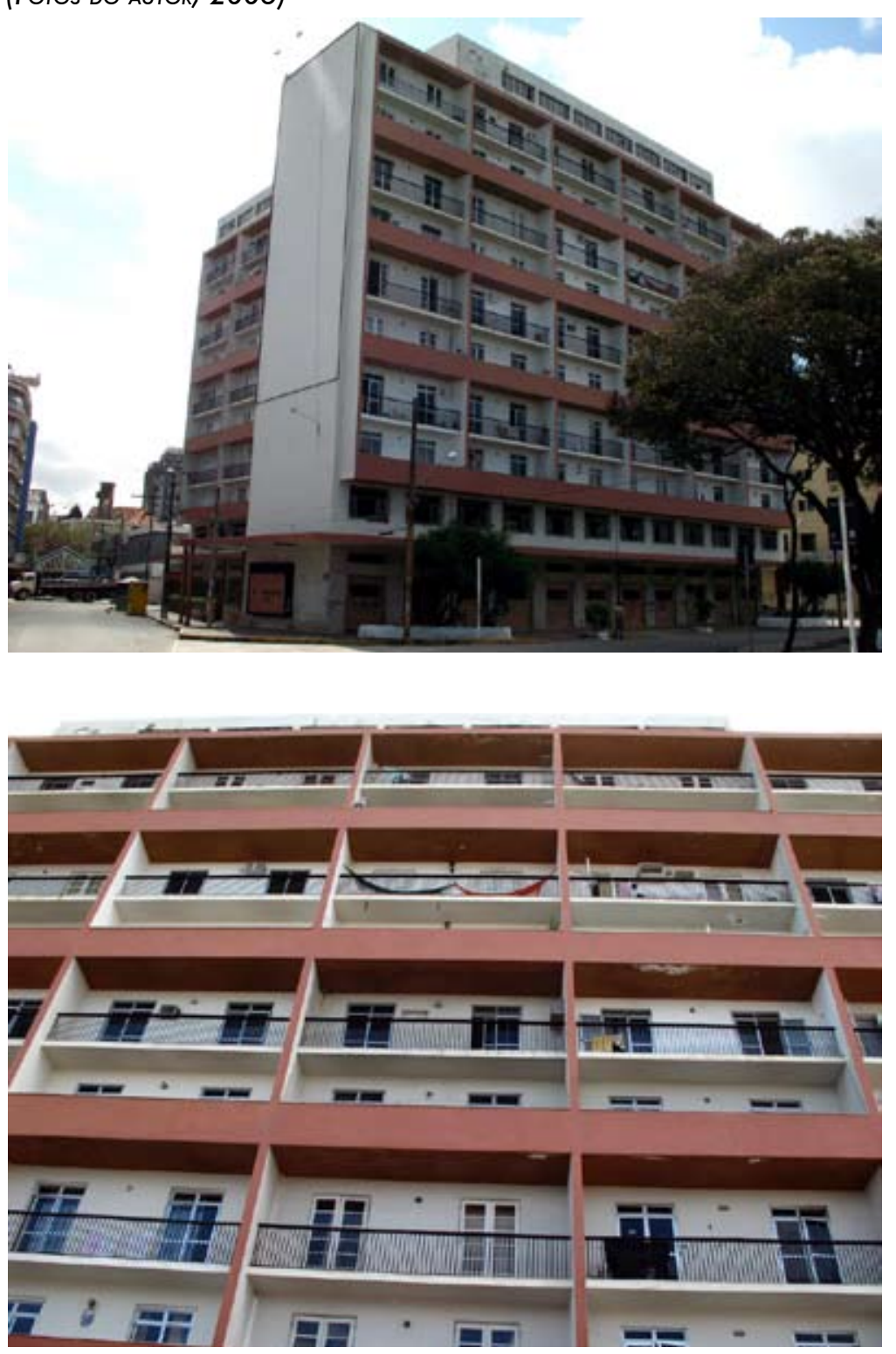

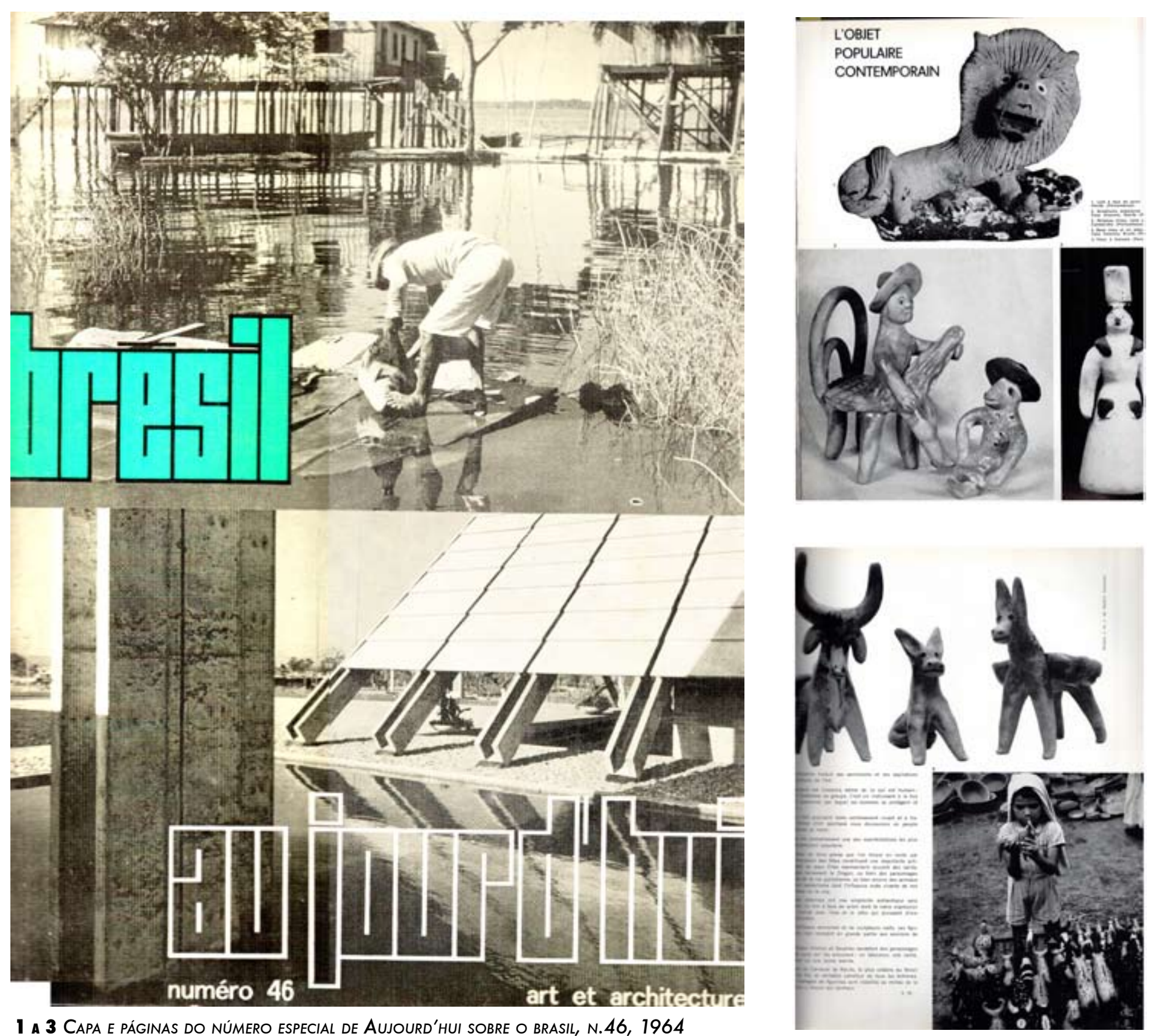

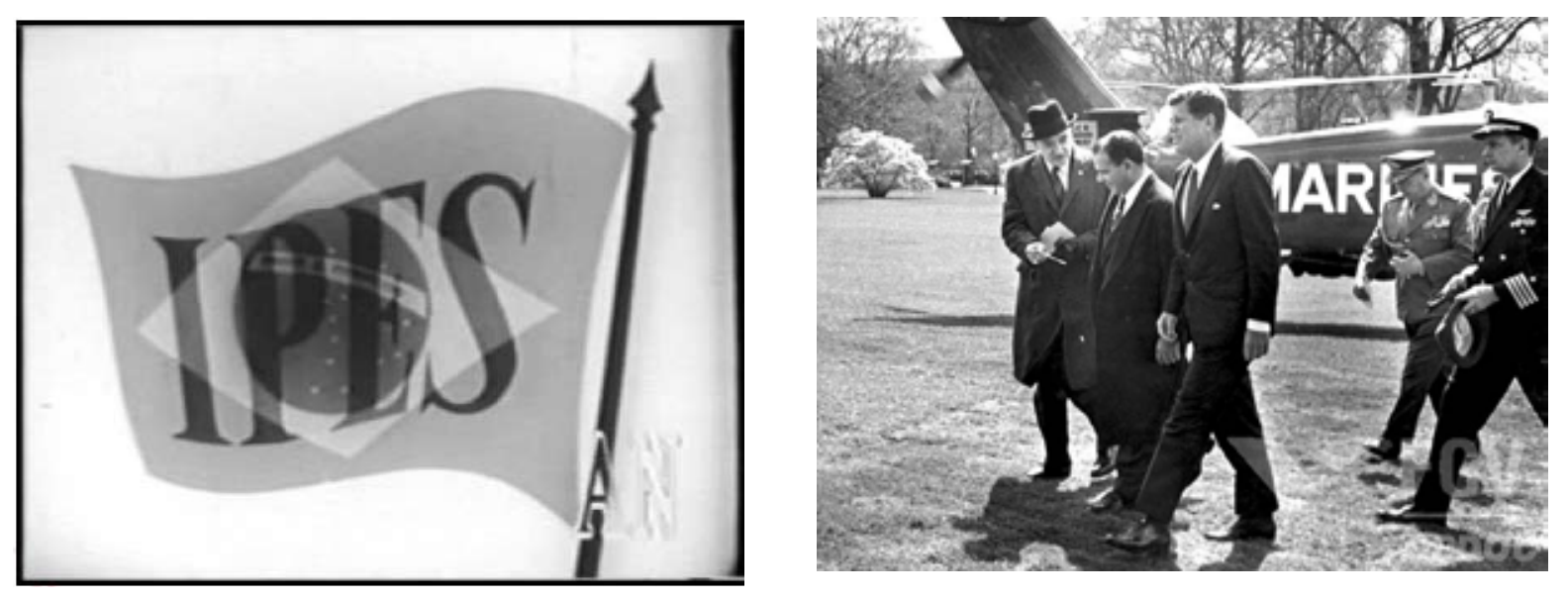

Presidente Gouflart: - A Constifuiceào Deve Ser Revisfa Difrumatera FOI O MAJOR COMICIO O POVO COM JANGO COMECA A REFORMA

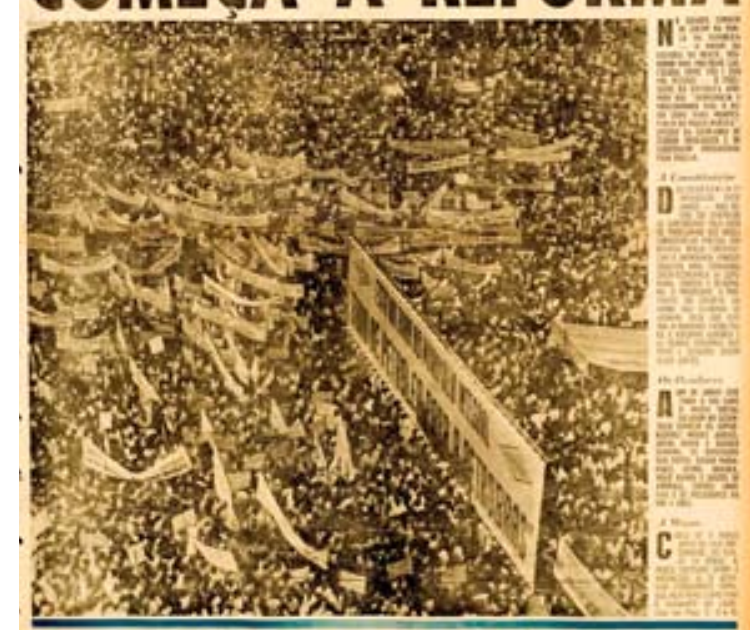
Decretos da Encampacão Das Refinarias e Desapropriaçădo de Terras, na Página 2
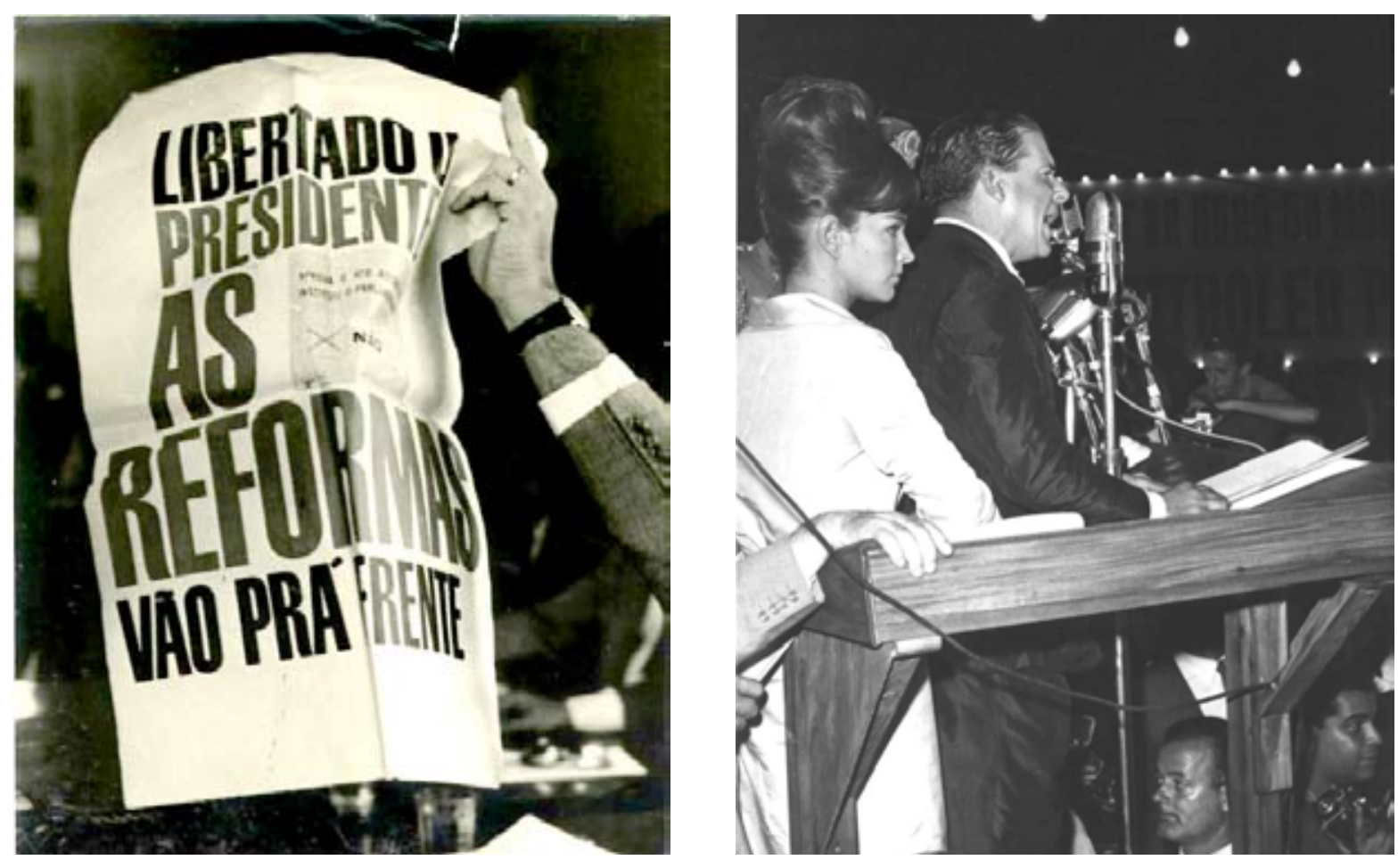

04 a 09 FILMES DO IPES, ATIVIDADES DO IBAD, RELACÕES

COM O GOVERNO KENNEDY, AS REFORMAS DE BASE E O COMICIO da Central: As PREsSÕes políticas no perído Jango (WWW.CPDOC.FGV.BR)

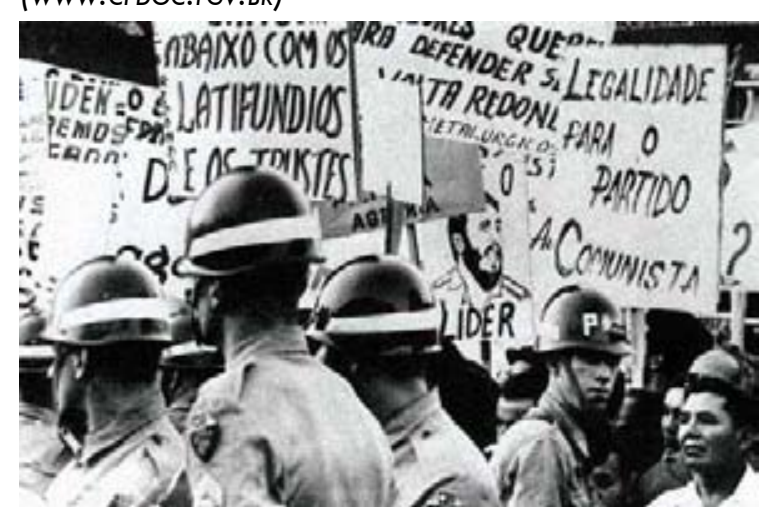




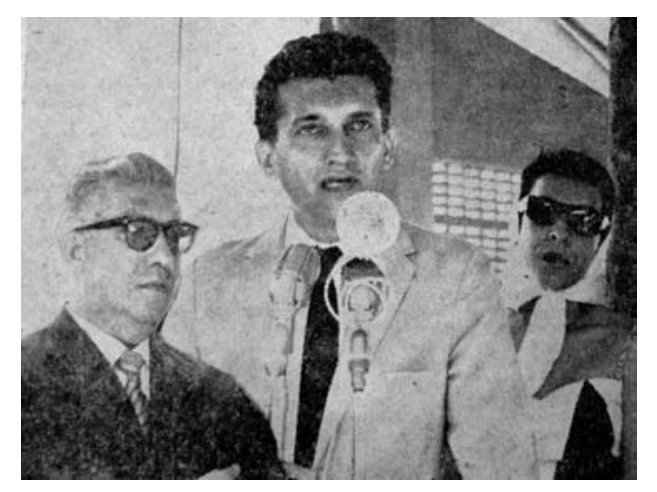

07 Celso Furtado (Última Hora, 1963)

08 E 09 OS EDIFICIOS ONDE FUNCIONOU A SUDENE:

Edificio JK, em Sto Antônio, Centro do Recife

(Arq. Helo Duarte, 1950) e Sudene (Arq. Mau-

RícIO CASTRO, 1970) (FOTOS DO AUTOR, 2007)
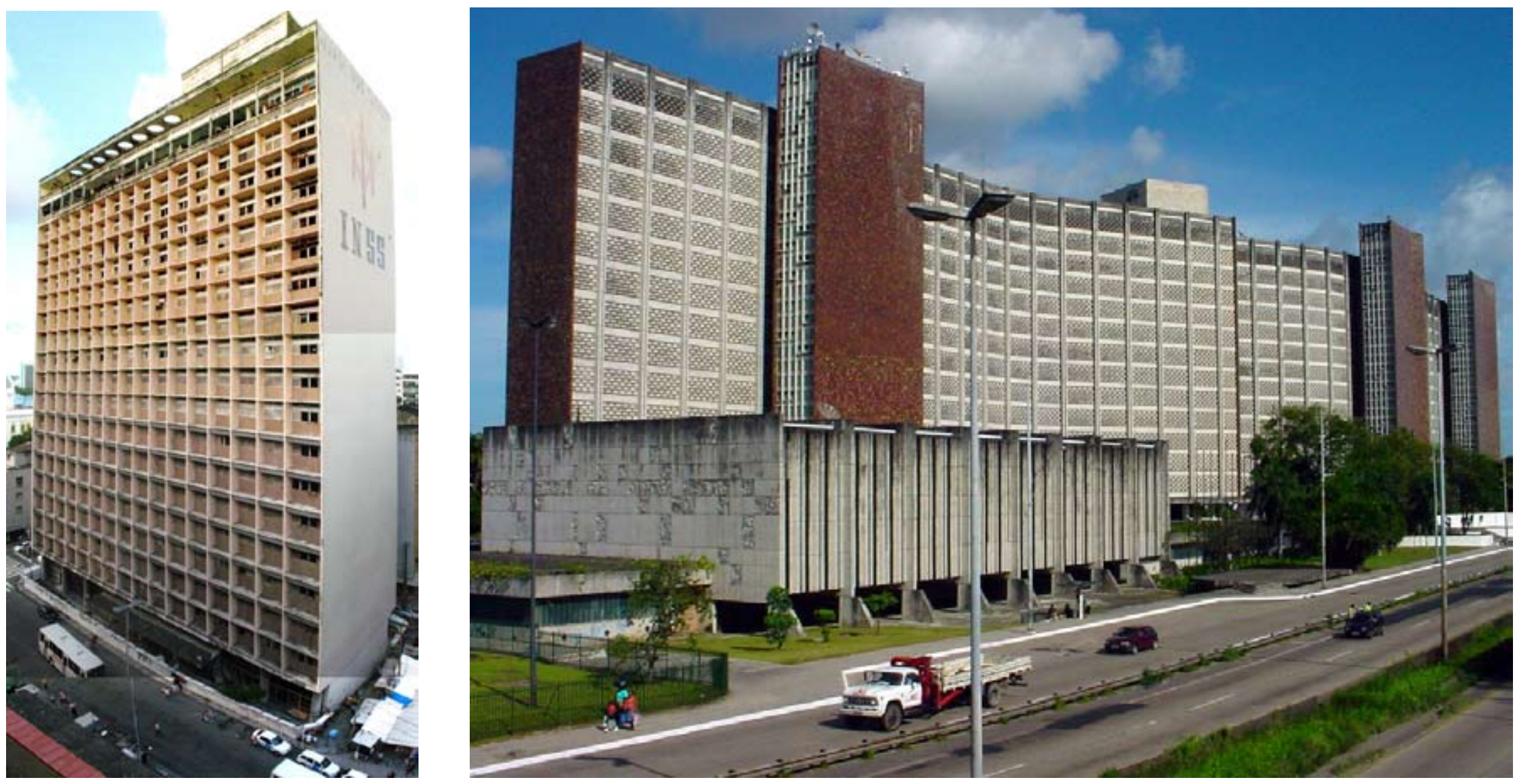


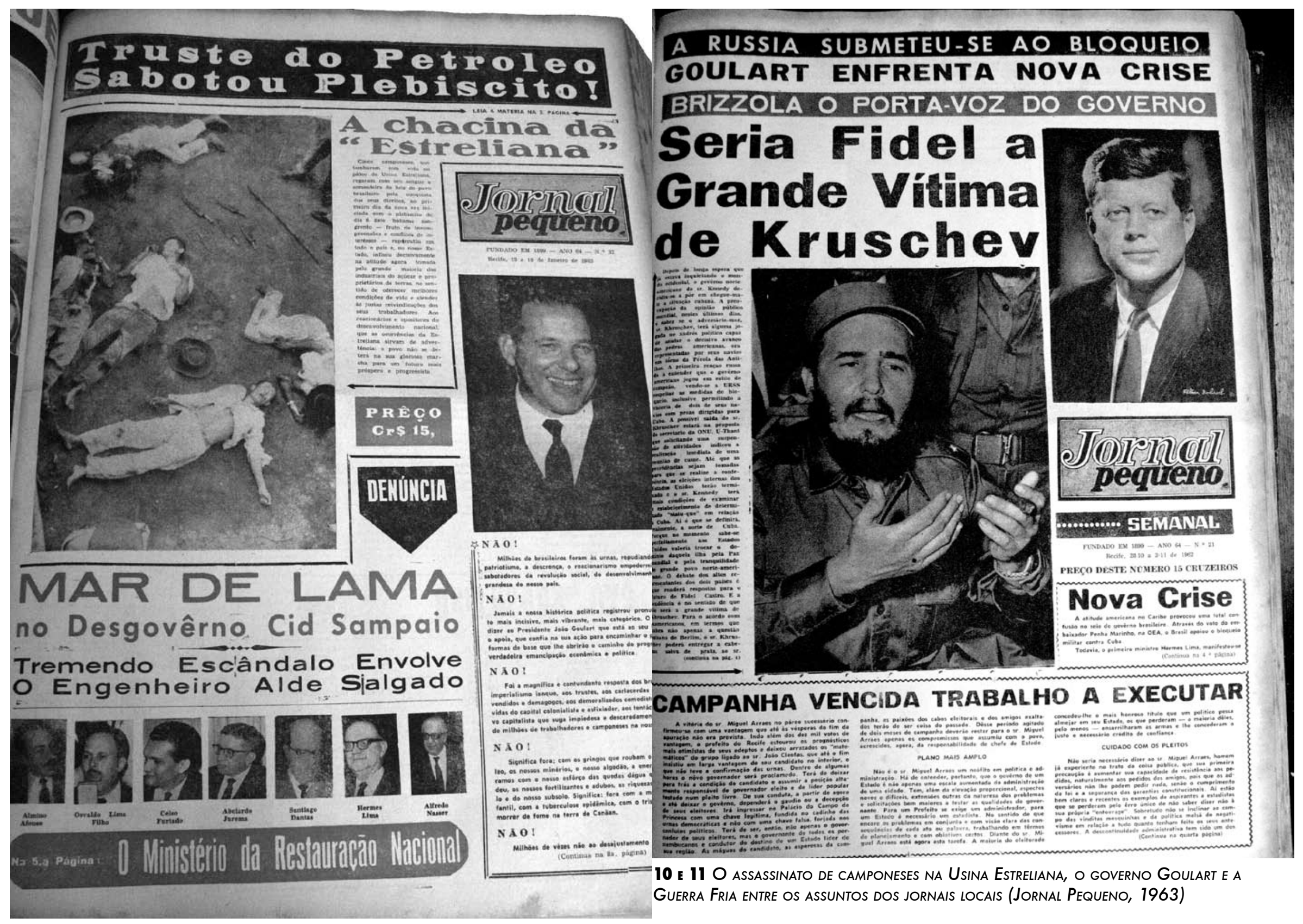



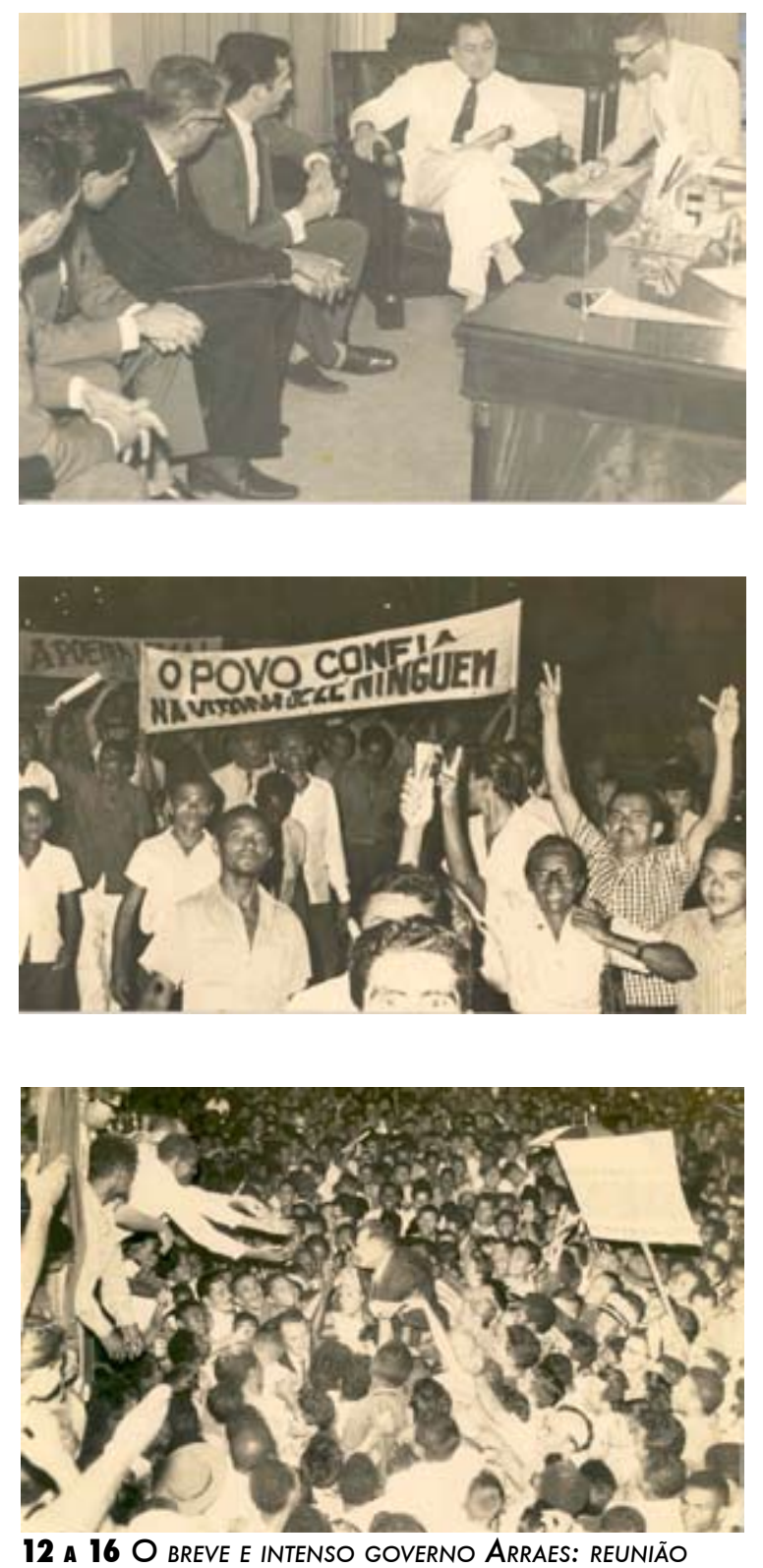

12 a 16 O BREVE E INTENSO GOVERNO ARRAES: REUNIÃO COM O SAl, A VITÓRIA ELEITORAL E A EQUIPE DE GOVERNO (FUNDAJ E ÚltIMA HORA, FEV. 1963)
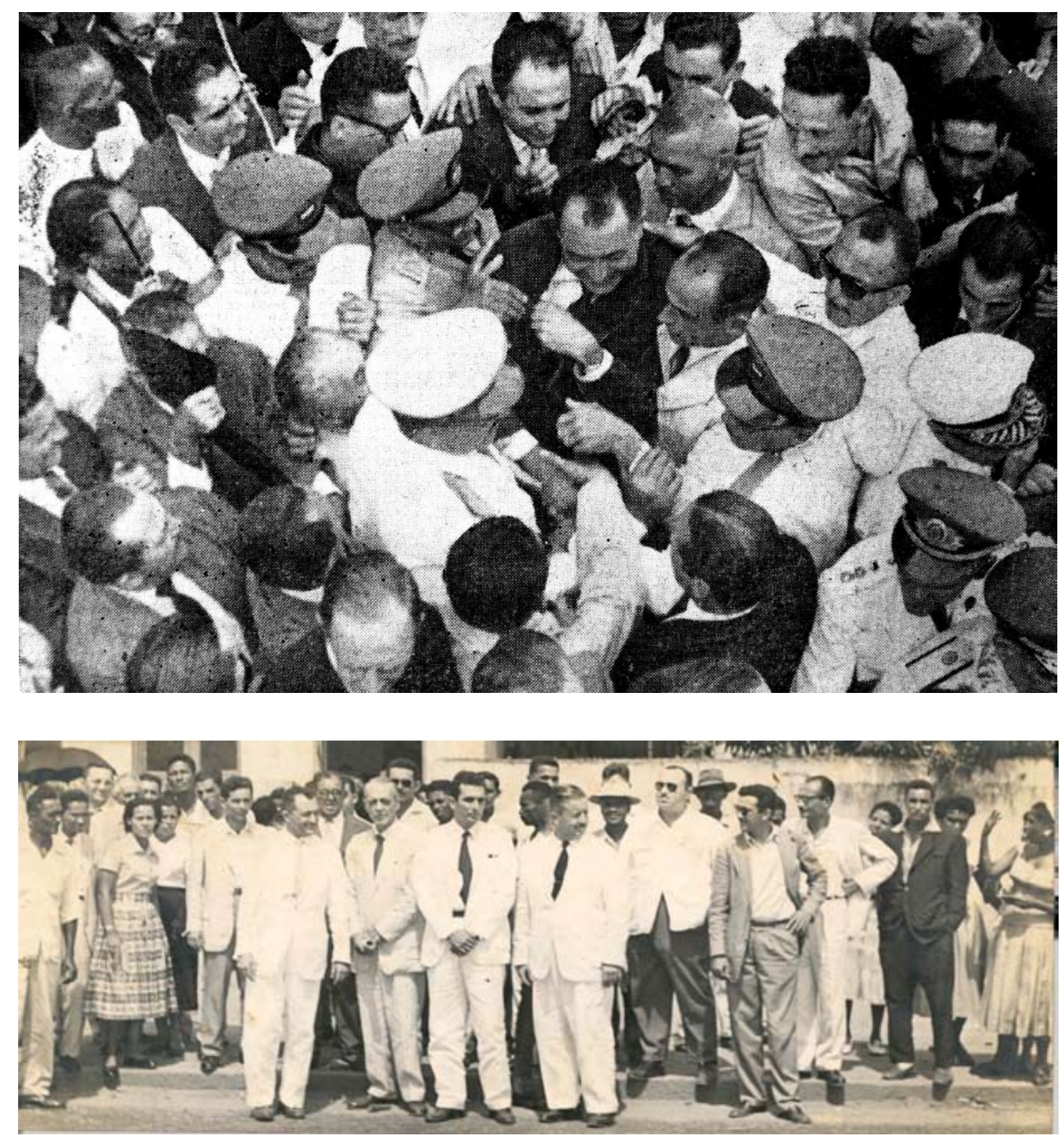

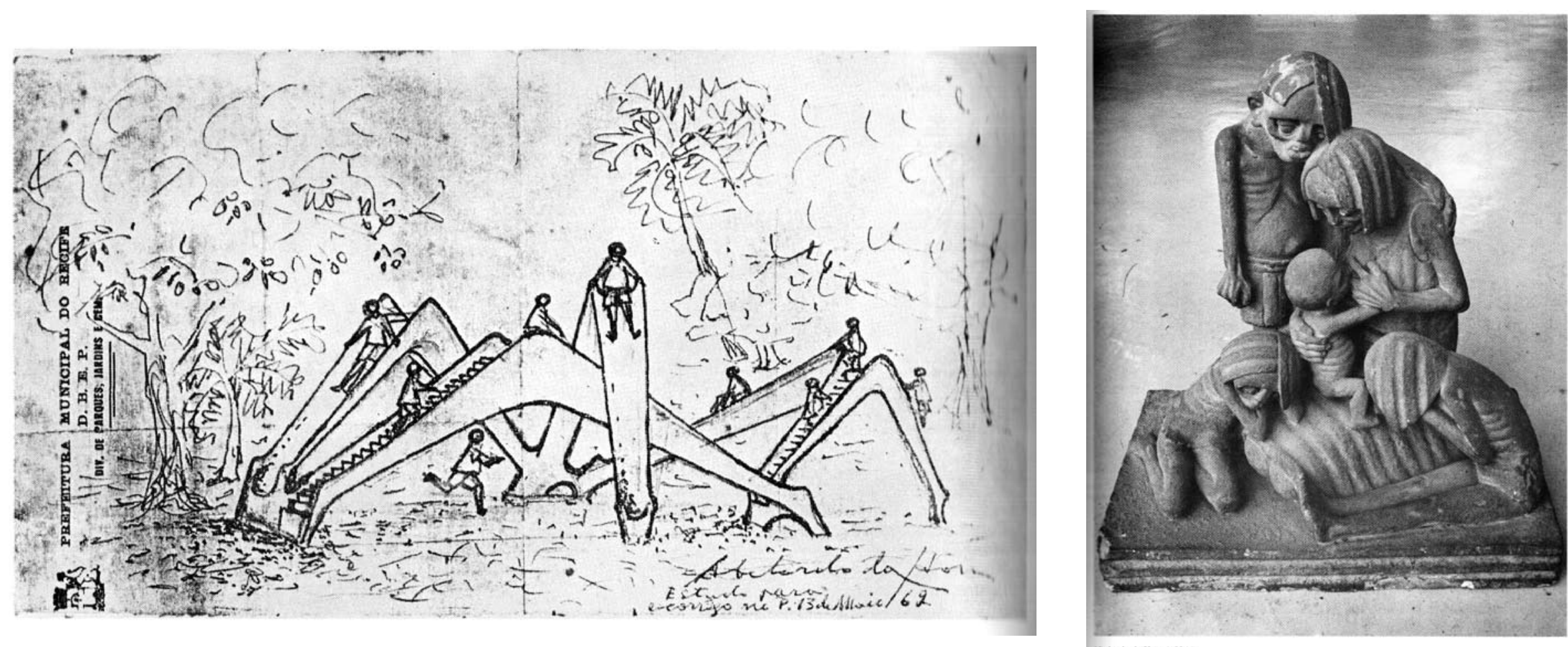

17 a 18 Abelardo da Hora, Projeto de praça em Dois Irmãos, de 1962 e escultura "Desamparados" (aMaral, 2003)

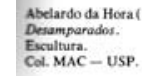



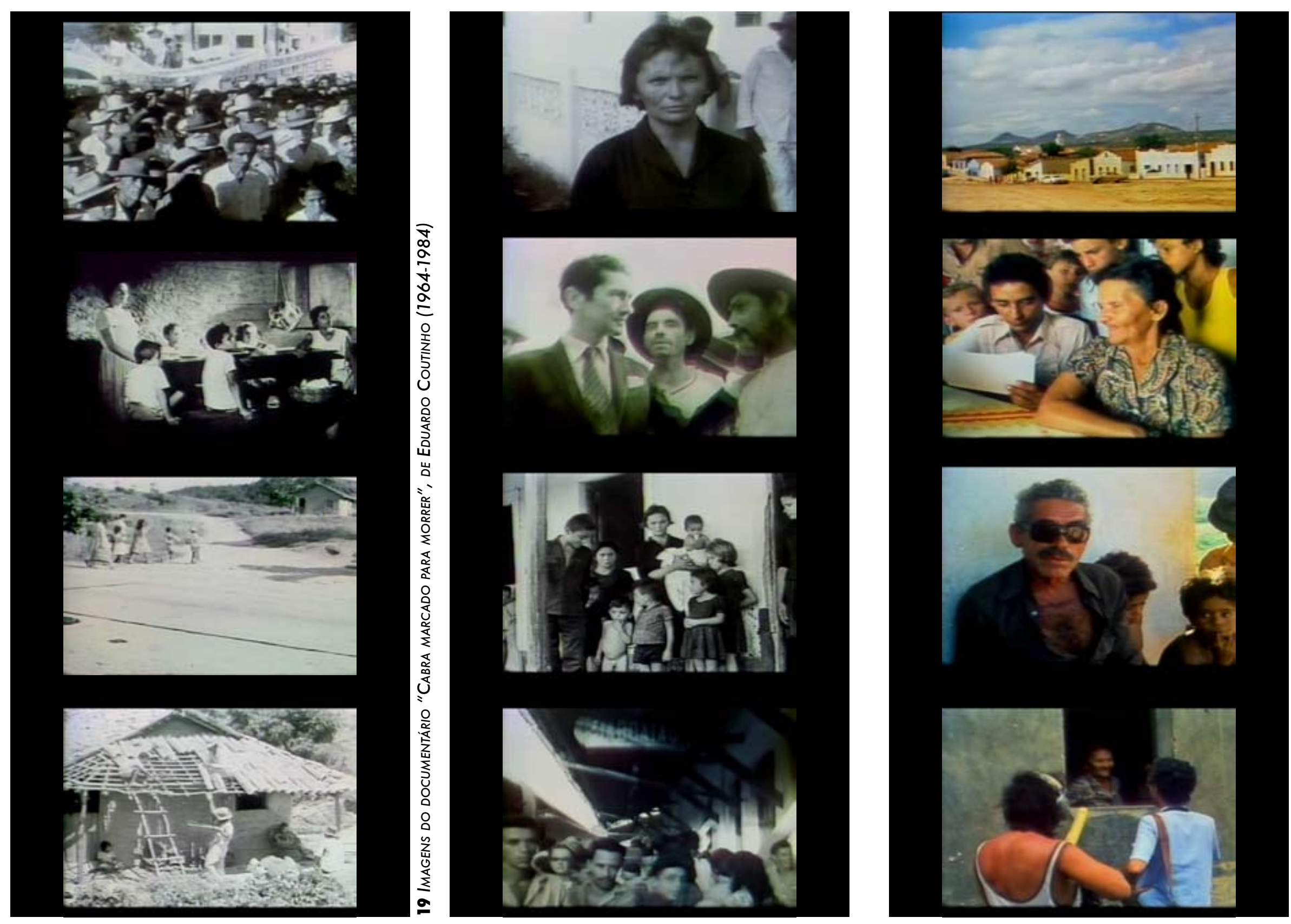

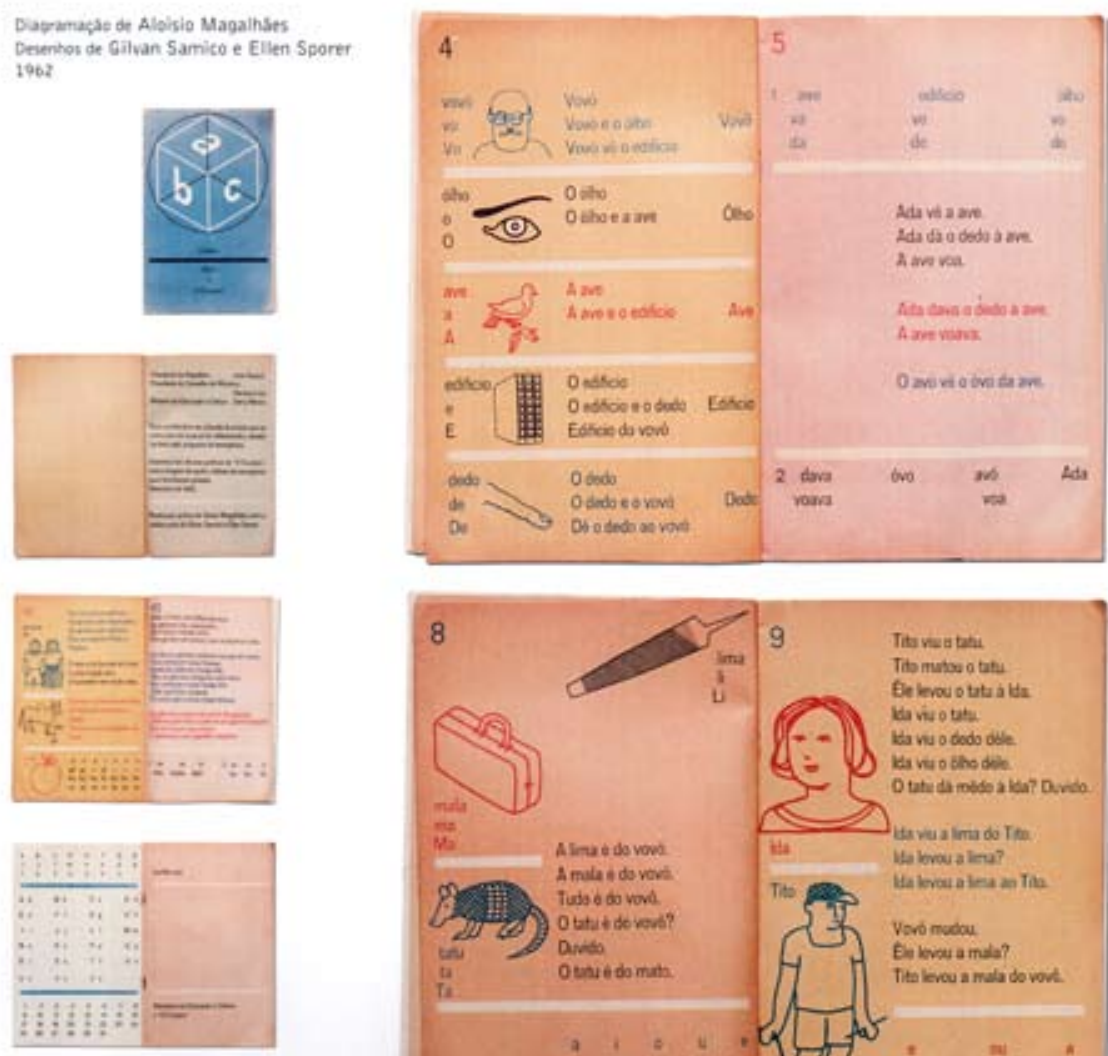

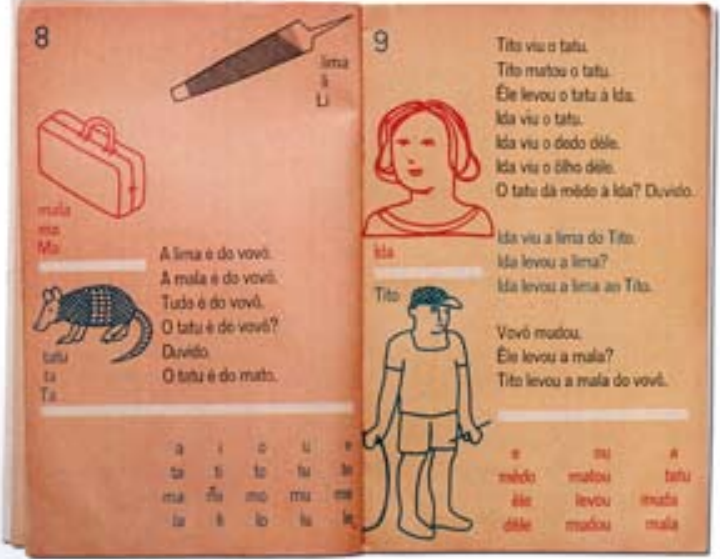

Embora năo apresente nenhuma inovaçăo no sentido dos processos de alfabetizaçăo, é curioso notar a atuaçăo de Aloisio Magalhảes, desde ce do, em projeto de tamanha magnitude. Da tiragem dessa cartilha, quatro milhøes de exemplares foram para distribulç̧o gratuita.

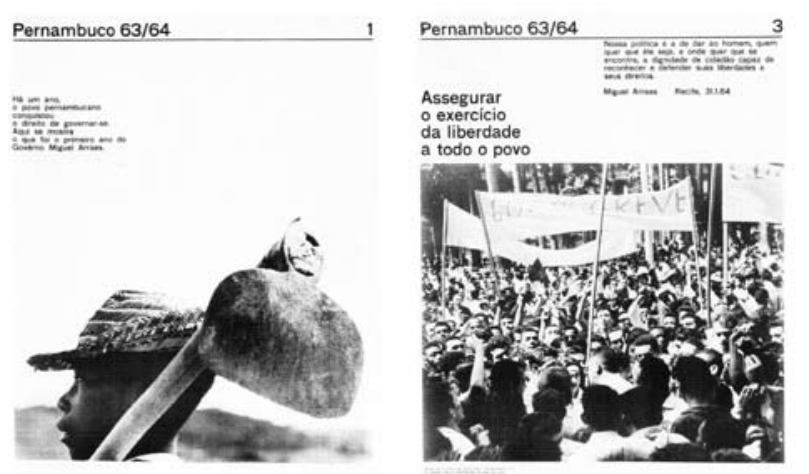

Exposição em cartazes sobre o

Pernambuco, fevereiro de 1964

A idéia de expor princípios e feitos do governo simultaneamente em dife vida de Aloisio, conceito a que recorreu mais de uma vez. Tudo indica, entretanto, que os cartazes não foram distribuídos, em função das cir cunstâncias políticas.

A programaçāo visual é assinada por Aloisio Magalhães e João Xavier, de quem não se tem notícias ao certo. Para registro, cabe notar que, em janeiro de 1964, seu amigo Francisco Brennand era o chefe da Casa Civil de Arraes e, em carta do dia 7, informava que o governador havia criado a Casa de Cultura de Pernambuco, cabendo.lhe a coordenação da nova será a realização de uma Bienal do Desenvolvimento, levando-se em conta especialmente os setores industriais e as atividades artesanais, tendo em vista sua integração ao sentido nacional que se deverá dar ao objeto fabricado no pais. rentes lugares, utilizando o recurso da impressão de cartazes, foi sem dúinstituição. Diz ele: Uma das primeiras promoçōes da Casa da Cultura
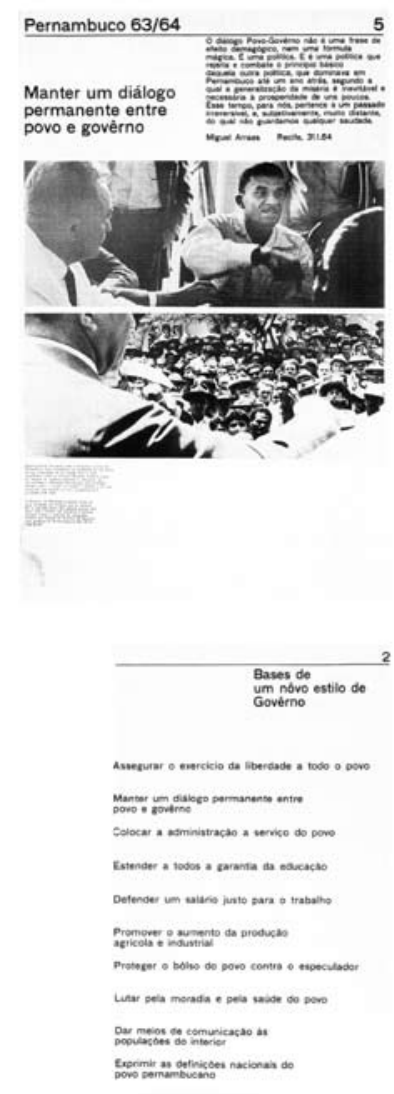

Bases do do
umphritio estio do
Governe

20 Cartilhas de alfabetizaÇão desenhadas por Aloísıo Magalhães e ilustrada por Gilvan SaMico (SOUZa Leite, 2003)

21 Cartazes comemorativos do primeiro ano do Governo Arraes (Souza leite, 2003) 

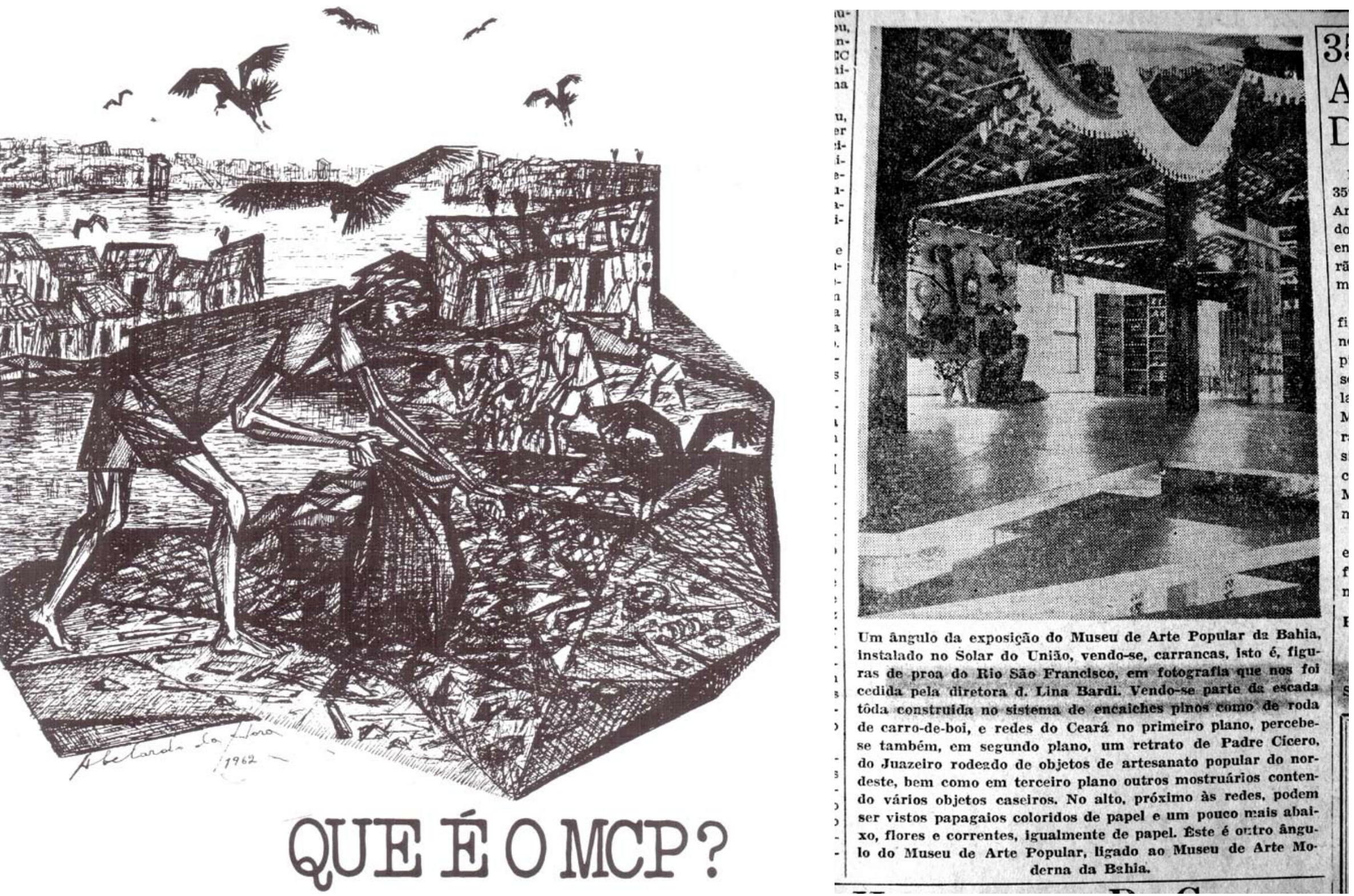

22 Gravura do álbum "Meninos do Recife", Abelardo da Hora, 1962

23 Nota sobre exposição "Nordeste" do Solar do Unhão no Jornal do Commércio, 1963 
24 Selos comemorativos da Aliança para o Progresso (Venezuela, 1966)

25 Aliança para o Progresso, Marcello Nitsche, 1965
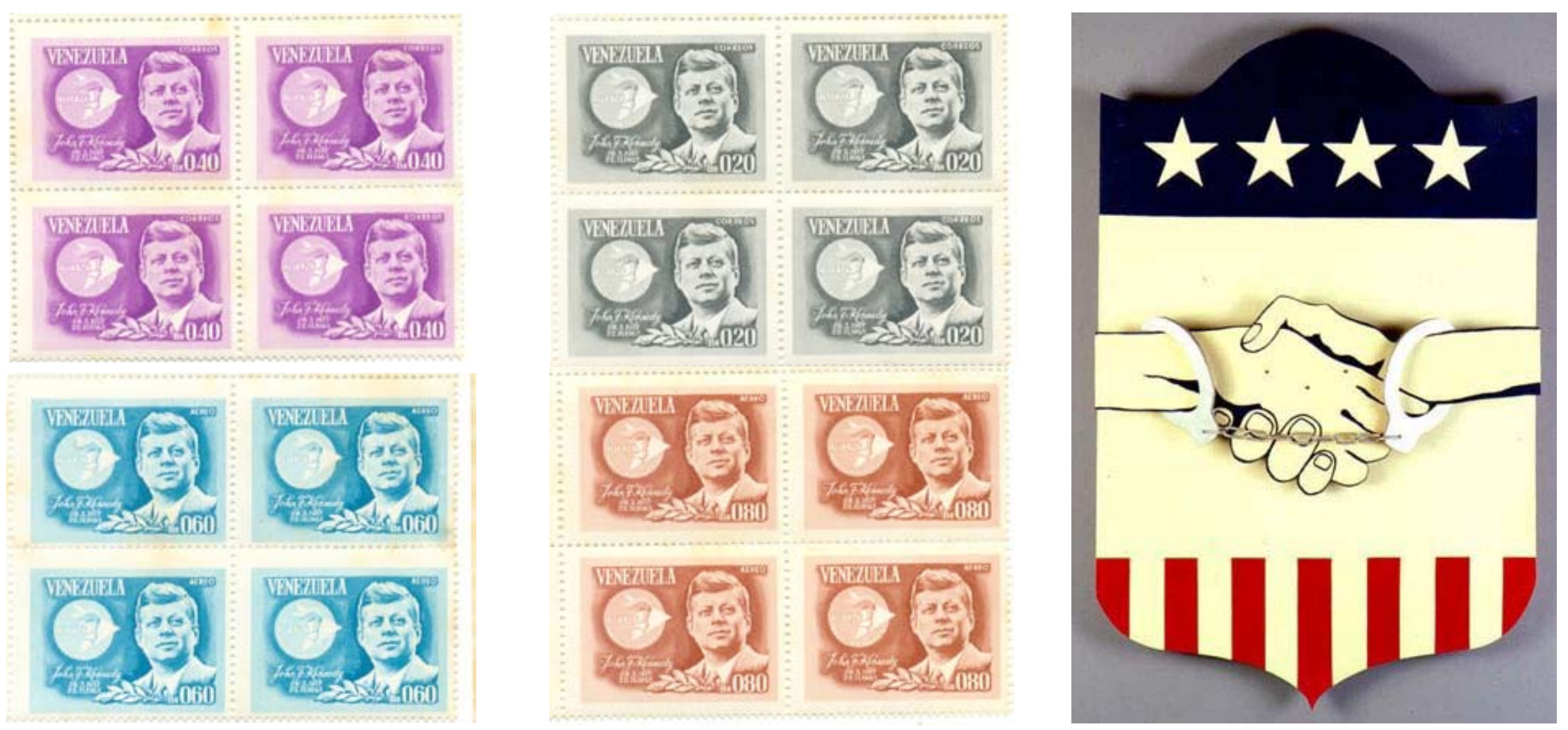


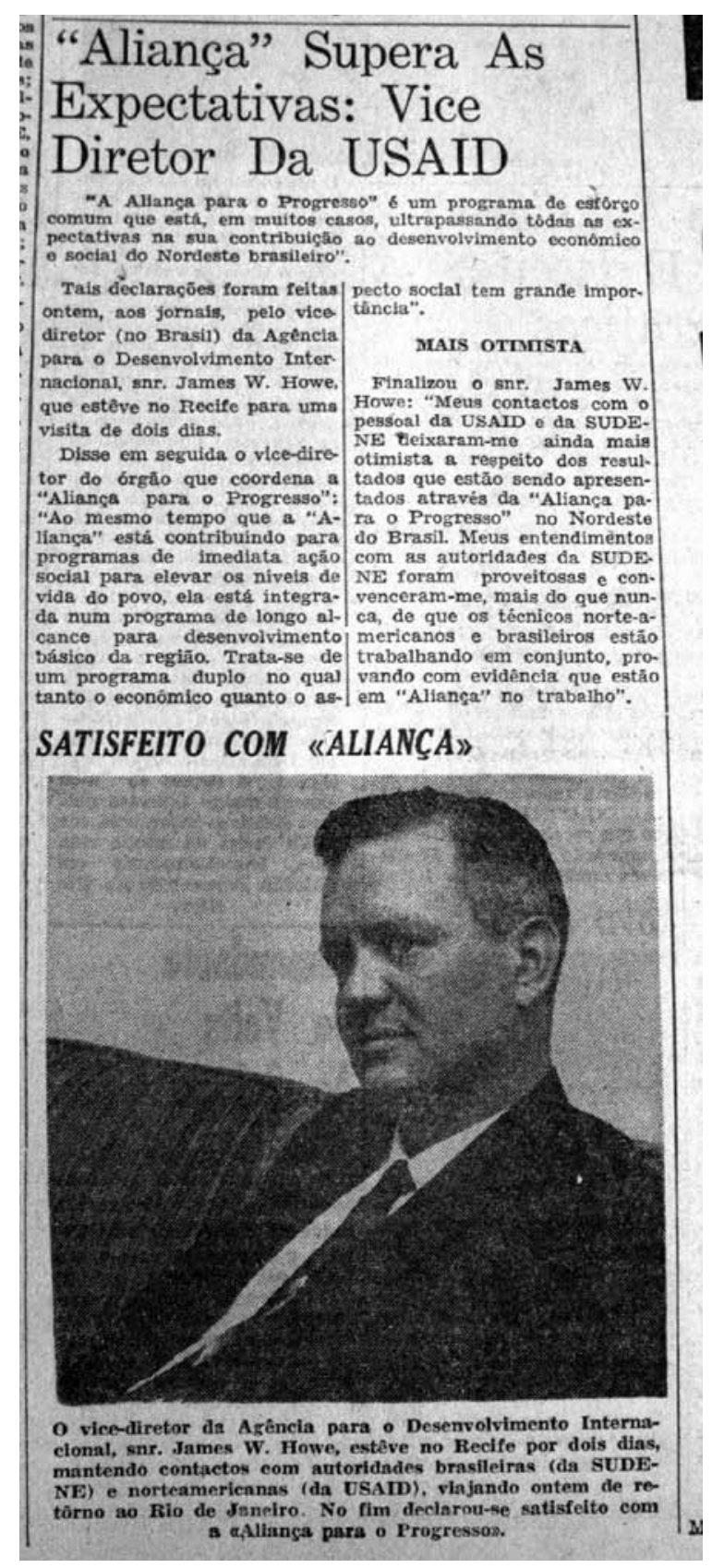

26 e 27 Reviravoltas em torno da Aliança para o Progresso e o assassinato de Kennedy (Jornal do Commércio, 1963)

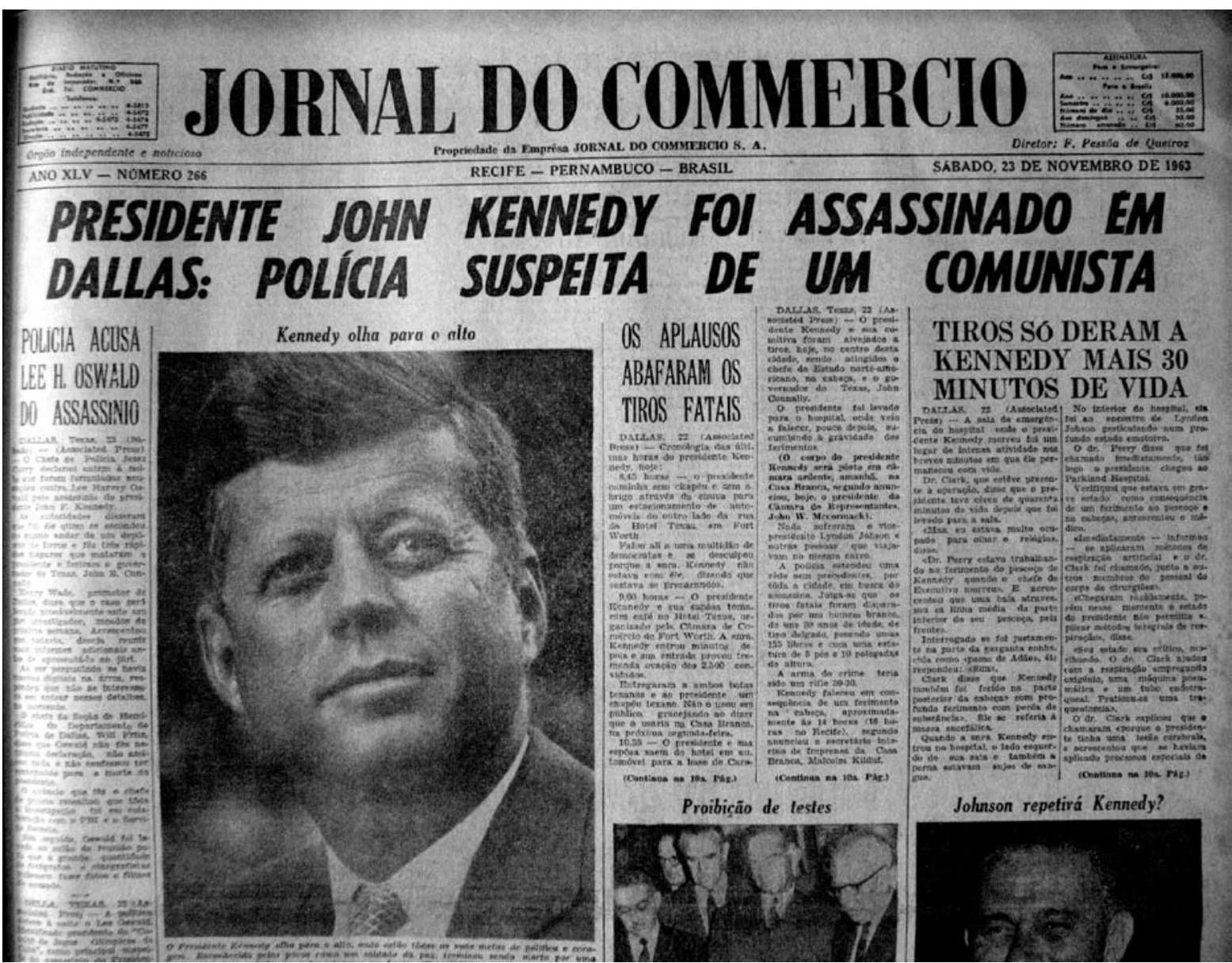




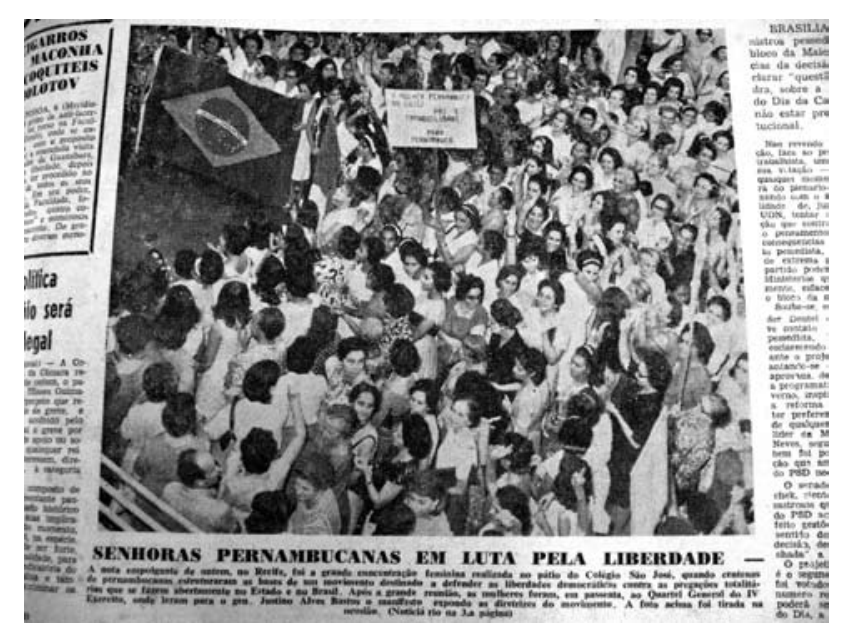

AL DO COMMERCIO - Quinta-féra, ó de agôsto de 1963

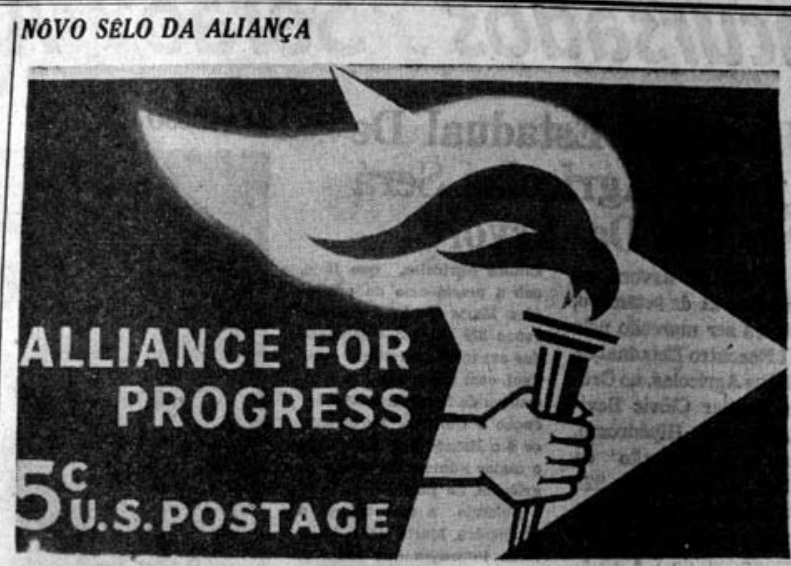

Este selo postal de 5 centavos de dólar, apresentando o simbolo verde e zul ximo dia 17 de agósto, data em que se comemorará o segundo aniversário

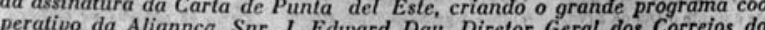
政, cretário-Geral da Organizaçäo dos Estados Americanos, um facsmile am-

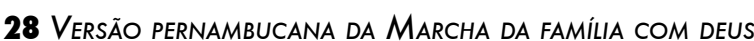
PELA LIBERDADE (JORNAL DO COMMÉRCIO, 1963)

29 Selo comemorativo da Aliança para o Progresso (Jornal DO COMMÉRCIO, 1963)

30 Relatório do GT dos acordos da Aliança publicado em DIVERSOS JORNAIS LOCAIS (JORNAL DO COMMÉRCIO, 1963)

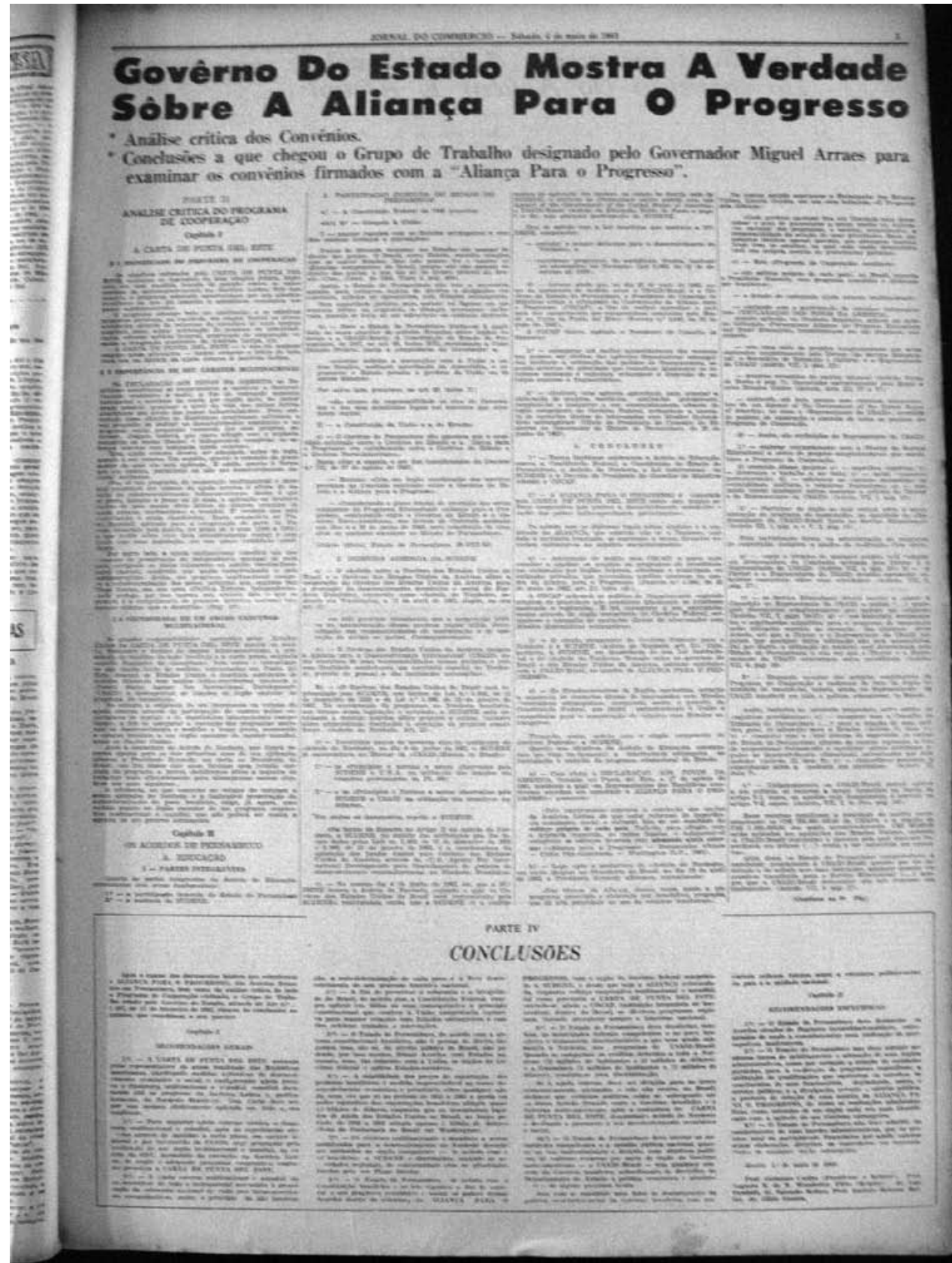


01 a 02 Casas de talpa (FUndaj/Col. Hab. Popular)

03 Despejo de camponeses no Engenho Camaragibe,

1960 (FUNDAJ/Col. Miguel Arraes)
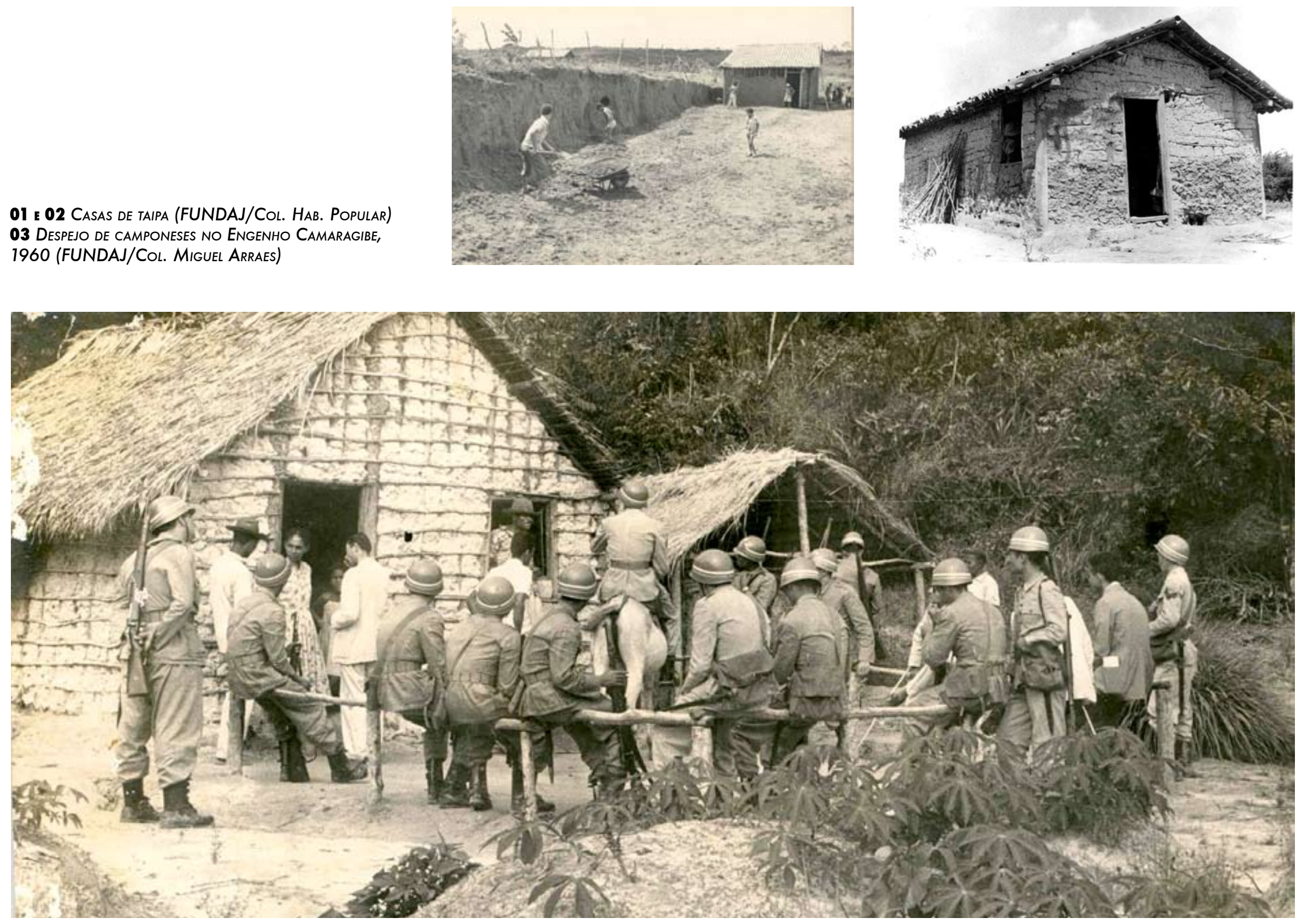

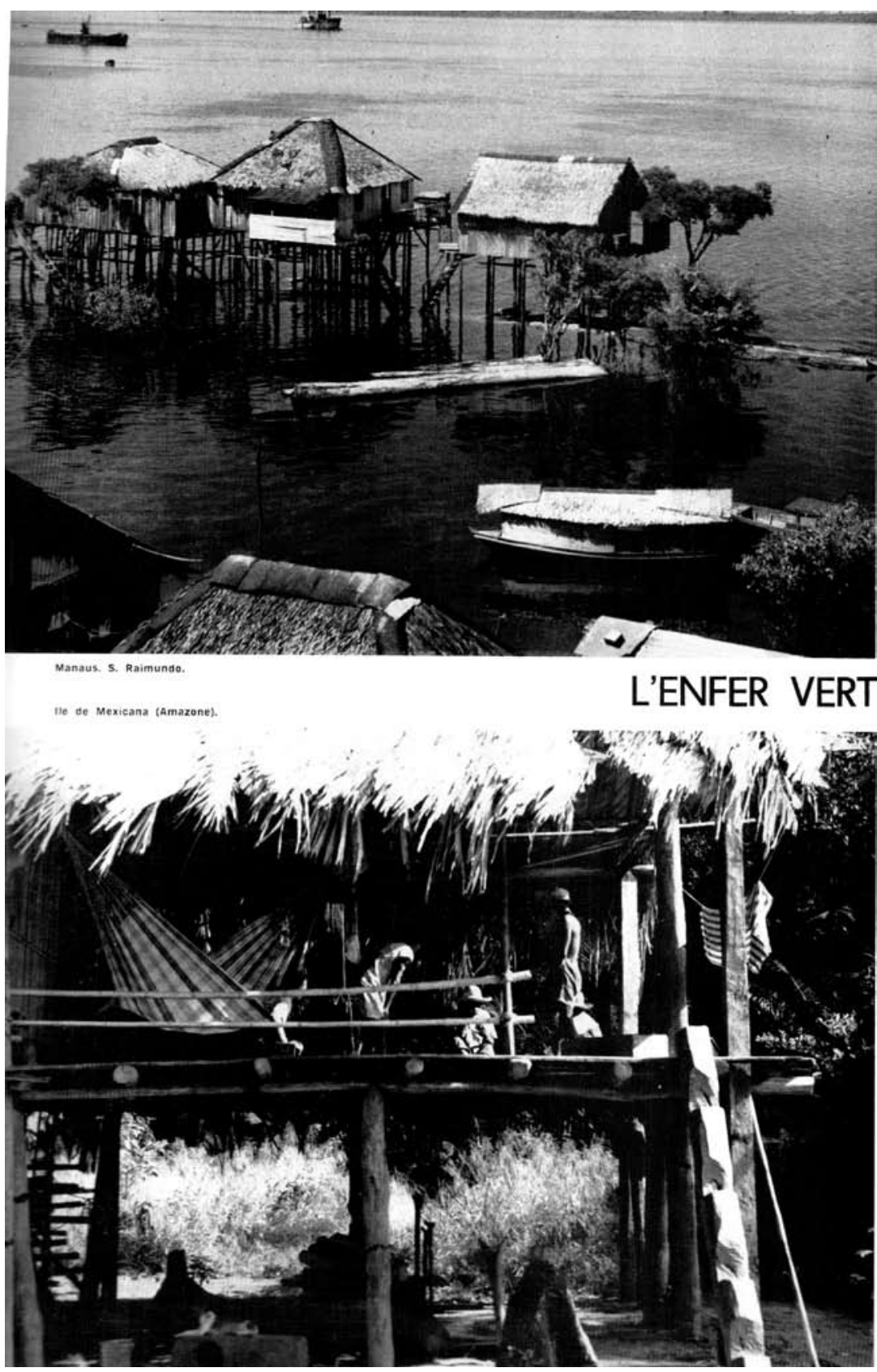

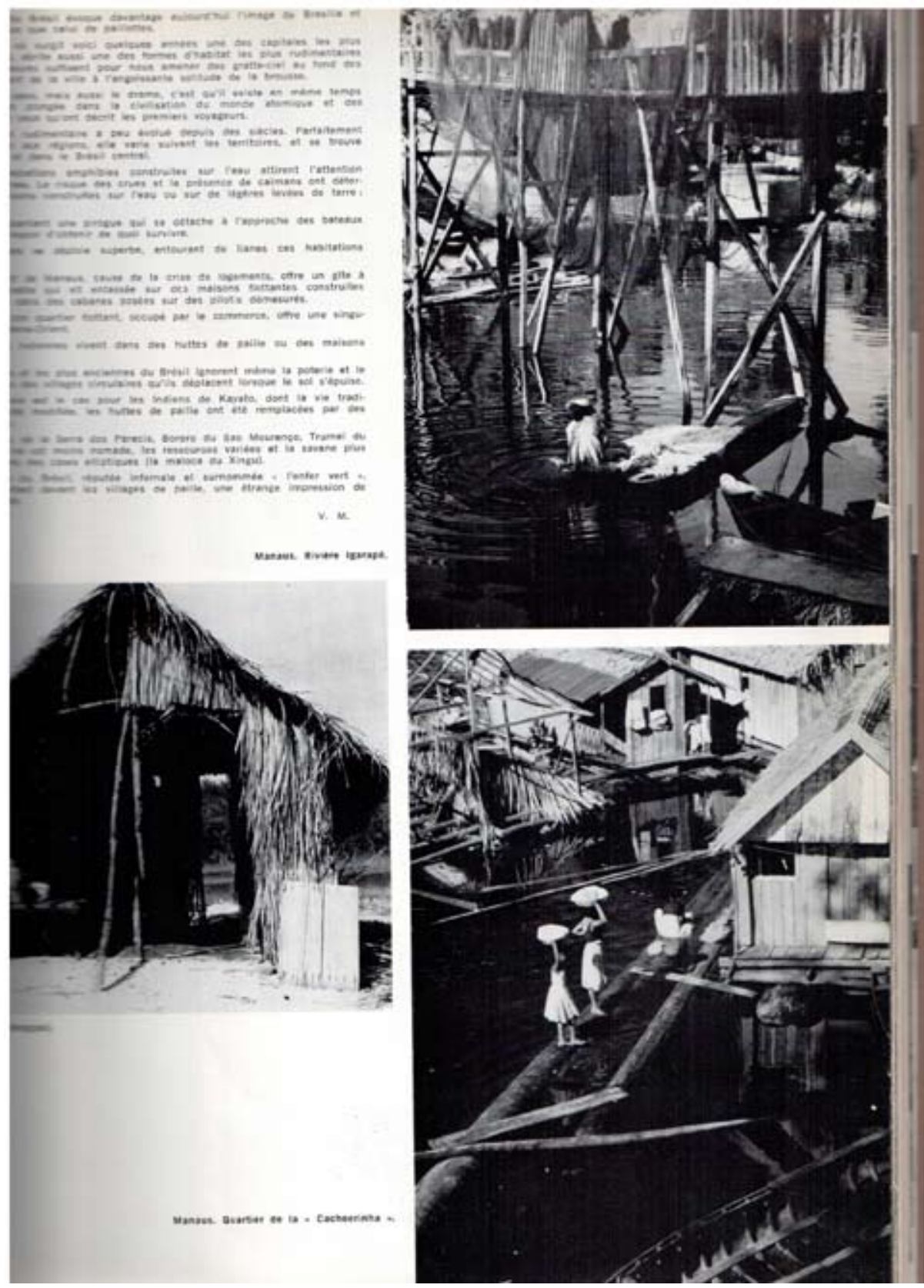


Organograma do Recife - cidade reaionol
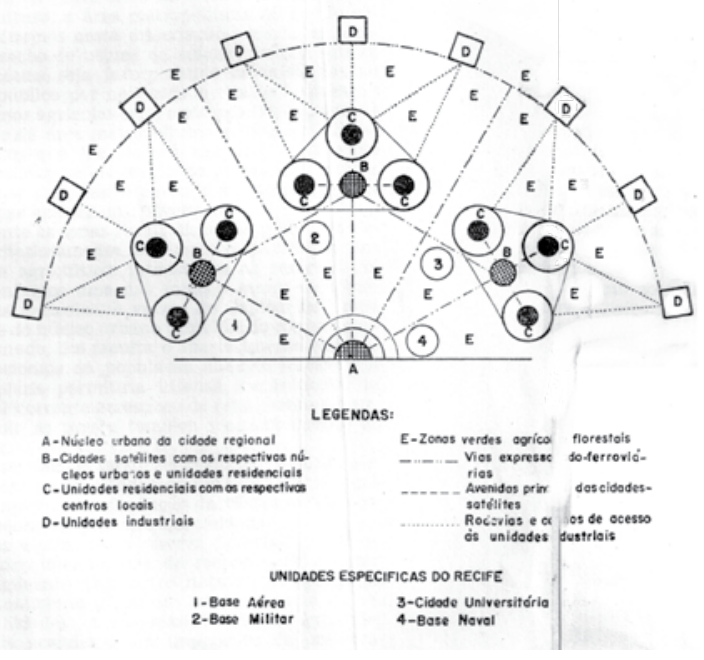

06 Organograma do Recife (Baltar, 1951)

07 Zonas de InfluÊnCIa do Estado de Pernambuco (CODEPE, 1955)

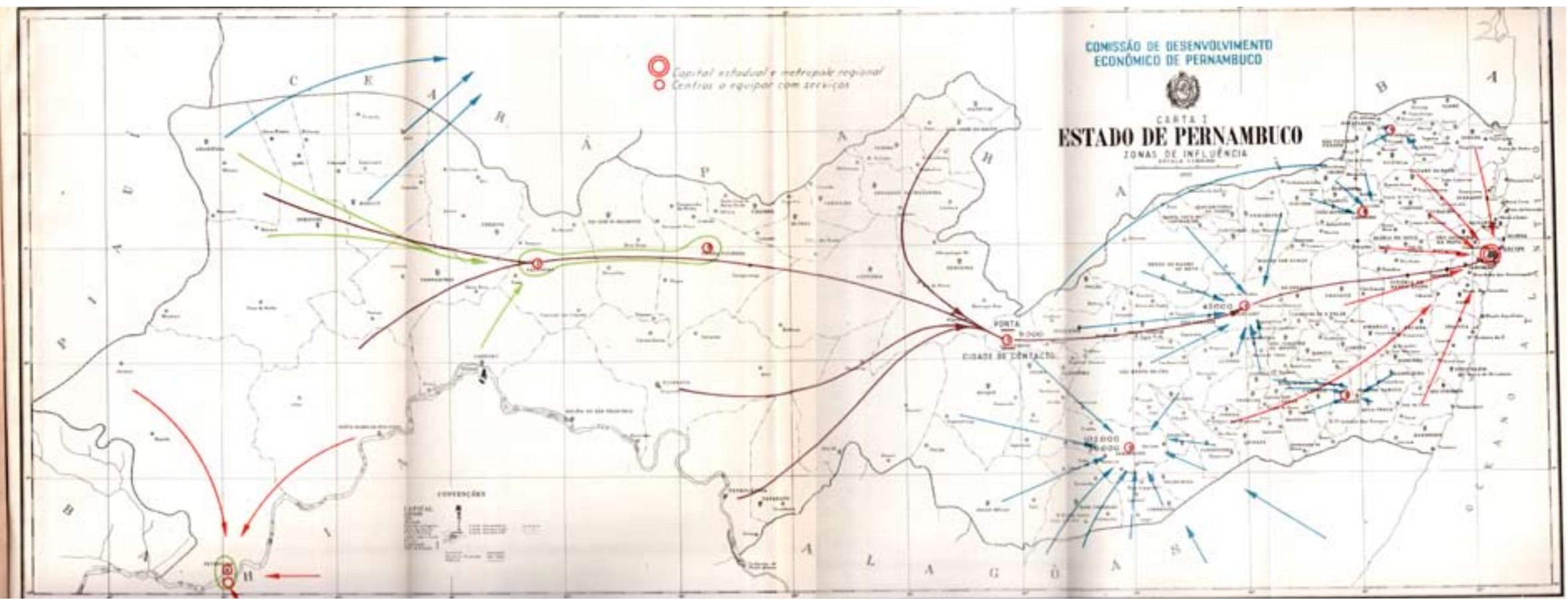


08 Região metropolutana proposta no Plano de Baltar (Baltar, 1951)

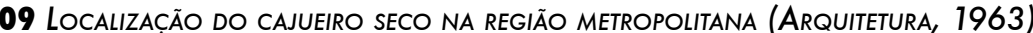
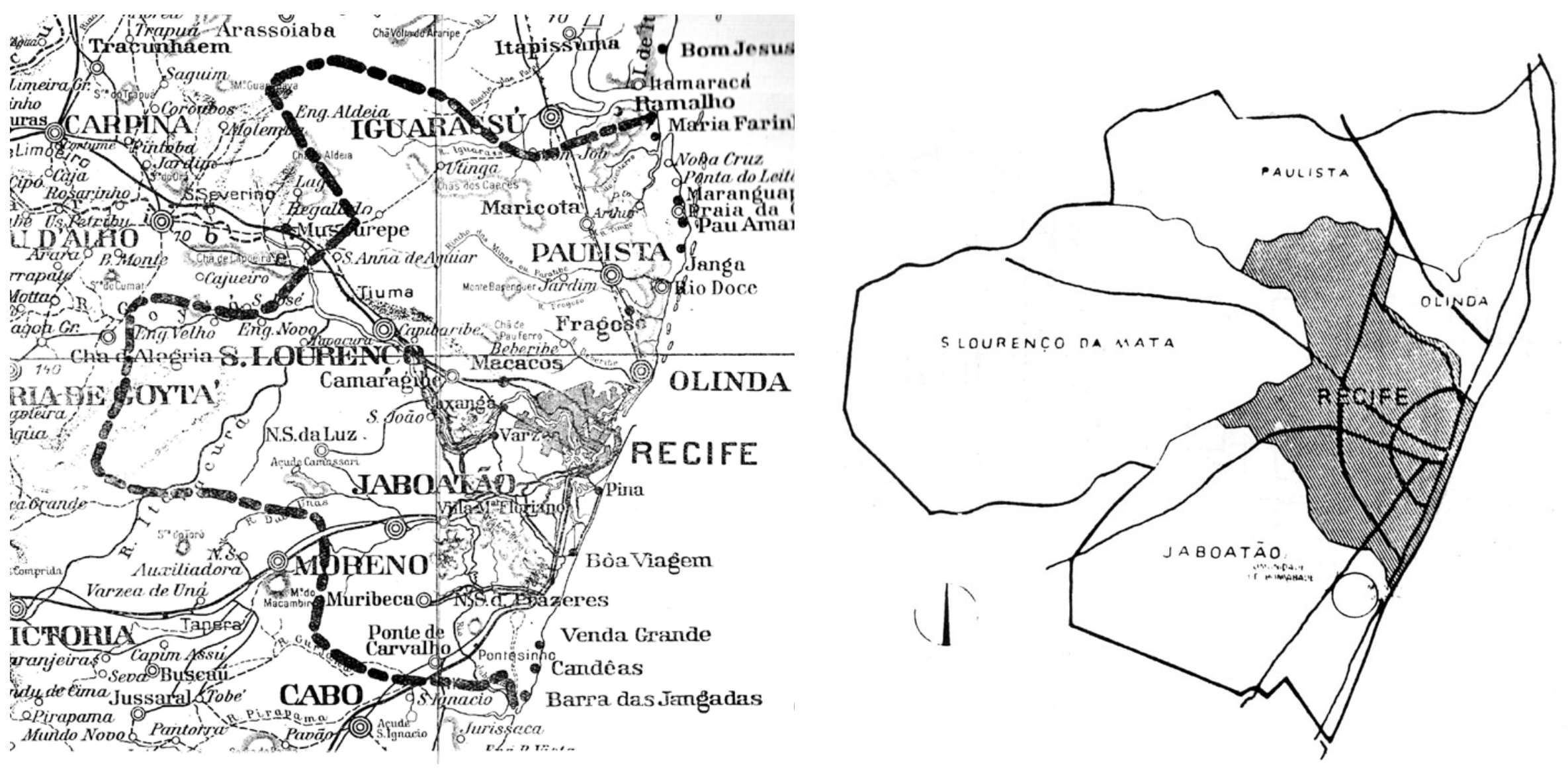
10 a 12 A questão da terra em Prazeres (Folha DO POVO, 1960) E A DENÚNCIA DA INVASÃO DOS Montes Guararapes (Diário de Pernambuco, 1963)
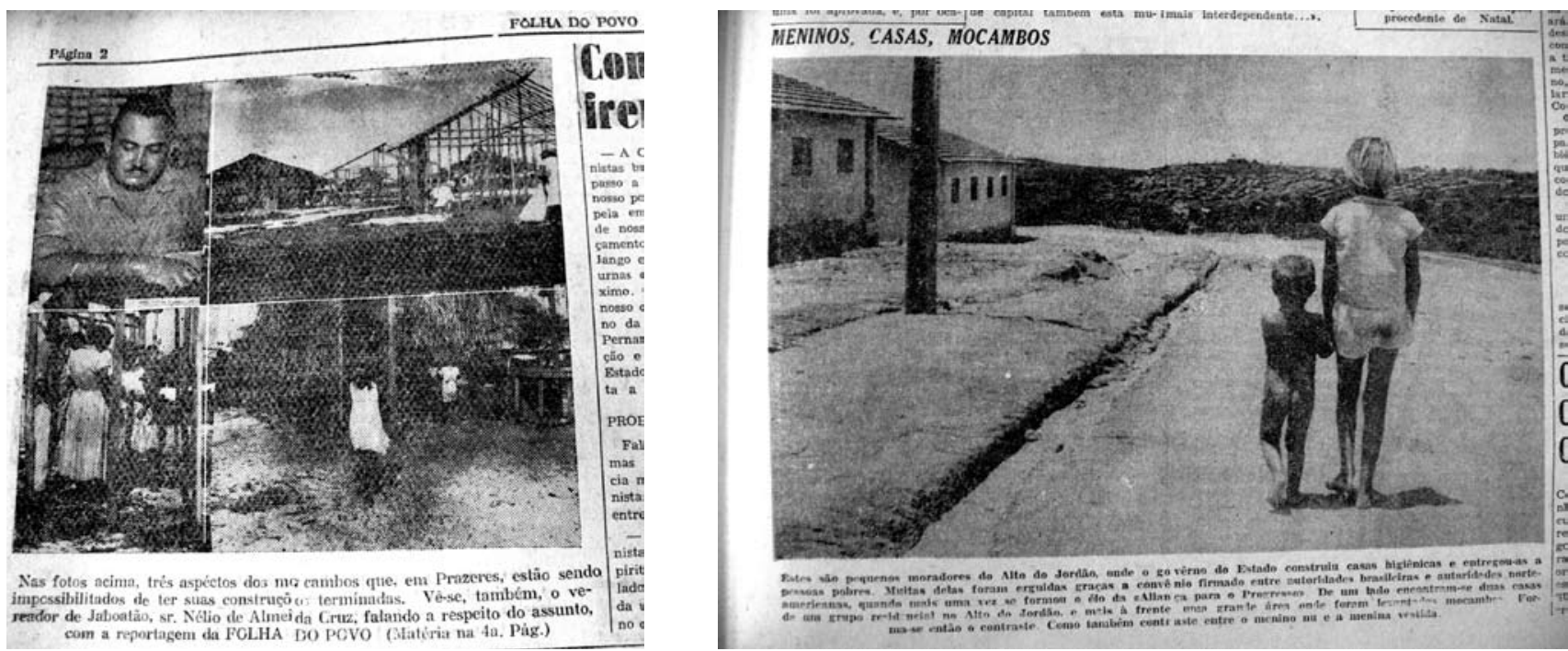

PRIMEIRO CADERNO

DIARIO DE PERNAMBUCO - DOMINGO, 10 DE MARCO DE 1963

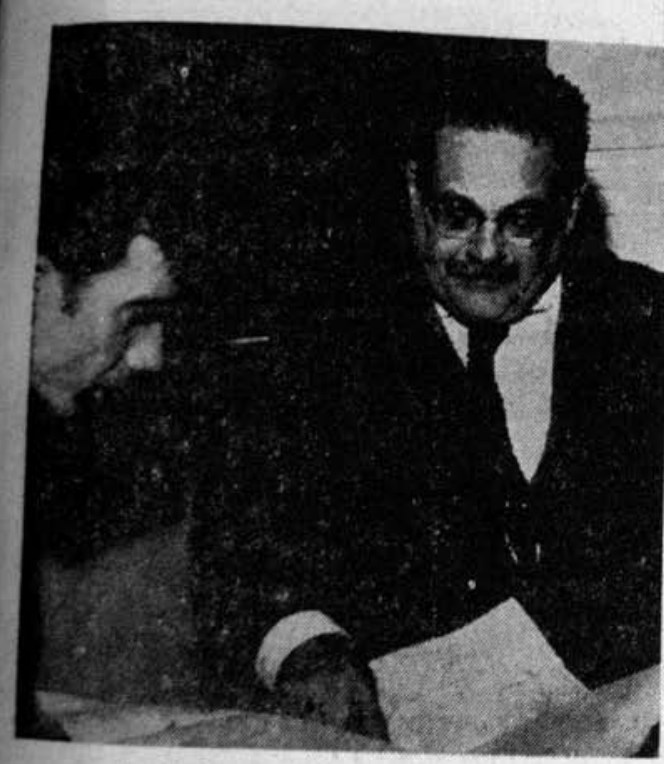

Montes Guararapes Invadidos Por Três Mil Mucambos: Protesto

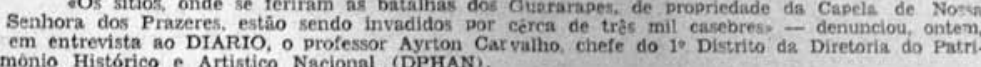
mons

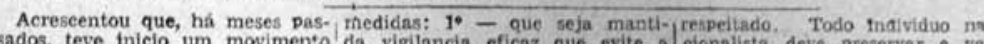

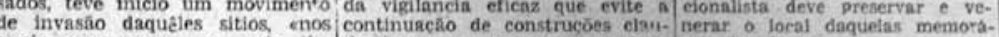

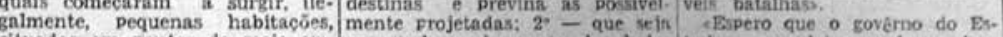

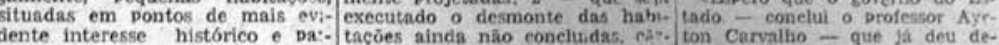

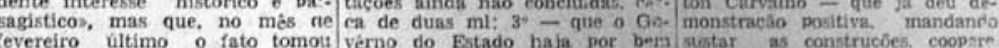

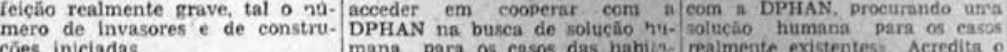

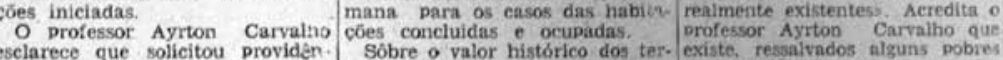

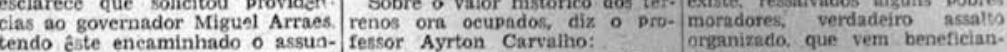

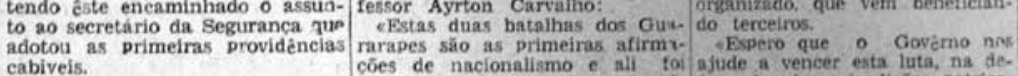

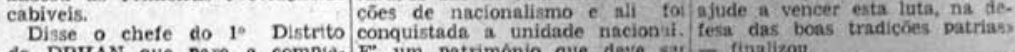

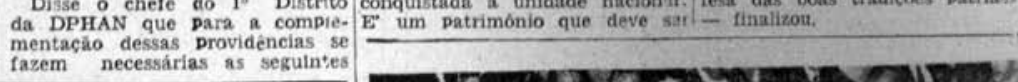




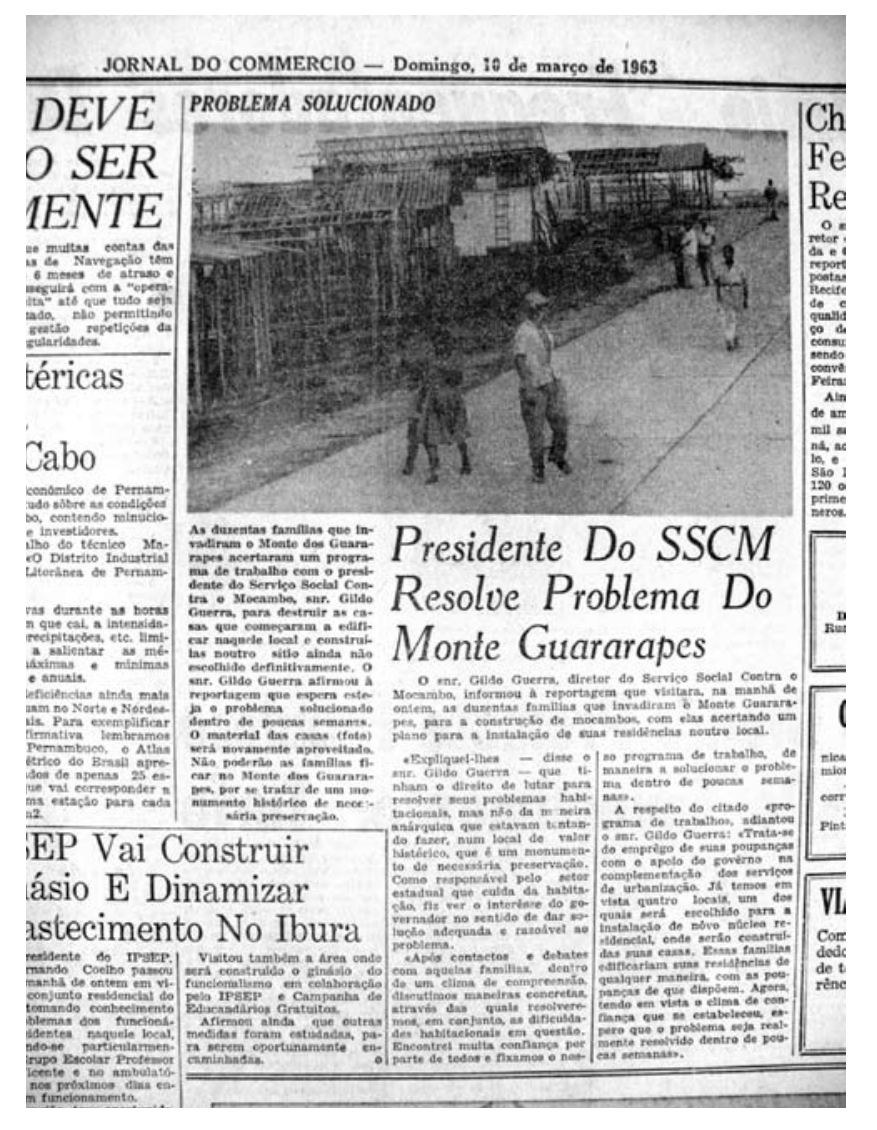

JORNAL DO COMMERCIO - D

Resolvido Problema De Localização Do Pessoal

Dos Montes Guararapes

¿A solução para o problema surgido com a inpelo Patrimônio Nacional, foi encontrada, com a a. quisição de uma área de 20 hectares, pertencente à Ordem dos Carmelitas, o que está situada nas proxtmidades daquêles montes», declarou, ontem, à nossa reportagem, o presidente do
Mocambo, snr. Gildo Guerra.

Como se sabe, houve recente- (ciaçio dos setores de abaste

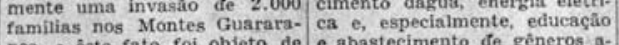
pes, $e$ éste fato foi objeto de e abastecimento đe gêneros

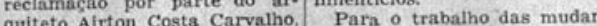

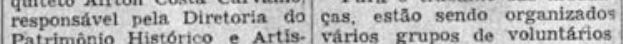
tico Naclonal.
tecrutados entre os interessacobtida a área necessária à dos, que se dedicaráo as vá-
transferéncia das casas cons.
rias tarefas no local das notransferéncia das casas cons.
truidas no local - acrescen. tou contratou o S.S.C.M. servicos de desmatamento, depográficos para levantamento minaress. de todo o terreno adquirida
Esseas servicos ja form inicta Esses servicos jas que estejam
dos e e e vale acentuars, - cisse,
concluicos até a próxima têr- concluindo - que essa expeTANO PILTO ca-ementa, que rornecera os riencia, que constitui a idela racío de um plano de urba- elementos para o desenvolvi-

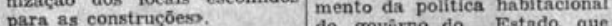
PLANO

sáo da Ordem dos Carmelitas afirmou - sob a orientaçió Batista Gadélha, procurado

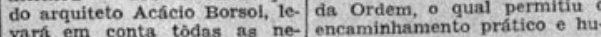
ara
cessidades, detendo-se nn apre-

\section{O COMMERCIO - Terça-feira, 23 de outubro de 1963} DEBATE NA INAUGURAÇÃO

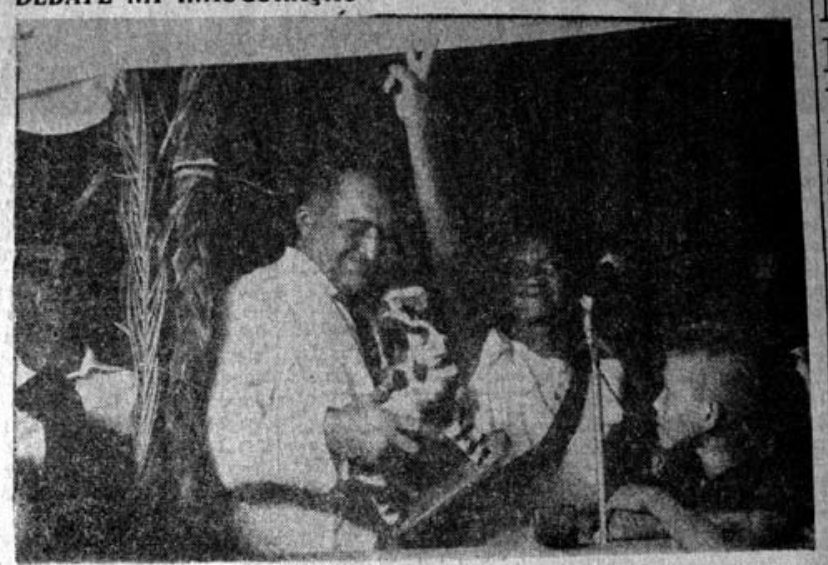

Plano De Conferência Sôbre Medidas Para Liquidar A Guerra Fria

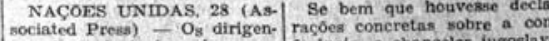

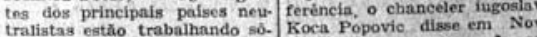

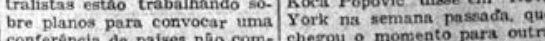

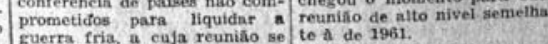

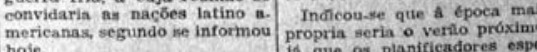
Fontes dirriomaticas disserama jam desempenthar um papel

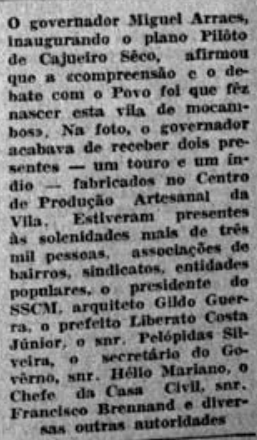

13 a 15 A RESOLUÇÃo dA QUESTÃo da INVASÃo dOS MONTES GUARARAPES E A APRESENTAÇÃO DA SOLUÇÃO (JORNAL DO COMMÉrCIO, 1963) 
16 Capela de Nossa Senhora dos Prazeres e a festa dos Prazeres (Jornal do Commercio, 1963)

17 InfRaESTRUTURA PaRA VISITACC̃O DO PARQUE HISTÓRICO

Nacional dos Guararapes - Arq Armando de Holanda,

1978 (FOTO DO AUTOR, 2006)
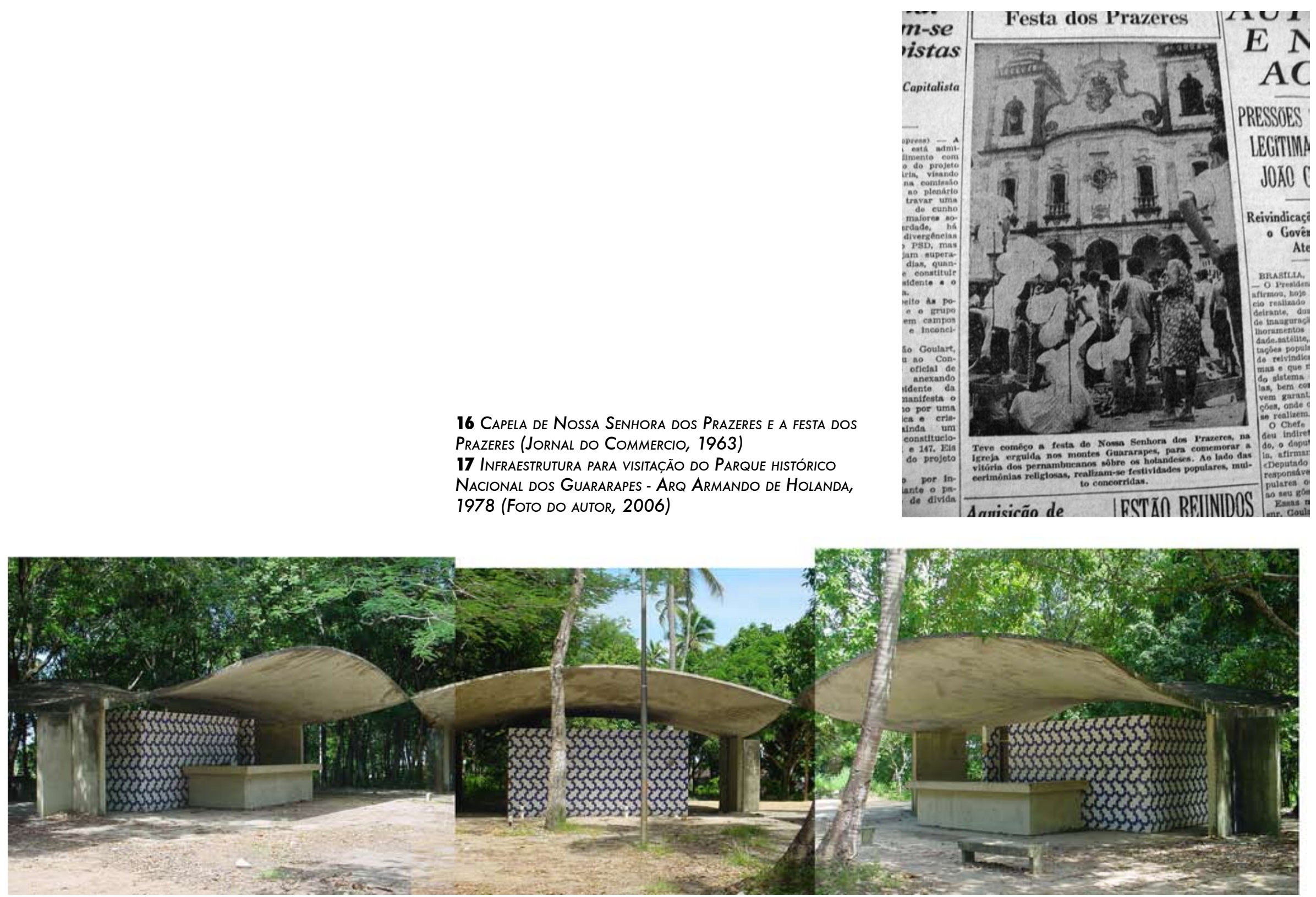
01 a 03 Imagens aéreas de Cajueiro Seco em 1963/64 (ACERVO BORSOI E A HORA, 1963)
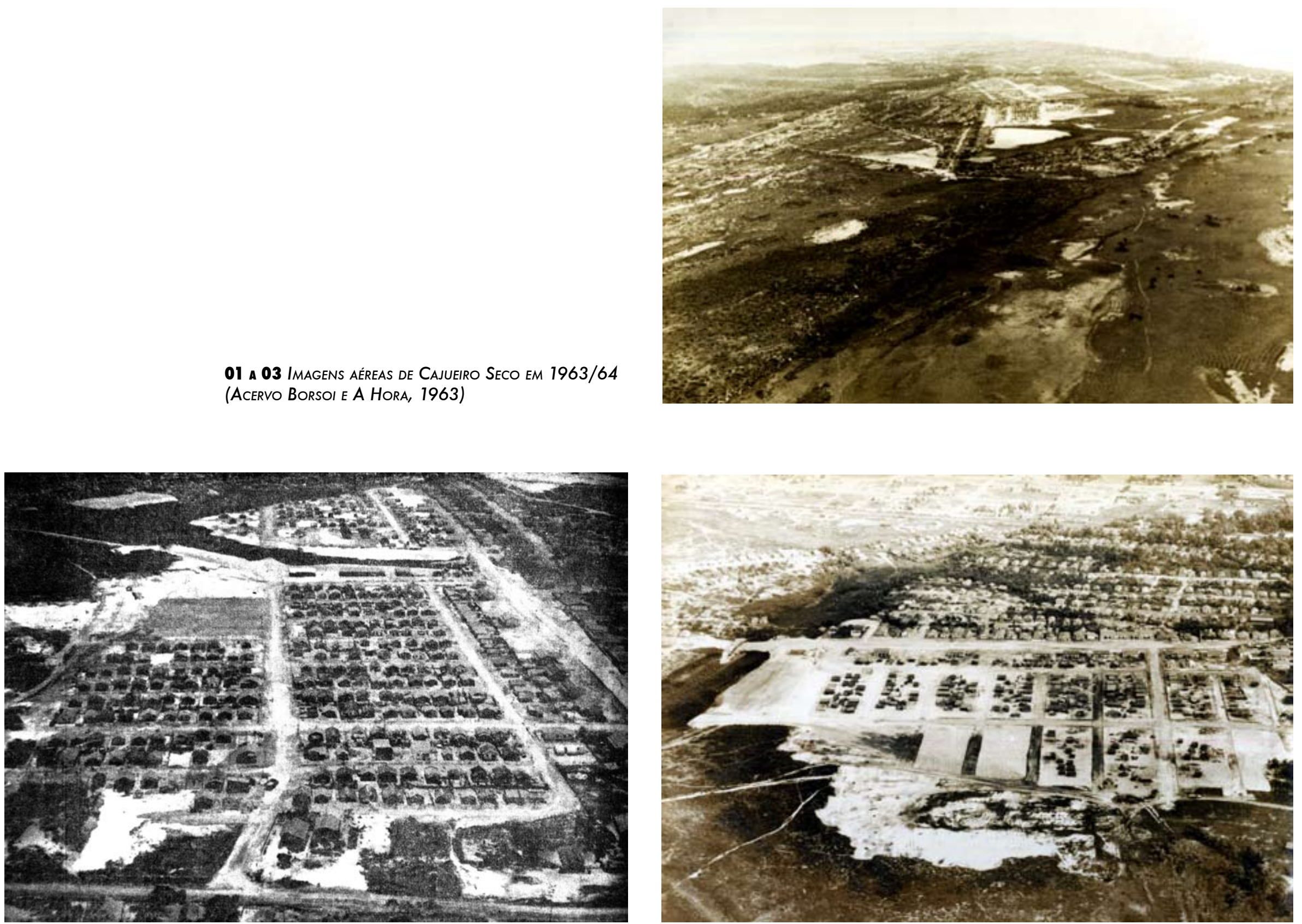


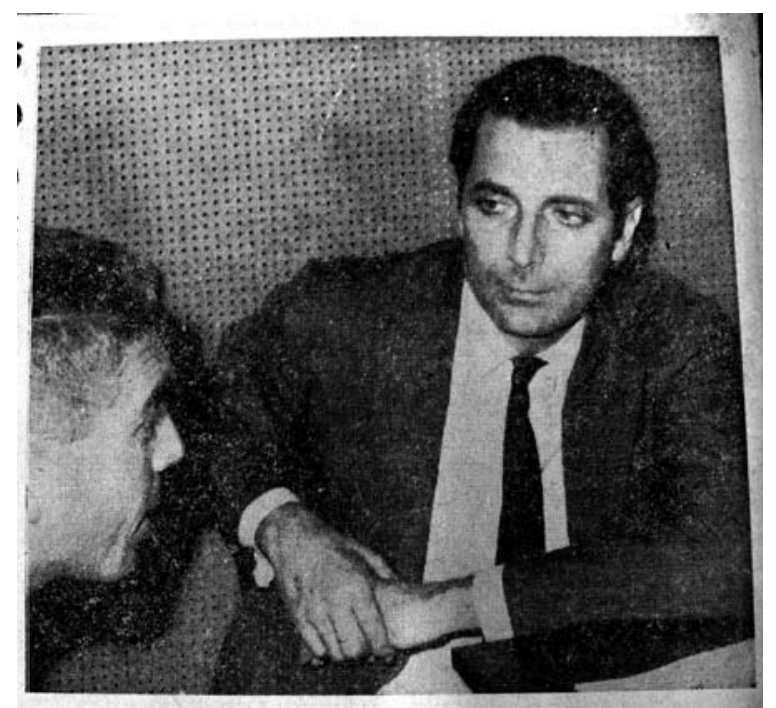

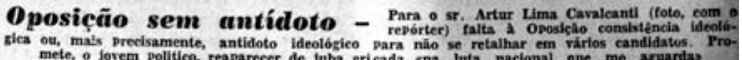

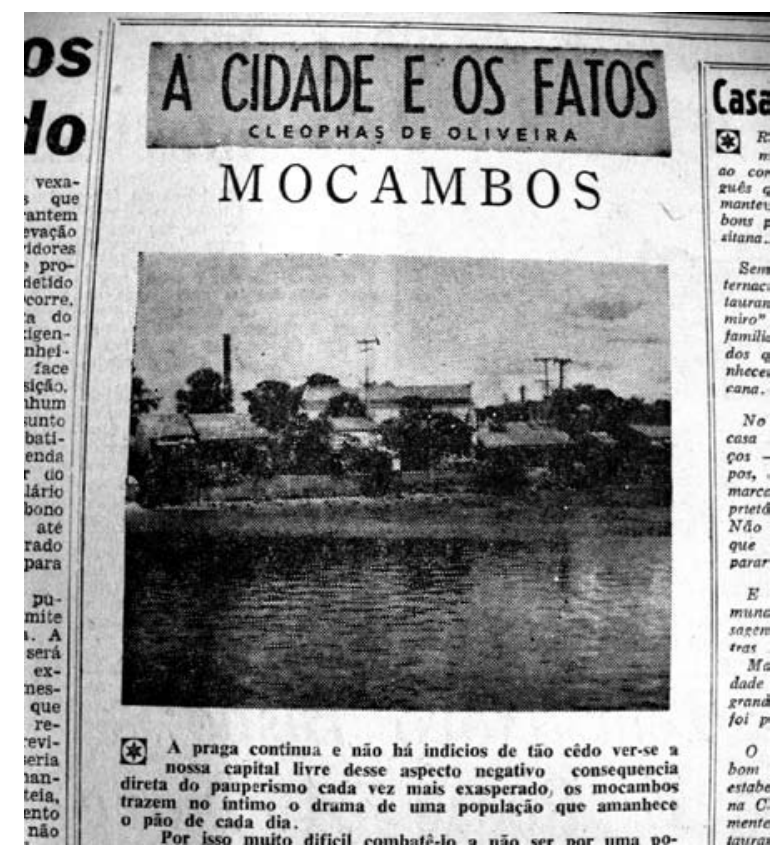

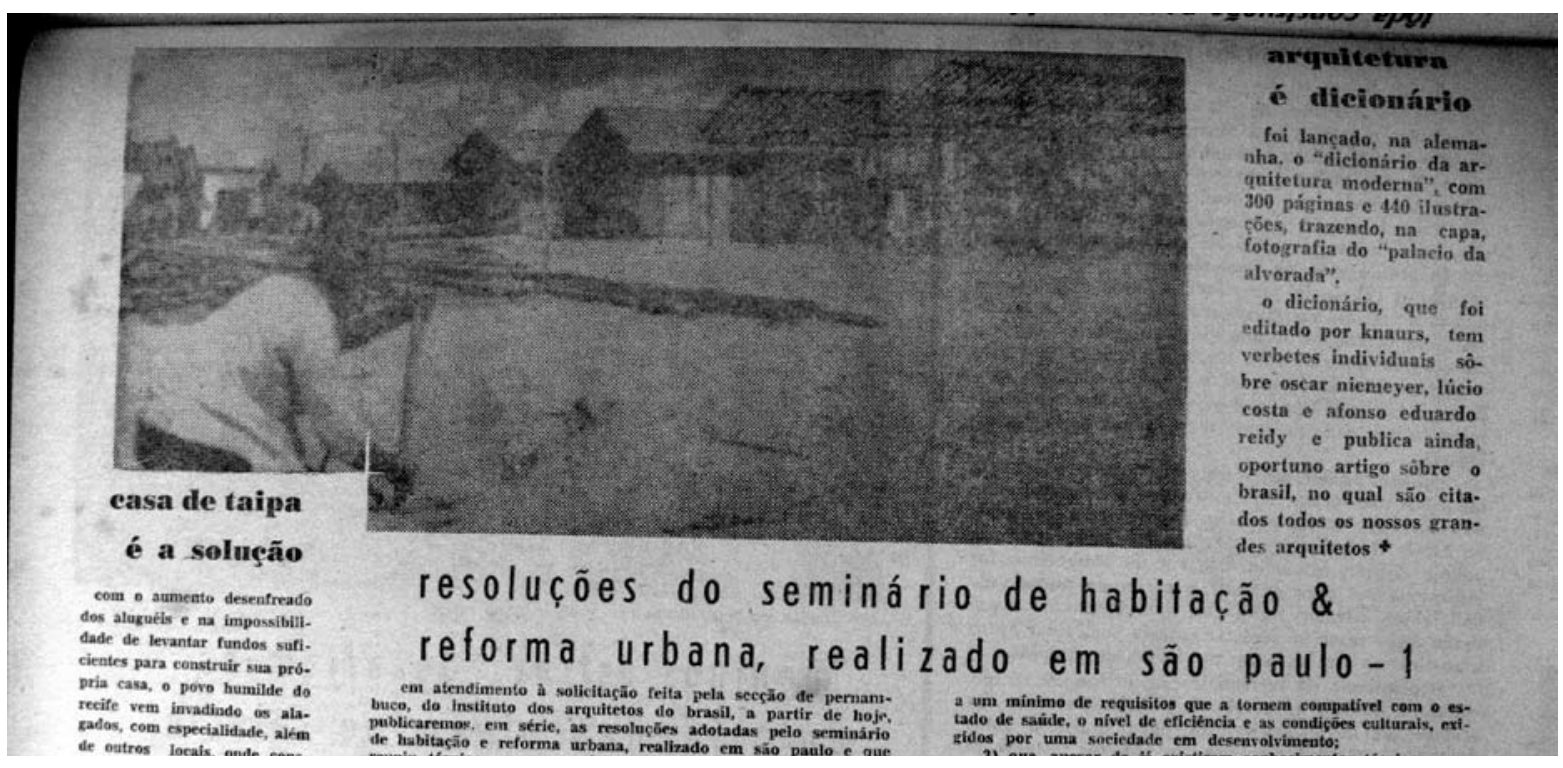

04 Artur lima Cavalcanth, arouiteto e deputado

federal pelo PTB (Jornal do Commercio, 1963)

05 "CASA de TAIPA É SOluCÃo" E AS RESOluC̣ões do

SHRU EM IMÓVEIS \& MÓVEIS (DIÁRIO DE PE,1963)

06 "MOCAMBOS" (DIÁRIO dE PE, 1963)

07 Nota sobre inauguração do CaJueiro Seco (DIÁRIO de PE, 1963)

08 NOTA SOBRE CASA PRÉ-FABRICADA EXPERIMENTAL EM Cajueiro Seco (Diário de PE, 1963)

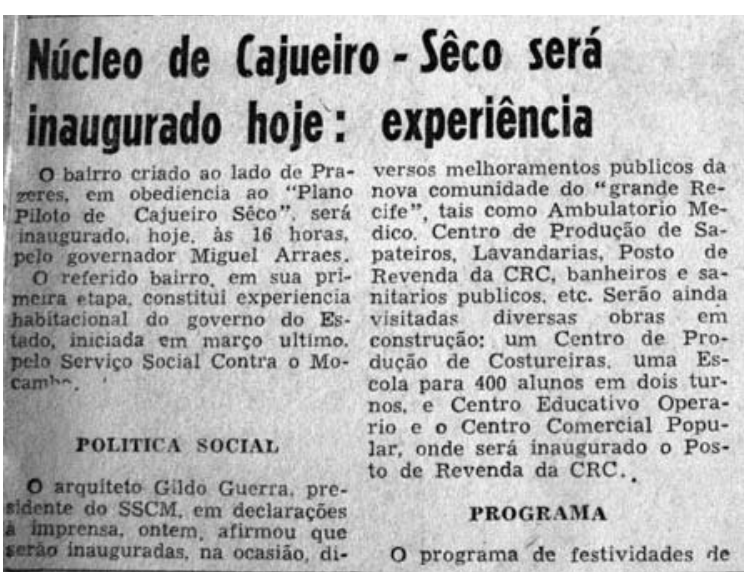

O SERVICO SOCIAL CON. TRA O MOCAMBO fez experiência, ontem, em Cajueiro Sêco, instalando, em quatro horas, uma casa pré-fa bricada, composta de quatro blocos conjugados de duas lâminas de fibra-cimento (amianto), pesando cada uma 60 quilos, cobertas por duas lâminas superiores, do mesmo material, pesando 40 quilos, formando assim um bolhão de ar para o isolamento térmico Tem 4 metros de largura por 8,10 de comprimento.

São casas desse tipo que pretende o SSCM instalar no Recife, para operários. 


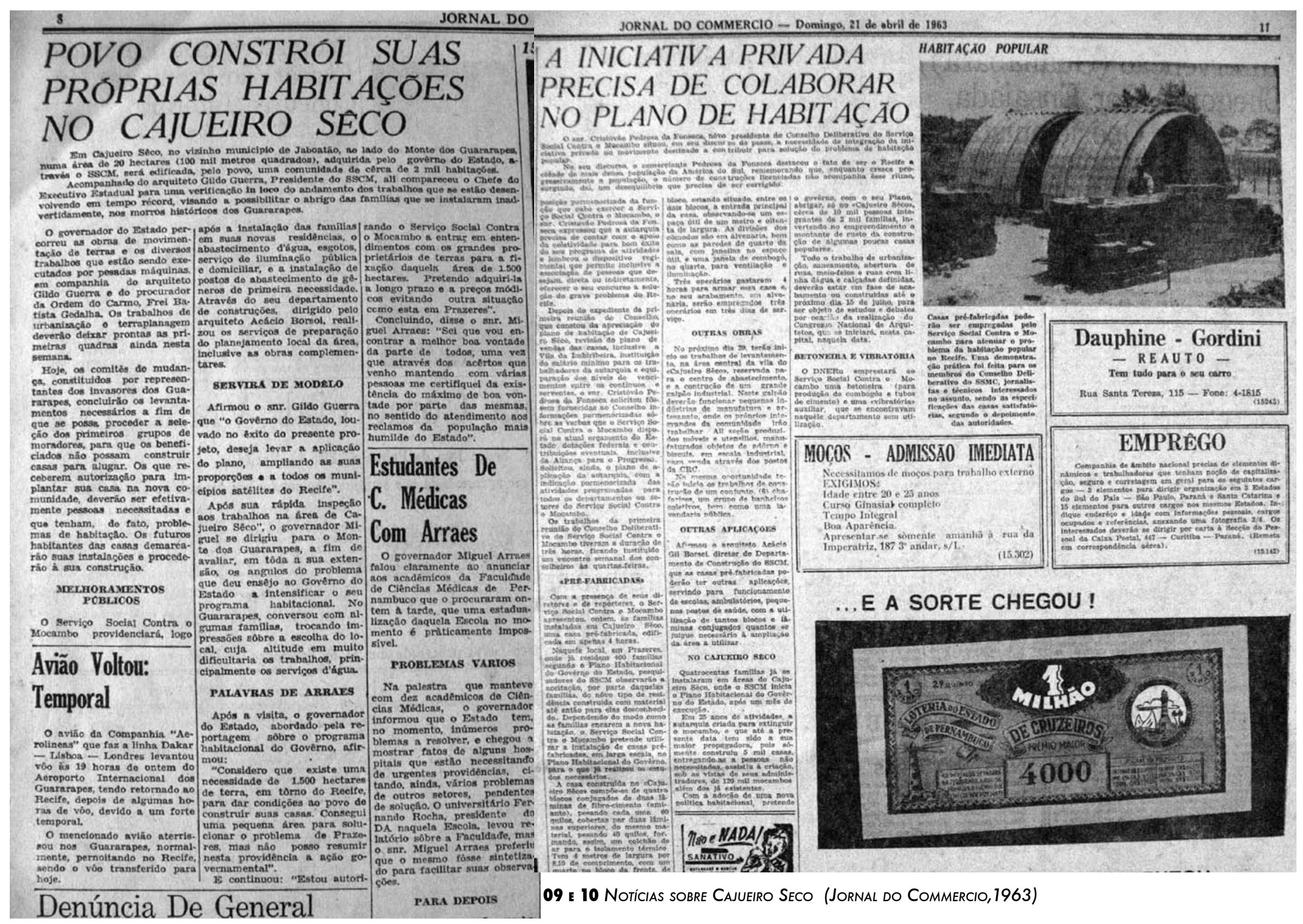



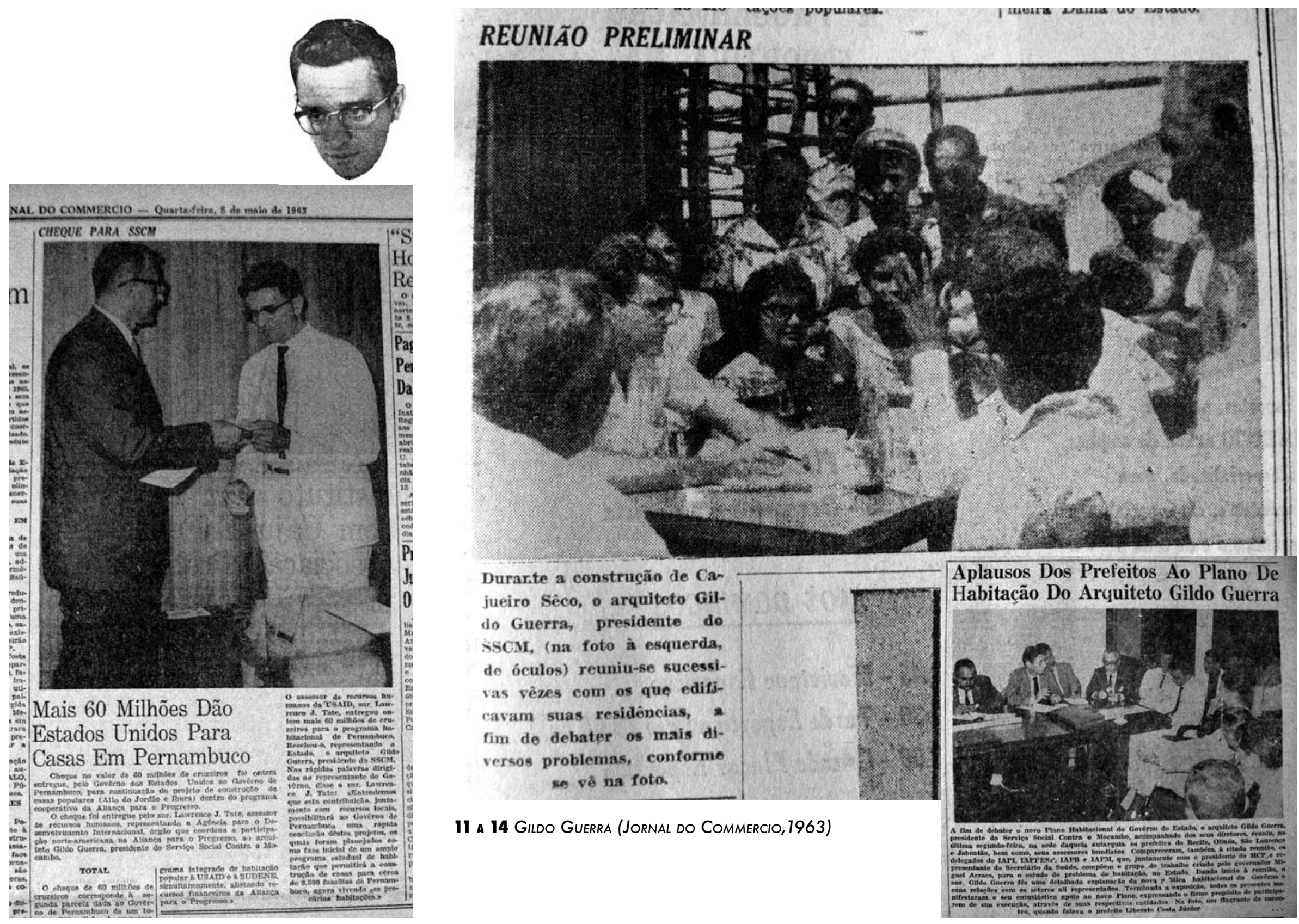

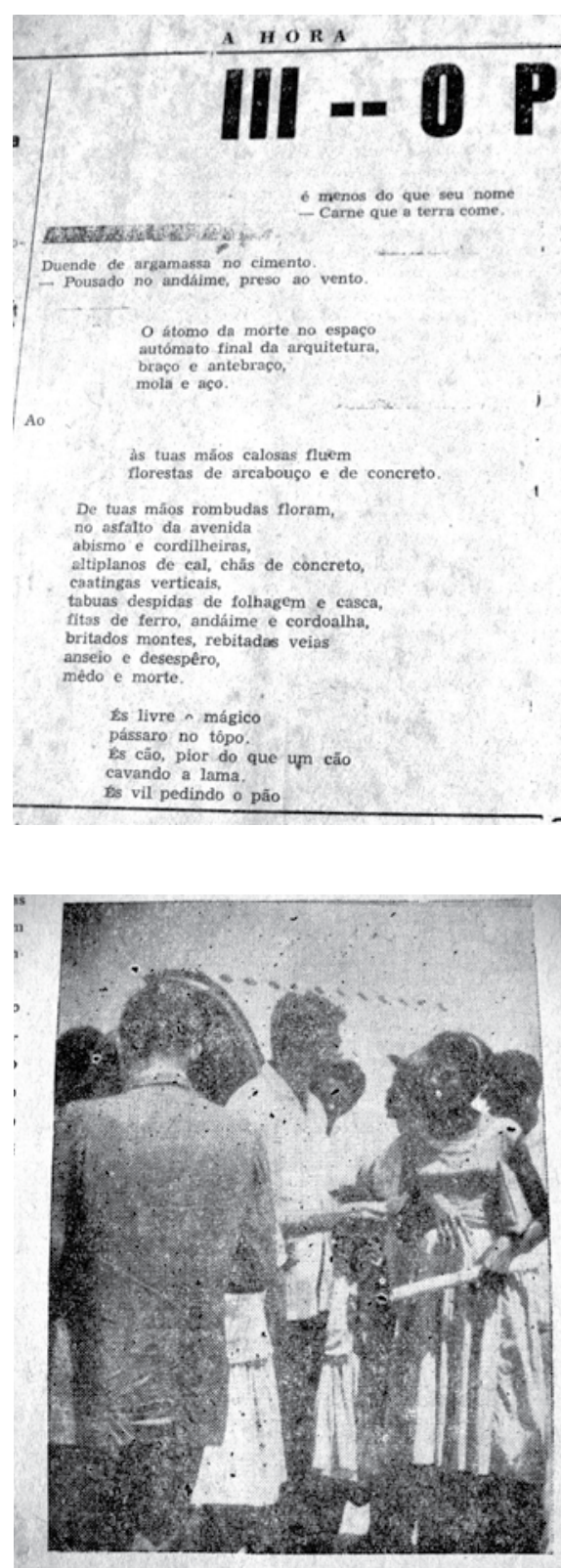

O PRESIDENTE DO S.S.C.M. NO MOMENTO EM QUE FALAVA COM HABITANTES DE CAUUETRO SECO
Recife, 29 de dezeimbro de 1962 LII pelo teu medo. plantando. on ompo de
em busca a Etemidade. is mais e menos a de in hiomem pres de humano em st exise. is mais que um dembinio construldo
- verticalmente vencido O anjo provisorio que apruma
na solidido do abismo em que se atima ruldo e cal, silencio e pesadelo
eo artiticio exato do arfuitete.
Pelo seu braes morre a petreira. seca o barreiro
pelo seu braso. E pela fome
que não tem fundo. que náo tem fund
Por seu desejo que nán te intorma.
Por seu mucambo
feito de lama. Por seu salário
que năo tem base que náo tem lema. Por seu menino Por sua causa nem fundamento, nem mesmo intento
lora a cidade, floresce o a affalto, madura o Tempo.

15 Poema "O Pedreiro, de Olímpio Bonald (A HORA, 1963)

16 E 17 Notícias e IMAGem SOBRE GILDO

Guerra e Cajueiro Seco(A Hora, 1963)

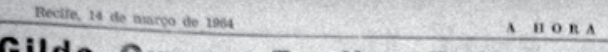

Explica Politica Habitacional do Govêrno Humanização Do Mocambo e Combate às Suas Causas

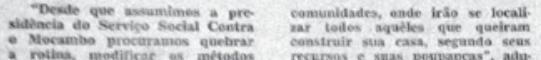

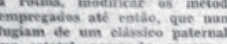

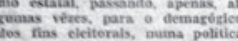

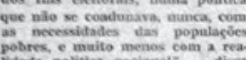

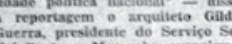

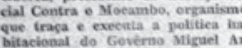

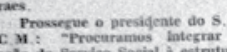

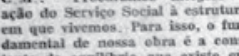

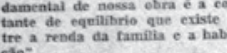

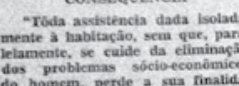

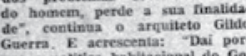

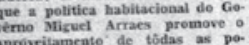

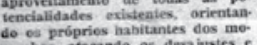

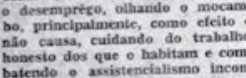

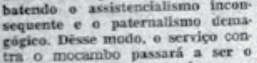

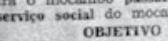

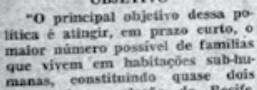

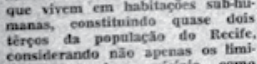

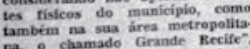

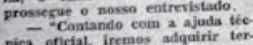

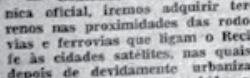

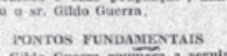

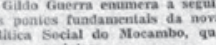

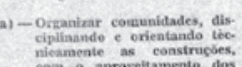

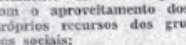

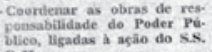

Sentido de um Programa

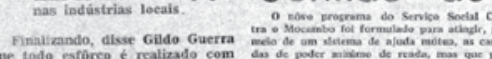

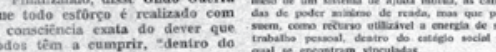

upirito do Govermo de Mignel Ar

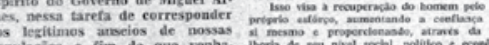

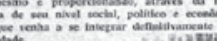

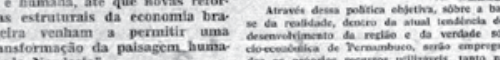

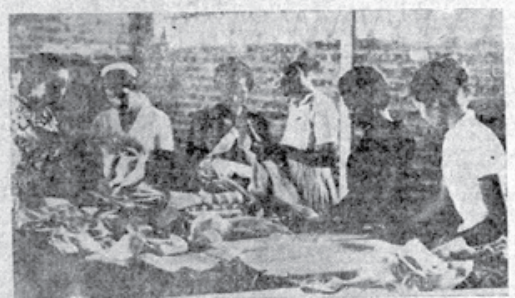

Cajueiro Sêco é

Mostra e Confirmacão

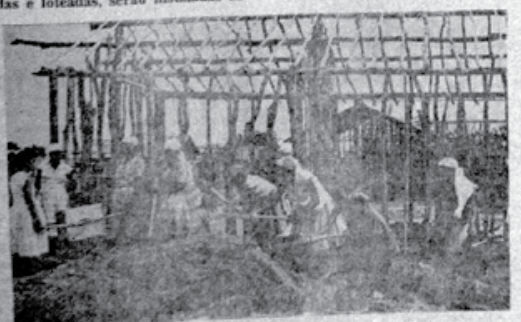

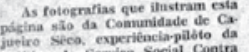

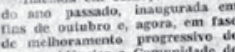

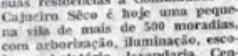

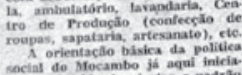

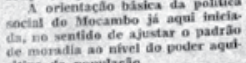

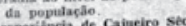

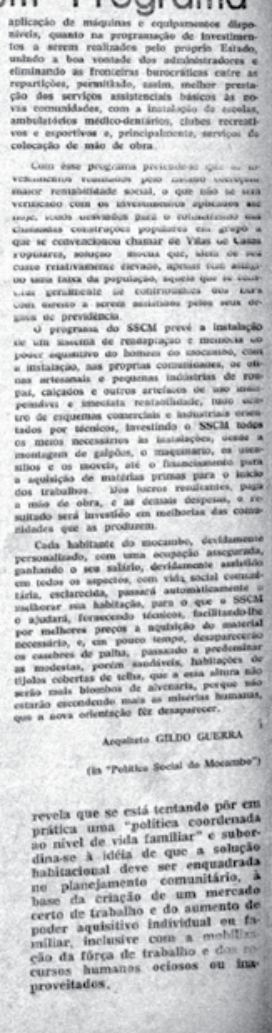




\begin{tabular}{|c|c|c|}
\hline ANEXO - 2 & DEPARTANENTO DE CONSTRUCÁO & \\
\hline S. S.C.M. & $\begin{array}{l}\text { MODIFICAGT̃ E ATUALIZAG ÁO } \\
\text { Do PROJETO OA COMUNIOAOE OE } \\
\text { CAJUEIRO SÊCO. }\end{array}$ & $1 / 2$ \\
\hline & ESCALA: $1: 3.000$ & \\
\hline
\end{tabular}

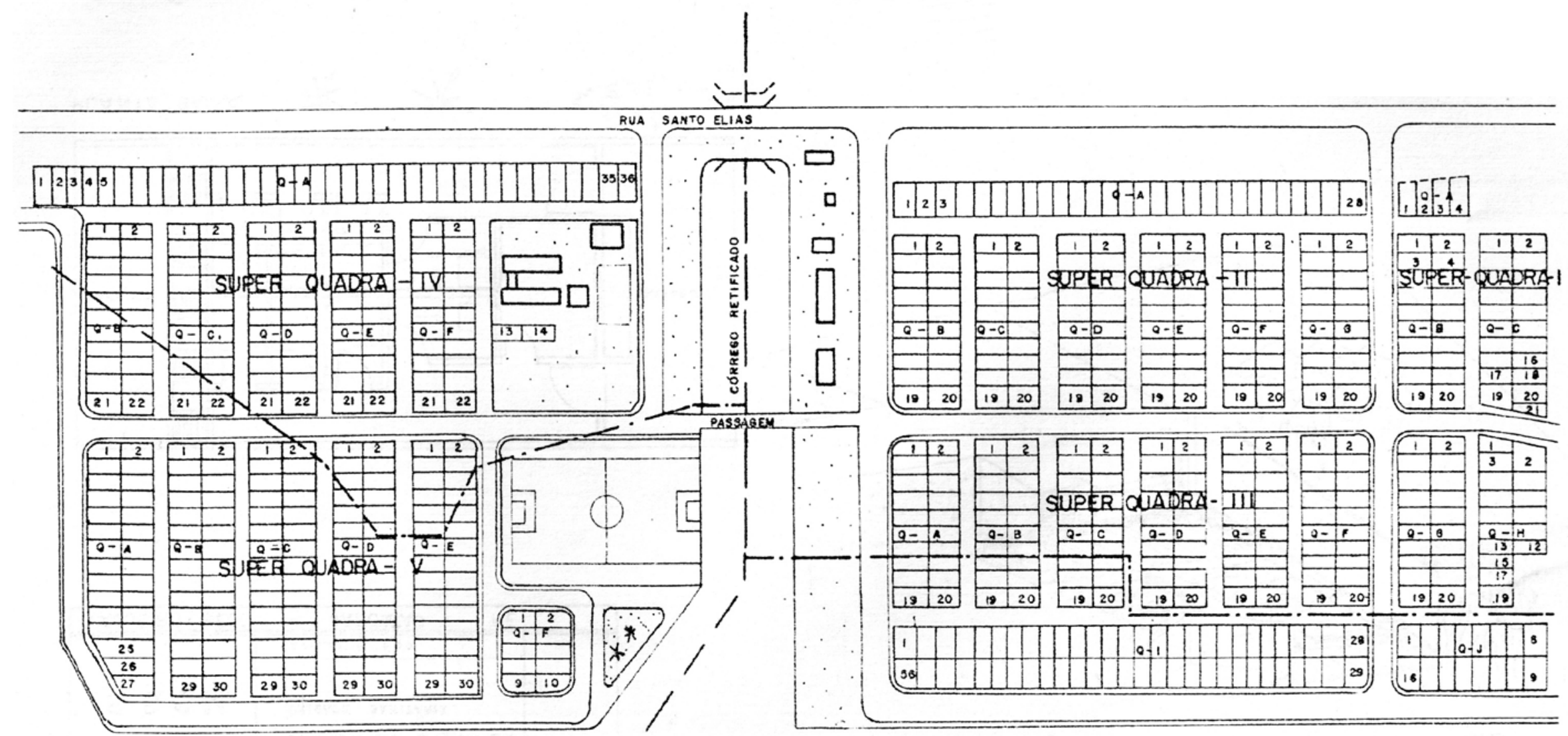




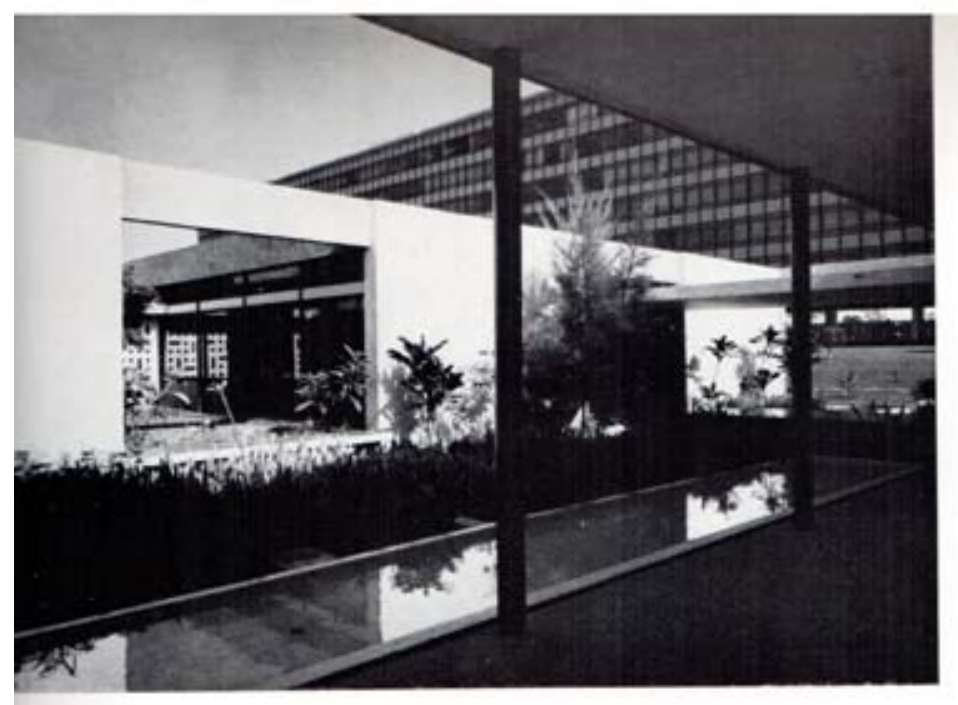

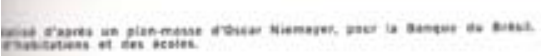

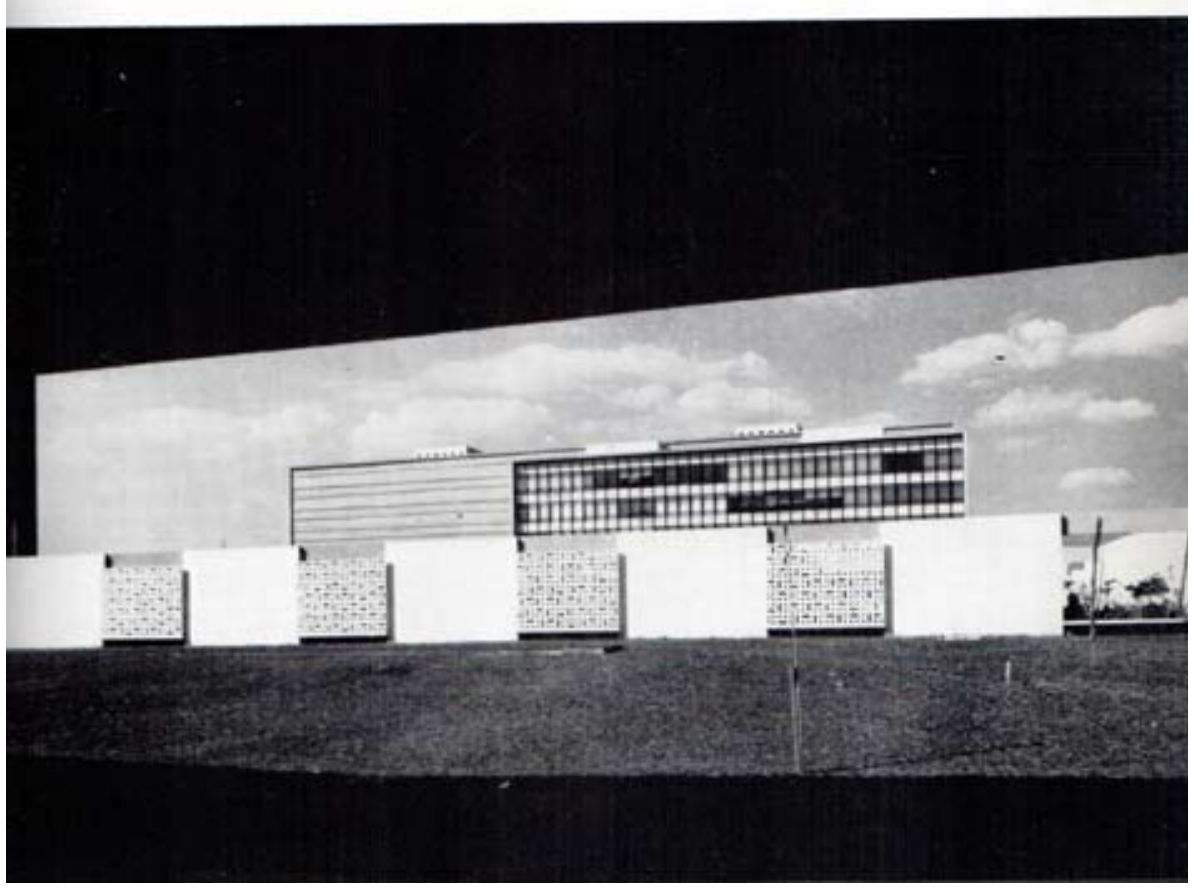

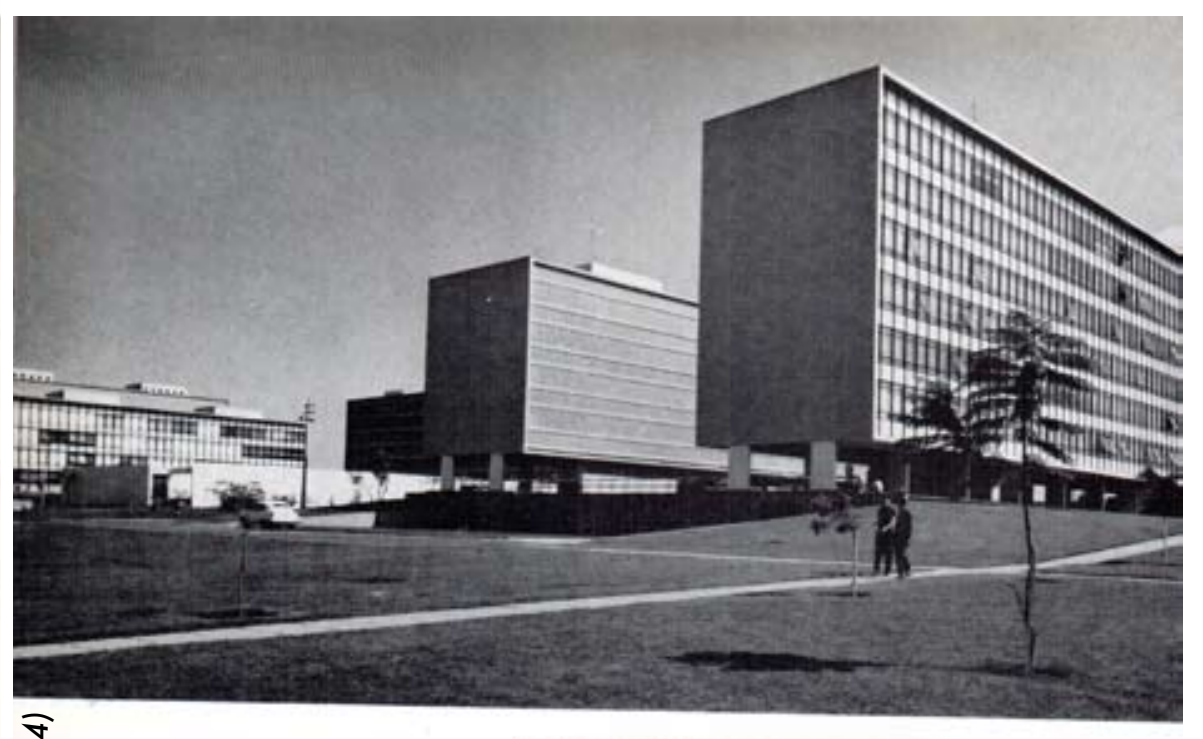

BRASILIA

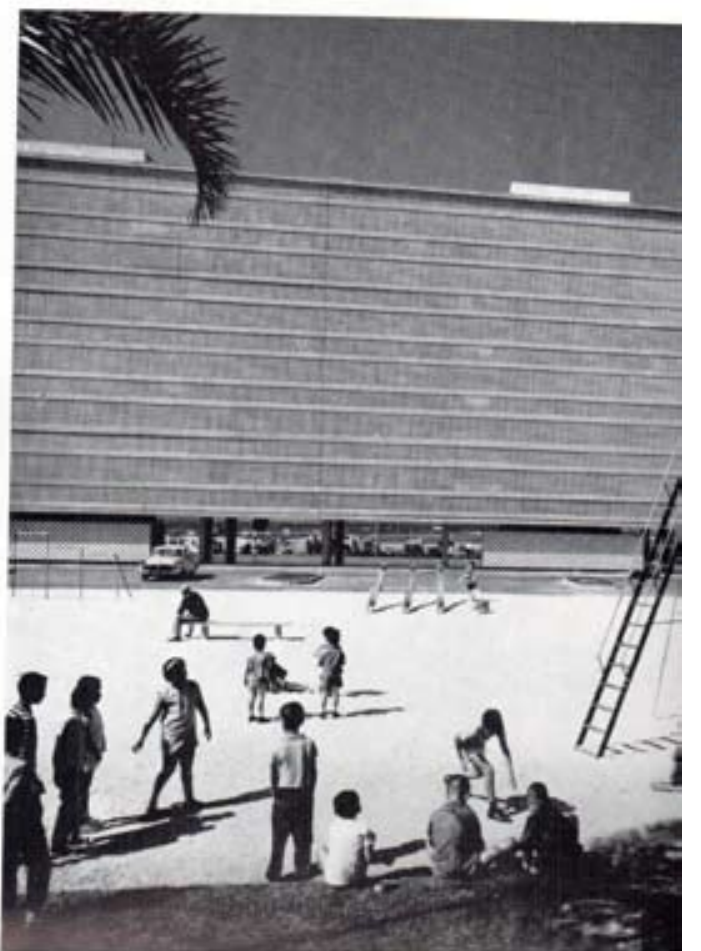




\begin{tabular}{|c|c|}
\hline ANEXO -3 & DEPARTAMENTO DE CONSTRUGTO \\
\hline \multirow[t]{2}{*}{ S. S. C. M. } & $\begin{array}{l}\text { COMUNDADEE, OE CAULEIRO SÉDO. } \\
\text { UNIDADE SANITÁRIA. }\end{array}$ \\
\hline & ESCALA: $1: 100$ \\
\hline CAJUEIRO SEC & - JABOATAO - PE \\
\hline
\end{tabular}

21 (VERAS, 1965)
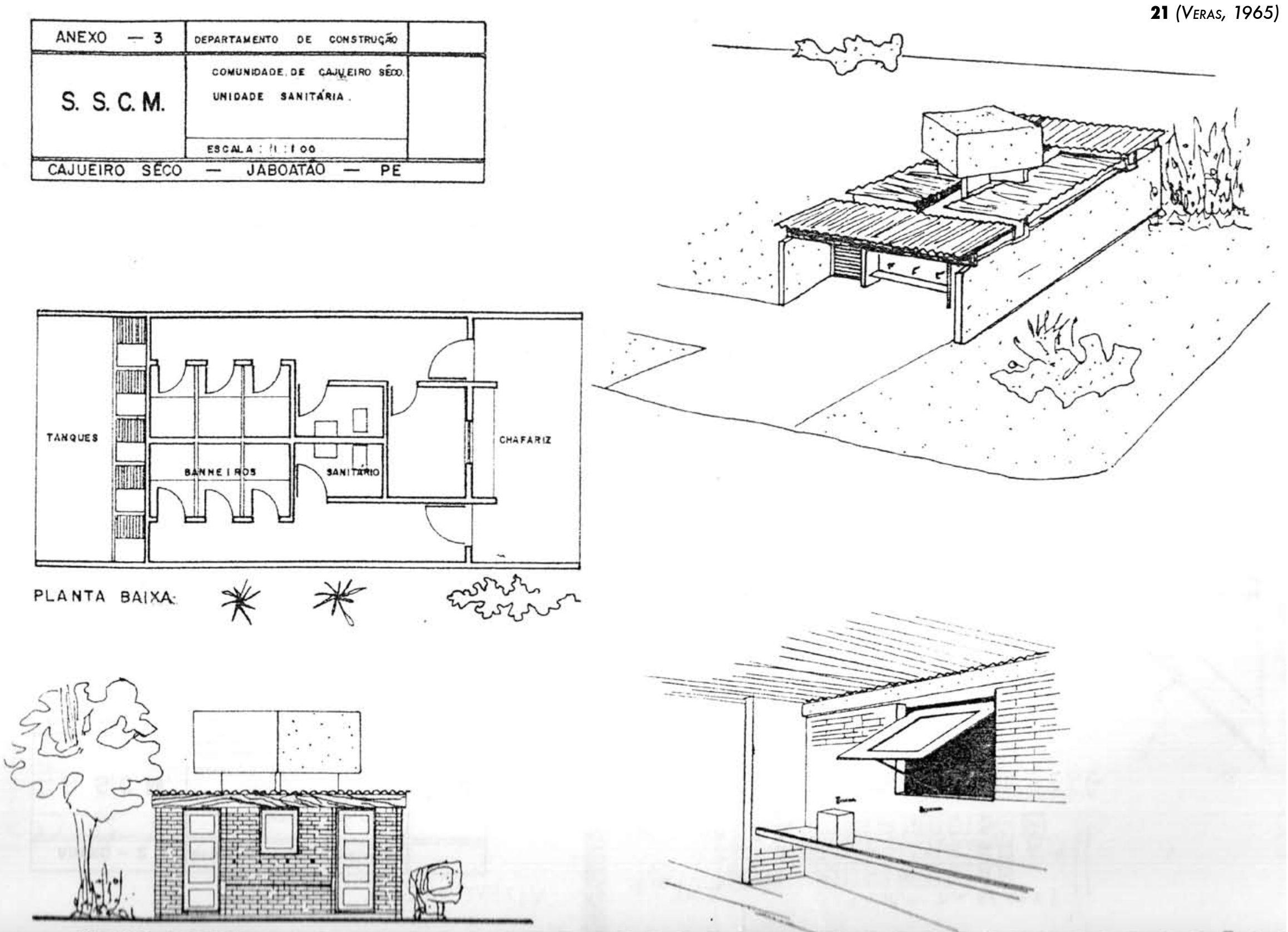

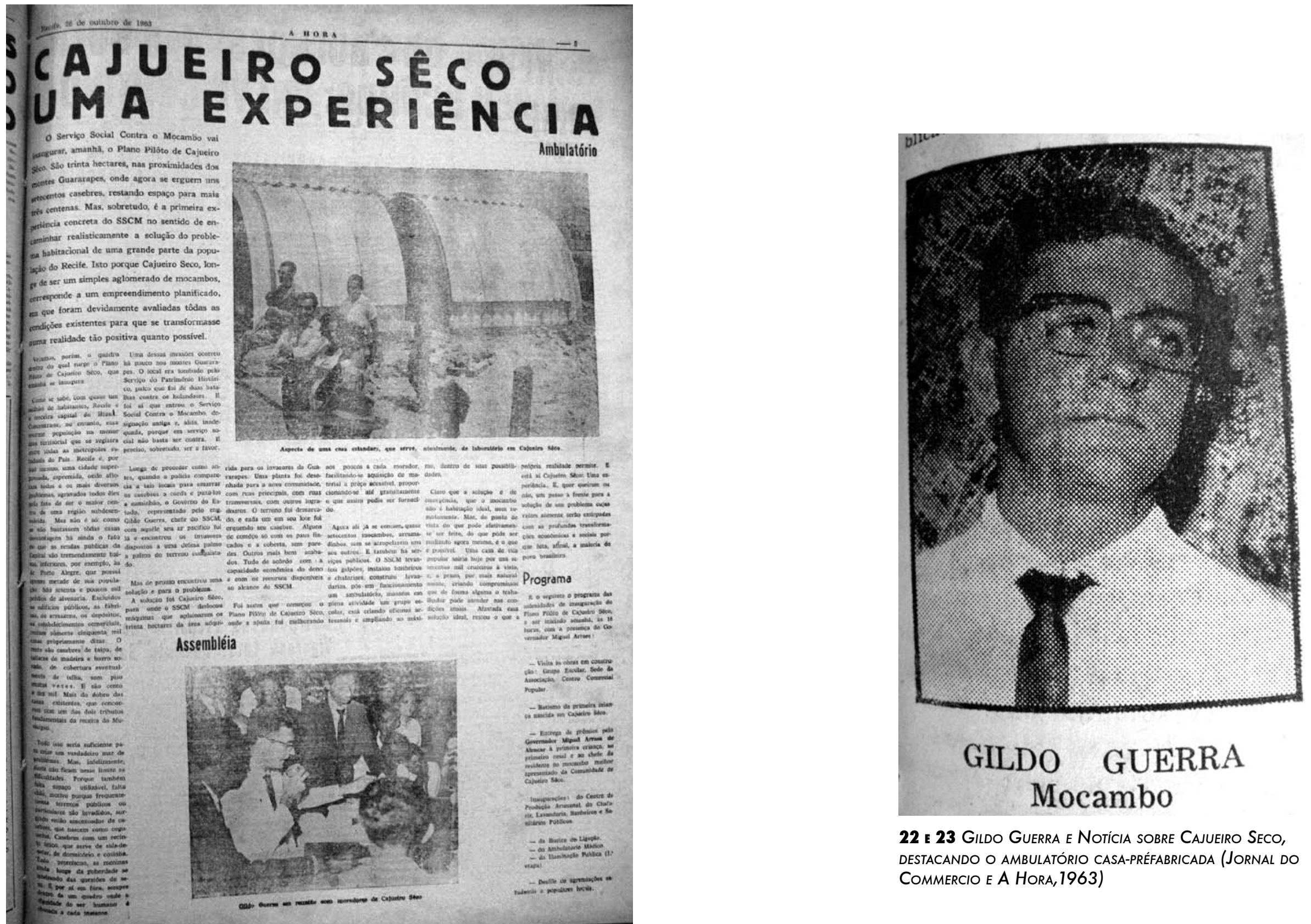

22 a 23 Gildo Guerra e Noticia sobre Cajueiro Seco, DESTACANDO O AMBULATÓRIO CASA-PRÉFABRICADA (JoRnal DO COMMERCIO e A HORA, 1963) 

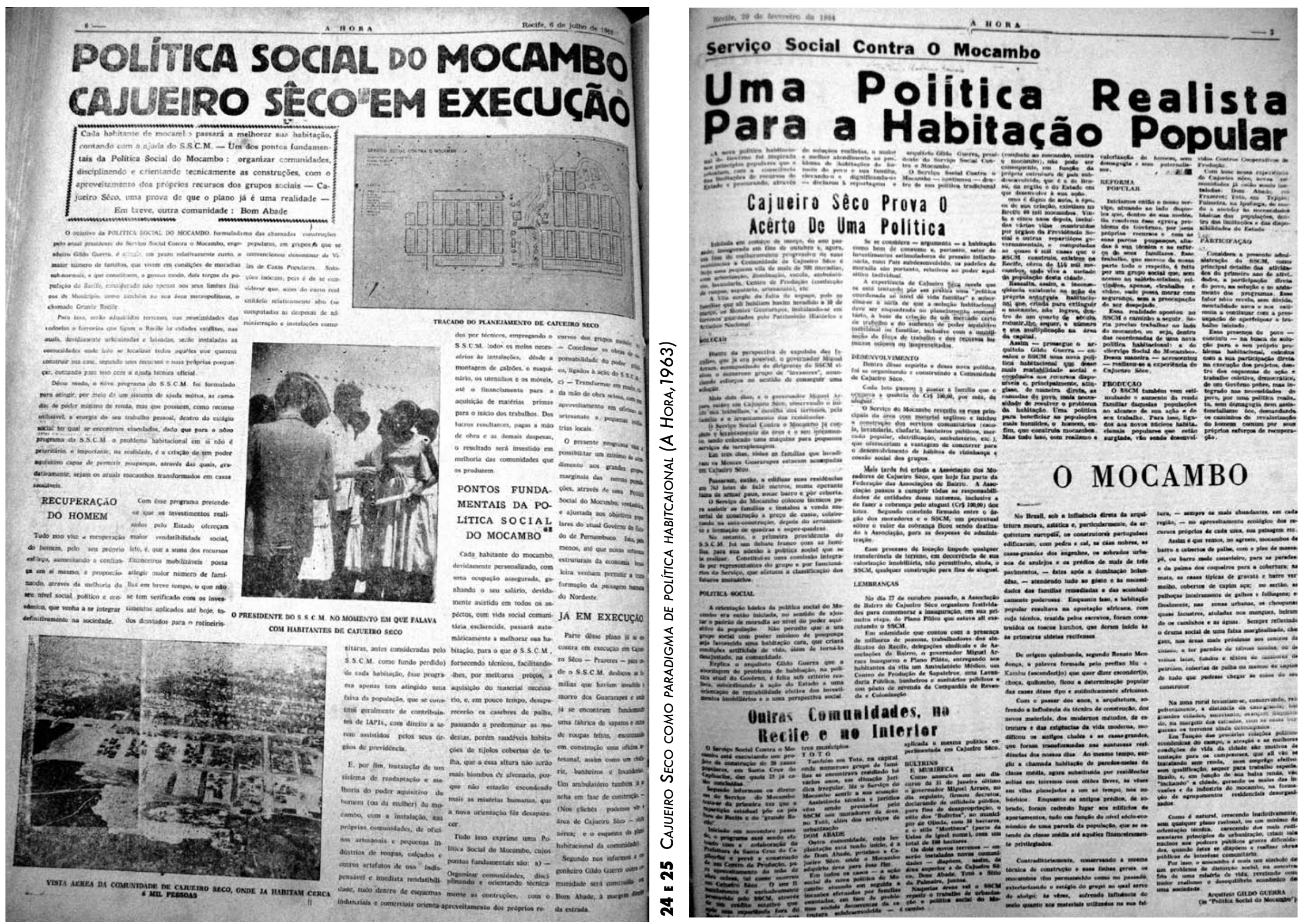

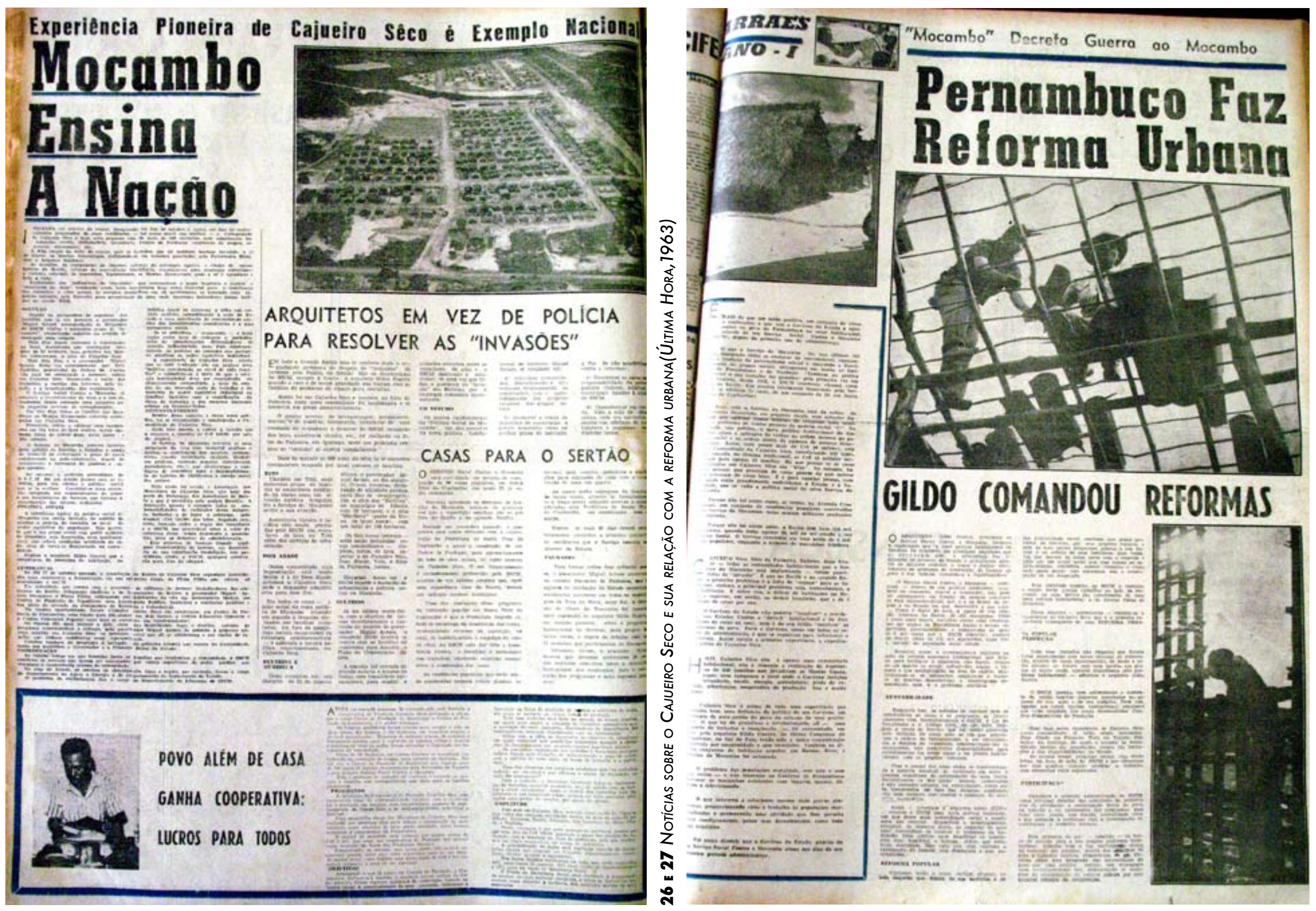

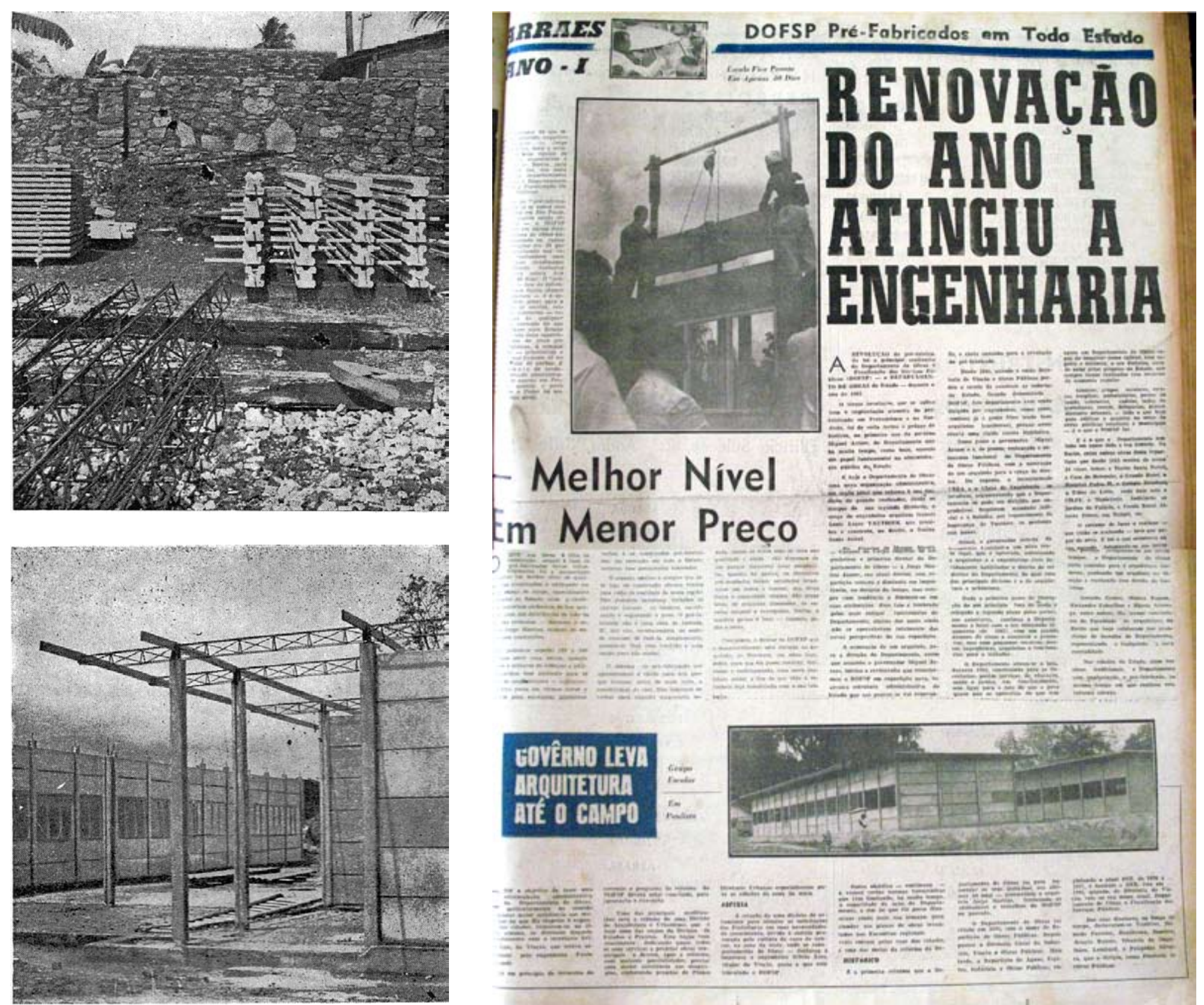

28 a 29 Sistema CoN-

STRUTIVO DOS GRUPOS

PRÉ-FABRICADOS DO DOFSP

(ARQUITETURA, 1965)

30 MATÉRIA SOBRE GRUPOS

PRÉ-FABRICADOS DO DOFSP

(ÚlIIMA HORA, 1963) 


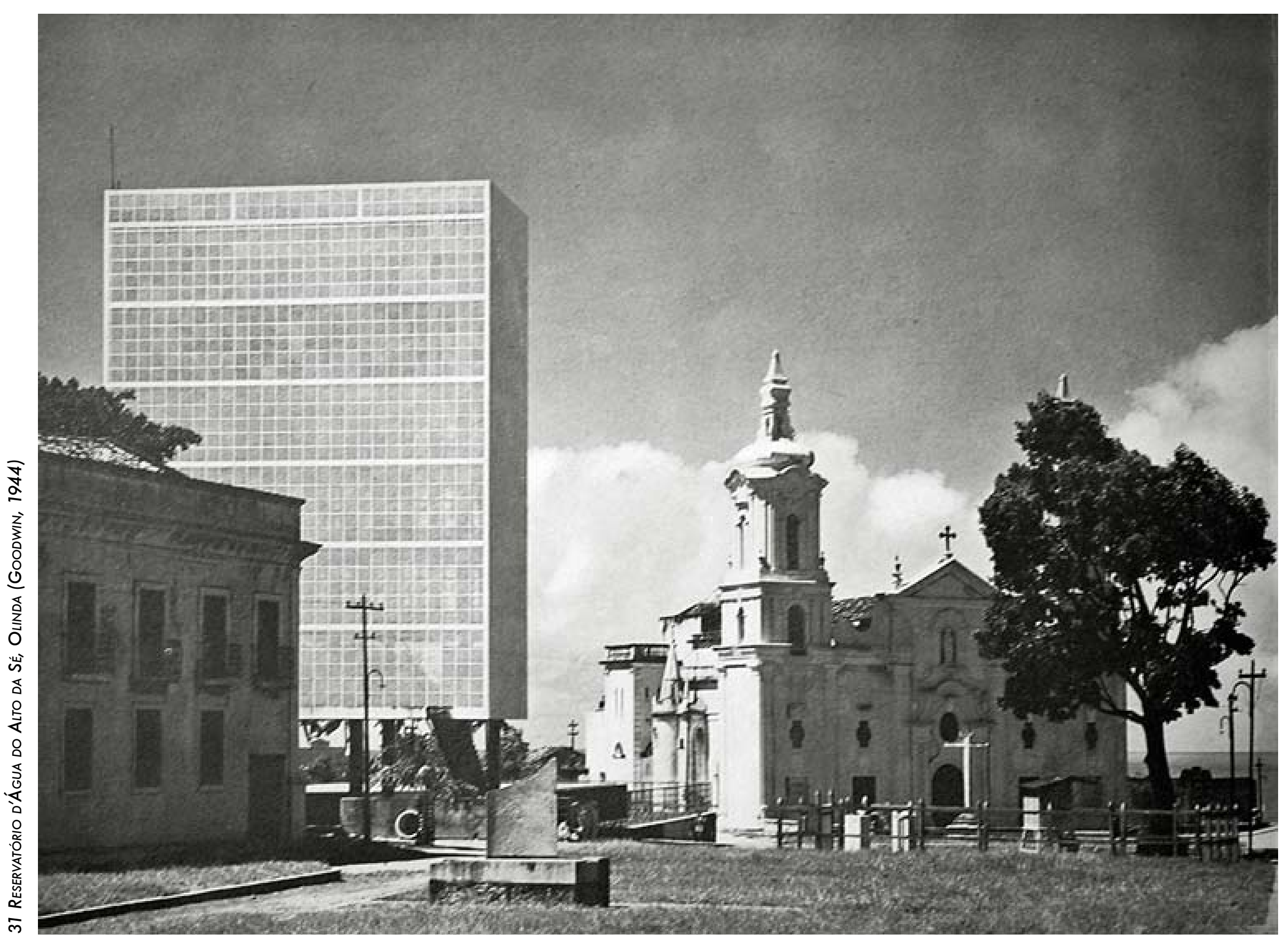




\begin{tabular}{|c|c|c|}
\hline ANEXO - 9 & 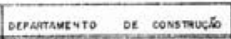 & \\
\hline S. S.C.M. & 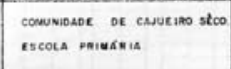 & $1 / 5$ \\
\hline जUEार० & 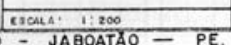 & \\
\hline
\end{tabular}
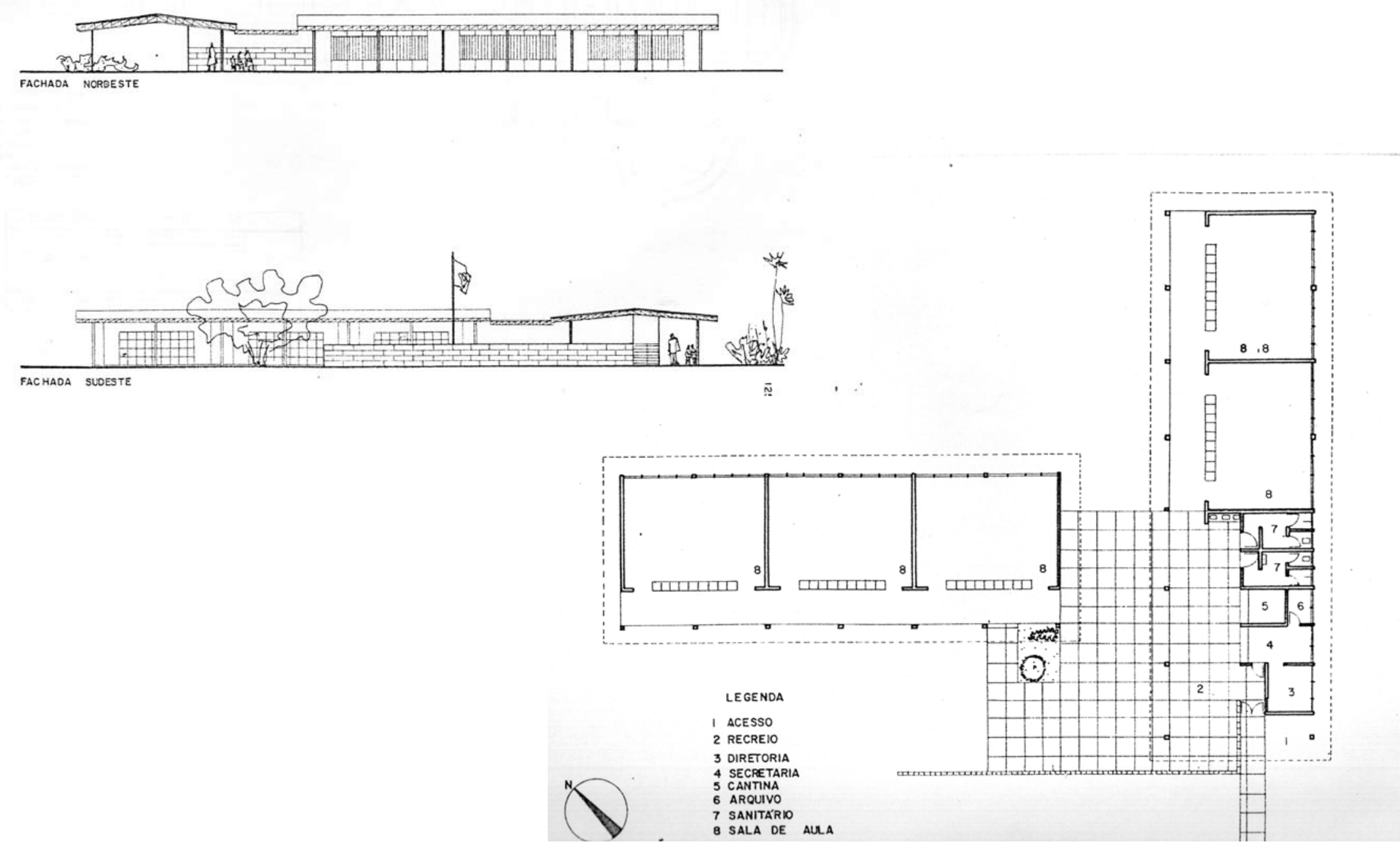
33 e 34 MatérIa e ANÚNCIO SObRe AS CASAS PRÉ-FABRICADAS BETON (DIÁRIO DE PE, 1963)

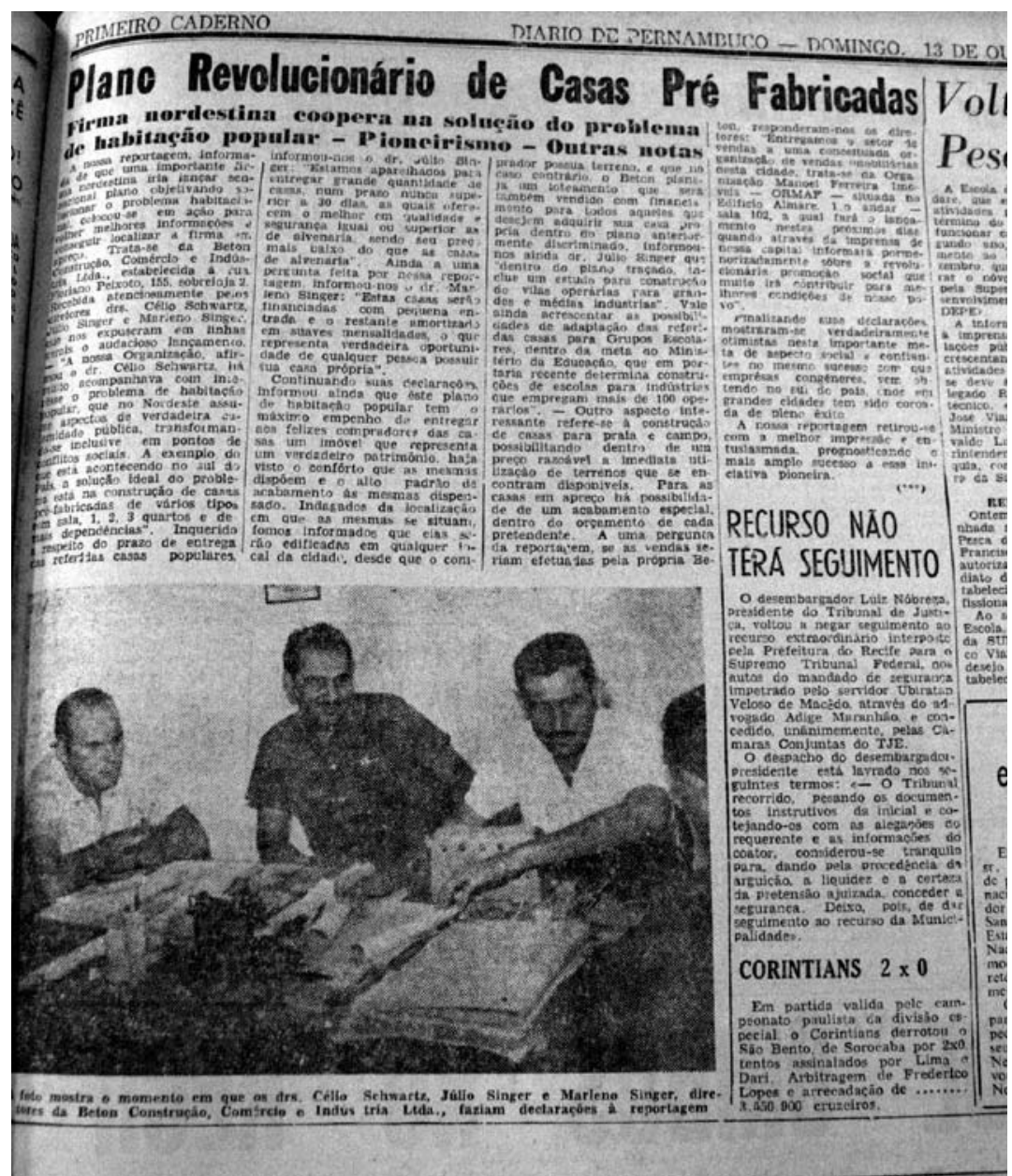

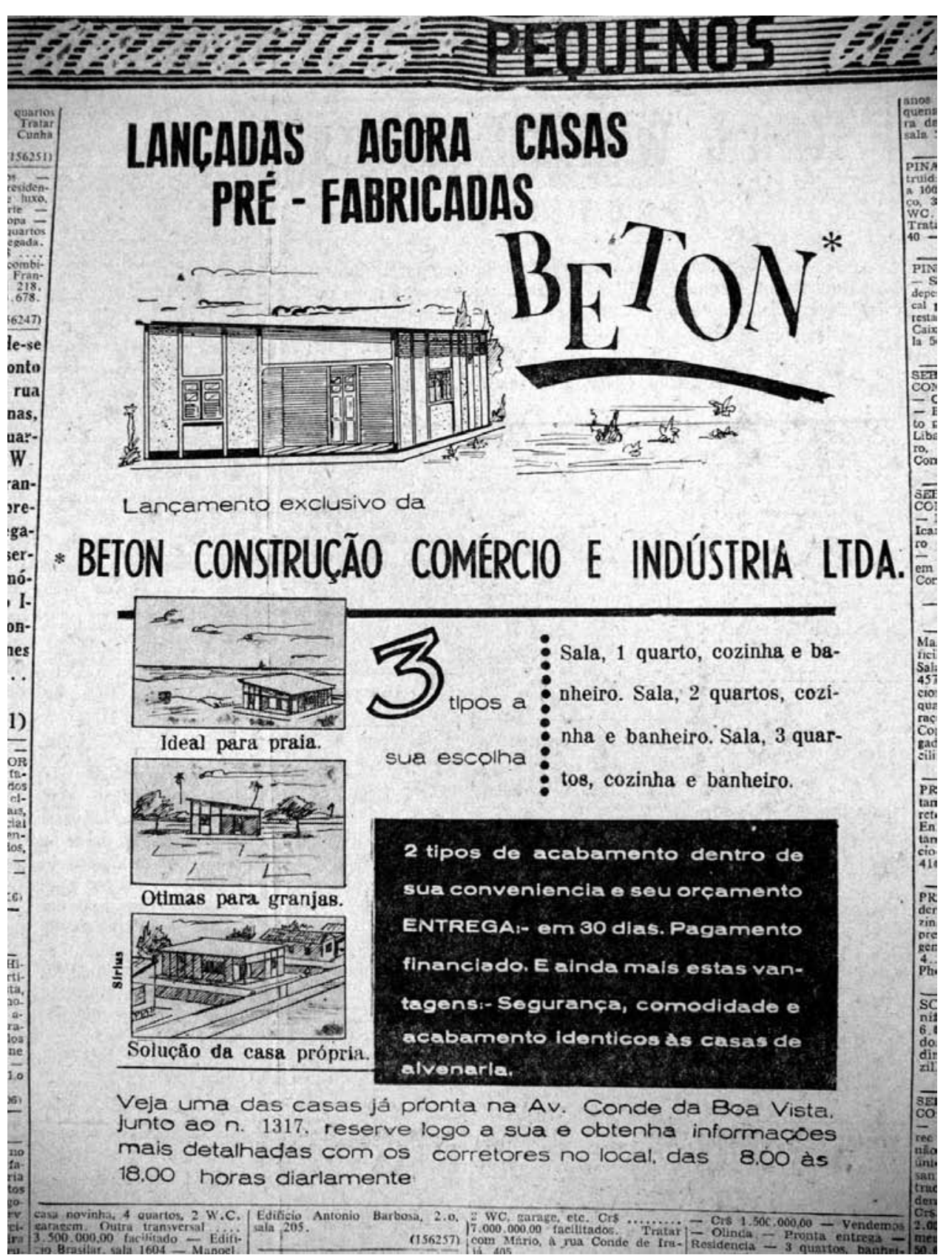




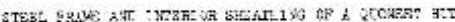

$\frac{d}{i}$

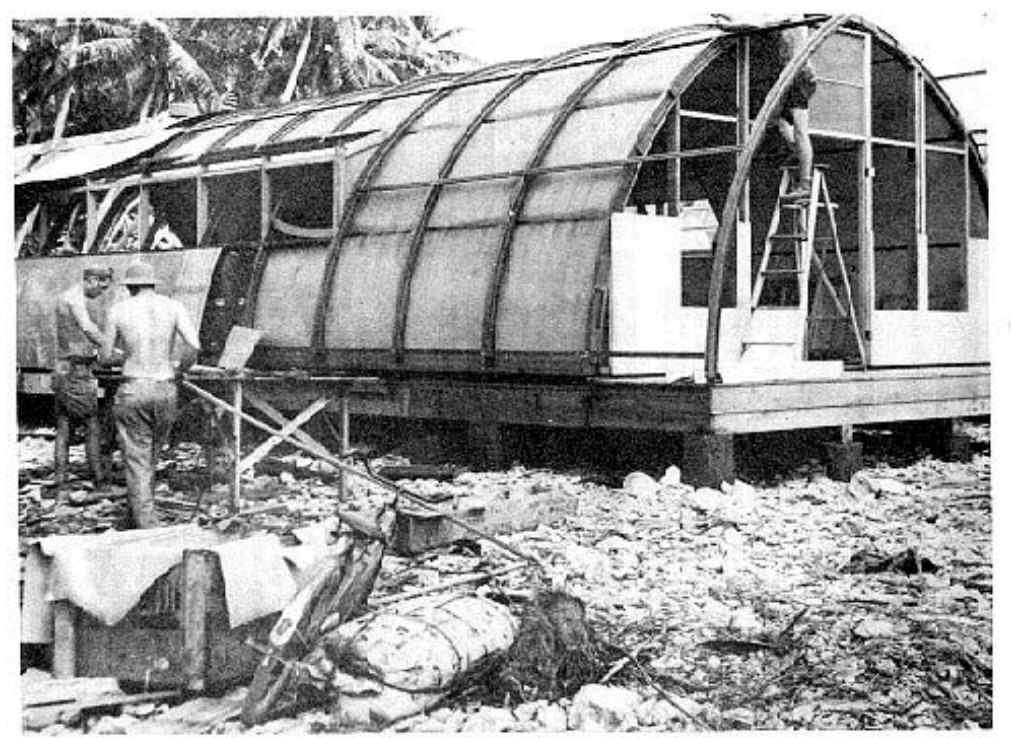

35 MARINES MONTANDO QUONSET HUT (CHIEl, 2006)

36 Desembarque de Quonset Hut

NO JAPÃO

(CHIEl, 2006)

37 i 38 ANÚNCIOS COMERCIAIS DE

QUONSET HUTS

(CHIEl, 2006)
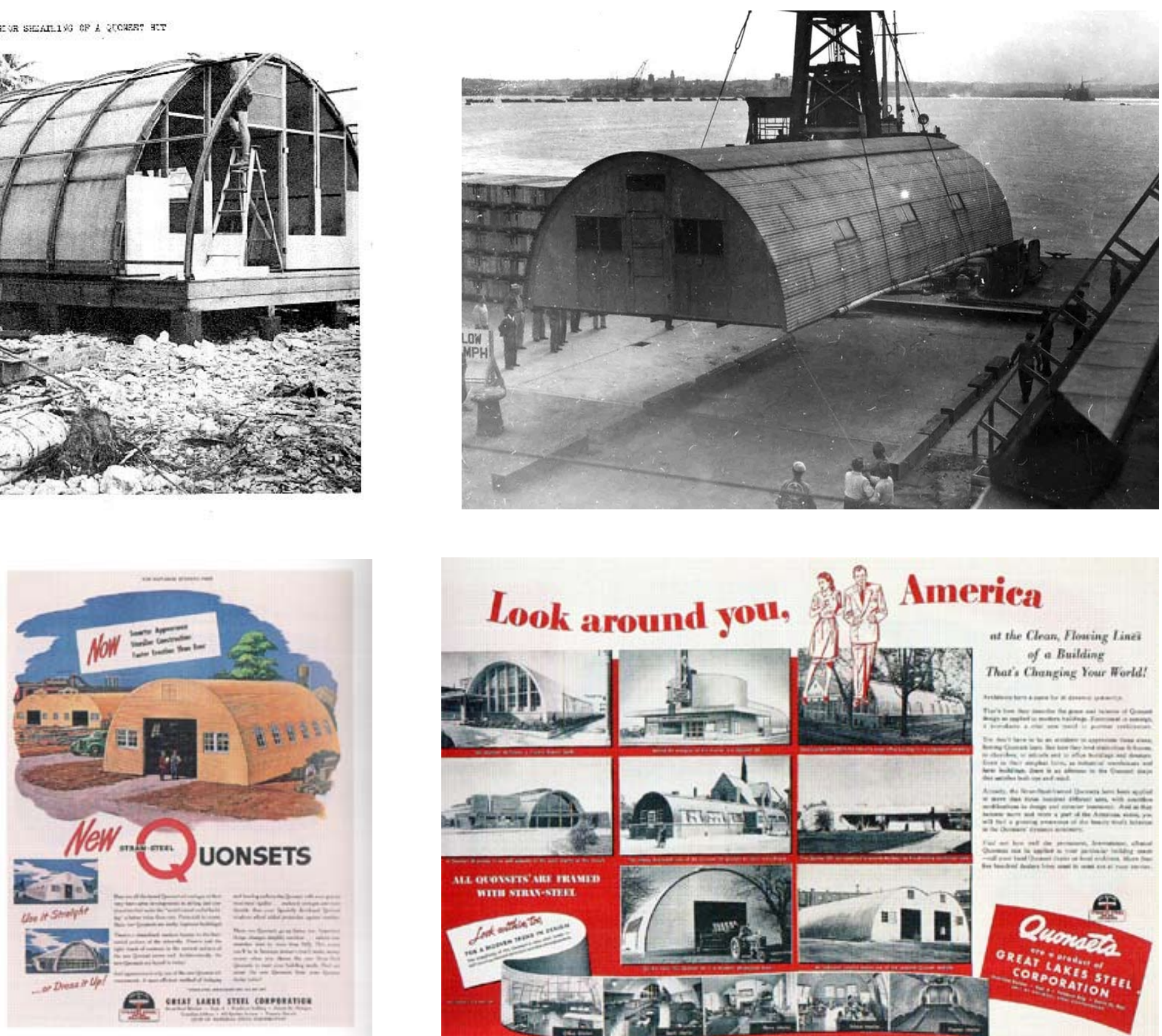

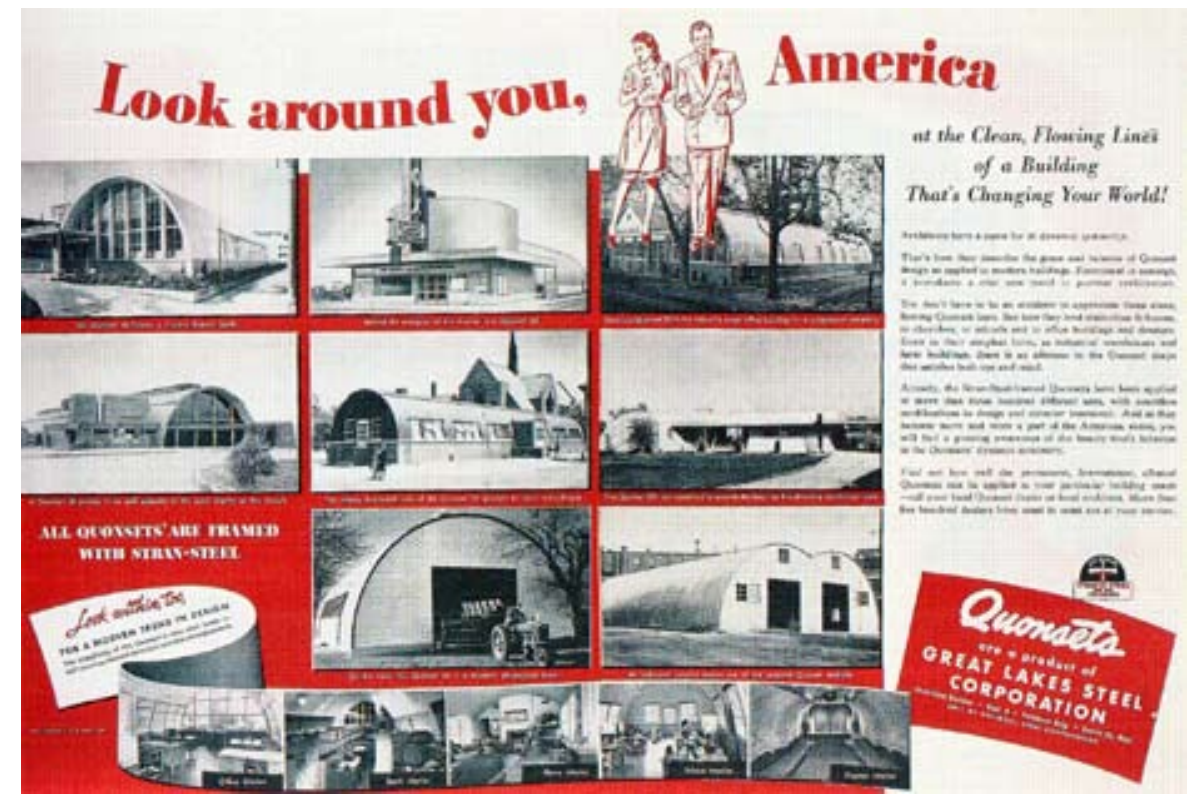




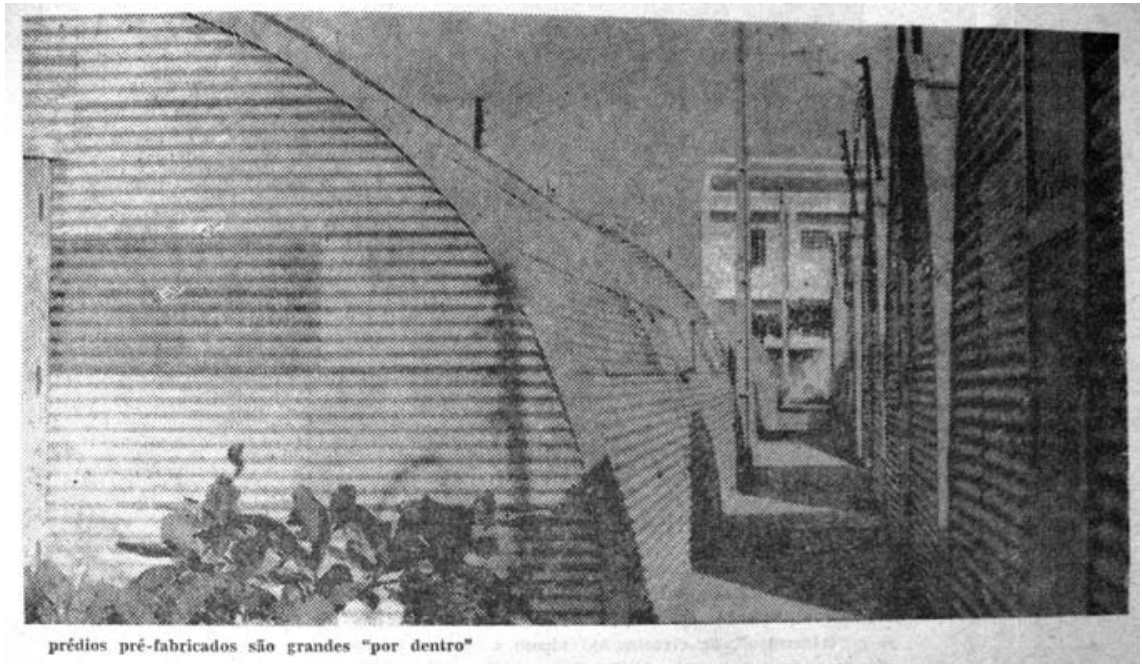

39 escola de Polícia (Diário de Pernambuco, 1963)

40 ambulatório do Cajuelro Seco (A Hora, 1963)

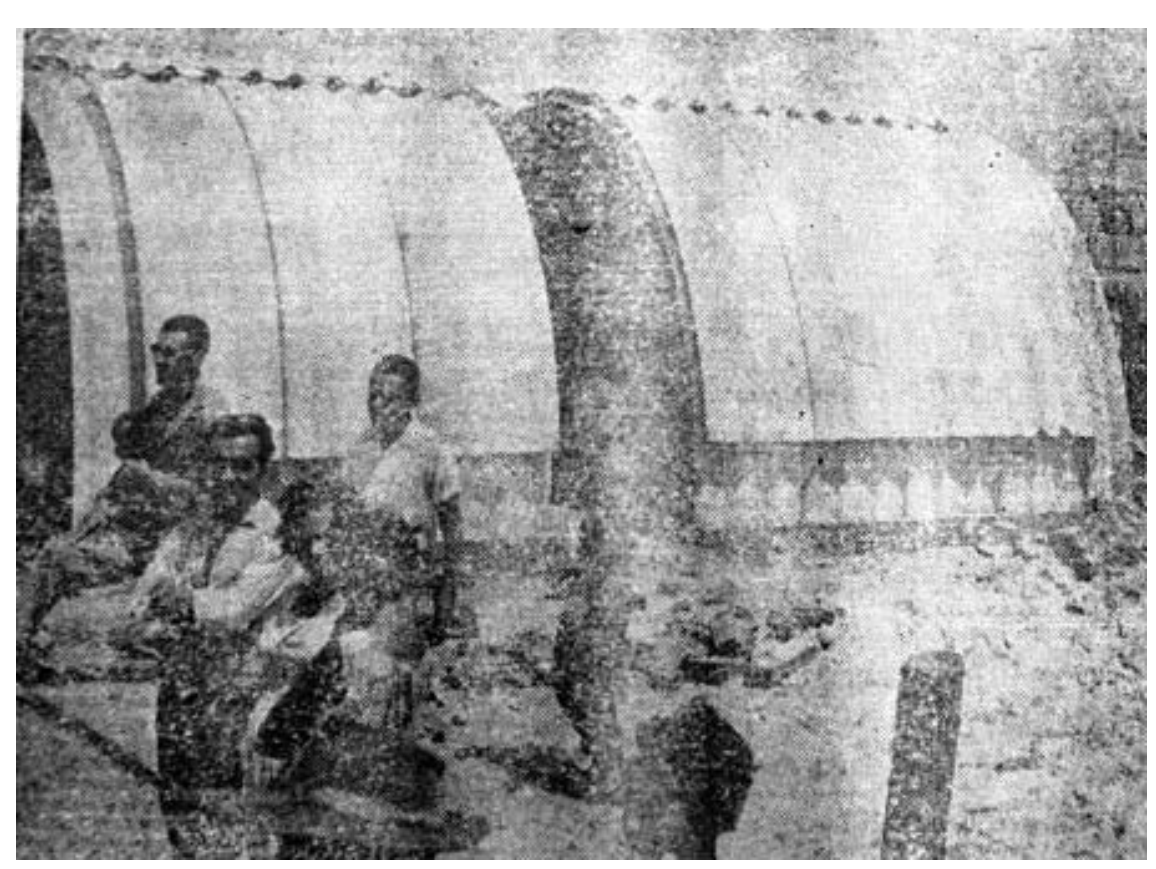

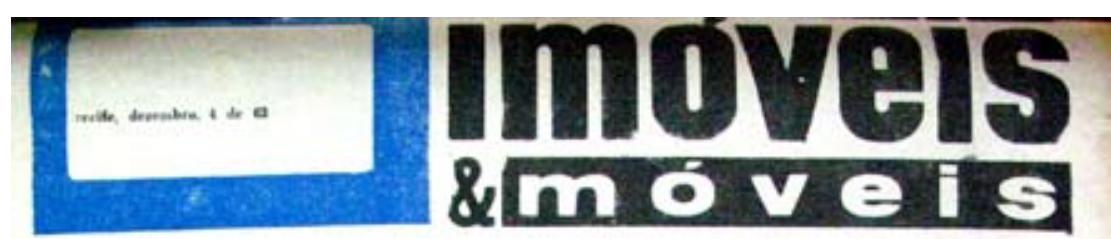

$-\cdots+\cdots$

veículos \& motores

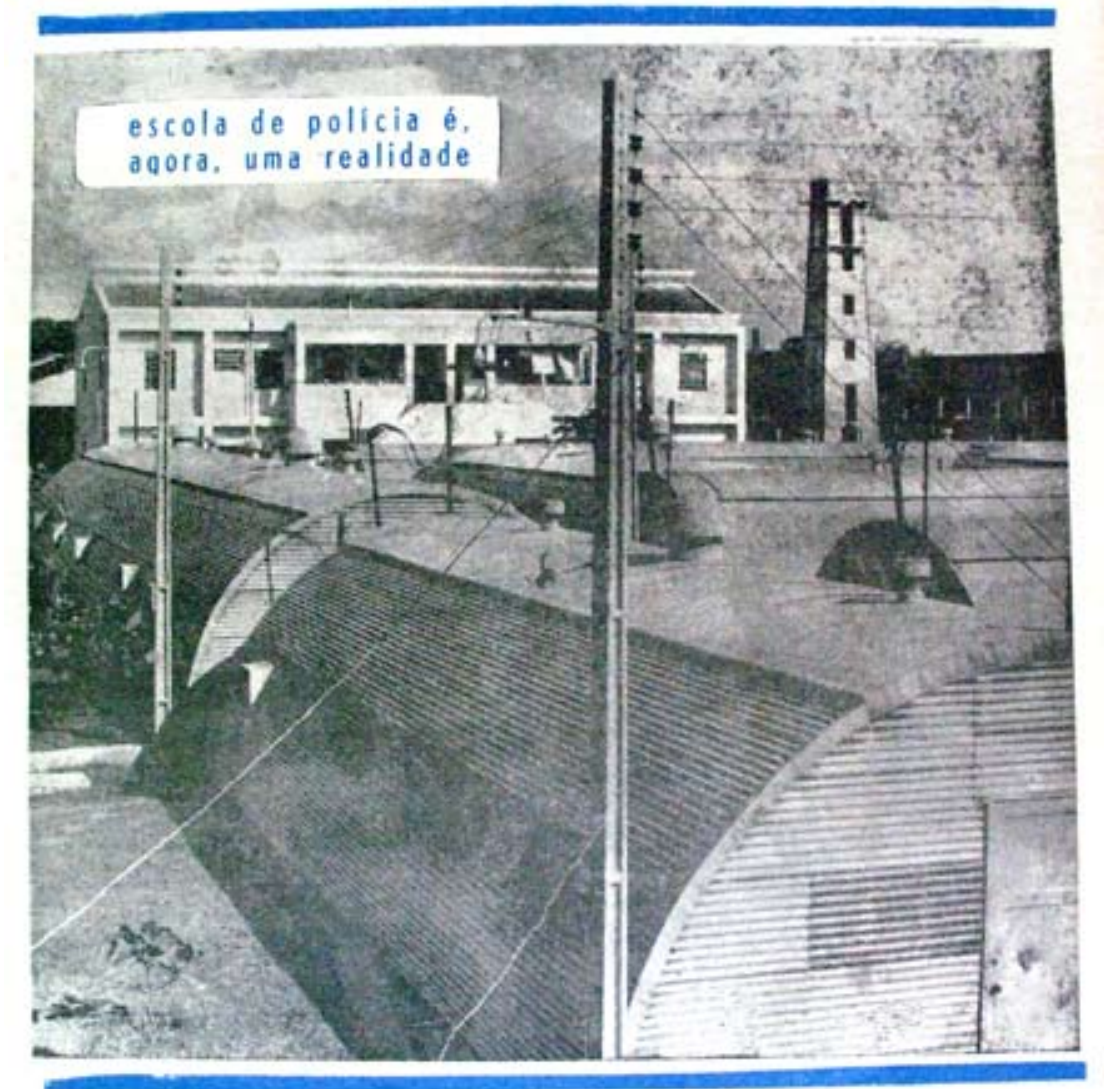

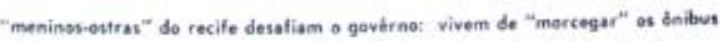

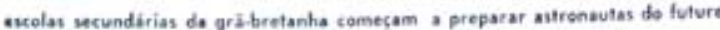
tabricentes do "mercurry" recordam es primei rot veiculen com motoc tipe v-öto

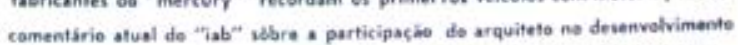

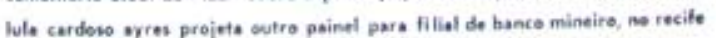

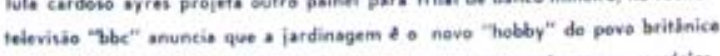

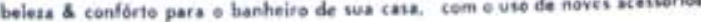


41 Detalme Cobogó (Borsol, 2007)

42,43,44 в 45 EdIFÍCIO SANTO ANTÔNIO -

ARQ. ACÁCIO GIL BORSOI - 1960

(FOTOS DO AUTOR, 2007)
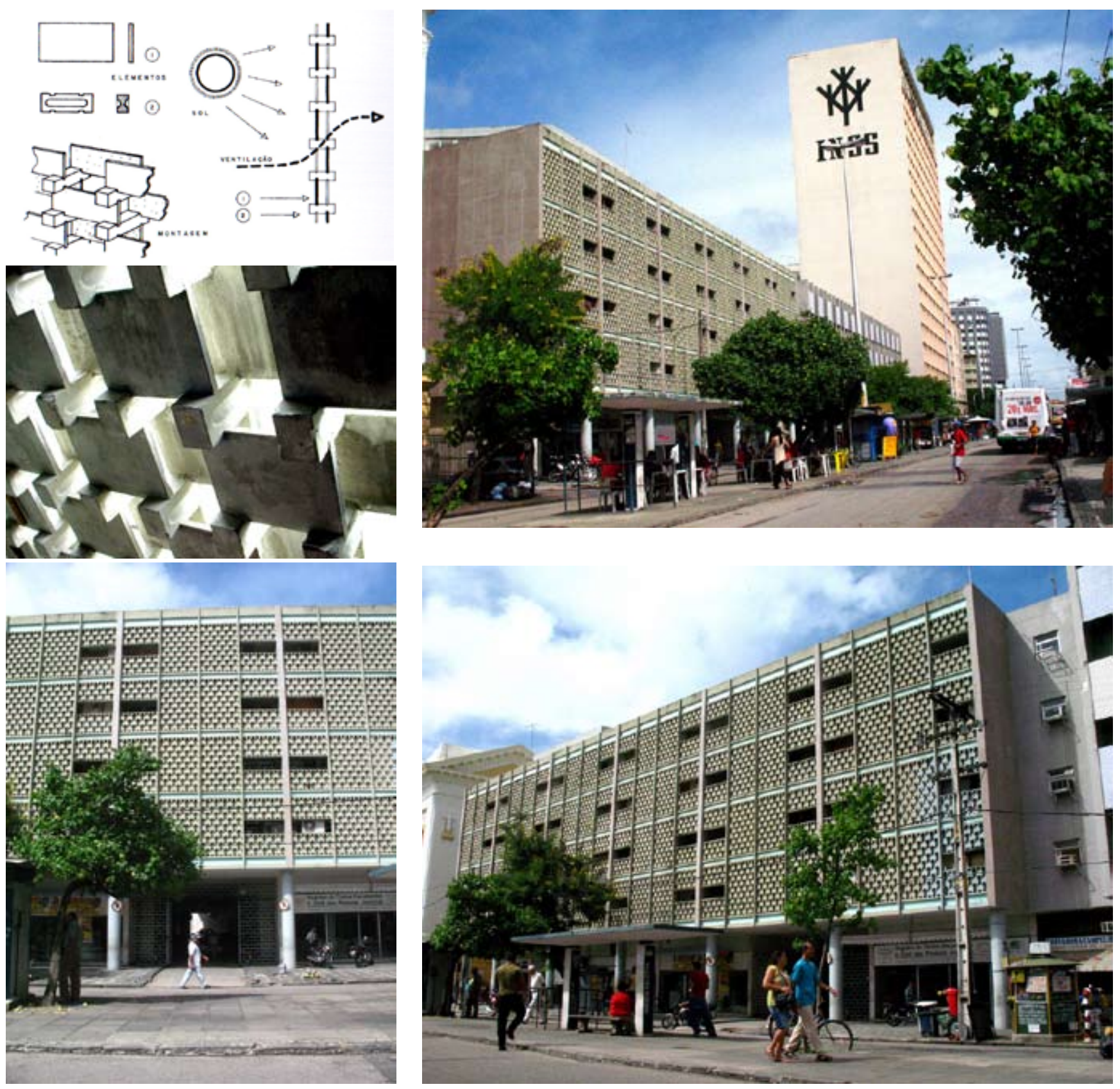

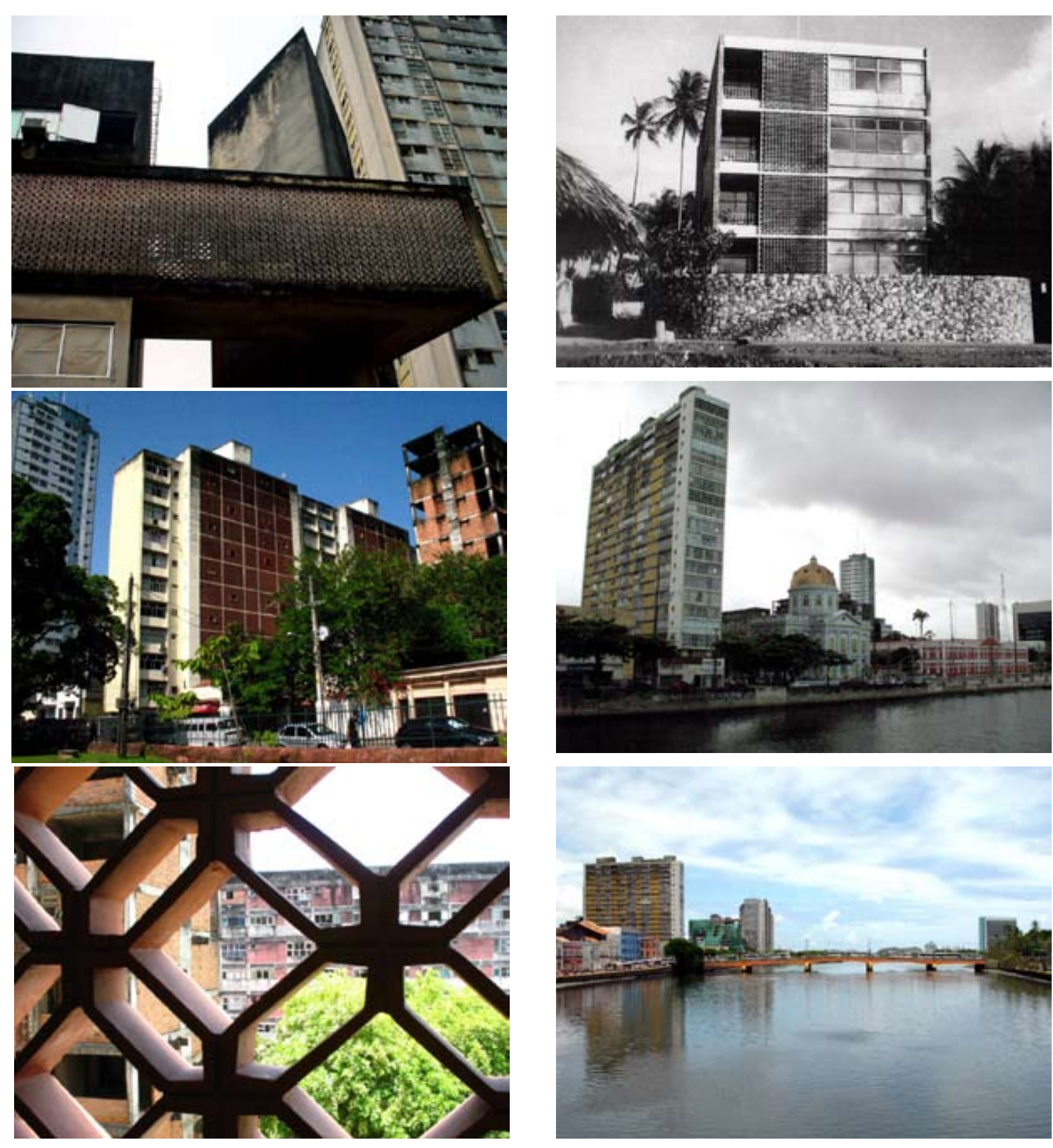

Projetos de Borsol nos ANos 1950 e 60

46 ED. AMAzOnas - 1963 (Foto do AUTOR, 2006) 47 ED. GUAJRU -1960 (AMORIM, 2007)

48 E 49 ED. UNIÃO -1957 (FOTO DO AUTOR, 2007)

50 E 51 Ed. Caeté-1955 (Foto do autor, 2007)

52 ED. CALIF́́RNIA -1953(BORSOI, 2007)

53 ED. Banco do BRASIL E BandePE -1960/69

(FOTO DO AUTOR, 2007)
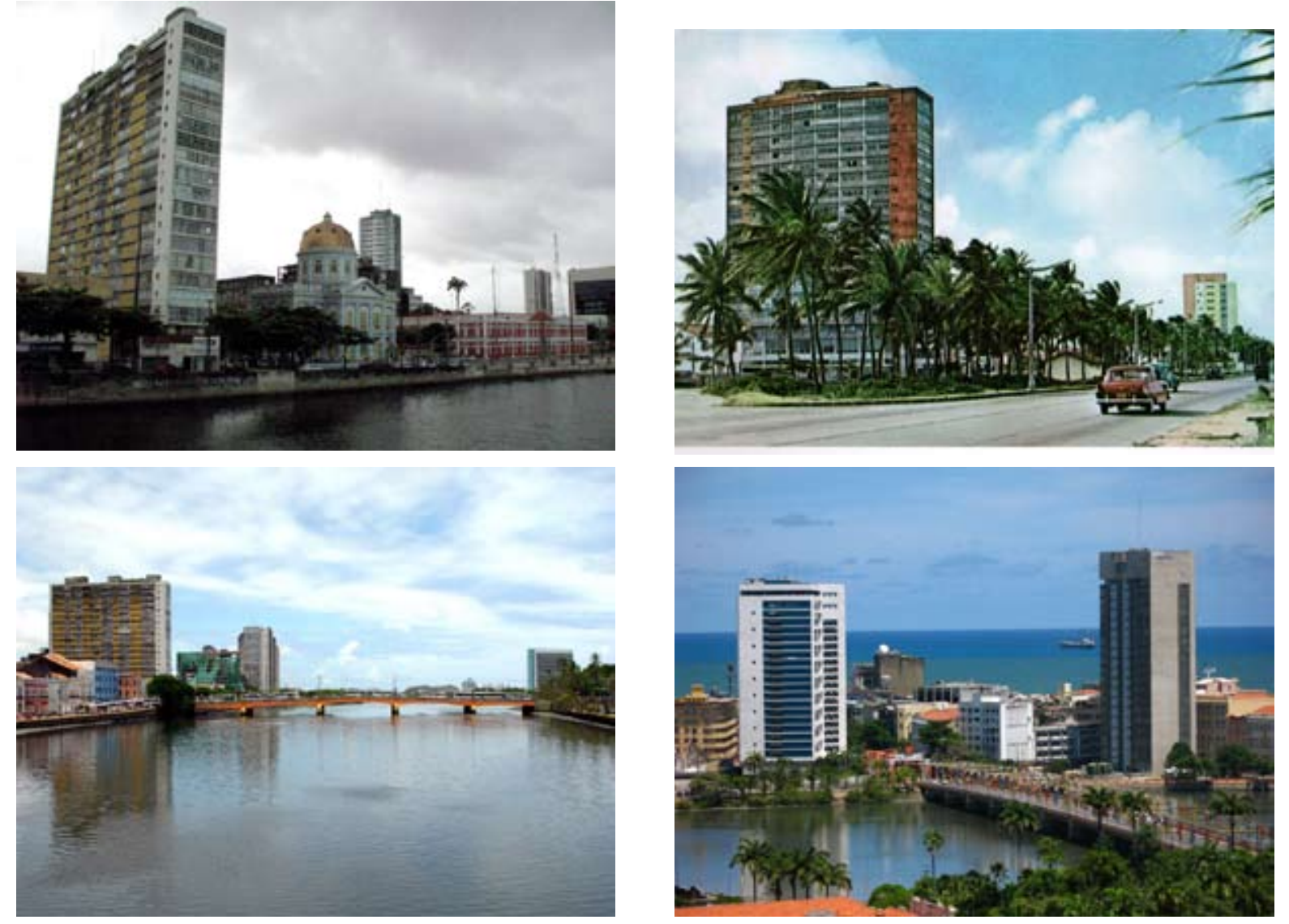

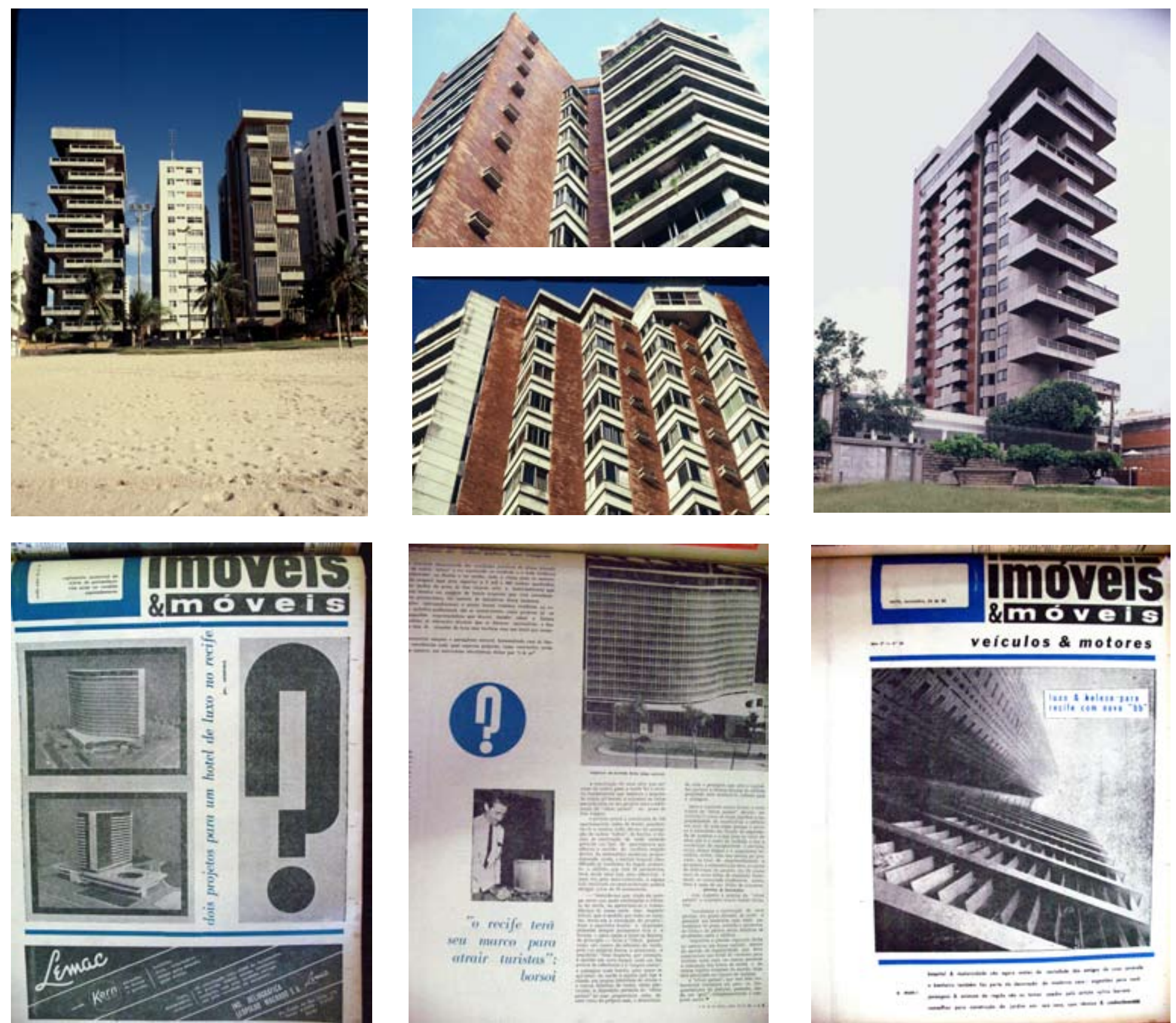

54,55,56 E 57 ED. MIRAGE -

1967, Portinari E Michelângelo

1969 (ACERVO BORSOI)

58, 59 a 60 Projetos Borsol

EM IMÓVEIS E MÓVEIS

(DIÁRIO dE PE, 1963) 

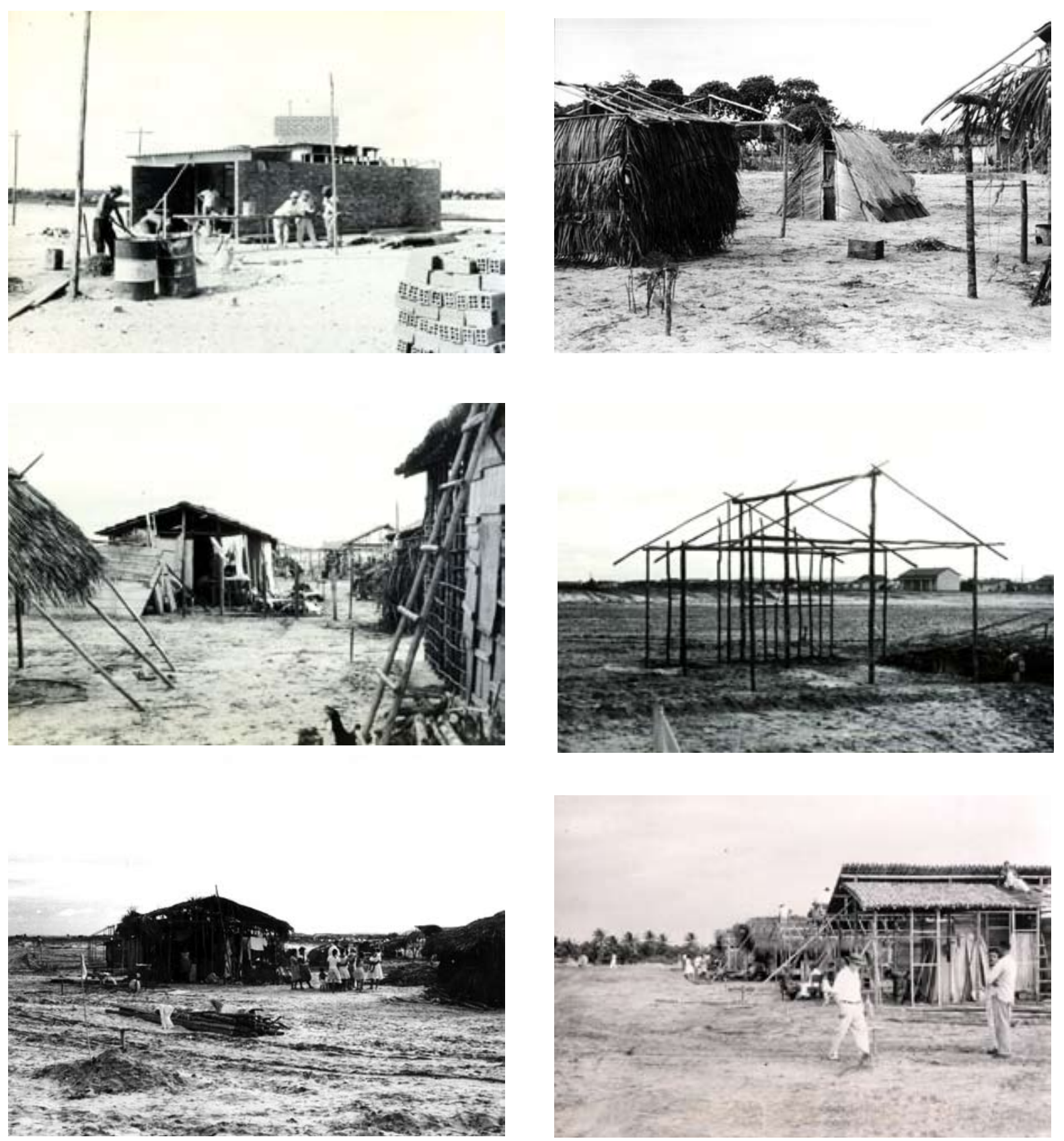

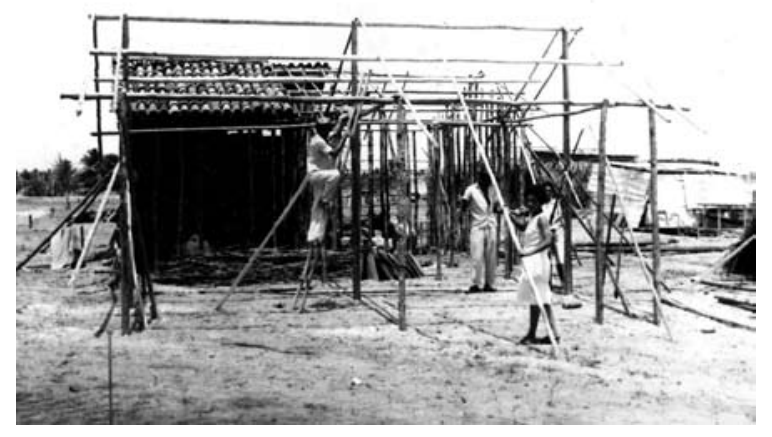

61 UNIDADE SANITÁrIA EM CONSTRUÇão (ACERVO BORSOI)

62 a 63 Primeiras casas do Cajueiro Seco (acervo BORSOI)

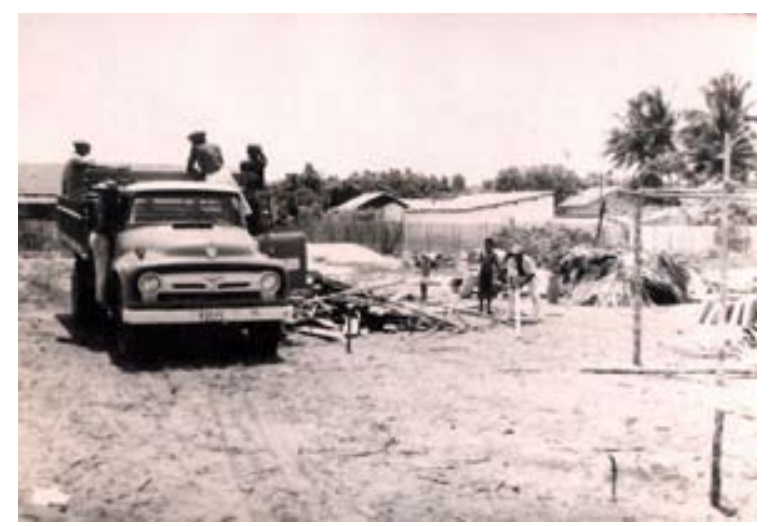




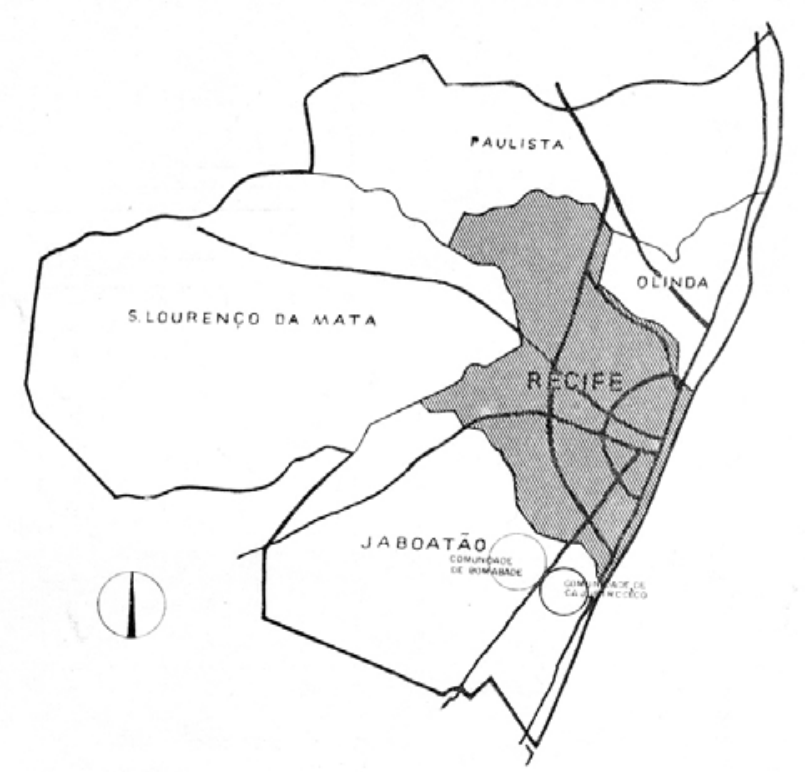

Cajuếro Sêco, uma experiêneia em construeâa

ARQUITETURA, em seu nimero 13, eleitoreira. o plano do Govérno Mipubbicoul, nesta secẫo, um trabalho in- guel Arrais, que presenta

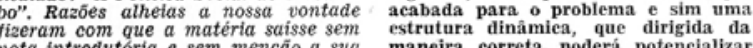
nota introcutoria e sem mençāo a sua Voltando ao assunto, ARQUITETURA
traz aos seus leitores os primeiros re-

sultados concretos as a politica exposta
naquele trabalho de autoria do arguiteto Gildo Guerra, prestidente do Sor-
vico Social Contra o Mocambo, que con-

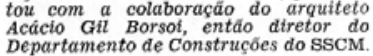

a POLITICa DO MOCaMBo

Flávio Marinho Régo, arquiteto parprojeto de Cajueiro Sêco, ao referir-se
a politica habitacional do Governo Mi-

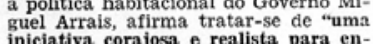
iniciativa corajosa e realista para en-
caminhar o angustiante problema humano e social de uma enorme e deses
perada massa humana marginalizadd. peracta massa humana marginalizata.
Bssa iniciativa, primeira de seu tipo
em nosso meio segundo creio foge ans em nosso meio, segundo creio, foge
moldes ja tradicionalizados das soly vala pela invasao dos Montes Guara-

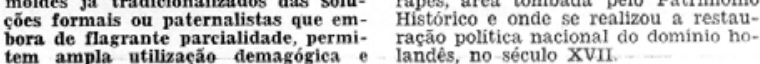
传

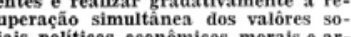
ciais, poititicos, economicos, morais e ar 0 resultado final refletirá a expresde cada comunidade, seu indice de mico e politico, comunidade essa ja in-
tegrada então positivamente no cono homem recuperado através da utitentece com o protegido social, desfi"excia sua faléncia existencial." EXPERIENCIA PILOTO

A idéia da experiência, agora trans-

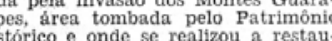

\section{Ao "Limite" da Casa Popular}

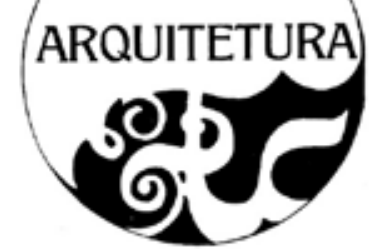

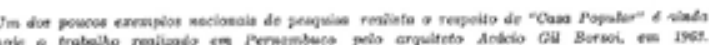

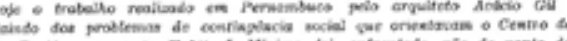

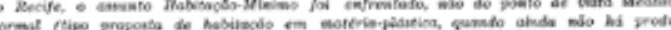

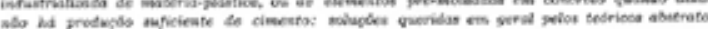

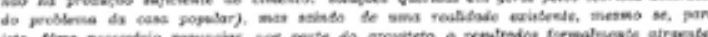

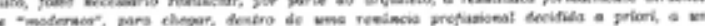

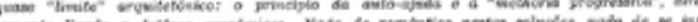

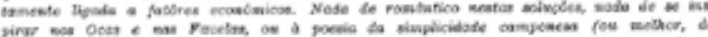

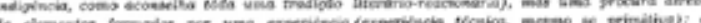

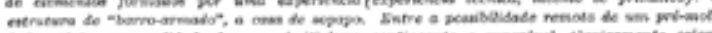

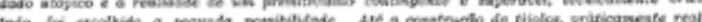

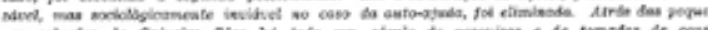

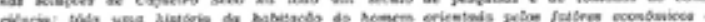

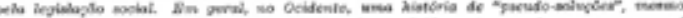

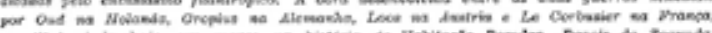

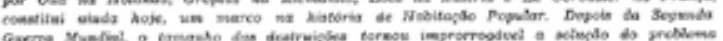
mases patote

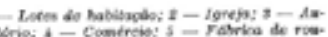

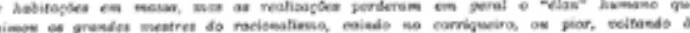

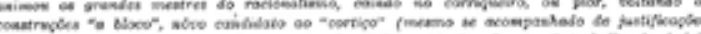

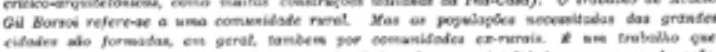

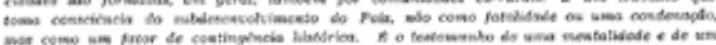

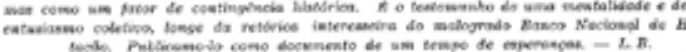

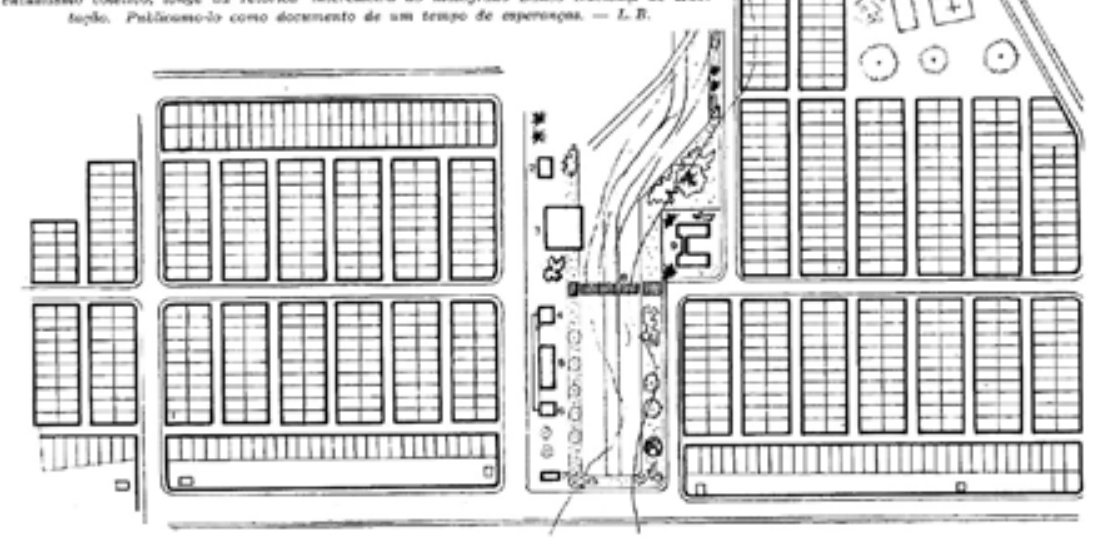

64 (ARQUITETURA, 1963)

65 (MIRANTE DAS ARTES, 1967) 
PANEL FABRICATION SEOUENCE

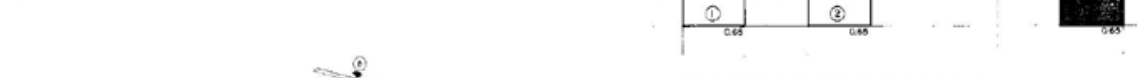

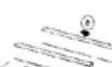
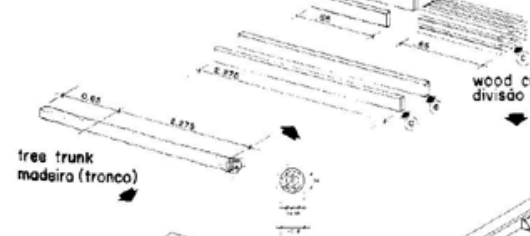

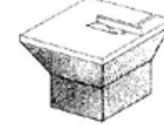

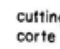
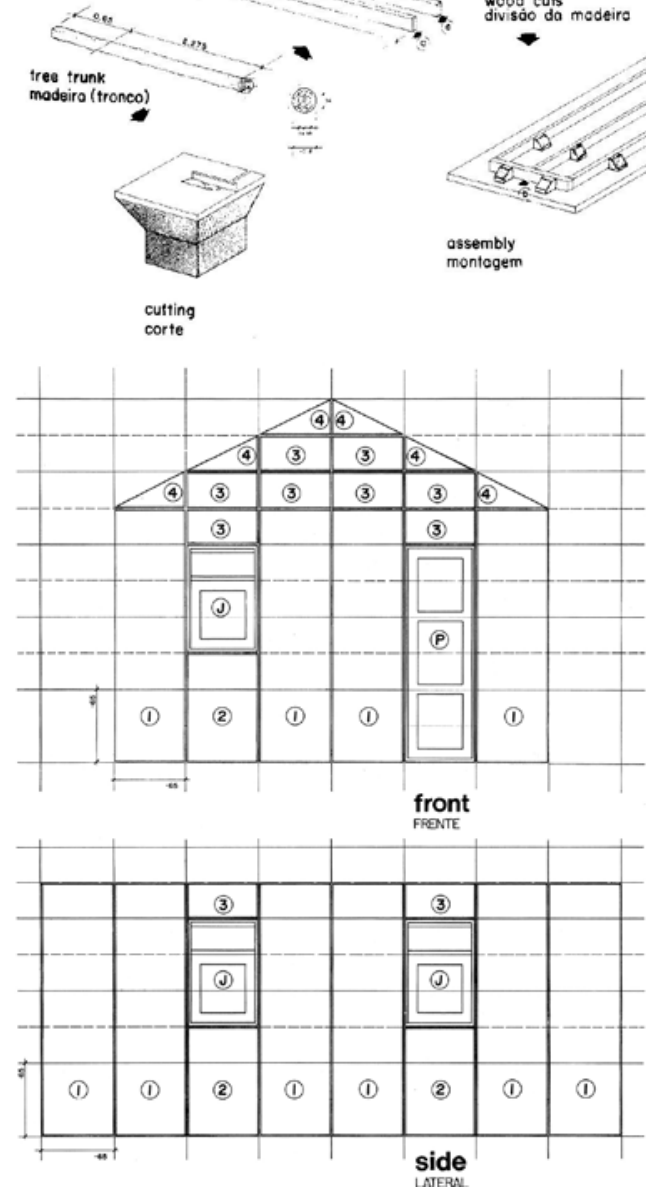

ossembly
montogem

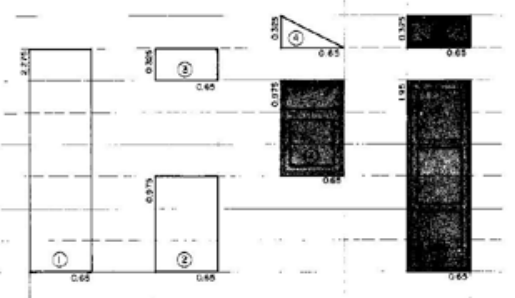

DOOR, WINDOW AND PANEL TYPES
TIPO DOS PAINEIS, PORTA E JANELA

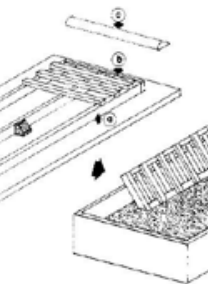

$\underset{\substack{\text { immunization } \\ \text { imunizocóo }}}{ }$

GRAPHIC PLANNING

PLANEJAMENTO GRÁFICO

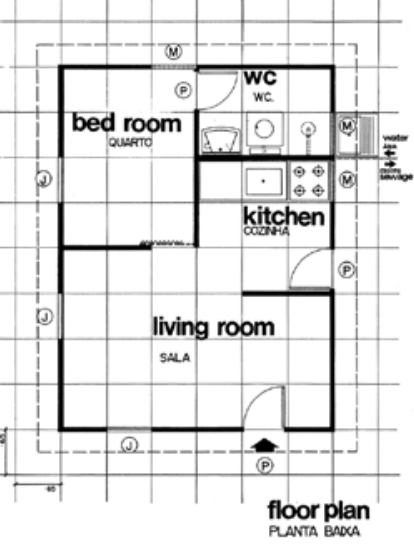

fig. 2

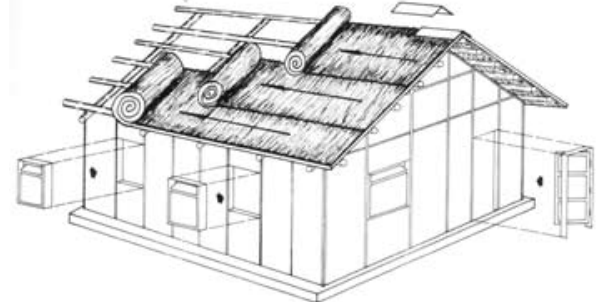

EXPLODED VEW OF HOUSE CONSTRUCTION
ESQUEMA DE MONTAGEM DA CASA

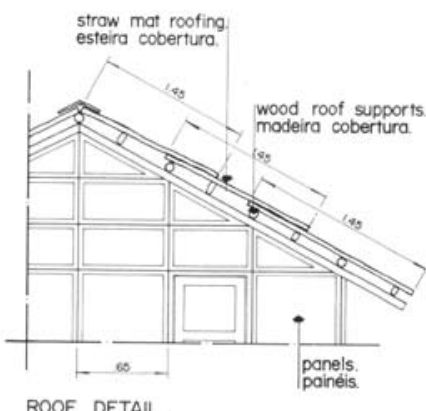

ROOF DETALL. COBERTURA

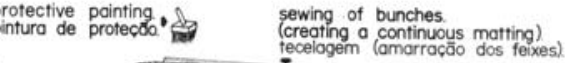

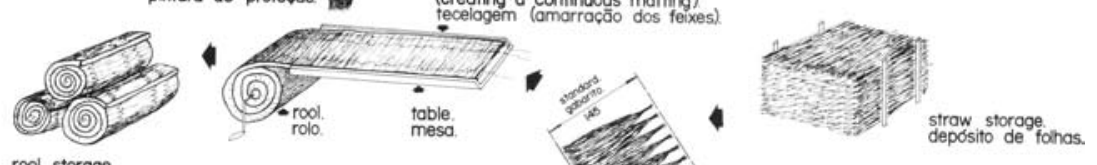

rool storoge,
deposito de rolos

pre-cut straw bunches,
feixes de folhas preporadas.

fig.1 FABRICATION SEQUENCE OF STRAW MATTING FOR ROOF

ESQUENA DE FABRICACAÁO DAS ESTEIRAS DE COBERTURA

BATHROOM ELENENTS IN PREE-FABRICATED CONCRETE
ESOUEMA DO EOU PAMENTO SANTTARIO PRE-MOLOADO EM CONCRETO

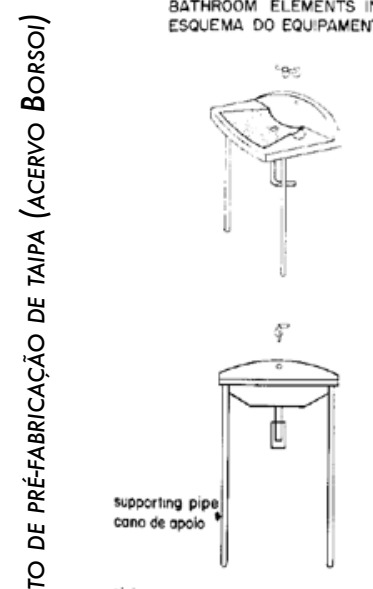

sink
levotótio

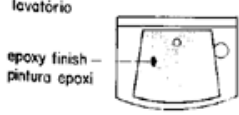
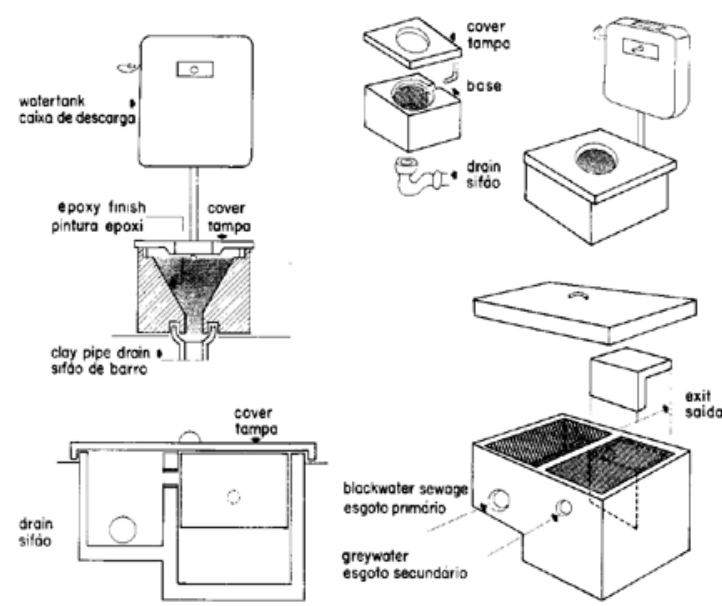

blockwoter sewage
espott prmmirio

greyworter 


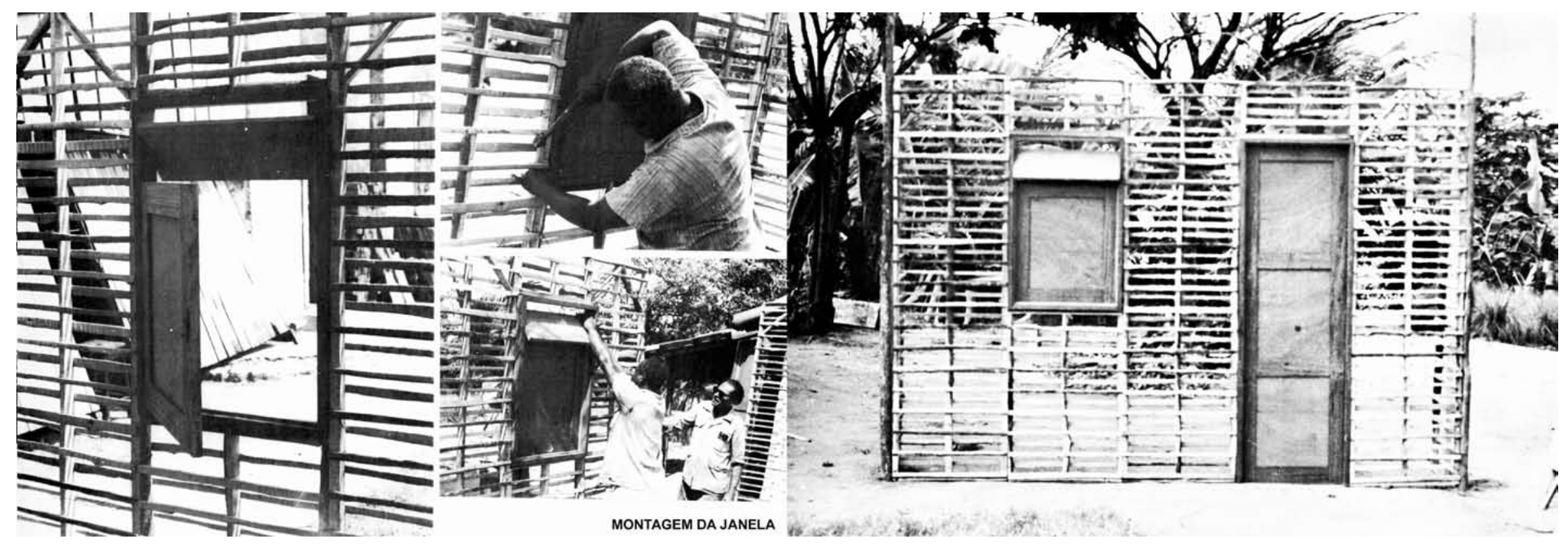

68, 69 E 70 Pré-FABRICAÇÃo eM tAIPA(ACERVO BORSOI)
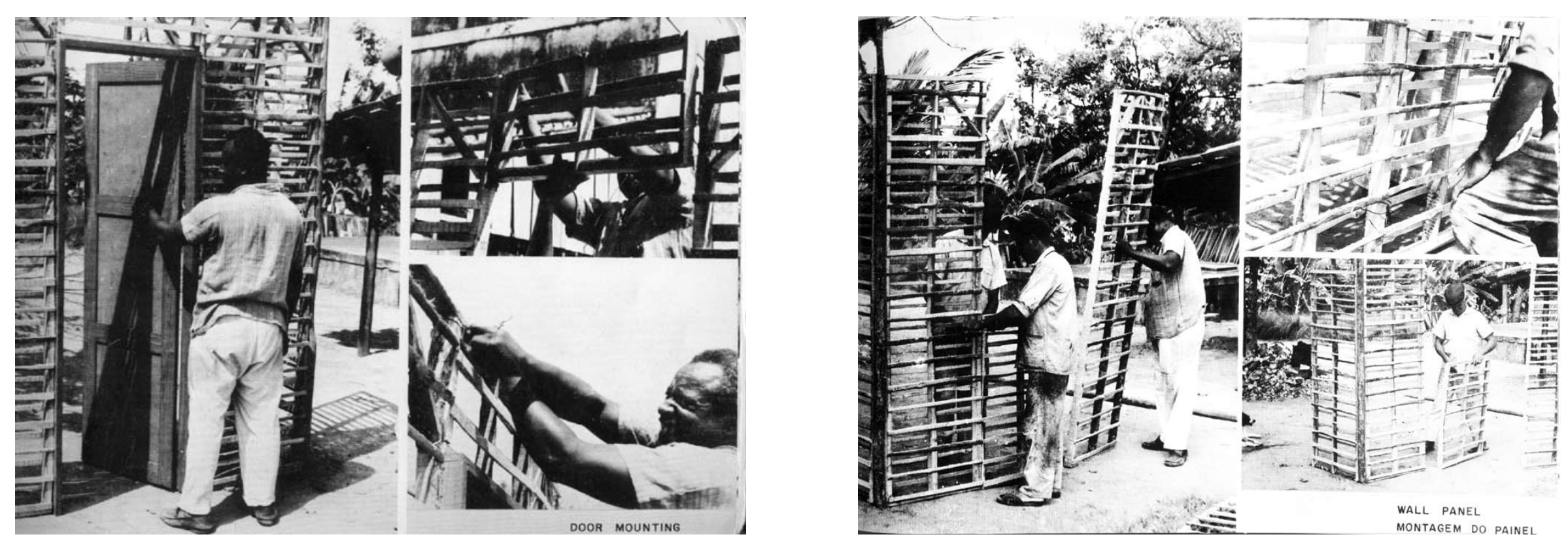


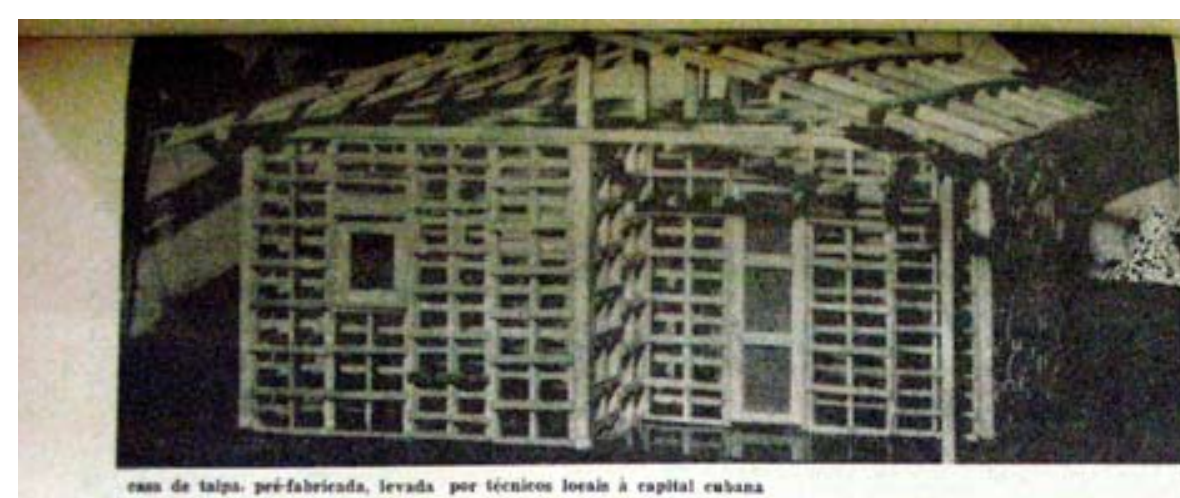

profensores

8 alumes de

arquitetura

levaram casa

de taipa do

nordeste

para o

eneontre

Internaeional

de havana

pernambuco mostrou casa de taipa ao encontro de arquitetos: havana
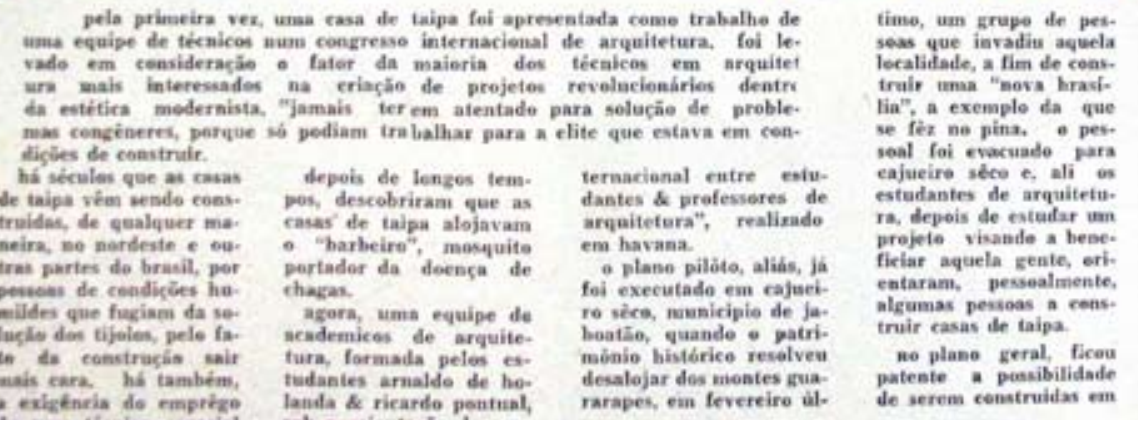

sirie e: "preb-labricadas"
as casas de taips, bastan

10. que tione meatads tana oficina especializa

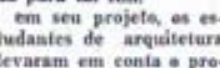
levaram emeanta op pro. "barbeirs", pertadar on lopen

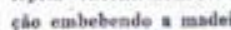

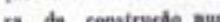
aleo especial, que inumi an a casa centra a bumb dode e insecto *

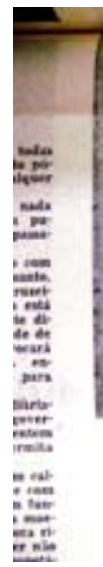

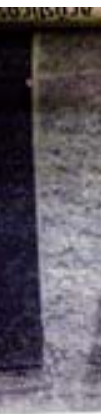

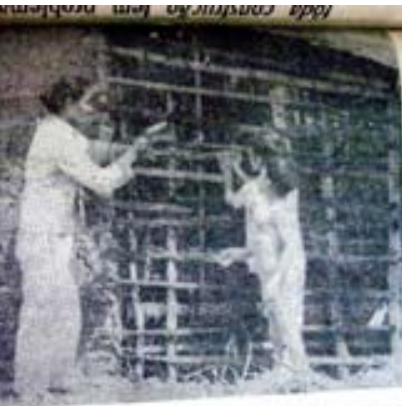

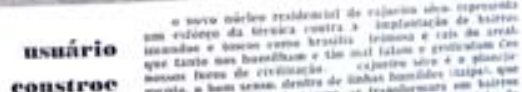

sas cas

stado Disciplina Habitaçăo Popular no

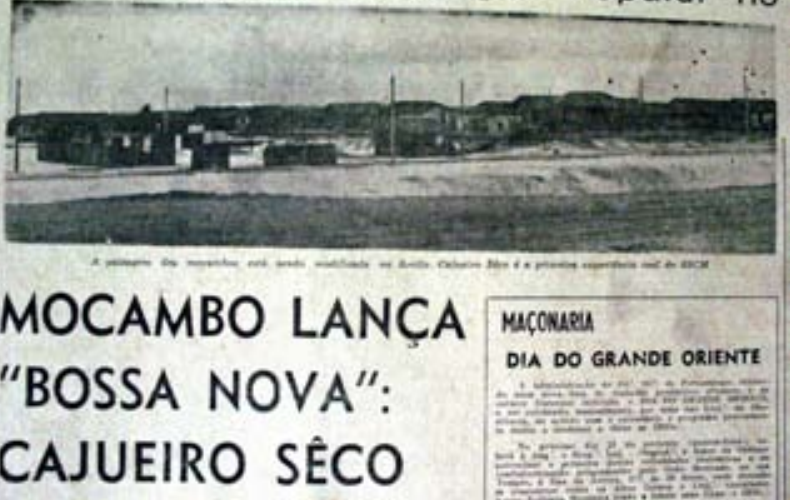

71 e 72 MatérIAs SOBRe a CASA de TAIPA NO CONGRESSO DA UIA EM CUba E AUTOCONSTRUÇÃo

(DIÁRIO DE PE, 1963)

73 e 74 MatérIas SObRe a INAUguração do Cajueiro

Seco (Última Hora, 1963)

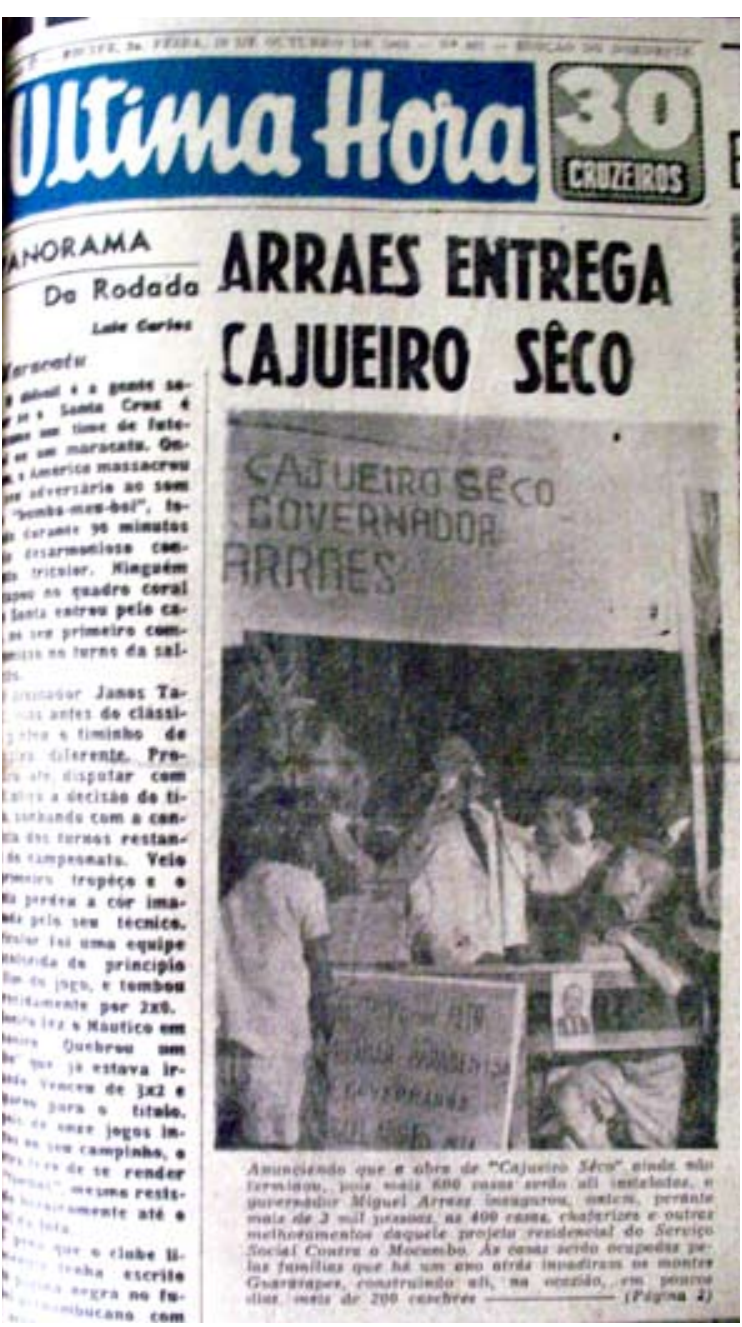


75 ETAPAS DA CONSTRUÇÃO TRADICIONAL EM TAIPA (SDAS PE)

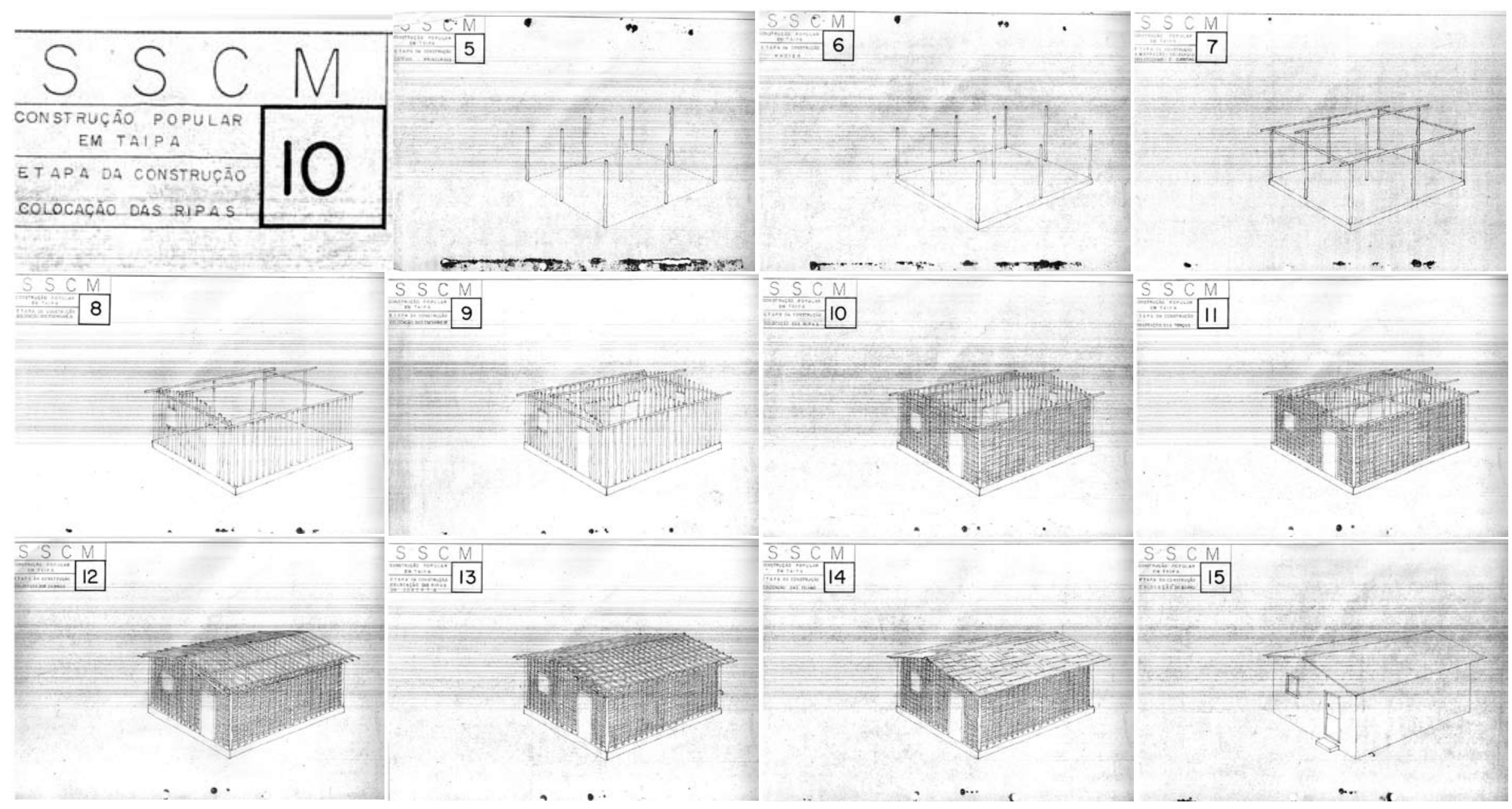



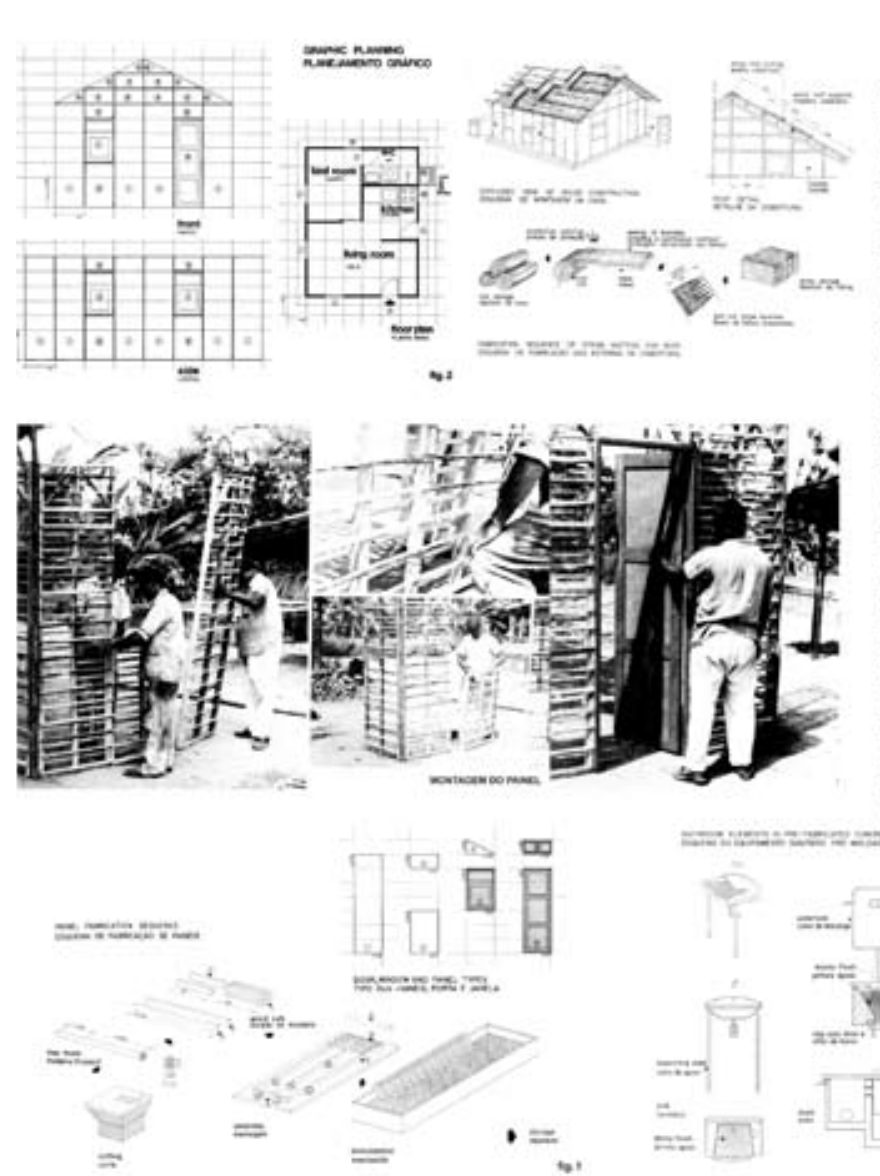

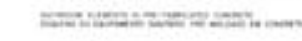
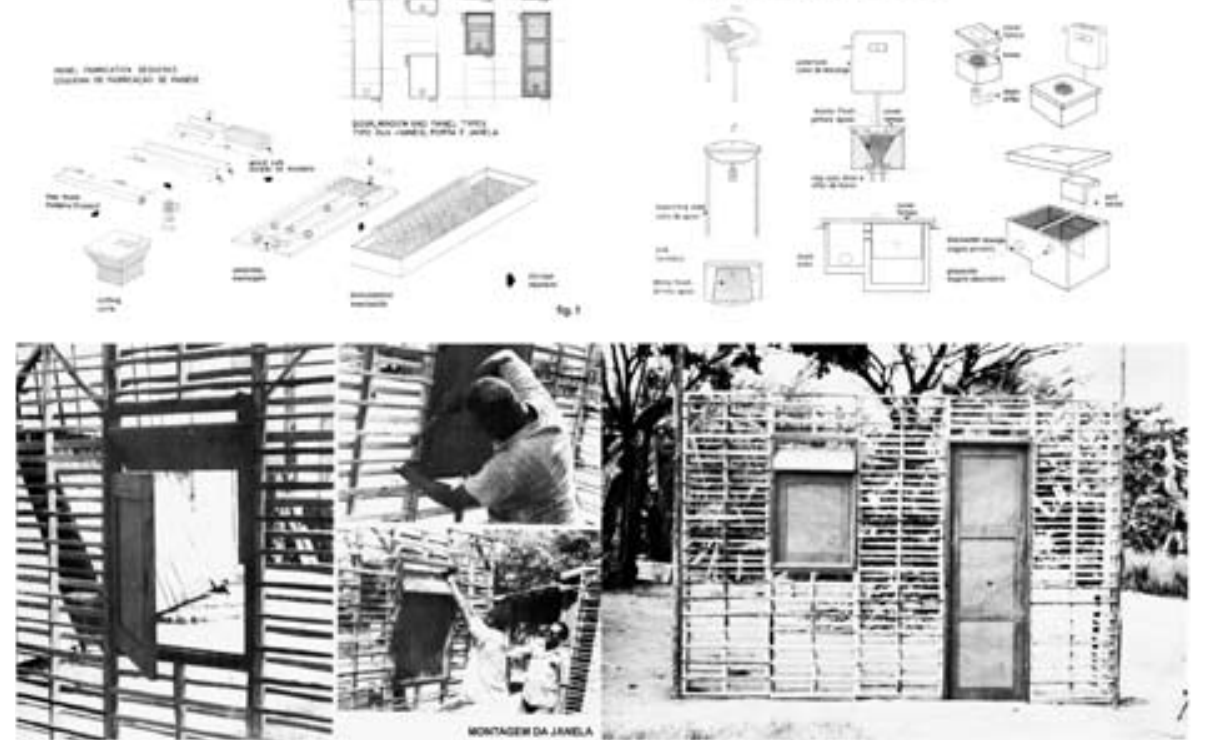
sond

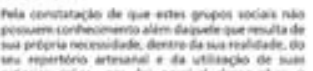

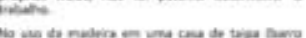

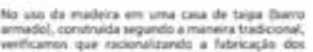
istions

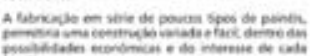

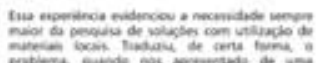

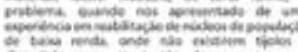

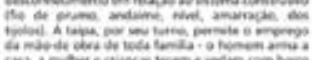

TAIPA 1963 CAJUEIRO SECO 1963

A

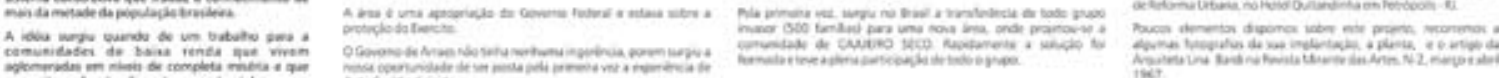

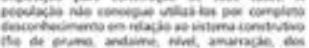

Mo "Limite" da Casa Popular
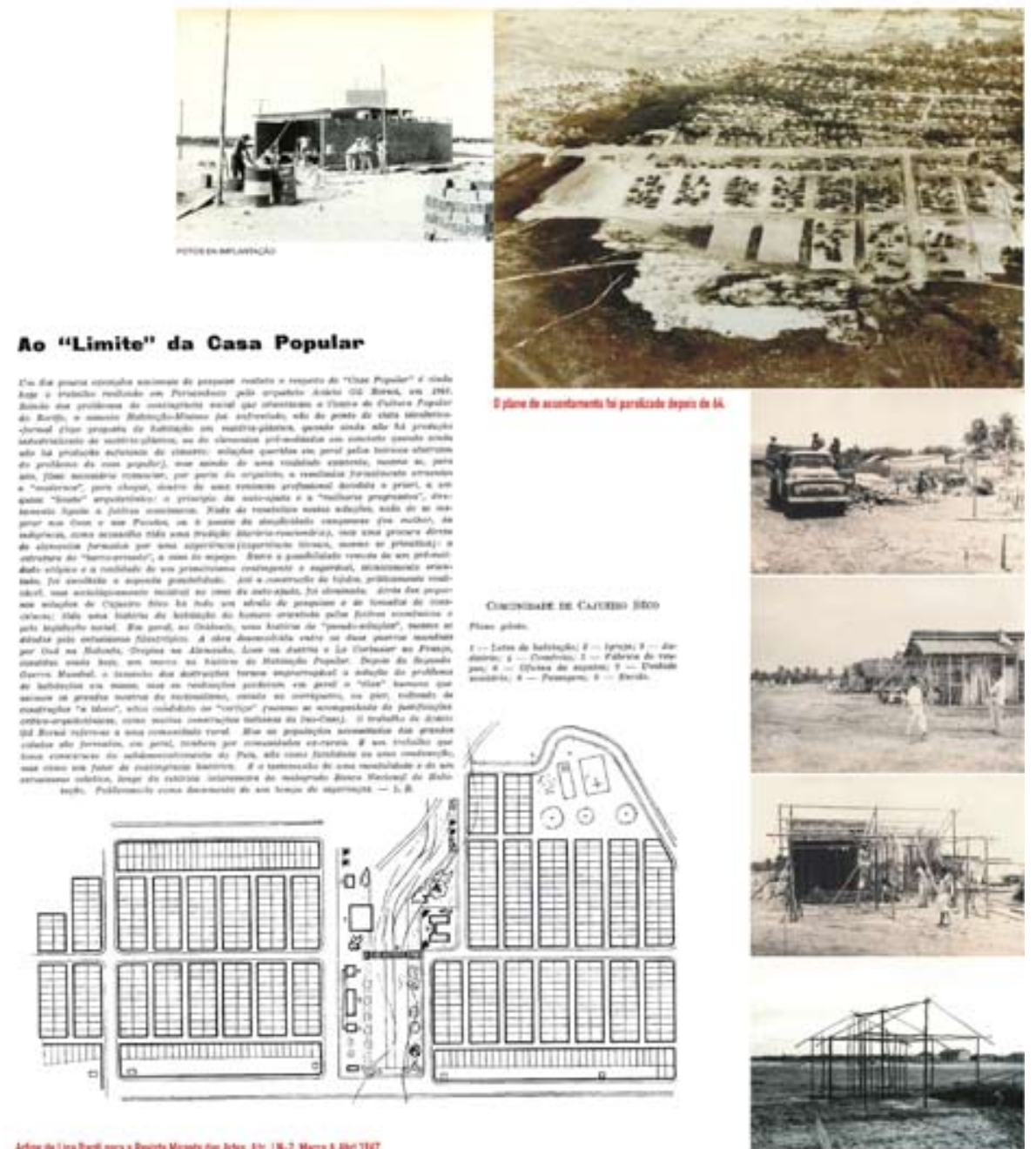

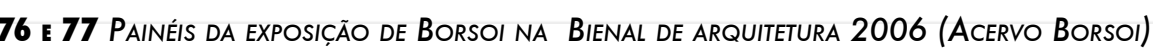



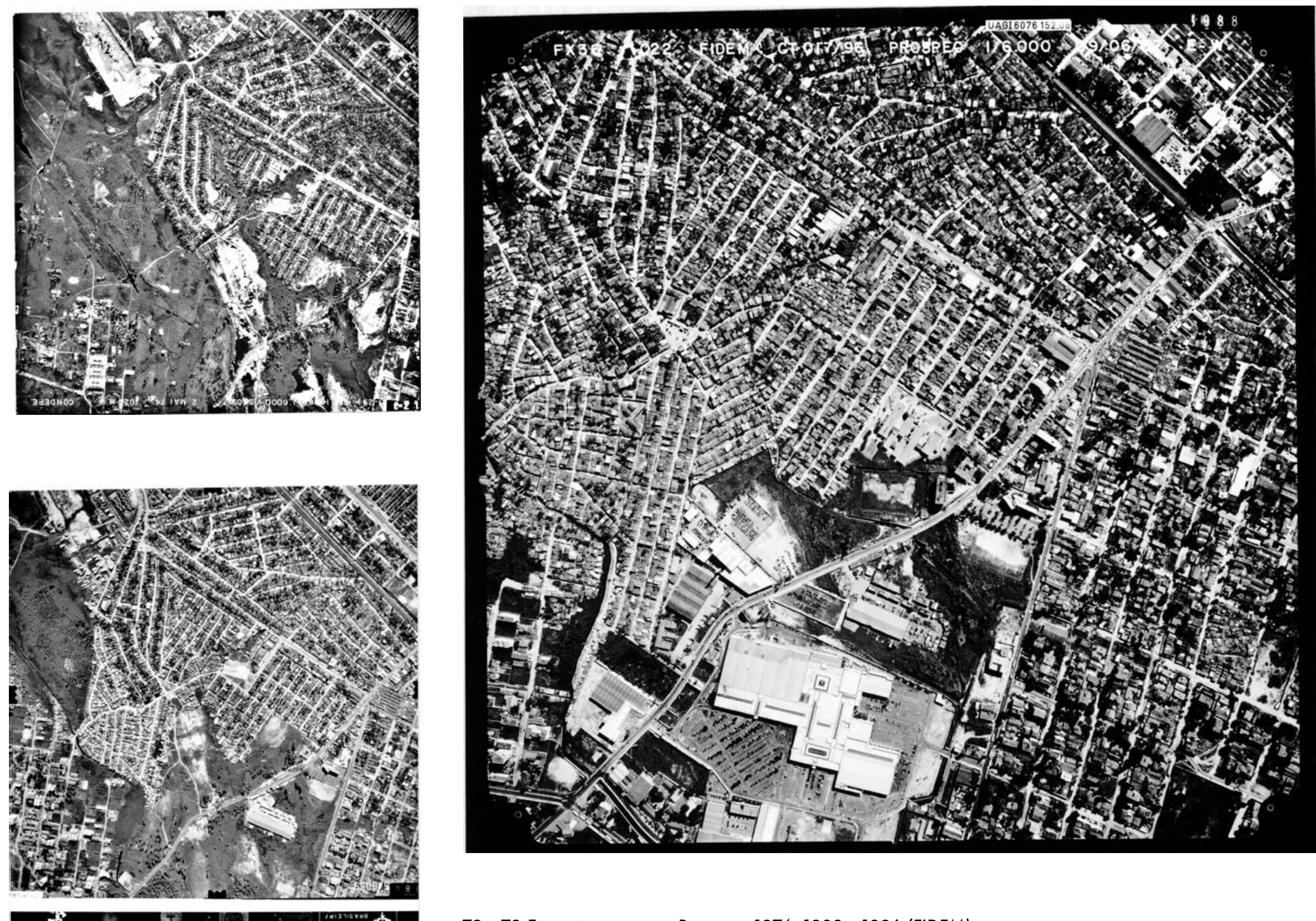

78 a 79 Evolução urbana de Prazeres - 1974, 1988 e 1996 (FIDEM) 

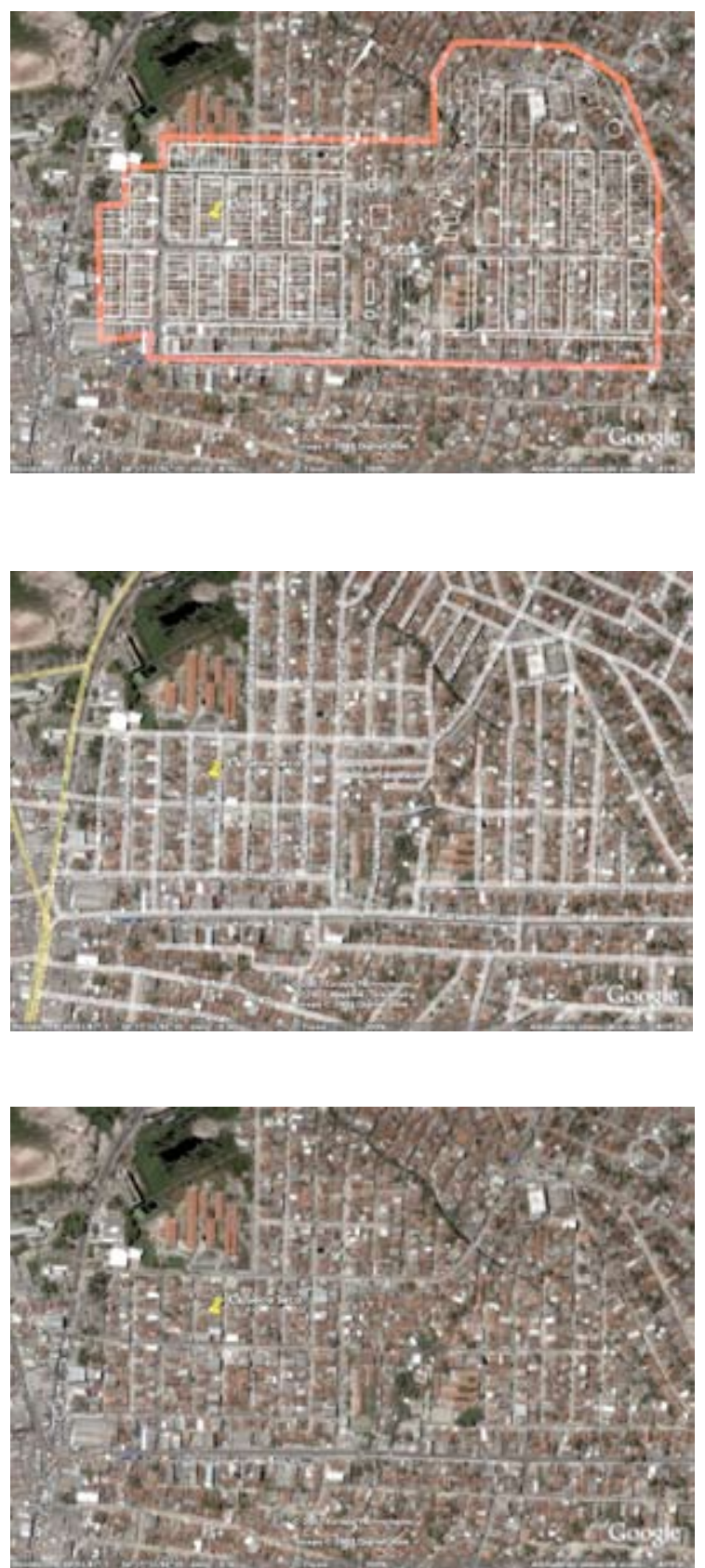

80 a 83 Localização aproximada do PROJeto uRbano na situação atUAl (GoOgle, 2007)

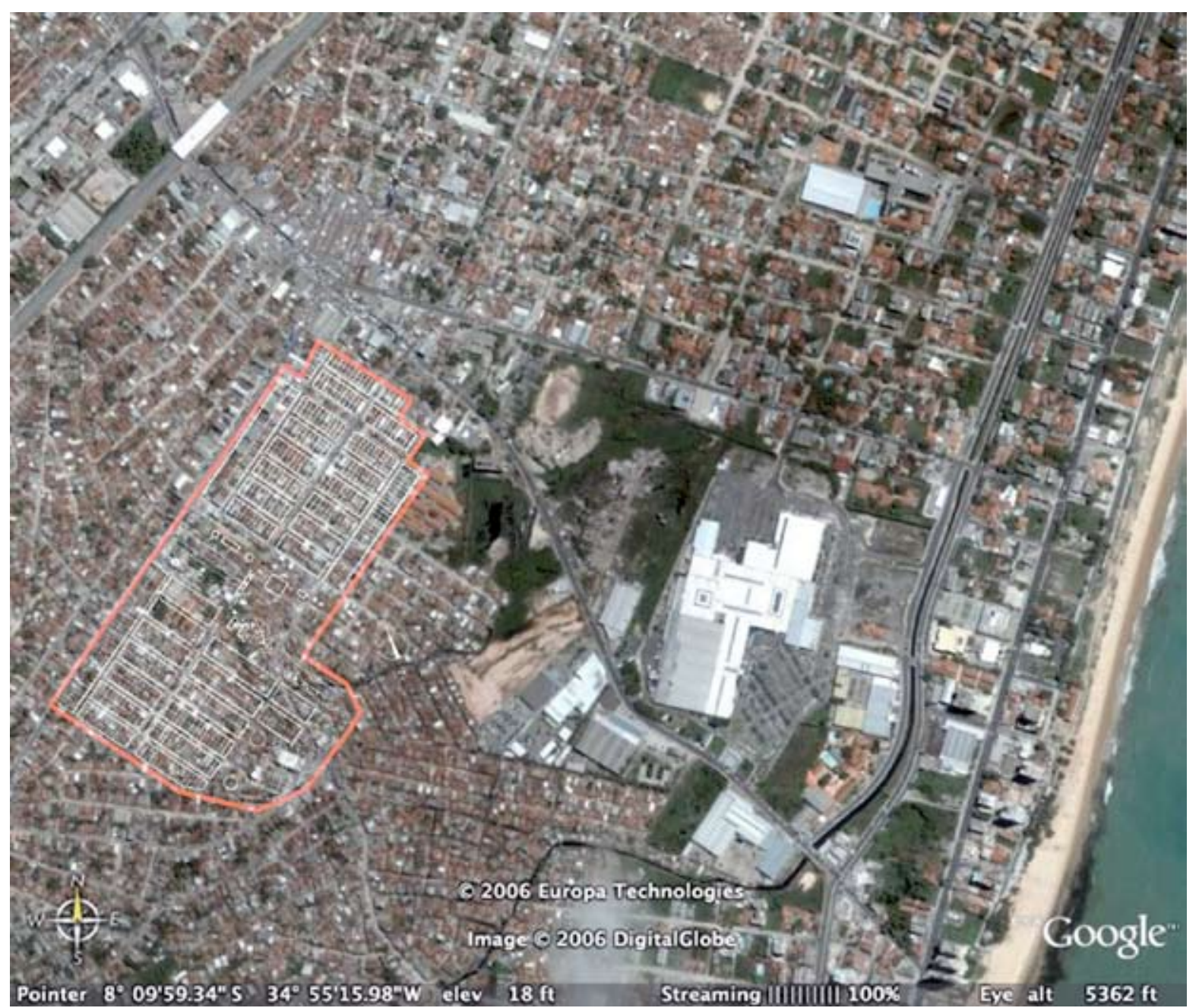



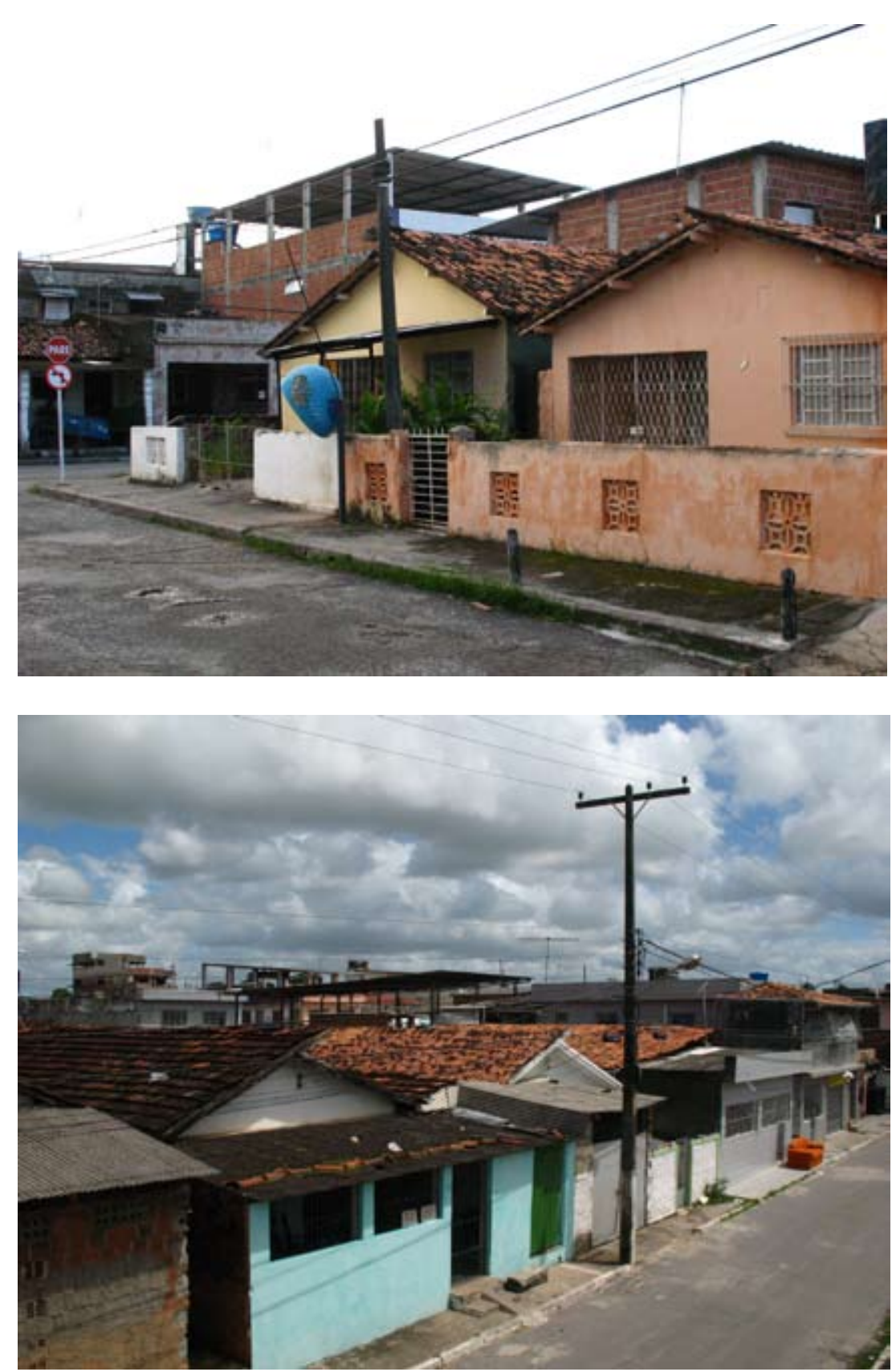

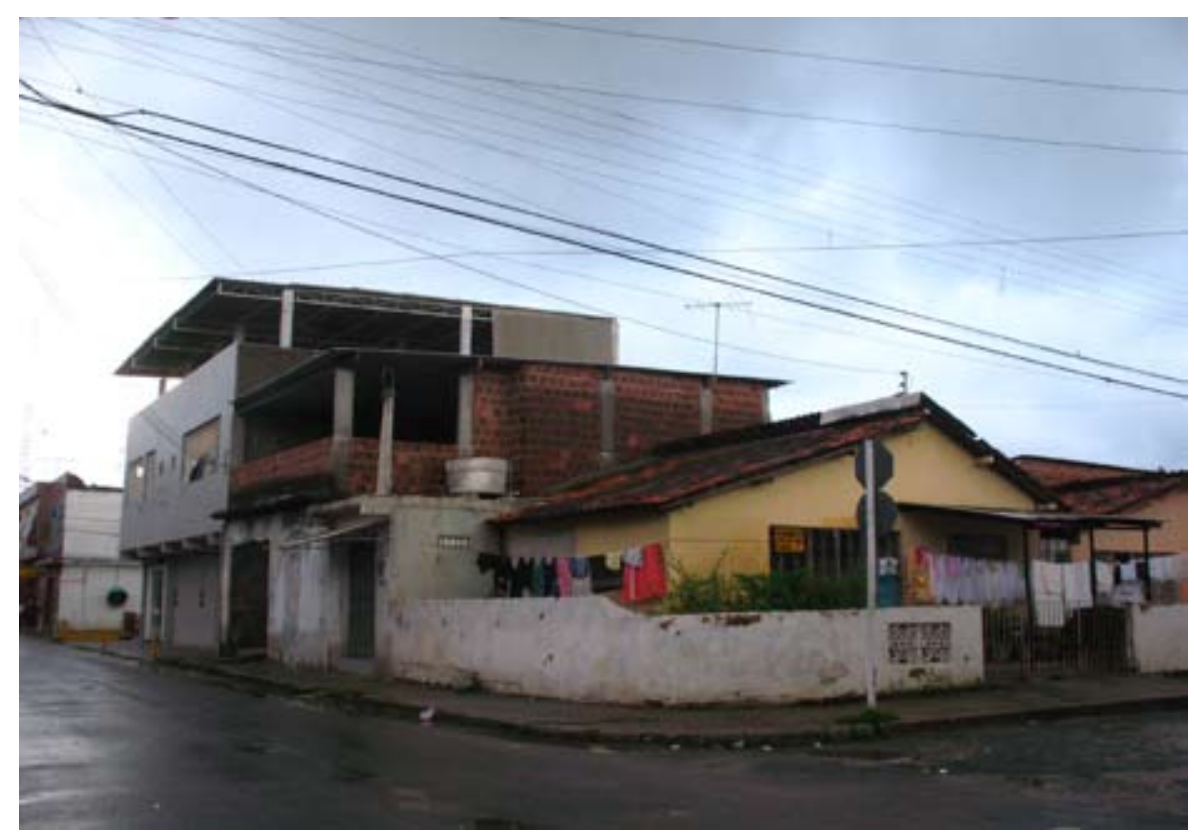

84 a 87 CAJueiro Seco hoje- Evoluções Progressivas das CASAS (Fotos do AUtor, 2007)

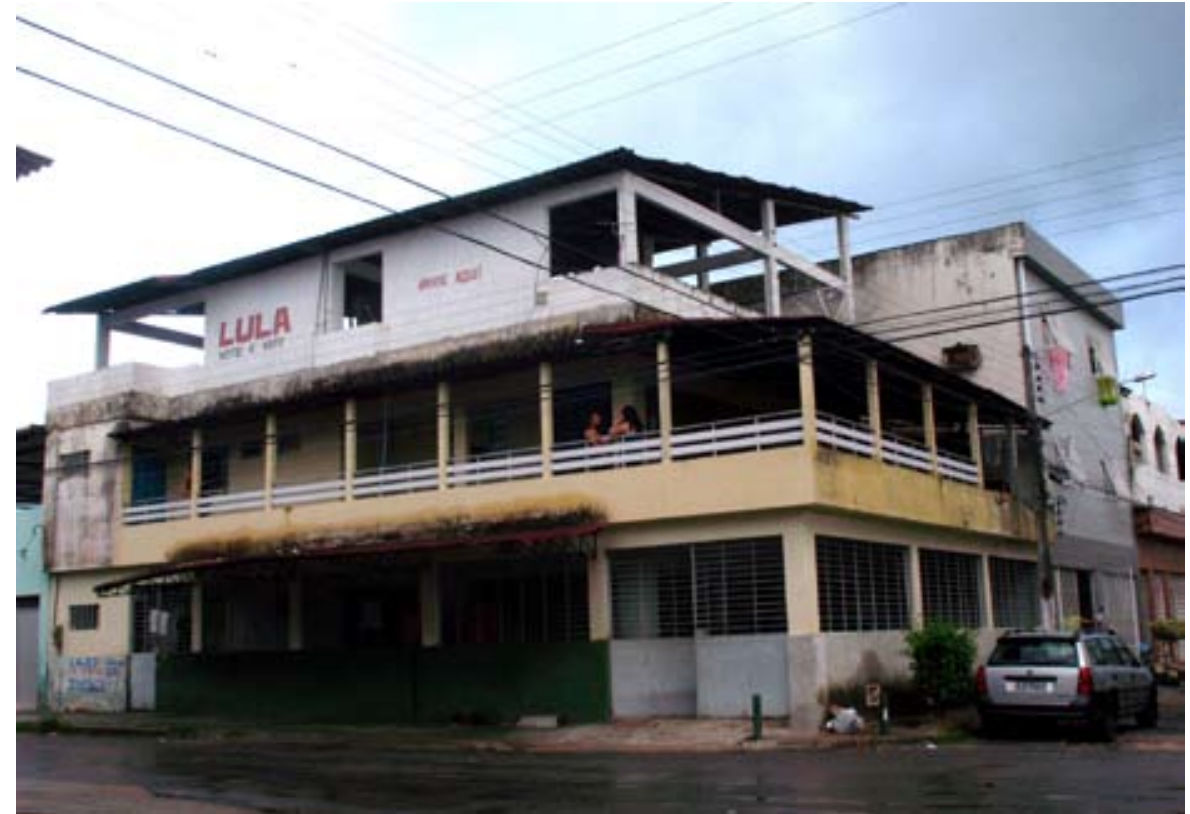




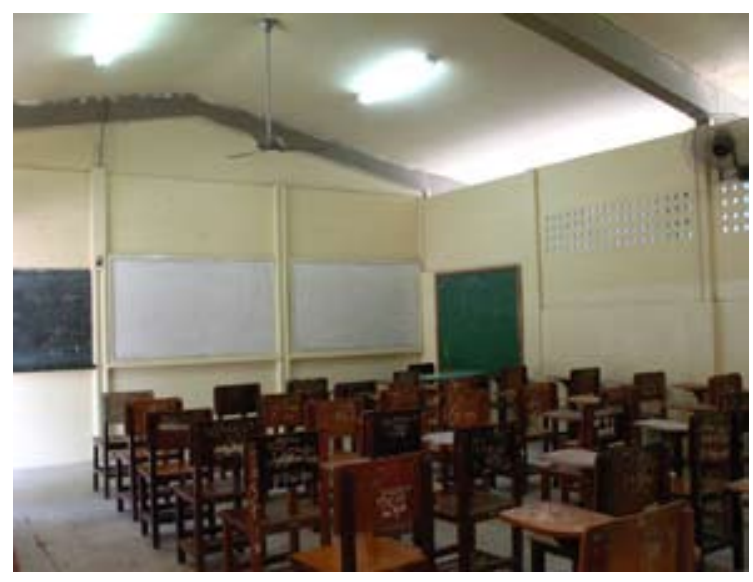

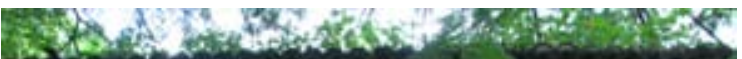
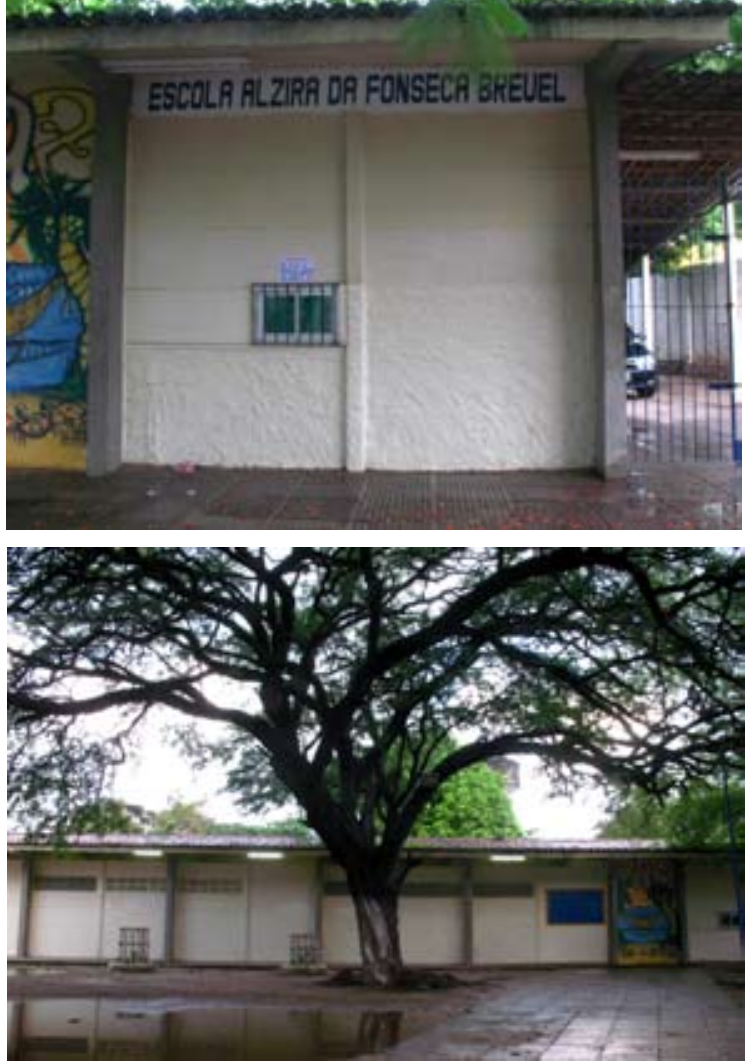

88 a 90 Cajueiro Seco hoje - Escola pré-Fabricada (Fotos do AUTOR, 2007)

91 ANTIGOS GALPÕES DAS COOPERATIVAS TRANSFORMADOS EM

ESCOLA (FOTO DO AUTOR, 2007)

92 CASA TRANSFORMADA EM IGREJA (FOTO DO AUTOR, 2007)

93 Cajueiro Seco hoje - Linha fÉrRea, Av. Barreto de Menezes

e Montes Guararapes (Fotos do autor, 2007)
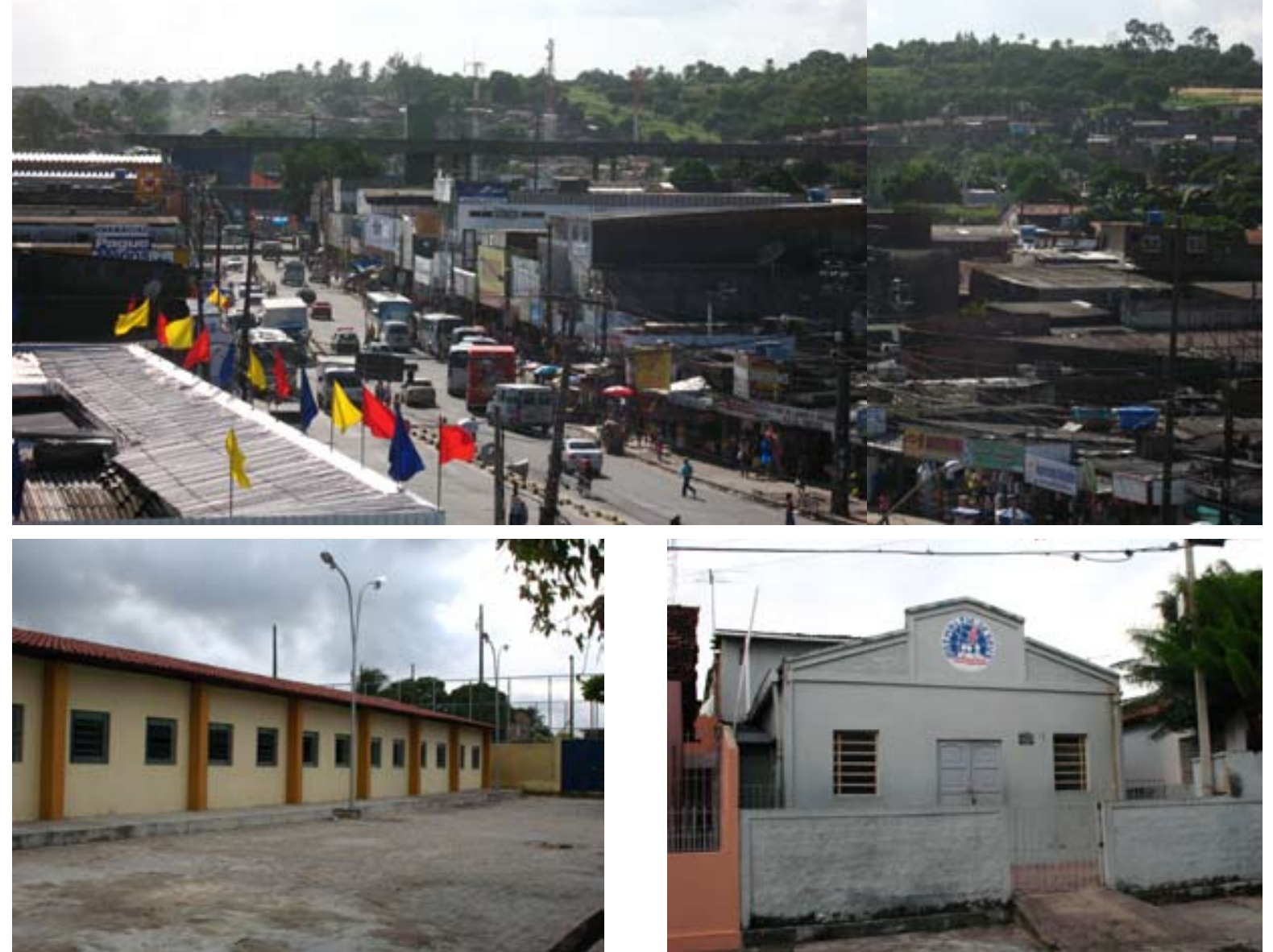

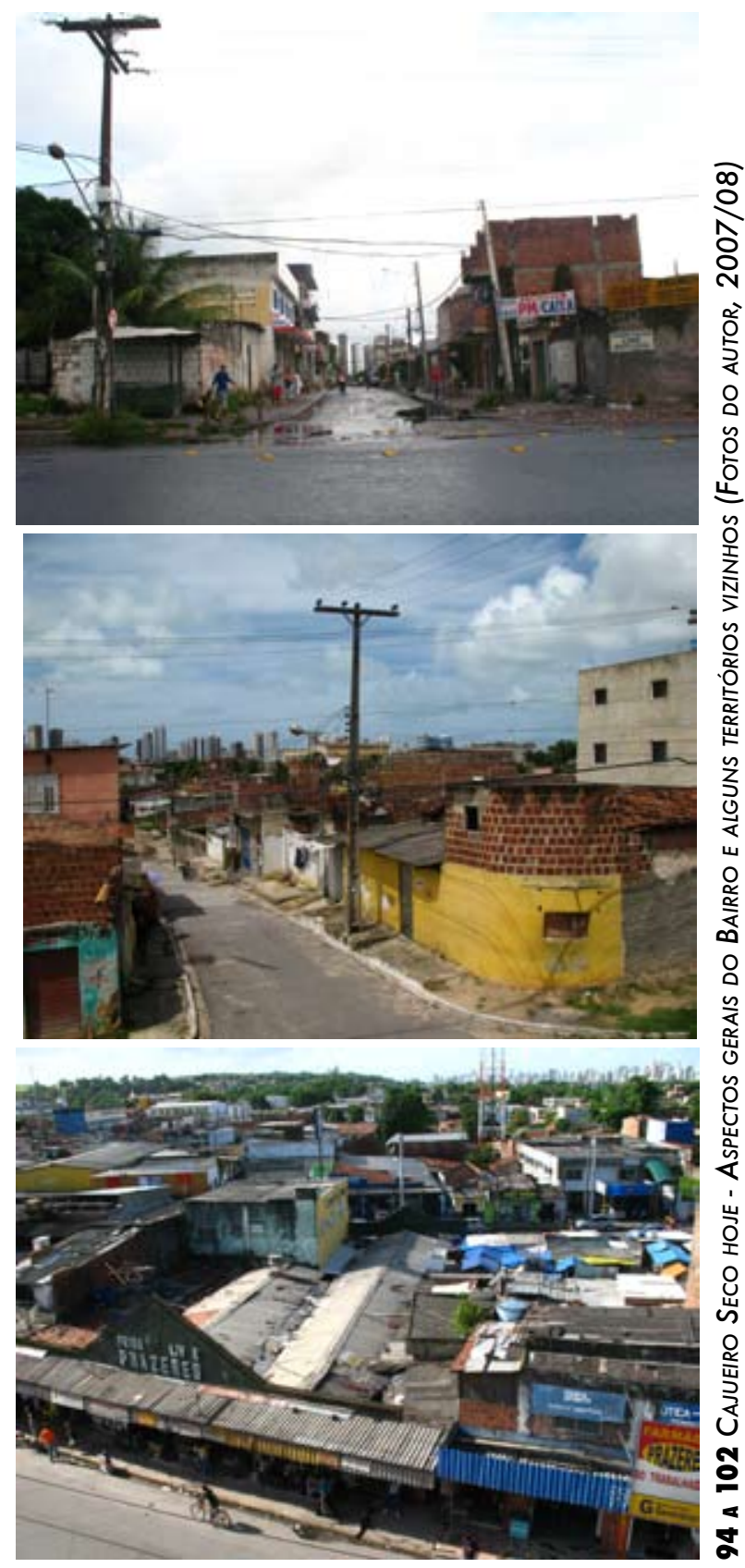

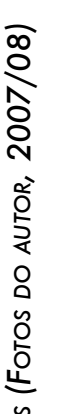
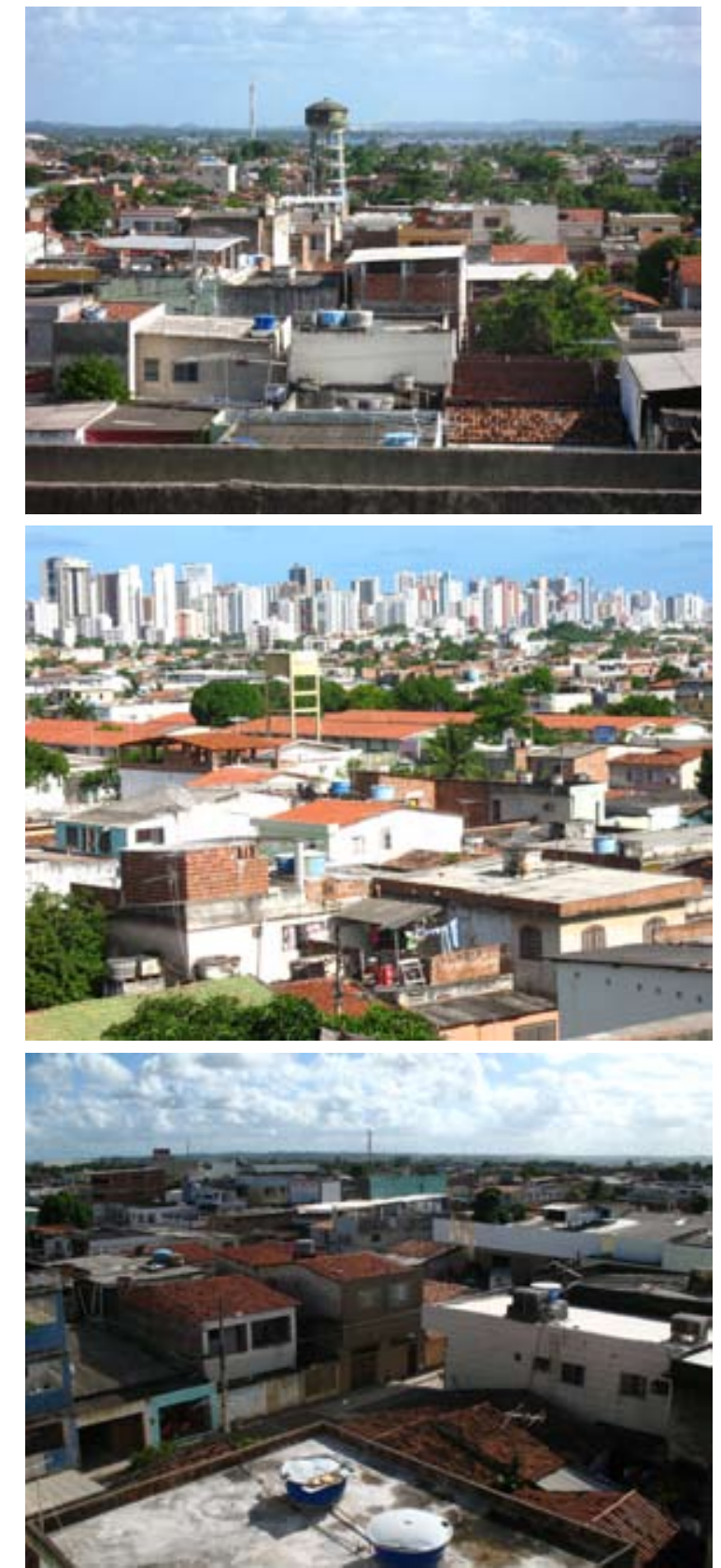
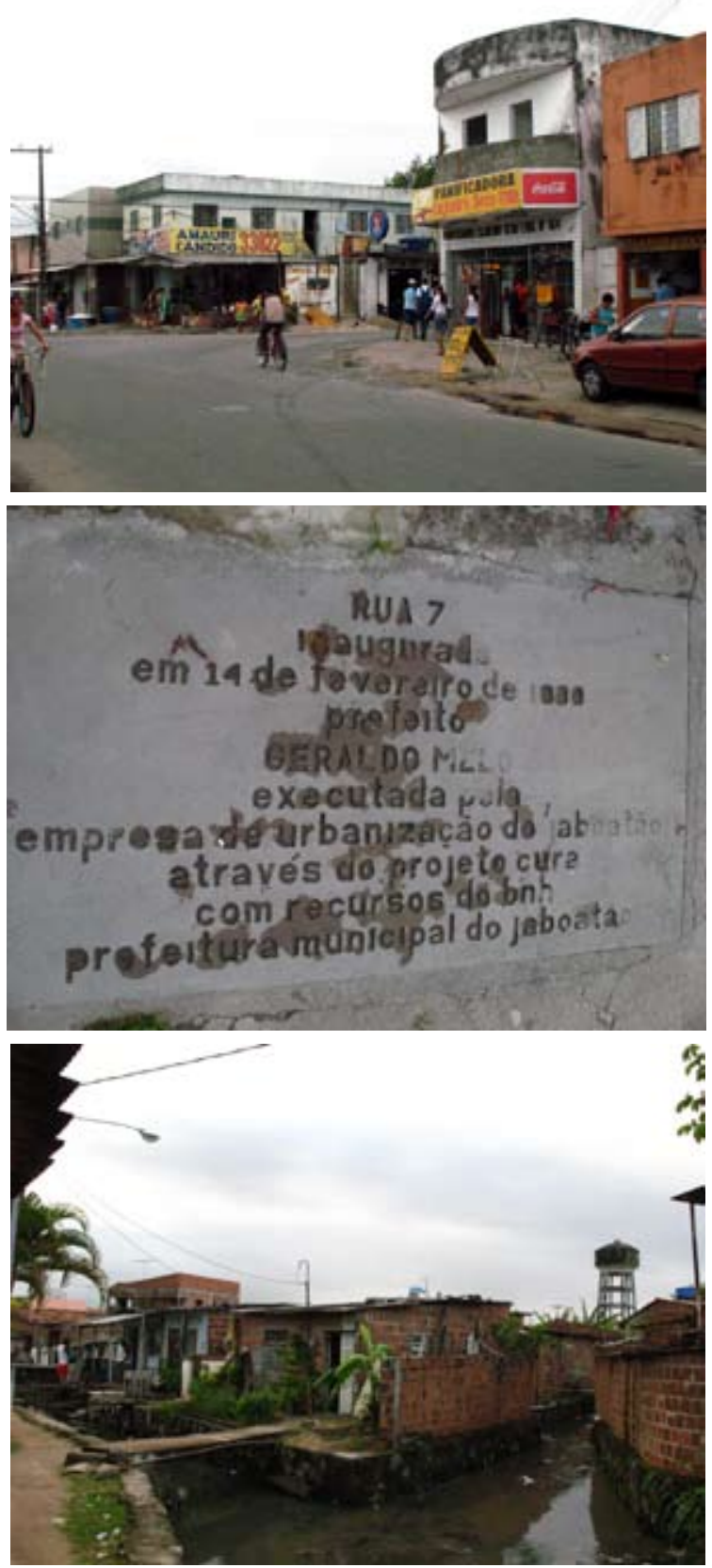

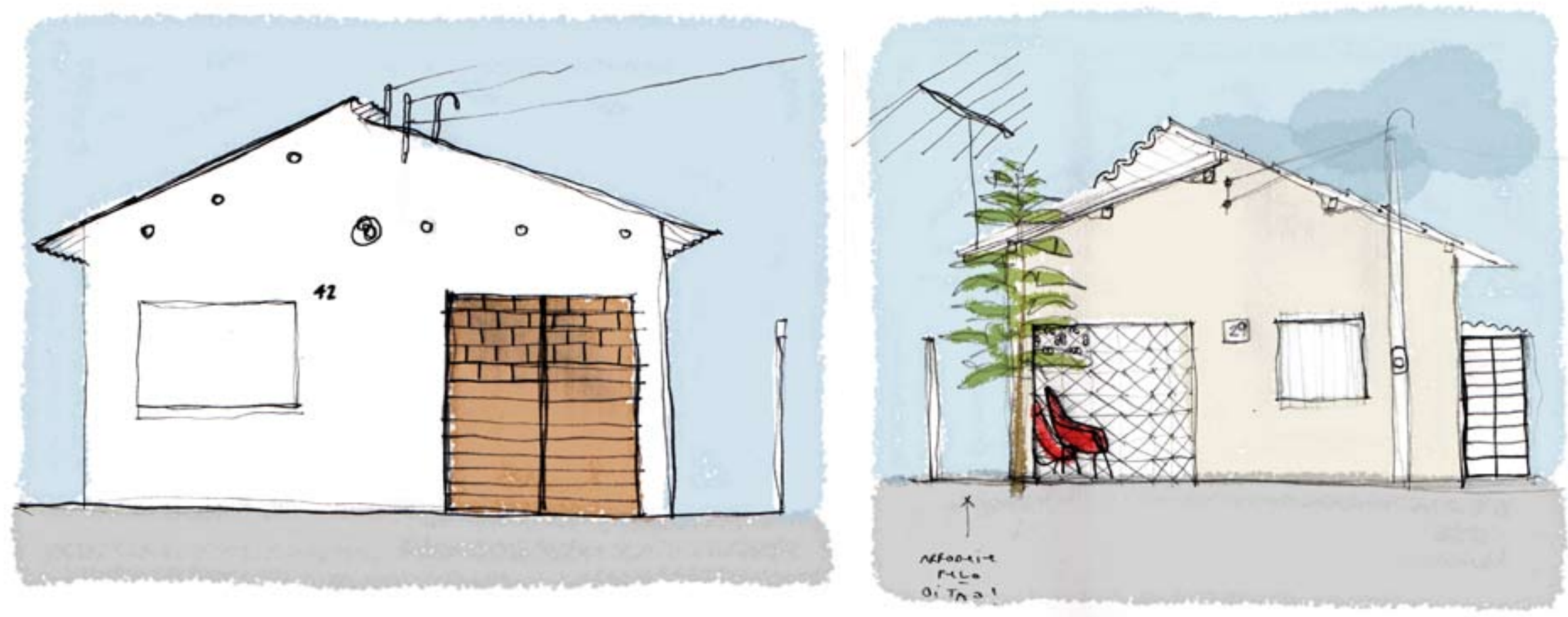

103 a 106 Casas do CaJueiro Seco(Croquis do autor, 2007)
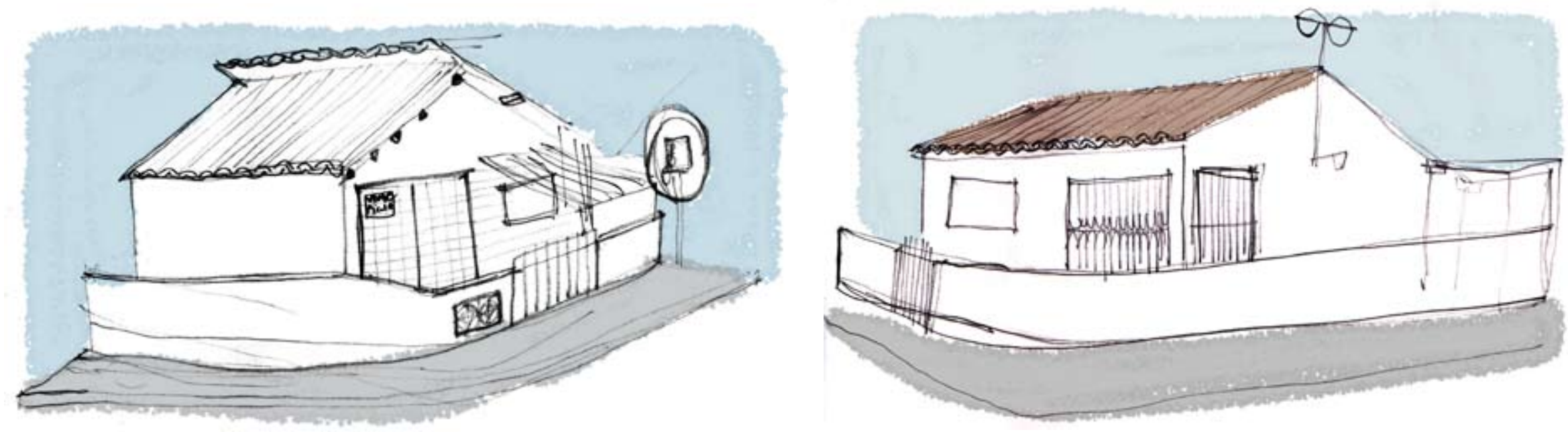